Editora Poisson

\title{
Tópicos em Administração Volume 19
}

\author{
1a Edição
}

Belo Horizonte

Poisson

2019 
Editor Chefe: Dr. Darly Fernando Andrade

\section{Conselho Editorial}

Dr. Antônio Artur de Souza - Universidade Federal de Minas Gerais

Ms. Davilson Eduardo Andrade

Dr. José Eduardo Ferreira Lopes - Universidade Federal de Uberlândia

Dr. Otaviano Francisco Neves - Pontifícia Universidade Católica de Minas Gerais

Dr. Luiz Cláudio de Lima - Universidade FUMEC

Dr. Nelson Ferreira Filho - Faculdades Kennedy

Ms. Valdiney Alves de Oliveira - Universidade Federal de Uberlândia

Dados Internacionais de Catalogação na Publicação (CIP)

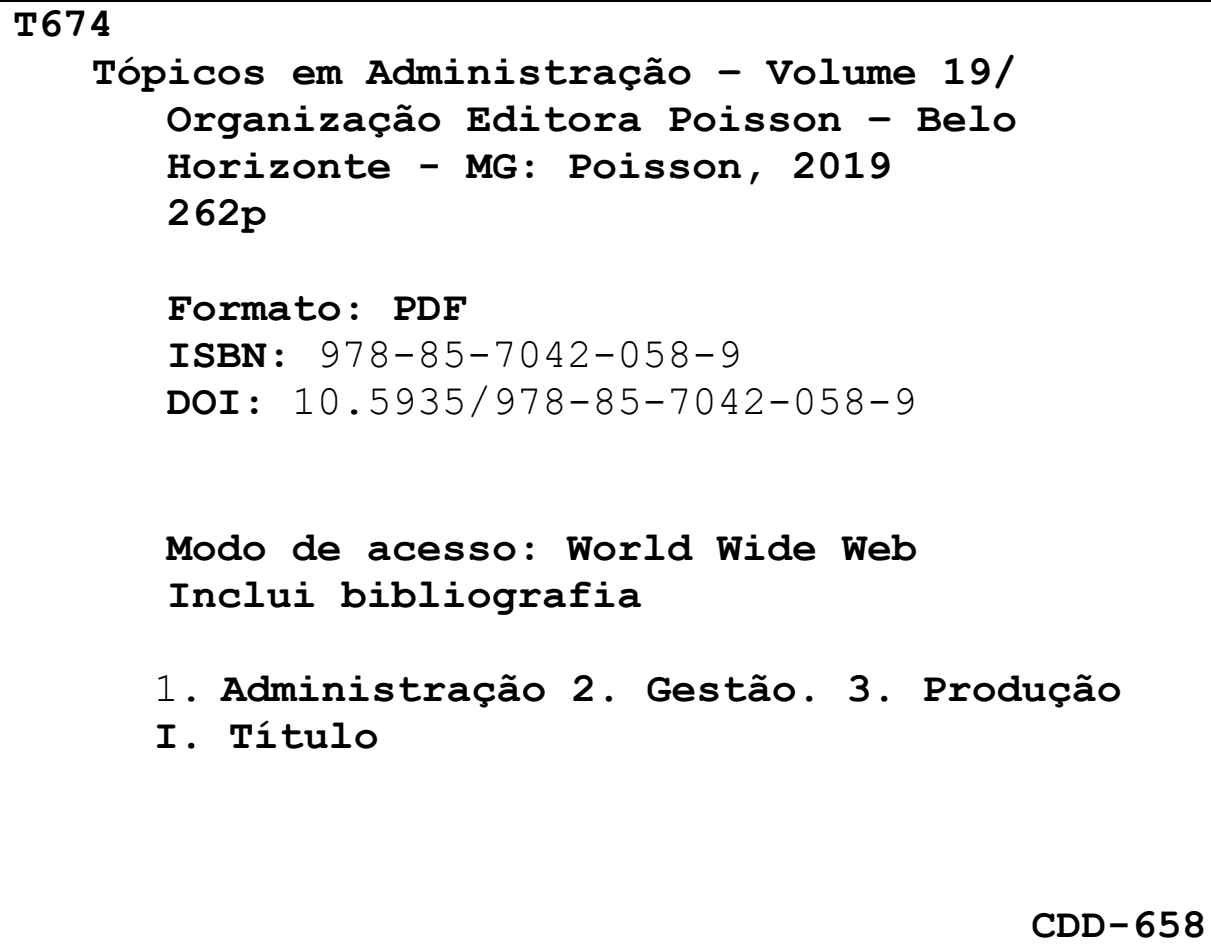

1. Administração 2. Gestão. 3. Produção

I. Título

CDD-658

O conteúdo dos artigos e seus dados em sua forma, correção e confiabilidade são de responsabilidade exclusiva dos seus respectivos autores.

$\underline{\text { www.poisson.com.br }}$

contato@poisson.com.br 


\section{SUMÁRIO}

Capítulo 1: Estratégia de preço no varejo: A incansável busca por um bom atendimento ao cliente.

Emília Isabel Gomes Vieira, André Geraldo da Costa Coelho, Maria das Graças da Silva Costa Coelho

Capítulo 2: Gestão de projetos como processo da gestão de ativos 15

Daniel Lyra Rodrigues, João Carlos Mosquim

Capítulo 3: Comportamento do consumidor surdo: Hábitos de compra e percepções sobre propagandas veiculadas em televisão e internet

Silvana Saionara Gollo, Jean Filipe Krebs, Angelita Freitas da Silva, Luciana Maria Bernstein Pavan

Capítulo 4: Indicadores de governança em iniciativas para o desenvolvimento sustentável: O caso dos Objetivos de Desenvolvimento Sustentável (ODS) ....... 46 David Barbalho Pereira, Allison Haley dos Santos, Laura Maria da Silveira da Fonseca

Capítulo 5: Stakeholders e seus relacionamentos em unidades franqueadas do ramo alimentício: Estratégias de influência e criação de valor 57 Ananda Silva Singh, Eduardo de-Carli, Ana Beatriz Murillo Oviedo, Thálita Anny Estefanuto Orsiolli

Capítulo 6: Estruturação da gestão de desempenho organizacional de uma empresa do terceiro setor 70

Ana Paula Vilas Boas Viveiros Lopes, Giulianna Franchi, Tatiana Montesso Bonomi, Thais Lopes Pessanha

Capítulo 7: Uma análise da Gestão Organizacional sob a ótica do quadro funcional: Estudo de caso em empresa familiar de pequeno porte do segmento varejista de materiais para construção civil no município de Macaé RJ. 80

Anírian Cristiane Unghare, Cremilce Barreto Silva

Capítulo 8: A compreensão e a gestão de talentos para empresários no sul do Brasil 95

Juliana Weber Fabião, Simone Portella Teixeira de Mello, Rogério da Silva Almeida, Luciana Nunes Ferreira, Ingrid Moreno da Silva

Capítulo 9: Perfil dos empreendedores negros egressos do curso de administração de uma IES em Mato Grosso (1984-2016) 106

Caryna Paes Barreto, Ivana Aparecida Ferrer Silva, Elba de Oliveira Pantaleão, Simone Hirata 


\section{SUMÁRIO}

Capítulo 10: Estratégias de gestão de pessoas e de políticas institucionais em uma consultoria de recrutamento e seleção em Mato Grosso 118

Daniela Martina Alves Aguilar, Valentina Santos Bauermeister, Rita Eliana Mazaro

Capítulo 11: Estratégia de educação empreendedora ativa: A Puffpet Indústria Universitária como experiência do fazer-saber. 126

Cecília Arlene Moraes, Elisabet Aguirre, Keiko Carolina Moraes Sasaki de Lucena

Capítulo 12: Desenvolvimento de habilidades técnicas e administrativas: Relato de capacitação com estudantes que atuam em estágio não obrigatório 136

Kamilla Clausen da Silva, Victória Oliveira Santos Barbosa Mendes, Júlia Maria Florentino da Mota, Alessandro Vinicius de Paula

Capítulo 13: Novas tecnologias no trabalho - desafios para gestores da terceira idade

Andrezza Vaz dos Reis, Patrícia Mara de Souza, Carlos Henrique da Mota Couto, Ionara Coelho Araújo, Ângela Cristina de Melo

Capítulo 14: Uma análise jurídico-afetiva, com aportes de Machado de Assis ... 154 Gabriella Cristina de Melo Amorim, José Nogueira de Moraes

Capítulo 15: Gestão escolar no município de Santa Maria/RS 165

Claudete Fogliato Ribeiro, Josseane Souza dos Santos

Capítulo 16: A produção de soja NGM pode ser uma estratégia vantajosa para o produtor brasileiro? 180

Ramesh Mohan Thadani, Augusto César Barreto Rocha

Capítulo 17: Relevância das notas explicativas sob a ótica da suficiência informacional: O caso petrobras 193

Victor Haruo Nitatori Rodrigues Lourenço, Isabel Cristina Sartorelli

Capítulo 18: Governança pública na gestão e operacionalização local do Sistema Único de Saúde: Um estudo de Ibirama (SC). 207

Amanda Beatriz Nasatto Corrêa, Bruna França Debroski, Marino Luiz Eyerkaufer 


\section{SUMÁRIO}

Capítulo 19: Adoção da computação em nuvem na esfera federal: Inovação no tribunal de contas da união

Luana Fernandes dos Santos, Manoel Veras de Sousa Neto

Capítulo 20: A real polêmica da lei n 13.655/2018: Identificando os sujeitos que disputam poder na arena principiológica 235

Ana Margareth Moreira Mendes Cosenza, Carlos Henrique Santana Cosenza

Autores: 


\section{Gapítulo 1}

\section{ESTRATÉGIA DE PREÇO NO VAREJO: A INCANSÁVEL BUSCA POR UM BOM ATENDIMENTO AO CLIENTE}

\section{Emília Isabel Gomes Vieira}

André Geraldo da Costa Coelho

Maria das Graças da Silva Costa Coelho

Resumo: Inseridas em um cenário de elevada competitividade, para se sobressaírem, as empresas, sobretudo, as relacionadas ao varejo farmacêutico, em que a possibilidade de diferenciação é muito baixa, vêm percebendo a importância de investirem em táticas capazes de elevar a eficiência operacional e assegurar a satisfação dos consumidores no tocante ao atendimento. Neste sentido, o objetivo deste estudo consistiu em identificar de que modo as estratégias organizacionais e as informações referentes ao preço de gôndola podem impactar na qualidade do atendimento ao cliente da farmácia Ômega Ltda. Para tal investigação utilizouse da observação in loco e aplicação de entrevista semiestruturada. Para a definição de ações estratégicas aplicou-se o método GUT.

Palavras-chave: Atendimento ao Cliente. Preço. Método GUT 


\section{INTRODUÇÃO}

O Brasil é um dos maiores mercados consumidores de medicamentos, ocupando a sexta posição no ranking mundial, contando com cerca de 70,4 mil farmácias. Pereira e Bastos (2009) afirmam que a possibilidade de diferenciação no varejo farmacêutico é muito baixa devido à similaridade dos produtos ofertados. Deste modo, a concorrência exerce grande impacto sobre o setor, sendo que muitas empresas concorrem pelo mesmo nicho de mercado.

Nascimento (2014) elucida que neste cenário de elevada competitividade, as empresas têm procurado táticas alternativas para aumentar a eficiência operacional e se colocar cada vez mais próximas do consumidor. Para tanto, é fundamental a adoção de estratégias organizacionais voltadas para a valorização do capital humano, pois somente colaboradores motivados e devidamente treinados serão capazes de atender satisfatoriamente aos clientes, buscando conhecer suas necessidades e superar suas expectativas.

Em conformidade com o exposto, Costa, Santana e Trigo (2015) asseveram que a qualidade do atendimento ao cliente é crucial para o sucesso e a lucratividade de um empreendimento, haja vista que é por meio de um bom atendimento que se atrai e retêm clientes. Assim, a empresa ao optar pela busca da qualidade, almeja a fidelização dos consumidores, usando técnicas destinadas a cultivá-los e atraí-los, criando uma defesa contra a concorrência.

Além da qualidade do atendimento, Kotler e Armstrong (2007) dizem que as empresas inteligentes vêem a determinação de preço como uma importante ferramenta estratégica para gerar valor para seus clientes, sendo este um fator determinante na construção de estratégias de relacionamento com 0 consumidor.

Nesse sentido, é interessante considerar os aspectos relacionados às necessidades do consumidor ao traçar estratégias de gestão, visto que no estudo do comportamento do consumidor o preço se torna um aspecto de grande importância, pois é uma variável que gera receita direta, fazendo com que as ações inerentes ao preço sejam relevantes no varejo (Vieira \& Matos, 2012).

O presente estudo buscou identificar de que modo as estratégias organizacionais e as informações referentes ao preço de gôndola podem impactar na qualidade do atendimento ao cliente da farmácia ômega Ltda. Para tal investigação utilizou-se da observação in loco e aplicação de entrevista semiestruturada. Para definir ações estratégicas para a empresa pesquisada aplicou-se o método GUT.

O presente relato encontra-se dividido em cinco seções: a primeira, que se refere a esta introdução, contextualiza a pesquisa e apresenta o problema pesquisado. A segunda contempla o referencial teórico que embasa a análise. Nesta etapa aborda-se sobre os temas relacionados à qualidade do atendimento ao cliente, importância do treinamento e estratégia de preços. A seção seguinte aborda sobre a metodologia utilizada para alcance do objetivo proposto. Na quinta seção são apresentados os resultados alcançados. Por fim, são feitas as considerações finais.

\section{FUNDAMENTAÇÃO TEÓRICA}

\subsection{QUALIDADE NO ATENDIMENTO AO CLIENTE COMO DIFERENCIAL COMPETITIVO NO VAREJO FARMACÊUTICO}

De acordo com Lobos (1991, p.14) "qualidade é tudo o que alguém faz ao longo de um processo para garantir que um cliente, fora ou dentro da organização, obtenha exatamente aquilo que deseja em termos de características intrínsecas, custo e atendimento". Matos (2000) define cliente como toda pessoa que freqüenta o estabelecimento, adquirindo produto ou serviço para consumo próprio ou distribuição, e que sofre algum tipo de interferência ou influência, seja do contato com pessoa ou setor organizacional.

Tendo em vista que o consumidor é o responsável por gerar receitas e proporcionar lucros, a organização precisa conhecer seus clientes, compreender suas opiniões, percepções, necessidades e anseios, para assim, atendê-los de forma satisfatória e conduzi-los à fidelização. Segundo Cobra (2011) o comportamento do consumidor é motivado pela sensação de satisfação das expectativas, que ocorre no momento da compra. Deste modo, Las Casas (2006) ressalta que o primeiro passo para atender e cativar o cliente é identificar sua necessidade e avaliar os fatores que a originam, haja vista que esta pode estar ligada a uma experiência 
anterior em que o produto não atendeu às expectativas e ocasionou em uma nova demanda de compra.

Neste entendimento, Kotler (2000) explica que para elevar o nível de atendimento e alavancar o potencial competitivo, é necessário criar um relacionamento com o cliente, escutar suas indigências, resolver seus problemas com agilidade, superar suas expectativas.

Além disso, é indispensável o total conhecimento acerca dos produtos e serviços oferecidos.

Considerando que o atual cenário competitivo é caracterizado por clientes cada vez mais exigentes e pouco fieis, os gestores, sobretudo, os relacionados ao setor varejista, para sobreviverem e se destacarem, deparam-se com grandes e constantes desafios.

Araújo e Martins (2010) explicam que, no Brasil, nos últimos anos o ramo de varejo tem passado por intensas mudanças, alavancadas, notadamente, pela globalização dos mercados e pelo elevado nível de concorrência. Segundo Parente (2000, p. 22), "varejo consiste em todas as atividades que englobam o processo de venda de produtos e serviços para atender a uma determinada necessidade pessoal do consumidor final". Conforme a American Marketing Association este setor compra de fornecedores atacadistas ou fabricantes, e vende aos consumidores finais (Las Casas, 2006).

Dentre os vários setores que constituem o varejo, destacamos o farmacêutico que vem evoluindo de forma extraordinária. Silva e Sampaio (2016) explicam que as farmácias passaram do tradicional estabelecimento, com arranjo de prateleiras de madeira, às grandes redes, com atendimento $24 \mathrm{~h}$, vendas por telemarketing e comércio virtual.

Tendo em vista as especificidades do setor farmacêutico cabe dizer que a qualidade do atendimento é, indiscutivelmente, fator determinante na decisão de compra dos clientes, que avaliam a maneira como o atendente se comporta, suas atividades e o conhecimento sobre os medicamentos e materiais comercializados, para prestar as orientações necessárias. Nesse sentido, Gronroos (2003) enfatiza que um excelente atendimento cria um diferencial competitivo distinto e sustentável. Além do que, Teles, Bilenky, Reis e Donzelli (2013) salientam que no cenário atual, as farmácias competem com os supermercados, padarias que disputam mercado com as lojas de conveniência, por serem diferentes tipos de varejo vendendo as mesmas categorias de produtos.

\subsection{A IMPORTÂNCIA DO TREINAMENTO COMO ESTRATÉGIA DE ATENDIMENTO}

Defronte um cenário de grande concorrência, as organizações tem percebido a importância do capital humano na alavancagem do negócio. Deste modo, tem intensificado esforços e investimentos em processos de capacitação e treinamento. Segundo Tachizawa (2001), o principal objetivo do treinamento é o aperfeiçoamento do desempenho funcional, aumento da produtividade e aprimoramento das relações interpessoais.

Marras (2011) expõe que o treinamento tratase de um processo de curto prazo, pelo qual pessoas ou grupos adquirem características de outros grupos, e tem por intuito repassar ou adquirir conhecimento, competência ou atitudes relacionadas à execução de determinadas tarefas.

O treinamento é uma importante ferramenta estratégica para elevar a eficiência operacional e colocar a organização cada vez mais próxima do consumidor. Las Casas (2006) explica que o treinamento compreende o caminho mais lógico para aumentar o desempenho da equipe e alcançar os objetivos organizacionais, pois, permite a otimização de recursos e a formação de uma equipe mais coesa. Além disso, contribui para a elevação do faturamento e dos lucros, e ainda, reflete na diminuição da rotatividade.

De acordo com Nascimento (2014), em se tratando do varejo farmacêutico, a dificuldade na obtenção de mão-de-obra qualificada para algumas funções (onde há necessidade de conhecimento específico voltado para medicamentos) tem sido um problema enfrentado por várias empresas do setor. Uma alternativa tangível para essa deficiência é a própria organização preparar seus colaboradores para o preenchimento destas vagas por meio de recrutamento interno.

Há também uma necessidade da continuidade do treinamento sob a ótica das frequentes mudanças nas legislações que englobam este setor varejista. Tais reciclagens profissionais podem ser ministradas por meio de instrutores internos 
(Farmacêuticos das próprias Redes), visto o poder do conhecimento técnico do profissional e a economia quando analisamos os custos deste tipo de treinamento (Nascimento, 2014).

Outra questão que merece destaque é quanto ao treinamento de abertura de loja, uma vez que a exposição correta dos produtos no ponto de venda e a boa comunicação entre atendente e cliente se tornam fatores determinantes para o consumidor durante a decisão de compra. Martins (2014) explica que o processo de abertura de loja compreende desde a abertura da porta da loja até a entrada do operador no sistema gestor da organização. O processo em questão possibilita a redução de problemas relacionados à disposição dos produtos no ambiente físico e no sistema gestor da organização, possibilitando ao consumidor identificar com maior facilidade a qual grupo cada item pertence, a visualização do preço, além de facilitar a identificação da necessidade de reposição do estoque.

\subsection{A INFLUÊNCIA DA ESTRATÉGIA DE PREÇO NA DECISÃO DE COMPRA}

O preço é considerado um importante elemento de diferenciação, sendo um dos principais elementos a serem considerados pelos consumidores na decisão de compra. Do ponto de vista das empresas é por meio dos preços que há o retorno dos seus investimentos e obtenção de lucros. Para se adequar ao mercado, as empresas adaptam suas táticas mercadológicas, sendo que o preço é o elemento mais facilmente ajustável. Assim, em períodos de dificuldade, há a tendência de diminuir os preços ou aumentálos em épocas de maior demanda (Las Casas, 2006)

$\mathrm{Na}$ visão dos economistas, os clientes são seguidores de preço. Deste modo, graças aos meios de comunicação formal e informalpropagandas, anúncios, folders, sites, amigos, colegas de trabalho e familiares-, os consumidores estão mais atentos e informados sobre o valor a pagar e os descontos, estimulando o varejo a utilizar táticas capazes de proporcionar afixação de preços competitivos (Kotler \& Keller, 2006).

Considerando que as relações de consumo são fruto do vínculo jurídico gerado pela interação entre consumidor e fornecedor, nem sempre a convivência é amigável. O preço é um componente relevante no processo de compra, sendo, por vezes, o responsável por muitos desgastes entre consumidores e fornecedores.

Em face da necessidade de regulamentar e nortear essa relação, foram criadas Leis e Decretos. Em 1990 foi promulgada a Lei № 8.078/90 que dispõe sobre o Código de Direito e Defesa do Consumidor (CDC). Esta lei, em seu art. 31 apresenta, entre outros pontos, a importância do preço e demais características que completam o conjunto de informações que permeiam a correta apresentação dos produtos e serviços, como por exemplo, a questão das informações sobre o produto, linguagem utilizada, características, composição, garantia e até sobre os riscos à saúde e segurança do consumidor (Brasil, 1990).

Nesta perspectiva, em 2004 foi sancionada a Lei 10.962/2004 que trata especificamente da oferta e afixação de preços dos bens e serviços ofertados ao consumidor, esta que foi regulamentada pelo Decreto 5.903/2006. Conforme descrito Decreto em seu Art. 2o, 'os preços de produtos e serviços deverão ser informados adequadamente, de modo a garantir ao consumidor a correção, clareza, precisão, ostensividade e legibilidade das informações prestadas'. Além disso, devem estar sempre visíveis. No art. $6^{\circ}$ consta que 'os preços de bens e serviços para o consumidor nos estabelecimentos comerciais, admitem as seguintes modalidades de afixação: direta ou impressa na própria embalagem; de código referencial; ou de código de barras (Brasil, 2006).

\section{METODOLOGIA}

Este estudo foi realizado no período de Abril a Junho de 2017, em uma filial de uma rede de farmácias localizada na mesorregião do Jequitinhonha, no estado de Minas Gerais. A organização estudada não autorizou a divulgação de sua razão social, sendo então, denominada neste relato como Ômega Ltda. Ela conta, atualmente, em seu quadro de pessoal com um total de 28 colaboradores, alocados, conforme suas aptidões e qualificações, entre as funções de: atendente, perfumista, gestão, caixa e farmacêutico. A farmácia em questão oferece além de medicamentos, cosméticos, eletrônicos e conveniência em geral. 
Para o desenvolvimento deste relato, utilizouse, quanto aos meios, o método de pesquisa bibliográfica que tem como objetivo proporcionar ao pesquisador contato direto com material dito ou escrito sobre o assunto (Lakatos, 2010). Assim, foram consultados livros, revistas, artigos, leis e dissertações que dizem respeito ao atendimento ao cliente, estratégia de preços e varejo farmacêutico.

Quanto aos fins, a pesquisa possui caráter descritivo e exploratório. Descritivo tendo em vista que os fatos foram pesquisados e analisados sem a interferência do pesquisador, ou seja, os fenômenos foram estudados, mas não manipulados por quem realizou a pesquisa. E, exploratório, objetivando levantar informações sobre o tema para se alcançar a definição e determinação do desígnio (Andrade, 2010).

As informações foram obtidas por meio de entrevista semiestruturada e observação in loco. A entrevista foi realizada junto ao gerente e sub-gerente da farmácia com intuito de conhecer, do ponto de vista da empresa, os problemas existentes no que diz respeito à influência da estratégia de preços no atendimento ao cliente. Entretanto, a observação direta foi basilar para se obter subsídios relevantes para se alcançar 0 objetivo proposto, haja vista que os pesquisadores, com base em seus conhecimentos teóricos e práticos, perceberam problemas que não foram relatados, sendo que alguns não são nem percebidos como tal.

Como método de análise, aplicou-se a técnica de matriz GUT. Esta, trata-se de uma ferramenta da qualidade, que por meio da priorização das ações, auxilia na tomada de decisão. Ela é composta por letras que significam Gravidade, Urgência e Tendência. A Gravidade representa a importância dos problemas em relação aos outros apresentados; a Urgência indica o quanto é fundamental o tempo para resolução do problema; e a Tendência diz respeito à evolução do problema, se ele tende a crescer ou diminuir com o tempo (Seleme \& Stadler, 2008).

A matriz GUT determina pesos de acordo com o nível de importância do problema de 1 a 5. Assim, um problema tido como gravíssimo terá nota 5 , que é o maior peso. Se precisar de uma ação imediata pode se atribuir nota 5, e se a tendência for de piora a curto prazo terá nota 4. Assim irá representar
(G) 5. (U) 5. (T) 4, perfazendo 100 pontos (Seleme \& Stadler 2008). Deste modo, foram listados, pontuados e classificados os problemas identificados quanto à estratégia de preços adotada pela empresa e os reflexos no atendimento ao cliente, apresentando plano de ação com possíveis soluções.

Em relação à forma de abordagem da pesquisa, a tipologia utilizada foi qualitativa, pois corresponde de maneira mais profunda aos problemas relacionados à ciência e ao conhecimento de natureza abstrata, do que os aspectos metodológicos (Severino, 2007).

\section{RESULTADOS E ANÁLISES}

Neste capítulo estão contidos os resultados alcançados mediante levantamento feito na Farmácia Ômega, visando atender ao proposto neste relato técnico, que consistiu em identificar de que modo as informações entre o sistema de gestão e o preço de gôndola podem impactar no atendimento ao cliente. As implicações serão apresentadas conforme o grau de importância identificado.

Os principais problemas identificados dizem respeito à afixação e visibilidade dos preços dos itens expostos nas gôndolas. Constatouse que há divergência entre os preços expressos nas gôndolas e os registrados no caixa, o que provoca certa irritação e insatisfação no consumidor. Além disso, notou-se que falta a precificação de alguns produtos, sendo este fato atribuído a um elevado giro de mercadorias na farmácia. Esta questão também gera transtornos aos clientes, que, por vezes, enfrentam a fila no caixa apenas para conferir o valor de produtos e acabam por não adquiri-los.

Identificou-se ainda que não existe, no estabelecimento, equipamentos para leitura de código de barras. Vale lembrar que o preço tem suas definições explícitas nas Leis no 8.078/90 e no10.962/2004 e no Decreto $5.903 / 2006$. Por este motivo, a empresa pode ser alvo de ações na justiça, o que não é interessante para sua reputação.

$\mathrm{Na}$ perspectiva de agilizar o atendimento, observou-se a necessidade de instalar mais um terminal de caixa. A farmácia realiza, em média, 700 atendimentos diários, ficando quase impossível evitar a formação de filas nos caixas. Todavia, para que seja possível a instalação do novo terminal é necessária a 
reorganização do mobiliário e do espaço físico.

Outra situação que chamou atenção diz respeito ao serviço de televendas, que, atualmente é feito pelos colaboradores que atendem no balcão. Nesta situação, se o telefone tocar e não houver nenhum vendedor disponível, o cliente acaba por esperar muito tempo na linha ou, às vezes, nem é atendido.

A empresa, para oferecer um atendimento de qualidade ao consumidor, necessita manter um quadro de colaboradores motivados e preparados. Neste entendimento é primordial fornecer condições de trabalho adequadas que garantam seu bem estar. Nesse sentido, observou-se que o espaço para lanches é inapropriado, $\mathrm{q}$ que sugere uma reorganização da sala já existente como forma de amenizar o problema. E como não há um espaço próprio para realização de reuniões, recomenda-se que a empresa estude a viabilidade de ampliação do espaço físico.

Ainda em relação às condições físicas do ambiente, percebeu-se que os climatizadores instalados no ambiente da farmácia fazem ruídos. O som emitido pelos aparelhos não provoca um incômodo tido como exagerado, até porque a farmácia acompanha as condições de trabalho pelo registro da visita da médica do trabalho periodicamente. Entretanto, para pessoas com audição mais aguçada ele pode ser visto como um desconforto.

Tabela 1: Matriz de Gravidade, Urgência e Tendência

\begin{tabular}{|c|c|c|c|c|c|}
\hline Problema & Gravidade & Urgência & Tendência & $\begin{array}{l}\text { Grau crítico } \\
(\text { GxUxT) }\end{array}$ & $\begin{array}{l}\text { Sequência de } \\
\text { atividades }\end{array}$ \\
\hline Preços diferentes entre a gôndola e o caixa. & 5 & 5 & 4 & 100 & 10 \\
\hline Falta de preço nas gôndolas. & 5 & 5 & 3 & 75 & $2^{\circ}$ \\
\hline $\begin{array}{l}\text { Necessidade de instalação de um leitor de código } \\
\text { de barras. }\end{array}$ & 4 & 4 & 3 & 48 & 30 \\
\hline Necessidade de instalação de um terminal de caixa. & 3 & 4 & 3 & 36 & $4^{\circ}$ \\
\hline Aprimoramento do serviço de televendas. & 3 & 3 & 3 & 27 & $5^{\circ}$ \\
\hline $\begin{array}{l}\text { Espaço inadequado para reuniões e lanche dos } \\
\text { funcionários. }\end{array}$ & 2 & 1 & 3 & 6 & $6^{\circ}$ \\
\hline $\begin{array}{l}\text { Ruído causado pelo funcionamento do aparelho } \\
\text { climatizador. }\end{array}$ & 2 & 1 & 1 & 2 & $7^{\circ}$ \\
\hline
\end{tabular}

Nota. Fonte: dados da pesquisa, resultado do diagnóstico (2017)

Tabela 2: Ordenação dos problemas e apresentação de possíveis soluções

\begin{tabular}{|c|c|c|}
\hline Ordem & Problemas & Soluções \\
\hline $1^{\circ}$ & $\begin{array}{l}\text { Preços diferentes entre a } \\
\text { gôndola e o caixa. }\end{array}$ & $\begin{array}{l}\text { Treinamento para os colaboradores responsáveis pela função, com a Técnica de } \\
\text { Abertura de Loja; Conferência semanal dos preços afixados na gôndola e os registrados } \\
\text { no caixa. }\end{array}$ \\
\hline $2^{\circ}$ & $\begin{array}{l}\text { Falta de preço nas } \\
\text { gôndolas. }\end{array}$ & $\begin{array}{l}\text { Encarregar um ou mais colaboradores para o processo de etiquetação das gôndolas, } \\
\text { assim que os produtos chegarem à loja. } \\
\text { Se não houver possibilidade de contratação imediata, vê-se como solução viável para } \\
\text { este problema, o remanejamento mensal e rotativo de um colaborador para etiquetar, } \\
\text { conferir e organizar os produtos nas gôndolas do setor. Considerando que neste período } \\
\text { este terá reduzido o seu volume de vendas, deve ser paga uma gratificação financeira } \\
\text { pelo serviço desempenhado. }\end{array}$ \\
\hline $3^{\circ}$ & $\begin{array}{l}\text { Necessidade de instalação } \\
\text { de leitor de código de } \\
\text { barras }\end{array}$ & $\begin{array}{l}\text { Aquisição de leitores de código de barras e instalação em locais estratégicos da loja. } \\
\text { Tais aparelhos devem estar ao alcance do consumidor, nas áreas de vendas e ser de } \\
\text { fácil acesso. Esse procedimento além de regularizar a situação do estabelecimento, } \\
\text { viabiliza agilidade no autoatendimento. }\end{array}$ \\
\hline $4^{\circ}$ & $\begin{array}{l}\text { Necessidade de instalação } \\
\text { de um terminal de caixa }\end{array}$ & $\begin{array}{l}\text { Instalação de mais um terminal de caixa. } \\
\text { Contratação de funcionário para desempenhar a função. }\end{array}$ \\
\hline $5^{\circ}$ & $\begin{array}{l}\text { Aprimoramento do serviço } \\
\text { de televendas }\end{array}$ & $\begin{array}{l}\text { Contratar ou designar um funcionário somente para o atendimento de televendas. } \\
\text { Tendo em vista o grande volume de vendas fechadas pelo telefone, aponta-se a } \\
\text { contratação ou remanejamento de um funcionáriopara essa função, nesse último caso, } \\
\text { estudar o atual quadro funcional. }\end{array}$ \\
\hline $6^{\circ}$ & $\begin{array}{l}\text { Espaço inadequado para } \\
\text { lanche e realização de } \\
\text { reuniões com os } \\
\text { funcionários }\end{array}$ & $\begin{array}{l}\text { Ampliação do espaço existente para os lanches e arranjo de horário para as reuniões; } \\
\text { Pelas observações no local fica claro que é impossível efetuar obras de ampliação, } \\
\text { nesse contexto recomenda-se que a organização busque oportunidades que ofereçam } \\
\text { formas de aumentar o espaço físico da loja. }\end{array}$ \\
\hline $7^{\circ}$ & $\begin{array}{l}\text { Ruído causado pelo } \\
\text { funcionamento do aparelho } \\
\text { climatizador. }\end{array}$ & $\begin{array}{l}\text { Trocar os aparelhos de climatizador por modelos mais modernos que não emitam ruídos } \\
\text { ou por aparelhos de ar condicionado. }\end{array}$ \\
\hline
\end{tabular}

Nota. Fonte: dados da pesquisa, resultado do diagnóstico (2017) 


\section{CONSIDERAÇÕES FINAIS}

De acordo com o embasamento teórico, foi possível entender o quanto um atendimento de qualidade influencia no alcance dos propósitos organizacionais, especialmente, no varejo farmacêutico em que as possibilidades de diferenciação são mínimas, e, além da concorrência com outras farmácias, há, em muitos casos, a disputa com os mercados e lojas de conveniência. Assim, torna-se evidente a importância de investimentos em treinamento, capacitação e no bem estar dos funcionários, como estratégia de diferenciação, haja vista que não há, neste setor, uma variação significativa nos preços dos materiais e medicamentos. Logo, os consumidores são cativados pela forma como ocorre a prestação de serviço. Além disso, pôde-se compreender que a política de fixação de preços é um fator que reflete diretamente na qualidade de atendimento percebida pelo cliente.

Este estudo foi realizado com intuito de verificar de que modo as estratégias organizacionais e as informações referentes ao preço de gôndola podem impactar na qualidade do atendimento ao cliente da farmácia ômega Ltda. Mediante o levantamento feito na por meio de visita in loco e aplicação de entrevistas, constatou-se que, na maioria das vezes, os clientes, ao procurarem a farmácia trazem consigo dúvidas e questionamentos sobre o tipo de medicamento que precisam para situações específicas, ou, se estão munidos de receitas médicas desejam informações sobre medicamentos genéricos, substitutos e até mesmo reações dos remédios. Percebeu-se que os atendentes possuem conhecimento para esclarecer a contento os questionamentos dos clientes. Todavia, ressalta-se a importância de cursos periódicos de reciclagem e política de treinamento para novos contratados.

\section{REFERÊNCIAS}

[1] Andrade, M. M. de. (2010). Introdução à metodologia do trabalho científico (10a ed.). São Paulo: Atlas.

[2] Araújo, S., \& Martins, E. (2010). Análise da ruptura de produtos nas gôndolas supermercadistas: um problema enfrentado por um supermercado de pequeno porte. XXX Encontro Nacional de Engenharia de Produção, São Paulo.

[3] Decreto $\mathrm{n}$ - 5.093 , de 20 de setembro de 2006 (2006). Regulamenta a Lei no 10.962, de 11
Outras questões observadas e apontadas como essenciais para assegurar um atendimento de qualidade dizem respeito à adequação da estrutura física para proporcionar melhores condições de trabalho, Necessidade de instalação de um terminal de caixa e aprimoramento do serviço de televendas.

Quanto à estratégia de afixação de preços, foram identificadas algumas deficiências, as quais interferem diretamente na qualidade de atendimento percebida pelo cliente, como: preços diferentes entre a gôndola e o caixa, produtos sem precificação, ausência de leitor de código de barras para conferência do valor dos itens expostos.

A aplicação da ferramenta de análise matriz GUT possibilitou o delineamento de uma escala de necessidade de resolução dos problemas, conforme sua Gravidade, Urgência e Tendência. Identificou-se que os problemas relacionados à afixação dos preços são os mais críticos para a empresa. Sugerindo a realização de treinamento de abertura de loja e a contratação de novos funcionários, ações estas que são necessárias para que a farmácia ômega desempenhe práticas mais assertivas no seu atendimento, amenizando os problemas encontrados.

Diante de tais informações, é importante que a farmácia, ao planejar suas ações futuras, leve em consideração o diagnóstico levantado para que tais estratégias estejam condizentes com sua realidade, buscando a resolução dos problemas identificados de atendimento aos clientes, a partir da aplicação da técnica de Gravidade, Urgência e Tendência. Para que, assim, venha a alcançar vantagem competitiva em um mercado, cada vez mais concorrido e possa maximizar seus resultados.

de outubro de 2004, e a Lei no 8.078, de 11 de setembro de 1990. Brasília. Recuperado em 23 Maio, 2017, de http://www.planalto.gov.br/ccivil_03/_ato2004006/2006/Decreto/D5903.htm

[4] Lei no 10.962, de 11 de outubro de 2004 (2004). Dispõe sobre a oferta e as formas de afixação de preços de produtos e serviços para o consumidor. Brasília. Recuperado em 23 Maio, 2017, 
http://www.planalto.gov.br/ccivil_03/_ato20042006/2004/lei//10.962.htm

[5] Lei no 8.078, de 11 de setembro de 1990. Dispõe sobre a proteção do consumidor e dá outras providências. Brasília. Recuperado em 22 Maio, 2017, de http://www.planalto.gov.br/ccivil_03/leis/L8078.htm

[6] Cobra, M. (2011). Marketing básico: uma perspectiva brasileira (4a ed.). São Paulo: Atlas.

[7] Costa, A. S C., Santana, L. C. de., \& Trigo, A. C. (2015). Qualidade do atendimento ao cliente: um grande diferencial competitivo para as organizações. Revista de Iniciação Científica, Vol 02, nº2, pp. 155-172.

[8] Grönroos, C. (2003). Marketing: gerenciamento e serviços (2a ed.) Rio de Janeiro: Elsevier

[9] Kotler, P. (2000). Administração de Marketing (10a ed.) São Paulo: Prentice Hall do Brasil.

[10] Kotler, P., \& Keller, K. L. (2006). Administração de marketing (12a ed.) São Paulo: Pearson Prentice Hall.

[11] Kotler, P., \& Armostrong, G.(2007) Princípios de marketing (12a ed.) São Paulo: Prentice Hall.

[12] Lakatos, E. M.(2010). Fundamentos de metodologia científica (7a ed.) São Paulo: Atlas

[13] Las Casas, A. L.(2006). Administração de marketing: conceitos, planejamento e aplicações à realidade brasileira (1a ed.) São Paulo: Atlas.

[14] Lobos, J. (1991). Qualidade! Através das pessoas (9a ed.) São Paulo: Hamburg.

[15] Marras, J. P. (2011). Administração de recursos humanos: do operacional ao estratégico (14a ed.) São Paulo: Saraiva.

[16] Martins, A. N.(2014). Hypermarcas inova e melhora exposição dos produtos no PDV. Revista Decnews. São Paulo: Contento.
[17] Matos, C. L.(2000). Avaliação e Análise do Desempenho dos Processos de Serviço,numa Agência Bancária, sob a ótica de seus Clientes e Funcionários da "Linha de Frente". Dissertação de Mestrado. Programa de Pós-Graduação em Engenharia de Produção, Universidade Federal de Santa Catarina, Santa Catarina, Brasil.

[18] Nascimento, A. M. B. do. (2014). Treinamento e Desenvolvimento como Forma de Recrutamento Interno no Varejo Farmacêutico. Congresso Nacional de Excelência em Gestão.

[19] Parente, J. (2000) Varejo no Brasil. São Paulo: Atlas.

[20] Pereira, P. F. P., \& Bastos, F. C. (2009). Um estudo sobre a fidelização de clientes a partir de estratégias de marketing de relacionamento no segmento de farmácias e drogarias. VI Simpósio de Excelência em Gestão e Tecnologia. Resende.

[21] Seleme, R., \& Stadler, H. (2009). Controle da qualidade: as ferramentas essenciais (20a. ed.) Curitiba: Ibpex.

[22] Severino, A. J. (2007). Metodologia do trabalho científico (23a ed.) São Paulo: Cortez.

[23] Silva, N. C. S., \& Sampaio, L. G. (2016). Planejamento estratégico e controle gerencial no varejo farmacêutico: O papel do farmacêutico diante de um mercado mais competitivo. ÚNICA Cadernos Acadêmicos, 3(1).

[24] Tachizawa, T.(2001). Gestão com pessoas: uma abordagem aplicada às estratégias de negócios (5a ed.) Rio de Janeiro: FGV.

[25] Teles, C.C., Bilenky. J., Reis. V. S., \& Donzelli O. (2013) O varejo aplicado ao mercado farmacêutico. Fórum de Administração, 2(1).

[26] Vieira, V. A., \& Matos, C. A de. (2012). A influência da apresentação do preço sobre as avaliações dos clientes. Revista de Administração Contemporânea, 16 (4) pp.544-565. 


\section{Eapítulo 2}

\section{GESTÃO DE PROJETOS COMO PROCESSO DA GESTÃO DE ATIVOS}

\section{Daniel Lyra Rodrigues João Carlos Mosquim}

Resumo: É comum a reclamação da comunidade de manutenção em relação à gestão de projetos, pois as entregas nem sempre são conforme o desejado e/ou atingem o grau de qualidade requerido. Assim, este trabalho discute a fonte deste problema e uma proposta de mudança inovadora na cultura de gerenciamento de projeto nas indústrias, partindo do modelo reducionista que após a entrega, impacta negativamente a área de manutenção, para um modelo sistêmico e holístico em que os projetos deixam de fazer parte de um processo isolado, com início, meio e fim, e passam a integrar à área de Gestão de Ativos da organização, entregando benefícios, confiabilidade, sustentabilidade e gerando valor para a empresa. A base do estudo está relacionada à limitação temporal do projeto, conforme preconiza o Guia PMBOK e os perigos que podem ocorrer com o entendimento incorreto dessa limitação, a busca constante pela competitividade e a sustentabilidade das organizações e as inovações introduzidas no mercado, com a metodologia da gestão de ativos, considerando-se aspectos do Guia PMBOK, da norma NBR ISO 21500, da metodologia PRINCE2, referentes à gestão de projetos e da norma NBR ISO 55000 de gestão de ativos e muita vivência de dificuldades práticas. E no final, mostrar que a gestão de projetos e a gestão de ativos podem apoiar-se mutuamente, quer seja em sistemas de gestão já consolidados ou no desenvolvimento de novos negócios.

Palavras-chave: Gestão de Ativos, Gestão de Projetos, Integração de Processos 


\section{INTRODUÇÃO}

A função da Manutenção é manter ou recolocar um item em estado no qual possa desempenhar uma função requerida enquanto que a função engenharia da manutenção é à otimização dos equipamentos, dos processos de modo a alcançar uma melhor mantenabilidade, confiabilidade e disponibilidade dos equipamentos, entregues pela área de gerenciamento de projetos. Neste aspecto, a área de gestão de projetos desempenha um papel fundamental e impactante na carga de trabalho futura da área de manutenção. Ocorre que ainda existem enormes barreiras entre essas áreas e nem sempre a visão empresarial, holística e sistêmica é levada em consideração. As entregas dos projetos nem sempre estão plenamente alinhadas com as necessidades da manutenção, que seja por problemas internos de qualidade dos projetos, quer seja na deficiência dos requisitos mínimos necessários.

E, como será discutido neste artigo, é impossível para uma organização dissociar o Planejamento Estratégico e seus desdobramentos, das áreas de Gestão de Ativos e de Gestão de Projetos. O processo da Gestão de Ativos tem seu início na identificação da necessidade, associada ao planejamento estratégico e termina no descomissionamento deste ativo, passando pelas áreas de aquisição e operação, considerando-se em todas as fases, os riscos operacionais e financeiros para o negócio.

Neste aspecto é importante diferenciar os processos de gestão de ativos existentes e de novos ativos que devem estar alinhados com todo o processo de tratamento de ativos da organização.

\section{DELINEAMENTO DO PROBLEMA}

Tem-se que aproximadamente que $70 \%$ dos projetos apresentam problemas na entrega, quer seja internos ao projeto ou fora do limite desse. $\mathrm{E}$ se perguntar ai homem de manutenção, esse percentual chega a 100\%. $\mathrm{E}$ como falhas internas, devido à baixa qualidade no detalhamento ou execução, pode-se citar:

- Não cumprimento dos prazos parciais ou total.

- $\quad$ Estouro no orçamento.

- Resultados críticos de Segurança, Saúde e Meio Ambiente.
- Nível de qualidade abaixo da expectativa.

- Comunicação deficiente.

- Nível elevado de estresse na equipe.

- Conflitos entre os departamentos internos.

- Falta de recursos.

- Planejamento deficiente.

- Monitoramento e Controle apenas reativo.

E como falhas externas, devido à baixa qualidade na elaboração dos requisitos mínimos necessários, pode-se citar:

- Requisitos não atendidos.

- $\quad$ Funcionalidade deficiente.

- Retorno do investimento menor do que o previsto.

- Alto custo e dificuldade de manutenção do ativo.

- Ciclo de vida do ativo menor do que o esperado.

- Tecnologia adotada pouco amigável ou ultrapassada.

- Sustentabilidade organizacional.

\section{PROPOSTA DE DISCUSSÃO}

Este trabalho procura discutir porque essas falhas externas ao projeto ocorrem, as deficiências que os processos atuais de gestão de projetos possuem e induzem as pessoas a interpretarem parcialmente o que seja projeto e apresentar uma proposta com uma visão sistêmica e holística que contribuiriam de maneira significativa para melhorar os resultados da confiabilidade, da competividade, da sustentabilidade e para a organização como um todo.

\section{FUNDAMENTAÇÃO TEÓRICA}

A discussão está baseada nas normas NBR ISO 21500, NBR ISO 55000, no Guia PMBOK e na metodologia PRINCE2 em relação aos benefícios gerados à organização, quando das entregas e encerramentos dos projetos. É importante lembrar uma importante mudança realizada pela ISO em abril de 2012, no apêndice 3 do anexo SL de suas diretrizes, que cria uma estrutura idêntica para todas as normas de sistemas de gestão, criadas ou revisadas, a partir daquela data. Tal mudança permitiu, nos últimos três anos, um alinhamento não somente de estrutura, mas também da definição de conceitos utilizados nas principais normas de gestão, auxiliando 
as corporações a utilizá-las de forma integrada, em sua gestão.

A figura 1 propõe um modelo de posicionamento onde, as normas de gestão de riscos (ISO 31000:2009) e projetos (ISO 21500) apoiam as principais normas de sistemas de gestão, utilizadas atualmente.

Figura 1 - Normas de gestão de riscos e projetos como principais apoios às normas de sistemas de gestão, utilizadas atualmente.

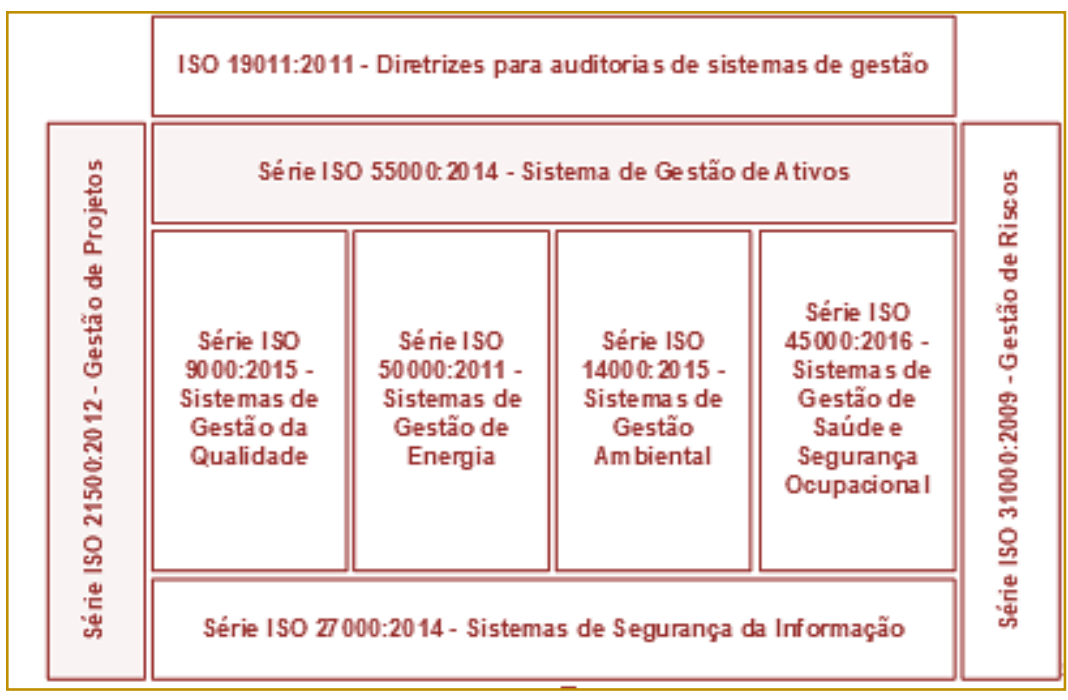

\subsection{MANUTENÇÃO}

Segundo a norma ABNT NBR 5462-1994, "mantenabilidade" é a capacidade de um item ser mantido ou recolocado em condições de executar suas funções requeridas, sob condições de uso especificadas, quando a manutenção é executada sob condições determinadas e mediante procedimentos e meios prescritos".

As dificuldades aparecem porque nem sempre as funções requeridas estão plenamente contempladas nas especificações do projeto, podem ocorrer divergências no processo de aquisição e ainda ocorrem falhas internas no processo de construção e montagem, comprometendo-se assim a confiabilidade e a disponibilidade do equipamento ou sistema. Parte desse problema tem sido resolvida pela engenharia da manutenção e por metodologias como RCM, TPM, etc., mas atua-se de maneira reativa, no efeito e não na causa.

Atualmente a manutenção vive a sua quarta geração evolutiva. $\mathrm{O}$ foco é a competitividade e a busca pela competitividade exige da manutenção uma visão sistêmica, holística, estratégica, em que o quebra-conserta não faz mais sentido. Busca-se a excelência da manutenção durante todo o ciclo de vida do ativo. 
Figura 2 - Evolução da função Manutenção

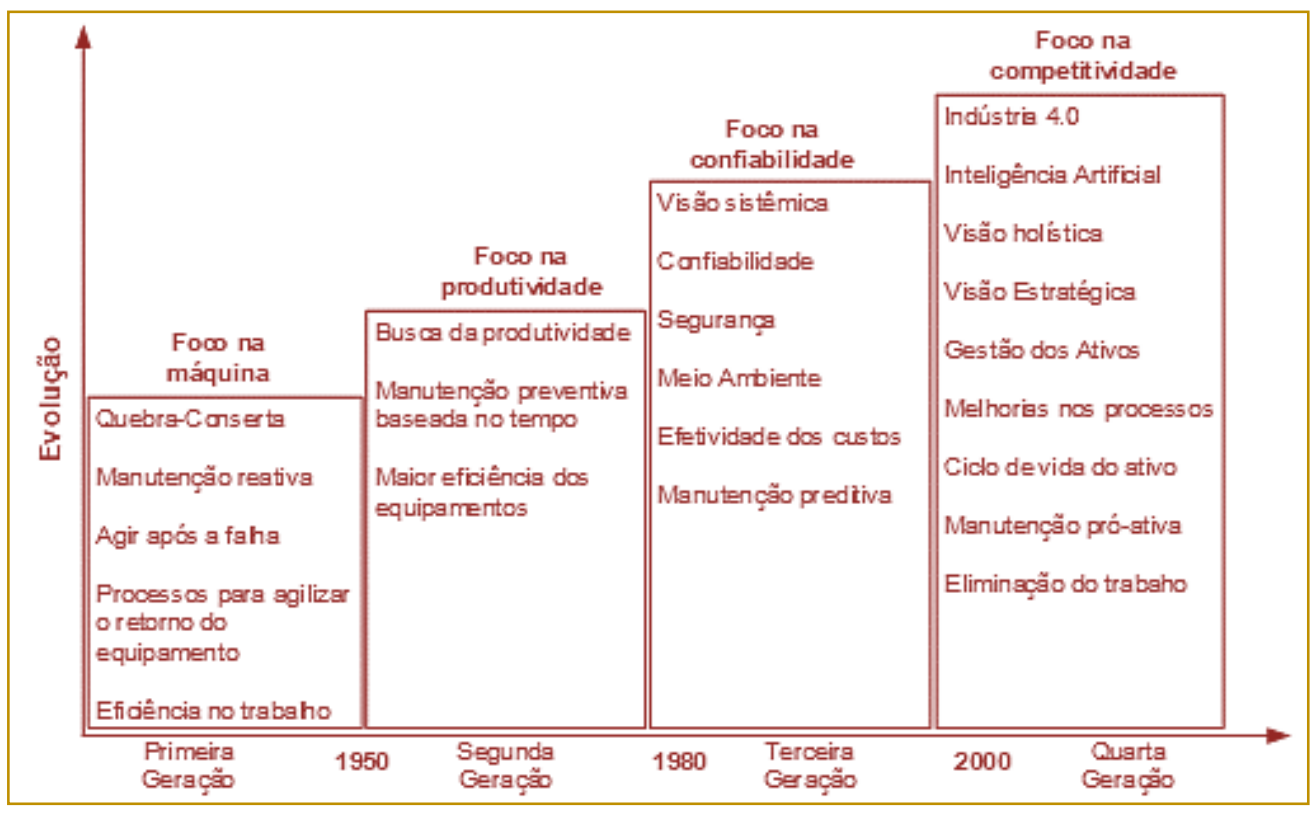

E considerando-se estes aspectos, não é possível dissociar o processo de gestão de projetos do processo de gestão de ativos. É necessário que exista uma perfeita integração, para que seja atingida a visão estratégica.

\subsection{ABNT NBR ISO 21500-2012}

A NBR ISO 21500, Orientações sobre gerenciamento de projetos, define projeto como "um conjunto único de processos que consiste em atividades coordenadas e controladas com datas de início e fim, empreendidas para atingir os objetivos do projeto". E traz também o conceito de entrega, mas a palavra usada é benefícios, como resultado de um projeto para as empresas.

Ou seja, é esperado que as entregas de um projeto agreguem valor aos ativos da organização.

O que se espera de todo projeto é que suas entregas tragam benefícios, agreguem valor e contribua para a sustentabilidade da organização.

A figura 1 da norma NBR ISO 21500:2012, para facilitar o entendimento, poderia ser redesenhada como mostrado na figura 3:

Figura 3 - Desdobramento da figura 1 da norma NBR ISO 21500:2012, adaptada pelos autores).

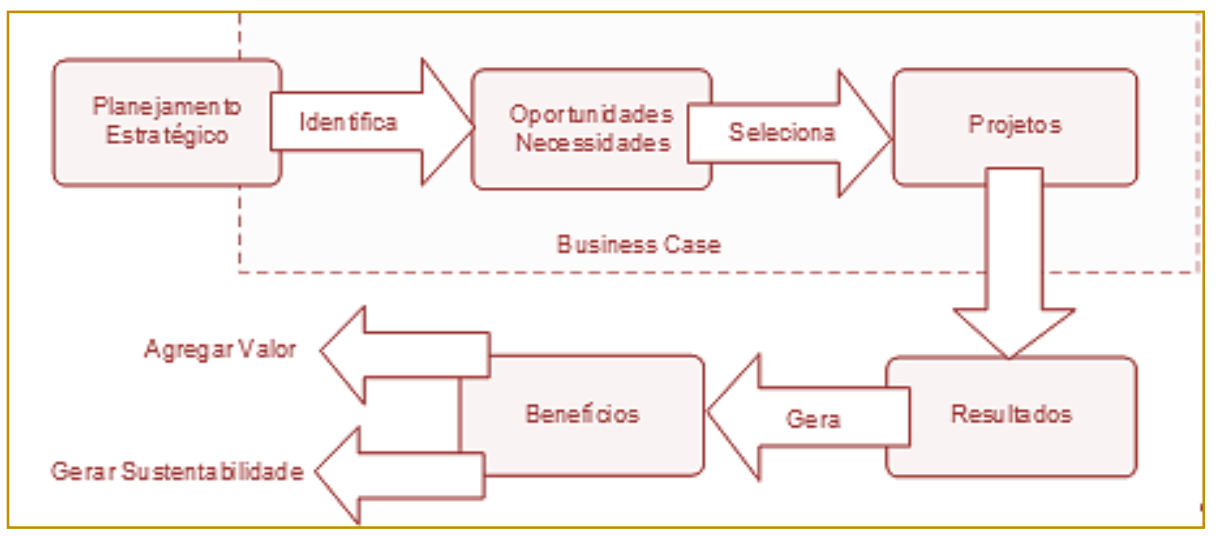

Como mostra a figura 3, a sustentabilidade de um projeto, em seus diversos aspectos, é o resultado mensurável de todas as etapas anteriores, durante todo o ciclo de vida do 
ativo. Durante os processos internos ao projeto, a partir do Termo de Abertura, pouca ação pode-se tomada em relação à sustentabilidade, pois esta nasce junto com as especificações técnicas, os requisitos mínimos dos equipamentos e sistemas. Para uma clara definição da melhor oportunidade, na fase de elaboração do Business Case, no mínimo é necessário um projeto conceitual e um projeto básico. Nessas fases é que a discussão da sustentabilidade do projeto ganha corpo e não pode ser negligenciada.

\section{3 - GUIA PMBOK}

O Guia PMBOK, 6ª edição (Um Guia do Conhecimento em Gerenciamento de
Projetos), define projeto como "um esforço temporário empreendido para criar um produto, serviço ou resultado único". Este conceito reforça a tese da temporariedade do projeto, que possui um início, um meio e um fim. E no final, junto com os processos de encerramento, o processo de entrega. $\mathrm{E}$ entrega significa disponibilizar todos os requisitos solicitados pelas partes interessadas, na fase inicial.

E como mostra a figura 4, adaptada da figura 2.1 do Guia PMBOK, define claramente os limites do que é considerado "projeto". Assim, um projeto tem a sua formalização nos processos de iniciação e seu término no processo de encerramento, com as em tregas.

Figura 4 - Limites do Projeto, adaptada da figura 2.1, página 562 - Limites do Projeto do Guia PMBOK 6ํㅡㄹição

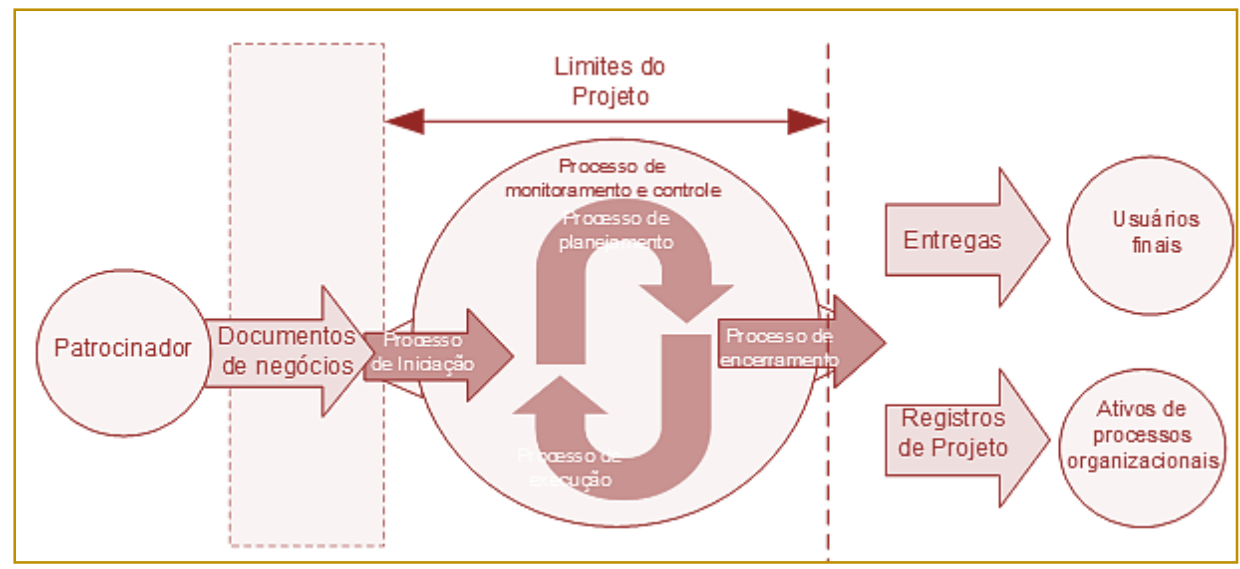

Para reforçar a definição dos limites do projeto, pode-se também recorrer ao Documento de Abertura do Projeto (Project Charter) e as entradas do projeto para subsidiar a emissão. Neste processo de iniciação, o projeto é oficializado quando o termo de abertura for aprovado.

De acordo com o Guia PMBOK, "embora a equipe de gerenciamento do projeto possa ajudar a redigir o termo de abertura do projeto, este padrão pressupõe que a avaliação, aprovação e o financiamento do caso de negócio são externos aos limites do projeto". Estes conceitos deixam claro a diferenciação, para a área de gerenciamento de projetos entre o ciclo de vida do produto gerado pelo projeto e o ciclo de vida do produto ou ativo na organização.
O processo para desenvolver o termo de abertura do projeto tem como entradas, de acodo com o Guia PMBOK os seguintes documentos:

- $\quad$ Especificação do trabalho do projeto.

- Business case.

- Acordos.

- Fatores ambientais da empresa.

- $\quad$ Ativos de processos organizacionais.

O termo de abertura do projeto é um documento oficial da organização e deve ser emitido pela alta liderança e deve conter algumas informações e/ou premissas importantes do projeto, como:

\footnotetext{
- Descrição do Projeto.

- Objetivos.

- Descrição macro do escopo do projeto.

- Nome do Patrocinador.
} 
- Nome do Gerente do Projeto designado.

- Requisitos do projeto.

- Cronograma macro.

- Estimativa de custo.

- Principais restrições.

- Prinicipais Riscos.

Como pode ser observado, o termo de abertura de um projeto representa uma fase intermediária da gestão do ativo e incial de um projeto.

\subsection{PRINCE2 FOUNDATION}

De acordo com a PRINCE2 Foundation, (Projetos em Ambientes Controlados Projects In Controlled Environments), projeto é uma estrutura temporária, criada para entregar um ou mais produtos de negócios, de acordo com um business case válido, e a entrega é considerada como algo que traz benefícios à organização, que agrega valor ao negócio.

A metodologia traz três aspectos importantíssimo, como segue:

- É baseado em um Business Case válido

- A entrega é considerada como algo que traz benefícios à organização.

- A entrega é considerada como algo que agrega valor ao negócio.

Assim, considera o projeto não como um processo isolado, mas como parte de um todo na organização e da grande ênfase no desdobramento do planejamento estratégico, na elaboração do Business Case. O Business Case torna-se assim a chave para o sucesso do projeto, pois é um estudo documentado de aspectos fundamentais do negócio e incorpora na elaboração, estudo de viabilidades, de mercado, melhor técnica e avanços tecnológicos, confiabilidade e disponibilidade desejada, impactos de meio ambiente, etc.

\section{5 - ENTREGAS COMO FATOR GERADOR DE VALOR}

Da rápida exposição acima, considerando-se a norma NBR 1 SO 21500, o Guia PMBOK ou o Prince2, pode-se concluir que o processo de gestão de projeto guarda muita semelhança entre si. A grande diferença está relacionada como é considerada a entrega do projeto, enquanto o Guia PMBOK se preocupa com o projeto em si, tanto a norma NBR ISO 21500 , como o PRINCE2, dão ênfase aos benefícios que o projeto traz para a organização, que valor agrega para a empresa, pessoas ou sociedade enquanto que a norma de Gestão de Ativos considera o ativo desde 0 nascimento da ideia/necessidade até o descomissionamento. O ativo gerado pelos projetos quer seja tangível ou intangível, tem como finalidade de agregar valor, gerar benefícios e sustentabilidade à organização.

\section{6 - GESTÃO DE ATIVOS}

- Ativo tangível - são os bens concretos, físicos de propriedade de uma organização, como máquinas, equipamentos, imóveis, capital financeiro, estoque, etc.

- Ativo intangível - são os bens não concretos ou físicos de propriedade de uma organização, mas que são percebidos pelas partes interessadas ou pela sociedade, como marca, estratégia, cultura organizacional, relacionamento com as pessoas e a sociedade, conhecimento, capacidade de inovação, governança, política de desenvolvimento, retenção de talentos, patentes, clientes, direitos autorais, tecnologia, etc.

- Classificação dos Ativos - Físicos, Humanos, Intangíveis, Informacionais, Financeiros.

- Ciclo de vida de um ativo - Intervalo de tempo que começa com a identificação da necessidade de um ativo e termina com a desativação do ativo ou quaisquer responsabilidades.

- Obsolescência planejada - Os produtos do projeto já nascem com data prevista para serem retirados do mercado ou abandonados internamente à organização.

- Depreciação - também conhecida como desvalorização está relacionada à obsolescência natural ou desgaste do ativo.

A figura 5 permite a visualização das fases de ciclo de vida de um ativo físico, em conjunto com o detalhamento dos processos de projetos agregados a um ativo físico ao longo de sua vida, desde o projeto de criação/aquisição e instalação, passando pelos projetos de grandes paradas de manutenção e finalmente do projeto de seu descomissionamento final. Os processos de projetos foram descritos conforme definição da norma NBR ISO 21500:2012. 
Figura 5 - Fases do Ciclo de vida de um ativo, alinhadas a grupos de processos de projetos.

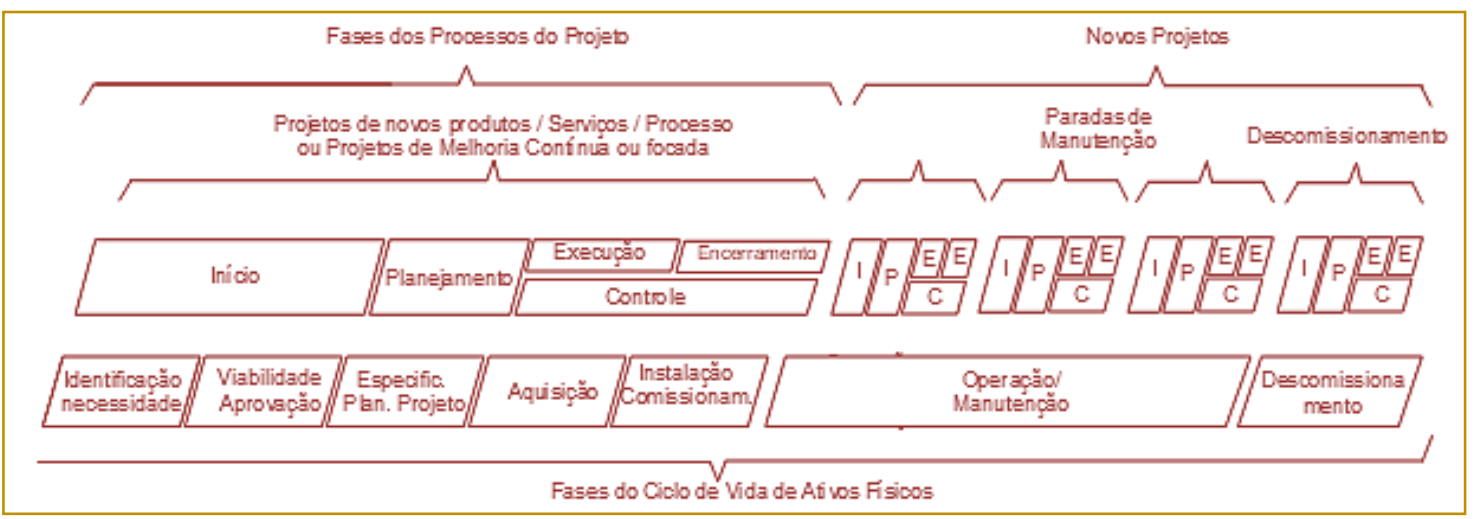

De acordo com o IAM - Institute of Asset Management, os atributos e princípios chaves da gestão de ativos estão listados na figura 6.
Existe uma grande preocupação com a integração.

Figura 6 - Princípios e atributos da gestão de ativos

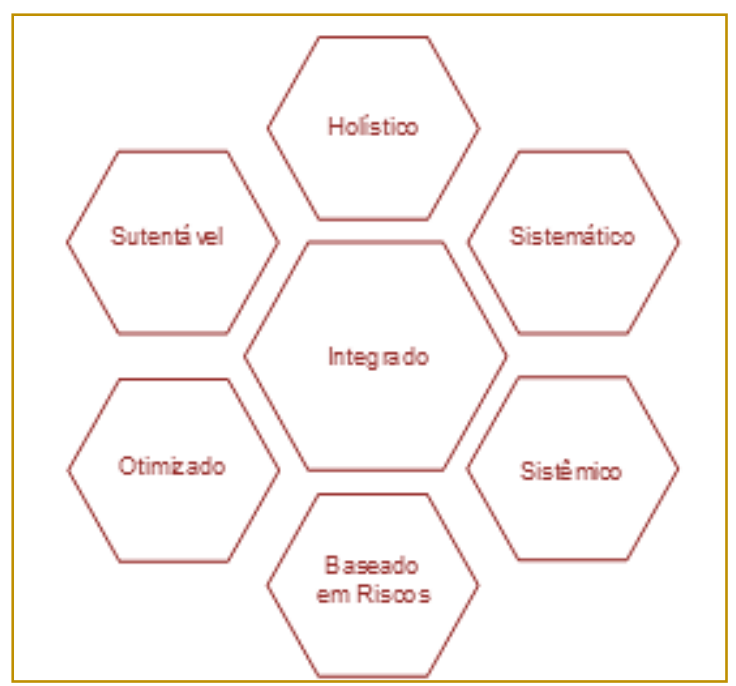

Fonte IAM - Institute of Asset Management.

A figura 7 mostra o Modelo Conceitual da Gestão de Ativos do IAM - Institute of Asset Management. Pode ser notado que muitos dos processos coincidem com processos da gestão de projetos. 
Figura 7 - Modelo Conceitual da Gestão de Ativos -

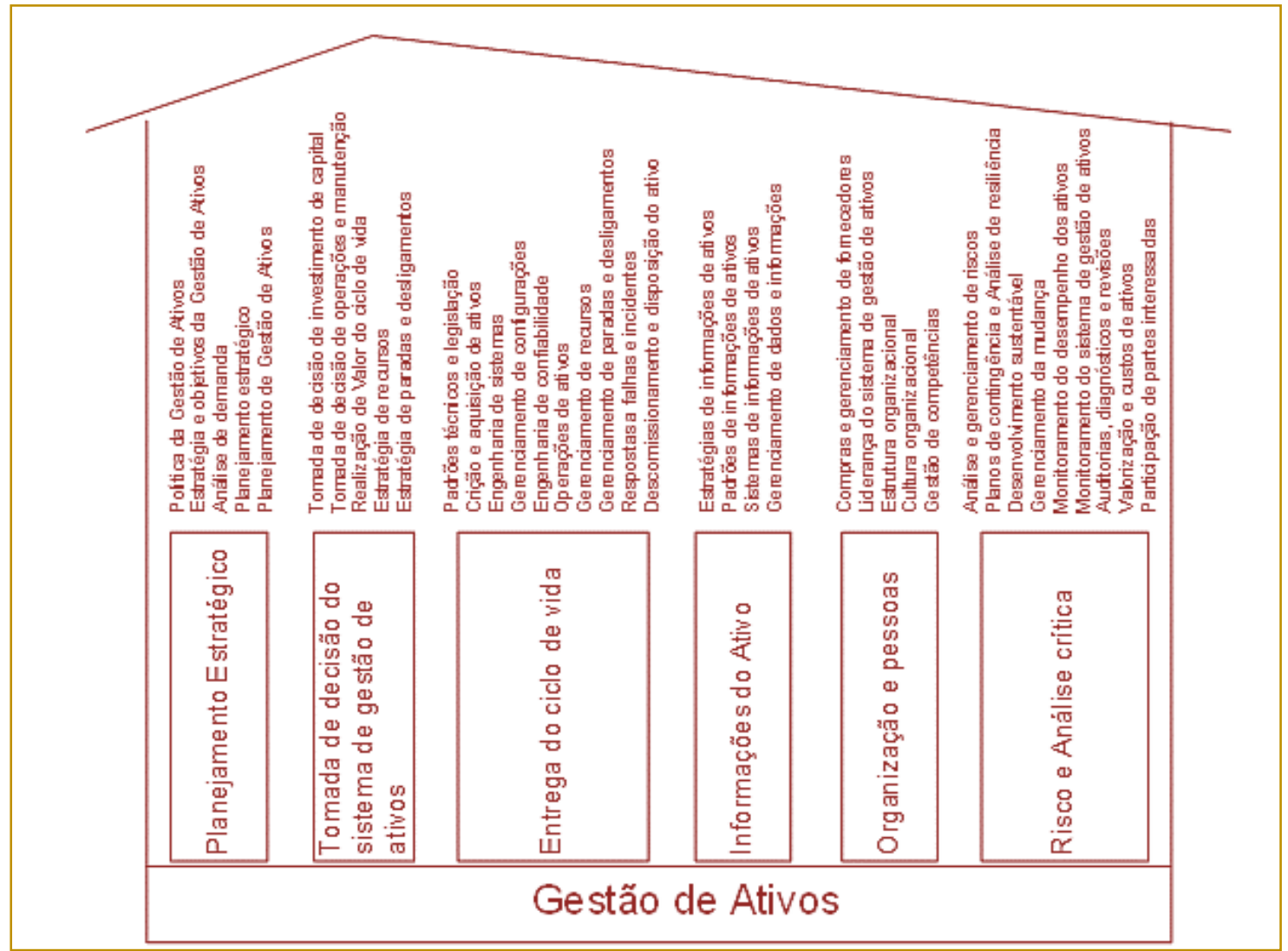

Fonte IAM - Institute of Asset Management.

\subsection{ABNT NBR ISO 55000B-2014 - GESTÃO} DE ATIVOS GERAL, PRINCÍPIOS E TERMINOLOGIA.

\section{A série de normas NBR ISO 55000 está dividida como segue:}

- $\quad$ NBR ISO 55000 - Gestão de Ativos Visão Geral - Princípios e Terminologia, 2014. - $\quad$ NBR ISO 55001 - Gestão de Ativos Sistemas de Gestão - Requisitos, 2014.
- $\quad$ NBR ISO 55002 - Gestão de Ativos Sistemas de Gestão - Diretrizes para Implementação, 2014.

A gestão de ativos, de acordo com essa norma, é a atividade coordenada de uma organização para obtenção de valor de seus ativos, ou seja, como mostra a figura 8 , a gestão de todos os ativos torna-se um componente integrado à gestão da organização, alinhada as estratégias de negócio e as estratégias corporativas. 
Figura 8 - Gestão de Ativos na organização, adaptado da Norma NBR ISO 55.000.

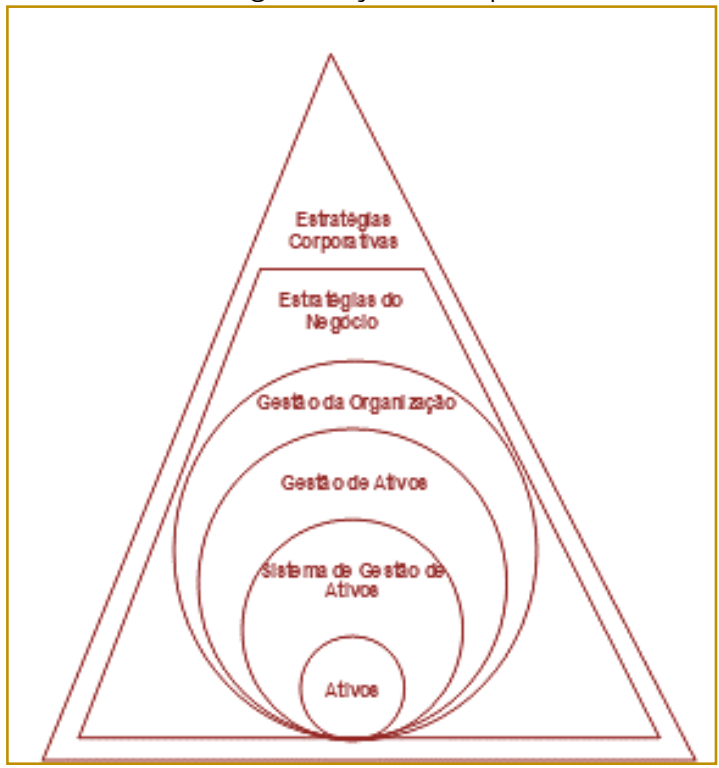

\subsection{1 - PRINCÍPIOS DA GESTÃO DE ATIVOS:}

- Fornecer valor para a organização e partes interessadas.

- Desdobrar as intenções estratégicas em tarefas, decisões, atividades técnicas e financeiras.

Figura 9 - Relação entre os elementos chaves de um sistema de Gestão de Ativos, adaptado da figura B1 da Norma ISO 55.000.

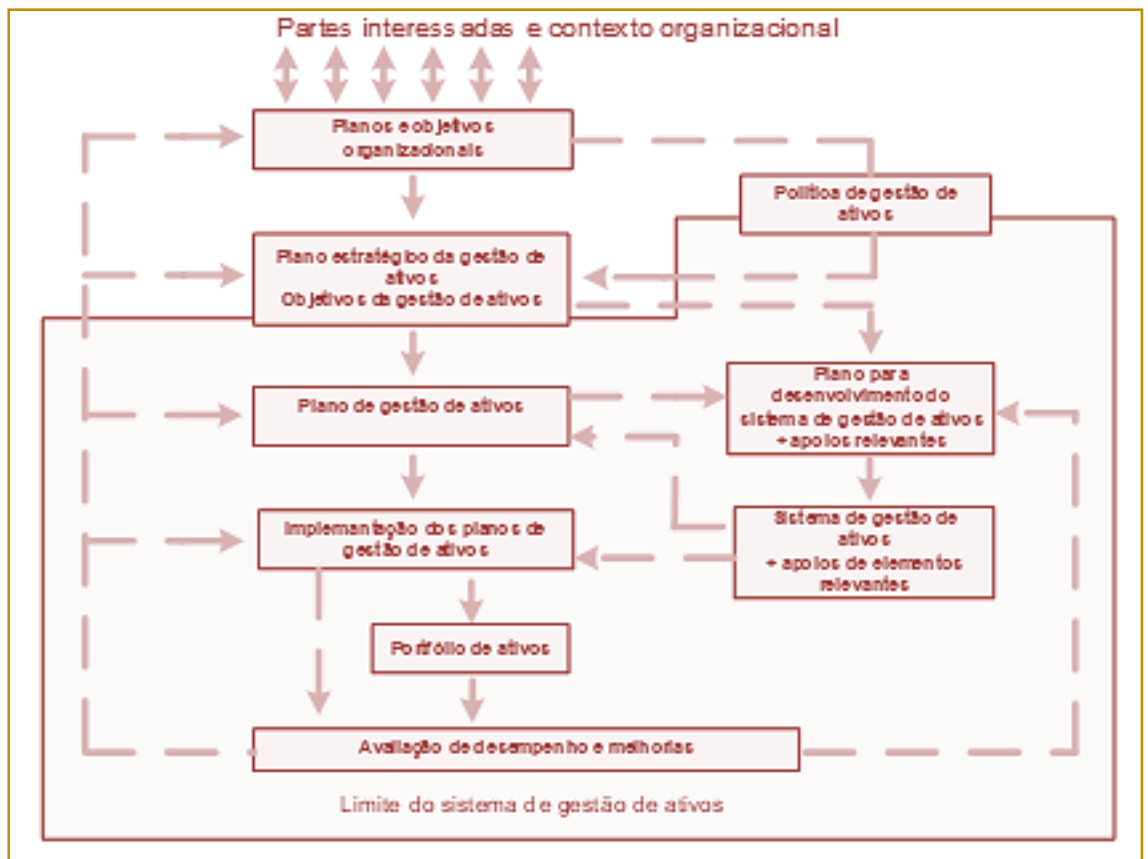




\section{DESENVOLVIMENTO}

\subsection{MODELO DA VISÃO DE PROJETO POR GRANDE PARTE DO MERCADO}

A cultura de gerenciamento de projetos hoje praticada no Brasil está muito relacionada ao apresentado na figura 3.4 - Limites do Projeto do Guia PMBOK, figura 5 deste trabalho. Ou seja, é dada grande ênfase à fase executiva do projeto e pouca ênfase ou até mesmo negligenciada as fases críticas antes da emissão do termo de abertura e nas fases após a entrega do projeto. Limita-se o processo de gerenciamento do projeto em uma fase intermediária da gestão do ativo. Todas as técnicas, metodologias e ferramentas estão focadas dentro deste limite. Perde-se assim a visão sistêmica e holística da geração do ativo.

A figura 10 exemplifica o que é considerado como limite do projeto.

Figura 10 - Ciclo de vida limitado do projeto.

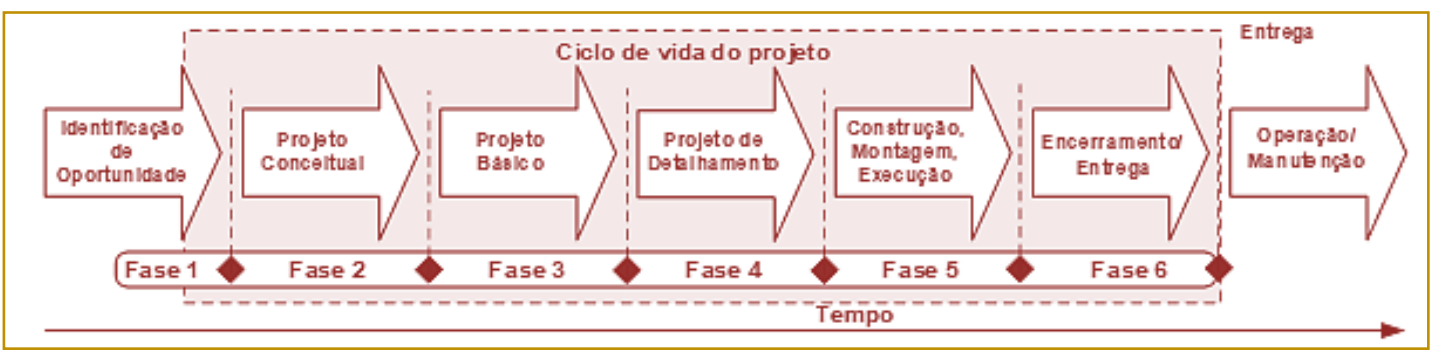

Estas fronteiras do projeto têm trazido para as organizações muitos problemas, pois é necessário que se considere que os ativos entregues por um projeto não se encerra com as entregas desse projeto. A NBR ISO 21500 e o PRINCE2, de uma maneira mais abrangente, recomendam que as organizações busquem obter benefícios tangíveis ou intangíveis de seus projetos. E para piorar a situação, em muitos casos, nem uma entrega ocorre no final do projeto, mas sim, um abandono e a organização com sua equipe do dia a dia, da operação e/ou manutenção, acabam por finalizar aspectos importantes e não concluídos dos projetos. E neste caso, o desgaste para a equipe de projeto é enorme.

Estas entregas, sem considerar a organização como um todo e o aspecto de geração de um novo ativo geram uma enormidade de falhas externas ao projeto.

\subsection{MODELO EM QUE O CICLO DE VIDA DO ATIVO É CONSIDERADO}

Para solucionar o problema resultante do modelo muito usado atualmente, a área de gerenciamento de projetos precisa ser mais amplamente integrada aos demais processos da organização. No modelo proposto a seguir, procura-se fazer com que o processo de gerenciamento de projeto faça parte integrante do todo. Se todo projeto tem como resultado as suas entregas, e essas entregas estão relacionadas à geração de novos ativos, quer sejam tangíveis ou intangíveis, este processo de gestão de ativos torna-se mais abrangente que o de gerenciamento de projetos.

Conforme discutido no item Introdução Gestão de Ativos, percebe-se claramente a preocupação com o ciclo de vida do ativo e não apenas com o ciclo de vida do projeto. Pelo exposto, a área de gerenciamento de projetos precisaria aumentar os seus limites, como indicado na figura 11, o que a tornaria de difícil execução, mas essencial para a geração de novo ativo e para a organização. 
Figura 11 - Ciclo de vida completo de um ativo.

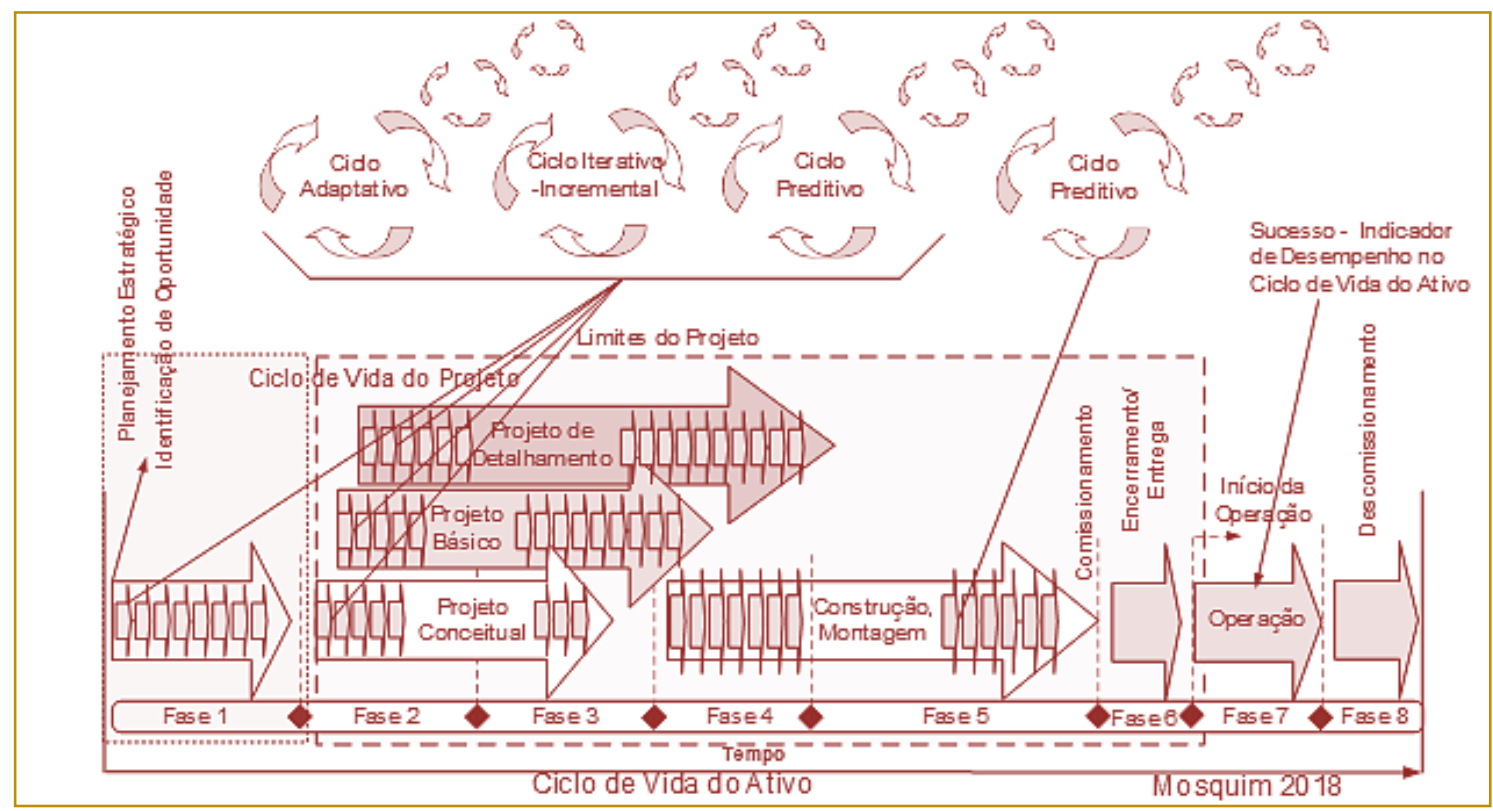

Se existe a necessidade de limitação no tempo da área de Gerenciamento de Projetos, como amplamente conhecida nos dias atuais, a solução é transformar esta área em mais um processo da área de Gestão de Ativos. Dessa maneira, seria garantida uma perfeita integração de todo as áreas envolvidas com a geração do novo ativo. O novo ativo que será incorporado ao portfólio, precisa estar alinhado com o sistema de gestão de ativos dessa organização. Ou seja, para que isto venha a ocorrer, este novo ativo, deste o surgimento da ideia ou necessidade, na fase de planejamento estratégico, já deve estar alinhado com o sistema de gestão de ativos.

Fica muito evidente que nas fases iniciais do projeto Conceitual e do projeto Básico, trabalha-se em uma ambiente de muitas dúvidas, de muitas incertezas. A integração entre todas as áreas da empresa é fundamental nestas fases do projeto, pois todo o conhecimento de engenharia, manutenção, operação, suprimento, precisam ser compartilhados, para que se encontre a melhor alternativa para a organização. Nesta fase inicial são identificados os verdadeiros indicadores de sucesso do projeto, que não estão no ciclo de vida do projeto, mas sim, no ciclo de vida do ativo.

Como o ambiente nas fases iniciais do projeto conceitual e básico, procura-se dar passos pequenos, sempre considerando-se a criticidade.

A figura 12 sugere a relação entre os elementos chaves de um sistema de gestão de ativos, com a inclusão de novos ativos e exemplifica como ficaria este fluxo. 
Figura 12 - Relação entre os elementos chaves de um sistema de Gestão de Ativos, com a incorporação de novos ativos, adaptado da figura B1 da Norma ISO 55.000.

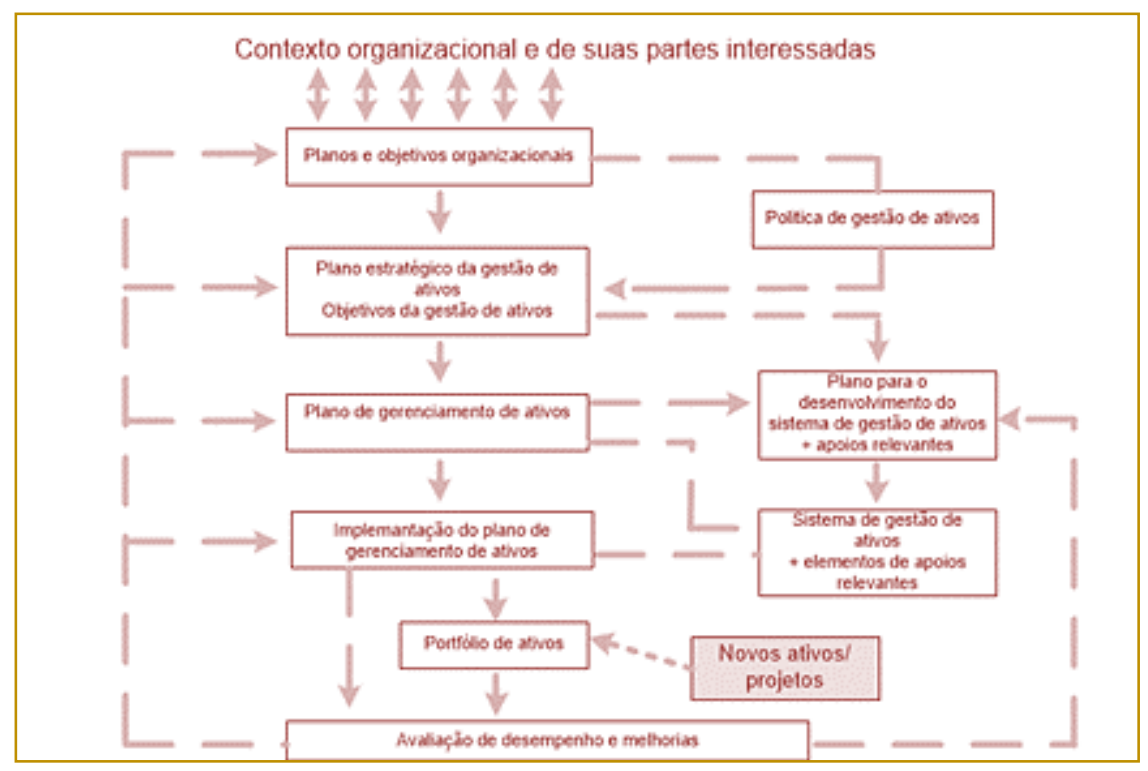

E na visão empresarial e da manutenção, o ciclo de vida do projeto representa apenas uma pequena parcela da vida útil do ativo. As técnicas para melhorar a confiabilidade, disponibilidade do ativo são empregadas na fase denominada de operação/manutenção, quando na realidade, muitos dos problemas foram gerados nas fases de levantamento dos requisitos mínimos de qualidade do ativo e na fase de construção e montagem. Em resumo, quando se aplica técnicas/metodologias como, gestão de ativos, TPM ou RCM, está, na verdade, atuando no efeito do problema e não diretamente na causa $E$ porque não aplicar a técnica do RCM na fase de elaboração dos requisitos, a fim de se identificar problemas em alguma função.

Figura 13 - Ciclo de vida do Ativo

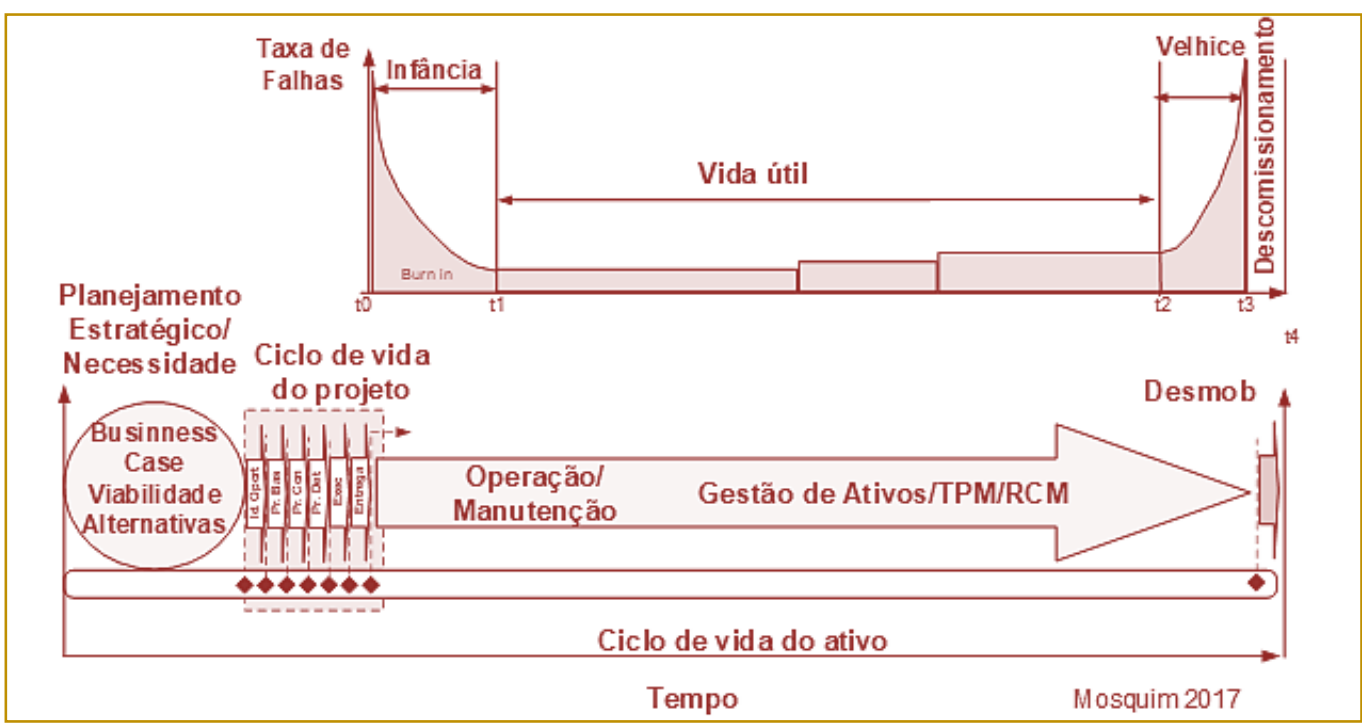


Muito embora a curva da banheira representada na figura 13 seja apenas teórica, mas suficientemente clara para mostrar o comportamento do ativo, ao longo do seu ciclo de vida.

A utilização da engenharia da manutenção e técnicas/metodologias como RCM, TPM, contribuem para a melhora da confiabilidade do equipamento/sistema, como mostra os degraus na curva da banheira. E mostra também a importância da especificação, elaboração dos requisitos e da boa qualidade nos processos de construção e montagem.

\subsection{INDICADORES DE SUCESSO DO} PROJETO, NO DO CICLO DE VIDA DO PROJETO E NO CICLO DE VIDA DO ATIVO

Outro fator de muita importância está associado ao real significado do "Sucesso". O que é o sucesso em um projeto?

Costuma-se definir indicadores de desempenho que abrangem apenas o ciclo de vida do projeto, como custo, prazo, segurança, saúde, meio ambiente, etc. Isso não é necessário mas não suficiente para a organização. O que realmente importa para a organização são os indicadores associados ao Ciclo de Vida do Ativo, principalmente na fase de operação/produção. Alcançar esses indicadores de desempenho, definidos na fase do projeto e medido ao longo dos anos de operação, é o verdadeiro sucesso.

E os indicadores de desempenho no Ciclo de Vida precisam também serem buscados, mas não como indicador de sucesso, mas como uma obrigação contratual.

Um exemplo bem prática está relacionado às paradas de manutenção. O sucesso não está em se cumprir o prazo, custo, segurança e saúde, muito embora seja um bom indicador da competência profissional da equipe, mas o sucesso será medido durante a próxima ou próximas campanhas.

\subsection{ESTRUTURA ORGANIZACIONAL}

Um dos grandes problemas enfrentados nas organizações está relacionado ao isolamento entre os departamentos e a dificuldade de comunicação entre eles e seus elementos. Normalmente os projetos e a geração de novos ativos estão a cargo da área de engenharia. Por mais que se procure e incentive, ocorre que existe na prática um distanciamento entre a engenharia e a manutenção, o futuro gestor do ativo.

Figura 14 - Processo de gestão de ativos e a gestão de projetos na organização isolados.

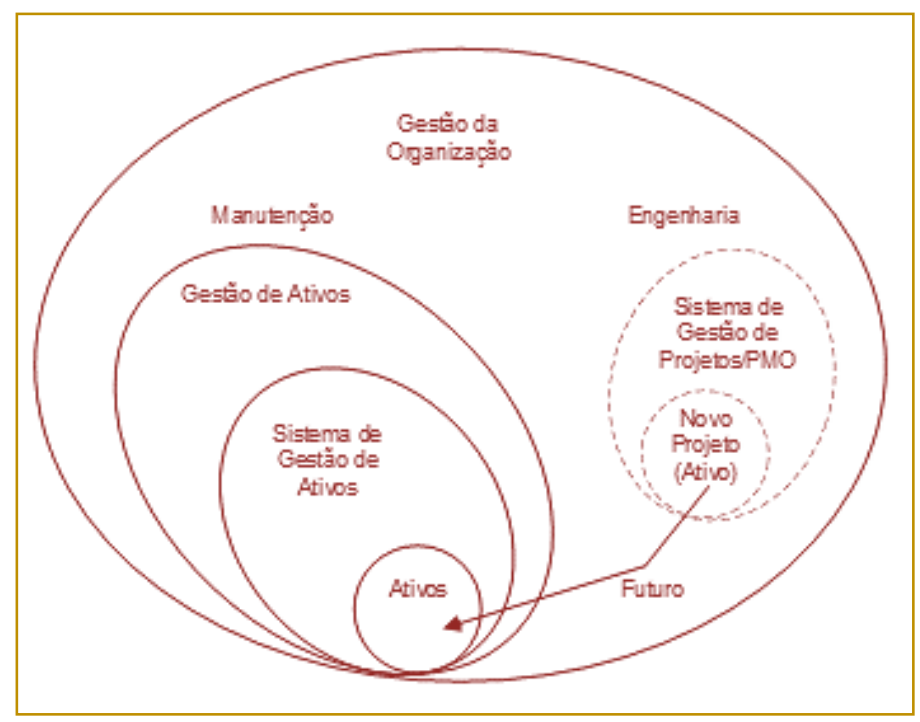


A área de projetos, de uma maneira geral e pela definição, por considerar o projeto como algo limitado no tempo, acaba por fazer com que o pensamento das pessoas diretamente envolvidas, atue dentro desse limite, esquecendo-se de integrá-lo à organização.

E devido a estas características, muitos termos pejorativos são associados aos projetos, como:

- Não se entrega projetos, abandonase.

- $\quad$ Projeto é igual obra de igreja, nunca acaba.

- Presente de grego.

- Mais um abacaxi.

O que se busca não é eliminação do processo de gerenciamento de projetos, mas sim, a sua perfeita integração com a gestão de ativos e os processos de gestão da organização. Esta maneira de organizar e integrar os processos da gestão de ativos com a gestão de projetos traz enormes benefícios à organização. E desta maneira, a integração, a visão sistêmica e holística, a gestão sistemática, a análise de riscos, o sistema otimizado e sustentável, deixariam de serem pilares da gestão de ativos e passariam a ser integrados com a gestão de projetos. Devido a esta dificuldade foi proposto um modelo de estrutura organizacional em que as áreas de engenharia/projetos estão próximas e integradas na estrutura. Esta aproximação facilita o contato entre as áreas, à migração de pessoas de uma área para outra e observância do estado da arte, por todos.

Como mostra a figura 15, a estrutura facilita uma clara integração entre as áreas de manutenção e de engenharia/projeto e gera uma facilidade de migração de pessoas entre essas áreas e assim, do conhecimento. Nestas condições, a área de gestão de projetos passaria por uma profunda melhora, no que se refere à integração com todas as partes interessadas e na garantia de que o ativo entregue realmente agregue valor à organização.

Figura 15 - Processo de gestão de ativos e a gestão de projetos na organização integrados.

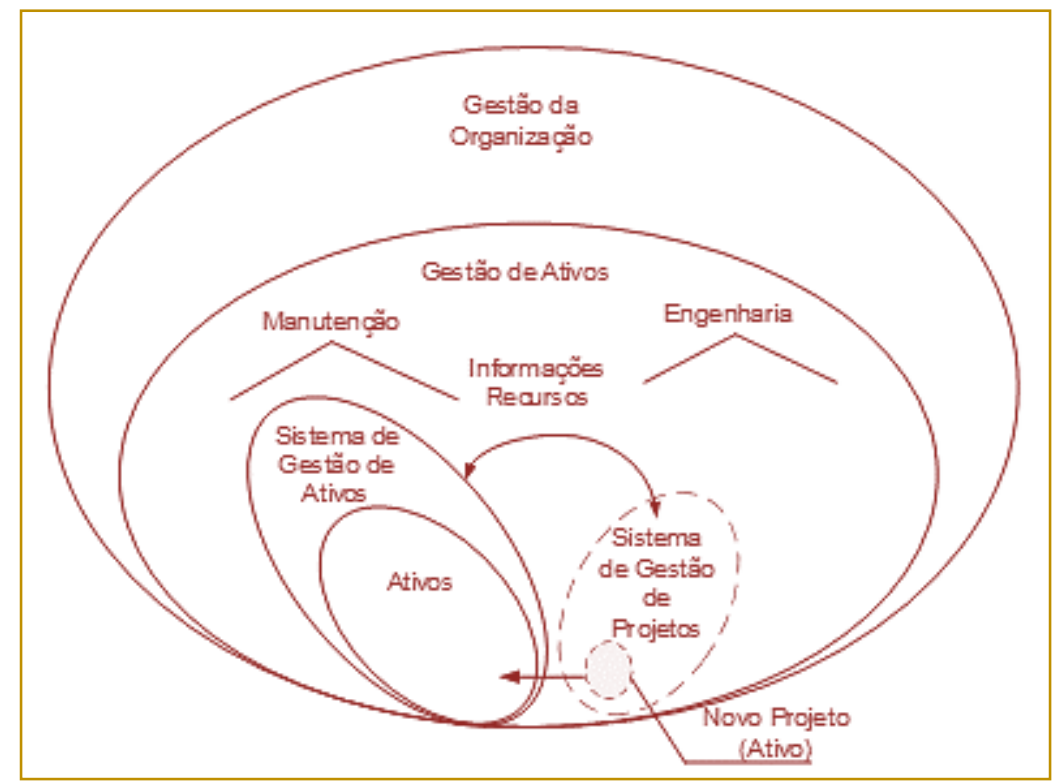

As entregas significam à incorporação de um novo ativo, aos ativos na organização e se os processos de gerenciamento de projetos e de gestão de ativos estiverem em sintonia, ocorrerá uma perfeita harmonia com os demais ativos existentes.

Finalmente, a figura 16 enuncia a sincronização das fases de ciclo de vida de um ativo, em conjunto com as fases dos projetos que compõem a vida de um ativo desde a identificação de suas necessidades, até seu descomissionamento final. Da mesma maneira que a figura 1 demonstrou a viabilidade da integração das normas de sistemas de gestão, a figura 16 demonstra que o sistema de indicadores também pode ser integrado, permitindo a medição de desempenho de ativos físicos com a mesma 
função, ao longo de todo o seu ciclo de vida. A partir da gestão integrada, enunciada na figura 16, é possível avaliar completamente o impacto de cada ativo físico para todas as partes interessadas, envolvidas no processo. Somente através de tal integração, a gestão de ativos consegue atingir consistentemente seu objetivo de sempre equilibrar custos, riscos e desempenho do negócio e a gestão de programas e portfólios de projetos, atingirem completamente suas metas de integração, escopo, custos, tempo, recursos, riscos e comunicação.

Figura 16 - Sincronização das fases de ciclo de vida de um ativo físico, fases de processos de projetos que a compõem e respectivos indicadores.

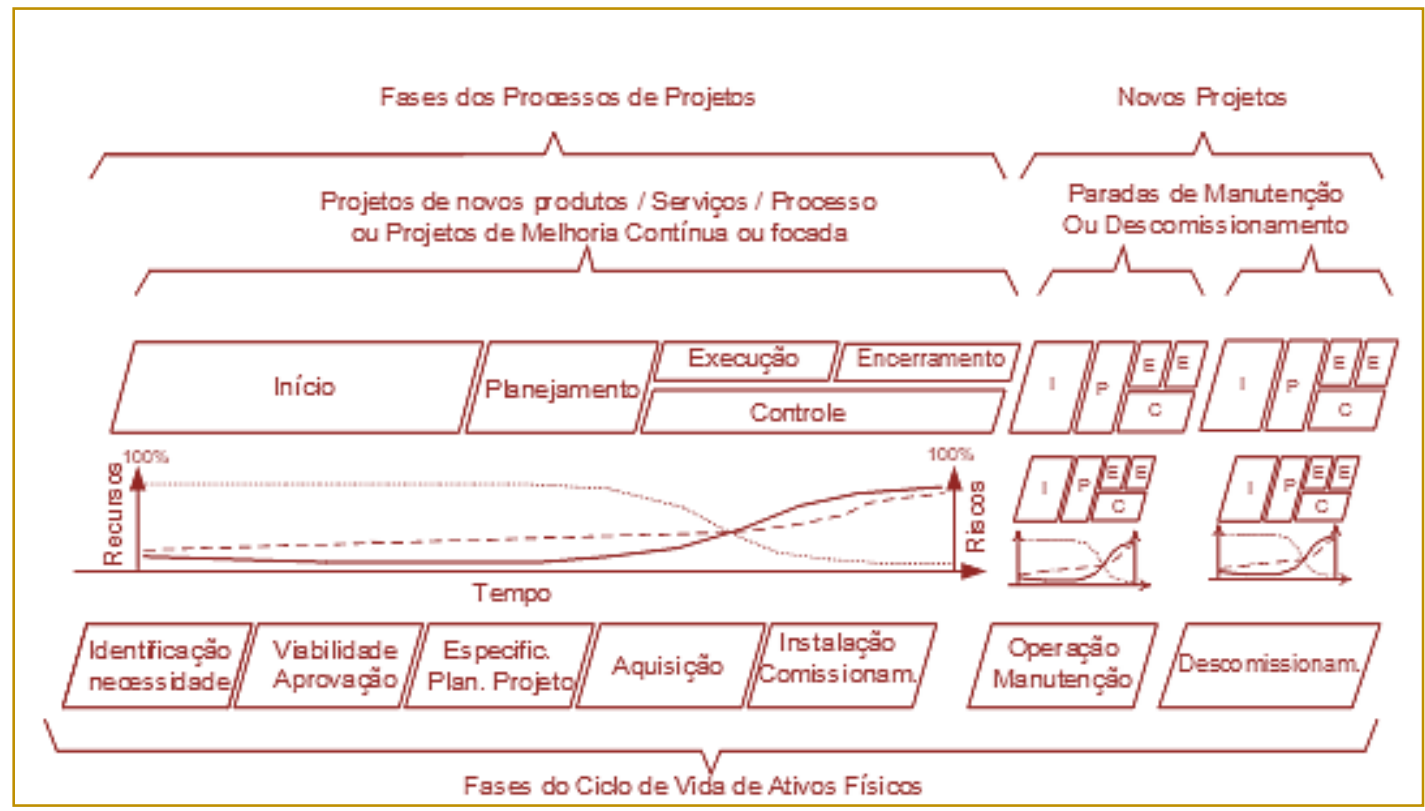

Nas fases de concepção, projeto conceitual, básico, detalhamento e implantação dos projetos, são definidas premissas de desempenho para a fase de operação até a expectativa de vida útil o Descomissionamento. Esses indicadores de desempenho servirão como base para a avaliação do sucesso ou não do projeto, durante todo o seu ciclo de vida e balizará a necessidade de novos estudos de engenharia, para melhorias em algum processo. Esta integração do processo de gestão do projeto com a gestão de ativos resolve um dos grandes problemas da estanqueidade da gestão de projetos e da visão parcial do processo pela área de projetos.

E com um resumo final, a figura 17 mostra como a necessidade de integração de todos os processos dentro de uma organização e a importância que deve ser dado ao Planejamento Estratégico e seu desdobramento.

E assim, entender que todo projeto incorpora novos ativos, é um processo que gera mudanças e afeta toda a organização. 
Figura 17 - Integração dos processos dentro de uma organização

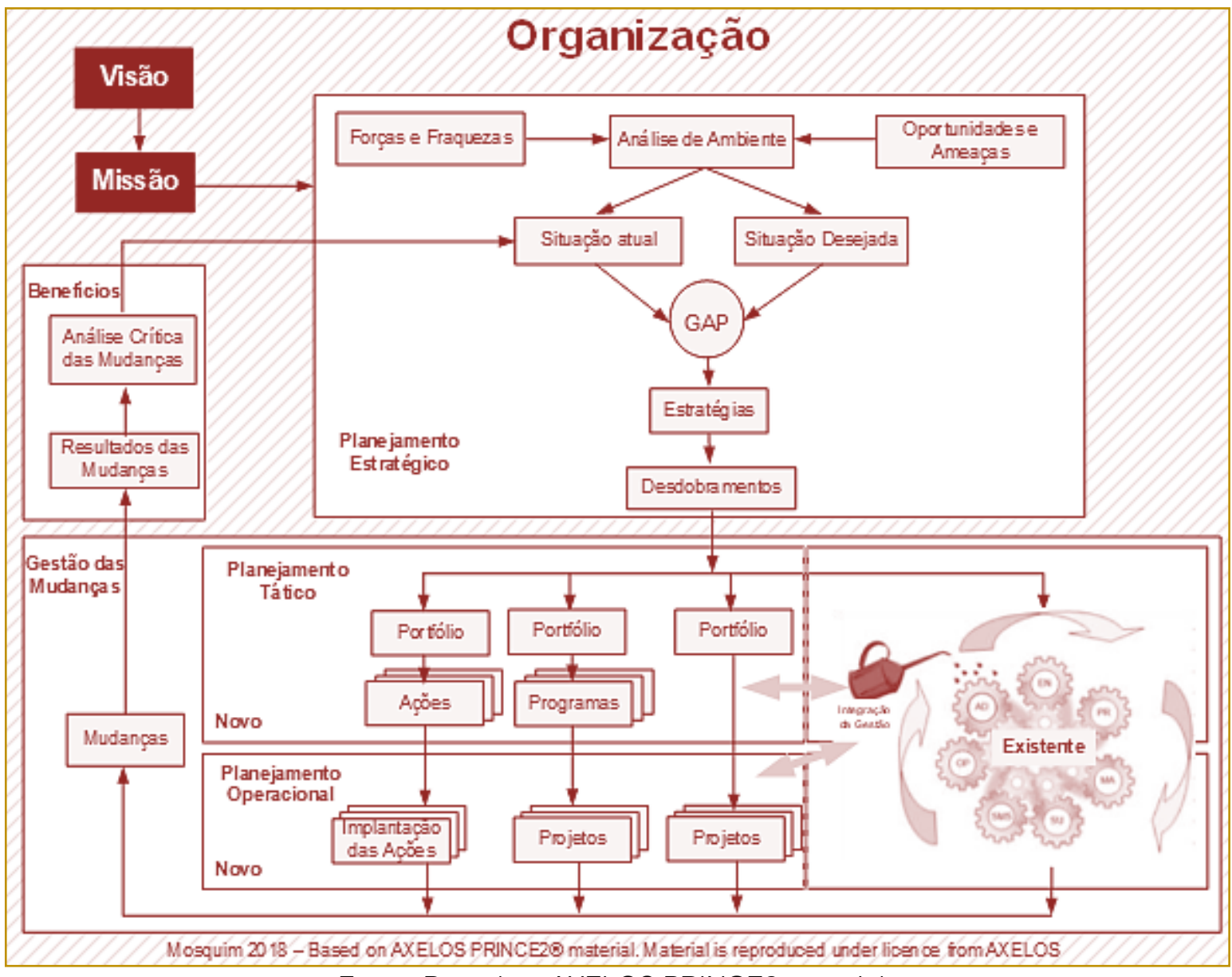

Fonte: Based on AXELOS PRINCE2 material.

\section{RESULTADOS ESPERADOS}

Como resultados, esperam-se as seguintes melhorias na organização:

- Integração entre as áreas de projetos e gestão de ativos.

- Harmonia na organização.

- Confiabilidade/Disponibilidade.

- $\quad$ Competitividade da organização.

- Diminuição das barreiras entre os departamentos.

- $\quad$ Facilidade de migração de pessoas.

- Disseminação do conhecimento.

- Clima organizacional.

- Visão sistêmica e holística da área de gestão de projetos.

- Qualidade da especificação e requisitos do equipamento/produto/sistema.

- $\quad$ Comunicação interna e externa

\section{COMENTÁRIOS}

- A busca por excelência fez com que áreas importantes das organizações, como à de Gestão de Ativos e à de Gestão de Projetos, partissem por caminhos isolados e específicos, inclusive com a publicação de normas isoladas entre si.

- Muitos dos processos, muito embora comuns, são tratados de maneira isolados e não sistêmica, criando-se assim, barreiras e desconfianças entre os departamentos.

- Como o ciclo de vida de um ativo é definido como o Intervalo de tempo que começa com a identificação da necessidade de um ativo e termina com a desativação do ativo ou quaisquer responsabilidades, o processo que gerência o ativo, denominado Gestão de Ativos torna-se mais abrangente e completo na organização. 
- Considerando-se que as entregas de todo projeto são ativos tangíveis ou intangíveis que serão incorporados à organização e que projeto é definido como um evento temporário, com início, meio e fim, os processos de gestão de projetos devem fazer de um processo maior denominado Gestão de Ativos, sem perder as suas especialidades e características.

\section{CONCLUSÕES}

- A gestão de projetos e a gestão de ativos podem apoiar-se mutuamente, quer seja em sistemas de gestão já consolidados ou no desenvolvimento de novos negócios.

- A articulação de passos para o planejamento e controle dos ciclos previstos pelas duas filosofias de gestão podem ser integrados facilmente, por meio de curvas de investimentos, riscos e desempenho.

- Não existem conflitos conceituais entre as normas ABNT NBR ISO 21500:2012 e a ABNT NBR ISO 5500:2014, mas sim, que os processos da área de gestão de processos fazem parte de um processo mais abrangente denominado de gestão de ativos.

\section{REFERÊNCIAS}

[1] ABNT, Associação Brasileira de Normas Técnicas - ABNT NBR ISO 21500 - Orientações sobre Gerenciamento de projeto, 2012, 43 páginas.

[2] ABNT, Associação Brasileira de Normas Técnicas - ABNT NBR ISO 55000 - Gestão de Ativos - Visão Geral, princípios e terminologia, 2014, 23 páginas.

[3] ABNT, Associação Brasileira de Normas Técnicas - ABNT NBR ISO 55001 - Gestão de Ativos - Sistemas de Gestão - Requisitos, 2014, 16 páginas.

[4] ABNT, Associação Brasileira de Normas Técnicas - ABNT NBR ISO 55002 - Gestão de ativos - Sistemas de gestão - Diretrizes para a aplicação da ABNT NBR ISO 55001, 2014, 38 páginas.

[5] Axelos, Global Best Practice, 2017

[6] IAM - Institute of Asset Management Asset Management - an anatomy - Version 3,
- A integração dos processos da ABNT NBR ISO 21500-2012 com os processos da ABNT NBR ISO 55000:2014, dentro de uma estrutura organizacional integrada, melhorará o tratamento dos anseios das partes interessadas, contribuirá para a melhora do clima organizacional, facilitará a integração entre as pessoas e facilitará a busca por excelência na organização.

- $\quad$ E entender que a Sustentabilidade e a Confiabilidade do projeto nascem junto com o projeto conceitual e projeto básico.

- $\quad$ A integração do processo de gestão de projetos ao processo maior da gestão do ciclo de vida do ativo agrega valor à organização pois embute uma visão de continuidade dos processos.

- A elaboração de indicadores de desempenho para o ciclo de vida do ativo, ainda na fase de concepção e implantação dos projetos servirá como base para a gestão da qualidade na implantação e durante a fase de operação, para avaliação se os objetivos estão sendo atendidos ou não.

download realizado em 21/12/2015. Disponível em https://theiam.org/what-is-asset-

management/anatomy-asset-management, 84 páginas.

[7] Moschin, John. S. Exa., O Prazo. Rio de Janeiro: Qualitymark, 2012, 208 páginas.

[8] Moschin, John. Gerenciamento de Paradas de Manutenção, Rio de Janeiro: Brasport, 2015, 278 páginas.

[9] Mosquim, João e Lyra Rodrigues, Daniel. Revista Mundo PM Project Management - edição 70 -2016 - Integração entre Gestão de Ativos e Gestão de Projetos

[10] Project Management Institute. Guia PMBOK: Um guia do conjunto de conhecimentos em gerenciamento de projetos. $5^{\mathrm{a}}$ ed. Newtown Square: PMI, 2013, 616 páginas. 


\section{Bapítulo 3}

\section{COMPORTAMENTO DO CONSUMIDOR SURDO: HÁBITOS DE COMPRA E PERCEPCÕES SOBRE PROPAGANDAS VEICULADAS EM TELEVISÃO E INTERNET}

\section{Silvana Saionara Gollo}

Jean Filipe Krebs

Angelita Freitas da Silva

Luciana Maria Bernstein Pavan

Resumo: O consumidor surdo tem dificuldades para compreender as informações faladas nas propagandas, sendo fundamental que o processo de comunicação seja diferenciado para tornar-se mas acessível e permitir a decisão de compra. O artigo tem como objetivo investigar o comportamento do consumidor surdo, enfatizando seus hábitos de compra e opinião sobre as propagandas veiculadas na televisão e internet. A pesquisa classifica-se quanto a abordagem do tema e objetivos como quantitativa e exploratória. A população é formada por consumidores surdos em dois municípios do Alto Uruguai Gaúcho, totalizando 125 surdos cadastrados. Destes selecionou-se uma amostra de 55 consumidores surdos com a técnica de amostragem não-probabilística. Os dados apontam que os consumidores surdos fazem compras em lojas físicas e on-line e buscam informações sobre produtos e serviços no Google, site e facebook das empresas. Os veículos de comunicação mais utilizados são a internet, televisão, revistas e jornais. Os consumidores surdos consideram que as propagandas em televisão não são acessíveis, pela falta de legenda, informações em LIBRAS e informações visuais. A acessibilidade nas propagandas pela internet são dificultadas pelo uso de palavras difíceis. Constatou-se que é preciso adequar a forma de apresentação das propagandas para que tenha uma sociedade inclusiva.

Palavras-chave: comportamento do consumidor; propagandas; consumidor surdo 


\section{INTRODUÇÃO}

A gestão em marketing é um dos principais fatores para garantir os resultados positivos nas empresas, pois é através desta que a empresa passa a conhecer o consumidor, o mercado, os recursos internos e, a partir disso, se estrutura e define estratégias para alcançar seus objetivos. Sendo assim, um fator importante é a segmentação do mercado, para definir produtos e processo de comunicação, distribuição e precificação adequadas às necessidades e expectativas de um público determinado, para traçar uma estratégia sustentável.

O "ser" consumidor é uma parte de cada um dos seres humanos, que têm suas motivações para alcançar suas ambições, para conquistar alguns espaços ou para realização pessoal. Segundo Karsaklian (2009), todos os consumidores são dotados de personalidade, o que faz com que tenham preferências por diferentes tipos de produtos, tendo diferentes percepções da realidade. Essa percepção ajuda o consumidor a desenvolver atitudes positivas ou negativas com relação aos produtos, se agradando de uns e tendo opiniões contrárias de outros, assim cada consumidor assume um comportamento próprio. O estilo de vida, a cultura, o mundo que está ao seu redor é que vão influenciar o comportamento de compras do consumidor.

Entender o comportamento do consumidor é fundamental para as empresas criarem estratégias de apresentação e divulgação de seus produtos e serviços através de propagandas, criando-as de uma forma que agrade e seja acessível ao consumidor. Um ponto importante a ser analisado, na opinião de Karsaklian (2009) é a percepção do consumidor, que significa a maneira de reagir aos produtos através dos sentidos. As empresas já perceberam o quanto as imagens, embalagens influenciam o consumidor no processo de compra, valendose da estimulação seja pela visão, audição, o olfato, o tato e o paladar. É comprovado que os sentidos facilitam a aprendizagem, nas relações consumidor/produto, os sentidos vão proporcionar uma maior atenção e interesse por determinada mercadoria, pois a estimulação física ativa os receptores sensoriais, desencadeando a sensação por estimulações externas ou internas influenciando o comportamento do consumidor.
Quando se fala em consumidor é fundamental se ter em mente que as pessoas são diferentes, e, assim deve-se ter conhecimento de quem são os consumidores e quais são suas necessidades e desejos. Nesse sentindo, deve ser considerado que, além das pessoas serem diferentes, existem àquelas com necessidades especiais, como o consumidor surdo, que só terá acesso às informações veiculadas pela empresa se estas informações estiverem acessíveis. O consumidor surdo apresenta uma diferença linguística e cultural se comunicando através da Língua Brasileira de Sinais (Libras), tendoa como a primeira língua, reconhecida oficialmente em lei. O decreto no 5.626 de 22 de Dezembro de 2005 reconheceu a Libras como língua oficial brasileira, regulamentando a Lei $n^{\circ}$ 10. 436, de 24 de abril de 2002, que dispõe sobre a Língua Brasileira de Sinais Libras, e o art. 18 da Lei $n^{\circ}$ 10.098, de 19 de dezembro de 2000, no entanto, este por si só, não garante a inclusão do surdo e o reconhecimento da mesma como sua língua oficial e de direito.

Segundo dados do Instituto Brasileiro de Geografia e Estatística (IBGE), em 2000, 14\% da população brasileira apresentava algum tipo de deficiência, já em 2010 esse número subiu para $24 \%$, total de 45,6 milhões de pessoas. Desses 45,6 milhões de pessoas com deficiência, 9,7 milhões apresentam alguma deficiência auditiva, o que representa $5 \%$ da população brasileira. Segundo Oliveira (2012) das pessoas com deficiência são no mínimo 24,6 milhões de consumidores ativos, desses 48\% com deficiência visual, 23\% com deficiência motora, $16 \%$ com deficiência auditiva, 9\% deficiência mental e $4 \%$ deficiência física.

Para o consumidor surdo é fundamental que a empresa tenha um processo de comunicação diferenciado, em especial, no que tange às propagandas. Segundo Limeira (2010), uma das tarefas do marketing é o processo de comunicação, a explanação de um produto e que este agrade o consumidor, e esta comunicação deve ser de maneira completa, que apresente o produto e que convença seu público. A comunicação integrada tem como objetivos de fixar o produto na mente do consumidor, apresentar o produto com uma mensagem única, mas consistente, que seja compreendida, de marca diferenciada, que "ofereça ao consumidor informações e incentivos e que convença o consumidor a adquirir aquele produto ou os serviços de 
determinada empresa e ao mesmo tempo, que gere iniciativas para as empresas conhecerem seu público". (LIMEIRA, 2010, p. 272.). No caso do consumidor surdo é preciso apresentar os produtos visualmente, com informações visíveis, que possam ser tocadas e sentidas de todas as maneiras, para um real conhecimento do produto antes de ser adquirido. O surdo não tendo o canal auditivo para obter as informações faladas nas propagandas, precisará obtê-las por meio dos outros canais sensoriais, como o visual, o tato, o olfato ou o paladar e o profissional de marketing através da propaganda deve levar em conta esse diferencial e promover a este público maneiras de que as informações cheguem até estes consumidores.

Neste contexto, o presente artigo tem como objetivo analisar o comportamento do consumidor surdo e suas opiniões sobre as propagandas veiculadas na televisão e na internet.

Sabe-se que muitas das informações importantes que constam nas propagandas na televisão são faladas, ou quando aparecem em imagens, como por exemplo, valores e prazos de pagamento, aparecem soltas, como informações perdidas. Sendo assim, como é possível que o surdo entenda o contexto da mensagem que a empresa está querendo passar?. O consumidor é dotado de personalidade, percepções e motivações, apresentando necessidades e desejos. Mas, com propagandas ilegíveis para o surdo é possível despertar seu desejo por algum produto ou serviço?. Os consumidores precisam de informações para realizarem escolhas entre produtos e serviços similares, mas como o surdo vai diferenciar um do outro e saber qual tem o melhor custo-benefício se ele não tem acesso às informações apresentadas na televisão ou nos meios digitais? Assim sendo, é importante pesquisar se há acessibilidade nas propagandas de produtos e serviços para os consumidores surdos. O tema proposto neste artigo é de extrema relevância, pois busca investigar o comportamento e opinião do consumidor surdo diante de propagandas veiculadas na forma tradicional, que podem não ser totalmente compreendidas pelo consumidor com algum tipo de deficiência.

Com o intuito de viabilizar a análise de dados foram elencados conceitos relevantes para a pesquisa apresentando um referencial teórico sobre a identidade e cultura surda, comportamento do consumidor e composto de comunicação. Apresenta-se a metodologia do artigo e a apresentação dos dados da pesquisa, que permitem as considerações finais.

\section{REFERENCIAL TEÓRICO}

Este item apresenta conceitos sobre a temática, apresentando o embasamento legal, as ideias e conclusões de autores sobre o sujeito surdo, buscando compreender o comportamento de compra destes consumidores e o que é importante para que as propagandas, realizadas pelas empresas, sejam acessíveis. Após, é necessário entender sobre a comunicação em marketing, como ela se estrutura e o que os autores relatam sobre a propaganda para o sujeito surdo. Cabe ressaltar a importância das tecnologias digitais que podem ser utilizadas como ferramentas de intervenção na comunicação com os surdos, tendo em vista que os mesmos estão inseridos em um mundo visual.

\subsection{COMPORTAMENTO DO CONSUMIDOR}

Conforme Karsaklian (2009, p.20) "o estudo de comportamentos de consumo é uma ciência aplicada que tem por objetivo compreender os comportamentos de consumo adotando uma perspectiva pluridisciplinar", sendo fator importante na definição de estratégias eficazes para a empresa. Segundo a autora o "ser consumidor" é uma parte do ser humano, pois ser consumidor é alimentar-se, vestir-se, divertir-se, resumindo, ser consumidor é viver. Assim, o consumidor tem suas preferências, suas motivações e busca determinadas conquistas e resultados para conquistar seu espaço e alcançar a realização profissional e pessoal.

Segundo Karsaklian (2009), o ponto de partida do ato de compra é a necessidade, que conduzirá a uma motivação, a qual despertará o desejo. Com base nesse desejo, nascem as preferências por formas de atender a motivação inicial, que estarão relacionadas ao autoconceito, que seria a tendência em escolher um produto que corresponda ao conceito que ele gostaria de ter de si mesmo. Em sentido oposto à motivação, surgem os freios, que são a consciência de risco relacionada ao produto. Entre a motivação e os freios, impõe-se a personalidade, a qual desembocará no 
autoconceito. A soma de todas essas variáveis resultará na percepção sobre os produtos, que desencadeará atitudes positivas ou negativas com relação a eles, e na efetivação ou não da compra. Segundo Mowen (2010) afirmam que o comportamento do consumidor envolve a análise de unidades que compram através do processo de troca na aquisição, consumo e disponibilidade de mercadorias, serviços, experiências e ideias. $\mathrm{Na}$ visão de Schiffman (2015, p. 1), o comportamento do consumidor focaliza como os indivíduos tomam decisões para utilizar seus recursos disponíveis (tempo, dinheiro, esforço) em itens relativos ao consumo. Isso incluem o que eles compram, por que compram, quando compram, onde compram, com que frequência compram, quantas vezes usam o que compram, como avaliam o que compram após a compra, o impacto dessas avaliações em futuras compras e como se desfazem do que compram.

\subsubsection{FATORES QUE INFLUENCIAM COMPORTAMENTO DO CONSUMIDOR}

O profissional de marketing precisa conhecer os tipos de clientes e considerar que inúmeros fatores influenciam a maneira que faz o consumidor tomar suas decisões de compra, fatores que se somam ou se excluem para gerar uma escolha do cliente pelos produtos e serviços oferecidos. São esses: os fatores culturais, o contexto do mercado, os determinantes sociais, as condições pessoais, as características psicológicas das pessoas e a estrutura de poder. Os fatores culturais são os valores e crenças criados pela sociedade, passado de geração a geração no ambiente familiar e reforçado pela escola e pela religião. Segundo Karsaklian (2009, p. 271) "a cultura é a programação mental e coletiva das pessoas num contexto específico". As mudanças culturais afetam a vida do consumidor e a tecnologia promove a disseminação destas mudanças, como culto à saúde e beleza física, informalidade no vestir, uso da internet para compra e lazer, mais autonomia para as crianças e adolescentes e a participação da mulher nas decisões de compra, unindo-se a real situação de mercado em que se encontra nosso país. Mudanças ocorreram referentes ao mercado dos negócios como, foco no cliente, mercados globalizados, consciência da empresa em sua responsabilidade social e em sua atividade fim, levando a empresa a buscar estratégias para alcançar seus objetivos e servir ao seu cliente. (BRETZKE, 2000, p.54).

O fator econômico altera o contexto de mercado, a situação de emprego e salários, a disponibilidade de crédito para consumo e a oferta de produtos atingem o comportamento do cliente para as compras. Segundo Bretzke (2000, p.52) "quanto mais o povo recebe, mais poderá comprar". Ainda conforme Bretzke (2000) os fatores sociais são decisórios nas escolhas do cliente. As pessoas são influenciadas pelo contexto em que vivem, são criados hábitos de compra, sempre vinculados a um ponto de referência, como por exemplo, na infância a família e os colegas de aula, e na vida adulta o meio de trabalho. Assim as pessoas formam seu comportamento consumidor. Os fatores pessoais influenciam o comportamento do cliente, como a idade e ciclo de vida, situação econômica e estilo de vida. Algumas mudanças de hábitos, expectativas de vida e novas metas, fazem com que as pessoas mudem seu jeito de ser consumidor. Os fatores psicológicos e a personalidade de cada pessoa também influenciam o comportamento do mercado consumidor. Segundo Bretzke (2000), alguns fatores psicológicos são importantes de serem estudados para compreenderem o comportamento do cliente, como por exemplo, a motivação que é o impulso que leva a pessoa a agir e buscar sua satisfação. Outros fatores importantes no processo de decisão de marketing são a percepção e a atitude. A percepção é o processo das pessoas prestarem atenção aos estímulos de marketing e do meio ambiente e agir influenciados por eles, ou seja, é o processo de selecionar, organizar e interpretar informações para formar uma imagem do mundo. Já a atitude com relação a um produto, serviço ou marca, é a avaliação positiva ou negativa, que o cliente faz de produtos ou serviços. (BRETZKE, 2000, p. 76). Ainda conforme o autor, esses fatores, além de influenciarem significativamente $\mathrm{o}$ consumidor, são difíceis de serem modificados. Um dos maiores desafios do marketing é desenvolver estratégias na comunicação e aceitação do produto a ser oferecido ao consumidor com diferentes características pessoais, emocionais e culturais. 


\subsection{O PROCESSO DE COMUNICAÇÃO DE MARKETING}

Segundo Kotler e Armstrong (2007) a comunicação em marketing é assunto relevante e complexo, sendo um desafio para os profissionais da área de marketing, pois envolve diversos e diferentes itens, que apresentam um caráter sistêmico e que estão em constante evolução, especialmente pelo surgimento de novas formas de comunicação advindas dos avanços da tecnologia da informação e do comportamento, cada vez mais, mutante dos consumidores. Segundo Kotler (2009), o processo de comunicação tem início pelo emissor, que é quem escolhe o código para expressar sua mensagem, dirigida ao receptor, que, por sua vez, descodifica a mensagem. O receptor dará uma resposta ao emissor, ou seja, o feedback. Os ruídos, ou seja, elementos imprevistos e fora do controle do emissor, poderão intervir neste processo, reduzindo a eficácia da comunicação.

Shimp (2009) o processo de comunicação abrange o planejamento, a criação, a integração e a implementação de diversas formas de comunicação (publicidade, promoção de vendas, eventos, etc.) que são lançadas ao longo do tempo para os clientes ou clientes potenciais almejados de uma marca. Crescitelli e Shimp (2012, p. 7) ressaltam a importância da comunicação de marketing, apontando-a como um aspecto fundamental da missão geral de marketing e um dos principais determinantes do sucesso de uma marca. Os autores definem a comunicação de marketing como "o conjunto de todos os elementos no mix de marketing de uma marca que facilitam trocas ao estabelecer significado compartilhado com os clientes daquela marca." A comunicação é tida como parte fundamental da estratégia de uma empresa. Kotler e Keller (2012, p. 512) reforçam o papel central da comunicação de marketing, afirmando que esta "[...] representa a voz da empresa e de suas marcas; é o meio pelo qual ela estabelece um diálogo com seus consumidores e constrói relacionamentos."Nesse sentido, o gestor deverá acompanhar o processo de comunicação, tentando evitar os ruídos e escolhendo os melhores métodos para que o receptor, ou seja, o consumidor, receba a informação corretamente, estimulando-o a comprar o produto ou serviço.

\subsubsection{COMPOSTO DE COMUNICAÇÃO}

Para Ogden (2007), o composto de Comunicação Integrada de Marketing é formado por seis elementos básicos: propaganda, promoção de vendas, venda pessoal, relações públicas e publicidade, marketing direto e marketing digital. Uma das principais funções da comunicação de marketing é a formação de imagem da marca, que pode ser entendida segundo Limeira (2000, p.274) "como o conjunto de percepções, crenças, ideias e associações cognitivas ou afetivas que uma pessoa tem sobre um produto". Essas percepções condicionam suas atitudes e o comportamento do consumidor que irá adquirir um produto que se identifique consigo mesmo e com a imagem que pretende transmitir aos outros. A forma que o produto é apresentado transmite significados, demonstra a identidade da pessoa e transfere a imagem da marca para o consumidor. Algumas atividades integram o composto de comunicação de marketing e proporcionam mais informações ao cliente que são: propaganda, promoção de vendas, vendas, marketing direto, relações públicas, publicidade ou assessoria de imprensa, promoção de eventos, merchandising e comunicação no ponto de venda, atendimento ao cliente, comunicação pela internet e embalagem.

Segundo o mesmo autor, a propaganda é uma forma de comunicação paga, possui um patrocinador, é dirigida a um público definido e veiculada por mídia de massa que procura estimular a aquisição do produto. A promoção de vendas é uma ferramenta de marketing que promove a oferta de incentivos de curto prazo por um patrocinador identificado, com ou sem o apoio da propaganda que estimule a aquisição do produto, através de ofertas como brindes, descontos, prêmios e bonificações. Já a venda é a forma de comunicação persuasiva e interativa, realizada por meio do contato pessoal. O marketing direto é o conjunto de atividades de comunicação impessoal e direta entre a empresa e o cliente. As relações públicas são os chamados stakeholders, que visam criar atitude favorável em relação a empresa e ao que ela comercializa. A publicidade se refere, a divulgação, sem custos adicionais, de informações sobre as atividades da empresa. Além disso, o composto de marketing envolve a assessoria de imprensa, a promoção de eventos, o merchandising e comunicação no 
ponto de venda que são formas de comunicar e expor os produtos que estão a venda. Outros fatores importantes para o composto de marketing são o atendimento ao cliente propriamente dito, as formas de comunicação pela internet e a embalagem dos produtos.

\subsubsection{A PROPAGANDA: CONCEITO E CARACTERÍSTICAS E MIIDIAS}

Conforme Limeira (2000, p. 284) "a propaganda é a comunicação impessoal de uma mensagem dirigida ao público-alvo do produto, paga por um patrocinador identificado, veiculada em meios de comunicação de massa ou dirigidos, que visa a criar imagem e estimular a aquisição do produto." Para Limeira (2000) para se ter eficácia com a veiculação das propagandas, todas as peças da campanha devem estar integradas e conter os mesmos elementos centrais da ideia criativa. Entre os requisitos para uma propaganda eficaz o autor apresenta as seguintes características: chamar a atenção, ter uma única ideia central, ser relevante, diferenciada e envolvente, ser percebida como entretenimento, gerar emoção e o desejo de comprar o produto, criar uma personalidade diferenciada para a marca, poder ser repetida ao longo do tempo e apresentar com clareza os benefícios do produto, convencer que os benefícios serão alcançados e diferenciar $\mathrm{o}$ produto em relação à concorrência. Para o autor, é a partir da definição da estratégia de conteúdo definida pela empresa é que poderá ser elaborada a propaganda. Para criar uma propaganda, o administrador de marketing de ter com clareza as respostas para os seguintes questionamentos: quem é 0 publico-alvo da mensagem; o que o públicoalvo deve saber e sentir sobre o produto; por que o público deve saber e sentir dessa maneira e qual a forma mais eficaz de comunicação com o público-alvo?

Tomando por base os objetivos da comunicação cada empresa estabelece a forma como as informações vão ser veiculadas, pensando sempre na melhor alternativa para atingir o público em potencial. Conforme Limeira (2000) para definir o tipo de mídia a ser utilizada é necessário conhecer o público-alvo e saber qual é seu comportamento de consumo, para assim definir qual será o possível impacto de cada uma das mídias que podem ser utilizadas. Ainda segundo o autor, para veiculação das propagandas o administrador de marketing pode optar entre os tipos de mídia: televisão, rádio, revistas, jornais, internet, outdoors, mala direta.

\subsection{O CONSUMIDOR SURDO E SEU PROCESSO DE COMUNICAÇÃO}

Neste item são apresentados aspectos relativos a identidade, cultura e processo de comunicação para o consumidor surdo.

\subsubsection{CONSUMIDOR SURDO: IDENTIDADE E CULTURA}

Os estudos sobre a surdez mostram a importância da cultura para o sujeito construir sua própria identidade e se estabelecer como indivíduo na sociedade e a questão de sua escolarização que devem estar incluídos num contexto crítico relacionado à situação linguística, social, comunitária e cultural. Pois os surdos "têm características culturais que marcam seu jeito de ver, sentir e se relacionar com o mundo, e a cultura do povo é visual". (QUADROS, 2002, p.10).

Conforme Skliar (1998, p.11), "a cultura surda é toda voltada ao visual". As crianças surdas têm certo grau de dificuldade em relação à compreensão das metáforas e as várias significações que uma palavra pode expressar. Assim, o trabalho com a língua de sinais é fundamental para entenderem e compreenderem textos escritos em português. A constituição da identidade é outra peculiaridade do povo surdo, uma vez que a mesma "[...] se constrói dentro de uma cultura visual, essa diferença precisa ser entendida não como uma construção isolada, mas como construção multicultural" (SKLIAR, 1998, p. 57)

O surdo tem como sua primeira língua (língua materna) a Libras, e a leitura para ele só teria significado pleno na sua língua. Mesmo sabendo o português, ao ler vai ter de associar a palavra ao sinal em Libras. De acordo com Santana (2007), a língua de sinais, além da importância para a aprendizagem do escrito e da leitura, permite uma mediação com o pensamento.

Para ler ou para escrever, é necessário ter uma língua para fazer a mediação. (...) $\mathrm{Na}$ surdez, esse significado poderia ser transmitido pela língua de sinais. O surdo lê uma palavra escrita em português e atribuiIhe sentido pela língua de sinais. Há 
momentos em que ele não consegue compreender as palavras escritas, mas, como o leitor ouvinte, o surdo pode ler algumas palavras, deixar de ler outras, e com base nas que reconhece atribuir um sentido ao texto. (SANTANA, 2007, p.195).

\subsubsection{ACESSIBILIDADE DO CONSUMIDOR SURDO NO PROCESSO DE COMUNICAÇÃO}

O campo de marketing encontra na comunidade surda uma possibilidade de produção de consumidores, e assim se volta a pensar em estratégias específicas, como o uso da Libras, para anunciar e vender, por meio de argumentos emotivos que impulsionam desejos de consumir. Assim, as empresas devem ter o interesse de persuadir e convencer, ou seja, de influir no comportamento da comunidade surda consumidora. Segundo Sant'Anna (2009, p.80) "quanto mais conhecermos o valor das palavras, as necessidades, os desejos e impulsos humanos e as emoções que desencadeiam, mais saberemos sobre a técnica de persuasão e seu modo de operar". Assim, utiliza-se da língua de sinais com um diferencial que agrega valores da comunidade surda, qual seja sua língua e sua experiência visual, para atingir objetivos de consumo.

A linguagem é fundamental para a comunicação, possibilitando a construção da mensagem a ser falada e, conforme Reichert (2006) os surdos acessam as informações das propagandas e programas de televisão pela intermediação de um ouvinte e pela leitura de imagens que não são a eles endereçadas. Ellsworth (2001), em sua pesquisa relata sobre o cinema, mas podemos comparar os resultados também para programas da televisão brasileira, onde as produções não são endereçadas ao surdo. Segundo a autora, o surdo teria que estar em uma posição que contemplasse as expectativas de uma produção televisiva no sentindo de compartilhar seu significado e a linguagem é fundamental nesse processo. $\mathrm{Na}$ programação direcionada ao ouvinte é como se o surdo tivesse sua subjetividade recortada, numa narrativa que não foi feita para ele e que the dá poucas condições de acessar o seu conteúdo.

Conforme Reichert (2006) o surdo não acessa as mensagens sonoras da televisão, e como no som estão contidas informações as quais ele não toma conhecimento, sua leitura e interpretação se dá pelas imagens, pelos movimentos das cenas e pelas luzes que se modificam conforme a mensagem que querem transmitir.

Ainda segundo o autor, a dependência na tradução das informações sonoras prejudica o entendimento da mensagem, tendo em vista que o ouvinte tende a resumir a informação no momento de repassar ao surdo. $O$ direito a ter acesso à comunicação, passa pelo direito de qualidade do acesso. Barbero (2004), ao escrever que o ver se transforma em um paradigma conceitual, nos faz pensar que passa pelo direito surdo a diminuição da distância entre comunicação e democracia, ou seja, é de direito do surdo ter acesso ao que é informado pela mídia.

Ter acesso ao que é veiculado em língua portuguesa possibilita não só o acesso às informações, mas também a participação social e política surda.

\subsubsection{PROPAGANDA PARA O SUJEITO SURDO}

No momento de fazer uma propaganda acessível ao consumidor surdo deve-se pensar nos processos de comunicação e como a mesma pode se tornar atrativa ao consumidor despertando seu desejo. Conforme Canclini (2008, p. 62) "os produtores e emissores não só devem seduzir os destinatários, mas também justiçar-se racionalmente". Conforme Canclini (2008, p.70), "nós seres humanos, intercambiamos objetos para satisfazer necessidades que fixamos culturalmente", para integrarmo-nos com outros e para nos distinguirmos de longe, para realizar desejos e para pensar nossa situação no mundo, para controlar o fluxo errático dos desejos e dar-Ihe constância ou segurança em instituições e rituais. Compreende-se que os surdos são convidados, seduzidos a incluir-se nesse universo de consumo, sentindo a necessidade e o desejo de estar conectado a esta sociedade consumidora, na qual a propaganda cria estratégias para vender ideias, persuadir e convencer um novo público.

Segundo Sant'Anna (2009, p.80) "quanto mais conhecermos o valor das palavras, as necessidades, os desejos e impulsos humanos e as emoções que desencadeiam, mais saberemos sobre a técnica de persuasão e seu modo de operar", ou seja, 
hoje a publicidade procura atingir o seu consumidor-alvo estimulando suas emoções, atendendo as suas necessidades e respondendo a seus anseios. Assim, utiliza-se da Libras como um diferencial que agrega valores da comunidade surda, qual seja sua língua e sua experiência visual, para atingir objetivos de consumo.

Para atingir as pessoas surdas com o conteúdo da propaganda é muito importante reconhecer a diferenças lingüísticas e culturais do sujeito surdo, assim como diz Gesser (2009):

A língua de sinais tem todas as características lingüísticas de qualquer língua humana natural. É necessário que nós, indivíduos de uma cultura de língua oral, entendamos que o canal comunicativo diferente (visual-gestual) que o surdo usa para se comunicar não anula a existência de uma língua tão natural, complexa e genuína como é a língua de sinais (GESSER, 2009, p. 21-22)

Quando a propaganda não apresenta legenda ou tradução em Libras, a mensagem a ser passada fica de difícil compreensão para a pessoa surda. Conforme Reichert (2006) parte sonora que traz o diálogo, os comentários, e as explicações fica de difícil ou impossível acesso para as pessoas surdas ocasionando uma leitura "incompleta", "fragmentada" e ou "inexistente" das informações. Ainda conforme o autor, diante dos diferentes programas televisivos os surdos que possuem maior conhecimento do português escrito e maior habilidade de leitura, preferem o uso da legenda. Já os surdos que não possuem maior intimidade com o português preferem assistir aos programas que possuem intérprete de Libras fazendo a tradução.

Geralmente nos comerciais aparecem palavras soltas, como por exemplo, marcas de roupas, carros, perfume entre outros e, sem legenda ou tradução em Libras, os surdos precisam tentar captar a mensagem no contexto das imagens e movimentos. Para permitir a acessibilidade é importante que as propagandas tenham legenda ou interpretação em Libras. A acessibilidade na mídia está garantida no artigo 19 da Lei 10098/2000, que diz que os serviços de radiodifusão sonora e de sons e imagens adotarão plano de medidas técnicas com o objetivo de permitir o uso da linguagem de sinais ou outra subtitulação, para garantir o direito de acesso à informação às pessoas portadoras de deficiência auditiva. Assim, cabe às empresas estabelecer estratégias de acessibilidade ao consumidor surdo.

Uma ferramenta que pode ser utilizada na intervenção com o surdo é o vídeo, apresentando as informações em Libras. A tradução do texto escrito na língua oficial do país para um vídeo com a tradução na Língua de Sinais, representa a possibilidade para muitos surdos de acessar informações. Assim como os vídeos, o computador é outra ferramenta importantíssima para o surdo, bem como para pessoas com outras deficiências. Conforme Perlin e Miranda (2003, p.218) "a experiência visual significa a utilização da visão, (em substituição total a audição), como meio de comunicação". Desta experiência visual surge a cultura surda representada pela língua de sinais, pelo modo diferente de ser, de se expressar, de conhecer o mundo, de entrar nas artes, no conhecimento científico e acadêmico.

Assim, é estratégico usar as tecnologias digitais como alternativas na apresentação de informações sobre os produtos para os consumidores surdos. As imagens vêm ganhando lugar de destaque nessa sociedade e as interfaces gráficas estão predominando cada vez mais por meio das câmeras fotográficas, vídeos, televisão, telas de computadores, celulares, smartphones e tablets. Destaca-se que "nas últimas décadas esta forma de letramento começa a se diversificar dando espaço para outras formas de linguagem: as imagéticas, sensoriais em geral, sonoro e digital que estão presentes nas tecnologias da informação e comunicação". (SILVA. et al., p. 215, 2013). Enfatizando a percepção das imagens como linguagem, é importante estimular a relação entre os surdos e as tecnologias digitais. Para o surdo as informações passados em língua oral tornamse de difícil compreensão. Segundo Silva et al (2013, p.233, in VALLE, 2013) a utilização de imagens e da língua oficial do surdo, através das novas tecnologias, vão contribuir para a interpretação do surdo sendo uma forma de atraí-lo, fazendo com que ele tenha acesso as informações e com isso despertar e atender seus desejos.

\section{METODOLOGIA}

3.1 CLASSIFICAÇÃO DA PESQUISA: quanto a abordagem do tema e objetivos da pesquisa classifica-se como quantitativa e exploratória. 
A pesquisa quantitativa, segundo Samara (2007, p.50), "busca uma análise das relações de consumo, respondendo à questão da quantidade, sendo estes resultados analisados e interpretados a partir de médias e percentuais das respostas obtidas". Para Malhotra (2006, p.98 ) a pesquisa exploratória "é um tipo de pesquisa que tem como principal objetivo ajudar a compreender a situação-problema enfrentada pelo pesquisador" e, (...) "as características desta pesquisa são que as informações necessárias são fornecidas apenas de forma muito ampla, a amostra é simples e nãorepresentativa". Quanto ao procedimento técnico, foi utilizado o levantamento de campo, através da aplicação de questionários.

\subsection{PLANO DE AMOSTRAGEM: o processo} de elaboração de uma amostragem inclui cinco estágios que estão relacionados e são relevantes para todos os aspectos do projeto de pesquisa de marketing. Estas fases são: definição da população-alvo e da composição da amostra, a escolha das técnicas da amostragem, determinar o tamanho da amostra e a execução do processo da amostra. (MALHOTRA, 2006, p.320).

\subsubsection{DEFINIÇÃO DO PÚBLICO-ALVO: nesta} pesquisa a população é formada por consumidores surdos de Erechim e Passo Fundo. Segundo dados da Associação dos Surdos do Alto Uruguai em Erechim existem em torno de 55 surdos cadastrados. Já em Passo Fundo, segundo a Associação dos Surdos de Passo Fundo, possui em torno de 70 surdos. Assim, a população deste estudo é de 125 surdos. O público-alvo são os consumidores surdos, homens e mulheres, a partir de 15 anos. 3.2.2 Determinação do Tamanho da Amostra: pesquisou-se uma amostra de 55 consumidores surdos selecionados dentre o público-alvo definido para o estudo.

\subsubsection{DETERMINAÇÃO DO TAMANHO DA} AMOSTRA: pesquisou-se uma amostra de 55 consumidores surdos selecionados dentre 0 público-alvo definido para o estudo.

\subsubsection{TÉCNICA DE AMOSTRAGEM: para a} escolha da técnica de amostragem, o pesquisador precisa decidir a abordagem utilizada, se amostragem probabilística ou não-probabilística. Nesta pesquisa utilizou-se a amostragem não-probabilística que "é uma técnica de amostragem de conveniência, confia no julgamento pessoal do pesquisador, pode oferecer boas estimativas das características da população, mas não permitem uma avaliação objetiva da precisão dos resultados amostrais". (MALHOTRA, 2006, p. 325). Justifica-se o uso da nãoprobabilística tendo em vista que não foi possível uma definição precisa da populaçãoalvo, o que não invalida o estudo, entretanto, não permite generalizações das respostas da amostragem para o todo populacional.

\subsection{INSTRUMENTO DE COLETA DE DADOS:} o instrumento de coleta de dados é um questionário, composto por três módulos, buscando informações referentes ao perfil do consumidor (módulo I), aos hábitos que podem levar a decisão de compra (módulo II) e às questões relacionadas à acessibilidade das propagandas (módulo III). Foram elaboradas perguntas dicotômicas e de múltipla escolha.

3.4 PLANO DE ANÁLISE DOS DADOS: OS dados do questionário da pesquisa descritiva serão analisados de forma quantitativa. Neste caso, os dados foram sistematizados em tabela excell, (calc) e as informações relacionadas com as teorias relativas ao comportamento de compra do consumidor surdo e composto de comunicação (propaganda).

\section{ANÁLISE DOS RESULTADOS}

Com a finalidade de atingir os objetivos propostos pelo artigo, são apresentados e analisados os dados obtidos, relacionados ao perfil dos consumidores surdos, hábitos de compra e opiniões sobre as propagandas veiculadas televisão e internet.

\subsection{PERFIL DOS ENTREVISTADOS SURDOS}

a) Perfil geográfico: $73 \%$ dos participantes da pesquisa moram em Erechim e $27 \%$ em Passo Fundo. Destes, 34\% moram na área central destas cidades e 63\% dos entrevistados moram em diferentes bairros da área urbana e somente $2 \%$ moram no meio rural. 
b) Perfil demográfico e socioeconômico: $59 \%$ são do sexo masculino e $41 \%$ são do sexo feminino; $54 \%$ dos entrevistados são jovens na faixa etária dos 15 a 24 anos, 24\% são adultos de 25 a 34 anos, 20\% estão na faixa etária dos 35 aos 44 anos e apenas um participante tem entre 45 e 54 anos; $63 \%$ dos entrevistados são solteiros, $17 \%$ são casados e $17 \%$ vivem em união estável, sendo $2 \%$ viúvos. Com relação à escolarização dos entrevistados pode-se constatar que 90\% possuem Ensino Médio Completo, 27\% estão cursando o Ensino Superior, 2\% possuem o Ensino Superior completo e 15\% estão cursando ou já concluíram cursos de PósGraduação. Estes dados relevantes, pois o grau de escolarização influência diretamente a compreensão do português. Outro fator importante na identificação do perfil dos consumidores é a identificação se os surdos estão inseridos no mundo do trabalho. Constatou-se que $56 \%$ dos entrevistados estão trabalhando, em atividades como indústria (20\%), setor público (17\%), comércio (10\%), prestação de serviço (10\%), estudantes (15\%), desempregados (15\%), os demais são aposentados ou dedicam-se aos afazeres domésticos. Em relação ao convício familiar, observou-se que $34 \%$ dos entrevistados moram com mais duas pessoas, $27 \%$ moram com três pessoas, $20 \%$ moram com mais de três pessoas, $17 \%$ e somente $2 \%$ moram sozinhas. Com relação a filhos, $80 \%$ dos entrevistados não têm filhos, 10\% tem um filho e $10 \%$ tem dois filhos.

\subsection{HÁBITOS DE COMPRA E DIFICULDADES NO PROCESSO DE COMUNICAÇÃO DO CONSUMIDOR SURDO}

Quanto aos hábitos de compras foram solicitadas informações sobre compras em internet e lojas físicas, os veículos de comunicações utilizados e as principais dificuldades na comunicação.

\subsubsection{HÁBITOS DE COMPRA EM LOJAS} FÍSICAS E INTERNET: Os dados apontam que $39 \%$ dos entrevistados nunca compraram pela internet, $34 \%$ compram raramente e $27 \%$ tem como hábito fazer compras pela internet. Dentre os produtos mais comprados destacam-se os eletrônicos (52\%), materiais esportivos (36\%), livros (28\%), CD e DVD $(28 \%)$ e roupas e calçados (16\%). Dos entrevistados que não possuem o hábito de comprar pela internet, a maioria deles, $74 \%$, afirmaram que não realizam a compra por não confiarem nos sites, 23\% responderam que não entendem o boleto ou como usar o cartão e $10 \%$ não entendem as informações disponibilizadas em português. Com relação ao local onde os entrevistados buscam informações sobre os produtos e serviços, constatou-se que $69 \%$ fazem a pesquisa no Google, $41 \%$ no site da empresa, $13 \%$ no Faceboook da empresa e apenas 3\% nos blogs. Na sequência, buscou-se identificar quais são os produtos mais procurados em compras realizadas diretamente nas lojas: roupas (47\%), materiais esportivos (29\%) e os produtos eletrônicos (24\%) e calçados (24\%). O que chama a atenção na apresentação destes dados é que os consumidores procuram mais os produtos eletrônicos na internet do que nas lojas. Com relação a forma de pagamento, a maioria dos consumidores surdos relataram pagar em dinheiro, totalizando $60 \%$ dos entrevistados, $38 \%$ realizam o pagamento com cartão, $18 \%$ no crediário e 15\% com boleto bancário. Dente os veículos de comunicação mais utilizados, percebeu-se que $68 \%$ dos participantes da pesquisa buscam informações na internet, 32\% na televisão, $12 \%$ em revistas e 10\% em jornais. Quando compram em lojas os surdos de comunicam de diferentes formas sendo que $61 \%$, escrevem em um papel o que eles gostariam e mostram para o vendedor, $37 \%$ fazem leitura labial, $20 \%$ tenta se comunicar em LIBRAS, $15 \%$ mostram na prateleira o produto que querem e alguns entrevistados, $7 \%$, declararam não conseguir se comunicar. Quanto as principais dificuldades que o consumidor surdo enfrenta no momento da compra, constatou-se que $33 \%$ não conseguem entender como funciona 0 produto, 33\% não entendem as formas de pagamento, $26 \%$ não sabem o preço certo do produto ou serviço e $10 \%$ encontram outras dificuldades

\subsection{O PROCESSO DE COMUNICAÇÃO PARA O CONSUMIDOR SURDO}

Neste item o objetivo foi identificar questões relacionadas a acessibilidade nas propagandas pelo surdo, investigado-se a percepção dos consumidores surdos sobre as propagandas veiculadas em televisão e internet. 


\subsubsection{ACESSIBILIDADE E DIFICULDADES NAS PROPAGANDAS VEICULADAS NA INTERNET E NA TELEVISÃO}

Os dados da pesquisa permitem constatar que para $63 \%$ dos consumidores surdos as propagandas na televisão não são acessíveis, já com relação a acessibilidade das informações sobre os produtos e serviços disponíveis na internet, $77 \%$ consideram que as informações estão acessíveis.

Um número expressivo de consumidores consideram que as propagandas na televisão não são acessíveis e dentre as principais dificuldades apontadas pelos consumidores surdos, estão: $39 \%$ que quando a propaganda tem legendas estas são muito rápidas, dificultando a compreensão; 27\% apontaram como dificuldade a falta de legenda, 24\% apresentaram a limitação de não ter informações em LIBRAS, 24\% disseram que têm poucas informações visuais e $17 \%$ afirmaram que, mesmo com a função closed caption ativada, faltam palavras o que impossibilita a compreensão. Nesse ponto é importante ressaltar o que foi dito por Skliar (1998, p.11), "a cultura surda é toda voltada ao visual". Assim, o trabalho com a língua de sinais é fundamental para entenderem e compreenderem textos escritos em português. É importante ressaltar que o surdo tem como sua primeira língua a Libras, e a leitura para ele só teria significado pleno na sua língua. Mesmo sabendo o português, ao ler vai ter de associar a palavra ao sinal em Libras. De acordo com Santana (2007), a língua de sinais, além da importância para a aprendizagem do escrito e da leitura, permite uma mediação com o pensamento.

Com relação as dificuldades encontradas na acessibilidade nas propagandas na internet, verificou-se que $42 \%$ dos participantes da pesquisa disseram não saber se as informações dos sites são seguras, 34\% que são usadas palavras muito difíceis, o que dificulta a compreensão, 13\% ter dificuldade em encontrar sites de compra e $13 \%$ relataram ter dificuldades em entender as formas de pagamento pela internet.

Para que se possa pensar em estratégias de como fazer uma propaganda acessível, é imprescindível conhecer as necessidades dos consumidores surdos e também é muito importante saber como o servidor gostaria que a propaganda fosse para que ele tivesse mais facilidade de compreender as informações. Neste ponto, 63\% dos participantes destacaram que as propagandas deveriam ter legenda, igual nos filmes, 44\% gostariam que tivesse a tradução em Libras, com a janela na lateral da tela, $15 \%$ gostariam do closed caption e $15 \%$ que as propagandas tivessem mais imagens e desenhos. Esses resultados vão ao encontro do que foi dito por Reichert (2006) que afirma que quando a propaganda não apresenta legenda ou tradução em Libras, a mensagem a ser passada fica de difícil compreensão para a pessoa surda. Para o referido autor, o surdo não acessa as mensagens sonoras da televisão, e como no som estão contidas informações as quais ele não toma conhecimento, sua leitura e interpretação se dão pelas imagens, pelos movimentos das cenas e pelas luzes que se modificam conforme a mensagem que querem transmitir.

\subsection{FATORES DA COMUNICAÇÃO QUE INFLUENCIAM NA DECISÃO DE COMPRA DO CONSUMIDOR SURDO}

Com relação aos fatores que influenciam a decisão de compras na internet, 68\% dizem que preferem comprar quando tem vídeo ou imagem que mostra e explica como usar o produto, 20\% quando mostra preço e como pode fazer o pagamento, $18 \%$ quando usa palavras simples em português e $15 \%$ disseram que a utilização de imagens influencia na decisão de compra. Esses resultados demonstram como é importante para os surdos a exploração das questões visuais, pois, conforme afirmado por Quadros (2002, p. 10) os surdos "têm características culturais que marcam seu jeito de ver, sentir e se relacionar com o mundo, e a cultura do povo é visual". Os consumidores surdos foram questionados se comprariam produtos porque a propaganda na televisão ou internet está expressa em Libras ou tem legendas. Neste caso, 53\% afirmaram que consideram a propaganda acessível um diferencial da empresa e que isso faria diferença na escolha do produto.

Com a apresentação e análise dos dados pode-se perceber a importância de identificar quais são as necessidades do consumidor surdo para que ele tenha acesso às informações que a empresa está querendo passar sobre seus produtos. Além disso, destaca-se a relevância da linguagem para a comunicação, pois é através do domínio da língua que o ser humano tem a possibilidade de construir e interpretar as mensagens. 


\section{CONSIDERAÇÕES FINAIS}

Percebe-se que as campanhas publicitárias de produtos e serviços, em sua grande maioria, utilizam como forma de divulgação das informações, propagandas faladas, utilizando para isso a língua portuguesa, não apresentando legenda. Com a situação exposta, a pessoa surda, que não ouve a mensagem que está sendo veiculada, não terá acesso às informações que estão sendo divulgadas $e$, consequentemente, não terá conhecimento sobre o produto ou serviço que está sendo apresentado. O surdo, assim como todas as pessoas, tem necessidades e desejos a serem satisfeitos, no entanto, eles não têm acesso às informações faladas, mas sim, se comunicam através da Língua Brasileira de Sinais (LIBRAS), sendo possível também que eles entendam o contexto de uma informação escrita em português, considerando que a comunicação para o surdo é espaço-visual.

Com a realização do estudo pode-se perceber a importância dos profissionais da área de marketing terem uma atenção diferenciada para 0 atendimento das necessidades dos consumidores surdos, pois, conforme Limeira (2000), o marketing deve criar valor para o cliente e gerar vantagem competitiva duradoura para a empresa. Para criar valor para o cliente a empresa precisa conhecer o perfil do consumidor, e no caso do consumidor surdo, deve ter clareza que o mesmo se comunica através de outra língua, a LIBRAS. Um fato relevante na análise dos dados foi que os consumidores surdos entrevistados (ossuem ensino médio completo (90\%), e alguns estão cursando ensino superior ou pós-graduação, apontando que o grau de escolarização influência diretamente a compreensão do português. Outro fator importante identificado com a pesquisa é que a maioria dos participantes da pesquisa trabalham em diferentes segmentos do mercado, mostrando que há alguma inclusão social do surdo na sociedade.

Com relação a comunicação no ato de compra em lojas físcias, grande parte dos consumidores surdos para conseguirem expressar o que precisam comprar escrevem a necessidade em um papel, alguns tentam fazer leitura labial, mas mesmo assim, todos apontam para a necessidade da comunicação em Libra. Constatou-se que o consumidor surdo possui muitas dificuldades de comunicação com os vendedores, como de entender como funciona o produto, em saber o preço e em entender como funciona o pagamento.

Ainda com relação as propagandas na televisão e na internet constatou-se a falta de acessibilidade nas propagandas na televisão e o entendimento de que a internet apresenta mais opções de acessibilidade. As principais limitações nas propagandas na televisão estão em não ter legenda ou informações em Libras, e quando tem legenda os textos passam muito rápido, impossibilitando a compreensão. Outro recurso disponível na televisão é o closed caption que auxilia na comunicação, no entanto, esse recurso é limitado, pois faltam palavras e assim algumas frases ficam incompreensíveis. Skliar (2001, p. 27) ressalta que "a surdez é uma experiência visual [...], e isso significa que todos os mecanismos de processamento da informação e todas as formas de compreender o universo em seu entorno, se constroem como experiência visual.". A forma escrita da língua portuguesa, através das legendas, é um caminho através do qual os surdos alfabetizados conseguem ter acesso às informações. Segundo Reichert (2006, p.62) "as palavras se esclarecem num jogo de imagens onde o surdo faz ligações para compreender a mensagem e fazer a partir disso uma nova construção da diferença e da imagem que os narram". Com relação à acessibilidade das propagandas na internet foi apontada a falta de confiança nos sites e a utilização de palavras consideradas difíceis para os surdos.

Com a pesquisa pode-se constatar que para que a propaganda seja acessível é importante que a mesma tenha legenda ou tradução simultânea em Libras, além de explorar a utilização das imagens e investir na utilização de informações visuais. Informações como preço e forma de pagamento devem estar disponíveis. Além disso, as palavras utilizadas em português devem ser simples e sempre que possível é importante que se mostre como utilizar o produto e não somente falar sobre ele. Se o consumidor tem deficiência auditiva ou é surdo, a comunicação deve ser visual, utilizando legenda, imagens e, sempre que possível, a Língua Brasileira de Sinais (LIBRAS). Para o consumidor surdo o ideal seria possuir um intérprete de LIBRAS em cada local de prestação de serviços e no comércio, ou terem colaboradores com 
conhecimento em LIBRAS. A LIBRAS tem uma estrutura própria e diferenciada da língua escrita, dificultando a interpretação de propaganda na língua portuguesa, daí vê-se a importância de produtos serem divulgados e apresentados ao cliente surdo com imagens e em LIBRAS.

Uma empresa que contempla a diversidade adquire um diferencial competitivo, diante de mercados cada vez mais competitivos, visto que saber lidar com as diferenças é fundamental para o sucesso e sustentabilidade do negócio. Deve ocorrer uma quebra de paradigmas, mudança de

\section{REFERÊNCIAS}

[1] Barbero, J. Martí \& REY, Gernan. (2004). Os exercícios do ver: hegemonia audiovisual e ficção televisuva. São Paulo: Senac.

[2] Brasil. Decreto № 5.626, de 22 de dezembro de 2005 . (2005). Regulamenta a Lei no 10.436, de 24 de abril de 2002, que dispõe sobre a Língua Brasileira de Sinais - Libras, e o art. 18 da Lei no 10.098, de 19 de dezembro de 2000. Disponível em

http://www.planalto.gov.br/ccivil_03/_ato20042006/2005/decreto/d5626.htm>. Acesso em 06 de julho de 2017

[3] Lei no 10.436, de 24 de abril de 2002. (2002). Dispõe sobre a Língua Brasileira de Sinais - Libras e dá outras providências. Disponível em

<http://www.planalto.gov.br/ccivil_03/leis/2002//104 36.htm> Acesso em 06 de julho de 2017.

[4] Lei no 10.098, de 19 de dezembro de 2000. (2000). Estabelece normas gerais e critérios básicos para a promoção da acessibilidade das pessoas portadoras de deficiência ou com mobilidade reduzida, e dá outras providências. http://www. planalto.gov.br/ccivil_03/leis//10098.htm. Acesso em 06 de julho de 2017.

[5] Bretzke, Miriam. (2000). Marketing de relacionamento com CRM para competir em tempo real. São Paulo: Atlas.

[6] Canclini, Néstor Garcia. (2008). Consumidores cidadãos: conflitos multiculturais da globalização. Trad. Mauricio Santana Dias. 7. Ed. Rio de Janeiro: Editora UFRJ.

[7] Crescitelli, E. \& Shimp, T. (2012). Comunicação de marketing: integrando propaganda, promoção e outras formas de divulgação. São Paulo: Cengage Learning.

[8] Ellswosth, Elisabeth. (2001). Modos de endereçamentos: uma coisa de cinema, uma coisa de educação também. In: SILVA, Tomaz Tadeu valores e de conceitos e eliminar barreiras atitudinais, para que assim se alcance uma sociedade inclusiva e com responsabilidade social. Esse importante fator foi comprovado com a pesquisa, visto que a maioria dos participantes consideram que a realização de propagandas acessíveis é um diferencial competitivo da empresa e que este posicionamento influencia na decisão de compra do consumidor surdo. A partir dos dados obtidos podem ser propostas estratégias para elaboração de propagandas na televisão e na internet acessíveis aos consumidores surdos.

(Org). Nunca fomos humanos nos rastros do sujeito. Belo Horizonte: Auntêntica, (p.8-76).

[9] Gesser, Audrei. (2009). LIBRAS? Que língua é essa? Crenças e preconceitos em torno da língua de sinais e da realidade surda. São Paulo: Parábola Editoral.

[10] IBGE. Instituto Brasileiro de Geografia e Estatística.

(2010).

<http://www.ibge.gov.br/home/estatistica/populaca o/censo2010/caracteristicas_religiao_deficiencia/ca racteristicas_religiao_deficiencia_tab_pdf.shtm>. Acesso em 08 de agosto de 2017.

[11] Karsaklian, Eliane. (2009). Comportamento do Consumidor. - 2. ed. - 4. reimpr. - São Paulo: Atlas.

[12] Kotler, P. \& Armstrong, G. (1993). Princípios de Marketing. Rio de Janeiro: Prentice Hall do Brasil.

[13] Kotler, Philip. (2009). Administração de Marketing: análise, planejamento, implementação e controle. 5. ed. São Paulo: Atlas.

[14] Kotler, P. \& Keller, K. L. (2012). Administração de Marketing. 14ํㅡ. Ed. São Paulo: Pearson Prentice Hall.

[15] Lemke, J. L. (2002). Travels in hypermodality. Visual Communication, London, v. 1, n.3, p.299-325.

[16] Limeira, Tânia Maria Vidigal. (2000). Administração das Comunicações de Marketing. In: DIAS, Sergio Roberto (Coordenador). São Paulo: Saraiva.

[17] Malhotra, Naresh. (2006). Pesquisa de marketing: uma orientação aplicada/ Naresh Malhotra; tradução Laura Bocco. - 4. Ed. - Porto Alegre: Bookmam.

[18] Mowen, J. C. \& Minor., M. (2010). Comportamento do Consumidor. São Paulo: Atlas. 
[19] Ogden, James R. (2007). Comunicação Integrada de marketing: conceitos, técnicas e práticas/ Prentice Hall.

[20] Oliveira, Luiza M. B. Cartilha do Censo 2010 - Pessoas com Deficiência. (2012). Secretaria de Direitos Humanos da Presidência da República (SDH/PR), Secretaria Nacional de Promoção dos Direitos da Pessoa com Deficiência (SNPD). Coordenação-Geral do Sistema de Informações sobre a Pessoa com Deficiência; Brasília : SDHPR/SNPD, Disponível em http://www.pessoacomdeficiencia.gov.br/app/sites/ default/files/publicacoes/cartilha-censo-2010pessoas-com-deficienciareduzido.pdf. Acesso em 08 de agosto de 2017.

[21] Perlin, Gládis \& Miranda, Wilson. (2013). Surdos: o narrar e a política. Ponto de Vista, Florianópolis, n.05, p.217-226.

[22] Quadros. Ronice. O tradutor e o intérprete da língua brasileira de sinais e língua portuguesa. Secretaria de Educação Especial - Programa Nacional de Apoio á Educação de surdos. Brasília: MEC/SEESP, 2002.

[23] Reichert, André Ribeiro. Mídia Televisiva sem Som. (2006). Porto Alegre, UFRGS, Dissertação de Mestrado, Universidade Federal do Rio Grande do Sul, Programas de Pós-Graduação em Educação. Disponível em < file:///C:/Users/user/Downloads/000592430\%20(1).p df>. Acesso em 03 de abril de 2016.

[24] Samara, Beatriz Santos. (2007). Pesquisa de marketing: conceitos e metodologia/ Beatriz Santos Samara, José Carlos de Barros. - 4. Ed.São Paulo: Pearson Prentice Hall.
[25] Sant'Anna, Armando. (2009). Propaganda: teoria, técnica e prática. 8. ed. São Paulo: Pioneira Thomson Learning, 2009.

[26] Santana, A. P. (2007). Surdez e linguagem: aspectos e implicações neurolinguísticas. São Paulo: Plexus,

[27] Schiffman, L. G (2015) Comportamento do consumidor. Rio de Janeiro : LTC

[28] Schwartz, Andréa \& Haber, Jaques. (2006). Cartilha atendendo bem pessoas com deficiência. Publicada pela Febraban - Federação Brasileira de Bancos. Coordenação: Andréa Schwartz e Jaques Haber. Disponível em: $<$ http://www.febraban.org.br/arquivo/cartilha/cartilh a_arquivos/cartilha_atendimento.pdf >Acesso em 09/05/2017.

[29] Silva, Ivani Rodrigues, et al.(2013). O uso de jogos eletrônicos no processo ensinoaprendizagem de surdos. In. Valle, et al. Educação digital: a tecnologia a favor da inclusão. Porto Alegre: Penso, p. $213-238$.

[30] Shimp, T.A. (2009). Comunicação integrada de marketing: propaganda e promoção. Porto Alegre: Bookman.

[31] Skliar, C. B. (1998). A surdez: um olhar sobre as diferenças. Porto Alegre: Editora Mediação.

[32] Valle, Luiza E. L. R. do. (2013). Inclusão digital na alfabetização: importância da aprendizagem inicial na vida de todos. In. Valle, L. E. L.R., et al. Org. Educação Digital: a tecnologia a favor da inclusão. Porto Alegre: Penso. 


\section{Capítulo 4}

\section{INDICADORES DE GOVERNANCA EM INICIATIVAS PARA O DESENVOLVIMENTO SUSTENTÁVEL: O CASO DOS OBJETIVOS DE DESENVOLVIMENTO SUSTENTÁVEL (ODS)}

\section{David Barbalho Pereira}

Allison Haley dos Santos

Laura Maria Silveira da Fonseca

Resumo: Analisa os aspectos conceituais de governança considerados na elaboração dos indicadores consolidados nos Objetivos de Desenvolvimento Sustentável (ODS), a partir de pesquisa bibliográfica voltada para o conceito e dimensões da governança e desdobramentos na sua mensuração. Considera como categoriais de análise de indicadores de governança os seguintes elementos: accountability; eficácia; integração e cooperação entre stakeholders; integridade; participação social; e transparência. Apresenta como resultados uma expressiva defasagem em uma abordagem integral do conceito na Agenda 2030 - fator que tende a estagnar a mensuração de importantes metas dos ODS. Aponta a necessidade de pesquisas futuras voltadas para a identificação dos desafios na construção e consolidação de indicadores de governança, principalmente em escala global.

Palavras-chave: Objetivos de Desenvolvimento sustentável. Governança. Indicadores. 


\section{ASPECTOS INTRODUTÓRIOS}

Dada a multiplicidade de stakeholders envolvidos na consecução de iniciativas e pactos voltados para o Desenvolvimento Sustentável (DS), emerge o desafio de desenvolver arranjos e mecanismos de governança que fomentem condições institucionais para a gestão orientada para o DS. Essa preocupação se coloca recorrentemente nas discussões que envolvem o alcance dos Objetivos de Desenvolvimento Sustentável (ODS). No entanto, quando considerada a complexidade e subjetividade inerente ao conceito e condições favoráveis à "boa governança", emergem as seguintes questões: Como acompanhar o progresso e consolidação dos mecanismos de governança? Os processos de monitoramento e avaliação e indicadores propostos nos ODS são capazes de apreender as diversas nuances do conceito?

É sabido que o desenvolvimento de mecanismos de monitoramento e avaliação possuem como base a consolidação e análise periódica e continuada de indicadores que possibilitem a apreensão de aspectos da realidade. Coloca-se como desafio central desses processos a construção de painéis de indicadores que possibilitem a mensuração e visualização do progresso de metas e objetivos, orientando as instâncias de tomada de decisão quanto às áreas prioritárias de ação, melhoria no desempenho e alcance de resultados.
Embora se notem esforços de diversos organismos internacionais na elaboração de indicadores de DS, observa-se a carência de informações que subsidiem o processo de tomada de decisão. Além disso, coloca-se um dilema científico na adoção de indicadores e medidas que representam de forma consistente as metas para se atingir um nível de DS uniforme em todas as regiões do planeta.

Enquanto conceito multidimensional, o desenvolvimento de ações para 0 DS demanda de robusta estrutura institucional e de governança, dada a diversidade de stakeholders nele envolvido e as diversas escalas para nas quais tais iniciativas são empreendidas.

Reconhecendo que a consolidação de indicadores se coloca como fator primordial no desenvolvimento de processos de monitoramento e avaliação de iniciativas de DS, o presente trabalho é motivado pela seguinte questão: Como a governança é mensurada pelos indicadores dos Objetivos de Desenvolvimento Sustentável?

\section{PERCURSO METODOLÓGICO}

O presente trabalho se caracteriza como uma pesquisa descritiva e exploratória, fazendo uso da análise de dados secundários por meio de abordagem qualitativa. São adotadas como técnicas de pesquisa a pesquisa bibliográfica e a pesquisa documental.

Figura 1. Percurso metodológico da pesquisa

\begin{tabular}{|l|l|l|}
\hline \multicolumn{2}{|c|}{ Etapa 1 } & \multicolumn{2}{|c|}{ Etapa 2 } \\
Pesquisa bibliográfica: & $\begin{array}{l}\text { Categorização das dimensões e } \\
\text { princípios para a boa } \\
\text { Governança. }\end{array}$ & $\begin{array}{l}\text { Análise dos indicadores do } \\
\text { ODS 16 e ODS 17 à luz das } \\
\text { governança. Elaboração de } \\
\text { categorias de boa governança, } \\
\text { conforme levantado na pesquisa } \\
\text { bibliográfica. }\end{array}$ \\
\hline
\end{tabular}

Fonte: Os autores (2017).

Inicialmente, realiza-se pesquisa bibliográfica voltada para a apreensão do conceito e dimensões compreendidas pela literatura sobre governança. Essa etapa subsidia a sistematização de aspectos a serem contemplados em indicadores voltados para a governança no âmbito dos ODS, de modo a nortear a análise para o apontamento das áreas que demandam maior aprimoramento conceitual e metodológico na consecução da governança para o DS. A definição das categorias para análise considera a recorrência e relevância dos fatores nos conceitos de governança revisitados na literatura da área.

Considerando que a pesquisa documental "[...] cobre uma ampla variedade de fontes, incluindo estatísticas oficiais, fotografias, textos e dados visuais, em geral." (May, 2004, p. 205), adota-se como documento de referência para análise a Agenda 2030 
(PNUD, 2015?. Não paginado) - documento que sistematiza os Objetivos de Desenvolvimento Sustentável, suas respectivas metas e indicadores. De modo particular, são analisados os indicadores do ODS 16 "Promover sociedades pacíficas e inclusivas para o desenvolvimento sustentável, proporcionar o acesso à justiça para todos e construir instituições eficazes, responsáveis e inclusivas em todos os níveis" e ODS 17: "Fortalecer os meios de implementação e revitalizar a parceria global para o desenvolvimento sustentável" voltados diretamente para aspectos de governança para o DS.

\section{SOBRE O CONCEITO E PRINCÍPIOS DE GOVERNANÇA}

O conceito de governança não é dotado de unanimidade dentre os estudos na área (Matias-Pereira, 2008). Da mesma forma que diferentes conceitos são postos na literatura, diversas são as percepções dos princípios que a sustentam - aspectos comumente identificados como características e diretrizes de uma "boa governança". A Figura 2 exemplifica diferentes concepções de governança e boa governança localizados em diferentes perspectivas conceituais (gestão pública, governança corporativa, governança internacional, etc.).

Figura 2. Compilação de conceitos de governança em iniciativas para o DS

\begin{tabular}{|c|c|}
\hline Autoria & a e de boa governança \\
\hline $\begin{array}{l}\text { Independent } \\
\text { Evaluation Group } \\
\text { World Bank } \\
\text { (2007, p. } 71 . \\
\text { Tradução nossa'.) }\end{array}$ & $\begin{array}{l}\text { [...] estruturas, funções, processos e tradições organizacionais que foram } \\
\text { implementadas no contexto do ambiente de implementação de um programa } \\
\text { "para garantir que o [programa] seja executado de tal forma que ele atinja seus } \\
\text { objetivos de forma efetiva e de forma transparente. }\end{array}$ \\
\hline $\begin{array}{l}\text { Matias-Pereira (2008, } \\
\text { p. 34) }\end{array}$ & $\begin{array}{l}\text { [...] capacidade governativa em sentido mais amplo, envolvendo a capacidade da } \\
\text { ação estatal na implantação das políticas e na consecução das metas coletivas, } \\
\text { incluindo "o conjunto dos mecanismos e procedimentos para lidar com a dimensão } \\
\text { participativa e plural da sociedade". }\end{array}$ \\
\hline $\begin{array}{l}\text { SDSN } \\
(2014, \text { p.124. } \\
\text { Tradução nossai })\end{array}$ & $\begin{array}{l}\text { O setor público, as empresas e outras partes interessadas se comprometem com a } \\
\text { boa governança, incluindo a transparência, a responsabilidade, o acesso à } \\
\text { informação, a participação, o fim do imposto e os paraísos secretos e os esforços } \\
\text { para acabar com a corrupção. }\end{array}$ \\
\hline $\begin{array}{l}\text { GrupoBanco Mundial } \\
\quad(2017, \text { p. 3). }\end{array}$ & $\begin{array}{l}{[\ldots] \text { o processo por meio do qual atores estatais e não estatais interagem para }} \\
\text { conceber e implementar políticas públicas no âmbito de um dado conjunto de } \\
\text { regras informais que moldam e são moldadas pelo poder. }\end{array}$ \\
\hline
\end{tabular}

Fonte: Independent Evaluation Group (IEG). World Bank. (2007) Sourcebook for evaluating global and regional partnership programs indicative: principles and standards. (p.71) Washington: IEG. Matias-pereira, J. (2008). Manual de gestão pública contemporânea. 1. ed. (p. 34). São Paulo: Atlas. Sustainable Development Solutions Netowork (SDSN). (2014). Indicators for sustainable development goals: a report by the leadership. (p. 124). Council of the Sustaiable Development Solutions Network. [s.I.]: SDSN. Grupo Banco Mundial. (2017). Governança e a lei. (p. 3). Washington: Banco Mundial. Relatório do desenvolvimento mundial.

Os recortes apontados possibilitam compreender a governança enquanto capacidade governativa de interação entre governo e demais stakeholders para processos de tomada de decisão na formulação e implementação de políticas públicas, adotando práticas de accountability, participação social e transparência.

Alguns aspectos perpassam diversas concepções na literatura da área. Como exemplo, cita-se a diversidade de atores sociais (estatais e não estatais) nas arenas de tomada de decisão e valores como transparência e accountability. Souza e Cândido (2009, p. 174) reforçam que no âmbito da administração pública, o significado da governança "[...] vem ultrapassando a dimensão operacional para incorporar aspectos da articulação dos mais diversos atores sociais e arranjos institucionais". Além disso, entende-se como pertinente considerar a "[...] cooperação entre vários níveis de governo, setor provado e sociedade civil" (Nações Unidas, 2008, p. 21. Tradução nossaiii.). Esse aspecto se coloca como contexto no qual se dão os mecanismos de governança.

A elaboração e implementação de políticas públicas envolvem uma negociação entre diversos atores. $O$ ambiente no qual decisões (sobre políticas) são tomadas é a 
arena de negociação de políticas públicas ou seja, o espaço em que diversos grupos e atores interagem e negociam aspectos de domínio público, e no qual os acordos resultantes levam a mudanças futuras nas regras formais (legislação). É nesse ambiente que a governança se manifesta. (Grupo Banco Mundial, 2017, p. 7)

Em uma perspectiva alinhada aos estudos da gestão pública, Matias-Pereira (2008) descreve um escopo de abordados na literatura da área de governança:

Os aspectos frequentemente evidenciados na literatura acadêmica sobre a governança estão relacionados: à legitimidade do espaço público em constituição; à repartição do poder entre aqueles que governam e aqueles que são governados; aos processos de negociação entre os atores sociais (os procedimentos e as práticas, a gestão das interações e das interdependências que desembocam ou não em sistemas alternativos de regulação, o estabelecimento de redes e os mecanismos de coordenação); e à descentralização da autoridade e das funções ligadas ao ato de governar. (MatiasPereira, 2008, p. 35).

Enquanto conceito diretamente vinculado ao processo de tomada de decisões e interação entre stakeholders, observa-se significativo caráter de subjetividade à ele inerente - o que reflete enquanto desafio para mensuração e desenho de indicadores para os seus processos de monitoramento e avaliação.

O caráter multidimensional de políticas e estratégias de DS demanda a criação e fortalecimento da esfera institucional para viabilização e integração dos stakeholders nas arenas de tomada de decisão e consecução de políticas públicas, ao passo que "[...] o cumprimento de todos os objetivos de desenvolvimento [sustentável] exigira uma sólida compreensão de governança para viabilizar politicas publicas mais eficazes". (Grupo Banco Mundial, 2017, p. 4). Costa et al (2012, p. 60) colocam que "embora de maneira transversal, o conceito de governança perpassa as preocupações dos tratados e conferências internacionais sobre desenvolvimento sustentável". Dessa forma, a governança é colocada como condição necessária à efetividade de políticas de DS.

A diversidade de concepções e campos de estudo sobre a governança se refletem na diversidade de contribuições na literatura sobre os princípios que a fundamentam, conforme colocado na Figura 3.

Figura 3. Princípios e dimensões de governança segundo IFAC (2001), Stoddart et al (2011) e World Bank Institute (2008)

\begin{tabular}{|c|c|c|}
\hline $\begin{array}{l}\text { International Federation of } \\
\text { Accountants - IFAC (2001) }\end{array}$ & World Bank Institute (2008) & $\begin{array}{l}\text { Stoddart et al } \\
\text { (2011. Tradução nossa) }\end{array}$ \\
\hline $\begin{array}{l}\text { Princípios de governança }{ }^{\text {iv. }} \\
\text { - Transparência; } \\
\text { - Integridade; } \\
\text { - Responsabilização } \\
\text { Dimensões de governançav: } \\
\text { - Padrão de comportamento; } \\
\quad \text { Estruturas e } \\
\text { processos organizacionais; } \\
\text { - Controle de risco; } \\
\text { - Relatório externo. }\end{array}$ & $\begin{array}{l}\text { Voz e responsabilidade; } \\
\text { " } \quad \text { Estabilidade política e } \\
\text { ausência de violência/terrorismo; } \\
\text { " } \quad \text { Eficácia do governo; } \\
\text { " Qualidade normativa; } \\
\text { " } \quad \text { Regime de direito; } \\
\text { " Controle da corrupção. }\end{array}$ & $\begin{array}{l}\quad \text { Princípios de governançavi. } \\
\text { - Princípio da precaução; } \\
\text { " } \quad \text { Princípio do poluidor- } \\
\text { pagador; } \\
\text { "Responsabilidades } \\
\text { comuns mas diferenciadas; } \\
\text { Acesso à informação, } \\
\text { participação e justiça; } \\
\text { Bens globais comuns; } \\
\text { - Equidade integeneracional; } \\
\text { "Reforma das instituições } \\
\text { internacionais regida por } \\
\text { princípios de comunidade. }\end{array}$ \\
\hline
\end{tabular}

Fonte: International Federation Of Accountants (IFAC). (2001). Governance in the Public Sector: A Governing Body Perspective International Public Sector Study. Nova lorque: IFAC.

Stoddart, H. (ed.) et al. (2011). A pocket guide to sustainable development governance. Stakeholder Forum. Commonwealth Secretariat.

World Bank Institute. Governance matters 2008: Indicadores de governança 1996-2007. Documento online não paginado.

Norteados por diferentes ênfases e esferas de governança, as concepções elencadas pelo IFAC, World Bank Institute e Stoddart et al fazem uso de elementos comuns para sua 
estruturação. Para a realização da análise no presente trabalho, sugere-se o agrupamento desses princípios em seis categorias de análise: accountability; eficácia; integração e cooperação entre stakeholders; integridade; participação social; e transparência, conforme trazido na Figura 4.

Figura 4. Quadro analítico para análise dos indicadores de governança

\begin{tabular}{|c|c|}
\hline Categoria & Descrição \\
\hline [A] Accountability & $\begin{array}{l}\text { Aspectos voltados para "[...] conjunto de mecanismos e procedimentos que } \\
\text { induzem os dirigentes governamentais a prestar contas dos resultados de suas } \\
\text { ações à sociedade, garantindo-se dessa forma maior nível de transparência e a } \\
\text { exposição pública das políticas públicas." (Matias-Pereira, 2008, p. 36). }\end{array}$ \\
\hline [B] Eficácia & $\begin{array}{l}\text { Esforços, políticas e mecanismos voltados para mensuração e alcance de metas } \\
\text { e objetivos pactuados para o DS nas escalas global, nacional e local. }\end{array}$ \\
\hline $\begin{array}{l}\text { [C] Integração e } \\
\text { Cooperação entre } \\
\text { stakeholders }\end{array}$ & $\begin{array}{l}\text { Desenvolvimento de mecanismos de integração entre os múltiplos stakeholders } \\
\text { nas diversas escalas de políticas para o DS. }\end{array}$ \\
\hline [D] Integridade & $\begin{array}{l}\text { Combate ao exercício do poder público em benefício privado, inclusive as } \\
\text { pequenas e grandes formas de corrupção, além do "aprisionamento" do estado } \\
\text { pelas elites e pelos interesses privados. (World Bank Institute, 2008. Não paginado.). }\end{array}$ \\
\hline [E] Participação social & $\begin{array}{l}\text { Participação da população dos países na escolha do seus respectivos } \\
\text { governos, liberdade de expressão, liberdade de associação e comunicação libres. } \\
\text { (World Bank Institute, 2008. Não paginado). }\end{array}$ \\
\hline [F] Transparência & $\begin{array}{l}\text { Aspectos voltados para a publicização dos dados e informações } \\
\text { governamentais; inteligibilidade de informações oriundas de mecanismos } \\
\text { de avaliação e monitoramento de políticas públicas. }\end{array}$ \\
\hline
\end{tabular}

Fonte: Matias-pereira, J. (2008). Manual de gestão pública contemporânea. 1. ed. São Paulo: Atlas.

World Bank Institute. Governance matters 2008: Indicadores de governança 1996-2007. (2008). Documento online não paginado.

Entende-se que a sistematização aqui proposta pode contribuir na análise de políticas e de aspectos de governança em políticas públicas de diversas naturezas, e principalmente voltadas para o DS. O tema se coloca com centralidade na agenda global e exige discussões que congregue stakeholders para além do poder público em seus diversos níveis de governo.

\subsection{A DIMENSÃO GOVERNANÇA NOS ODS}

Reconhecido como o mais relevante acordo global voltado para o DS, os Objetivos de Desenvolvimento Sustentável (ODS) consistem em um pacto acordado entre diversos países no ano de 2015 para uma agenda de intenções e objetivos a serem desenvolvidos nas escalas global, nacional e local para o quinquênio 2015-2030. processo de sua construção é capitaneado pela Organização das Nações Unidas (ONU), por meio do programa das Nações Unidas (PNUD). Estrutura-se em 17 grandes objetivos e 169 metas.

As discussões em governança devem permear todos os objetivos postos na Agenda 2030. No entanto, abordam de forma direta ODS 16 e 17 abordam de forma direta o desenvolvimento de aspectos e condições para governança.

O ODS 16 possui como tema "Paz, Justiça e Instituições Eficazes, objetivando: "Promover sociedades pacíficas e inclusivas para o desenvolvimento sustentável, proporcionar o acesso à justiça para todos e construir instituições eficazes, responsáveis e inclusivas em todos os níveis" (PNUD, 2015. Não paginado). Estrutura-se em 17 metas, conforme descrito na Figura 5. 
Figura 5. Metas do ODS 16

\begin{tabular}{|c|c|c|}
\hline $\begin{array}{l}\text { 16.1 Reduzir significativamente } \\
\text { todas as formas de violência e } \\
\text { as taxas de mortalidade } \\
\text { relacionada, em todos os lugares. }\end{array}$ & $\begin{array}{l}\text { 16.2 Acabar com abuso, } \\
\text { exploração, tráfico e todas as } \\
\text { formas de violência e tortura } \\
\text { contra crianças. }\end{array}$ & $\begin{array}{l}\text { 16.3 Promover o Estado de } \\
\text { Direito, em nível nacional e } \\
\text { internacional, e garantir a } \\
\text { igualdade de acesso à justiça, } \\
\text { para todos. }\end{array}$ \\
\hline 6 indicadores & 2 indicadores & 1 indicador \\
\hline $\begin{array}{l}\text { 16.4 Até } 2030 \text {,reduzir } \\
\text { significativamente os fluxos } \\
\text { financeiros e de armas ilegais, } \\
\text { reforçar a recuperação e } \\
\text { devolução de recursos roubados, } \\
\text { e combater todas as formas de } \\
\text { crime organizado. }\end{array}$ & $\begin{array}{l}16.5 \text { Reduzir substancialmente } \\
\text { a } \\
\text { corrupção e o suborno em todas } \\
\text { as suas formas. }\end{array}$ & $\begin{array}{l}\text { 16.6 Desenvolver instituições } \\
\text { eficazes, responsáveis e } \\
\text { transparentes em todos os níveis. }\end{array}$ \\
\hline Não consta $(m)$ indicador(es) & 1 indicador & Não consta(m) indicador(es) \\
\hline $\begin{array}{l}16.7 \text { Garantir a tomada de } \\
\text { decisão } \\
\text { responsiva, inclusiva, participativa } \\
\text { e representativa em todos os } \\
\text { níveis. }\end{array}$ & $\begin{array}{l}\text { 16.8 Ampliar e fortalecer a } \\
\text { participação dos países em } \\
\text { desenvolvimento nas instituições } \\
\text { de governança global. }\end{array}$ & $\begin{array}{l}16.9 \text { Até } 2030 \text {, fornecer } \\
\text { identidade } \\
\text { legal para todos, incluindo o } \\
\text { registro de nascimento. }\end{array}$ \\
\hline Não consta(m) indicador(es) & 18 indicadores & 1 indicador \\
\hline $\begin{array}{l}\text { 16.10 Assegurar o acesso público } \\
\text { à informação e proteger as } \\
\text { liberdades fundamentais, em } \\
\text { conformidade com a legislação } \\
\text { nacional e os acordos } \\
\text { internacionais. }\end{array}$ & $\begin{array}{l}\text { 16.a Fortalecer as } \\
\text { instituições nacionais relevantes, } \\
\text { inclusive por meio da } \\
\text { cooperação internacional, para a } \\
\text { construção de capacidades em } \\
\text { todos os níveis, em particular } \\
\text { nos países em desenvolvimento, } \\
\text { para a prevenção da violência e } \\
\text { o combate ao terrorismo e ao } \\
\text { crime. }\end{array}$ & $\begin{array}{l}\text { 16.b promover e fazer cumprir leis } \\
\text { e políticas não discriminatórias } \\
\text { para o desenvolvimento } \\
\text { sustentável. }\end{array}$ \\
\hline 1 indicador & 2 indicadores & Não consta(m) indicador(es) \\
\hline
\end{tabular}

Fonte: Programa das Nações Unidas (PNUD). (2015). Plataforma para agenda 2030. Recuperado em 20 junho, 2017, de http://www.agenda2030.com.br/consulta.php. Documento online não paginado.

Já o ODS 17 versa sobre "Parcerias e Meios de Implementação", explicitando como intenção principal "Fortalecer os meios de implementação e revitalizar a parceria global para o desenvolvimento sustentável" (PNUD, 2015?. Não paginado). Nesse sentido, são traçadas 19 metas e respectivos indicadores, conforme exposto na Figura 6:

\section{Figura 6. Metas do ODS 17}

17.1 Fortalecer a mobilização de recursos internos, inclusive por meio do apoio internacional aos países em desenvolvimento, para melhorar a capacidade nacional para arrecadação de impostos e outras receitas.
17.2 Países desenvolvidos implementarem plenamente os seus compromissos em matéria de assistência oficial ao desenvolvimento, inclusive o compromisso apresentado por vários países desenvolvidos de alcançar a meta de $0,7 \%$ da renda nacional bruta para assistência oficial ao desenvolvimento (RNB/AOD) aos países em desenvolvimento, e 0,15 a $0,20 \%$ da RNB/AOD para os países de menor desenvolvimento relativo; provedores de AOD são encorajados a considerarem definir uma meta para prover pelo menos $0,20 \%$ da RNB/AOD para os países de menor desenvolvimento relativo.

\section{Não consta $(m)$ indicador(es)}

17.3 Mobilizar recursos financeiros adicionais para os países em desenvolvimento a partir de múltiplas fontes.
Não consta( $m$ ) indicador(es)

17.4 Ajudar os países em desenvolvimento a alcançar a sustentabilidade da dívida de longo prazo, por meio de políticas coordenadas destinadas a promover o financiamento, a redução e a reestruturação da dívida, conforme apropriado, e tratar da dívida externa dos países pobres altamente endividados para reduzir o superendividamento. 
(continuação ...)

Figura 6. Metas do ODS 17

\section{1 indicador}

17.5 Adotar e implementar regimes de promoção de investimentos para os países de menor desenvolvimento relativo.
1 indicador

17.6 Melhorar a cooperação regional e internacional Norte-Sul, Sul-Sul e triangular e o acesso à ciência, tecnologia e inovação, e aumentar o compartilhamento de conhecimentos em termos mutuamente acordados, inclusive por meio de uma melhor coordenação entre os mecanismos existentes, particularmente no nível das Nações Unidas, e por meio de um mecanismo global de facilitação de tecnologia global

Não consta(m) indicador(es)

17.7 Promover o desenvolvimento, a transferência, a disseminação e a difusão de tecnologias ambientalmente corretas para os países em desenvolvimento, em condições favoráveis, inclusive em condições concessionais e preferenciais, conforme mutuamente acordado 1 indicador Banco de Tecnologia e o mecanismo para a implementação eficaz e em ciência, tecnologia e inovação para os países de menor desenvolvimento relativo até 2017 , e aumentar o uso de tecnologias capacitadoras, em particular tecnologias de informação e

capacidades em países em todos os objetivos de desenvolvimento sustentável inclusive por meio da cooperação

\section{\begin{tabular}{l|l}
17.8 Operacionalizar plenamente o & 17.9 Reforçar o apoio internacional
\end{tabular}} de desenvolvimento de capacidades orientada do desenvolvimento de comunicação

$\mathrm{Não}$ consta $(m)$ indicador(es) 17.10 Promover um sistema multilateral de comércio universal, baseado em regras, aberto, não discriminatório e equitativo no âmbito da Organização Mundial do Comércio, inclusive por meio da conclusão das negociações no âmbito de sua Agenda de Desenvolvimento de Doha. 14 indicadores

17.13 Aumentar a estabilidade macroeconômica global, inclusive por meio da coordenação e da coerência de políticas.

1 indicador

17.11 Aumentar significativamente as exportações dos países em

desenvolvimento, em particular com o objetivo de duplicar a participação dos países de menor desenvolvimento relativo nas exportações globais até 2020.

\section{Não consta(m) indicador(es)}

17.14 Aumentar a coerência das políticas para o desenvolvimento sustentável desenvolvimento, a fim de apoiar os planos nacionais para implementar Norte-Sul, Sul-Sul e triangular 1 indicador

17.12 Concretizar a implementação oportuna de acesso a mercados livres de cotas e taxas, de forma duradoura, para todos os países de menor desenvolvimento relativo, de acordo com as decisões da Organização Mundial do Comércio, inclusive por meio de garantias de que as regras de origem preferenciais aplicáveis às importações provenientes de países de menor desenvolvimento relativo sejam transparentes e simples, e contribuam para

facilitar o acesso ao mercado Questões sistêmicas Não consta(m) indicador(es)

Não consta( $m$ ) indicador(es)

17.15 Respeitar o espaço político e a liderança de cada país para estabelecer e implementar políticas para a erradicação da pobreza e o desenvolvimento sustentável

Não consta( $m$ ) indicador(es)

17.17 Incentivar e promover parcerias públicas, público- privadas, privadas, e com a sociedade civil eficazes, a partir da experiência das estratégias de mobilização de recursos dessas parcerias Dados, monitoramento e prestação de contas.

Não consta $(m)$ indicador(es)

Não consta( $m$ indicador(es) 17.16 Reforçar a parceria global para o desenvolvimento sustentável
complementada por parcerias multissetorias, que mobilizem e compartilhem conhecimento, experiência, tecnologia e recursos financeiros para apoiar a realização dos objetivos do desenvolvimento sustentável em todos os países, particularmente nos países em desenvolvimento.

Não consta $(m)$ indicador(es)

17.18 Até 2020, reforçar o apoio ao desenvolvimento de capacidades para os países em desenvolvimento, inclusive para os países de menor desenvolvimento relativo e pequenos Estados insulares em desenvolvimento, para aumentar significativamente a disponibilidade de dados de alta qualidade, atuais e confiáveis, desagregados por renda, gênero, idade, raça, etnia, status migratório, deficiência, localização geográfica e outras características relevantes em contextos nacionais.

1 indicador

17.19 Até 2030, valer-se de iniciativas existentes, para desenvolver medidas do progresso do desenvolvimento sustentável que complementem o produto interno bruto e apoiar o desenvolvimento de capacidades em estatística nos países em desenvolvimento

3 indicadores

Fonte: Programa das Nações Unidas (PNUD). (2015). Plataforma para agenda 2030. Recuperado em 20 junho, 2017, de http://www.agenda2030.com.br/consulta.php. Documento online não paginado.

Observa-se que das 31 metas elencadas, 15 não dispõem de indicadores desenhados para monitoramento e avaliação. Presume-se que a mensuração dos aspectos por elas contemplados se coloca como desafio central na análise de desempenho dos aspectos de governança.

\section{DISCUSSÕES E RESULTADOS}

A interseção entre as categorias de governança e os indicadores dos ODS estão sintetizadas nas Figuras 7 e 8 . A partir da análise do conteúdo das metas e indicadores, são identificados os casos nos quais as categorias de análise são 
contempladas no seu conteúdo. Essa interseção é sinalizada com o sinal "O" nas referidas Figuras. Ressalta-se que a vinculação dos indicadores às categorias propostas considera a meta nas quais se inserem.

Figura 7. Indicadores do ODS 16 e categorias de análise de governançavii

\begin{tabular}{|c|c|c|c|c|c|c|}
\hline Meta & Indicador & {$[\mathrm{A}]$} & C] & D] & [E] & [F] \\
\hline 16.5 & $\begin{array}{l}\text { Percentual de empresas enfrentando pelo menos um pedido de } \\
\text { pagamento de suborno }\end{array}$ & & & $\mathrm{O}$ & & \\
\hline 16.8 & $\begin{array}{l}\text { Percentual de direito a voto dos países em desenvolvimento na } \\
\text { Assembleia Geral da ONU }\end{array}$ & & O & & & \\
\hline 16.8 & $\begin{array}{l}\text { Percentual de direito a voto dos países em desenvolvimento na } \\
\text { Organização Mundial do Comércio }\end{array}$ & & $\mathrm{O}$ & & & \\
\hline 16.8 & $\begin{array}{l}\text { Percentual de direito a voto dos países em desenvolvimento no } \\
\text { Banco Africano de Desenvolvimento }\end{array}$ & & $\mathrm{O}$ & & & \\
\hline 16.8 & $\begin{array}{l}\text { Percentual de direito a voto dos países em desenvolvimento no } \\
\text { Banco Interamericano de Desenvolvimento }\end{array}$ & & $\mathrm{O}$ & & & \\
\hline 16.8 & $\begin{array}{l}\text { Percentual de direito a voto dos países em desenvolvimento no } \\
\text { Banco Internacional de Reconstrução e Desenvolvimento }\end{array}$ & & $\mathrm{O}$ & & & \\
\hline 16.8 & Percentual de direito a voto dos países em desenvolvimento no & & $\mathrm{O}$ & & & \\
\hline & Conselho de Segurança da ONU & & & & & \\
\hline 16.8 & $\begin{array}{l}\text { Percentual de direito a voto dos países em desenvolvimento no } \\
\text { Conselho Econômico e Social das Nações Unidas }\end{array}$ & & $\mathrm{O}$ & & & \\
\hline 16.8 & $\begin{array}{l}\text { Percentual de direito a voto dos países em desenvolvimento no } \\
\text { Corporação Financeira Internacional }\end{array}$ & & $\mathrm{O}$ & & & \\
\hline 16.8 & $\begin{array}{l}\text { Percentual de direito a voto dos países em desenvolvimento no } \\
\text { Fundo Monetário Internacional }\end{array}$ & & $\mathrm{O}$ & & & \\
\hline 16.8 & $\begin{array}{l}\text { Percentual de países em desenvolvimento na composição da } \\
\text { Corporação Financeira Internacional }\end{array}$ & & $\mathrm{O}$ & & & \\
\hline 16.8 & $\begin{array}{l}\text { Percentual de países em desenvolvimento na composição da } \\
\text { Organização Mundial do Comércio }\end{array}$ & & O & & & \\
\hline 16.8 & $\begin{array}{l}\text { Percentual de países em desenvolvimento na composição do } \\
\text { Banco Africano de Desenvolvimento }\end{array}$ & & $\mathrm{O}$ & & & \\
\hline 16.8 & $\begin{array}{l}\text { Percentual de países em desenvolvimento na composição do } \\
\text { Banco Interamericano de Desenvolvimento }\end{array}$ & & $\mathrm{O}$ & & & \\
\hline 16.8 & $\begin{array}{l}\text { Percentual de países em desenvolvimento na composição do } \\
\text { Banco Internacional para Reconstrução e Desenvolvimento }\end{array}$ & & O & & & \\
\hline 16.8 & $\begin{array}{l}\text { Percentual de países em desenvolvimento na composição do } \\
\text { Conselho de Segurança da ONU }\end{array}$ & & $\mathrm{O}$ & & & \\
\hline 16.8 & $\begin{array}{l}\text { Percentual de países em desenvolvimento na composição do } \\
\text { Conselho Econômico e Social das Nações Unidas }\end{array}$ & & O & & & \\
\hline 16.8 & $\begin{array}{l}\text { Percentual de países em desenvolvimento na composição do } \\
\text { Fundo Monetário Internacional }\end{array}$ & & 0 & & & \\
\hline 16.10 & $\begin{array}{l}\text { Número de casos de assassinato, sequestro, desaparecimento } \\
\text { forçado, detenção arbitrária e tortura de jornalistas, pessoal de } \\
\text { mídia associado, sindicalistas e defensores dos direitos humanos } \\
\text { nos últimos } 12 \text { meses }\end{array}$ & & & & & O \\
\hline 16.a & $\begin{array}{l}\text { Percentual de países com Instituições nacionais de Direitos } \\
\text { Humanos independentes, em conformidade com os Princípios de } \\
\text { Paris }\end{array}$ & & O & & & \\
\hline 16.a & $\begin{array}{l}\text { Percentual de países que aplicaram para o credenciamento de } \\
\text { Instituições nacionais de Direitos Humanos independente em } \\
\text { conformidade com os Princípios de Paris }\end{array}$ & & O & & & \\
\hline
\end{tabular}

Legenda: [A] Accountability; [B] Eficácia; [C] Integração e cooperação entre stakeholders; [D] Integridade; [E] Participação social; [F] Transparência. Fonte: Programa das Nações Unidas (PNUD). (2015). Plataforma para agenda 2030. Recuperado em 20 junho, 2017, de http://www.agenda2030.com.br/consulta.php. Documento online não paginado.

Os indicados do ODS 16 são fortemente orientados para a representatividade dos países em espaços de tomada de decisão, utilizando-se do percentual de países em desenvolvimento em organismos internacionais de desenvolvimento, segurança, desenvolvimento social e econômico, economia e comércio. Em menor expressão, são contemplados aspectos de combate à corrupção e transparência referindo-se à disponibilidade de informações de segurança e justiça.

As categorias de accountability $[A]$, eficácia [B] e participação social [E] não são 
contempladas de forma direta no referido hall de indicadores - fator que pode se colocar como grande desafio no fortalecimento das instituições rumo, uma vez que não são pensados indicadores para monitoramento desses aspectos.

Figura 8. Indicadores do ODS 17 e categorias de análise de governança

\begin{tabular}{|c|c|c|c|c|c|c|c|}
\hline Meta & Indicador & {$[\mathrm{A}]$} & [B] & C] & D] & {$[E]$} & {$[F]$} \\
\hline 17.3 & $\begin{array}{l}\text { Volume de remessas (em dólares dos Estados Unidos) como proporção } \\
\text { do PIB total }\end{array}$ & & & $\mathrm{O}$ & & & \\
\hline 17.4 & $\begin{array}{l}\text { Percentual do serviço da dívida em relação à exportação de bens e } \\
\text { serviços }\end{array}$ & & & O & & & \\
\hline 17.6 & Assinaturas de Internet fixa de banda larga por 100 habitantes & & & $\mathrm{O}$ & & & \\
\hline 17.8 & Percentual de indivíduos usuários de Internet & & & $\mathrm{O}$ & & & \\
\hline 17.9 & $\begin{array}{l}\text { Valor em dólares de assistência técnica e financeira desembolsado } \\
\text { (incluindo por meio de Norte-Sul, Sul-Sul ou cooperação triangular) para } \\
\text { países em desenvolvimento }\end{array}$ & & $\mathrm{O}$ & & & & \\
\hline 17.10 & $\begin{array}{l}\text { Tarifa média de importação de armamentos a nível mundial, do } \\
\text { ponto de vista da condição preferencial }\end{array}$ & & & $\mathrm{O}$ & & & \\
\hline 17.10 & $\begin{array}{l}\text { Tarifa média de importação de armamentos a nível mundial, do } \\
\text { ponto de vista da nação mais favorecida }\end{array}$ & & & $\mathrm{O}$ & & & \\
\hline 17.10 & $\begin{array}{l}\text { Tarifa média de importação de petróleo a nível mundial, do ponto de } \\
\text { vista da condição preferencial }\end{array}$ & & & $\mathrm{O}$ & & & \\
\hline 17.10 & $\begin{array}{l}\text { Tarifa média de importação de petróleo a nível mundial, do ponto de } \\
\text { vista da nação mais favorecida }\end{array}$ & & & O & & & \\
\hline 17.10 & $\begin{array}{l}\text { Tarifa média de importação de produtos agrícolas a nível mundial, do } \\
\text { ponto de vista da condição preferencial }\end{array}$ & & & $\mathrm{O}$ & & & \\
\hline 17.10 & $\begin{array}{l}\text { Tarifa média de importação de produtos agrícolas a nível mundial, do } \\
\text { ponto de vista da nação mais favorecida }\end{array}$ & & & $\mathrm{O}$ & & & \\
\hline 17.10 & $\begin{array}{l}\text { Tarifa média de importação de produtos industrializados a nível } \\
\text { mundial, do ponto de vista da condição preferencial }\end{array}$ & & & $\mathrm{O}$ & & & \\
\hline 17.10 & $\begin{array}{l}\text { Tarifa média de importação de produtos industrializados a nível } \\
\text { mundial, do ponto de vista da nação mais favorecida }\end{array}$ & & & 0 & & & \\
\hline 17.10 & $\begin{array}{l}\text { Tarifa média de importação de produtos têxteis a nível mundial, do ponto } \\
\text { de vista da condição preferencial }\end{array}$ & & & 0 & & & \\
\hline 17.10 & $\begin{array}{l}\text { Tarifa média de importação de produtos têxteis a nível mundial, do ponto } \\
\text { de vista da nação mais favorecida }\end{array}$ & & & 0 & & & \\
\hline 17.10 & $\begin{array}{l}\text { Tarifa média de importação de todos os produtos a nível mundial, do } \\
\text { ponto de vista da condição preferencial }\end{array}$ & & & $\mathrm{O}$ & & & \\
\hline 17.10 & $\begin{array}{l}\text { Tarifa média de importação de todos os produtos a nível mundial, do } \\
\text { ponto de vista da nação mais favorecida }\end{array}$ & & & 0 & & & \\
\hline 17.10 & $\begin{array}{l}\text { Tarifa média de importação de vestuário a nível mundial, do ponto de } \\
\text { vista da condição preferencial }\end{array}$ & & & 0 & & & \\
\hline 17.10 & $\begin{array}{l}\text { Tarifa média de importação de vestuário a nível mundial, do ponto de } \\
\text { vista da nação mais favorecida }\end{array}$ & & & 0 & & & \\
\hline 17.18 & $\begin{array}{l}\text { Número de países com um plano nacional de estatística que está } \\
\text { totalmente financiado e em implementação }\end{array}$ & & & 0 & & & \\
\hline 17.19 & $\begin{array}{l}\text { Número de países que realizaram ao menos um censo populacional e } \\
\text { habitacional nos últimos } 10 \text { anos }\end{array}$ & & $\mathrm{O}$ & & & & \\
\hline 17.19 & $\begin{array}{l}\text { Percentual de países que realizaram pelo menos um censo populacional } \\
\text { nos últimos } 10 \text { anos }\end{array}$ & & $\mathrm{O}$ & & & & \\
\hline 17.19 & $\begin{array}{l}\text { Valor em dólares de todos os recursos disponibilizados para fortalecer a } \\
\text { capacidade estatística em países em desenvolvimento }\end{array}$ & & & & & & O \\
\hline
\end{tabular}

Legenda: [A] Accountability; [B] Eficácia; [C] Integração e cooperação entre stakeholders; [D] Integridade; [E] Participação social; [F] Transparência. Fonte: Programa das Nações Unidas (PNUD). (2015). Plataforma para agenda 2030. Recuperado em 20 junho, 2017, de http://www.agenda2030.com.br/consulta.php. Documento online não paginado. 
Já nas metas do ODS 17, não são contempladas de forma direta as categorias de accountability $[A]$, integridade [D] e participação social [E]. Destaca-se o expressivo hall de indicadores que contemplam a categoria de Integração e cooperação - aqui direcionado principalmente para indicadores de integração comercial entre os países. Não são identificados indicadores voltados para a integração e cooperação de stakeholders para processos de tomada de decisão, formulação e implementação de políticas públicas.

Indicadores de natureza monetária são utilizados para mensurar aspectos compreendidos nas categorias de eficácia e transparência por meio do aprimoramento da capacidade estatística dos países. Embora as informações contempladas pelos indicadores monetários careçam de uma compreensão mais ampla dos vieses de governança e do DS, a sua adoção possui maior viabilidade ao processo de monitoramento, uma vez que as informações já possuem coleta e sistematização consolidadas dos países inseridos nos fluxos comerciais globais. Aponta-se como desafio a elaboração e utilização de indicadores e métricas desenhadas especificamente para as dimensões social e ambiental.

Da forma como se coloca, o hall de indicadores voltados para a governança não possibilita o monitoramento e avaliação desse conceito no alcance dos ODS. Embora contemple nuances, desconsidera aspectos centrais no seu manejo, principalmente relacionados à accountability e participação social.

Entende-se que fatores como a diversidade de sistemas de governo, desenhos institucionais e mecanismos de gestão dos países se colocam como uma das principais causas na indefinição de indicadores dessa natureza, uma vez que são adotados nos países diversos desenhos e processos de formulação, implementação e avaliação de políticas públicas e processo de tomada de decisão.

Considerando que a sistemática adotada para coleta, sistematização e publicidade de informações governamentais se coloca como fator central no tratamento de várias nuances da boa governança, aponta-se como caminho a identificação e monitoramento desses mecanismos consolidados nas esferas nacionais como possibilidade na consolidação de indicadores de governança.

\section{CONSIDERAÇÕES FINAIS}

Embora recorrentes na literatura voltada para caracterização da "boa governança", as aspectos de accountability e participação social não são diretamente consideradas no hall de indicadores voltados para a governança nos ODS. Já os aspectos de eficácia, integridade e transparência são mencionados de forma mínima. Observa-se maior relevância de elementos da categoria de integração e cooperação entre stakeholders.

Dado esse cenário, presume-se que a verificação do progresso e identificação de áreas prioritárias de ação quanto aos aspectos de governança da Agenda 2030 está inclinada à estagnação.

Mesmo que alguns elementos de governança sejam passíveis de mensuração por meio dos indicadores postos, a sua concepção não abarca diversos aspectos desejáveis do que a literatura caracteriza como "boa governança", o que limita a identificação de áreas prioritárias e ação estratégica de governança entre as nações e demais stakeholders no âmbito do DS, bem como o desenvolvimento de práticas e políticas mais abrangentes de governança.

O hall de indicadores desenhados para a governança dos ODS se concentram em aspectos de integração e cooperação entre países, utilizando de métricas e dados já utilizados nos fluxos econômicos e comerciais. É notada a ausência de indicadores pautados pelas dimensões ambiental e social no manejo da governança em nível global.

Uma agenda de pesquisas futuras pode explorar as dificuldades da elaboração e consolidação de indicadores e mecanismos de monitoramento e avaliação de governança em escala global. 


\section{REFERÊNCIAS}

[1] Costa, G. B. da et al. (2012). Desenvolvimento sustentável: governança e indicadores para o setor público. Revista Grifos, n. 32-33.

[2] Grupo Banco Mundial. (2017). Governança e a lei. Washington: Banco Mundial. Relatório do desenvolvimento mundial.

[3] Independent Evaluation Group (IEG). World Bank. (2007) Sourcebook for evaluating global and regional partnership programs indicative: principles and standards. Washington: IEG. I4] International Federation Of Accountants
(IFAC). (2001). Governance in the Public Sector: A Governing Body Perspective International Public Sector Study. Nova lorque: IFAC.

[5] Matias-pereira, J. (2008). Manual de gestão pública contemporânea. 1. ed. São Paulo: Atlas. May, T. (2004). Pesquisa social: questões, métodos e processos. 3. ed. Porto Alegre: Artmed. Programa das Nações Unidas (PNUD). (2015). Plataforma para agenda 2030. Recuperado em 20 junho, 2017 de http://www.agenda2030.com.br/consulta.php. Documento online não paginado.

[6] Nações Unidas. (2008). Achieving sustainable development and promoting development cooperation: dialogues at the economic and social council. Nova lorque: Nações Unidas. Economic \& social affairs.

[7] Souza, S. M. A. \& Cândido, G. A. (2009). Relações entre as formas de governança de arranjos produtivos com a competitividade e o desenvolvimento local sustentável. Revista Gestão Industrial, 5(1), pp. 161-187.

[8] Stoddart, H. (ed.) et al. (2011). A pocket guide to sustainable development governance. Stakeholder Forum. Commonwealth Secretariat.

[9] Sustainable Development Solutions Netowork (SDSN). (2014). Indicators for sustainable development goals: a report by the leadership. Council of the Sustaiable Development Solutions Network. [s.I.]: SDSN.

[10] World Bank Institute. Governance matters 2008: Indicadores de governança 1996-2007. (2008). Documento online não paginado.

[11] [...] structures, functions, processes, and organizational traditions that have been put in place within the context of a program's authorizing environment "to ensure that the [program] is run in such a way that it achieves its objectives in an effective and transparent manner.

[12] The public sector, business, and other stakeholders commit to good governance, including transparency, accountability, access to information, participation, an end to tax and secrecy havens, and efforts to stamp out corruption.

[13] There is now acceptance of the fact that we need to bring about a shift to a more inclusive concept of governance, including cooperation of various levels of government, the private sector and civil society (NAÇÕES UNIDAS, 2008, p. 21.).

[14] Tradução de Oliveira et al (2009) do original: openness; integrity; accountability.

[15] Tradução de Oliveira et al (2009) do original: standards of behavior; organizational structures and processes; control; external reporting. The precautionary principle; polluter pays principle; common but differentiated responsibilities; access to information, participation and justice; the global commons; integenerational equity; commonwealth principles on the reform of international institutions.

[16] No hall de indicadores do ODS 16, entendese como pertinente a análise dos itens das metas 16.5, 16.8, 16.10 e 10.a, referentes ao fortalecimento das instituições para o DS. Os indicadores das metas 16.1, 16.2, 16.3 e 16.se referem aos temas de justiça e construção de sociedades pacíficas, sendo desconsiderados para os fins deste trabalho. 


\title{
Bapítulo 5
}

\section{STAKEHOLDERS E SEUS RELACIONAMENTOS EM UNIDADES FRANQUEADAS DO RAMO ALIMENTICIO: ESTRATÉGIAS DE INFLUENCIA E CRIAÇÃO DE VALOR}

\author{
Ananda Silva Singh \\ Eduardo De-Carli \\ Ana Beatriz Murillo Oviedo \\ Thálita Anny Estefanuto Orsiolli
}

Resumo: O sistema de franquias, considerado por muitos autores como sendo um ato empreendedor, vem sendo cada vez mais utilizado como uma fonte alternativa para a alta de desemprego ocasionalmente acentuada do país. Desse modo, o crescimento deste sistema torna necessária a compreensão de fatores que possam levá-lo ao sucesso, sendo um deles o estreitamento do relacionamento que o franqueador estabelece com seus stakeholders. A compreensão dos interesses destes atores sociais bem como da influência que exercem sobre o empreendimento contribui para orientar as ações e estratégias do empreendedor, o auxiliando a usufruir da potencial criação de valor obtida a partir desses relacionamentos. Frente a tal perspectiva, este trabalho insere-se no contexto ao analisar as estratégias de influência dos stakeholders e a criação de valor nas unidades franqueadas do ramo alimentício, localizadas na cidade de Uberlândia/MG. Para tal, é realizado um estudo de caso qualitativo, sendo que os dados foram coletados a partir de entrevistas semiestruturadas e analisados através da Análise de Conteúdo. Os resultados mostram quem são os stakeholders, suas estratégias de influência e a dependência que as unidades estudadas possuem para com eles. Ainda, mostram as maneiras pelas quais os stakeholders criam e usufruem de valor proveniente de seus relacionamentos com as unidades franqueadas.

Palavras-chave: stakeholders, unidades franqueadas, empreendedorismo, estratégias de influência, criação de valor 


\section{INTRODUÇÃO}

A abordagem da 'Teoria dos Stakeholders' ou dos Grupos de Interesses voltada para estratégia surgiu em meados dos anos 1980, com o intuito de tentar suprir a deficiência das estruturas tradicionais de estratégia que não estavam ajudando os gerentes a desenvolver novas direções estratégicas nem a criar novas oportunidades no meio de tantas mudanças (Freeman \& McVea, 2000).

A análise dessa abordagem, ou seja, do relacionamento de empreendimentos diversos (sejam estes, pequenas, médias ou grandes empresas, cooperativas, dentre outros) com seus stakeholders, bem como os benefícios que podem ser obtidos a partir destas parcerias, tem se tornado assunto relevante na literatura relacionada a esta temática (Freitas \& Hoffmann, 2012; Hoffmann, Procopiak Filho, \& Rossetto, 2008; Pavão \& Rossetto, 2013; Phan, Butler, \& Lee, 1996). Não raro, estudos sobre a temática estão em crescimento (Laimer \& Figueiredo, 2015).

Dentro deste contexto, alguns estudos têm contribuído para a compreensão das relações existentes entre stakeholders e estratégia. Hillman e Keim (2001) apontam que um indício do aumento do capital de acionistas está em melhorar a relação com stakeholders, sejam eles clientes, fornecedores ou funcionários. Autores como Freeman (1984), Donaldson e Preston (1995), Metcalfe (1998) complementam que não só os acionistas devem ter seus interesses atendidos e usufruir da criação de valor, mas sim todos os demais grupos de interesses de uma organização, para que ambos se beneficiem.

Dada a importância de estudos sobre o tema e do relacionamento entre a organização e seu grupo de interesses, possibilita-se conhecer e compreender os interesses dos stakeholders, a dependência que possuem para com as unidades com as quais se relacionam e, consequentemente, a influência que exercem sobre as mesmas, a fim de levar estes fatores em consideração durante o planejamento e execução das operações de curto e longo prazo. Dessa forma, poderá ocorrer, inclusive, geração de valor a partir dos relacionamentos existentes entre as unidades de análise e seus grupos de interesses.

Ao se relacionar, as partes interatuantes podem vir a desenvolver-se mutuamente, a gerar benefícios para ambas e, consequentemente, manterem-se ativas no mercado. Um exemplo desse tipo de relacionamento pode estar nas franquias. Estes tipos de empreendimentos merecem destaque por apresentarem crescimento, apesar do encolhimento da economia no ano de 2016 (Lima, 2016). De acordo com a Associação Brasileira de Franchising (ABF, 2019), o setor cresceu $9,2 \%$ em $2016,8 \%$ em 2017 e 7\% em 2018, algo que se deu principalmente porque houve melhorias nos resultados positivos do segmento de serviços, nos índices de confiança, em inovações, fatores esses que contribuíram para tais melhorias.

Nessa perspectiva, dado que a franquia apresenta maior segurança ao empreendedor, por já ser um negócio testado e por já possuir uma reputação, este cenário também se vê presente na cidade de Uberlândia - MG, na qual a maioria dos investidores de franchising são pessoas que deixam seus empregos atuais para investir em unidades franqueadas, sendo que "investir no segmento de franchising tem as suas vantagens como a expansão do crédito para abertura de empresas, segurança do negócio já formatado, conhecido, com suportes necessários, valores de investimentos e retornos atrativos, além da opção de escolha entre diversos ramos da economia" (Serifa Comunicação Integrada, 2016). Segundo Belafonte (2016), o setor alimentício é o que mais se destaca dentre todos os segmentos de franquias na cidade de Uberlândia, correspondendo a $21 \%$ do total na região, seguido dos setores de negócios, serviços e outros varejos - que correspondem a $15 \%$ do total - e do esporte, saúde e beleza, que totalizam $13 \%$ das franquias locais. Dada a importância local deste segmento, encontrase nele a motivação para definir os objetos de análise deste trabalho: unidades franqueadas do ramo alimentício da cidade de Uberlândia.

Diante deste contexto, o presente trabalho busca responder ao seguinte problema de pesquisa: De que forma ocorre a relação entre unidades franqueadas do ramo alimentício, localizadas na cidade de Uberlândia/MG, e seus stakeholders para o sucesso da organização, a partir das estratégias de influência que exercem sobre elas e da criação de valor usufruído pelos mesmos e pelas unidades franqueadas.

Sendo assim, o objetivo do presente trabalho consiste em verificar quais são as estratégias de influência exercidas pelos stakeholders sobre as unidades franqueadas nas quais 
estão envolvidos e de que forma se dá a criação de valor dos stakeholders para com as unidades, e vice-versa. Para auxiliar o cumprimento deste objetivo, o trabalho possui como objetivos específicos: identificar quem são os grupos de interesse das unidades estudadas, quais são seus interesses e quais são os métodos que utilizam para atingi-los.

Para responder à questão de pesquisa, este artigo encontra-se estruturado em quatro seções, além da presente introdução: referencial teórico, contendo conceitos relevantes referentes ao empreendedorismo, franchising, criação de valor e influência dos stakeholders na organização; procedimentos metodológicos utilizados para a coleta e análise dos dados; análise dos resultados encontrados e conclusão, contendo as considerações finais do trabalho, suas limitações e sugestões de pesquisas futuras.

\section{REFERENCIAL TEÓRICO}

\subsection{EMPREENDEDORISMO E O FRANCHISING}

A origem do termo 'empreendedorismo' advém, segundo apontam Hisrich e Peters (2004), da Idade Média, como aquele que incentiva brigas; no século XVII, a pessoa com responsabilidade de dirigir ação militar; no século XVII, a pessoa que compra e processa matéria-prima para depois vendê-la (Richard Cantillon); no século XIX, como a pessoa que aproveita oportunidades e promove o progresso (Jean Baptist Say, Francis Walker); no século XX, retoma 0 sujeito como quem inova, maximiza oportunidades, corre riscos moderados (Joseph Schumpeter, Peter Drucker); no século XXI é quem lida com a complexidade.

Esses fatores indicam que o empreendedor pode ser caracterizado como alguém que assume riscos, que provê transformações no processo produtivo para alavancar o retorno, que promove alterações no fluxo circular tradicional da produção, é o agente do processo de destruição criativa, é quem cria novos produtos e/ou métodos de produção que se sobrepõe aos antigos (Shumpeter, 1983).

Empreender é "criar algo novo com valor, dedicando o tempo e o esforço necessários, assumindo riscos financeiros, psíquicos e sociais correspondentes e recebendo as consequentes recompensas da satisfação e independência econômica e pessoal" (Hisrich \& Peters, 2004, p. 29). Há quatro aspectos básicos que um empreendedor deve compreender: (1) o empreendedor deve criar algo que tenha valor para ele e para o público-consumidor para $\mathrm{O}$ qual $\mathrm{O}$ empreendimento é desenvolvido; (2) o empreendedor deve dispender tempo e esforços suficientes para a criação do empreendimento e também que o mesmo seja possível de ser operacionalizado; (3) o empreendedor deve ter consciência dos riscos aos quais poderá estar susceptível; e (4) existem recompensas - independência, satisfação pessoal, recompensa financeira as quais serão desfrutadas pelo empreendedor, em casos de sucesso total ou parcial do empreendimento (Peres, 2009).

Empreender é o ato de inovar, de desenvolver a 'destruição criativa', de criar algo novo para que possa angariar uma nova oportunidade de mercado, sendo que está no empreendedor a responsabilidade pelo desenvolvimento organizacional, uma vez que desloca o estado de equilíbrio, causa alterações da vida econômica a partir da própria iniciativa do empreendedor (Shumpeter, 1983), apresenta novas maneiras de combinar recursos, para citar apenas alguns aspectos.

Isso está atrelado à capacidade que o empreendedor possui em perceber a diversificação de mercados e adapta a produção de sua empresa de acordo com a demanda, uma vez que "toda empresa é uma reunião de atividades que são executadas para projetar, produzir, comercializar, entregar e sustentar seu produto" (Porter, 1989, p. 33), e deve realizar de forma eficiente e eficaz, para que possa manter o mercado onde atua, conquistar novos e produzir cada vez mais e melhor, de modo cada vez menos custoso, para atingir maior competitividade.

Para tanto, há necessidade de renovação e melhoria constante da qualidade de bens e serviços, a manutenção dos processos técnicos de produção, como técnicas de diagnóstico e avaliação de desempenho para utilização inteligente de recursos da organização, extraindo ao máximo sua capacidade, lidar com mudanças, implementá-las e administrá-las, avaliar diferentes aspectos para a tomada de decisão com menores chances de erro, para que haja soma de conhecimentos, habilidades no decorrer do progresso das atividades e do ciclo de vida organizacional. 
Ressalta-se que a velocidade em que o empreendedor enfrenta desafios, aliado à capacidade de absorver novos conhecimentos e desenvolver novas habilidades durante o ciclo de vida organizacional é um fator que determina o sucesso ou não da empresa (Grapeggia \& Minuzzi, 2008). Vale destacar a importância atribuída ao empreendedorismo apontada pela revista "Empreendedorismo no Brasil", cujos dados advém do consórcio GEM (Global Entrepreneurship Monitor), entendendo que o empreendedorismo é fundamental para gerar riquezas, promover crescimento econômico e aprimorar condições de vida da população, sendo um fator-chave para gerar empregos e renda (Greco, 2014).

É nessa perspectiva que enquadra-se 0 franchising. Apesar de, por um lado, o franchising não ser associado ao empreendedorismo, principalmente pelo fato de imitar um formato de sucesso já existente (Kaufmann \& Dantb, 1999), por outro, o ato de franquear uma empresa consiste como um ato empreendedor (Hoy \& Shane, 1998; Tuunanen, Hoy, Torikka, \& Hyrsky, 2005). Isto se dá por conta de a franquia depender de dois empreendedores para ter sucesso - o franqueador e o franqueado (Shane \& Hoy, 1996) e também pelo fato do franchising possuir várias características similares às do empreendedorismo, tais quais a criação de novos negócios e o fato de estar sempre buscando novas oportunidades (Falbea, Dandridgeb \& Kumarc, 1998).

Ainda corroborando com os autores que defendem a franquia como sendo um ato empreendedor, sob a perspectiva estratégica, o franqueador agrega valor ao franqueado através de aspectos como marca, tecnologia, análise do local de implantação da unidade e um sistema pronto de negócios. Ademais, o franqueado também agrega valor ao sistema de franquias a partir da criação de estratégias e de soluções para problemas existentes (Phan et al., 1996). Desta forma, considerouse esta perspectiva da franquia, para fins de estudo no presente trabalho.

\subsection{STAKEHOLDERS: CONCEITOS E SUA INFLUÊNCIA NAS ORGANIZAÇÕES}

O termo stakeholder pode ser definido como sendo "qualquer grupo ou indivíduo que é afetado por ou pode afetar o alcance dos objetivos de uma organização" (Freeman \& McVea, 2000, p. 4). Ainda, para Mitroff e Linstone (1993) stakeholders são quaisquer indivíduos, grupos, organizações, instituições que podem tanto afetar como serem afetadas pelas políticas de um indivíduo, grupo, organização ou instituição.

Nos estudos relacionados à identificação dos stakeholders, segundo Frooman (1999), três questões gerais devem ser explicadas: (1) quem eles são, (2) o que eles querem e, (3) como eles estão agindo (meios) para atingir seus objetivos. Alsos, Hytti e Ljunggren (2011) observaram, em um estudo de caso, que muitas vezes o que os stakeholders querem resulta na necessidade de equilibrar um conjunto complexo de metas conflitantes. As expectativas dos grupos de interesse são interdependentes, devendo a gestão escolher soluções subótimas, com o intuito de balancear e atender a expectativas diversas.

Ainda, para Frooman (1999), no que diz respeito ao que os stakeholders realizam para alcançar seus objetivos, existem duas abordagens que auxiliam a compreensão de como os atores socais influenciam na formação de estratégias e que devem ser consideradas na análise: (1) os tipos de estratégias utilizadas por eles para influenciar a organização e (2) os fatores determinantes na escolha.

Além disso, para o autor, há quatro tipos de estratégias de influência dos stakeholders sobre a organização, isto é, retenção direta, retenção indireta, uso direto e uso indireto, e quatro tipos de relações sobre recursos, como o poder que possuem, alta dependência, baixa dependência e poder da organização, como pode ser visualizado no Quadro 1. 
Quadro 1 - Relação de dependência do stakeholdere da organização.

\begin{tabular}{|c|c|c|c|}
\hline \multirow{4}{*}{ 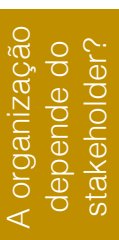 } & & \multicolumn{2}{|c|}{ O stakeholder é dependente da organização? } \\
\hline & & Não & Sim \\
\hline & Não & Indireta/ Retenção (Baixa dependência) & $\begin{array}{c}\text { Indireta/ uso } \\
\text { (Poder da organização) }\end{array}$ \\
\hline & Sim & Direta/ Retenção (Poder do stakeholder) & $\begin{array}{c}\text { Direta/ uso } \\
\text { (Alta dependência) }\end{array}$ \\
\hline
\end{tabular}

Fonte: Adaptado de Frooman (1999).

O modelo representado pelo Quadro 1 possibilita a análise das estratégias de influência dos stakeholders, conciliando conceitos da 'Teoria dos Stakeholders', que engloba os relacionamentos de empreendimentos diversos (Freitas \& Hoffmann, 2012; Pavão \& Rossetto, 2013) com conceitos da 'Teoria da Dependência de Recursos', que engloba aspectos referentes ao comportamento das organizações e o seu contexto (Pfeffer \& Salancik, 1978). Tem como objetivo identificar qual tipo de influência estratégica é possível se observar, a partir da relação entre a organização e seus grupos de interesse, na busca pelos recursos que estes últimos têm a oferecer (Pavão, Dalfovo, Escobar, \& Rossetto, 2012).

A partir do Quadro 1 é possível observar que, quando há baixo nível de dependência da organização com o stakeholder, utiliza-se de estratégias de influência indireta e de retenção de recursos; quando há alto nível de dependência, utiliza-se de estratégias diretas e de uso. Já quando o relacionamento entre stakeholder e organização é marcado pelo poder desta última, o stakeholder usará uma estratégia de influência indireta e de uso; enquanto que, quando o relacionamento entre o stakeholder e a organização é marcado pelo poder do primeiro, este utilizará uma estratégia de influência direta de retenção de recursos (Frooman, 1999). Ainda, é possível inferir que: (a) a estratégia direta corresponde àquela em que o stakeholder manipula 0 provimento de recursos; (b) a estratégia indireta ocorre quando dois ou mais stakeholders se associam, a fim de manipular o provimento de recursos - ainda que indiretamente -, influenciando as tomadas de decisão da empresa (Freitas \& Souza, 2011).

A importância de se conhecer as estratégias de influência dos stakeholders para com a organização fornece uma possibilidade de obtenção de respostas às questões sobre quais ações os atores sociais poderão implementar para tentar alcançar o que almejam da organização (Frooman, 1999), isto é, em questão, as ações estabelecidas por empreendedores com vistas a delinear formas que beneficiem concomitantemente a organização e seus grupos de interesse.

Desse modo, o empreendedorismo implica em um processo de criação de valor pela combinação de recursos para explorar uma oportunidade $e$, considerando-se os stakeholders como sendo recursos humanos, é possível inferir que estes, combinados, representam potencial para agregar valor para a organização com a qual estão envolvidos (Kuratko, Morris, \& Schindehutte, 2015; Roberts, Stevenson, Sahlman, Marshall, \& Hamermesh, 1996).

Não raro, recursos são valiosos para que empresas aprimorem sua eficiência e eficácia para que a estratégia venha a evoluir (Barney, 1991). Conforme Prahalad e Ramaswamy (2000, p. 169), o "valor está associado às experiências; os produtos e serviços facilitam experiências individuais e experiências medidas pela comunidade" e os stakeholders podem contribuir direta e/ou indiretamente para as experiências individuais e coletivas, por isso podem contribuir para a criação de valor para as organizações com as quais estão envolvidos.

\section{METODOLOGIA}

A pesquisa em questão caracteriza-se por possuir natureza descritiva, dado que os pesquisadores não interferiram nos fatos, tendo sido estes apenas analisados, classificados e interpretados (Raupp \& Beuren, 2003) e possui abordagem qualitativa, vez que evita lidar com números e que aborda interpretações das realidades sociais dos fenômenos em questão, (Bauer \& Gaskell, 2002), ou seja, das estratégias de influência e criação de valor por parte dos colaboradores e stakeholders das unidades franqueadas analisadas. Já quanto aos meios, utilizou-se o estudo de caso, visto que este permite a compreensão de fenômenos complexos (no caso, estratégias de influência 
dos stakeholders em relação às organizações e criação de valor), possibilitando uma análise em profundidade de assuntos que se deseja compreender (Yin, 2015).

Nesta pesquisa foram analisadas duas unidades franqueadas (aqui chamadas de Unidade 1 e Unidade 2) de uma franquia alimentícia, localizadas na cidade de Uberlândia - MG. A escolha destes locais para se analisar os fenômenos desejados ocorreu devido à alimentação corresponder ao segmento de franquia que mais se destaca na cidade (representatividade de 21\%) (Bittencourt Consultoria, 2016) e ao fato destes fenômenos carecerem de estudos atualizados na literatura.

A técnica de coleta de dados utilizada foi a entrevista semiestruturada, sendo realizada no primeiro semestre de 2017 com o empreendedor e stakeholders (definidos sob o ponto de vista do empreendedor) das franquias, totalizando 10 entrevistados: 01 profissional de cada nível (estratégico, tático e operacional) de cada unidade franqueada (total de 05 entrevistados, visto que 0 profissional de nível estratégico empreendedor - é o mesmo para ambas unidades), 01 fornecedor (comum para ambas unidades) e 04 consumidores das unidades franqueadas (02 entrevistados de cada unidade).

Para análise do construto "estratégias de influência" e para identificar quem são os stakeholders das unidades franqueadas, utilizou-se um roteiro semiestruturado específico para identificar a percepção do gestor. A leitura do Quadro 1 supracitado (Frooman, 1999) permitiu operacionalizar o roteiro de entrevista para levantamento das estratégias de influência dos stakeholders sobre as unidades franqueadas.

Para analisar os demais componentes das categorias estudadas, utilizou-se um roteiro específico para tal, destinado aos demais stakeholders, conforme aspectos identificados na literatura sobre os fenômenos estudados: os interesses dos stakeholders (Frooman, 1999; Alsos et al., 2011), métodos para atingir esses interesses - incluindo suas estratégias de influência - (Frooman, 1999) e criação de valor (Donaldson \& Preston, 1995; Freeman, 1984; Metcalfe, 1998; Prahalad \& Ramaswamy, 2000).

Os profissionais entrevistados foram denominados de acordo com os seguintes códigos:

Tabela 1: Códigos utilizados para cada stakeholder entrevistado.

\begin{tabular}{|l|c|}
\multicolumn{1}{|c|}{ Profissional entrevistado } & $\begin{array}{c}\text { Código utilizado na apresentação dos } \\
\text { resultados }\end{array}$ \\
\hline Empreendedor (tanto da Unidade 1 quanto da 2) & Empreendedor \\
\hline Profissional de nível estratégico da Unidade 1 & Estratégico 1 \\
\hline Profissional de nível estratégico da Unidade 2 & Estratégico 2 \\
\hline Profissional de nível tático da Unidade 1 & Tático 1 \\
\hline Profissional de nível tático da Unidade 2 & Tático 2 \\
\hline Profissional de nível operacional da Unidade 1 & Operacional 1 \\
\hline Profissional de nível operacional da Unidade 2 & Operacional 2 \\
\hline Fornecedor (tanto da Unidade 1 quanto da Unidade 2) & Fornecedor \\
\hline Consumidores da Unidade 1 & Consumidor 1.1/ Consumidor 1.2 \\
\hline Consumidores da Unidade 2 & Consumidor 2.1/ Consumidor 2.2 \\
\hline \multicolumn{2}{|c|}{ Fonte: Elaborado pelos autores (2017). } \\
\hline
\end{tabular}

Os dados foram apresentados e, em seguida, analisados a partir da técnica da análise de conteúdo (Bardin, 2016), sob a perspectiva das seguintes categorias definidas à priori à coleta de dados: (1) stakeholders (componentes: quem são, seus interesses e métodos para atingi-los), (2) stakeholders e suas estratégias de influência na organização, e (3) stakeholders e a criação de valor.

\section{ANÁLISE DOS RESULTADOS 4.1.CARACTERIZAÇÃO DAS UNIDADES FRANQUEADAS ESTUDADAS}

As unidades franqueadas foram criadas em 2012 (Unidade 1) e em 2014 (Unidade 2), a partir da identificação - através de pesquisas de mercado - de desejo dos potenciais consumidores pelo tipo de comida ofertada pela franquia, na cidade de Uberlândia - MG. Outro motivo impulsionador para a criação 
das unidades franqueadas foi seu potencial de retorno financeiro. Cabe destacar que, quando das entrevistas, ambas possuiam 15 colaboradores cada e estavam em funcionamento de segunda a domingo, das 10 até as 22 horas.

Nessa perspectiva, tem-se que tais unidades franqueadas podem ser consideradas um empreendimento empreendedor (Hoy \& Shane, 1998; Tuunanen et al., 2005), pois dispenderam da ideia de empreender, de tempo e esforço (elaboração de plano de negócios, de pesquisas de mercado), recursos financeiros e conhecimento (recursos próprios do proprietário e graduação do mesmo em área de conhecimento correlata) para que fossem operacionalizados.

Além disso, os empreendimentos e o empreendedor estiveram susceptíveis a riscos (fechamento do estabelecimento no qual as unidades franqueadas se encontram localizadas, risco dos clientes não gostarem do padrão de produto oferecido, estrutura oferecida pelo estabelecimento não ser adequada para a operação, dentre outros) e a recompensas para o empreendedor (independência, satisfação pessoal ao poder lidar com pessoas e contribuir para que realizem seus sonhos) e para o próprio negócio (retorno esperado para sua continuidade), possuindo os aspectos que caracterizam uma franquia, conforme aponta Peres (2009). Frente a tais aspectos, a seguir, delineia-se quem são os stakeholders e sua importância na relação de negócios.

Nas Unidades 1 e 2 aqui estudadas foram analisados aspectos referentes aos seus stakeholders, com o intuito de identificá-los, avaliar seus interesses e estratégias de influência, além da criação de valor usufruída por eles e pelas organizações, decorrente de seu relacionamento.

\subsection{STAKEHOLDERS: QUEM SÃO, SEUS INTERESSES E MEIOS PARA ATINGI-LOS}

Nesta categoria analisou-se quem são os stakeholders das unidades franqueadas estudadas, o que almejam e como estão agindo para atingir seus objetivos (Frooman, 1999). Foi possível identificar os grupos de interesse das unidades franqueadas: a franqueadora, os fornecedores (tanto os qualificados, ou seja, os que já passaram por um crivo de qualidade e podem fornecer para a unidade franqueada, quanto os homologados, ou seja, os que possuem todos os crivos necessários para que possam fornecer de acordo com as prerrogativas da unidade franqueadora), os clientes, a vigilância sanitária, o estabelecimento no qual a unidade franqueada se encontra localizada, o sindicato, os gestores (gerente e coordenador) e os demais funcionários (chefe de cozinha, chefe de cozinha especializada, cozinheiro, cozinheiro especializado, auxiliar de limpeza, auxiliar de cozinha e auxiliar de cozinha especializada).

Observou-se, também, que as expectativas dos stakeholders (Frooman, 1999) são bastante diversificadas (Alsos et al., 2011): reconhecimento (Tático 1), atender o cliente com excelência (Fornecedor), crescimento profissional (Tático 2 e Operacional 1): "Minhas expectativas, crescer... e quem sabe, abrir meu próprio negócio" (Operacional 1) e aprendizado (Tático 2, Operacional 1 e Operacional 2): "Aprender, me especializar nessa área" (Operacional 2); "Aqui a gente aprende a lidar com o público, um pouquinho de cada coisa" (Operacional 1).

Já os principais interesses da maioria dos consumidores entrevistados (Consumidor 1.2, Consumidor 2.1, Consumidor 2.2) consistem em obter comida a preço justo e de qualidade. Estes resultados vão ao encontro do apontado por Alsos et al. (2011), que afirma que aquilo que os stakeholders querem resulta num conjunto complexo de metas conflitantes, que devem ser gerenciadas com soluções sub-ótimas para tentar atender às suas expectativas.

No que concerne aos meios que os stakeholders utilizam para atingir seus objetivos foram apontados: a assiduidade, a boa convivência e a disponibilidade, o estreitamento do relacionamento fornecedorcliente e a busca de conhecimento para conseguir o aprendizado. Ainda, outros meios que contribuem para atingirem os seus objetivos correspondem às estratégias de influência - abordadas a seguir - que os mesmos podem exercer para com a organização.

\subsection{STAKEHOLDERS E SUAS ESTRATÉGIAS DE INFLUÊNCIA NA ORGANIZAÇÃO}

A relação de dependência existente entre a organização e seus stakeholders foi identificada a partir do modelo de Frooman 
(1999) e das entrevistas realizadas com os gestores das unidades franqueadas. A relação existente nas unidades estudadas foi a seguinte:

Quadro 2 - Relação de dependência entre stakeholder e organização.

\begin{tabular}{|c|c|c|c|}
\hline \multirow{4}{*}{ 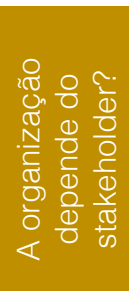 } & & \multicolumn{2}{|c|}{ O stakeholder é dependente da organização? } \\
\hline & & Não & $\operatorname{Sim}$ \\
\hline & Não & $\begin{array}{l}\text { Fornecedor qualificado Gerente } \\
\text { Coordenador Chefe de cozinha Cozinheiro } \\
\text { Auxiliares (cozinha, cozinha especializada e limpeza) }\end{array}$ & \\
\hline & Sim & $\begin{array}{l}\text { Sindicato Vigilância sanitária Cliente } \\
\text { Chefe especializado de cozinha }\end{array}$ & $\begin{array}{l}\text { Franqueadora } \\
\text { Fornecedor } \\
\text { homologado }\end{array}$ \\
\hline
\end{tabular}

Fonte: Adaptado de Frooman (1999), a partir dos dados coletados.

A partir das relações de dependência entre a organização e seus stakeholders é possível identificar, de acordo com a matriz de Frooman (1999), as possíveis estratégias utilizadas que possuem. No Quadro 2 observa-se que os stakeholders que têm alta dependência da organização são a franqueadora, por possuir alto grau de controle sobre a franqueada ao ditar regras e padrões que deve seguir, como a estrutura formal, ingredientes a serem utilizados, além dos fornecedores homologados, pois as unidades franqueadas devem comprar alguns produtos apenas deles, não tendo flexibilidade de comprá-los de outros fornecedores.

É notável a alta relação de dependência entre o fornecedor homologado e as unidades franqueadas: "O que procuramos é tornar o cliente parte do nosso negócio" (F12). Assim, estes stakeholders adotam uma estratégia direta e de uso de recursos ao se relacionarem com a franqueada. Confirma-se, portanto, o que Frooman (1999) aponta, quando afirma que a estratégia direta é aquela em que o stakeholder manipula o fornecimento de recursos para uma organização (como faz o fornecedor homologado); e a estratégia de uso é aquela na qual ele busca impor condições às organizações no fornecimento de recursos (como faz a franqueadora).

No que diz respeito aos stakeholders que adotam uma estratégia indireta (quando relacionam-se com outro com o intuito de manipular o fornecimento de recursos) e de retenção de recursos (cessam o fornecimento de recursos com intenção de mudar certo comportamento em uma organização) para com a franqueadora, encontram-se os fornecedores qualificados (não possuem contrato fixo com a franqueada e não são constantes opções na seleção da mesma), o gerente, coordenador, chefe de cozinha, cozinheiro e auxiliares (são facilmente substituíveis). Todos estes stakeholders devem se relacionar com outros, caso queiram manipular o fornecimento de recursos para a organização (Frooman, 1999), visto que, isolados, não possuem poder suficiente para tal.

Em contrapartida, a organização apresenta alta dependência de seus clientes, pois estes ditam o padrão, nível de serviço e qualidade de produtos que esperam; do sindicato e da vigilância sanitária, pois trabalham com o intuito de defender os interesses e direitos dos colaboradores e garantia da qualidade e higiene dos produtos; e do chefe especializado de cozinha, devido à dificuldade de se encontrar mão-de-obra qualificada para a especialidade para a qual o mesmo é contratado.

Entretanto, estes stakeholders não dependem da organização, pois possuem outras opções (como a concorrência e outros locais para trabalhar, quando se trata dos clientes e do chefe de cozinha, respectivamente) e outros estabelecimentos com os quais trabalham (no caso do sindicato e da vigilância sanitária). Sendo assim, visto que, apesar de não serem dependentes das unidades, estes stakeholders detêm poder em relação à franqueada e manipulam o fornecimento de recursos à organização, devido à mesma possuir alto grau de dependência para com eles.

A partir destes resultados, pode-se inferir que a dependência excessiva de algum ator social pode não ser benéfica para a organização, dado que qualquer falha que este stakeholder possa vir a ter poderá impactar de forma 
significativa e negativa na organização com a qual se relaciona.

\subsection{STAKEHOLDERS E A CRIAÇÃO DE VALOR}

Observou-se, nas entrevistas, que as unidades franqueadas agregam valor para a franqueadora, a partir da criação de estratégias e de soluções para problemas existentes, tendo em vista procurar saná-los de modo a que ambos obtenham benefícios (Phan et al., 1996):

[...] a franqueada tem experiência do dia-adia, ela mostra para a franqueadora a necessidade do cliente... A franqueadora elabora até mesmo novos cardápios de acordo com a preferência dos consumidores das unidades franqueadas, passadas a ela pelas unidades franqueadas (Empreendedor).

A nossa loja agrega muito para o nome da franquia, tanto na questão de vendas, de coordenação, de higiene, de padrão (Tático 2)

Não só a franqueadora tem seu valor agregado a partir de relacionamentos dos stakeholders com as organizações estudadas. Concordando com Freeman (1984), Donaldson e Preston (1995) e Metcalfe (1998), os próprios stakeholders também usufruem da criação de valor proveniente do estreitamento do seu relacionamento com as unidades franqueadas:

Aprendi a agir em grupo..., eu não tinha essa habilidade. Aprendi aqui a conversar, a dar ideias (Operacional 2).

Tanto os fornecedores quanto os entregadores falam que aqui é a melhor loja, porque o empreendedor chama eles pra tomar café com a gente, fala pra eles pegarem algo para comer [...] se ele tiver troco no bolso, ele troca pro vizinho quando ele pede, pra não deixar ele passar necessidade... quando vem algum cliente e faz alguma reclamação, ele faz questão de ir lá na mesa, sentar com a pessoa, conversar, perguntar de que jeito ele gosta do prato, e não cobra... (Tático 2)

Tem um fornecedor homologado, que vem e fala "preciso bater meta", o empreendedor fala "pode pegar" (a quantidade faltante para o fornecedor atingir a meta dele) ... mesmo que a gente não esteja precisando daquela quantidade. Tem uns fornecedores que não entregam sábado e domingo, mas se a gente estiver precisando de algo, eles pegam o carro deles e trazem pra gente mesmo nesses dias (Tático 2)

Observa-se, a partir das falas dos entrevistados, que o empreendedor busca estreitar seu relacionamento com os fornecedores, confirmando a relação de parceria, previamente exposta em fala do fornecedor. Ainda, observa-se também a criação de valor para a unidade franqueada, através de sugestões fornecidas pelos stakeholders às unidades franqueadas, sendo estas feitas de diversas formas:

Apresento quando me pedem alguma sugestão por meio daquelas pesquisas de satisfação (Consumidor 2.2).

[...] a cada novidade de produto e ideias, nós compartilhamos com o franqueado através de reunião e apresentação da novidade, e com isso recebemos sempre o feedback seja ele positivo ou não. Esse relacionamento esclarece um pouco sobre a nossa ideia de termos parceiros e não apenas clientes (Fornecedor).

A gente sempre dá sim. [...] E eles dão essa abertura pra gente expor as ideias. Damos as ideias no dia-a-dia, às vezes chegamos na gerente e damos alguma ideia, a gente tem muita conversa, tanto com o grupo de funcionários quanto com os donos (Operacional 1).

Destaca-se a abertura dada pelos gestores Tático 1, Tático 2 e Empreendedor para que os funcionários desenvolvam ideias e sugestões no dia-a-dia (visto que o Empreendedor 1.2 se encontra presente nas unidades franqueadas com frequência):

No dia a dia, no café da manhã, porque na hora do café da manhã senta todo mundo, inclusive o Empreendedor, todos os dias. Nisso, a gente já conversa... O Empreendedor é super aberto a ideias... qualquer coisa que você pensar, você chega e conversa com o Empreendedor se quiser mudar de horário, ela faz de tudo pra mudar... eles deixam os meninos escolher seus horários entre si (manhã-tarde), eles só têm que avisar os coordenadores, gerentes e donos (Tático 2).

Observou-se que as unidades franqueadas agregam valor para a franqueadora, e que os stakeholders também usufruem da criação de valor (Donaldson \& Preston, 1995; Freeman, 1984; Metcalfe, 1998; Prahalad \& Ramaswamy, 2000) proveniente de seu relacionamento com as unidades 
franqueadas. Ademais, observou-se a proximidade entre o empreendedor e seus colaboradores e fornecedores, contribuindo para relacionamentos de parceria entre eles (Barney, 1996).

Dessa forma, pode-se inferir que o estreitamento do relacionamento das unidades franqueadas com seus stakeholders pode gerar frutos positivos para tanto para o negócio quanto para os atores sociais a ele relacionados, através da geração de valor. Ainda, o perfil do empreendedor das unidades franqueadas aqui analisadas mostrou-se aberto a novas ideias e sugestões, o que torna essa atividade frequente entre os colaboradores das unidades e, consequentemente, contribui para sua maior participação e proximidade no processo de gestão dos negócios. Isso favorece a geração de ideias e sugestões de melhorias, contribuindo para agregar valor ao empreendimento.

\section{CONSIDERAÇÕES FINAIS}

Diante de cenários representados por uma economia instável, investir em franquias vem se mostrando uma das alternativas para aqueles empreendedores que desejam fugir da alta do desemprego. Entretanto, a abertura de negócios próprios demanda conhecer aspectos do negócio que possuem potencial de contribuição para o sucesso do mesmo, tal qual a criação de valor que pode ser obtida a partir do relacionamento destes empreendimentos com seus grupos de interesses. Ademais, conhecer o grau de dependência que cada unidade franqueada possui com cada stakeholder e, consequentemente, as estratégias de influência que estes exercem sobre elas, contribui para elaborar e direcionar ações e estratégias que atendam não só aos interesses das organizações, como também dos demais grupos de interessados. Isso tende a fortalecer os laços entre os atores que constituem a rede e até mesmo obtendo vantagens a partir do estreitamento destes relacionamentos.

Dessa maneira, o objetivo geral deste trabalho inseriu-se neste contexto, analisando as estratégias de influência e criação de valor obtida a partir dos relacionamentos de duas unidades franqueadas do ramo alimentício com seus stakeholders, especificamente na cidade de Uberlândia-MG.
A partir dos resultados encontrados, ainda que as organizações devam evitar a dependência excessiva de fornecedores e outros membros da sua cadeia produtiva, no caso analisado, a própria natureza do sistema de franquias exige alta dependência de alguns stakeholders (Frooman, 1999), como a franqueadora e os fornecedores homologados. Isso acaba por 'engessar' algumas tomadas de decisão das unidades franqueadas, visto que são altamente controladas pelas franqueadoras e altamente dependentes dos insumos dos fornecedores homologados. Assim, diferentemente de outros sistemas de organizações, que não possuem relação de dependência excessiva com outros atores sociais, inevitavelmente, as unidades franqueadas têm de aprender a lidar com possíveis falhas desses grupos de interesses com os quais possuem relação de alta dependência, Assim, os gestores das unidades franqueadas devem contemplar em seu planejamento estratégico, ações voltadas para lidar com eventuais falhas ou exigências urgentes desses fornecedores homologados e/ou franqueadora.

No tocante à criação de valor, observou-se que o perfil do empreendedor contribui para a participação dos colaboradores no processo de gestão do empreendimento e sua consequente criação de valor, através de contribuições para a unidade franqueada (como as sugestões e ideias que eventualmente dão ao empreendedor a respeito de melhorias na operação, por exemplo). Também, observou-se que o estreitamento de relacionamentos contribui para a criação de valor para o empreendimento, dado que foi possível observar congruência da mesma com os dados evidenciados empiricamente. O relacionamento estreito entre as unidades franqueadas e seus stakeholders contribui para o desenvolvimento de relacionamentos de parcerias entre esses grupos de interesses (Barney, 1996), e não meramente relacionamentos comerciais pontuais.

Dado que a literatura carece de estudos atualizados que tratam desta temática, a principal contribuição teórica deste trabalho reside em apresentar dados empíricos que evidenciam, na prática, como ocorrem essas estratégias de influência e criação de valor, a partir do relacionamento das unidades franqueadas aqui analisadas com seus stakeholders. 
Os resultados obtidos apresentam também contribuições gerenciais, visto que a identificação do grau de dependência dos stakeholders com as organizações e a relação direta que possuem com a influência que exercem sobre as mesmas contribui para orientar ações e planejamentos estratégicos referentes ao empreendimento. A partir disto, pode-se inferir que organizações devem evitar a dependência excessiva de determinados parceiros, a fim de que eventuais falhas nos mesmos gerem grandes impactos negativos em suas operações.

Apesar de tais contribuições e do cumprimento do objetivo proposto, o presente estudo apresentou algumas limitações. A primeira delas consiste na análise de um caso único, o que não possibilita generalização dos resultados. Para tanto, sugere-se que sejam realizadas pesquisas similares em outras unidades franqueadas, do mesmo ramo e de ramos diferentes, para que sejam identificados pontos de convergência e de divergência entre as organizações estudadas e para que seja possível obter resultados passíveis de generalização.

Dado que não foram ouvidos todos os stakeholders identificados (como as pessoas jurídicas, por exemplo, devido à dificuldade

\section{REFERÊNCIAS}

[1] ABF, Associação Brasileira de Franchising (2019). Desempenho do Franchising Brasileiro Projeções 2018/2019. Disponível em: https://www.abf.com.br/numeros-do-franchising/. Acesso em 08/02/2019.

[2] Alsos, G. A., Hytti, U., \& Ljunggren, E. (2011). Stakeholder theory approach to technology incubators. International Journal of Entrepreneurial Behavior \& Research, 17(6), 607-625. Disponível em:

http://www.emeraldinsight.com/doi/abs/10.1108/13 552551111174693. Acesso em 20/01/2019.

[3] Bardin, L. (1977). Análise de conteúdo. Lisboa: Edições 70.

[4] Barney, J. B. (1991). Firm resources and sustained competitive advantage. Journal of Management, 17(1), 99-120.

[5] Barney, J. B. (1996). Gaining and sustaining competitive advantage. Reading: AddisonWesley Publishing Company.

[6] Bauer, M. W., \& Gaskell, G. (2002). Pesquisa qualitativa com texto, imagem e som: um manual prático. Petrópolis: Vozes.

[7] Belafonte, C. (2016). Uberlândia registra crescimento de $8 \%$ no número de franquias. Disponível

http://www.correiodeuberlandia.com.br/cidade-e- de adesão), sugere-se, para pesquisas futuras, a realização de entrevistas com os demais grupos de interesses, com o intuito de verificar suas percepções. Outra sugestão de trabalhos futuros reside em realizar análises comparativas com unidades de outros segmentos de franquias com significativo market-share (por exemplo, esporte, beleza, lazer), a fim de identificar similaridades e diferenças nos aspectos aqui estudados (estratégias de influência e criação de valor). Um ponto de análise futura também consiste na identificação da relação entre os dois construtos aqui analisados separadamente, ou seja, as estratégias de influência e a criação de valor. Tais construtos são comumente analisados de forma individual e raramente, de forma conjunta.

Diante dos resultados apresentados, observou-se que os stakeholders das unidades franqueadas de fato contribuem para a criação de valor tanto para as unidades, quanto para a franqueadora, e a forma como as estratégias de influência impactam as ações das organizações estudadas. Assim, espera-se ter contribuído para o desenvolvimento do tema em questão.

regiao/uberlandia-registra-crescimento-de-8-nonumero-de-franquias/. Acesso em 18/01/2019.

[8] Bittencourt Consultoria. (2016). Uberlândia tem mercado promissor para franquias. Disponível em:

http://www.bittencourtconsultoria.com.br/noticias/u berlandia-tem-mercado-promissor-parafranquias.html. Acesso em 06/02/2019.

[9] Donaldson, T., \& Preston, L. E. (1995). The Stakeholder Theory of the Corporation: Concepts, Evidence, and Implications. The Academy of Management Review, 20(1), 65-91. Disponível em: http://amr.aom.org/content/20/1/65.abstract. Acesso em 08/02/2019.

[10] Falbea, C. M., Dandridgeb, T. C., \& Kumarc, A. (1998). The effect of organizational context on entrepreneurial strategies in franchising. Journal of Business Venturing, 14, 125-140. Disponível em: http://www.sciencedirect.com/science/article/pii/SO 883902697000992. Acesso em 19/01/2019.

[11] Freeman, R. E. (1984). Strategic Management: a stakeholder approach. Boston: Pitman.

[12] Freeman, R. E., \& McVea, J. (2000). A stakeholder approach to strategic management. In: 
Handbook of strategic management (pp. 189-207). Oxford: Blackwell Publishing.

[13] Freitas, C. A., \& Hoffmann, V. E. (2012). A percepção das estratégias de influência dos stakeholders e sua relação com a estratégia genérica: estudo de caso em pequenas empresas comerciais do litoral norte catarinense. Brazilian Business Review, 9(2), 1-25. Disponível em: http://www.spell.org.br/documentos/ver/7526/apercepcao-das- estrategias-de-influencias-dosstakeholders-e-sua-relacao-com-a-estrategiagenerica-- estudo-de-caso-em-pequenasempresas-comerciais-do-litoral-norte-catarinense. Acesso em 22/01/2019.

[14] Freitas, C. A., \& Souza, S. C. de. (2011). A influência dos stakeholders na elaboração da estratégia em pequenas empresas. REBRAE Revista Brasileira de Estratégia, 4(1), 77-89. Disponível em: http://www2.pucpr.br/reol/pb/index.php/rebrae?dd1 $=5691 \& d d 99=v i e w \& d d 98=p b$. Acesso em 08/02/2019.

[15] Frooman, J. (1999). Stakeholder influence strategies. The Academy of Management Review, 24(2), 191-205. Disponivel em: https://www.jstor.org/stable/259074?seq=1\#page_s can_tab_contents. Acesso em 08/02/2019.

[16] Grapeggia, M. \& Minuzzi, J. (2008). Estágios de crescimento da empresa Cacau Show com base no ciclo de vida organizacional. Revista TECAP, v. 2, n. 2. Disponível em: http://www14.unopar.br/envi/uploads/File/caso\%20 4\%20cacau\%20show.pdf. Acesso em 11/01/2019.

[17] Greco, S. M. S. S. (coord.) (2014). Global Entrepreneurship Monitor. Empreendedorismo no Brasil 2015. Curitiba: IBQP.

[18] Hillman, A. J., \& Keim, G. D. (2001). Shareholder value, stakeholder management, and social issues: What"s the Botton Line? Strategic Management Journal, 22(2), 125-139. Disponível em: http://onlinelibrary.wiley.com/doi/10.1002/10970266(200101)22:2\%3C125::AID-

SMJ150\%3E3.0.CO;2-H/abstract. Acesso em 08/02/2019.

[19] Hisrich, R. D., \& Peters, M. P. (2004). Empreendedorismo $\left(5^{\mathrm{a}}\right)$. Porto Alegre: Bookman.

[20] Hoffmann, V. E., Procopiak Filho, J. A., \& Rossetto, C. R. (2008). As estratégias de influência dos stakeholders na organização da construção civil: setor de edificações em Balneário Camboriú SC. Ambiente Construído, 8(3), 21-35.

[21] Hoy, F., \& Shane, S. (1998). Franchising as an entrepreneurial venture form. Journal of Business Venturing, 13(2), 91-94. Disponível em: http://www.sciencedirect.com/science/article/pii/S0 883902697000645. Acesso em 09/01/2019.

[22] Kaufmann, P. J., \& Dantb, R. P. (1999). Franchising and the domain of entrepreneurship research. Journal of Business Venturing, 14(1), 5-
16.

Disponível

em:

http://www.sciencedirect.com/science/article/pii/SO 883902697000955. Acesso em 15/12/2018.

[23] Kuratko, D. F., Morris, M. H., \& Schindehutte, M. (2015). Understanding the dynamics of entrepreneurship through framework approaches. Small Business Economics, 45(1), 113. Disponível em: https://link.springer.com/article/10.1007/s11187015-9627-3. Acesso em 08/02/2019.

[24] Laimer, C. G., \& Figueiredo, M. (2015). Estudos sobre Franquia: uma pesquisa bibliométrica no período de 1993 a 2014. Revista Global Manager (online), vol. 15, n. 2. Disponível em:

http://ojs.fsg.br/index.php/global/article/view/1761. Acesso em 16/01/2019.

[25] Lima, D. I. (2016). Na contramão da economia, franquia cresce com fama de negócio seguro. Disponivel em: http://www1.folha.uol.com.br/mercado/2016/06/178 0585-na-contramao-da-economia- franquia-crescecom-fama-de-negocio-seguro.shtml. Acesso em 08/02/2019.

[26] Metcalfe, C. E. (1998). The stakeholder corporation. Journal of Business Ethics, 7(1), 30$36 . \quad$ Disponível em: http://onlinelibrary. wiley.com/doi/10.1111/14678608.00083/abstract. Acesso em 22/01/2019.

[27] Mitroff, I. I., \& Linstone, H. A. (1993). The Unbounded Mind: Breaking the Chains of Traditional Business Thinking. Oxford University Press.

[28] Pavão, Y. M. P., Dalfovo, M. S., Escobar, M. A. R., \& Rossetto, C. R. (2012). A influência dos stakeholders no ambiente estratégico de uma cooperativa de crédito: efeitos da munificência. Revista de Ciências Da Administração, 14(34), 24 38.

Disponível em:https://periodicos.ufsc.br/index.php/adm/article/ view/2175-8077.2012v14n34p24. Acesso em 04/02/2019.

[29] Pavão, Y. M. P., \& Rossetto, C. R. (2013). Os stakeholders no processo de formação da estratégia de empresas cooperativadas. In Anais do VI Encontro de Estudos em Estratégia. Bento Gonçalves (RS): Anpad. Disponível em: http://www.anpad.org.br/admin/pdf/3Es383.pdf. Acesso em 02/02/2019.

[30] Peres, T. G. (2009). A importância do empreendedorismo e o sistema de franquias: o caso de uma rede de fast-food. Instituto Universitário de Lisboa. Disponível em: http://hdl.handle.net/10071/1679. Acesso em 22/01/2019.

[31] Pfeffer, J., \& Salancik, G. R. (1978). The External Control of Organizations: A Resource Dependence Perspective. (Harper \& Row, Ed.). Palo Alto: Stanford University Press.

[32] Phan, P. H., Butler, J. E., \& Lee, S. H. 
(1996). Crossing Mother: Entrepreneur-Franchisees" attempts to reduce franchisor influence. Journal of Business Venturing, 11(5), 379-402. Disponível em:http://www.sciencedirect.com/science/article/pii 1088390269600050X. Acesso em 22/01/2019.

[33] Porter, M. E. (1989). Vantagem competitiva: criando e sustentando um desempenho superior. 3. Ed. Rio de Janeiro: Campus.

[34] Prahalad, C. K., \& Ramaswamy, V. (2000). Co-opting Customer Competence. Harvard Business Review, 78(1), 79-87. Disponível em: https://hbr.org/2000/01/co-opting- customercompetence. Acesso em 06/02/2019.

[35] Raupp, F. M., \& Beuren, I. M. (2003) Metodologia da pesquisa aplicável às ciências sociais. In M. Beuren (Ed.), Como elaborar trabalhos monográficos em contabilidade: teoria e prática. São Paulo: Atlas.

[36] Roberts, M., Stevenson, H., Sahlman, W., Marshall, P., \& Hamermesh, R. (1996). New Business Ventures and the Entrepreneur. Chicago: Irwin Publishing.

[37] Serifa Comunicação Integrada. (2016).
Franquia é um nicho para quem quer aplicar dinheiro de rescisão trabalhista ou poupança. Disponível em: http://www.serifacomunicacao.com.br/release/franq uia-e-um-nicho-para-quem-quer-aplicar-dinheirode-rescisao-trabalhista-ou-poupanca/. Acesso em 08/02/2019.

[38] Shane, S. A., \& Hoy, F. (1996). Franchising: a gateway to cooperative entrepreneurship. Journal of Business Venturing, 11, 325-327.

[39] Schumpeter, J. A. (1983). Teoria do Desenvolvimento Econômico. São Paulo: Abril Cultural.

[40] Tuunanen, M., Hoy, F., Torikka, J., \& Hyrsky, K. (2005). Franchising as an entrepreneurial activity - a contemporary policy perspective. Budapest. Disponível em:https://emnet.univie.ac.at/fileadmin/user_upload /conf_EMNet/2005/papers/TuunanenHo yTorikkaHrysky.pdf. Acesso em 06/02/2019.

[41] Yin, R. K. (2015). Estudo de Caso: Planejamento e Métodos. Porto Alegre: Bookman. 


\section{Bapítulo 6}

\section{ESTRUTURAÇÃO DA GESTÃO DE DESEMPENHO ORGANIZACIONAL DE UMA EMPRESA DO TERCEIRO SETOR}

\section{Ana Paula Vilas Boas Viveiros Lopes \\ Giulianna Franchi}

Tatiana Montesso Bonomi

Thais Lopes Pessanha

Resumo: O atual nível de gestão do desempenho organizacional em que se encontram as empresas exige que gestores renovem a maneira de tratar os dados de desempenho, criando novos indicadores para avaliação da coerência entre as estratégias escolhidas pela organização e o resultado alcançado. Para as organizações do terceiro setor, esta necessidade não é diferente. O objetivo deste estudo consistiu-se em desenvolver, junto à OSCIP escolhida como objeto de estudo, uma estrutura de gestão de desempenho organizacional e para isto, a metodologia científica escolhida foi o estudo de caso. De acordo com o planejamento estratégico da empresa, foram definidas algumas variáveis para a criação de indicadores que tornam possível uma melhor avaliação de seus resultados.

Palavras-chave: Desempenho organizacional. Planejamento estratégico. Indicadores. Terceiro setor. 


\section{INTRODUÇÃO}

A importância da gestão na vida humana está diretamente relacionada à necessidade de viver em sociedade, colaborando para atingimento de um objetivo comum. A gestão do desempenho organizacional torna-se extremamente importante para que os caminhos traçados pela organização estejam de acordo com os objetivos definidos no seu planejamento estratégico.

As ONGs tornaram-se necessárias com o passar dos anos, acompanhando as mudanças significativas no modo de vida da sociedade moderna. E, por este motivo, a gestão do desempenho organizacional é um tema importante para estas instituições.

No caso das Organizações da Sociedade Civil de Interesse Público (OSCIPs), foco desta pesquisa, a gestão está diretamente relacionada à combinação de dois aspectos: promoção social das ações desenvolvidas e financeiro. Isto porque, os papéis que as OSCIPs possuem atualmente geram a necessidade de avaliação dos resultados obtidos segundo estes aspectos. Desta forma, há a necessidade de se combinar indicadores financeiros e não financeiros para uma análise eficiente, eficaz e efetiva do desempenho organizacional de OSCIPs.

No entanto, muitas empresas encontram dificuldades na implantação de suas estratégias. As inúmeras falhas que podem ocorrer, fazem com que as organizações busquem a utilização de ferramentas que proporcionem alcançar o objetivo estabelecido de maneira eficiente e eficaz (NIVEN, 2007).

Adicionalmente, conforme Tenório (2002), a carência de registros sistemáticos não permite a criação de indicadores e, portanto, da avaliação dos resultados citados anteriormente. A implantação de uma sistemática de registro de dados torna-se essencial para que, posteriormente, ferramentas de análise sejam utilizadas.

\subsection{OBJETIVO}

O objetivo deste estudo consiste em desenvolver, junto à OSCIP escolhida como objeto de estudo, uma estrutura de gestão de desempenho organizacional que possibilite a avaliação dos objetivos atingidos conforme o planejamento estratégico da instituição.

\subsection{QUESTÃO DE PESQUISA}

Esse trabalho visa responder à seguinte pergunta: Como a gestão do desempenho organizacional pode melhorar a avaliação de resultados de uma empresa de investimento familiar do terceiro setor?

\subsection{METODOLOGIA}

O trabalho em questão é caracterizado como estudo de caso de caráter exploratório, pois segundo Gil (1991) a pesquisa exploratória envolve levantamento bibliográfico, entrevistas com pessoas que tiveram experiências práticas com o problema pesquisado e análise de exemplos que estimulam a compreensão do estudo. Foi realizada uma entrevista não-estruturada que, segundo Marconi e Lakatos (2003, p. 197), neste tipo de entrevista, "O entrevistador tem liberdade para desenvolver cada situação em qualquer direção que considere adequada". É uma forma de poder explorar mais amplamente uma questão.

\subsection{A EMPRESA}

A empresa em questão é o braço social de uma empresa de investimentos familiar. Tratase de uma organização sem fins lucrativos que tem como propósito transformar e potencializar vidas para catalisar o desenvolvimento sustentável da sociedade. Para isso, atua nas áreas de Educação e Esporte.

\section{FUNDAMENTAÇÃO TEÓRICA}

\subsection{DESEMPENHO ORGANIZACIONAL}

A definição de boas estratégias, acompanhada da escolha das ferramentas adequadas para a obtenção dos indicadores de resultado, é o alicerce fundamental para o bom desempenho organizacional. Desta forma, segundo Martins (2013), após a definição da estratégia, é preciso transformála em ações para obter resultados. Esses resultados, normalmente são levantados através da análise de números, chamados indicadores.

Os valores obtidos por meio desses indicadores podem ser comparados com outros benchmarks para o posicionamento do resultado. Valores padrões estabelecidos anteriormente, resultados de concorrentes ou 
até mesmo valores históricos podem ser esses benchmarks para que uma análise de melhorias venha a ser realizada.

A medição do desempenho contribui, segundo Spitzer (2007) para clarificar expectativas, promover consistência, fornecer sinais de risco, permitir precisões e objetivar previsões, promover motivação e melhorar as soluções dos problemas, a tomada de decisões, os alinhamentos e a execução de metas, melhorar a responsabilidade e aumentar a objetividade. Sendo assim, a medição de desempenho permite fazer uma análise geral facilitada.

\subsection{BALANCED SCORECARD (BSC)}

O êxito do sistema de gestão estratégica desenvolvido por Kaplan e Norton se deve a vários fatores, tendências e necessidades do setor empresarial, sendo estes relacionados a identificação por parte do mundo empresarial, como um todo, de que os indicadores financeiros eram insuficientes para auxiliar na gestão das empresas, pois, os valores migraram dos ativos tangíveis, para os intangíveis da corporação. Ou seja, a vantagem competitiva migrava do investimento em ativos físicos para a gestão estratégica baseada no conhecimento.

Outro ponto identificado pelas corporações foi - fato do desempenho das empresas não estar associado a estratégia competitiva, mantendo a atenção dos executivos em medir, o que não significava gerenciar, sendo assim, a conscientização da carência de se criar uma nova estrutura, linguagem e sistema de comunicação e informação, era extremamente necessária para garantir o entendimento de que a criação de uma boa estratégia não iria garantir bons resultados e sim uma implementação eficaz dessa estratégia, de modo que o aprendizado, compreensão e conhecimento da mesma esteja completamente disseminada entre os colaboradores da organização (HERRERO FILHO, 2005).

BSC visa implementar a estratégia da organização de maneira a obter um equilíbrio entre os indicadores de desempenho. Sendo assim, a Balanced Scorecard é uma excelente ferramenta, pois, equilibra indicadores financeiros e operacionais, ou seja, complementa as medidas de desempenho do passado com medidas que impulsionam o desempenho futuro e organiza esses indicadores em quatro perspectivas para medir o desempenho organizacional, sendo estas a financeira, a dos clientes, a dos processos internos da empresa, e do aprendizado e crescimento (SERRA et al., 2014; KAPLAN; NORTON, 1997).

Para Herrero Filho (2005) deve-se primeiramente avaliar a posição competitiva da empresa e, para isso, se faz necessário responder as seguintes perguntas: Qual a estratégia competitiva da empresa levando sua visão e missão em consideração? Com base nessa estratégia, quais os indicadores de desempenho mais importantes? Qual o relacionamento entre esses indicadores qualitativos e quantitativos? Quais indicadores realmente validam o sucesso do negócio para criar valor a longo prazo? O BSC busca responder a todas essas perguntas e identificar quais as atividades críticas que geram valor aos stakeholders (partes interessadas), ou seja, que geram valor a quem é afetado, de forma direta ou indireta, por alguma decisão, atividade ou resultados da organização.

Segundo Kaplan e Norton (1997) a maioria das empresas tem dificuldade em alinhar suas medidas de desempenho às suas estratégias, pois, buscam melhorar os resultados através de uma melhor qualidade, custos mais baixos e menores tempos, mas sem identificar os processos estratégicos, ou seja, os que devem apresentar um excelente desempenho, para que a estratégia da empresa seja bem-sucedida, por isso, é importante se vincular as medidas do Balanced Scorecard à estratégia organizacional.

Para a implementação do BSC existem quatro etapas contínuas que são necessárias. A primeira é a definição da estratégia, que deve especificar os objetivos e as metas da empresa, a segunda é a definição das medições da estratégia, sendo os indicadores devem ser na menor quantidade possível para que não ocorra sobrecarga de informações, e devem também seguir uma relação de causaefeito para que as iniciativas ineficientes que não tenham grande influência no sistema sejam excluídas. A terceira é a integração entre os indicadores no sistema de gestão, ou seja, o BSC deve ser integrado nas práticas do $\mathrm{RH}$, na cultura interna e em toda a estrutura da organização. A última etapa é a frequência que esses indicadores e os consequentes resultados são revistos, pois, quando o BSC estiver em funcionamento, este 
precisa ser revisado periodicamente para verificar se os indicadores estão realmente mostrando o desempenho da organização da forma correta, se o BSC está indicando se a estratégia é bem-sucedida, se a estratégia mudou desde a última revisão, se os indicadores precisam ser alterados, entre outros (SERRA et al., 2014).

Sendo assim, para um entendimento geral de forma objetiva, o BSC é um sistema de gestão que compreende a estratégia da empresa com metas, objetivos, medidas e iniciativas implementadas e estabelecidas com o objetivo de se alcançar um fácil entendimento e compreensão pelos colaboradores da organização e é também uma ferramenta gerencial que possibilita identificar e transformar os ativos intangíveis em valor para os stakeholders (HERRERO FILHO, 2005).

\subsection{TABLEAU DE BORD (TB)}

Segundo Epsen; Mazoni (1998) apud Cordeiro Filho (2009) a ferramenta Tableau de Bord (TB) foi utilizada primeiramente por engenheiros na otimização dos processos de produção para um melhor entendimento entre as ações e o desempenho do processo, ou seja, para uma maior percepção das relações causa e efeito. Posteriormente, passou a ser utilizada em altos níveis gerenciais, auxiliando os administradores através dos indicadores, pois, Ihes permite monitorar 0 desenvolvimento da organização, comparar com os objetivos pré-definidos e verificar se existe a necessidade de adotar ações corretivas.

A criação da ferramenta surgiu como reação dos gestores a percepção de que ferramentas financeiras não ofereciam todas as informações necessárias para a tomada de decisão. O TB, por sua vez, consiste em uma ferramenta sintética, pertinente e frequente, ou seja, utiliza alguns dados estratégicos sintetizado sem poucos indicadores e possui metodologia de atualização constante (SILVA, 2013).

O TB, portanto, cumpre sua missão em três níveis principais que permite sua utilização não somente para a comparação entre o previsto e o realizado, com base em um referencial, mas também fomentando a comunicação entre gestores e colaboradores e estimulando a tomada de decisão oportunamente e de maneira eficaz (SILVA, 2013).
Como principais funções, o TB permite uma melhor compreensão da realidade, auxiliando na redução da incerteza e na tomada de decisão. Por filtrar a informação essencialmente necessária, é extremamente eficiente para proporcionar maior estabilidade para quem pretende escolher a melhor decisão. Para cada decisão tem-se um risco inerente e, com o TB, pode-se obter uma visão bastante estruturada da área de ação, segundo as opções de desenvolvimento selecionadas, propondo relatar e prestar contas das situações percebidas. O TB possui também os papeis de facilitar a comunicação e a motivação, pois quando utilizado por um grupo de trabalho, atua como referencial comum. Tem como objetivo dinamizar a reflexão, pois, não apenas controla os alertas, como sugere ferramentas eficazes para avaliação das situações, permitindo um monitoramento constante (NUNES, 2015; CORDEIRO FILHO, 2009).

Segundo Silva (2013), o TB tem como função principal a obtenção de dados rapidamente para tomada de ação a curto prazo. Portanto, é uma ferramenta de gestão que não possui objetivo em si mesma, ou seja, sua aplicação fornece informações para a tomada de decisão das pessoas responsáveis por aqueles parâmetros medidos e pelos indicadores obtidos. Desta forma, torna-se uma ferramenta dinâmica e permanente, se modificando a cada nova melhoria aplicada aos parâmetros medidos, mas constantemente verificada por aqueles que necessitam tomar ação sobre algum desvio ou oportunidade de melhoria.

Segundo Silva (2013), o TB é elaborado em cinco etapas obrigatórias, sem as quais, o sucesso da ferramenta pode ser afetado. As etapas são: definição da visão e missão da organização, definição dos objetivos estratégicos, determinação das áreas chaves de resultado, definição dos objetivos operacionais, seleção de indicadores.

\subsection{PLANEJAMENTO ESTRATÉGICO}

Segundo Serra et al. (2014), o planejamento estratégico tem como objetivo determinar uma diretriz para a organização, afim de que a mesma obtenha ótimos resultados, para tal são definidos os objetivos e a estratégia que será implementada. Para tal decisão, são levados em consideração a análise do ambiente interno e o externo, quais as possibilidades de caminhos podem ser 
aplicadas, qual será a operacionalização da estratégia e quais são os recursos necessários para se monitorar, avaliar e controlar a operação.

Segundo Herrero Filho (2005), a estratégia tem a complexa função de conciliar os interesses apresentados pelos stakeholders, em conjunto com a coordenação das tarefas realizadas por todas as áreas da organização. Sendo assim, com base nesse preceito a natureza da gestão estratégica é desenvolver de forma arrojada, dinâmica e criativa, uma estratégia que certifique o sucesso da empresa no tempo presente, da mesma maneira que desenvolva as competências indispensáveis para o sucesso dos negócios no futuro.

Sendo preciso executar o plano para saber se é valido, Berliner e Brimson (1992) afirmam que para assegurar a implantação do plano estratégico da empresa, um fator chave é a medição de desempenho. O mesmo é considerado relevante pois conecta o que foi definido e a gestão operacional de fato operante nas empresas.

\subsection{ORGANIZAÇÕES NÃO GOVERNAMENTAIS}

As ONGs são organizações autônomas com o objetivo de complementar a atuação do Governo, atuando na sociedade com ações que visam o desenvolvimento social e, consequentemente, transformando-a (TENÓRIO, 2002).

Suas ações são financiadas por outras organizações e não possuem fins lucrativos, sendo a totalidade dos seus recursos destinados a ações sociais e para manter sua estrutura. Sua sobrevivência, portanto, não depende diretamente da situação econômica mundial ou de lucro gerado por suas atividades (TENÓRIO, 2002).

As ONGs tornaram-se extremamente necessárias com o passar dos anos, acompanhando as mudanças significativas no modo de vida da sociedade moderna. A seguir é discutido o impacto destas mudanças no modelo de gestão e atuação social das ONGs.

O desenvolvimento mundial das novas tecnologias, aumento da produtividade, transformação da comunicação e a consequentemente urbanização, tem impacto no desenvolvimento de problemas sociais como a pobreza, violência, poluição, conflitos por ideologias diferentes, entre outros (TENÓRIO, 2002). Tantos problemas sociais exigiram que a sociedade civil se tornasse agente ativo na organização de ações que minimizem ou até eliminem tais problemas.

Inicialmente, de caráter assistencialista, ligadas a grupos religiosos, as ONGs possuíam um papel de ação pontual, com o desenvolvimento de projetos que tinham como foco a resolução de problemas a curto prazo. Com o passar do tempo, a estratégia passou a ser o desenvolvimento de projetos que formem novos agentes sociais, ou seja, que tenham como foco a resolução de problemas a longo prazo (TENÓRIO, 2002).

As mudanças nos objetivos dos projetos desenvolvidos pelas ONGs resultaram na necessidade de reavaliar o tipo de gestão realizado por estas instituições.

Os papéis que as ONGs possuem atualmente geram a necessidade de avaliação dos resultados obtidos pelas ações promovidas em comparação ao investimento realizado, assim como ocorre nas indústrias, por exemplo. Ou seja, avaliar a combinação de suas ações sociais e os aspectos financeiros. Porém, conforme Tenório (2002), a carência de registros sistemáticos não permite a criação de indicadores e, portanto, da avaliação dos resultados citados.

Segundo estudos realizados por Tenório (2002), as características inerentes às ONGs e evolução do seu papel, conforme citado anteriormente, resultam em alguns pontos importantes de atenção com relação à gestão destas instituições. Ainda de acordo com a mesma pesquisa, os principais pontos são: o tipo de planejamento realizado pelas ONGs está relacionado às fontes de financiamento e, em muitos casos, não é documentado; em muitos casos, as ONGs não possuem um propósito claro, que delimite suas ações, defina objetivos e metas, impossibilitando a criação de indicadores e, consequentemente, a avaliação de resultados; a natureza de atendimento à sociedade em que se baseia as atividades das pessoas que trabalham em ONGs faz com que novos projetos sejam incluídos de acordo com critérios como disponibilidade de tempo dos recursos humanos em atender o projeto escolhido, o que ocupa a maior parte do tempo da equipe e impossibilita a avaliação do retorno para a instituição; são instituições que prezam pela informalidade, o que torna os processos menos burocráticos, porém dificulta a gestão 
organizacional pela falta de definição de responsabilidades, funções e registro de dados; por fim, o tipo de trabalho desenvolvido possui dificuldade para ser avaliado, pelo caráter qualitativo e de longo prazo, além do produto deste trabalho não se tornar mercadoria e, portanto, necessitar de doações para se concretizar.

\section{ESTUDO DE CASO}

O presente trabalho aplicou os conceitos estudados anteriormente para a elaboração de indicadores que possam ajudar na gestão do desempenho da OSCIP em questão, para isso, o cenário atual da empresa será contextualizado antes da análise dos dados coletados.

\subsection{MÉTODO DE PESQUISA}

A partir da revisão bibliográfica realizada, foi elaborado o roteiro de entrevistas, presente no anexo A. O roteiro de entrevistas contém as questões chaves para a determinação do cenário atual em que a OSCIP se encontra, no que diz respeito ao seu planejamento estratégico e avaliação do desempenho organizacional. É necessário o entendimento pleno do planejamento estratégico da OSCIP, mesmo que não seja uma prática sistematizada, para que se possa levantar as necessidades de medição, a partir de objetivos definidos.

Foram realizadas três entrevistas, sendo essas com dois coordenadores de projetos e um da área de gestão financeira. Os dois coordenadores são responsáveis por projetos diferentes e independentes, possuindo total controle decisório dentro do que foi estabelecido para seus projetos. Já o responsável pela gestão financeira, é um nível acima pois cabe a ele decidir qual será o budget para cada projeto.

As entrevistas foram realizadas de forma semiestruturada pois uma integrante do grupo seguiu o roteiro pré-definido (Ver Anexo A), porém, as mesmas foram realizadas de forma informal, não sendo gravadas. Devido aos times serem muito enxutos, o tempo hábil dos entrevistados é limitado e por isso a melhor forma encontrada para a coleta dessas informações foi através de entrevistas semiestruturadas embora tenham sido disponibilizados dados e documentos de controle utilizados pela empresa que foram essenciais para o entendimento de seu funcionamento.

Uma breve reunião foi realizada para apresentação do trabalho que seria desenvolvido. Posteriormente, foram realizadas as entrevistas semiestruturadas que possibilitaram o levantamento dos dados que serão descritos nos próximos tópicos deste trabalho.

Além das entrevistas, também foram utilizadas como instrumento de coleta de dados planilhas de controle da empresa (Ver Anexo B). Por fim foi realizada uma reunião para apresentar os resultados desta pesquisa.

Após a coleta de dados foram levantadas questões e necessidades importantes da empresa com relação à medição do desempenho organizacional. Estas necessidades foram analisadas cuidadosamente e resultaram na proposta de indicadores de desempenho e de sistematização a serem utilizados pela OSCIP.

\subsection{A EMPRESA}

A OSCIP é um braço social de uma empresa de investimentos familiar que tem como principal objetivo atuar de maneira ativa na sociedade através de projetos nas áreas de educação e esporte que modifiquem de maneira holística os indivíduos e, consequentemente, a sociedade.

Atualmente, a OSCIP possui seus projetos próprios e outros em que participa em parceria. Pela dificuldade de se obter informação a respeito dos projetos em parceria, não é realizado um monitoramento constante. São levantados somente, ao término do projeto, qual foi o montante investido e a quantidade de indivíduos impactados direta ou indiretamente. Estas informações não são eficientes no sentido de informar se o projeto atende aos objetivos definidos no Planejamento Estratégico. Isso porque o objetivo da empresa não está relacionado ao ganho financeiro, mais sim ao alto impacto das ações visando o desenvolvimento da sociedade.

Entre as dificuldades encontradas para a implantação das estratégias definidas, temos a falta de indicadores. Os indicadores são importantes para a avaliação do processo de implantação da estratégia e auxiliam no fortalecimento do comprometimento. 


\subsection{PLANEJAMENTO ESTRATÉGICO}

Com a construção do propósito da OSCIP, os objetivos da empresa a longo prazo foram estabelecidos, possibilitando uma avaliação do desempenho organizacional a partir de indicadores. O processo de definição dos objetivos consiste em uma longa e complexa análise de toda a história que a OSCIP percorreu, definição dos caminhos que ainda quer percorrer e dos objetivos a serem alcançados. Isso permitiu que todos os esforços das equipes que compõem a empresa pudessem caminhar com um mesmo foco, facilitando a comunicação interna e definição de prioridades.

Os objetivos foram explorados pelos investidores, que definem, de maneira geral, o motivo de existência da OSCIP para aqueles que atuam colaborando para o atingimento dos resultados esperados. Os objetivos são, portanto, a forma concreta e mensurável de analisar quais os resultados são esperados pelos investidores.

\subsection{DESEMPENHO ORGANIZACIONAL E SEUS INDICADORES}

No planejamento estratégico definido, alguns indicadores e metas foram determinados para os objetivos pré-estabelecidos, no que diz respeitos aos projetos próprios da OSCIP.
A utilização de uma ferramenta de desempenho organizacional pode auxiliar no desenvolvimento de indicadores que realmente auxiliem na tomada de decisão, como indicadores de eficiência, de desenvolvimento, financeiros e processos. Nenhuma ferramenta foi implantada até o momento, pois seria necessário um passo anterior para que qualquer ferramenta fosse utilizada de maneira adequada: um Planejamento Estratégico que traduzisse a missão e visão da OSCIP e considerando que o mesmo foi realizado, torna-se possível implementar tais indicadores e ferramentas.

\subsection{ELABORAÇÃO DOS INDICADORES \\ 4.1.1 INDICADORES}

No que compete ao conjunto de indicadores de eficiência, considera-se como fundamento a perspectiva dos clientes, que segundo Serra et al. (2014) traduz de forma métrica os fatores que são importantes para o cliente e que refletem os objetivos da organização.

Primeiramente foi considerado o indicador de alcance que, em uma análise comparativa, quanto maior o indicador de alcance, melhor é o projeto em nível de abrangência.

$$
\text { Indicador de alcance }=\frac{\text { Quantidade de pessoas atingidas }}{\text { Tempo de vida do projeto }}
$$

Adotou-se também o indicador de impacto, no qual quanto maior o número de citações do projeto em mídias específicas e influentes, maior será o impacto positivo do mesmo não só a nível de visibilidade para a OSCIP, mas, também uma forma de demonstrar a repercussão dos conhecimentos disseminados na sociedade como um todo.

$$
\text { Indicador de impacto }=\frac{\text { Quantidade de citações positivas }}{\text { Quantidade de citações }}
$$

\subsubsection{INDICADORES FINANCEIROS}

Por ser uma OSCIP e, portanto, depender de doações de patrocinadores ou investidores, é importante um indicador onde se possa controlar as despesas e a variação do orçamento, que foi baseado na perspectiva financeira do BSC.

$$
\text { Indicador de recurso comprometido }=\frac{\text { Aporte de recurso financeiro no projeto }}{\text { Total de recursos financeiros da OSCIP }}
$$

Quanto maior o resultado, maior a parcela de recurso da OSCIP investida no projeto em questão. Sugere-se também o indicador de investimento, no qual quanto maior a quantidade de pessoas envolvidas no projeto, menor é o custo do projeto, logo, melhor o resultado. 


$$
\text { Indicador de investimento }=\frac{\text { Investimento }}{\text { Quantidade de pessoas }}
$$

\subsubsection{INDICADORES DE DESENVOLVIMENTO}

No conjunto de indicadores de desenvolvimento, foi utilizada como base a perspectiva da aprendizagem e crescimento, que segundo Serra et al. (2014), enfatiza a melhoria contínua dos processos da organização, investindo nas pessoas envolvidas no projeto, onde o bem-estar dos colaboradores é essencial para alcançar o bom resultado operacional e financeiro.

$\mathrm{O} \mathrm{RH}$ da OSCIP realiza uma avaliação de desempenho anual dos funcionários, definindo metas, percentuais atingidos, avaliando em termos de habilidades e capacidades no âmbito técnico e pessoal, sendo avaliado para a definição de novas metas buscando o crescimento profissional constante.
Utilizar o resultado dessa avaliação é uma forma de avaliar o desenvolvimento anual dos colaboradores, sendo importante para que, combinado com os outros indicadores, os gaps sejam relacionados e propostas de melhorias possam influenciar de maneira positiva nos indicadores financeiros, de eficiência ou processo.

\subsubsection{INDICADORES DE PROCESSOS}

Com relação aos indicadores de processos, o mesmo utiliza como pilar a perspectiva dos processos internos, que identificam os processos mais críticos para atingir os objetivos das demais perspectivas.
Indicador de pontualidade $=\frac{\text { Atividades do cronograma atendidas no prazo }}{\text { Total de atividades no cronograma }}$

$$
\text { Indicador de coleta }=\frac{\text { Total de dados não coletados }}{\text { Total de dados necessários para avaliação }}
$$

A princípio, esses indicadores são pontos de riscos e podem influenciar na qualidade do trabalho. Eles poderão ser modificados esporadicamente, pois é preciso acompanhar as mudanças nos projetos.

\subsection{FERRAMENTA PROPOSTA}

Propõe-se a utilização do TB para efetuar a gestão dos indicadores, que conforme apresentado, foram construídos através das perspectivas do BSC.

Por ser uma ferramenta de fácil utilização, tornar um hábito a alimentação dos dados, envolve um processo de comprometimento e conscientização, pois a base precisa deste acompanhamento para atingir o objetivo de tornar mais fácil o gerenciamento dos projetos, bem como, manter um histórico do desempenho alcançado, afim de se explorar os pontos positivos identificados, aprimorar os pontos negativos e promover a melhoria continua nos projetos, tornando o portfólio da OSCIP repleto de dados que possam facilitar a apresentação e relacionamento com futuros novos parceiros.

A base de dados necessária, foi desenvolvida de forma prática, para que fique claro qual informação que precisa ser coletada e inserida no painel. Através dos dados inseridos na base de dados, são calculados os indicadores desenvolvidos automaticamente. Por fim, o painel de controle foi elaborado com estrutura visual que nos permite analisar de forma explícita, objetiva e organizada os indicadores criados, bem como permite filtrar de forma ágil um projeto em específico para avaliar seus resultados, bem como um segmento de atuação, um pilar em específico ou relações entre indicadores. 
Figura 4: Painel De Controle.
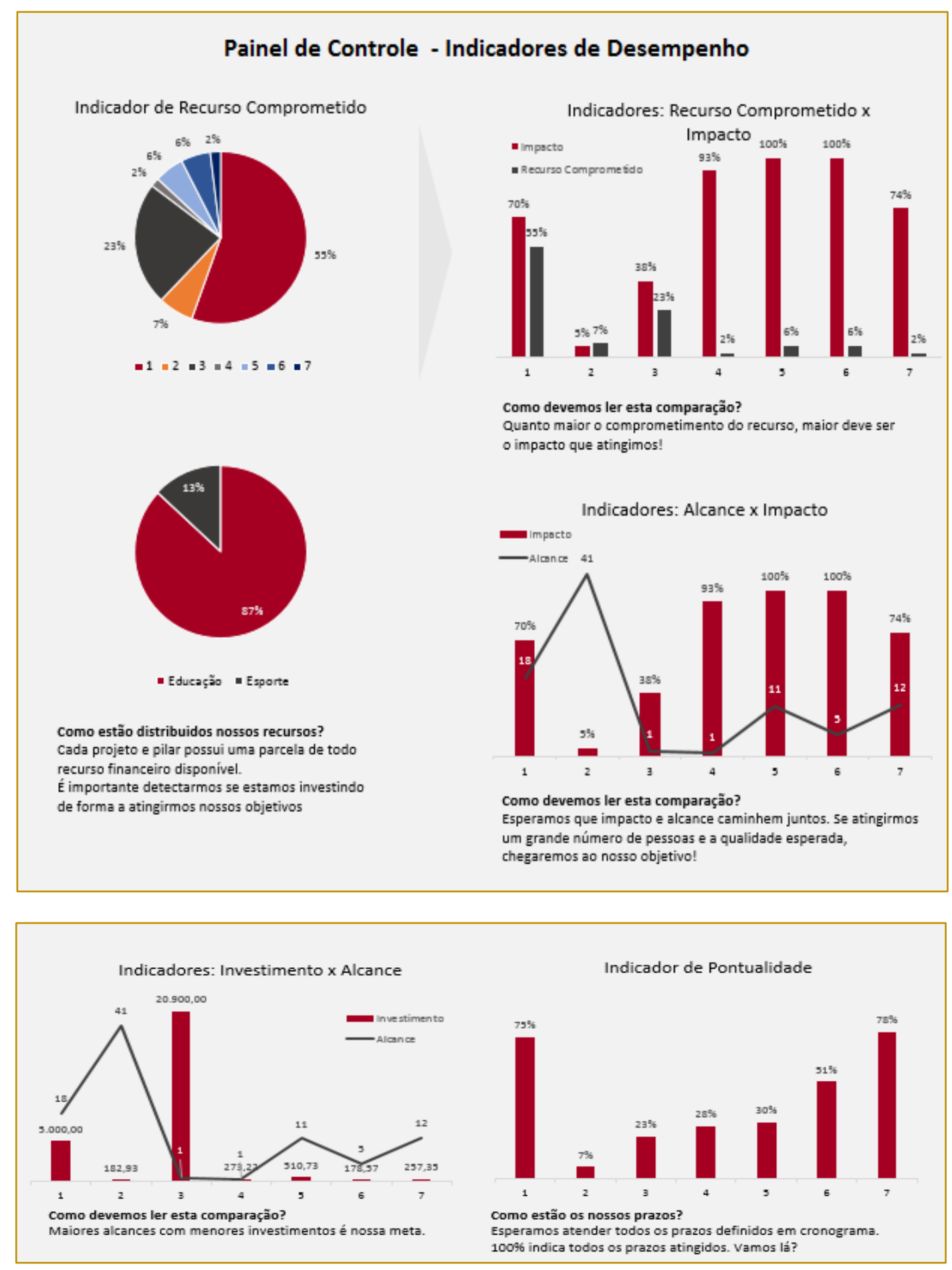

Fonte: Autor 


\section{CONCLUSÃO}

Ao se estudar a estrutura e funcionamento interno da OSCIP escolhida, foram encontradas diversas oportunidades no que tange gerenciamento de projetos e gestão de desempenho organizacional.

Como resultado das técnicas implementadas, pode-se perceber que a base desenvolvida é de fácil utilização e mantê-la atualizada é de extrema importância para obterem-se os resultados esperados. Sendo assim, é recomendado que os dados sejam "alimentados" frequentemente. A ferramenta desenvolvida permite a rápida visualização dos resultados existentes até o momento para o acompanhamento e avaliação, o que possibilita a definição de estratégias para um plano de ação nos casos onde a eficiência

\section{REFERÊNCIAS}

[1] Berliner C.; Brimson, J. A. Gerenciamento de custos em indústrias avançadas: base conceitual CAM-I.N. São Paulo: T. A. Queiroz, 1992.

[2] Cordeiro Filho, J.B. Modelos de avaliação de desempenho e controle estratégico de gestão: do Tableau de Bord ao Balanced Scorecard. In: XXIX Encontro Nacional de Engenharia de Produção. Anais..., Salvador: ABEPRO, 2009.

[3] Fleury, A. C.; Fleury, M. T. Estratégias competitivas e competências essenciais. Gestão e Produção, São Paulo, v.10, n.2, p.129-144, ago 2003.

[4] Gil, A. C. Métodos e técnicas de pesquisa social. 3. ed. São Paulo: Atlas, 1991.

[5] Herrero Filho, E. Balanced scorecard e a gestão estratégica: uma abordagem prática. 10. ed. Rio de Janeiro: Elsevier, 2005.

[6] Hronec, S.M. Sinais vitais: usando medidas de desempenho de qualidade, tempo e custo para traçar a rota para o futuro da empresa. São Paulo: Makron Books, 1994.

[7] Kaplan, R. S.; Norton, D. P. A estratégia em ação: balanced scorecard. Boston Massachusetts: Elsevier, 1997.

[8] Marconi, M. A.; Lakatos, E. M. Fundamentos da metodologia científica. 5. ed. São Paulo: Atlas, 2003.

[9] Martins, V. F. Gestão do desempenho organizacional numa entidade sem fins lucrativos. 2013. 57 f. Dissertação (Mestrado) - Curso de Economia, Universidade de Coimbra, Coimbra, 2013.

[10] Niven, P. R.Balanced scorecard passo-apasso: elevando o desempenho e mantendo resultados. 2. ed. Rio de Janeiro: Quality mark Editora Ltda, 2007. esperada não esteja ocorrendo. O acompanhamento constante também permite que a cultura preventiva seja incorporada pela OSCIP.

Sendo assim, a base desenvolvida funciona como um Tableau de bord, atuando como painel de controle, para a rápida visualização e compreensão dos resultados, assim como permite manter uma base de dados extensa e um histórico sistematizado para facilitar no desempenho dos futuros projetos e identificar os pontos que deixaram a desejar e as oportunidades de melhoria. A ferramenta então desenvolvida pelo grupo atingiu o objetivo esperado de utilizar inicialmente os preceitos do Balanced Scorecard, juntamente com o conceito de Tableau de bord, objetivando auxiliar a OSCIP a atingir os objetivos esperados.

[11] Nunes, P. Tableau de Bord. Knoow, 2015. Disponível em: <http://knoow.net/cienceconempr/gestao/tableaude-bord/>. Acesso em: 23 out. 2016.

[12] Rezende, J. F. Balanced Scorecard e a gestão do capital intelectual: alcançando a performance balanceada na economia do conhecimento. Rio de Janeiro: Campus, 2003.

[13] Rodniski, C. M.; Diehl, C. A.; Zwirtes, A. Tableau de bord: proposal of application in Brazilian agribusiness. Revista Universo Contábil, [S.I.], v. 9, n. 2, p.63-82, 30 jun. 2013. Disponível em: <http://dx.doi.org/10.4270/ruc.2013213>. Acesso em: 18 abril 2017.

[14] Rummerler, G. A., Branche, A. P. Melhores desempenhos das empresas. 2. ed. São Paulo: Makron Books, 1994.

[15] Serra, F. R. et al. Gestão estratégica: conceitos e casos. São Paulo: Atlas, 2014.

[16] Silva, J. P., Tableau de bord. Uma ferramenta competitiva. Dissertação (Mestrado) Curso de Contabilidade de Fiscalidade Empresarial, Instituto Superior de Contabilidade e Administração de Coimbra, Coimbra, 2013.

[17] Slack, N.; Chambers, S.; Johnston, R. Administração da produção. 3. ed. São Paulo: Atlas, 2009.

[18] Spitzer, D. R. Transforming performance measurement: rethinking the way we measure and drive organizational success. Broadway, New York: Amazom, 2007

[19] Tenório, F. G. Gestão de ONGs: principais funções gerenciais. 6 ed. Rio de Janeiro: Editora FGV, 2002. 


\section{Capítulo 7}

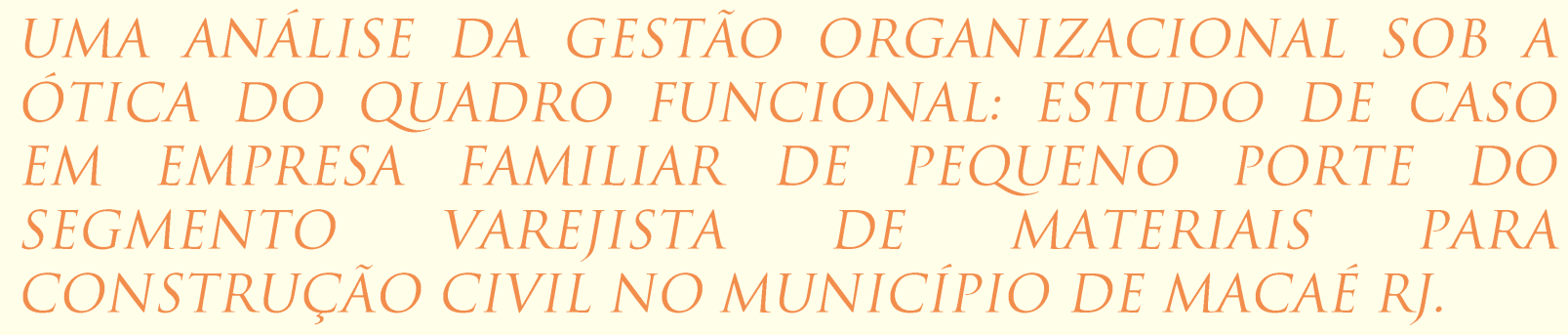

Anírian Cristiane Unghare

Cremilce Barreto Silva

Resumo: Gerenciar uma organização não é tarefa fácil, ainda mais quando a empresa é familiar. No entanto, é importante ressaltar que as mesmas apesar de serem pequenas, merecem atenção, pois são responsáveis por uma parcela significativa na geração de emprego. Pensando neste aspecto é que este estudo foi realizado e teve como objetivo principal identificar pontos críticos na gestão organizacional interna que possam estar impactando no comportamento e na satisfação dos colaboradores, comprometendo a motivação e o clima organizacional, consequentemente o crescimento, a produtividade e lucratividade da empresa. O estudo tem como base um referencial teórico baseado em literaturas da área dando relevância ao estudo, contou também com uma pesquisa de campo para coleta dos dados, aplicando um questionário junto aos colaboradores da empresa. Após a análise, verificou-se a falta de preparo dos gestores em relação ao tratamento de algumas necessidades de seus colaboradores, ao monitoramento de informações relativas ao quadro funcional e ao sistema de gerenciamento adotado (comunicação, tecnologias utilizadas, clima organizacional e motivação, dentre outros).

Palavras chave: Gestão Organizacional; motivação; ambiente organizacional. 


\section{INTRODUÇÃO}

Devido ao cenário mundial, políticas públicas e econômicas do país, percebe-se a necessidade de gestão organizacional de excelência a fim de amenizar os impactos da crise vivenciada. Para as organizações privadas que dependem diretamente da compra e venda de mercadorias, ter objetivos claros, estratégias e metas voltadas para inovação e competitividade, passa a ser um diferencial e consequentemente supera as expectativas dos clientes, desde a gestão interna da empresa até o pós-venda. Nesta busca de um futuro promissor, torna-se indispensável que a empresa tenha além de foco no cliente uma visão voltada para o seu quadro funcional, afinal é o capital humano que propicia maior alavancagem. E ainda, a empresa que mantém um planejamento estratégico atualizado, observando as mudanças de cenário, pode reinventar-se para não perder fatias de mercado.

Para Martins, (2007, p.01) o mundo empresarial atual apresenta um elevado grau de competição, mudanças e adaptações. Por isso "é preciso que as organizações tenham objetivos bem definidos para enfrentar as mudanças e estratégias cada vez mais inovadoras em sua gestão para atender os clientes com eficiência".

Em se tratando de uma empresa familiar e de pequeno porte, voltada para o segmento do comércio varejista de materiais para construção civil e tendo como propósito a continuidade da empresa, diretores e gerentes devem dar prioridade à atualização constante da gestão e integração dos processos; tecnologias; relações entre colaboradores, gerentes e diretoria. Neste contexto e mais especificamente para este estudo, os mesmos deverão também, disponibilizar recursos, estrutura adequada e ambiente propício à qualidade de vida dos colaboradores o que aumentará a eficácia das tarefas; dos procedimentos; organização das informações; treinamento e desenvolvimento. Quando a estrutura organizacional não se mantém atualizada, torna-se difícil transmitir conhecimento para os seus colaboradores, deixando-os insatisfeitos, despreparados e automaticamente desmotivados para o trabalho.

É essencial, que todos os envolvidos com a empresa saibam que o foco principal para continuidade é o cliente. Dessa forma é preciso que os colaboradores executem suas tarefas com habilidade, agilidade e tenham um bom relacionamento interno e externo com toda a esfera organizacional. Precisam estar preparados e bem direcionados na resolução de qualquer tipo de problema que possa surgir em relação à reclamação do cliente, ou terão poucas chances de vencer os desafios lançados pelo mercado, pois cada cliente perdido representa um cliente ganho pela concorrência.

Devido ao grande número de informações e a complexidade de uma organização por menor que ela seja, é notável a grande dificuldade de se gerar um clima organizacional favorável ao bom desempenho do trabalho, afim de prestar um atendimento eficaz ao cliente. O crescimento e continuidade da companhia também poderão ser impactados positivamente ou negativamente, visto que alguns fatores podem ser facilitadores e outros prejudiciais no que diz respeito à fidelização e conquista de novos clientes internos e externos.

A Gestão Organizacional é um assunto amplo e de grande discussão, porém aqui se abre um viés para aspectos relacionados ao sentimento do colaborador enquanto participante de um sistema aberto que influencia e é influenciado pelo todo. Sentimentos esses com relação ao tratamento recebido; qualidade de vida; realização da comunicação entre a direção e seus colaboradores; conhecimento da cultura organizacional predominante; tecnologias utilizadas na interligação entre colaboradores, empresa e processos, são algumas das questões discutidas neste estudo.

Nesse contexto a pergunta que norteia essa pesquisa é saber como o quadro funcional enxerga a gestão organizacional atual e no que isso pode impactar na satisfação de trabalhar nesta empresa, visualizar se isto também pode influenciar no nível de motivação e de bem-estar no ambiente de trabalho. Para tornar essa pesquisa mais estruturada, foi muito relevante o planejamento de algumas etapas, as quais auxiliaram nas respostas dos elementos supramencionados e na posterior análise. Incialmente procurou-se entender os processos internos de gestão existentes na empresa. Num segundo momento, foi verificado junto ao quadro de funcionários vários fatores de satisfação com relação ao seu trabalho e à gestão. Com essas informações foi possível então identificar possiveis falhas que poderiam estar refletindo nas expectativas do colaborador em relação ao seu trabalho e oferecendo também 
informações detalhadas para o conhecimento dos próprios gestores que se bem aproveitadas possibilitam melhorias a favor da empresa.

\section{FUNDAMENTAÇÃO TEÓRICA}

\subsection{A GESTÃO ORGANIZACIONAL}

Para Rodriguez, (2002, p.155-156), gestão é a forma de gerenciar a área de material e como as compras e entregas podem ser feitas, como a função planejamento atua, onde um grupo planeja e outro executa, ou, a forma como as pessoas se relacionam, quando são realizadas reuniões formais. "É a forma como os relacionamentos entre as pessoas se estabelecem na busca de um objetivo comum." A gestão deve ser bem definida, muitas vezes, ela é implícita, ou seja, não é claro e nem visível para a maioria dos empregados, ou às vezes nem mesmo existe. Para a adequada sinergia entre as pessoas da organização, a mesma deve ser explícita e perfeitamente clara para todos, com objetivos bem estruturados e organizados a fim de que ocorra integração entre os seus sistemas.

Rodriguez diz que:

Modelo de gestão é a apresentação de forma estruturada e organizada de como ocorre à integração entre os seus sistemas internos, formais e informais que fazem com que seja assegurado o atendimento às estratégias do negócio suportadas pelas pessoas dentro de uma organização formal de poder. (RODRIGUEZ, 2002, p. 156).

Ainda para Rodriguez, (2002, p. 156) utilizando a definição do modelo de gestão acima, descreve os três pilares básicos de sustentação do modelo que são "as pessoas, os Processos e a Tecnologia, suportados pela Educação e Aprendizagem e orientados pelas estratégias e Clientes", sendo descritas e resumidas a seguir:

- Pessoas: representa o comportamento esperado das pessoas, fortemente suportado pela cultura da organização, crenças e valores. Os profissionais do conhecimento serão aqueles que trarão um diferencial competitivo para a organização;

- Processos: representa os sistemas formais de fluxo de informações e processos decisórios.

- Tecnologia: relacionada à infraestrutura de software e equipamentos necessários ao fluxo de informações.
- Educação e aprendizagem: representa as atividades e os resultados voltados para a educação continuada dos empregados.

- Estratégia: relacionada ao mercado e a questões externas que direcionam a forma de atuação da organização.

Já para Gonçalves, (2000, p. 06), o objetivo da gestão organizacional é oferecer produtos e serviços que agreguem valor, o mais rápido que puder e com redução de custos, pois "o preço pago é somente um ponto considerado pelo cliente".

Gonçalves diz que:

A importância dos processos essenciais na gestão das empresas vai da identificação e definição desses processos, passa pelo aperfeiçoamento de tais processos, pela priorização deles na gestão da empresa como um todo, e chega até a redefinição da estrutura organizacional e do funcionamento da empresa em função dos seus processos básicos (GONÇALVES, 2000b, p.12).

De acordo com Araujo, (2011, p. 24-25), "o mais importante, mais relevante, fundamental e essencial, é entender que a gestão de processos se torna uma tecnologia de gestão organizacional". Cruz (2005), diz que um dos conceitos de processos é quanto à existência, são a introdução de insumos (entradas ou inputs) num ambiente, formado por procedimentos, normas e regras que, ao processarem os insumos, transformaram-nos em resultados que serão enviados (saídas ou outputs) aos clientes do processo.

Krajewski, Ritzman e Malhotra (2009) coloca que uma postura que poderá ajudar os gestores a programarem os valores da empresa é obter espírito de liderança para fazerem com que seus liderados cumpram o que é exigido, avaliando se suas decisões são coerentes com os princípios éticos da empresa - "Suas ações precisam estar alinhadas com o que dizem". Ter pessoas que realmente tenham conhecimento do planejamento estratégico, qualidade, tecnologia, comunicação, cultura, clima, e principalmente motivadas, para exercerem as tarefas, só então poderão entender o contexto e a importância do seu trabalho. Ter convicção que seus colaboradores sabem responder às perguntas a seguir: trabalha?

O que é a organização em que - $\quad$ Por que, e para que ela existe? 
- Qual o negócio dela?

- $\quad$ Para onde ela está seguindo?

- $\quad$ Quais são as principais aspirações da empresa?

Tanto processo quanto pessoas de uma organização possuem clientes, "uns são clientes externos, que atuam como usuários finais ou intermediários e, que adquirem os produtos ou serviços da empresa, outros são clientes internos, que são os funcionários ou processos que recebem insumos de outros e executam seu trabalho" (KRAJEWSKI, RITZMAN e MALHOTRA 2009, p.05).

De acordo com Araújo (2006, p.25), "o gestor organizacional precisa estar aberto para o novo, refletir sobre si mesmo, sobre o mundo e sobre as empresas de maneira geral, assim como repensar (sempre) suas qualidades, potencialidades e limitações". Da mesma forma, precisa ser um difusor de modernas tecnologias de gestão das organizações e, acima de tudo, praticá-las no dia a dia.

Vergara diz que:

Espera-se que um gestor/líder seja hábil na busca de clarificação de problemas. Você deve usar mais tempo em identificar claramente o problema que a empresa tem do que fazê-lo apressadamente e ficar arrependido pelo restante de seus dias. A ciência diz que: quando se parte de premissa errada, pode-se chegar a uma bela conclusão, mas ela estará errada. Às vezes, você pode supor que tem em um problema de estratégia, quando ela está vinculada às necessidades de educação; outras que tem um problema de estrutura, quando ele é de escolha de tecnologia. Às vezes, você pode perder precioso tempo, tentando melhorar a forma de algo, quando a questão é indagar se este algo merece continuar (VERGARA, 2007, p.89).

Oliveira (1995) faz alguns destaques, e acolhemos os que melhor expressam o que a prática da consultoria e, em seguida a ação do executivo /gestor:

- Processo: a ação do gestor não se constitui em uma ação com base apenas no processo. O gestor está envolvido com um conjunto, nem sempre lógico, de atividades do cotidiano da organização. Sua ação é quase desordenada, mas seria um atrapalhado de forma responsável.

- Interatividade: essas, sim, devem interagir constantemente entre todos os níveis da organização; gestão, operacional e institucional, e assim obter uma boa parceria.

- Agente de mudanças: o gestor é um agente interno e externo na execução das mudanças, deve ser comprometido com a estrutura social. Exige-se acima de tudo forte dose de compreensão da natureza humana. E isso faz parte do talento exigido para o exercício desse trabalho que tem na relação interpessoal uma marca muito forte.

- Responsabilidade assumida: o gestor assume a responsabilidade do cargo, com uma vantagem de estar no cotidiano da organização, tem condições de fazer as adaptações e ajustes necessários para as atividades em desenvolvimento.

- Auxilio nas tomadas de decisões: o gestor não auxilia apenas na tomada de decisão, ele é parte da decisão e, vez por outra, auxilia na decisão, mas, na realidade, seu trabalho é mesmo o de decidir.

A partir das visões dos autores citados percebe-se claramente que a Gestão Organizacional exerce papel fundamental. Ela torna-se indispensável não somente para a gestão vertical como também para a gestão horizontal, onde os impactos ocorrem de maneira substancial e onde estão os clientes (internos e externos) e fornecedores (internos e externos), atores essenciais para a sobrevivência das empresas.

\subsubsection{O PAPEL DA LIDERANÇA ORGANIZACIONAL}

O papel do líder é de fundamental importância para energizar e criar a confiança necessária a todos os colaboradores, construindo assim uma única equipe, com objetivos claros e bem definidos.

Segundo Chiavenato (2006, p.157), liderança é um tipo de influenciação entre pessoas; onde, uma pessoa influencia a outra em função dos relacionamentos existentes entre elas. "A influência é uma transação interpessoal na qual uma pessoa age no sentido de modificar ou provocar o comportamento de outra, de maneira intencional". Está ligado ao conceito de poder e de autoridade, abrangendo todas as maneiras pelas quais se introduzem as mudanças no comportamento de pessoas ou grupos de pessoas.

Para Rodriguez (2002, p. 101-102), o líder é o elemento fundamental em todo o processo de mudança, pois é a partir dele que a empresa 
irá programar a mudança. "O líder deve sempre ser o elemento ativo". Ele também será acometido pela mudança, a partir do momento que está à frente desse processo, e sofrerá diretamente com o sucesso ou com o fracasso de uma mudança.

Chiavenato (2006, p.159-160) expõe que "em um estudo pioneiro sobre liderança, fizeram uma pesquisa para verificar o impacto causado por três diferentes estilos de liderança e os climas sociais resultantes." Para esses autores, existem três estilos básicos de liderança, a autocrática, a liberal e a democrática, resumidas a seguir:

- Liderança autocrática: apenas o líder decide e fixa as diretrizes, sem qualquer participação do grupo; determina providências para a execução das tarefas, uma por vez, na medida em que são necessárias e de modo imprevisível para o grupo; determina qual a tarefa que cada um deverá executar e qual o seu companheiro de trabalho; é um líder dominador nos elogios e nas críticas ao trabalho de cada um.

- Liderança liberal: total liberdade para tomada de decisões grupais ou individuais, com participação mínima do líder. A participação do líder no debate é limitada, apresentando apenas alternativas ao grupo, esclarecendo que poderia fornecer informações desde que solicitadas. Tanto a divisão das tarefas como a escolha dos colegas fica por conta do grupo. O líder não faz nenhuma tentativa de avaliar ou regular 0 curso das coisas. Faz apenas comentários quando perguntado.

- Liderança democrática: as diretrizes são debatidas e decididas pelo grupo que é estimulado e assistido pelo líder. O próprio grupo esboça providências e técnicas para atingir o alvo com o aconselhamento técnico do líder. As tarefas ganham novos contornos com os debates. A divisão de tarefas fica a critério do grupo e cada membro tem liberdade de escolher seus próprios colegas. O líder procura ser um membro normal do grupo, é objetivo e estimula com fatos, elogios ou críticas.

De toda forma pode-se concluir que a liderança se faz necessária e acontece de várias formas: liberal, autocrática, democrática, todas tem o seu valor. Todavia deve ser mantido o bom senso e podendo ser exercida de várias formas, contudo respeitando a situação em que o indivíduo se encontra o grau de autoridade e responsabilidade a ele concedida para a tomada de decisões. O processo de comunicação visa sempre a consecução de um ou mais objetivos. O gestor para ser bemsucedido como líder deve saber lidar com aspectos relativos à motivação, à comunicação, às relações interpessoais, ao trabalho em equipe e à dinâmica de grupo.

\subsubsection{COMUNICAÇÃO ORGANIZACIONAL: FATOR FUNDAMENTAL}

Para Rodriguez (2002, p. 121-147), a redução de perdas de comunicação deve ser vista como de responsabilidade de todos da empresa, desde o topo da organização até o seu menor nível hierárquico. Eliminação dos filtros de comunicação introduzidos pelo nível de gerência intermediária, principalmente com relação à filtragem de problemas, soluções e novas ideias. Diz também que "Comunicação e informação são como o "oxigênio" necessário para o funcionamento da organização". Sem eles a organização não se viabiliza como inovadora. Há empresas que confundem a questão da segurança de informações para que o conhecimento da empresa não seja prematuramente difundido. Dessa forma, restringe aos seus empregados o acesso às informações de forma exagerada, o que acaba prejudicando o desempenho dos empregados e gerando um clima de desconfiança; os empregados acabam sentindo dificuldades para colocar suas ideias de forma aberta e desprovida de dogmas vigentes.

As comunicações íntegras, personalizadas e diretas são de grande importância. Deve ser utilizado um entendimento diferenciado às diversas pessoas que integram com a organização como um plano de comunicação e marketing, envolvendo os clientes, fornecedor, sociedade, empregados e acionistas (RODRIGUEZ, 2002, p.453)

Segundo Araújo (2006, p.105), para que o projeto de construção de uma nova realidade organizacional seja possível, "a comunicação é considerada como fator fundamental a ser administrado, de forma a promover o comprometimento e confiança entre as pessoas nas ideias de aperfeiçoamento". Garantir que todas as pessoas possam expressar-se livremente a respeito de tudo que se relacione com suas tarefas e também sobre aspectos interpessoais capazes de afetar o trabalho que desempenham sem que haja qualquer tipo de censura ou mesmo repressão. A liberdade de comunicação deve ser absolutamente natural. 


\subsection{CULTURA ORGANIZACIONAL}

Chiavenato (2006. P.266), conceitua cultura Organizacional, como "um padrão de assuntos básicos compartilhados, que um grupo aprendeu como maneira de resolver seus problemas de adaptação externa e de integração interna e que funciona bem a ponto de ser considerado válido e desejável para ser transmitido aos novos membros como forma correta de perceber, pensar e sentir em relação aos problemas".

Em outras palavras cultura organizacional representa as normas informais e não escritas que orientam o comportamento dos membros de uma organização no dia- a- dia e que direcionam suas ações para o alcance dos objetivos organizacionais. "No fundo, é a cultura que define a missão e provoca o nascimento e o estabelecimento dos objetivos" e precisam ser alinhados com outros aspectos das decisões e ações da organização; como planejamento, organização, e controle para que se possa conhecer melhor a organização. CHIAVENATO (2006, p.267)

Segundo Wagner III e Hollenbeck (2000, p.367), "cultura de uma organização é uma maneira informal e compartilhada de perceber a vida e a participação na organização, que mantém os seus membros unidos e influencia o que pensam sobre si mesmos e seu trabalho". Trabalhar com pessoas diferentes faz parte do dia a dia de um gestor. É de vital importância ter sensibilidade para compreender e aceitar as diferenças. Provavelmente, tornará a tarefa mais fácil e leve.

Cury diz que:

Cultura compreende um conjunto de propriedades do ambiente de trabalho, percebidas pelos empregados, constituindose numa das forças importantes que influenciam o comportamento. A cultura compreende além das normas formais, também o conjunto de regras não escritas, que condicionam as atitudes tomadas pelas pessoas dentro da organização; por esse motivo, o processo de mudança é muito difícil, exigindo cuidado e tempo. Para se obter uma mudança duradoura, não se tenta mudar as pessoas, mas as restrições organizacionais que operam sobre elas (CURY,2009, p. 286).

Em resumo a cultura auxilia no cumprimento de metas e objetivos organizacionais. Tal cultura pode beneficiar como prejudicar, visto que os valores e princípios da organização são fatores que podem fazer circular toda a participação positiva ou negativa do colaborador.

\subsubsection{CLIMA ORGANIZACIONAL E A INFLUÊNCIA NO AMBIENTE EMPRESARIAL}

Segundo Chiavenato (2006, p. 274), "o clima é percebido de diferentes maneiras pelos diferentes indivíduos". Tem grande influência na motivação, desempenho humano e satisfação no trabalho, mas depende das condições econômicas da empresa, da estrutura organizacional, da cultura, das oportunidades de participação pessoal, do significado do trabalho, da escolha da equipe, do preparo e treinamento da equipe, estilo de liderança, da avaliação e remuneração da equipe.

Dentro de muitos conceitos, empresas devem dar total importância à prestação de serviços oferecendo o melhor atendimento aos seus clientes. É obrigação de toda a equipe de serviços em prestar atenção nos detalhes e nos anseios dos clientes. Na visão de Shapiro e Sviokla (1994, p. 49-59), uma das indicações mais exatas de um relacionamento ruim ou em decadência é a ausência de queixas do cliente. "Ninguém jamais fica tão satisfeito, especialmente durante um longo período de tempo". Diante disso, ouvir os consumidores tem que ser do interesse de todos (MCKENNA, 1993, p. 45).

Chiavenato, diz que:

Clima organizacional refere-se especificamente às propriedades motivacionais do ambiente interno de uma organização, ou seja, aos aspectos internos da organização que levam à provocação de diferentes espécies de motivação aos seus participantes. Constitui a qualidade ou a propriedade do ambiente organizacional que é percebida ou experimentada pelos participantes da empresa e que influencia o seu comportamento. (CHIAVENATO, 2006, p. 273)

Segundo Luz (2003, p.185), clima organizacional de uma empresa está ligada ao, (querer fazer) das pessoas. O autor acredita que a instituição poderá adotar treinamentos de todas as formas para o colaborador aprender aquilo que esteja sendo passado que é a questão do (saber fazer), oferecer todas as ferramentas para a execução de um ótimo trabalho (poder fazer), porém se os colaboradores tiverem insatisfeitos não terão atitudes positivas em relação à prestação de serviços. "A eficiência 
dependerá de como os funcionários estão em termos de satisfação com a organização".

Concluindo a ideia dos autores, cabe ao gestor criar e desenvolver um clima organizacional favorável a convivência amistosa, com intervenções do seu estilo gerencial, na forma de administrar pessoas, nos estímulos (motivação), na avaliação de desempenho e acima de tudo no que diz respeito às formas de recompensas e remuneração.

\subsubsection{A INFLUÊNCIA DA MOTIVAÇÃO ORGANIZACIONAL}

Segundo, Vergara (2007, p. v 40), a origem da palavra motivação deriva do latim motivus, movere, que significa mover. Em seu sentido original, a palavra indica o processo pelo qual o comportamento humano é incentivado ou estimulado por algum tipo de motivo ou razão. Motivo, motor e emoção são palavras que têm a mesma raiz.

Para atingir objetivos é necessário desenvolver habilidades como: integração dos diferentes estímulos recebidos por meio de leitura, com situações da realidade organizacional, fazer reflexão e crítica; análise e síntese; disciplina intelectual; ação responsável e compartilhamento das descobertas. "Já dizia o velho Sócrates, os ensinamentos chegam às empresas como referência para que dirigentes e funcionários aprendam a pensar com disciplina." (VERGARA, 2007, p. 10-42).

Motivação remete à ideia de um produto acabado, é intrínseca, isto é, está dentro de nós, em um processo que se configura a cada momento, o fluxo permanente da vida. Tem caráter de continuidade, o que significa dizer que sempre tem-se a frente algo que motive, pois ninguém motiva ninguém. "Nós é que nos motivamos, ou não. Tudo o que os de fora podem fazer é estimular, incentivar, provocar nossa motivação." (VERGARA, 2007, p. 41).

De acordo com Maximiano (2006, p. 250), "no campo da administração, pessoa motivada usualmente significa alguém que demonstra alto grau de disposição para realizar uma tarefa ou atividade de qualquer natureza". Ainda para o mesmo autor, as pessoas também se motivam para fazer coisas que vão à direção oposta à desejada pela empresa, como greves, sabotagens, roubo de mercadorias ou invasões de fábricas que demitem funcionários. Por causa disso, qualquer ação ou manifestação observável das competências e características individuais, como falar, pensar, escrever, decidir ou não fazer nada, são exemplo de comportamentos. Por tanto todos têm comportamento que se baseia na ideia de que todo comportamento é acionado por algum tipo de estímulo, motivação, expectativa, recompensa, desempenho, objetivo, e valor dos resultados obtidos.

Maximiano (2006, p. 253), explicita que a teoria da expectativa procura explicar a cadeia de causas e efeitos que liga o esforço inicial ao resultado ou recompensa final. Os componentes principais da teoria da expectativa são os seguintes: o valor dos resultados, a associação entre o desempenho e a recompensa e a associação entre o esforço e o desempenho. O valor percebido dos resultados depende da satisfação ou insatisfação associada à sua obtenção e representa o atrativo que vai desencadear o esforço final. Na teoria da expectativa, o esforço depende do valor percebido da recompensa. (MAXIMIANO, 2006)

\section{MÉTODO DE PESQUISA}

O tipo de pesquisa utilizado foi à pesquisa exploratória através de um estudo de caso desenvolvido em uma empresa familiar de pequeno porte do segmento do comércio varejista de materiais para construção civil. Para Gil (2002) a pesquisa exploratória proporciona maior familiaridade com o problema (explicitá-lo). A pesquisa descritiva também foi contemplada, neste tipo de pesquisa, os fatos são observados, registrados, analisados, classificados e interpretados, sem que o pesquisador interfira neles. Isto significa que os fenômenos do mundo físico e humano são estudados, mas não manipulados pelo pesquisador (ANDRADE, 2010, p.112)

As fontes utilizadas foram as secundárias, provenientes das literaturas disponíveis, e das fontes primárias, ou seja, dados que ainda não tinham sido trabalhados, no caso os da empresa. Para Gil (2002, p.25), uma vez que foram coletados, os dados devem ser analisados, e servirão de sustentação para as respostas aos problemas e investigações, além disso, o autor relata que "estes dados precisam ter uma interpretação mais ampla, que por sua vez, confirmou os conhecimentos adquiridos anteriormente pelo pesquisador". O Instrumento de coleta de dados utilizado foi um questionário direcionado aos 23 colaboradores daquele estabelecimento, ressaltando que todos responderam a 
pesquisa. A análise das informações foi quantitativa e qualitativa, uma vez que, baseando-se na diferença entre as duas abordagens, Hubner (1998, p.56), ensina que "o que define uma análise como sendo qualitativa ou quantitativa não é o método de coleta, mas sim a forma de tratamento dos dados". A pesquisa quantitativa significou transformar opiniões em números, o que possibilitou a classificação e posterior análise, a qual denomina-se análise qualitativa.

\section{APRESENTAÇÃO E INTERPRETAÇÃO DOS RESULTADOS}

A pesquisa realizada demonstrou inicialmente o perfil dos entrevistados (funcionários). De acordo com o gráfico 01 (um) a maioria dos colaboradores tem entre 35 e 45 anos, partindo do pressuposto de que já possuem maturidade pessoal e profissional. Ainda no mesmo gráfico pode-se observar o tempo em que essa pessoa está trabalhando nessa profissão. Percebe-se que há pessoas com pouco tempo nessa atividade e outras pessoas que estão há bastante tempo praticando esse ofício, principalmente estas podem auxiliar muito no desenvolvimento de novas práticas, pelas experiências que trazem, ou ao contrário, podem trazer seus vícios de trabalho.

No que se refere às pessoas que possuem um tempo de atividade menor, possivelmente porque elas podem estar iniciando novas experiências de vida, ou até mesmo iniciando no mercado de trabalho. Ao verificar a terceira informação do gráfico visualiza-se que a grande parte dos colaboradores está na empresa há mais de um ano, desta forma a veracidade nas respostas dos questionários tem maior peso por já estarem inseridos e já conhecerem bem a empresa e seus procedimentos.

Por último e não menos importante a informação sobre o nível de instrução dos participantes, o que pode indicar que as pessoas que trabalham nessa empresa não procuram adquirir conhecimento porque não querem, ou não enxergam os benefícios de se aprofundar nos estudos, ou ainda por motivos particulares não puderam fazer essa escolha, dentre muitas outras hipóteses. Isso pode influenciar também nas questões de gestão organizacional, impactar no atendimento ao cliente, além de dificultar na implantação de novas abordagens de gestão devido ao desconhecimento e falta de capacitação técnica, ou ainda presumir que a gestão não possui foco nas pessoas.

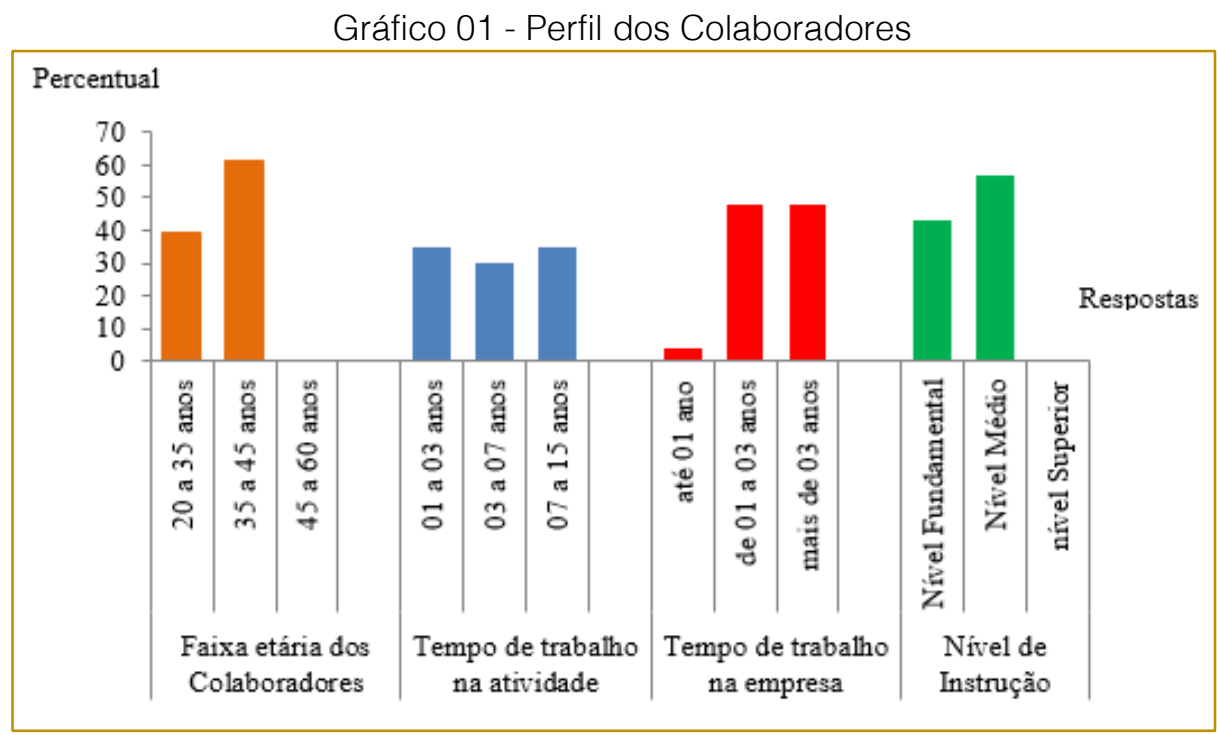

Um outro grupo de questões investigou de forma objetiva alguns pontos relacionados a processos, liderança, e obrigações com os colaboradores. Esses pontos são

apresentados no gráfico 02 (dois) a seguir: 
Gráfico 02 - Visão dos colaboradores quanto ao funcionamento da empresa

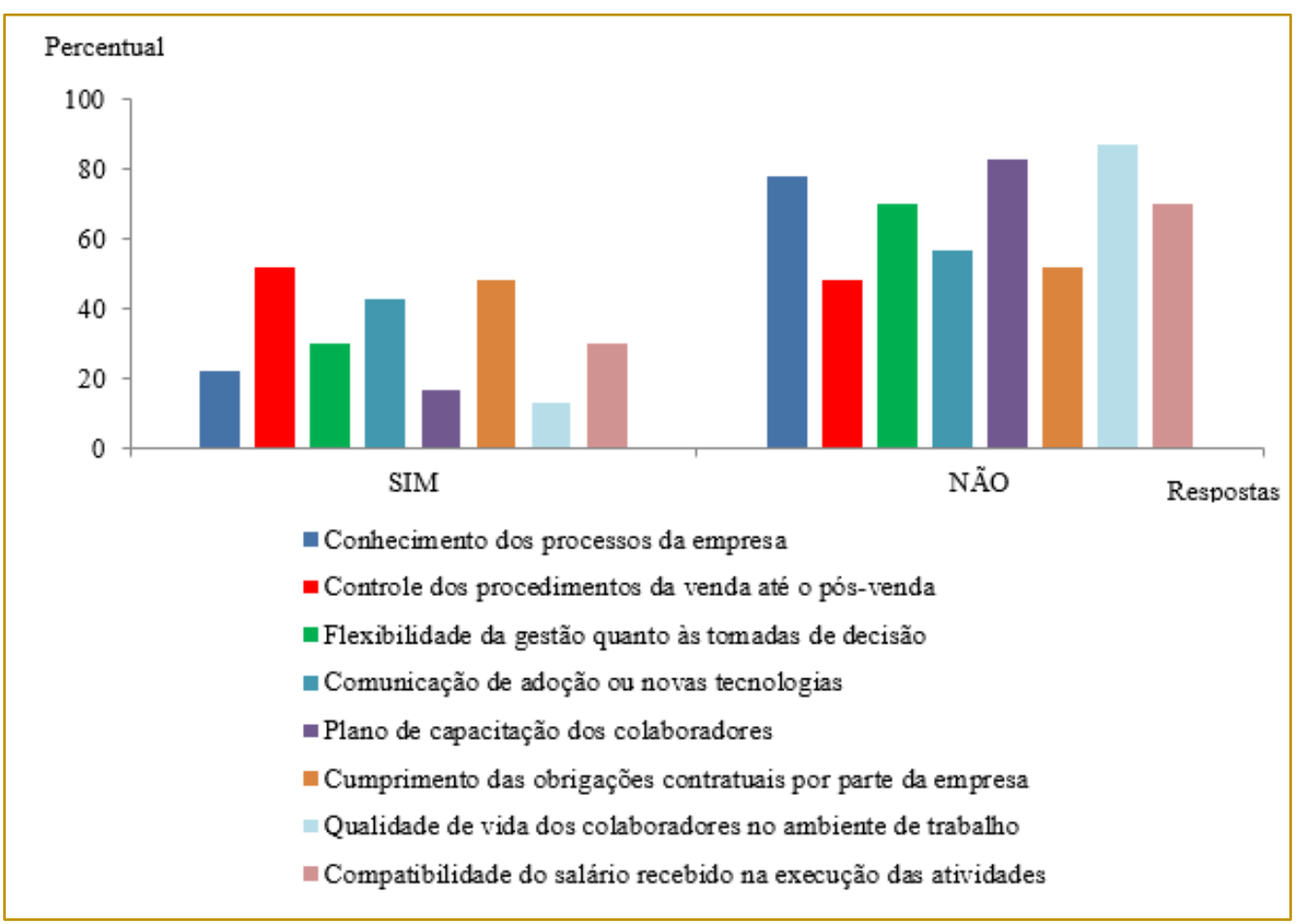

Conforme se verifica acima, praticamente todas as perguntas realizadas aos colaboradores relativas a esse grupo tiveram como resposta "NÃO". Isto pode ser visto como grande falta de gestão organizacional na empresa.

Os dois primeiros assuntos foram relacionados à gestão dos processos operacionais. Ao analisar o perfil dos colaboradores, entende-se que a empresa não tem mão de obra qualificada, ou os processos não são claros ou até mesmo não existem, ainda mais quando se trata de procedimentos através de sistema de informação, que exige habilidades específicas. Isso pode estar acontecendo devido à falta de conhecimento da equipe gestora em transmitir como as tarefas devem ser executadas e treinamento adequado aos colaboradores. Gonçalves, (2000, p. 12), reafirma através da fala de que "a importância dos processos essenciais na gestão das empresas vai da identificação e definição desses processos, passa pelo aperfeiçoamento, pela priorização deles na gestão da empresa como um todo, e chega até a redefinição da estrutura organizacional e do funcionamento da empresa em função dos seus processos básicos".

O terceiro ponto refere-se à flexibilidade da equipe gestora em ouvir opiniões dos colaboradores, no auxílio das tomadas de decisão. Entretanto o que se percebe, é que eles não se sentem fazendo parte desse processo, muito menos que suas ideias possam ser ouvidas para melhorias e tomadas de decisão.

Relativo à comunicação de adoção ou novas tecnologias as opiniões se dividiram, mas ainda a grande parte defende que a gestão poderia transmitir de forma mais clara as mudanças relacionadas as tecnologias adotadas. As informações coletadas em um sistema de informação podem ser entendidas como as entradas, que após serem processadas serão transformadas em saídas, sejam, na linha de produção que será transformado em produtos ou serviços ou ainda, quando se trata de um sistema de informação onde sairão dados (informações) importantes que poderão auxiliar as pessoas a executarem suas atividades e aos gestores nas tomadas de decisão.

Para Rodriguez (2002, p. 53), a tecnologia deixa de ser um luxo ou um equipamento para poucos e passa a ser uma necessidade básica para execução do trabalho. Com o uso da tecnologia de informação, os dados se transformam em informação e em conhecimento, gerando, após a aplicação do conhecimento, novos eventos que terminam por gerar novos dados. "Cria-se assim um ciclo sem fim de acúmulo do conhecimento da empresa". 
Fechando esse grupo tem-se os últimos quatro pontos, todos direcionados aos colaboradores. Nesses, eles opinaram sobre a Gestão em relação ao tratamento de alguns aspectos específicos. Como pode ser observado no gráfico, na opinião dos colaboradores plano de capacitação foi um dos pontos que teve maior incidência de "Não", o que pode significar que a empresa precisa rever o seu plano de desenvolvimento de novos treinamentos e cursos de qualificação, ou ainda promover incentivo ao colaborador para que ele procure por exemplo cursar um nível superior. Segundo Chiavenato (2006, p.167), a organização deve se desenvolver constantemente "para acompanhar também as mudanças que há no mundo em que se vive, há aquelas que são fundamentais e constantes na estrutura interna da empresa, na comunicação e comportamento dos colaboradores, e no processo de tecnologia utilizado". Todas as empresas aprendem conscientemente ou não, esse é o requisito fundamental para a sua existência.

De acordo com as informações coletadas a empresa está cumprindo com suas obrigações contratuais para metade de seus colaboradores. A outra parte informa que não há esse cumprimento. Isso muito tem haver com a cultura organizacional praticada, principalmente em empresas de pequeno porte ou familiares que tendem a impor valores aos colaboradores pelos quais os mesmos não concordam.

Complementando a informação anterior as opiniões referentes a compatibilidade do salário recebido na execução das atividades, percebe-se a insatisfatoriedade profissional dos participantes. É importante ressaltar que a insatisfação não é proveniente somente do salário. Observa-se através de dados anteriores, que se referem a gestão organizacional, está mais ligada a inflexibilidade, a falta de liderança, a comunicação, a tecnologia usada pela empresa do que a questão salarial.

Para finalizar, conforme apresenta o gráfico, o ponto mais crítico desse grupo esta relacionado a qualidade de vida. Foi observado que a empresa não oferece benefícios aos seus colaboradores como, por exemplo, plano de saúde e odontológico, vale alimentação, etc.

A qualidade de vida no trabalho faz-se necessário, já que é dos colaboradores que se obtêm os resultados para a sobrevivência de todos que fazem parte da empresa. Tendo em vista que em um ambiente harmonioso, bem estruturado e com as necessidades fisiológicas dos colaboradores atendidas, todos terão mais satisfação em executar suas tarefas e fazendo com que a empresa seja mais lucrativa, gerando um maior índice de produtividade e competitividade.

Porém, para atingir estes níveis é necessário certo equilíbrio entre o que os colaboradores necessitam e o que a empresa pode atender, para que não se torne oneroso e seja algo que os colaboradores realmente vejam como um diferencial. A qualidade do clima organizacional deve ser gerenciada juntamente com a qualidade de vida dos colaboradores da empresa, pois ambos têm ligação entre si, e resultando em maior motivação para os colaboradores.

Gráfico 03 - Visão dos colaboradores quanto à aspectos organizacionais

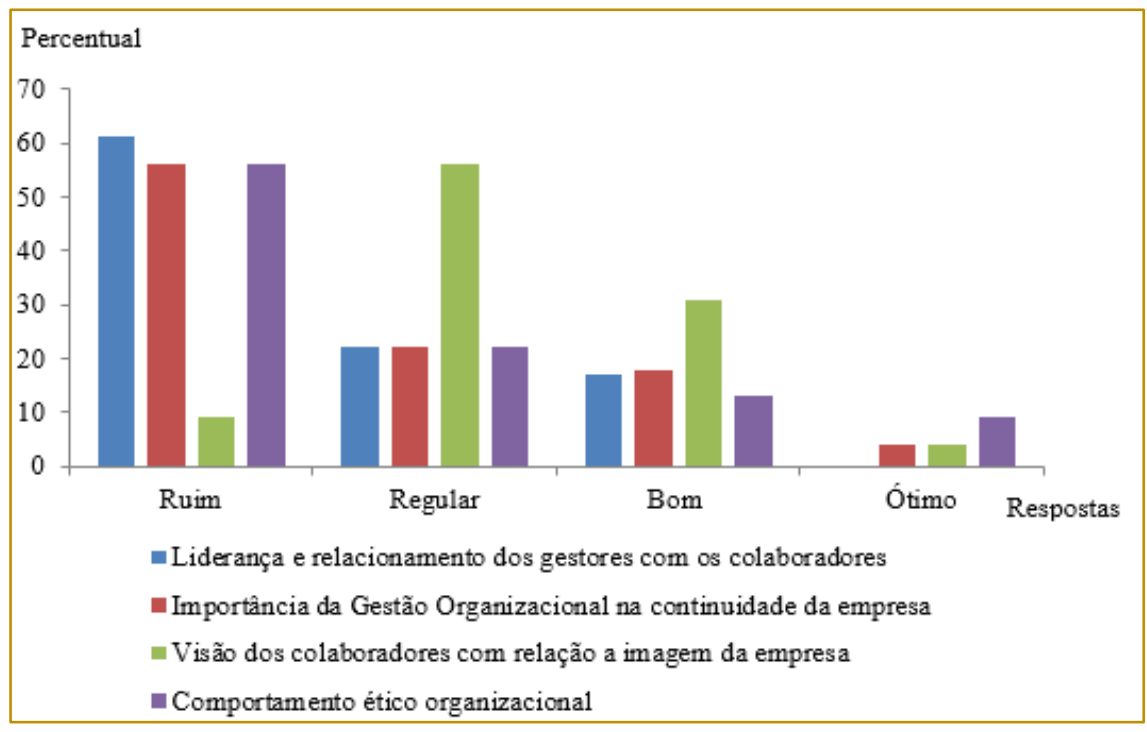

Tópicos em Administração - Volume 19 
Esse grupo analisou as opiniões dos colaboradores em relação a quatro pontos fundamentais para o crescimento e continuidade da empresa, fidelização de cliente interno e externo, e perspectivas futuras de manutenção e busca de novos talentos para a organização.

De forma geral o que se constata através dos resultados é que se tem uma visão negativa da gestão organizacional por parte de seus colaboradores. Praticamente em todos os pontos pesquisados. O único ponto que ainda se sobressai é o relacionado a imagem da empresa. Pela ótica de seus funcionários ela tem uma regular aceitação no mercado, ainda cabendo melhorias a serem desenvolvidas e mudanças a serem implementadas.

A liderança e o relacionamento são de grande importância para uma gestão inovadora, conciliadora, por proporcionar aos seus colaboradores um ambiente de trabalho agradável, levando-os a executarem suas tarefas com prazer. Foi verificado que a empresa tem alto grau de insatisfação no quesito relacionamento do gestor com 0 quadro funcional, manifestando um despreparo da equipe gestora ao lidar com os colaboradores. Sabe-se que se o relacionamento entre os membros da empresa não vai bem, seus resultados podem ser fragilizados e a empresa passar por retração no seu crescimento. Diante dessa realidade, um dos motivos que possam estar ocorrendo seja devido a cultura de seus gestores, necessitando de mudanças internas, as quais talvez nem percebam e que eles próprios precisem mudar. Chiavenato diz que:

A cultura organizacional mostra aspectos formais e facilmente perceptíveis, como as políticas e diretrizes, os métodos e procedimentos, os objetivos, a estrutura organizacional e a tecnologia adotada. Contudo, oculta alguns aspectos informais, tais como as percepções, os sentimentos, as atitudes, os valores, as interações informais, as normas grupais etc. Os aspectos ocultos da cultura organizacional são mais difíceis não somente de compreender e interpretar, como também de mudar ou sofrer transformações. (CHIAVENATO, 2006, p. 268) O comportamento ético organizacional é considerado um dos princípios/valores da gestão. Entende-se que seja um dos elementos centrais da avaliação do desempenho das empresas e dos seus responsáveis, a proposta ganha especial relevância no contexto das empresas com fins lucrativos. A ética pode resultar em importantes vantagens competitivas decorrentes de uma imagem positiva projetada na empresa e do aumento da satisfação e da melhoria do desempenho dos trabalhadores. Essa questão teve um grande impacto negativo sob a ótica dos entrevistados, o que propõe fortes medidas de melhoria principalmente relacionadas a equipe gestora, e, ainda demonstra o quanto é necessária a atenção da gestão voltada para as pessoas - principal capital intelectual. Complementando ainda a ideia, essa questão é vasta e influencia diretamente a imagem da empresa, a pesquisa apresenta pelas respostas coletadas que há um descolamento entre a ética e a imagem que os colaboradores têm da empresa.

Concluindo a análise desse grupo, pode-se afirmar e ainda reafirmar através do resultado mencionado no gráfico 03 , que para a empresa ter continuidade é preciso ter muita atenção com a maneira com que se faz Gestão Organizacional. A falta ou parte dela pode trazer insegurança a todos dentro da organização, todos devem conhecer os objetivos que precisam ser entendidos e integrados com as estratégias empresariais. Uma empresa sem gestão é como um barco desgovernado que não sabe onde quer chegar. Cabe a equipe gestora ter planejamento, estratégias e metas voltadas para os objetivos dando sustentabilidade a empresa.

Rodriguez (2002, p.155), diz que a "gestão deve ser bem definida, e muitas vezes, ela é implícita, ou seja, não é clara e nem visível para a maioria dos empregados, ou às vezes nem mesmo existe". Para a adequada sinergia entre as pessoas da organização, a gestão deve ser explícita e perfeitamente clara para todos, e com objetivos bem estruturados e organizados para que ocorra integração entre os seus sistemas.

Ainda para Rodriguez (2002, p. 54), "um diferencial competitivo de uma empresa competitiva e sustentável está no que ela sabe, em como utiliza o que sabe e a quão rápida é capaz de aprender e aplicar um novo conhecimento orientado ao mercado e cliente". A tecnologia deverá ser parte da estratégia da empresa e não uma parte da empresa. Devem-se adotar novos modelos de gestão que as torne mais rápidas na assimilação, aplicação de novos conhecimentos e tecnologias. 
Gráfico 04 - Satisfação dos Colaboradores

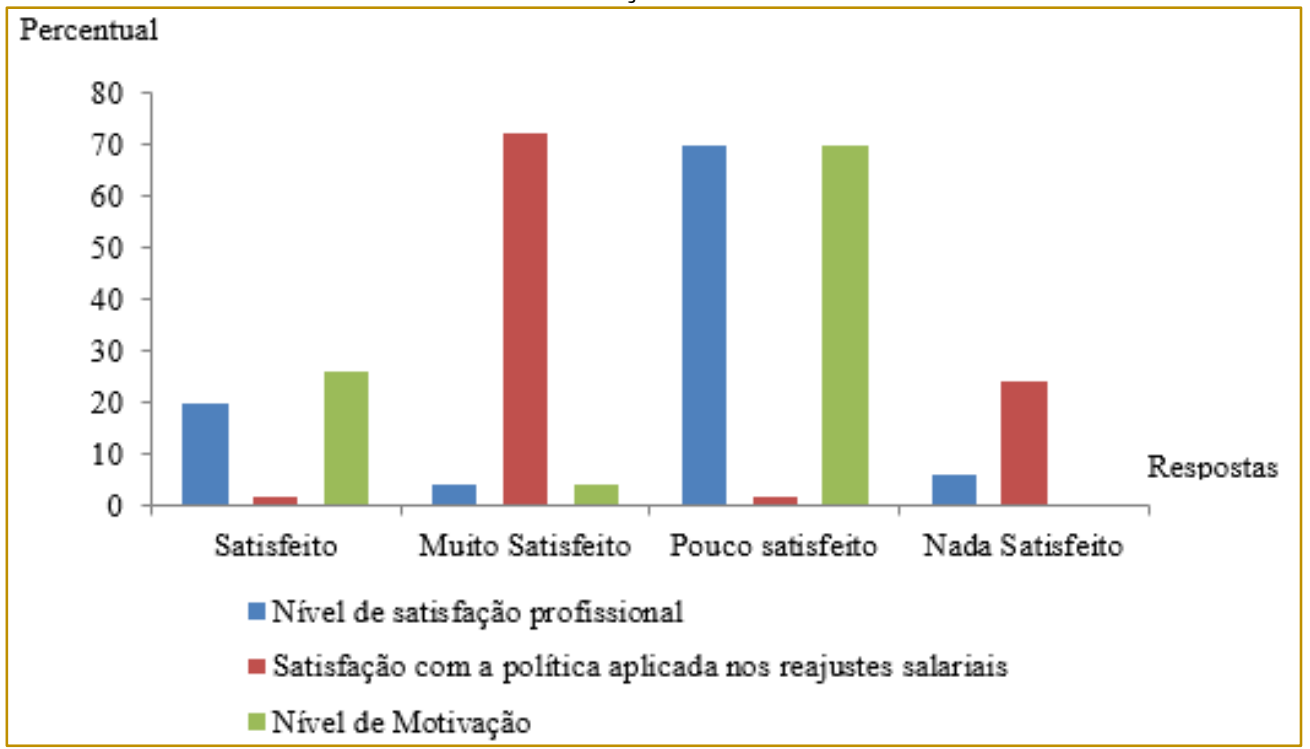

Dando continuidade à demonstração dos dados da pesquisa, o gráfico 04 apresenta a satisfação dos colaboradores em relação as atividades exercidas em seu trabalho, bem como as considerações relativas a política salarial aplicada nos reajustes.

Conforme se verifica no gráfico 04 , e pensando que o trabalhador passa maior parte do seu tempo na empresa, com este índice de insatisfação tão alto com o ambiente de trabalho, pressupõe-se que a situação da empresa em estudo, precisa tomar medidas com relação ao ambiente de trabalho. Vale lembrar que o trabalhador satisfeito com o seu trabalho, produz mais e melhor do que quando está insatisfeito, podendo deixar a empresa em desequilíbrio.

Chiavenato (2006, p. 276), diz que:

Cabe ao gestor criar e desenvolver um clima organizacional, com intervenções no seu estilo gerencial, no sistema de administrar pessoas, na questão da reciprocidade, na escolha do pessoal, no projeto do trabalho e no treinamento da equipe, no estilo de liderança, nos esquemas de motivação, na avaliação da equipe e, sobretudo, nos sistemas de recompensas e remuneração.

Quanto ao segundo ponto referente a política salarial, e com base nas informações apresentadas neste gráfico, fica demonstrado que a questão do salário, nem sempre é o item de maior importância para o trabalhador. Fica claro que a empresa estabelece e cumpre os reajustes salariais. Nos dias atuais o relacionamento interpessoal, ambiente de trabalho saudável, benefícios, motivação tem maior relevância para os colaboradores. Vale salientar que dados anteriores confirmam que qualidade de vida no ambiente de trabalho e satisfação profissional tem muitas vezes maior valor atribuído pelo colaborador do que o salário em si. Com esses relatos, é perceptível que as pessoas dão mais valor as relações e outras práticas que satisfaçam o seu próprio eu do que aos bens materiais, como por exemplo, o salário. Sendo assim, pode-se concluir que a empresa em estudo precisa voltar sua gestão para as pessoas, pois este é o seu maior patrimônio.

Apresenta-se em última análise desse gráfico 04 (quatro) a motivação dos colaboradores em relação ao seu trabalho e à empresa. Esse item é de grande relevância para a conclusão do estudo. Levando em conta que os colaboradores se encontram pouco motivados, pode-se inferir que a motivação pode estar impactando diretamente na produtividade. É sabido de toda classe empresarial que o profissional desmotivado poderá trabalhar contra a empresa, acarretando sérios prejuízos e diminuição da lucratividade da empresa.

Carvalho (2011, p. 25), confirma isso dizendo: "funcionários desmotivados, insatisfeitos ou sem ânimo para trabalhar, acabam executando suas tarefas de qualquer maneira". O que se percebe muitas vezes e que o colaborador trabalha simplesmente pelo fato de se manter no emprego, sem colocar afinco e empenho, chegando a nem concluir o serviço. Isso é perceptível de forma muito clara, quando se trata de tarefas relacionadas à linha de frente da empresa, onde os funcionários tem contato direto com 
os clientes e acabam muitas vezes não os

agradável.

atendendo de uma forma satisfatória ou

Gráfico 05 - Visão dos colaboradores quanto aos comunicados e esclarecimentos

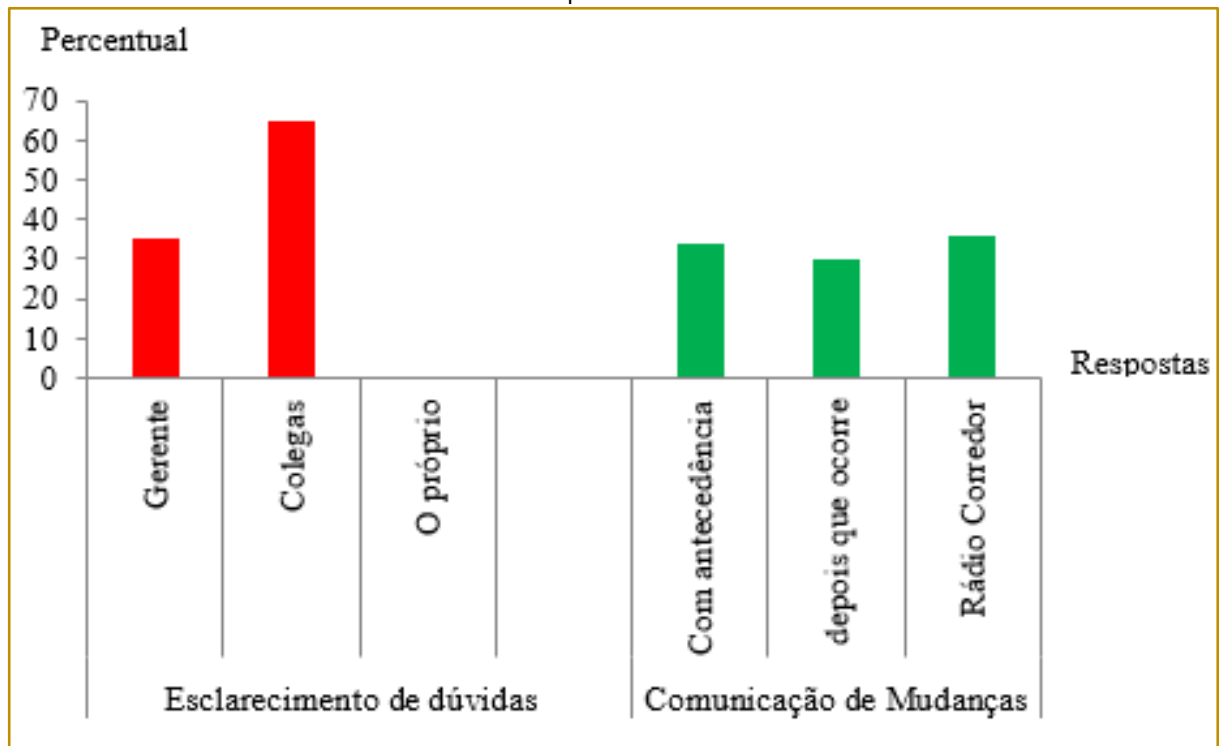

O último gráfico apresenta dois quesitos relativos a esclarecimento de dúvidas de trabalho e ao método de comunicação utilizado pela empresa nos processos de mudanças. Diante de dificuldades enfrentadas por colaboradores em exercer suas atividades do dia a dia, percebe-se que com a empresa pesquisada não é diferente. Ao surgir alguma dificuldade em executar suas tarefas recorrem aos colegas em maior frequência do que com a gerência, o que deveria ser o contrário. Pode-se verificar que a maioria dos colaborares procuram a solução dos problemas com os demais, quando na verdade o melhor, seria que, os problemas de trabalho fossem levados a gerência, e dessa forma fossem estudados as causas e os mesmos não viessem a acontecer novamente. Como já mencionado em gráfico anterior, os colaboradores sinalizam que a equipe gestora apresenta baixo grau de liderança entre os colaboradores, isso pode estar ocorrendo devido à falta de flexibilidade e ingerência por parte da equipe gestora. Na verdade, é o gestor que deve ter entendimento de todas as tarefas, todos os processos, pessoas e suas relações e ainda os produtos ou serviços a serem executados, para poder solucionar todas as dúvidas de seus colaboradores.

Segundo Vergara (2007, p.89), "é importante dedicar tempo em identificar claramente os problemas a serem solucionados, do que fazê-lo apressadamente. A ciência diz que: quando se parte de premissa errada, pode-se chegar a uma bela conclusão, mas ela estará errada."

No ponto de vista dos colaboradores a empresa em estudo utiliza métodos que não facilitam a boa comunicação. As informações chegam na maioria das vezes depois que ocorrem as mudanças ou chegam pelo ditado popular "Rádio Corredor". Ressalta-se que a comunicação não está auxiliando a empresa nas mudanças, já que ao ser transmitida de maneira equivocada, chega também transformada em uma outra informação muito diferente da primeira informação que foi acertada. Pode-se afirmar que a metodologia utilizada para comunicar suas decisões é informal e não é aconselhada em gestão de excelência. Pois assim, sua comunicação interna corre sérios riscos de desvio das regras não serem seguidas corretamente.

\section{CONCLUSÕES}

Ao se deparar com constantes transformações organizacionais, parte-se da premissa de que é imprescindível analisar as reações diretamente voltadas aos relacionamentos interpessoais dos colaboradores, ao ambiente de trabalho, comunicação, tecnologias utilizadas, liderança da equipe gestora em relação aos colaboradores. Através das informações coletadas fica perceptível a inflexibilidade da Gestão sob vários aspectos. No tocante, percebe-se que a grande massa de 
colaboradores não está motivada, não com políticas salariais, por exemplo, mas sim com a forma com que as ações ocorrem internamente. $\mathrm{O}$ que se presume através do estudo que a participação deles em relação também a tomada de decisões, é muito pequena, visto que o relacionamento interpessoal entre liderados e líderes está afetado, deixando o ambiente de trabalho comprometido, e não contribuindo para novos métodos e melhorias que poderiam ser sugeridas também pelos colaboradores. Pesquisas confirmam que o melhor tipo de Gestão é a que todos participam, manifestando suas opiniões. Isso faz o ambiente de trabalho agradável e deixa seus participantes mais motivados, aumentando a produtividade.

Alguns gestores mandam ou gerenciam e acreditam estar liderando, não fazendo nenhuma questão de melhorar o modo como lidam com as pessoas que estão em sua equipe, tratam-nas como se fossem máquinas. A consequência é que muitos

\section{REFERENCIAS}

[1] Andrade, M. M. , Introdução à Metodologia do Trabalho Científico, ed. 10, São Paulo: Atlas,2010.

[2] - Organização sistemas e Métodos e as tecnologias de gestão organizacional 2 ed, São Paulo: Atlas, 2006.

[3] Organização, sistemas e métodos e as tecnologias de gestão organizacional: arquitetura organizacional, benchmarking, empowerment, gestão pela qualidade total, reengenharia: volume I, 4 ed. São Paulo, Atlas,2011.

[4] Carvalho, K. M. C. Uma análise do clima organizacional em uma empresa varejista de móveis e eletros na cidade de picos - PI. 2011. 99. Monografia (Graduação em Bacharelado em Administração) Universidade Federal do Piauí, Picos Pl. Acesso em: 05/08/2017.

[5] Cervo, A. L. Bervian, P. A. Metodologia científica. 5.ed. São Paulo: Prentice Hall, 2007.

[6] Chiavenato, I. Administração Geral e Pública. Rio de Janeiro: Elsevier, 2006.

[7] Cruz, T. Sistemas, métodos e processamentos: Administração organizacional por meio de processos de negócios. 2 eds. revista atualizada e ampliada. São Paulo: Atlas, 2005.

[8] Cury, A. Organização e Métodos: Uma visão Holística. São Paulo, ed. Atlas, 2009

[9] Gonçalves, J. E. L. As empresas são grandes coleções de processos. Revista de profissionais estão deixando as empresas não pelo salário, mas pelo modelo de chefia. Dar voz aos colaboradores ajuda a empresa a produzir com eficiência, a gestão que faz a empresa melhorar seus resultados é a que se volta para as pessoas.

Contudo a pesquisa foi uma ótima oportunidade para averiguação do quanto esse tipo de modelo de Gestão Organizacional ainda é remanescente em pequenas e microempresas, familiares ou não, interferindo no comportamento e nas expectativas de um colaborador. O ser humano não evolui, não progride, não produz se não tiver perspectivas futuras positivas no seu ambiente de trabalho. Praticamente todos os pontos analisados nesse estudo levam a conclusão de que não há uma boa gestão, e não havendo pessoas satisfeitas com seu trabalho, motivadas, tendo prazer no que fazem provavelmente não haverá também sucesso na gestão organizacional de forma sistêmica.

Administração de Empresas. São Paulo, v.40, n.1, jan. / mar. 2000a.

[10] Processo, que processo. Revista de Administração de Empresas. São Paulo, v.40, n.4, out. / dez. 2000b.

[11] GIL, A. C. Como elaborar projetos de pesquisa. 4. ed. São Paulo: Atlas, 2002.

[12] Wagner III, J. A. ; Hollenbeck, J. R. Comportamento Organizacional. São Paulo: Saraiva, 2000.

[13] Hubner, M. M. C. Guia para elaboração de Monografias e Projetos de Dissertação de Mestrado e Doutorado. 2 ed. São Paulo: Pioneira, 1998.

[14] Hunter, J. C. O Monge e o Executivo: Uma história sobre a essência da liderança. Rio de Janeiro: Sextante. 2004.

[15] Krajewski, L.; Ritzman L.; Malhotra, M. Administração de Produção e Operações. 8a ed. Rio de Janeiro, Pearson, 2009.

[16] Luz, R. Gestão do clima organizacional. Rio de Janeiro: Qualitymark, 2003.

[17] Lakatos, E. M.; Marconi, M. A. Metodologia do trabalho científico.7 ed. São Paulo: Atlas, 2014.

[18] Martins, P. de O.; Lemos, D. M. R. Avaliação de Clima Organizacional e a Análise da Relação entre o Variável Comportamento da Chefia nas Demais Variáveis de Clima: Um Estudo de Caso em uma Instituição Financeira Capixaba. 
XXXI, EnaNPAD. Rio de Janeiro, 2007.Acesso em 05/08/2017.

[19] Maximiano, A. C. A. Teoria Geral da Administração: da revolução urbana à revolução digital, Ed.6, São Paulo: Atlas, 2006.

[20] Marconi, M. de A.; Lakatos, E. M. Técnicas de pesquisa: planejamento e execução de pesquisas, amostragens e técnicas de pesquisas, elaboração, análise e interpretação de dados. 7 . ed. São Paulo: Atlas, 2008.

[21] Mckenna, R. Marketing de relacionamento: estratégias bem-sucedidas para a era do cliente. São Paulo: Campus, 1993.
[22] Administração de processos. 2. ed. São Paulo: Atlas, 2012.

[23] Oliveira, M. A. Pesquisa de clima interno nas empresas: $O$ caso dos desconfiômetros avariados. São Paulo, Nobel, 1995.

[24] Rodriguez, M. V. Gestão Empresarial: Organizações que Aprendem: Qualitymark Petrobrás, Rio de Janeiro, 2002.

[25] Sviokla, J. J. ; SHAPIRO B. P. Mantendo Clientes. São Paulo: Makron Books, 1994.

[26] Vergara S. M. Gestão de Pessoas: Processos Motivacionais. São Paulo, Atlas, 2007. 


\section{Bapítulo 8}

\section{A COMPREENSÃO E A GESTÃo dE TALENTOS PARA EMPRESARIOS NO SUL DO BRASIL}

Juliana Weber Fabião

Simone Portella Teixeira de Mello

Rogério da Silva Almeida

Luciana Nunes Ferreira

Ingrid Moreno da Silva

Resumo: A gestão de pessoas está em constante mudança no que se refere a suas perspectivas de análise, em especial na sua expressão estratégica, emergindo novos desafios como atrair, reter e desenvolver talentos, contexto em que surge a Gestão de Talentos (GT). O objetivo deste estudo foi buscar significados para talentos, descrever o que compreende a gestão desses, assim como analisar quais são as práticas organizacionais recentes utilizadas na gestão de talentos. A revisão de literatura compreende artigos publicados na base científica SPELL $®$ Scientific Periodicals Eletronic Library nos últimos cinco anos. Na etapa empírica investigouse empresas na região sul do Brasil no que tange às práticas de GT, a partir de entrevistas com gestores. Os resultados revelam que o significado de talentos está em constante construção, e que as empresas não têm claro quais as práticas e ações devem adotar para captar, reter e desenvolver seus talentos, mas têm consciência que talentos são estratégicos para suas organizações. Entretanto, há equívocos no desenvolvimento de talentos. Por vezes, as organizações têm foco no treinamento, mas percebe-se a necessidade de uma educação corporativa, alinhando atributos e objetivos pessoais e profissionais aos objetivos estratégicos organizacionais. 


\section{INTRODUÇÃO}

A gestão de pessoas (GP) vive mudanças. Suas práticas tradicionais associadas à motivação, compensação, desempenho humano, desenvolvimento, relações de trabalho se associaram a temas mais emergentes e contemporâneos como: diversidade, foco em resultados organizacionais, novas tecnologias, trabalho em equipe, competências e gestão de talentos (GT). Observa-se um novo paradigma: o fomento à participação nas práticas de $\mathrm{RH}$ muito além do controle, estimulando autonomia nos colaboradores, o que requer conhecimento e relacionamento. Não é à toa que o século XXI está sendo chamado da era do conhecimento. A importância do conhecimento no contexto das organizações, convertido em capital intelectual, se revela como diferencial competitivo e fonte de poder no ambiente corporativo (STEWART, 1998; NOVAES, 2000).

Essa nova era é também da informação, pois trouxe mudanças no sistema produtivo, migrando de uma economia manufatureira para a de serviços. No Brasil, por exemplo, o setor de serviços corresponde a $61 \%$ do PIB brasileiro e a $71 \%$ dos empregos do país (LANDIM 2015). Isso impacta não só na economia, mas essencialmente no modus operandi das organizações, que passam de operacionais à estratégicas. Isso reflete na demanda por um profissional mais bem qualificado, com maior capacidade de inovação, agilidade e flexibilidade, tornando as empresas mais dependentes desses ativos intangíveis. São os profissionais de alta performance, os chamados talentos. Aqueles que fazem a diferença no desempenho de uma organização como destacam Mankins e Garton (2017).

$\mathrm{E}$ diante das mudanças no perfil dos profissionais e nas relações de trabalho, as organizações repensam suas práticas aplicadas à gestão de pessoas numa concepção mais estratégica, configurando um novo perfil de trabalhadores do conhecimento, que Sousa e Barreto (2015) destacam como talentosos e inovadores, aqueles que possuem visão sistêmica e que propõem a imediata solução de problemas e conflitos.

Neste contexto, a GT pode tornar-se um importante diferencial para as empresas, visto que a tecnologia está disponível para todas, e o que as diferencia é a capacidade de lidar com ela, que está diretamente ligada as pessoas e ao potencial que elas possuem e desenvolvem, ou seja, seus talentos.

As organizações reconhecem a necessidade de reavaliar suas práticas em gestão de pessoas como forma de se manterem competitivas. No brasil destacam-se os trabalhos realizados por Sarsur et al., 2003; Barreto et al., 2010 e Freitag et al., 2012, onde o tema é tratado sob o enfoque da área de Gestão de Pessoas. Já o relatório de 2013, realizado em âmbito internacional pela Society of Human Resource Management (SHRM) destaca que a gestão de talentos é, desde 2010, o tema chave e a prioridade dos líderes de $\mathrm{RH}$.

Segundo Ferrazza; Burtet e Scheffer (2015) a denominada guerra pelos talentos associa-se a um momento de transição da sociedade industrial para a pós-industrial. Apesar de ser um tema emergente e presente em muitos debates mundiais que abordam o futuro da GP, observa-se ainda confusão nas definições existentes do termo talento e da expressão Gestão de Talentos, instigando o questionamento: o que especificamente é Gestão de Talentos? Embora reconheçam a carência de uma definição consistente sobre a expresão, alguns autores afirmam que uma boa GT é muito importante para a estratégia da empresa.

Diante da importância da discussão sobre talentos e seus desdobramentos, o presente artigo visa descrever qual o conceito de talento utilizado pelas empresas pesquisadas, como a gestão desses acontece e quais são as práticas organizacionais implementadas para a gestão de talentos.

Cada vez mais, a necessidade de tornar as organizações mais competitivas torna-se um imperativo de sobrevivência. Vários modelos e práticas surgiram com este intuito, alguns muitos diferentes um dos outros. Entretanto, podemos achar um ponto em comum: a valorização e importância dos aspectos humanos para que os processos deem certo. Nas últimas décadas, essa procura tornou-se mais intensa, principalmente com o advento da globalização, que provocou a abertura dos mercados e forçou as empresas a concorrer num ambiente altamente competitivo e dinâmico, no qual o diferencial humano, representado pelos talentos, se destaca.

Nesse sentido, desde que o termo Talentos surgiu na literatura, muito se tem escrito sobre 
seus possíveis efeitos nas organizações (SARSUR et al., 2003; BEECHLER; WOODWARD, 2009), principalmente no que concerne às transformações no comportamento dos funcionários.

Assim surge uma pergunta fundamental, que deve ser respondida por meio de pesquisas empíricas: até que ponto as organizações entendem o que são talentos? E como atrair, reter e desenvolver talentos?

Este estudo propõe responder algumas dessas questões, adotando uma abordagem descritiva. Pretende-se, com base no referencial teórico, contribuir para a melhor compreensão do que são talentos, e contribuir para a produção de pesquisas contextualizadas na realidade brasileira, fundamentadas em estudo de caráter acadêmico.

Mesmo existindo estudos sobre o tema GT e seus possíveis efeitos no desempenho organizacional, entende-se que, devido à complexidade do assunto e às diversas perspectivas que podem ser adotadas para a sua compreensão, esse ainda é um tema suscetível à discussão.

\section{FUNDAMENTAÇÃO TEÓRICA}

O referencial teórico exposto a seguir objetiva apresentar, essencialmente, o conhecimento disponibilizado pela literatura especializada, o qual fundamenta a lógica do presente estudo. Prioriza-se, dessa forma, o entendimento sobre o que são talentos; a que se refere a gestão de talentos e, por fim, as práticas em gestão de talentos.

\subsection{O QUE SÃO TALENTOS?}

Não existe um consenso para definir talentos. Como destaca Galhardo-Galhardo (2011), o termo não é delimitado, é subentendido. Isso também é evidenciado na pesquisa sobre gestão de talentos realizada por Illes et al. (2010), quando identificaram diferentes formas de entendimento de talento em empresas de diferentes segmentos: como empregados-chaves de desempenho diferenciado; como aqueles com alto valor estratégico, mas escassos no mercado de trabalho; como pessoas com as competências centrais do negócio, que ocupam posições estratégicas; e como todos os empregados que preenchem os requisitos do trabalho. Parte dos conceitos de talento trazem características presentes no indivíduo, tais como desempenho, entrega de resultados, potencial, capacidade de transformar, de assumir riscos e de aprender, vontade de crescer, comprometimento e o sentimento de pertencimento.

A Gestão de Talentos ainda não tem um significado claro. A multiplicidade de conceitos revela a necessidade de estudos que ofereçam avanços significativos no entendimento do assunto. Em que realmente acreditam as empresas que hoje utilizam a expressão Gestão de Talentos em seus discursos e práticas de gestão? (FERRAZZA; BURTET; SCHEFFER, 2015).

$\mathrm{Na}$ literatura nacional e internacional, o uso do termo talento é frequentemente associado à figura de pessoas extraordinárias (SARSUR et al., 2003). Mas, a nomenclatura "estrela" parece ser a mais utilizada e difundida no universo corporativo quando se trata do assunto (BEECHLER; WOODWARD, 2009).

Para esses autores, talentos são "os melhores e mais brilhantes", remetendo à noção de ser diferente, sendo uma característica de alguns indivíduos. Na mesma linha de pensamento, Lima et al. (2011, p. 109) expressam que "um talento é sempre um tipo especial de pessoa. E nem sempre toda pessoa é um talento."

Baba (2016, p. 77), por sua vez, considera talento como um dom, que "quando desenvolvido, torna-se um talento, ou seja, algo que a pessoa faz muito bem e com facilidade. Normalmente, o talento da pessoa é algo que ela gosta muito de fazer, é uma paixão".

Chowdhury (2003) destaca que os profissionais talentosos necessitam de investimentos para desenvolver suas ideias, diferentemente de outros profissionais que por vezes estão presos a regras, hierarquias e resistentes à mudança e não possuem a coragem de inovar como os talentos.

Já Dresselhaus (2010), argumenta que o talento inclui um conjunto de atributos pessoais e experiência profissional, com capacidade de mudar e se adaptar a novos ambientes, agregando entusiasmo e energia para atuar no ambiente de negócios. Assim, é possível identificar pontos comuns entre as diversas abordagens: alto desempenho (potencial), entrega de resultado, capacidade para crescer, vigor, abertura para aprender e competência. O conceito de talentos nas organizações é ajustado conforme o cenário 
organizacional, considerando os elementos que envolvem a sua cultura e as características do ambiente, assim como as competências necessárias ao negócio (GALLARDO-GALLARDO, 2011).

Mais recentemente, Mankins e Garton (2017) salientam que tempo, talento e energia das pessoas, suas ideias e a implementação delas, são recursos escassos nas organizações. Para os autores, talento é aquele indivíduo consideravelmente mais capacitado ou inspirador do que outros, atuando em funções críticas, em setores de maior impacto sobre o desempenho da empresa. Logo, é a pessoa que faz a diferença em postos cruciais da organização.

A partir dos conceitos apresentados, optou-se por conceituar talentos como aqueles profissionais que se sobressaem acentuadamente no seu campo de atuação, apresentam um conjunto de competências que os diferenciam dos demais, são flexíveis à mudança, abertos ao desenvolvimento próprio, focados em oferecer um resultado mais que satisfatório para si e para a organização, disponibilizando seu conhecimento de forma a atingir resultados além dos esperados e evidenciados na prática, alinhados à cultura organizacional.

Sendo assim, pessoas talentosas são competentes, têm atributos atitudinais diferenciados, assim como conhecimentos e habilidades em sua área de atuação, apresentam um desempenho acima da média e são considerados profissionais de alta performance. Este potencial, junto à entrega de resultados, é considerado um diferencial competitivo da organização.

\subsection{O QUEÉ GESTÃO DE TALENTOS?}

O significado de Gestão de Talentos (GT) por vezes se equivale a outras expressões como 'estratégia de talentos', 'gestão de sucessão' e 'planejamento de recursos humanos', mas estas revelam certa confusão entre definições, termos e suposições elaboradas por autores que tratam do tema. A expresão GT pode ser entendida como um campo da gestão de pessoas que está alinhado às diretrizes estratégicas da organização para atrair, desenvolver e reter indivíduos com altos níveis de capital humano, com competência, personalidade e motivação (TARIQUE; SCHULER, 2010).
A abordagem do tema geralmente perpassa por três grandes áreas: atração, desenvolvimento e retenção. Capelli (2008) salienta que a essência da GT está na maneira simples de antecipar-se às necessidades organizacionais de capital humano e, então, traçar um plano para encontrá-los. Outra relação de GT está na análise interna do potencial humano da organização, com a finalidade de avaliar e conhecer sua capacidade produtiva, e assim atrair e manter talentos fidedignos. É o que alegam Lewis e Heckman (2006), ao enfatizarem os talent pools ou o banco de talentos. Conforme esses autores, o foco é interno à organização, iniciando pela obtenção de uma sólida compreensão da força de trabalho interna para realização de planejamento sucessório, de gestão e de recursos humanos, o que passa pela avaliação. Mas para lles et al. (2010), a GT compreende desenvolvimento e colaboração. A primeira pressupõe desde capacitação de lideranças a planejamento sucessório, e a segunda enfatiza a abordagem coletiva para recrutar, reter e desenvolver talentos com foco em benefícios futuros.

Conforme Dutra e Veloso (2013), existem quatro correntes de pensamento em torno do conceito de gestão de talentos. O autor se ampara nas contribuições de Lewis e Heckman (2006) e de Collings e Mellahi (2009) para explicar essas correntes. A primeira consiste na gestão de talentos enquanto outra denominação para a área de gestão de pessoas, tendo como foco as práticas específicas de gestão de recursos humanos como o recrutamento e desenvolvimento de pessoas, por exemplo.

$\mathrm{Na}$ segunda corrente, a gestão de talentos equivale ao planejamento de pessoal com o objetivo de projetar necessidades futuras, geralmente as de liderança. Para tanto, é necessário realizar o mapeamento dos profissionais, considerando as necessidades de pessoal atuais e futuras. A gestão da sucessão, por exemplo, se enquadra nessa corrente, pois reforça práticas e processos já conhecidos e aqueles de previsão de demandas de pessoal (LEWIS; HECKMAN, 2006).

A terceira corrente defende que todas as funções dentro da organização devem ser preenchidas com profissionais de alto desempenho e potencial, considerando que a gestão de talentos compreende a gestão desses profissionais. Contudo, não considera 
a existência daqueles empregados de médio e baixo desempenho. Por isso, não parece adequada a partir da perspectiva de que todas as posições da organização devem ser ocupadas por empregados de alto desempenho.

A última concepção se concentra na identificação de posições-chave, que têm o potencial de impactar a vantagem competitiva da empresa. Nesta corrente, a gestão de talentos envolve atividades e processos que buscam identificar posições estratégicas de gestão de talentosalém da identificação sistemática de posições estratégicas que contribuam para a vantagem competitiva da empresa. Então, esta corrente tem foco inicialmente na organização, seus processos e posições estratégicas e, após, na colocação de profissionais de alto potencial e desempenho nessas posições. A partir disso, cria-se um modelo diferenciado da área de gestão de pessoas, mais estratégico (COLLINGS; MELLAHI, 2009; HILLS, 2009).

\subsection{PRÁTICAS EM GESTÃO DE TALENTOS}

A área de recursos humanos tem um papel determinante na estratégia organizacional e nas práticas de gestão de talentos, que devem ser capazes de suprir os objetivos atuais e futuros da organização. É fundamental identificar as habilidades e competências de cada indivíduo que compõe a organização, para que esse possa atender a missão e os objetivos institucionais como também as atribuições do cargo. Além disso, potencializar os aspectos positivos e melhorar os pontos fracos faz parte das práticas de gestão de talentos e, conforme afirma Almeida (2009, p.4), "somente dessa forma podemos falar em gestão estratégica de recursos humanos".

As práticas de gestão de talentos estão diretamente relacionadas com a gestão estratégica, o que compreende a Gestão Estratégica de Talentos (GET) (COLLINS; MELLAHI, 2009). A GET é composta de atividades e processos numa perspectiva prática, os quais contribuem para a vantagem competitiva organizacional sustentável, construindo um novo setor de recursos humanos $(\mathrm{RH})$ mais estratégico, que facilite e promova 0 preenchimento das posiçõeschaves, desenvolva os profissionais em busca de um alto desempenho e recompense e gerencie os seus talentos de forma indiferenciada. Na busca por profissionais mais qualificados, as empresas investem em processos de recrutamento mais estruturados e, segundo Salve (2007, p. 39), "o primeiro passo da gestão de talentos é a atração, ou seja, o recrutamento daqueles funcionários que fazem a diferença e que são definidos como talentos". Mas, além de ações que impulsionem a atração de talentos, é fundamental propor práticas que contemplem múltiplos fatores. A retenção é uma delas, tendo em vista que a saída eventual de profissionais considerados talentosos se torna um custo indesejado, e seu objetivo é manter os melhores profissionais na empresa. Fatores relacionados à motivação e engajamento são essenciais e produzem um sentimento de justiça e reconhecimento: as práticas de motivação e engajamento são baseadas em tratar os colaboradores de forma justa, reconhecer seu valor, ouvir suas sugestões e prover oportunidades justas de crescimento profissional e pessoal (ARMSTRONG, 2006).

Nota-se, então, uma crescente preocupação relacionada aos aspectos de ambiente organizacional, carreira, remuneração, benefícios e desenvolvimento ao se tratar das práticas de GT. Segundo Branham (2002), as pessoas estão buscando maior equilíbrio entre a vida profissional e a pessoal. A criação de um plano estrutural de descrição de cargos e carreiras, que possuam requisitos e avaliação de faixas salariais que possibilitem ao colaborador projetar os níveis que pode chegar, bem como toda a trajetória durante o desenvolvimento de sua carreira na empresa, são exemplos de algumas práticas utilizadas que valorizam e retêm profissionais talentosos. O recrutamento interno é outra prática utilizada para valorização e reconhecimento dos recursos internos nas organizações, criando espaços para o crescimento e a realização pessoal. Outra política é a criação de promoções ou avanço por desempenho, onde o colaborador passa a ser avaliado e reconhecido por suas metas e resultados atingidos (SOUSA; BARRETO, 2015).

Parece ser indispensável que a organização possua uma política corporativa de desenvolvimento, com o objetivo de capacitar, qualificar, aprimorar e desenvolver as pessoas (SILVA, 2005). Cabe ressaltar que incentivar o desenvolvimento das pessoas é uma forma de renovar os conhecimentos, habilidades e atitudes, e assim agregar valor à corporação. $O$ quadro 1 a seguir sintetiza as 
Quadro 1: Práticas de Gestão de Talentos

\begin{tabular}{|l|c|}
\hline \multicolumn{1}{|c|}{ Prática } & \multicolumn{1}{c|}{ Autor(es) } \\
\hline Recrutamento mais estruturado & Salve (2007) \\
\hline Feedback como uma ação propondo a correção e a melhoria. & Silva (2005) \\
\hline Política corporativa de desenvolvimento & Neto; Mazza (2015) \\
\hline Carreira, remuneração e benefícios. & Sousa; Barreto (2015) \\
\hline $\begin{array}{l}\text { Criação de um plano de estrutura de cargos e carreiras com faixas salariais } \\
\text { promovendo o desenvolvimento }\end{array}$ & França (2009) \\
\hline $\begin{array}{l}\text { Recrutamento interno como forma de valorização do potencial interno da } \\
\text { organização }\end{array}$ & Sousa; Barreto (2015) \\
\hline $\begin{array}{l}\text { Promoções e avanços por avaliação de desempenho } \\
\text { Práticas relacionadas à qualidade de vida que promovam equilíbrio entre a } \\
\text { vida pessoal e profissional }\end{array}$ & $\begin{array}{c}\text { Branham (2002); Holtom et al. } \\
\text { (2008) }\end{array}$ \\
\hline
\end{tabular}

Fonte: Elaborado pelos autores

\section{MÉTODO DE PESQUISA}

A presente pesquisa caracteriza-se como qualitativa, de cunho descritivo, pois visa descrever as características de determinada população ou fenômeno, estabelecendo relações entre variáveis (GIL, 2008).

Do ponto de vista dos procedimentos técnicos utilizados, a pesquisa classifica-se, em um primeiro momento, como bibliográfica (GIL, 2008) por ter sido desenvolvida com base em material já elaborado, visto que procurou levantar artigos que versavam sobre o tema gestão de talentos. Num segundo momento podemos classifica-la como levantamento.

A metodologia é compreendida de pesquisa na base de dados SPELL $®$ Scientific Periodicals Eletronic Library, um repositório de artigos científicos que proporciona acesso gratuito à informação técnico-científica via web. A busca iniciou pela palavra-chave "talentos", tendo como resultado 25 artigos que tinham em seu resumo esta palavra. Utilizaram-se também os seguintes filtros: período, tipo de documento e idioma, considerando os últimos cinco anos. Do total, 13 foram descartados embora constasse a palavra-chave "talentos". Estes não problematizam o tema no âmbito da gestão de pessoas. Assim, após esse primeiro filtro analisou-se 12 artigos, os quais foram categorizados sob 3 aspectos: talentos, gestão de talentos e práticas de gestão de talentos.

A partir dessa pesquisa teórica, este estudo analisou o campo empírico, uma vez que investigou empresas que atuam no nicho de recrutamento e seleção. Então, foi verificado o que as empresas que recrutam pessoas entendem por talentos, e se essas empresas desenvolvem alguma prática de GT na organização. Essa etapa se deu por meio dos clientes de uma organização que atua com recrutamento, seleção, agenciamento de estagiários, treinamentos e capacitações, consultoria e assessoria em gestão de pessoas para empresas na região sul do Brasil. A empresa está consolidada no mercado e tem uma carteira de 163 clientes, pequenas e médias empresas de diversos segmentos que atuam na zona sul do RS. Foram realizadas duas perguntas básicas aos empresários: (i) O que são talentos? (ii) Há alguma prática da gestão de talentos na sua organização? As perguntas foram enviadas via e-mail. Obteve-se respostas de 15 clientes que possuem contratos ativos com a empresa, seja na área de consultoria ou de assessoria em gestão de pessoas. Esses clientes atuam nos seguintes segmentos: concessionária automotiva, comércios que atuam no varejo, instituição de ensino superior, cooperativa de crédito, escola de ensino médio, consultoria de agronegócios e incorporadora imobiliária.

\section{ANÁLISE DOS RESULTADOS}

O presente capítulo pretende descrever e analisar os dados coletados, tendo como base a fundamentação teórica e os procedimentos metodológicos estabelecidos anteriormente. A partir dos objetivos propostos, pretende-se descrever qual o conceito de talento utilizado pelas empresas pesquisadas, como a gestão desses acontece e quais são as práticas 
organizacionais implementadas na gestão de talentos.

Ao perguntar-se "O que são talentos?" os respondentes, empresários aqui descritos como $\mathrm{C} 1$ a $\mathrm{C} 15$, atestam que são profissionais que têm foco no resultado (C7 e C9); se entregam à organização além do desejado (C8); possuem alto desempenho (C4); buscam treinamento e desenvolvimento (C6); solucionam problemas (C4 e C7); suas competências profissionais são alinhadas às estratégias organizacionais ( $\begin{array}{lll}C & \text { e } & \text { C3); e }\end{array}$ buscam, assimilam e aplicam o conhecimento (C11). C7 e C9 salientam como característica fundamental o foco no resultado, destacando que "são àqueles que entregam além do desejado", enfatizando a contribuição de Dutra (2004, p. 56), quando destaca que "talentos se doam, entregam resultados", associando às realizações da pessoa, em determinado contexto, e associando àquilo que ela provê, produz ou entrega no trabalho. $\mathrm{O}$ alto desempenho é citado por C4 como um importante predicado que se realça pelo resultado acima da média. Freitag et al (2014), constataram atributos relativos à performance e potencial nas definições referente ao tema, corroborando com a ideia de realização e entrega de resultados advindo de uma performance diferenciada e de alto potencial.

Observa-se que para C6 e C11 aprendizagem e conhecimentos são essenciais na conceituação de talentos. Mas a diferença é que, no caso da aprendizagem, a resposta se relaciona com treinamento e desenvolvimento enquanto dimensões que contribuem para seu desenvolvimento profissional, mas não estão necessariamente alinhadas às estratégias da empresa. As respostas ratificam as contribuições de Ulrich (1999) quando o autor relata que é preciso apresentar habilidades que levem o indivíduo a aprender e crescer, remetendo à noção de aprendizagem e conhecimento, caracterizando um empregado que, embora tenha alto potencial e desempenho, ainda quer crescer dentro da organização e está disposto a fazer novas contribuições, enfatizando seu compromisso e contribuição (educação corporativa).

C4 e C7 enfatizam talentos enquanto solucionadores de problemas e remetem às observações de Souza e Barreto (2015), que destacam que os chamados trabalhadores do conhecimento, que são talentosos e inovadores, possuem visão sistêmica e por isso têm mais facilidade de propor a solução de problemas e conflitos de forma mais imediata. Competências também são mencionadas nas respostas de $\mathrm{C} 1$ e $\mathrm{C} 3$ e aparecem de formas distintas nas respostas. Uma (C1) está relacionada ao êxito como uma combinação do conjunto de conhecimentos, habilidades e atitudes, corroborando com Berger e Berger (2004) quando mencionam que talento é a combinação do conjunto de habilidades, competências e experiências necessárias para o desempenho no trabalho A outra (C3) alinha competências às estratégias organizacionais, ratificando o que Carrara et al (2014) identificaram nos talentos enquanto pessoas com as competências centrais do negócio, com alto valor estratégico para a organização. Outro conceito relatado refere-se a talento como aquele que "busca, assimila e aplica o conhecimento". Observa-se que a resposta infere a educação corporativa, pois alinha os conhecimentos profissionais adquiridos aos objetivos da organização e às estratégias do negócio.

A segunda questão apresentada aos empresários questiona se há alguma prática da gestão de talentos em suas organizações. Os resultados revelam que há: recrutamento interno (C5 e C14); ações de capacitação, treinamento, feedback, avaliação de desempenho, políticas de remuneração e benefícios (C2, C9 e C10); programas de desenvolvimento (C4 e C15), tendo em vista promoção e carreira, e programas de jovens talentos.

Quanto ao recrutamento interno, C12 e C13 informam que privilegiam a captação interna com o objetivo de "valorizar e reter pessoas, possibilitando o crescimento profissional." Todavia, se não há o perfil desejado, recorrem ao mercado. Em relação à valorização dos recursos internos, França (2009, p.33) diz que "o recrutamento interno se fundamenta na valorização dos recursos humanos já existentes na empresa, criando espaços para o crescimento e valorização pessoal".

Outros associam as práticas de GT à capacitação, treinamento, feedback e avaliação de desempenho, remuneração e benefícios. C5 destaca o "treinamento e desenvolvimento contínuo dos colaboradores, feedback (corretivo e de melhoria), avaliação de desempenho (360)." Os colaboradores com melhores resultados na avaliação de desempenho são reconhecidos e valorizados por meio de salário diferenciado e pacote de 
benefícios. A prática do feedback está sendo introduzida como uma política estratégica na gestão de talentos, já que viabiliza a oportunidade de melhoria do comportamento através de uma ação corretiva, conforme afirma Lombardo e Eichinger (2000), e altera seus comportamentos como resultado de sua aprendizagem, assim auxiliando o desenvolvimento pessoal e profissional. C15 também alinha as práticas aos investimentos em desenvolvimento de pessoal: "identificamos na nossa equipe os colaboradores que são talentosos e investimos em capacitação e treinamento". Já C2 alega que "após identificar o colaborador talentoso, investimos em capacitação e treinamento para aumentar o potencial." Observa-se, que a capacitação proporciona a melhora dos pontos fracos e maximiza os pontos fortes e que, para Almeida (2009, p.4), "só dessa forma podemos falar em gestão estratégica de recursos humanos." C5 elucida a prática de GT por meio da valorização, "com um programa de remuneração atrativo e que possibilite também promoções e avanços na carreira através de avaliações periódicas do desempenho".

Outros clientes associam as práticas à programas de desenvolvimento em suas organizações, com vistas à promoção na carreira. Para C4, "uma das práticas de gestão dos nossos talentos é a oferta de um programa de desenvolvimento estruturado, com a finalidade de desenvolver habilidades nos colaboradores e promover atividades práticas ao cargo almejado. Esse programa já está na sua $2^{2}$ edição, em 2016. Na primeira edição, em 2014, 90\% dos participantes foram promovidos para os cargos que almejavam e se desenvolveram no programa". C8 responde descrevendo o programa Backup, que visa identificar talentos dentro das unidades. Ele informa que levam esses profissionais para capacitações e ações de desenvolvimento. Dentro deste programa, qualquer colaborador, independente do cargo, pode se destacar e chegar à direção de uma unidade. Em parte, o "Backup" se insere no que Silva (2005) salienta como política corporativa de desenvolvimento. Com essa iniciativa empresarial, os colaboradores desempenham melhor suas atividades, conseguem aperfeiçoamento de suas competências, buscam promoções e contribuem eficientemente para o alcance das metas e desafios para empresa. Por fim, C15 menciona o Programa de jovens talentos que os colaboradores participam. É um programa de formação mensal com treinamentos comportamentais e técnicos, de modo a desenvolver capacidades de planejamento e de agregar conhecimentos. A partir do debate, elaborou-se a seguinte imagem que sintetiza a relação entre a teoria pesquisada e prática descrita em se tratando de talentos.

Figura 1: Radial de Talentos

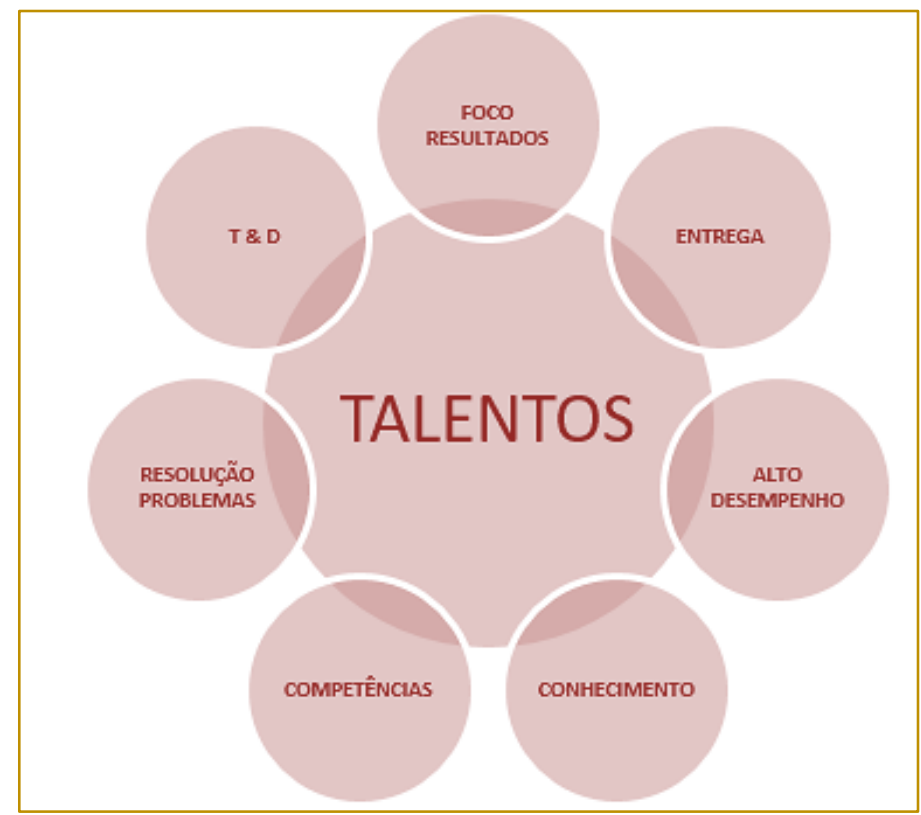

Fonte: Dados da pesquisa 


\section{CONCLUSÕES}

$\mathrm{Na}$ presente pesquisa foram levantados dados na base SPELL $®$ Scientific Periodicals Eletronic Library, um repositório de artigos científicos que proporciona acesso gratuito à informação técnico-científica via web. Após uma triagem inicial, foram selecionados 12 artigos, os quais foram categorizados sob 3 aspectos: talentos, gestão de talentos e práticas de gestão de talentos. Após, foi realizada uma pesquisa empírica com empresas da região sul do Brasil.

Foi identificado que as empresas estudadas entendem o conceito de talentos como "aqueles profissionais que se sobressaem acentuadamente no seu campo de atuação, apresentam um conjunto de competências que os diferenciam dos demais, são flexíveis à mudança, abertos ao desenvolvimento próprio, focados em oferecer um resultado mais que satisfatório para si e para a organização, disponibilizando seu conhecimento de forma a atingir resultados além do esperado e evidenciado na prática, alinhados à cultura organizacional".

As práticas são relatadas como ações direcionadas ao desenvolvimento, capacitação e treinamento. São programas direcionados a jovens talentos, educação corporativa, políticas de remuneração e benefícios, ações que contemplem a promoção e a carreira, recrutamento interno, avaliação de desempenho, feedback, promovendo ações corretivas e de melhorias, e programas de valorização e qualidade de vida. É evidente que talentos são estratégicos para qualquer organização, não apenas para

\section{REFERÊNCIAS}

[1] Almeida, Walnice. Captação e Seleção de Talentos com Foco em Competências. $2^{\underline{a}}$ ed. São Paulo: Atlas, 2009

[2] Armstrong, M. Armstrong's handbook of human resource management practice. 14 ed. New York: Kogan Page. 2014.

[3] Baba, Sri Prem. Propósito: a coragem de ser quem somos. Rio de Janeiro: Sextante, 2016.

[4] Barreto, Leilianne Michelle Trindade da Silva; Silva, Maira Patricia da; Fischer, André Luiz; Dutra, Joel Souza; Veloso, Elza Fátima Rosa; Amorim, Wilson Aparecido Costa de. Gestão de Pessoas Projetando Desafios e Tendências para 2015. In: Encontro da Divisão de Estudos Organizacionais da ANPAD, 6, 2010, Florianópolis Anais, Florianópolis: EnEO. Disponível em: a sobrevivência dessas no mercado e num mundo cada vez mais competitivo e corporativo, mas, sobretudo, para o desenvolvimento do potencial humano dos profissionais atuais. Estar em harmonia entre os objetivos pessoais e organizacionais parece ser o grande desafio atual, rompendo com retenção de talentos apenas por questões pecuniárias, dando enfoque para outras condicionantes como o sentir-se bem, estar bem, sintonizando sucesso profissional e organizacional.

Diante disso, corrobora-se com Ulrich (1999, p.29), quando o autor destaca que "as empresas bem-sucedidas serão aquelas mais experientes em atrair, desenvolver e reter indivíduos com habilidades, perspectivas e experiências suficientes para conduzir um negócio global". O desafio é desenvolver a sinergia que vai além da soma dos talentos individuais, promovendo uma organização mais harmônica e competitiva. E, ao que tudo indica, o maior legado que uma organização pode ter hoje em termos de vantagem competitiva é o valor humano de seus talentos.

Considerando-se as conclusões aqui relatadas, sugere-se a realização de novos estudos que permitam a ampliação dos conhecimentos concernentes ao tema em foco, pois percebe-se uma carência de estudos empíricos que ampliem e discutam sobre a Gestão de Talentos no Brasil - a maioria utiliza bibliografia internacional. Recomenda-se, assim, o desenvolvimento de estudos utilizando dados longitudinais e estudos de caso para maior compreensão e desenvolvimento desse tema.

<http://www.anpad.org.br/admin/pdf/eneo463.pdf> Acesso em: 05 mai. 2018.

[5] Beechler, Schon; Woodward, Ian C. The Global Talent War, 2009.

[6] Berger, L. A.; Berger, D. R. The Talent Management Handbook: Creating Organizational Excellence by Identifying, Developing, and Promoting Your Best People. Third Edition. New York: McGraw-Hill, 2017.

[7] Branham, L. Motivando as pessoas que fazem a diferença: 24 maneiras de manter os talentos de sua empresa. Rio de Janeiro, Campus, 2002.

[8] Capelli, P. Talent Management for the Twenty First Century, Harvard Business Review, v. March, p.74-81, 2008. 
[9] Carrara, T. M. P. et al. Fatores de retenção, permanência e desligamento de talentos e de performers. RACE: Revista de Administração, Contabilidade e Economia, v. 13, n. 3, p. 11191148, 2014.

[10] Chowdhury, Subir. A era do talento: obtendo alto retorno sobre o talento. São Paulo: Pearson Education do Brasil, 2003.

[11] Collings, D. G.; Mellahi, K. Strategic talent management: A review and research. Human Resource Management Review, v. 19, n. 4 , p. 304-313, 2009.

[12] Dresselhaus, L. Global talent management and the role of social networks. School of Management and Governance, University of Twente. Enschede, Dec. 2010. Disponível em: $<$ http://essay.utwente.nl/60381/1/MSc_Lena_Dresse lhaus.pdf>. Acesso em: 28 mai. 2018.

[13] Dutra, Joel Souza. Competências: Conceitos e instrumentos para a Gestão de Pessoas na empresa moderna. São Paulo: Atlas, 2004.

[14] Dutra, J. S.; Veloso, E. F. R. (Org). Desafios da gestão de carreira. São Paulo: Atlas, 2013.

[15] Ferrazza, Dayane S.; Burtet, Cecília G.; Scheffer, Angela B. B. REAd - Revista Eletrônica de Administração, Porto Alegre, RS, v. 21, n.1, Jan./Apr. 2015. Disponível em: <http://www.scielo.br/scielo.php?script=sci_arttext \&pid=S1413-23112015000100222 $>$. Acesso em: 05 mai. 2018.

[16] França, A. C. L. Práticas de Recursos Humanos - $\mathrm{PRH}$ : conceitos, ferramentas e procedimentos. São Paulo: Atlas, 2007.

[17] Freitag, B. B. et al. A gestão de talentos no campo da Gestão de Pessoas: tema emergente? Revista de Administração da UFSM, v. 7, n. 4, p. 629-643, 2014.

[18] Gallardo-Gallardo, E. What do we actually mean by talent in business? Does it really matter? Documents de Treball de la Facultat d'Economia i Empresa. Col.lecció d'Economia, E11/258, 2011. Disponível em: <http://diposit.ub.edu/dspace/handle/2445/34400>. Acesso em: 13 jun. 2018.

[19] Gil, Antonio Carlos. Como elaborar projetos de pesquisa. 6. ed. São Paulo: Atlas, 2017.

[20] Hills, A. Succession planning: or smart talent management? Industrial and Commercial Training, v.41, n.1, p.3-8, 2009.

[21] Holtom, Brooks C. et al. Turnover and Retention Research: A Glance at the Past, a Closer Review of the Present, and a Venture into the Future. The Academy of Management Annals v. 2, n. 1, p. 231-274, 2008.

[22] Iles, P. et al. Talent management and HRM in multinational company in Beijing: definitions, differences and drivers. Journal of World Business, v. 45, n. 2, p. 179-189, 2010.

[23] Landim, R. Mercado. Folha de São Paulo, SP, 31 de ago. 2015. Disponível em: <http://www1.folha.uol.com.br/mercado/2015/08/16 75715-setor-de-servicos-encolhe-pela-1-vezdesde-1990-estimam-economistas.shtml>. Acesso em: 18 de maio 2018.

[24] Lewis, R. E.; Heckman, R. J. Talent Management: A critical review. Human Resource Management Review, v. 16, p. 139-154, 2006.

[25] Lima, M. C. F. et al. Retenção de talentos na profissão de secretariado. Revista de Gestão e Secretariado, v. 2, n. 1, p. 101-130, 2011.

[26] Lombardo, M. M.; Eichinger, R. W. High potentials as high learners. Human Resource Management, Vol. 39, No. 4, p. 321-329, 2000.

[27] Mankins, M.; Garton, E. Tempo, talento, energia: supere as amarras organizacionais e alcance todo o potencial produtivo dentro da sua equipe. São Paulo: Novo Século Editora, 2017.

[28] Neto, R, A.; Mazza, A. C. A. A percepção dos gestores sobre as práticas de retenção de talentos adotadas em uma empresa de logística e distribuição. Revista Administração em Diálogo, v. 17, n. 1, p. 162-180, 2015.

[29] NOVAES, Washington. Os desafios do século XXI. Estud. Av., São Paulo, v. 14, n. 40, p. 107-115, Dezembro de 2000. Disponível em $<$ http://www.scielo.br/scielo.php?script=sci_arttext \&pid=S0103-

$40142000000300011 \&$ Ing $=p t \& n r m=i s o>$. Acesso em: 23 de jan. 2018.

[30] Salve, Cláudio Monteiro Goulart. Gestão de Talentos em pequenas empresas de Software em Belo Horizonte, 2007. Disponível em $<$ http://www.dominiopublico.gov.br/pesquisa/Detal heObraForm.do?select_action=\&co_obra $=126945>$ . Acesso em: 13 jan. 2018

[31] Sarsur, A. M. et al. Onde estão os talentos? Onde está a Gestão de Recursos Humanos? In: Encontro da Associação Nacional de Pós-Graduação e Pesquisa em Administração. Anais. São Paulo: Anpad, 2003.

[32] Shrm (Society for Human Resource Management). Workplace Forecast: the top workplace trends according to HR professionals, Fev. 2011

[33] Sousa, W. B.; Barreto, M. C. A Importância das Estratégias para a Retenção de Talentos. RAUnP - Revista Eletrônica do Mestrado Profissional em Administração da Universidade Potiguar, v. 7, n. 2, p. 9-14, 2015.

[34] STEWART, T. A. Capital Intelectual. Rio de Janeiro: Campus, 1998.

[35] Tarique, I.; Schuler, R. S. Global talent management: Literature review, integrative framework, and suggestions for further research. 
Journal of World Business, v. 45, n. 2, p. 122-133, 2010.
[36] Ulrich, D. Os campeões de recursos humanos: inovando para obter melhores resultados. São Paulo: Futura, 1999. 


\section{Capítulo 9}

\section{PERFIL DOS EMPREENDEDORES NEGROS EGRESSOS DO CURSO DE ADMINISTRAÇÃO DE UMA IES EM MATO GROSSO (1984-2016)}

\section{Caryna Paes Barreto}

Ivana Aparecida Ferrer Silva

Elba de Oliveira Pantaleão

Simone Hirata

Resumo: Objetiva-se com esta pesquisa identificar o perfil dos egressos negros que se consideram empreendedores e aqueles que empreendem do curso de Administração da Instituição de Ensino Superior localizada em Mato Grosso, no período de 1984 a 2016. A metodologia do presente artigo é um estudo exploratório descritivo, operacionalizado com suporte em uma survey a partir da aplicação de formulário googleforms com perguntas abertas e fechadas, cujo convite a participação foi encaminhado através de mídias sociais e correio eletrônico. Desse modo, o universo corresponde a base de dados fornecida pela Secretaria de Tecnologia da Informação (STI) da instituição nos citados anos. A taxa de resposta foi de $5 \%$, a amostra foi de 148 respondentes dado o intervalo de confiança de $92 \%$ e margem de erro de 0,7. Buscamos realizar um breve histórico do curso, identificar o perfil do egresso empreendedor negro e apontar os resultados e os respectivos impactos do curso de administração para o Estado de Mato Grosso. O perfil do empreendedor negro egresso do curso de administração da instituição, é em sua maioria homens, que consideram que o curso despertou em si o empreendedorismo e buscam por inovação e a maioria das empresas são microempresas e de médio porte.

Palavras-chave: Empreendedorismo; Relações Raciais; Egressos IES. 


\section{INTRODUÇÃO}

Na pesquisa "Os donos de negócio no Brasil: análise por raça/cor (2003-2013)", segundo os dados apontados pelo Serviço Brasileiro de Apoio às Micro e Pequenas Empresas (SEBRAE) indicam que o número de empreendedores negros superou $\mathrm{O}$ de empreendedores brancos, os fatores considerados são relativos ao aumento do número de empreendedores ( de 21,4 milhões para 23,5 milhões de pessoas) e o aumento de pessoas que passaram a declarar pretas e pardas.

Além desses fatores, a instituição de políticas afirmativas pelo governo federal através das Leis de Igualdade Racial (lei no12.288/2010) e de Cotas para o ensino superior (lei no12.711/2012), permitiu que estudantes de baixa renda oriundos de escolas públicas pudessem frequentar o ensino superior.

A Instituição de Ensino Superior (IES) com a aprovação de Resolução do Conselho Diretor 97/2011, passou a reservar $20 \%$ das vagas de todos os cursos por turno a alunos negros egressos de escolas públicas, com a intenção de promover o enfrentamento da desigualdade racial $e \quad o$ acesso $e$ permanência desses alunos no ensino superior, situação refletida pelo Instituto Brasileiro de Geografia e Estatística (IBGE) por meio da pesquisa Síntese de indicadores sociais: uma análise das condições de vida da população brasileira (2015), que demonstrou que no período de 10 anos, o total de alunos negros ou pardos que frequentavam o ensino superior, passou de 16,7\% em 2004 para 45,5\% em 2014.

Em vista desses fatos, a presente pesquisa tem como foco responder as seguintes questões: no período de 1984 a 2016 quantos egressos se declaram negros e empreendedores? Quantos empreenderam? É possível verificar uma maior inclusão de negros no curso de administração da IES na capital depois da implantação das cotas?

Dessa forma, o presente artigo tem como objetivo geral identificar o perfil do egresso negro empreendedor do curso de administração da IES. Em seus objetivos específicos, busca entender quem são os empreendedores negros, quais as contribuições do curso para a abertura e o gerenciamento da empresa, o impacto da geração de empregos e inovação em Mato Grosso.
A relevância do estudo está no fato de ser a primeira pesquisa sobre os empreendedores egressos negros desenvolvida desde a sua criação do curso de Administração da Instituição de Ensino Superior (IES) na capital em 1974 até os dias atuais.

A fundação do curso de administração ocorreu no ano de 1975, período de formação econômica e social, pois já se falava sobre a segunda divisão do estado em função de disputa política e econômica, entretanto somente dois anos depois essa separação ocorre oficialmente, por meio da lei complementar que cria o estado de Mato Grosso do Sul. Buscava-se naquela época o desenvolvimento e crescimento do estado de Mato Grosso, que recebia migrantes de outras regiões e países, era preciso estruturar a gestão pública, que na ocasião estava abalada.

$\mathrm{Na}$ década de 90, houve a política de interiorização do curso de administração através de convênios com as prefeituras de cidades que não possuíam campus da IES. Com essa alternativa, os municípios de Sorriso, Juína, Água Boa, Primavera do Leste e Canarana puderam ter turmas especiais do curso de Administração.

$\mathrm{Na}$ década de 2000, a adesão do departamento de Administração ao Programa de Apoio a Planos de Reestruturação e Expansão das Universidades Federais (Reuni) $)^{1}$ e expansão da Educação a Distância (EaD), possibilitaram o aumento no número de vagas ofertadas nas modalidades presencial (dobro do número de vagas nos turnos matutino e noturno) e à distância, sendo primeiramente em parceiria com o Banco do Brasil. Com o aumento das vagas dos cursos presenciais e à distância, tiveram início as discussões sobre a implantação de ações afirmativas $^{2}$ na IES com a criação do Programa de Inclusão Indígena "Guerreiros da Caneta" (PROIND), pela Resolução do Conselho de pesquisa e Extensão (CONSEPE) no 87/2007, com início em 2008.

Com a instituição do Estatuto da Igualdade Racial- Lei nำ12.288/2010, "destinada a garantir à população negra a efetivação da igualdade de oportunidades, a defesa dos direitos étnicos individuais, coletivos e difusos e o combate à discriminação e às demais forma de intolerância étnica" (BRASIL, 2010), a IES aprovou em 2011, a Resolução CONSEPE no97, que trata do sistema de reserva de $50 \%$ de vagas para alunos 
oriundos de escola pública, dos quais $20 \%$ apenas para negros também egressos de escolas públicas, com vigência a partir de 2012 por 10 anos.

Desta forma a pesquisa foi realizada através de uma survey aplicada através de formulário googleforms com perguntas fechadas e aberta, cujo convite a participação da enquete foi enviada por correio eletrônico, entre outras mídias sociais como facebook, whatsapp, cujos próprios egressos iam repassando a suas redes de contato. $O$ universo corresponde à base de dados fornecida pela Secretaria de Tecnologia da Informação (STI), unidade responsável pelos registros dos dados dos discentes na IES por meio do Sistema do Eletrônico do Serviço de Informações ao Cidadão (e-SIC) que apresentou o número de egressos de 1984 a 2016 na qual apontou um total de 2.703 concluintes. O plano amostral determinou a estratificação por década de curso para compreender as diferentes fases do egresso e momentos políticos e institucionais do curso. A taxa de resposta foi de $5 \%$, a amostra foi de 148 respondentes dado o intervalo de confiança de $92 \%$ e margem de erro 0,7.

Além da presente introdução 0 artigo se estrutura em cinco seções, sendo esta uma breve revisão de literatura que apresentará o contexto do negro no mercado de trabalho, um breve histórico da ascensão social do negro, empreendedorismo e o negro empreendedor. $\mathrm{Na}$ sequência tem-se a metodologia, as análises dos doaos com discussão dos resultados e finaliza-se o artigo com as considerações finais e as referências bibliográficas.

\section{NEGRO NO MERCADO DE TRABALHO}

De acordo com Davies (2009), é possível em nosso cotidiano identificarmos as perceptíveis diferenças socioeconômicas existentes quando se trata de grupos categorizados pela raça/cor. Quando se fala em mercado de trabalho, a divisão por cor é significante, a concentração de pretos e pardos é evidente nas piores condições de trabalho e remuneração. Estudiosos como Hasenbalg (2005) e Figueiredo (2009) indicam na questão da desigualdade racial, que existe uma diferença enconômica entre brancos e negros que é reflexo da raiz histórica do país. A herança deixada por séculos de escravismo e uma tradição de ocupar empregos de pouco prestígio social estão entre as causas da diferença.

A população negra se beneficiou das políticas sociais adotadas a partir dos anos 2000, para mitigar as injustiças sociais cometidas historicamente contra estes, conforme demonstrado na Pesquisa Nacional por Amostra de Domicílios (PNAD) de 2011, maior abertura para a inclusão da população negra nos postos de trabalho, o mercado de trabalho evoluiu positivamente ao ampliar o número de emprego aos negros.

De acordo com o Instituto de Pesquisas Aplicadas (IPEA) 2014, com relação a situação social da população negra houve um pequeno aumento de renda que é reflexo da redução da desigualdade racial com melhor acesso que os negros passaram a assumir melhores ocupações, em relação ao período anterior da pesquisa. Porém, é indiscutível que as características da ocupação e da remuneração disponibilizadas aos negros não são compatíveis aos dos brancos, pois as condições de inserções ainda são reflexos do racismo e da discriminação. Ainda é possível identificar que os negros recebem remunerações menores, ocupam posições mais precárias e são mais afetados pela desocupação. Segundo o estudo Retrato das Desigualdades de Gênero e Raça - 3aㅡ Edição, realizado pelo IPEA em 2008, os índices de escolaridade, renda e pobreza da população negra registraram melhoras entre 1996 e 2006.

Outro estudo desenvolvido pelo IPEA em 2004 apresenta trajetória da população negra comparada à branca e aponta demandas por políticas públicas, observa-se que há início de um processo de mudança em como as pessoas se veem. As pessoas passam a ter menos vergonha de dizer que são negras, não buscam se branquear para se legitimar socialmente, e essas mudanças estão em um processo linear e aberto, isso indica que esse processo está em curso.

Segundo Beghin e Jaccoud (2002), o IPEA apresenta ainda, na medida em que o debate da identificação racial ganha as páginas dos jornais e a sociedade vê que é um tema real, e que nas telenovelas os negros são apresentados como personagens poderosos e não apenas como inferiores, quando o negro é visto compondo o Supremo Tribunal Federal e ocupando os mais diversos cargos na política, não significa que o Brasil está se tornando uma nação de negros, mas está se assumindo como tal. Por outro lado, segundo 
Nogueira (2013, p.15), pesquisa do Instituto Ethos, perfil social, racial e de gênero das 500 maiores empresas do Brasil e suas ações afirmativas (2010), negras e negros seguem afastados dos espaços de direção e comando das empresas e organizações nacionais. Diante do contexto acima identifica-se certa evolução na sociedade marcada pela maneira de incluir o negro e apresentando-lhe maior igualdade de oportunidades. Sendo assim, levanta-se o seguinte questionamento.

Até que ponto é possível perceber a maior inclusão de negros no curso de administração da IES na capital?

O presente artigo tem como objetivo geral identificar o perfil do egresso negro do curso de administração da IES. Busca também, levantar as transformações na legislação bem como o programa de cotas. Analisar cronologicamente (ou cronologia histórica) o número de egressos negros e como estes estão inseridos na sociedade.

\subsection{BREVE HISTÓRICO DA ASCENSÃO SOCIAL DO NEGRO}

Para falarmos sobre o negro, é preciso que façamos uma retomada histórica sobre as relações raciais no Brasil. A partir dos anos de 1930, é possível nas diversas pesquisas encontrar evidências sobre a ascensão social do negro. Azevedo (1996, p.166) fala sobre o apadrinhamento, onde grande número de pardos e mestiços que adquiriam status elevado tinham a proteção dos brancos através do que ele chama de um mecanismo de proteção aos afilhados de cor. No passado pertencer ao serviço público era sinal de boas relações, onde pretos e pardos mantinham com os brancos tanto através do clientelismo (prática eleitoreira, onde alguns políticos privilegiam determinados "clientes" em troca de voto), quanto pelo apadrinhamento, pontua-nos Bacelar apud Figueiredo (2009, p.205):

"Pertencer ao serviço público, mesmo nas posições subalternas, já denotava alguma forma de prestígio, indicando, no mínimo, as boas relações com os donos do poder político [...] na medida que a inserção se dava pelo clientelismo e apadrinhamento.

Dessa forma, a não ausência do acesso do negro a hierarquia social mais elevada era garantida através dessa relação desigual entre negros e brancos. Os fatores como afeição, fidelidade, merecimento reconhecido aos que eram tidos como superiores, reforçavam uma definição de bens simbólicos atribuídos aos sujeitos dos setores dominados.

A afirmação de que as constantes mudanças no contexto social, vão impactar diretamente na vida dos que na estratificação social dificilmente conseguiriam ter acesso ao ensino superior, feita por Figueiredo (2009) que é exemplificada por meio da expansão do Estado nacional brasileiro e o aparecimento das empresas de economia mista, a admissão no serviço público passou a ser através de concurso, e por consequência as possibilidades de transformação na posição social destes indivíduos passaram a influenciar decisivamente na trajetória profissional destes.

Ainda a referida autora, ao estudar sobre as estratégias de ascensão utilizadas pelos profissionais liberais, observou que os recursos marcantes nas trajetórias dos negros entrevistados por ela, foram a associação do emprego público, do privado e da escolaridade elevada. Identificou em sua pesquisa que os recursos para 0 estabelecimento do empreendimento dos empresários/empregadores negros com baixa escolaridade na maioria das vezes vieram de demissão do emprego formal, onde o FGTS (Fundo de Garantia por Tempo de Serviço) foi utilizado para abertura do próprio negócio. Já os com maior escolaridade, formaram pequenas sociedades e utilizaram de recursos próprios, não necessariamente originários do FGTS, mas de economias pessoais. Figueiredo revela que nenhum deles teve apoio do capital familiar.

Já Teixeira (2003) aponta a importância da família e das redes de relações no percurso ascensional, onde analisou negros em ascensão: trajetória de alunos e professores universitários no Rio de Janeiro.

Sobre as desigualdades no acesso à educação e às diferenças de renda entre os trabalhadores brancos e negros, Figueiredo (2009) afirma que permanece a crença de que quando os negros são membros da classe média, estes são vistos e recebem tratamento como brancos, uma vez que as relações raciais no Brasil são consideradas como personalizadas.

A referida autora, ressalta que o status é tido como reconhecimento e aponta que alguns negros podem ser tratados como branco, pois tem poder aquisitivo comparável à eles. 
Porém, se este reconhecimento ultrapassa alguns espaços, estes indivíduos são vistos como negros e tratados como em geral se trata os negros no Brasil, com certa desconfiança. Normalmente isso ocorre quando os entrevistados estão em condição de consumir bens e serviços considerados caros ou luxuosos. No entanto, sabe-se que a classe média brasileira ainda, se declara branca de acordo com o IBGE no Censo Demográfico 2010, por posição na ocupação no trabalho principal segundo a cor ou raça no Brasil, será o empreendedorismo um espaço de ascensão social para o negro?

\subsection{FENÔMENO DO EMPREENDEDORISMO}

Na década de 1990, o Brasil passou por uma grande mudança em sua economia. O governo passou ter uma abertura econômica a novas empresas, o que impulsionou o surgimento neste período no Brasil de novos empreendedores. Estes tinham aflorado 0 espírito empreendedor. Esta característica está atrelada ao fator determinante causador do insucesso ou sucesso, o planejamento, conforme revela Bispo et. al. (2013).

Entidades criadas como o Serviço Brasileiro de Apoios às Micro e Pequenas Empresas (SEBRAE) e a Sociedade Brasileira para Exportação de Software (SOFTEX) alavancaram $O$ desenvolvimento do empreendedorismo no Brasil, propiciou que os empreendedores tivessem menor dificuldade em obter e abrirem, seus próprios negócios.

"O movimento do empreendedorismo no Brasil começou a tomar forma na década de 1990, quando entidades como SEBRAE (Serviço Brasileiro de Apoio às Micro e Pequena Empresas) e SOFTEX (Sociedade Brasileira para Exportação de Software) foram criadas. Antes disso, praticamente não se falava em empreendedorismo e em criação de pequenas empresas." (Dornelas, 2005, p. 26).

Outras iniciativas/programas também deram suporte ao empreendedorismo no Brasil: Sociedade Brasileira para Exportação de Software (SOFTEX); Empreendedores y Tecnologia (EMPRETEC) - programa das Organizações das Nações Unidas (ONU) para promoção de habilidades empreendedoras e de pequenos negócios; Brasil Empreendedor

- visa a melhor capacitação do profissional empreendedor; Incubadoras de empresas tradicionais, tecnológicas e mistas; Ensino do empreendedorismo nas universidades; Crescimento de Franquias; Opções/Alternativas de financiamento: Fundação de Amparo à Pesquisa do Estado de São Paulo (Fapesp), Financiadora de Estudos e Projetos (Finep); Associação Nacional de Entidades Promotoras de Empreendimentos Inovadores (Anprotec).

A pesquisa Global Entrepreneurship Monitor (GEM) de 2015 e SEBRAE em 2016, aponta que o empreendedorismo vem crescendo no Brasil (39,3\%) e que em cada 10 brasileiros, quatro são empreendedores ou fazem parte de alguma maneira da criação de uma empresa, destes, $42 \%$ são empreendedores por oportunidade.

\subsection{NEGRO EMPREENDEDOR}

É importante pontuarmos que nesta pesquisa consideramos a categoria negro em consonância com o IBGE, onde são considerados os pretos e pardos os que compõem a classificação da raça negra.

Em 2015 foi publicado um estudo inédito desenvolvido pelo SEBRAE, que buscou detectar as principais características dos donos de negócio no Brasil, este estudo identificou que a maior parte dos empreendedores brasileiros são afrodescendentes, esta pesquisa foi realizada com base na Pesquisa Nacional por Amostra de Domicílios (PNAD), que identificou que $49 \%$ dos donos de negócio são pretos ou pardos, $50 \%$ brancos e $1 \%$ são pertencentes a outros grupos populacionais.

Tabela 1. Distribuição dos donos de negócio no Brasil, em 2001 e 2011, por raça/cor (em \%)

\begin{tabular}{|c|c|c|}
\hline Cor/Raça & 2001 & 2011 \\
\hline Brancos & $56 \%$ & $50 \%$ \\
\hline Pretos e Pardos & $43 \%$ & $49 \%$ \\
\hline Outros & $1 \%$ & $1 \%$ \\
\hline TOTAL & $100 \%$ & $100 \%$ \\
\hline
\end{tabular}

Fonte: IBGE (PNAD 2001 a 2011, exceto 2010) adaptado de Barretto (2013, p.32). 
Neste mesmo referido estudo, é possível verificarmos que dentre o número de donos de negócio houve crescimento significativo para os donos de negócio no Brasil, que são negros. Enquanto em 2001 totalizavam
8.621.542 pessoas, em 2011 passaram a ser 11.084.027, enquanto nas outras categorias brancos e outros, o crescimento não foi significativo.

Tabela 2. Números de donos de negócio no brasil, entre 2001 a 2011, por raça/cor

\begin{tabular}{|c|c|c|}
\hline & 2001 & 2011 \\
\hline Brancos & 11.381 .845 & 11.494 .613 \\
\hline Pretos e Pardos & 8.621 .542 & 11.084 .027 \\
\hline Outros & 184.777 & 262.004 \\
\hline
\end{tabular}

Fonte: IBGE (PNAD 2001 a 2011) adaptado de Barretto (2013, p.32).

Sobre o protagonismo do empreendedorismo como fator de inclusão social, Barreto (2013, p.31), destaca:

\section{"O Brasil registra, na última década, a evolução de indicadores socioeconômicos que embasa a construção de uma sociedade mais desenvolvida e mais justa. Nesse processo, o empreendedorismo tem disso protagonista, como ocorre em tantas economias mais desenvolvidas, aqui no país ele também é um fenômeno de inclusão social. Adora temos mais elementos para apostar no potencial de transformação do empreendedorismo. Os negros, grupo historicamente discriminado, aumentaram a participação em atividades empreendedoras e comandam quase a metade do total de empresas no Brasil."}

Consideramos nesta pesquisa a categoria negra em consonância com o IBGE, que considera que os pretos e pardos são os que compõem a classificação da raça negra. Barretto (2013, p.36) sobre o estudo do Sebrae sobre as raças:

"[...] em uma década, diminuiu a distância entre a renda média dos empreendedores brancos e negros. Em 2001, a renda média do primeiro grupo era $141,3 \%$ maior que a do segundo. Em 2011, a diferença passou a ser de 94,3\%. A renda média dos negros empreendedores, nesse ano, era de $R \$ 1039,00$, enquanto a dos brancos era de $\mathrm{R} \$ 2019,00 . "$

Destaca-se a importância da formalização através do programa criado em 2010, o microempreendedor individual. Barretto (2013, p.34), aponta que o programa beneficia famílias em situação de pobreza e de extrema pobreza, e que o empreendedorismo além de ser uma porta de entrada para o mercado, é também uma porta de saída do Bolsa Família. Enfatiza-se a questão do microempreendedor individual, em função da possibilidade de autonomia financeira e empoderamento no sentido do cidadão conquistar a dignidade de gerar seu próprio emprego. Segundo Barretto $45 \%$ dos microempreendedores individuais que recebiam o Bolsa Família, ao superar a renda limite solicitam desligamento do programa. Com destaque para os empreendedores negros, sendo que o comércio é o setor com maior proporção de donos do negócio segundo a PNAD.

"[...] foram os empreendedores negros que apresentaram evolução mais forte em termos de rendimento médio real nos últimos anos. Nesse grupo, o rendimento médio real cresceu $70 \%$, passando de $\mathrm{R} \$ 612$ para R\$ 1039 por mês. Entre os donos de negócio brancos, a expansão foi de 37\%, subindo de $\mathrm{R} \$ 1.477$ para R\$2019 por mês. Na categoria "Outros", houve queda no rendimento médio mensal da ordem de 40\%, passando de $\mathrm{R} \$ 3.296$ para $\mathrm{R} \$$ 1.976." (Barretto, p.37, 2013)

Os impactos causados pelo empreendedorismo são diversos, visto que a pessoa empreendedora é capaz de transformar a realidade de uma região com seu conhecimento e criatividade. Schumpeter (1983) enfatiza que o empreendedor é um agente inovador que com sua atitude proativa consegue gerar valor para a sociedade por meio dos negócios, isto é, disponibilização de novos produtos e serviços, mercados e tipos de organizações que solucione algum problema específico e tenham significado para as pessoas.

E considerando ainda a colocação de Davies (2009) em que os empresários são considerados os verdadeiros dinamizadores da economia, porque vem destes o ânimo pronto para conceber e executar antes que outros, bens, produtos, dando início à 
formação de novos mercados. Davies concorda quanto à conduta empresarial e à condição de líder conforme Schumpeter (2005) e Bourdieau (2005):

\begin{abstract}
"Schumpeter (1982) considera a conduta empresarial como uma força modernizadora das sociedades, justamente porque ela preenche de ações inovadoras frente aos hábitos e os costumes (tradição). A condição de líder dos empresários transpassa as dimensões horizontais e verticais do campo da empresa; ele é um challenger (Bourdieau,2005), que cativa novos mercados, gera novos bens, promove novas formas de circulação de mercadorias, etc. Através de um "comportamento adaptado" (Schumpeter, ibid:60), os verdadeiros agentes do campo econômico (Bourdieau, ibid.) conciliam a sensibilidade ao mundo exterior às suas verdadeiras motivações pessoais.
\end{abstract}

Desta forma, os estudos sobre o empresariado têm comprovado que a racionalidade instrumental não é a única talvez nem a principal - motivação para as práticas empresariais ou capitalistas. As ações econômicas também são dotadas de sentidos distintivos ao lucro, como a persecução de desejos individuais tais como fundar uma dinastia, adquirir ascensão social, ser reconhecido por seu sucesso ou simplesmente pela procura de dificuldades, do mudar por mudar (Schumpeter, ibid:63)." (Davies, 2009, p.04)

Diante da expressividade deste grupo da população, é importante ressaltarmos o crescimento significativo do número destes donos de negócio no Brasil, que são negros, considerando, como dito anteriormente, o empreendedorismo como um protagonista do fenômeno de inclusão social. Inclusão social, por conta de que o empreendedorismo além de ser uma porta de entrada para o mercado é também uma porta de saída para novas realidades como um agente inovador, que consegue gerar valor para a sociedade por meio dos negócios, e/ou fator importante na diminuição da diferença entre a renda média dos empreendedores negros e brancos.

\section{METODOLOGIA}

O presente artigo é um estudo exploratório descritivo operacionalizado através de uma Survey aplicada aos egressos do curso de Administração. Tem o objetivo de identificar o perfil do egresso empreendedor negro, apontar os resultados e os respectivos impactos do curso de administração para o Estado de Mato Grosso. A relevância de tal estudo está no pioneirismo quanto ao levantamento do perfil do empreendedor negro no curso de Administração da IES.

Foi inspirado em estudos realizados pelo Massachussetts Institute Of Technology (MIT) e da Universidade Estadual de Campinas (Unicamp) que buscaram entender melhor o perfil de seu egresso e fortalecê-lo em rede para otimizar e projetar seus empreendimentos e negócios. A pesquisa qualitativa com dados secundários foi executada via pesquisa documental, analisando documentos e resoluções institucionais. Para o levantamento dos dados primários utilizou-se a técnica de questionário. Os dados quantitativos foram coletados via formulário eletrônico entre os meses de março a junho de 2017, o questionário foi elaborado através do googleforms e encaminhado nas redes sociais (facebook, e-mail, WhatsApp).

O universo corresponde a base de dados fornecidas pela instituição de 1984 a 2016 na qual apontou um total de 2.703 concluintes do curso de Administração. Houve dificuldade em adquirir os dados internamente em razão da Lei de Acesso à Informação (Lei no 12.527/2011). Os dados foram solicitados pelo Sistema do Eletrônico do Serviço de Informações ao Cidadão (e-SIC), referente a todos os egressos do Curso de Administração/IES em abril/2017, com resposta em maio/2017 contendo relatório sobre o quantitativo de egressos desde 1984 até 2016. A amostra estratificada por década de curso para compreender as diferentes fases do egresso e momentos políticos e institucionais do curso. 
Tabela 3-Plano amostral estratificado proporcional por período

\begin{tabular}{|c|c|c|c|}
\hline $\begin{array}{c}\text { Estratos por } \\
\text { Período }\end{array}$ & Egresso População & $\begin{array}{c}\text { Porcentagem dos } \\
\text { estratos }\end{array}$ & $\begin{array}{c}\text { Amostragem } \\
\text { estratificada } \\
\text { proporcional }\end{array}$ \\
\hline 1984 a 1990 & 624 & 0,23085 & 14 \\
\hline 1991 a 2000 & 910 & 0,33666 & 24 \\
\hline 2001 a 2010 & 810 & 0,29967 & 71 \\
\hline 2011 a 2016 & 359 & 0,13282 & 38 \\
\hline TOTAL & 2703 & $100 \%$ & 148 \\
\hline
\end{tabular}

Fonte: Elaborada pelas autoras.

A amostra foi de 148 discentes dado o intervalo de confiança de $92 \%$ e margem de erro 0,07. O formulário foi construído tomando por base pesquisas pré-existentes (Unicamp, 2016) e a revisão de literatura utilizada e lançado nas redes sociais em 27 de março de 2017 o formulário no googleforms contendo 22 perguntas fechadas e abertas, continha o convite a participação da enquete e foi enviado por correio eletrônico, via mídias sociais e próprios egressos iam repassando a suas redes de contato. Houve a preocupação em ser bem objetivo para não inviabilizar que os egressos rejeitassem a pesquisa. A maior dificuldade foi em chegar até o egresso e a estratégia utilizada foi o contato pelas redes sociais. A IES por meio do site institucional e o Conselho Regional de Administração de Mato Grosso (CRA/MT) auxiliaram na divulgação do link aos discentes egressos e os docentes do quadro, em especial os egressos.

Uma das limitações do estudo está na dificuldade em ter acesso ao egresso e o mesmo aceitar responder ao questionário. Outro fator que merece destaque é que o perfil da maioria dos respondentes é a de jovens, cuja familiaridade com as mídias digitais é maior, fato que justifica a menor adesão por parte dos respondentes da meia idade. Os dados coletados foram tabulados em planilhas eletrônicas e nos trazem informações relevantes a autoavaliação do curso e posteriormente poderá gerar uma rede de cooperação entre as empresas filhas.

\section{PERFIL DOS EGRESSOS NEGROS}

Do total de 148 respondentes egressos do curso de Administração da Instituição de Ensino Superior, temos que 61 respondentes identificaram-se como negros (pretos ou pardos), sendo 27 mulheres e 34 homens. Desse total, $25 \%$ das mulheres e $45 \%$ dos homens consideram ter perfil empreendedor, conforme tabela a seguir:

Tabela 4. Você se considera empreendedor?

\begin{tabular}{|c|c|c|c|}
\hline Sexo & Não & Sim & Total Geral \\
\hline Feminino & $18,33 \%$ & $25,00 \%$ & $43,33 \%$ \\
\hline Masculino & $11,67 \%$ & $45,00 \%$ & $56,67 \%$ \\
\hline Total & $30,00 \%$ & $70,00 \%$ & $100 \%$ \\
\hline
\end{tabular}

Fonte: Elaborada pelas autoras.

Para $70,49 \%$ do total de pretos e pardos, o curso de Administração despertou em si o empreendedorismo e para 29,51\%, não.

\subsection{PERFIL DOS EMPRESÁRIOS}

Do total de 148 respondentes egressos do curso de Administração da Instituição de Ensino Superior, temos que 61 dos respondentes $(41,2 \%)$ identificaram-se como negros (conforme critério do IBGE), sendo 27 mulheres e 34 homens.
Verificamos que 27 são empresários, que possuem empresas que estão localizadas nas regiões nordeste, centro oeste e sul do país, nos estados do Rio Grande do Norte/RN, Mato Grosso/MT, Goiânia/GO e Paraná/PR. Deste total, $8(29,62 \%)$ são empresários que se identificaram como negros, sendo 4 homens e 4 mulheres, onde 5 estão com idades entre 41 a 50 anos e 3 entre 25 a 32 anos.

Para $70,49 \%$ do total de pretos e pardos, o curso de Administração despertou em si o empreendedorismo e para 29,51\%, não. Este percentual é muito próximo das respostas 
quando questionados se eles se consideram com perfil empreendedor, no total de $70 \%$ sim e 30\%, não. Desse total, $25 \%$ das mulheres e
$45 \%$ dos homens consideram ter perfil empreendedor.

\section{Gráfico 1 - Principais ocupações por faixa etária}

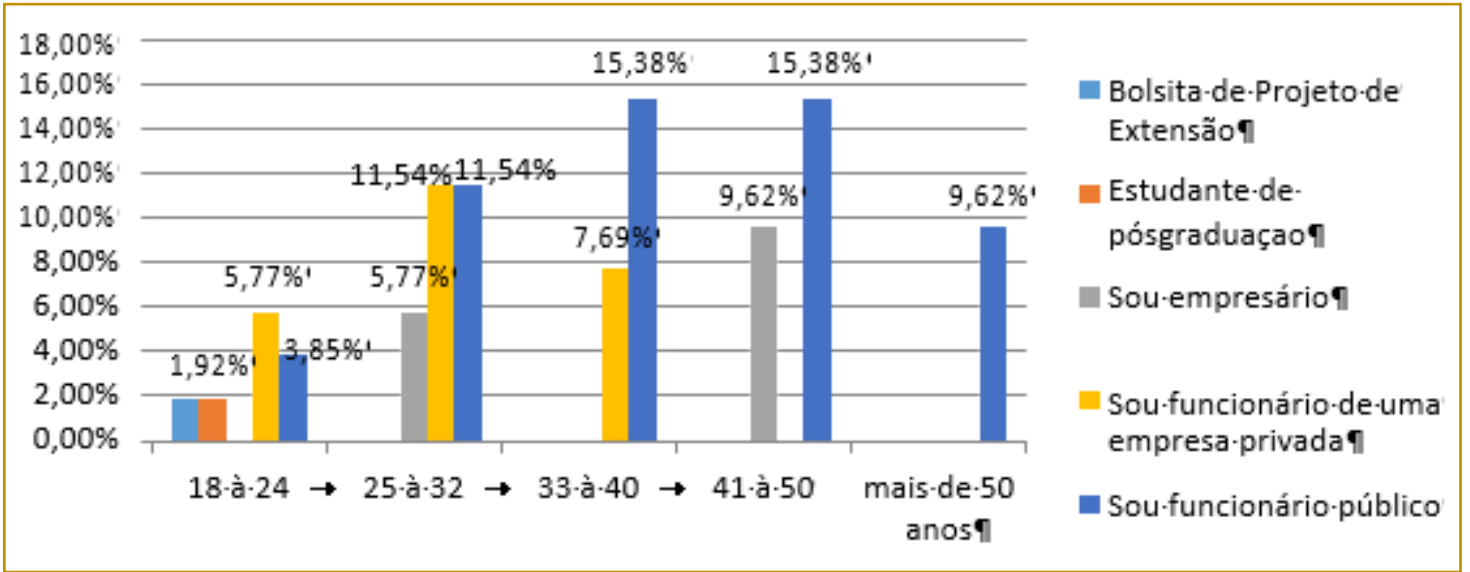

O gráfico acima, permite afirmarmos que dentre os respondentes da pesquisa, os egressos negros são profissionais que estão caracterizados como profissionais que buscam oportunidades, principalmente como servidores públicos e empregados de empresas privadas, refletindo ainda o objetivo de quando da criação do curso ainda em 1975.

Quanto correlacionamos o percentual dos que são empresários, com o dos respondentes que se consideram empreendedor ou que o curso despertou o empreendedorismo, observamos que ainda é pequeno o total destes empresários, diante disso, vislumbramos a possibilidade de um provavel reflexo da falta de incentivos adequados para empreender.

\subsection{PERFIL DOS EMPREENDEDORES}

Do total de 148 respondentes, 27 responderam que são empresários, e que possuem empresas, que estão localizadas em 4 estados do Brasil. Deste total, 8 (29,62\%) são empresários que se identificaram como negros correspondendo a 4 homens e 4 mulheres, percentual equilibrado quando comparado aos dados do SEBRAE (2015), no qual dos empreendedores negros, 29\% são mulheres e $71 \%$ homens, demonstrando que as mulheres estão empreendendo mais.

Além disso, 5 dos empreendedores negros têm entre 41 a 50 anos, com as empresas tendo em média 9,6 anos de existência, e 3 empreendedores negros têm entre 25 a 32 anos, e suas empresas têm em média 5 anos de abertura. Esses resultados quando comparados aos demais empreendedores (brancos e amarelos), 4 estão na faixa entre 41 a 50 anos, e média de 10,25 anos de existência do empreendimento, e 7 empreendedores entre 25 a 32 anos, com média de 14 anos de existência da empresa, verifica-se que o período de abertura é maior posto que 2 das empresas são foram abertas pela família do egresso e não apenas pelos ex-alunos diretamente.

Empreenderam por necessidade $12,5 \%$ do total, e em sua maioria $87,5 \%$ afirmaram que foi por oportunidade que empreenderam, este percentual é muito acima do indicado na Global Entrepreneurship Monitor - GEM (2015), onde $56,5 \%$ disseram ser motivados pela oportunidade.

Das empresas geradas, $37,50 \%$ são microempresas e $37,50 \%$ são empresas de médio porte. As empresas de grande porte correspondem a $12,50 \%$, mesmo percentual das empresas de pequeno porte. O total de empregos diretos gerados por essas empresas são de 445 oportunidades, das quais 40 são oriundas do setor de Comércio e as demais 405 vagas são do setor de Serviços, perfazendo o percentual de $78,90 \%$ das vagas geradas pelas empresas-filhas do curso de Administração, de forma que demonstram que os negros apesar de 
corresponderem a apenas $29,62 \%$ do total de empreendedores egressos, são os que mais geraram oportunidade de emprego. Os demais egressos geraram apenas 119 dos empregos diretos.

Segundo esses empreendedores, o curso de
Administração contribuiu total ou muito para abertura das empresas para 50\%, 37,50\% de forma razoável e 12,50\% pouco. Para a gestão, o curso contribuiu muito total ou muito para $72,50 \%$ dos egressos e razoável para $37,50 \%$.

Gráfico 2 - Contribuição para a gestão da empresa

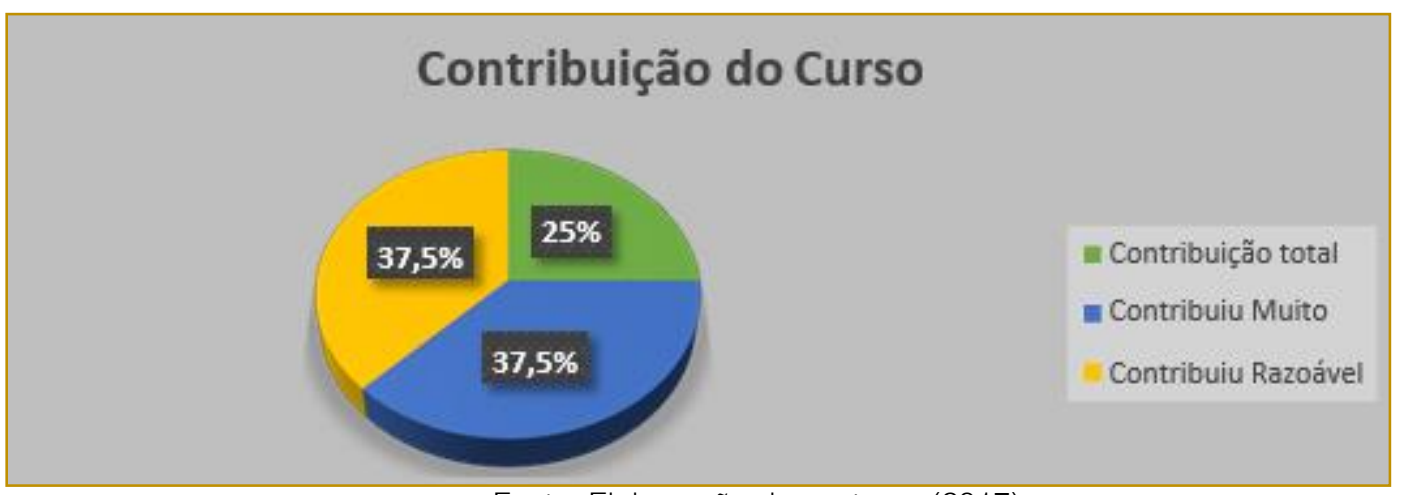

Fonte: Elaboração das autoras (2017).

Para $100 \%$ dos empreendedores negros egressos, $100 \%$ assinalaram buscar inovação, dos quais $37,50 \%$ responderam que por meio de cursos de pósgraduação/mestrado/doutorado, indicando que a qualificação ainda é um dos meios mais procurados para aprimoramento de conhecimentos e competências empreendedoras.

Tabela 5- Meios de busca por inovação

\begin{tabular}{|c|c|}
\hline Meio & $\%$ \\
\hline Internet e redes sociais & $12,50 \%$ \\
\hline Internet e redes sociais, Congressos e Feiras & $12,50 \%$ \\
\hline $\begin{array}{l}\text { Internet e redes sociais, livros, revistas e jornais impressos, congressos e } \\
\text { feiras }\end{array}$ & $25,00 \%$ \\
\hline $\begin{array}{l}\text { Internet e redes sociais, livros, revistas e jornais impressos, cursos de } \\
\text { aperfeiçoamento }\end{array}$ & $12,50 \%$ \\
\hline Pós-graduação/Mestrado/Doutorado & $37,50 \%$ \\
\hline
\end{tabular}

Fonte: Elaborada pelas autoras.

Das empresas geradas, 37,50\% são microempresas e $37,50 \%$ são empresas de médio porte. As empresas de grande porte correspondem a $12,50 \%$, mesmo percentual das empresas de pequeno porte. O total de empregos diretos gerados por essas empresas são de 445 oportunidades, das quais 40 são oriundas do setor de Comércio e as demais 405 vagas são do setor de Serviços, perfazendo o percentual de $78,90 \%$ das vagas geradas pelas empresas-filhas do curso de Administração, de forma que demonstram que os negros apesar de corresponderem a apenas $29,62 \%$ do total de empreendedores egressos, são os que mais geraram oportunidade de emprego. Os demais egressos geraram apenas 119 dos empregos diretos.

Segundo esses empreendedores, o curso de Administração contribuiu total ou muito para abertura da empresa para 50\%, 37,50\% de forma razoável e $12,50 \%$ pouco. Para a gestão, o curso contribuiu muito total ou muito para $72,50 \%$ dos egressos e razoável para $37,50 \%$. Para $100 \%$ dos empreendedores negros egressos, $100 \%$ assinalaram buscar inovação, dos quais 37,50\% responderam que por meio de cursos de pósgraduação/mestrado/doutorado, indicando que a qualificação ainda é um dos meios mais procurados para aprimoramento de 
conhecimentos

e

competências

empreendedoras.

\section{CONSIDERAÇÕES FINAIS}

A presente pesquisa aponta que o perfil do empreendedor negro egresso do curso de administração da IES, compreende $25 \%$ de mulheres e $45 \%$ de homens, onde em 70,49\% o curso de despertou em si o empreendedorismo, com geração de 445 oportunidade de empregos diretos, sendo $10 \%$ no setor de comércio e $90 \%$ no setor de serviços, e para $100 \%$ dos empreendedores negros egressos $100 \%$ buscam por inovação, quanto ao porte das empresas a maioria são microempresas e empresas de médio porte.

Ressaltamos o número de empregos diretos gerados pelos empreendedores negros que é significantemente maior que o número de empregos diretos gerados pelo restante dos empreendedores egressos. Embora existam 27 empresas-filhas abertas na amostragem de 148 pelos egressos do curso de Administração da IES respondentes à pesquisa, verifica-se que $29,62 \%$ foram abertas por negros. Os empreendedores egressos negros são responsáveis pela geração de $78,90 \%$ das vagas geradas pelas empresas-filhas do curso de Administração, foi possível identificar que elas não geraram impacto ou inovação local mesmo que 74\% delas estejam localizadas dentro do Estado

\section{REFERÊNCIAS}

[1] Azevedo, T. de. 1996. As elites de cor numa cidade brasileira: um estudo sobre a ascensão social e classes sociais e grupos de prestígio. Salvador, EDUFBA, 2ª ed., 1996.

[2] Barretto, L. A força dos negros no empreendedorismo. In NOGUEIRA, João Carlos (org.). Desenvolvimento e empreendedorismo afrobrasileiro: desafios históricos e perspectivas para o século 21. Florianópolis: Atilènde, 2013. 324p.

[3] Beghin, N. e Jaccoud, L. Desigualdades Raciais no Brasil: um balanço da intervenção governamental. Brasília, IPEA, 2002.

[4] Bispo, C.S. et al. (Orgs.): Administrando o Futuro Agora. 2013. Disponível em:<http://www.ibes.edu.br/aluno/arquivos/artigo_a dministrando_o_futuro_agora.pdf>. Acesso em: 25 ago. 2016.

[5] Brasil. Lei $n$ - 12.288, de 20 de julho de 2010. Institui o Estatuto da Igualdade Racial. Disponível em: < http://goo.gl/xSfn8m >. Acesso em 04/07/2017. de Mato Grosso. Devemos ressaltar que a não geração de inovação e descaracterização da matriz produtiva impressa para o Estado, considerando que o Estado de Mato Grosso é voltado para o agronegócio, com legislação específica de incentivo a esse setor, justificase a dificuldade em gerar inovação diante desta realidade local.

Diversas ações foram empreendidas no sentido de colaborar com o desenvolvimento de competências empreendedoras, podemos citar as disciplinas e eventos desevenolvidas pontualmente nas décadas passadas, de forma que o curso de Administração pouco contribuiu ou incentivou os egressos a empreenderem. Mas a pesquisa mostra também que o curso de Administração da IES, a partir do ponto de vista dos empreendedores negros, contribuiu de forma positiva para a abertura e gestão do negócio, tanto é que o maior número de empregos foram gerados por estes empresários negros egressos. Os empreendedores negros procuram por inovações e qualificação para aprimorar a gestão dos empreendimentos.

Constatamos ser cedo para analisarmos impactos das cotas no que tange os alunos negros, considerando o pouco tempo de implementação da política de ação afirmativa na IES, vemos como fator impossibilitante de verificação neste momento, mas vislumbramos a possibilidade de a questão ser objeto de estudos futuros.

[6] Lei $n$ ํ 12.711, de 29 de agosto de 2012. Dispõe sobre o ingresso nas Universidade Federais. Disponível em: < http://goo.gl/ZBFZ1q >. Acesso em 04/07/2017.

[7] Davies, F. A. Negro empresário, empresário negro: Reflexões sobre racionalidade, identidade e trajetória a partir de um estudo de caso. In: II Simpósio de Pós- Graduandos em Sociologia - USP, UNESP, UFRJ, UFSCar, UNICAMP, 2009, São Paulo. Anais do II Simpósio de Pós-Graduandos em Sociologia - USP, UNESP, UFRJ, UFSCar, UNICAMP, 2009

[8] Dornelas, J. C. A. Empreendedorismo: transformando ideias em negócios. $2^{\underline{a}}$ ed. Rio de Janeiro: Elsevier, 2005.

[9] Figueiredo, A. Fora do jogo: a experiência dos negros na classe média brasileira. Cad. Pagu [online]. 2004, n.23, pp. 199-228. ISSN 1809-4449. Disponível em:<http://dx.doi.org/10.1590/S010483332004000200007. > Acesso em 12/05/2017. 
[10] Global Entrepreneurship Monitor. Empreendedorismo no Brasil: 2016. Coordenação de Simara Maria de Souza Silveira Greco; diversos autores -- Curitiba: IBQP, 2017. 208 p. : il.

[11] Instituto Brasileiro de Geografia e Estatística. Censo demográfico

[12] 2010: resultados gerais da amostra características da população. Disponível em:<http://biblioteca.ibge.gov.br/visualizacao/perio dicos/99/cd_2010_resultados_gerais _amostra.pdf > Acesso em 26/05/2017.

[13]. Síntese de indicadores sociais: uma análise das condições de vida da população brasileira : 2015 / IBGE, Coordenação de População e Indicadores Sociais.- Rio de Janeiro : IBGE, 2015.

[14] Instituto de Pesquisa Econômica Aplicada Situação social da população negra por estado. Instituto de Pesquisa Econômica Aplicada; Secretaria de Políticas de Promoção da Igualdade Racial - Brasília: IPEA, 2014. 115 p. Disponível em http://www.seppir.gov.br/centraldeconteudos/publicacoes/pub-pesquisas/situacaosocial-da-populacao-negra-por-estado-seppir-eipea Acesso em 13/05/2017.
[15] . Os donos de negócio no Brasil: análise por raça/cor (2003-2013). / Marco Aurélio Bedê (Coord.) - Brasília: Sebrae, 2015.

[16] . Retrato das Desigualdades de gênero e raça / Luana Pinheiro ... [et al.]. - 3. ed. Brasília: Ipea: SPM: UNIFEM, 2008. 36 p. : gráfs., tabs.

[17] Serviço Brasileiro de Apoio às Micro e Pequenas Empresas e Enveavor. Relatório digital: Empreendedorismo nas Universidades Brasileiras, $2016 . \quad$ Disponível em <https://d335luupugsy2.cloudfront.net/cms\%2Ffiles \%2F6588\%2F1476473621Relatorio+Endeavor+digi tal+\%283\%29.pdf > Acesso em 25 de maio de 2017.

[18] Universidade Federal DE MATO GROSSO. Resolução consepe n. 82/2007. Dispõe sobre criação do Programa de Inclusão de Estudantes Indígenas "Guerreiros da Caneta" no âmbito da UFMT por um período de cinco anos a partir de 2008. Disponível em: https://goo.gl/t7z4S2 . Acesso em: 17/06/2017. Resolução Consepe n. 97/2011. Dispõe sobre a criação de um Programa de Ação Afirmativa destinado a estudantes egressos de escola pública e estudantes negros. Disponível em: https://goo.gl/MwPdgg. Acesso em: 17/06/2017.

\section{Notas}

1 Instituído pelo Decreto 6.096/2007, possibilitou a expansão do número de vagas oferecidas pelo curso e bem como de sua estrutura física. Foi por meio dessa adesão que a Faculdade de Administração e Ciências Contábeis puderam receber novas salas de aulas com a construção de um prédio didático

2 Ações afirmativas: os programas e medidas especiais adotados pelo Estado e pela iniciativa privada para a correção das desigualdades raciais e para a promoção da igualdade de oportunidades. (Lei da Igualdade Racial - Lei $n^{\circ}$ 12.288/10) 


\section{Gapítulo 10}

\section{ESTRATÉGIAS DE GESTÃO DE PESSOAS E DE POLÍTICAS INSTITUCIONAIS EM UMA CONSULTORIA DE RECRUTAMENTO E SELEÇÃO EM MATO GROSSO}

\section{Daniela Martina Alves Aguilar}

Valentina Santos Bauermeister

Rita Eliana Mazaro

Resumo: A rotina dentro de uma organização permite a apreensão de vários fenômenos, assim como a proposição de estratégias de gestão de pessoas e de políticas institucionais. O estágio em contextos organizacionais e do trabalho é pensado objetivando desenvolver o conhecimento de graduandos de Psicologia nessa área, ao propor a inserção de estagiárias em uma empresa de consultoria de recursos humanos com o apoio metodológico da observação participante e de entrevistas. Dessa forma, permitiu às estagiárias assimilar os processos desenvolvidos na empresa dos seus serviços ofertados, principalmente os de recrutamento e seleção. Como produto de tal experiência, proposições a respeito da implementação de ferramentas de controle de tempo e produtividade, de atividades de extensão de saberes, do redirecionamento do trabalho dos colaboradores, bem como a mudança estrutural da distribuição de salas foram feitas. 


\section{INTRODUÇÃO}

Oportunizado pela disciplina de Estágio Básico III, direcionada aos contextos organizacionais, o presente relato conta da inserção de duas alunas do curso de Psicologia de uma Universidade Federal em uma instituição privada. Objetiva-se, na inserção ativa de futuras profissionais, potencializar o processo de formação e oportunizar a conciliação da teoria aprendida em sala de aula com a prática, bem como visualizar a atuação do psicólogo nesses espaços. Esse processo foi viabilizado pela supervisão semanal junto da professora responsável pelo estágio, de modo que ela orientasse as práticas destas. Essa dinâmica permite que $o$ estudante vivencie $e$ compartilhe experiências profissionais que viabilizam a discussão da realidade efetiva, bem como reflexões éticas sobre seu processo de formação e sobre a atuação do psicólogo na organização.

No que diz respeito à organização cedente de estágio, esta oferece, majoritariamente, o serviço de recrutamento e seleção. Sendo assim, as atividades das estagiárias se pautaram na análise da dinâmica da instituição e dos processos ali desenvolvidos, na apreensão das práticas, na identificação de suas demandas e no reconhecimento de pontos positivos e benéficos exercidos na corporação. Pautado na observação participante, as estagiárias puderam interagir tanto com os colaboradores quanto com a comunidade, permitindo, assim, a compreensão das práticas e das necessidades circundantes dessa. Aliado a essa postura metodológica, a fim de enriquecer a coleta de dados, lançou-se mão de entrevista com a equipe dirigente da empresa, clarificando, às estagiárias, as percepções e ocorrências cotidianas destes para com a instituição. Posto isso, os principais levantamentos e encaminhamentos observados dizem respeito às práticas de gestão de pessoal e estrutural, às estratégias de gerenciamento de tempo, assim como à própria atuação dos profissionais empregados.

Assim, o presente relato objetiva mostrar a conciliação da teoria aprendida em sala de aula com a dinâmica da instituição, propondo práticas que possam solucionar as dificuldades encontradas neste contexto ou potencializar aquelas que já são proveitosas. Considera-se, então, que a presença do estagiário é importante para ambas as partes envolvidas.

\section{FUNDAMENTAÇÃO TEÓRICA}

Como dito anteriormente, o Estágio Básico III ocorre em contextos organizacionais; sendo que, uma das possibilidades de atuação é a Consultoria de Recursos Humanos. Orlickas (1999) afirma que a consultoria é uma forma de prestação de serviços realizada por um profissional capacitado, qualificado e preparado. As consultorias de recrutamento e seleção (R\&S) surgem para suprir as necessidades de algumas empresas, principalmente as de menor porte, pois é inviável para as mesmas manter em seus quadros de funcionários profissionais exclusivos para o processo de recrutamento e seleção. Assim, transferem para terceiros a função, de modo a diminuir os custos com tal atividade (Verloza, 2009).

Entretanto, a consultoria externa nem sempre é vantajosa, pois o consultor externo, por não ter vínculo empregatício com a empresa em que ele está prestando serviço, não vivencia o cotidiano da organização. Assim, se faz necessário que o mesmo estude a cultura, valores e filosofia da empresa para o processo de R\&S, de modo que ele conheça o perfil da empresa e faça de forma mais eficiente possível determinada função (Verloza, 2009).

De acordo com Flippo (1961 como citado em França, 2007, p. 30), "recrutamento é um processo de procurar empregados, estimulálos e encorajá-los a se candidatar a vagas em determinada organização". O recrutamento que as referidas consultorias realizam para as empresas é externo e, ainda segundo França (2007), "é a busca do candidato no mercado de trabalho ou em fontes específicas para o preenchimento do cargo" (p. 33). Esse tipo de recrutamento é vantajoso pois possibilita a inclusão de novas personalidades e talentos, a inovação da composição das equipes de trabalho e a atualização no estilo e nas tendências do mercado. Algumas das principais fontes de recrutamento são: consulta ao cadastro de candidatos da própria empresa; escolas de cursos técnicos, faculdades e universidades; sites especializados em oferta de candidatos; agências de emprego; anúncios em jornais, revistas, rádio, TV, etc. (França, 2007). 
Realizar o processo de R\&S de forma eficiente traz benefícios para a organização, pois pode evitar alto índice de absenteísmo, rotatividade elevada, gastos desnecessários com folhas de pagamento, entre outros (Verloza, 2009). Para isso, França (2007) define alguns fatores críticos de sucesso do processo seletivo: alinhamento com estratégia corporativa e políticas de $\mathrm{RH}$; informações sobre as atividades e habilidades da posição; contato com a área requisitante durante todo 0 processo; ética (divulgação de detalhes da posição e comunicação de resultados).

É mediante o processo de recrutamento que a empresa expõe o grau de profissionalismo com que trata os seus colaboradores. Um processo de recrutamento mal conduzido projeta uma imagem negativa da empresa. Qualidade no atendimento aos candidatos e retorno aos não escolhidos são fatores que elevam os resultados do recrutamento e seleção da empresa (França, 2007, p. 30).

É sabido que o processo de recrutamento necessita de criatividade para atrair o máximo de pessoal com o perfil desejado a participar do processo seletivo. Dessa forma, é necessário fazer a descrição detalhada do cargo, com pré-requisitos e competências exigidas, bem como é imprescindível adequar as expectativas dos candidatos, dimensionando suas capacidades e interesses à necessidade do trabalho (França, 2007).

Devido à isso, antes do processo seletivo é indispensável a realização de uma entrevista com o requisitante da vaga para conhecer as suas necessidades e expectativas e confirmar o perfil psicológico e a bagagem de conhecimentos necessários ao candidato; ou seja, é necessário ter uma "Análise" da Função, em que serão detalhadas as tarefas que o cargo envolve, quais as habilidades e conhecimentos necessários para o cargo, as responsabilidades que este exige, o horário de trabalho, o salário, entre outros. Assim, traça-se o candidato modelo, sendo que o contratado deverá ser o que mais se assemelhar a este (França, 2007).

A seleção é a escolha, entre os candidatos recrutados, daquele(s) mais adequado(s) para a organização, ou seja, aquele(s) com "maior afinidade das suas expectativas e potencialidades com as expectativas e necessidades previstas para o cargo ou posição em processo de preenchimento" (França, 2007, p.34). Por isso, "nem sempre significa escolher os candidatos que revelam aptidões ou capacidades nos seus índices mais elevados" (França, 2007, p.34).

Em adição ao que foi dito anteriormente, para o sucesso do processo seletivo, cabe ressaltar que, quanto maior for o envolvimento da área ou pessoa que receberá o candidato selecionado, maior a probabilidade de se acertar na escolha. Assim, a decisão sobre o preenchimento da vaga, a avaliação e comparação dos candidatos e a escolha final do candidato devem ser feitas a partir dos mesmos (França, 2007).

As principais técnicas utilizadas no processo seletivo são as entrevistas, provas de conhecimentos, testes psicológicos e técnicas vivenciais. "A utilização de diversas técnicas que se complementam pode diminuir a possibilidade de erro na escolha do candidato" (França, 2007, p. 36).

No que se refere às entrevistas, França (2007) afirma que estas devem seguir 4 estágios: abertura, pesquisa, troca e fechamento. $\mathrm{Na}$ abertura, o entrevistador se apresenta e expõe a proposta da entrevista e como será conduzida. Na pesquisa o objetivo é obter do candidato as informações necessárias para avaliação do seu perfil pessoal e profissional. A fim de auxiliar nesta parte, a referida autora nomeia alguns aspectos: desenvolvimento na carreira, relacionamento profissional, ambiente familiar, interesses pessoais, relacionamentos sociais e perspectivas futuras.

$\mathrm{Na}$ troca deve-se deixar o candidato fazer as perguntas que revelem seus interesses, valores, atitudes e preocupações. Por fim, o fechamento, no qual deve-se dar um breve feedback da entrevista e informar as etapas futuras do processo seletivo. Cabe lembrar que as entrevistas de triagem podem "verificar aspectos mais evidentes que são determinantes para a ocupação do cargo" (França, 2007, p. 40). Assim, por exemplo, para uma vaga de atendente de telemarketing, em que é necessário lidar com pessoas, ter paciência e boa comunicação, um candidato fora deste perfil não é indicado.

Ademais, é importante e recomendável que vários entrevistadores avaliem o mesmo candidato, a fim de minimizar fatores de ordem pessoal (do próprio entrevistador) que possam interferir no processo. Por isso, é de suma importância que a entrevista seja conduzida por um profissional experiente e que seja capaz de identificar quando fatores 
desse tipo (antipatia, atração, rejeição, etc) estiverem interferindo (França, 2007).

Com relação às provas de conhecimentos, França (2007) afirma que elas podem ser gerais ou específicas. As gerais visam avaliar o grau de cultura do candidato; pode ser uma simples redação para verificar a fluência da escrita, o conhecimento de português e a ordenação de ideias e pensamento. Cabe lembrar que elas têm baixa correlação com o desempenho profissional imediato. Já as provas específicas visam avaliar os conhecimentos profissionais que o candidato possui, que são imprescindíveis para o bom desempenho na função. É importante que esses instrumentos sejam desenvolvidos e validados internamente na empresa, para não eliminar bons candidatos.

Já com relação aos testes psicológicos, Santos (op. cit. como citado em França, 2007, p. 43) os define como provas ou verificação sistematizada, no sentido de medir (ou avaliar) um tributo qualquer. Eles podem ser divididos em psicométricos e de personalidade. Os psicométricos medem as aptidões individuais, como é o caso dos testes de inteligência. Já os testes de personalidade identificam traços de personalidade, aspectos motivacionais, interesses e distúrbios. É válido ressaltar que eles não permitem inferências precisas sobre - sucesso profissional do indivíduo, mas identificam aspectos que podem influenciar na vida profissional do mesmo (França, 2007).

Os testes psicológicos identificam elementos que, apenas com os métodos tradicionais (como entrevista e análise de um currículo), passam muitas vezes despercebidos (Dalbosco \& Consul, 2012). Dessa forma, mais uma vez podemos perceber a importância do psicólogo, pois, de acordo com Hutz, Bandeira e Trentini (2015), os testes psicológicos são de uso exclusivo do psicólogo. Assim, as empresas que contam com o auxílio deste profissional tendem a obter melhores resultados pois, conforme Dalbosco e Consul (2012), é por intermédio da avaliação psicológica que a empresa consegue filtrar melhor os candidatos com o perfil mais adequado para a vaga disponibilizada, podendo, dessa forma, realizar um prognóstico do desempenho do novo funcionário.

No mais, têm-se as técnicas vivenciais que, segundo França (2007) criam situações para os candidatos interagirem e participarem ativamente, de forma a ser avaliado seu comportamento social em situações préselecionadas. Essas técnicas podem ser provas situacionais, dinâmicas de grupo ou psicodrama.

França (2007) afirma que o candidato deve ser sempre informado claramente sobre as decisões da empresa.

Nunca deixar de demonstrar que a seleção de pessoal é feita com base nos critérios eleitos pela própria instituição e que isso não pode ser generalizado para outras situações e, especialmente, não significa que um candidato não admitido é incapaz, deficiente ou problemático. Apenas significa que para aquela função, naquela empresa, dentro daquele e apenas daquele período ele não será admitido, quer por motivos de excessiva concorrência, quer por falta de habilitação desejada, quer por características pessoais desejáveis naquela empresa ou, então, por problemas administrativos internos (França, 2007, p.46).

A partir disso, a autora ainda ressalta que essa decisão é delicada nos casos dos candidatos "contra-indicados", pois "essas classificações despertam estigmas que são prontamente absorvidos por quem as recebe, pois a pessoa vê frustrados os seus objetivos, sem conhecer os verdadeiros motivos"; por isso, tais esclarecimentos devem ser feitos desde o primeiro contato com o candidato, evitando sentimentos de inferioridade e incapacidade pessoal, que muitas vezes nem foram causa da não-contratação (p. 46).

Por fim, Verloza (2009) ressalta a necessidade e a importância de que os psicólogos sejam preparados eficientemente, para que estes sintam-se preparados e motivados para lidar com as mudanças constantes na sociedade, bem como, tenham os conhecimentos técnicos necessários para realizar de forma confiante as técnicas de recrutamento e seleção.

\section{METODOLOGIA}

Realizado entre os meses de maio e julho de 2017, o estágio contou com visitas semanais ao campo, de quatro horas de duração cada. Estas tiveram suporte metodológico na observação participante a fim de auxiliar na compreensão do cotidiano relacional da instituição e dos processos desenvolvidos pelos seus colaboradores. De acordo com Boni e Quaresma (2005), a observação 
participante é entendida na inserção ativa do pesquisador à comunidade a ser pesquisada, de forma que este se integra aos hábitos e costumes do grupo e começa a pertencer, mesmo que temporariamente, a este lugar.

Serva e Jaime (1995) auxiliam na compreensão desta postura ao discorrer sobre a relação entre o observador e o observado. Pelo fato de o pesquisador integrar-se a um mundo anteriormente estranho ao seu, este se encontra em uma posição de aprendiz em relação ao pesquisado, visto que a realidade do grupo já Ihe é familiar. Busca-se então, por parte do sujeito externo, clareza e apreensão dos processos e fenômenos vivenciados pelo grupo estudado, de forma a estabelecer o desenvolvimento das práticas, da comunicação e dos sentimentos experienciados e expressos no meio, visando uma participação e compreensão mais integral. Dessa forma, a experiência é priorizada de maneira que, como sugerido pelos autores, exista um aparato teórico sustentando as práticas, para que o pesquisador não se apegue apenas em propostas já construídas. Cruz (2002) ainda traz que, por meio da observação participante e da relação estabelecida nesse processo, há possibilidade da ocorrência de mudanças tanto no pesquisador quanto no contexto em que se encontra inserido, ao considerar o fato que há um contato direto do pesquisador com o fenômeno que objetiva a apreensão de informações.

Além disso, para a efetiva compreensão das particularidades da empresa e complementação da coleta de dados, foi realizada entrevista com a proprietária, cujo conteúdo explorava os aspectos das práticas de gestão de pessoas e das características da estrutura organizacional. A entrevista é concebida por Haguette (1997 como citado em Boni \& Quaresma, 2005, p. 72) como um processo marcado por interação social e que visa a coleta de informações, estas disponibilizadas pelo entrevistado ao entrevistador. Cruz (2002) afirma que, por meio da entrevista, é possível extrair elementos tanto objetivos quanto subjetivos a respeito de determinado assunto, de forma que os dados subjetivos consistem nas opiniões, crenças e atitude dos entrevistados. Utilizou-se, então, da entrevista semiestruturada para a obtenção de informações, a qual, para Boni e Quaresma (2005), viabiliza ao entrevistado explanar mais livremente sobre o tema proposto na combinação de perguntas abertas e fechadas.

Portanto, a prática das estagiárias se baseou na observação participante atrelada a entrevista com os pertencentes ao grupo que foram inseridas. Sendo assim, as atividades realizadas em campo se centraram na observação da rotina da instituição, no olhar do trabalho efetivo de seus colaboradores, visando a aprendizagem dos processos ali desenvolvidos e na execução de algumas tarefas, como a triagem de currículos e o contato com os candidatos às vagas disponíveis na empresa.

\section{DISCUSSÃO}

A experiência de inserção ao campo prático de estágio, aliado com a bagagem teórica adquirida pelas discentes nas disciplinas de Psicologia Organizacional e do Trabalho e de supervisão de estágio possibilitou um olhar atento frente ao exercício da Psicologia em uma empresa de consultoria de $\mathrm{RH}$ e até mesmo ao desenrolar da Gestão de Pessoas, seja esta com ou sem um profissional responsável, dentro de uma organização. Posto isso, alguns apontamentos puderam ser feitos após o período de observação no estágio, os quais serão discorridos abaixo.

A consultoria de Recursos Humanos $(\mathrm{RH})$ que oportunizou a experiência de estágio é uma franquia que atua oferecendo serviços de R\&S, avaliação comportamental ou psicológica e de administração e seleção de vagas para serviços temporários, estágios e terceirização. Sua matriz se encontra situada no sul do país e conta com unidades em mais 14 cidades do Brasil.

A atuação da unidade segue a proposta da franquia, disponibilizando serviços de consultoria de $\mathrm{RH}$, entretanto, além destes, dispõe também de avaliação psicológica, treinamento organizacional e elaboração de processos seletivos. Para a realização e efetivação deste trabalho, a empresa conta com sete colaboradores, sendo dois destes efetivos no recrutamento e seleção e outro temporário, dependendo do tipo e da quantidade de vagas disponíveis no momento; um auxiliar de serviços gerais; um responsável pela recepção; a atual gestora da empresa, responsável pelas questões burocráticas e pelo trabalho comercial e o responsável pela gestão de sistemas da empresa. 
As práticas efetivas de Gestão de Pessoas nessa organização ainda hão de ser implementadas e estão sendo encaminhadas para tal, visto que não ainda não há uma pessoa responsável para seu exercício, de forma que o R\&S de seus colaboradores é realizado pela diretora. Ademais, como benefício social é disponibilizado pela empresa o vale transporte, além de, em relação a alimentação, tem-se a oferta diária de café da manhã pela proprietária e esporadicamente o custeio do almoço dos funcionários. Atrelado à isso, os cargos de recepção e serviços gerais possuem salário fixo, em contrapartida, os cargos dos recrutadores apresentam remuneração variável, com salário fixo e comissão dada a à partir de uma porcentagem de lucro por vaga fechada.

Desde a primeira visita à campo, a acolhida das duas pessoas externas -as estagiáriasàquele grupo em questão -a empresa- se deu de maneira muito satisfatória, de forma que não houve estranhamento entre todos os envolvidos, possibilitando e facilitando uma integração positiva e a apreensão dos fenômenos que ali se desenvolviam. Percebeu-se, então, na proximidade das relações dos colaboradores e, talvez, pelo seu baixo contingente, que alguns protocolos formais eram quebrados, proporcionando uma interação amistosa ao cotidiano, mas que, possivelmente, pudesse vir a atrapalhar a breve estadia no recinto dos candidatos às vagas, trazendo para eles uma concepção mais informal do processo.

Dos serviços ofertados pela consultoria de $\mathrm{RH}$, o de R\&S foi experienciado em larga escala pelas estagiárias ao observar $\mathrm{O}$ exercício tanto do profissional graduado em Administração de $\mathrm{RH}$ quanto pela profissional da Psicologia. O R\&S são, de acordo com França (2007), processos integrados à estratégia de negócios da empresa, realizados por meio dos mais variados instrumentos, visando o preenchimento de uma vaga disponível no mercado. São, para Gondim e Queiroga (2013), procedimentos de captação de pessoas com características potenciais e avaliação dos candidatos com o perfil ideal, respectivamente.

Para Marras (2009), é responsabilidade do $\mathrm{RH}$ a captação e seleção primária e refinada dos profissionais no mercado de trabalho e o encaminhamento dos candidatos selecionados para a empresa, processo este marcado pelo recrutamento e seleção de pessoal. O autor afirma que o fluxo de trabalho de responsabilidade do R\&S depende de variáveis como rotatividade, aumento de quadro planejado e aumento de quadro circunstancial, não estando necessariamente ligado ao número de empregados da organização.

Observou-se que, eventualmente, a atividade dos profissionais recaía sobre práticas de R\&S rotineiras e menos refinadas devido a demanda de trabalho existente, principalmente na execução de entrevistas. A condução destas se dava de forma rápida e com interrupções na fala dos candidatos, deixando a expressão desses profissionais incompleta. Interrupções estas como atender ligações telefônicas durante a entrevista ou conversar sobre outro assunto com outros colaboradores da instituição.

Entretanto, considerando o exercício dos profissionais, é válido referenciar a energia dos mesmos quanto a busca de atualização constante de seus saberes, em que 0 discurso sobre leituras e outros tipos de orientação esteve sempre presente. Fato este que evidencia o empenho e o apreço pelo conteúdo teórico trabalhado por estes profissionais e a possibilidade de desenvolver outras competências requeridas em suas funções. Gondim e Queiroga (2013) trazem contribuições valiosas a respeito da necessária articulação entre a prática e a pesquisa no campo de R\&S.

As autoras apontam que, ainda que importante, esse exercício não vem sendo feito pelos responsáveis pela área devido a aplicação de procedimentos que acabaram por se tornar habituais e que deixam de lado os meios de controle e aperfeiçoamento dos processos por conta do cenário do mercado de trabalho atual, marcado pela concorrência e pela pressão temporal em relação ao "fechamento" de vaga, consequenciando a utilização de procedimentos de seleção menos complexos. Ambas as posturas acabam por comprometer a qualidade e veracidade do processo de avaliação como um todo e geram problemas éticos relacionados à elaboração dos pareceres.

Como exemplo, constatou-se irregularidades na forma de aplicação do teste Palográfico e instrução do mesmo ao candidato. De acordo com Alvez e Esteves (2004 como citado em Dalbosco \& Consul, 2012, pp.556-557) o teste Palográfico é um teste expressivo da personalidade; nele se avalia produtividade, 
rendimento no trabalho, ritmo no trabalho, necessidade de contato exterior, autoestima, ânimo, humor e vontade, relacionamento interpessoal, atitudes frente a figuras de autoridade, agressão, organização, ordem, emotividade, impulsividade, e aspectos depressivos. Além disso, houveram irregularidades durante as entrevistas. Percebe-se que, muitas vezes, o entrevistador direciona a fala do entrevistado, o que acaba por limitar a fala do mesmo e também pode não refletir a opinião deste.

Ao decorrer do estágio, a profissional de psicologia se envolveu em atividades de extensão de saberes junto com as estagiárias, como uma palestra a respeito do cenário de avaliação psicológica no país e uma pequena formação, junto à professora supervisora de estágio e à uma docente responsável pelas disciplinas de testes, a respeito da execução do teste psicométrico Palográfico. Percebeuse a importância do relacionamento entre pares para esta colaboradora e disposição de participar desse intercâmbio de saberes, bem como o apoio dos dirigentes da empresa para essa realização.

Apesar do desejo de aquisição do novo, cabe aqui pontuar que seria interessante a reciclagem das práticas já postas pela equipe, visando contribuir para o processo de R\&S e para os processos referentes aos outros serviços oferecidos, como a avaliação psicológica e comportamental, o trabalho com estagiários e terceirizados e a elaboração de processos seletivos.

A estrutura organizacional da instituição cedente de estágio se assemelha com a departamentalização por serviços, a qual, para França (2007), consiste no agrupamento de colaboradores que lidam com os mesmos ou semelhantes- produtos e serviços oferecidos pela empresa, de forma que, como percebido pela autora, há o aumento da integração entre pessoas envolvidas nesse setor. Pensando na empresa cedente de estágio, tem-se uma sala para os responsáveis pelo processo de $R \& S$ executarem todas as suas atividades, desde preparação de laudos, contato com os candidatos à própria entrevista e aplicação de testes; uma sala para a gerência da organização, em que as atividades ligadas ao setor comercial e contato ou prospecção de clientes são realizadas, assim como o manuseio de questões burocráticas e de gerência.
$\mathrm{Na}$ entrevista realizada com os proprietários da unidade, foram valiosas as informações fornecidas, visto que a percepção deles frente a dinâmica de sua instituição muito se assemelha com o que foi observado pelas estagiárias no período de estágio. Estas se centraram no esclarecimento de alguns dados formais da empresa e na concepção deles acerca da organização. Conteúdos referentes à dificuldade de implantação de um sistema (Timesheet) de organização, de tempo e produção e da centralização do trabalho foram trazidos.

Portanto, tem-se uma instituição com uma dinâmica positiva de interação e acolhimento, assim como de busca de informações relacionadas a teoria e a prática dos processos ali desenvolvidos. Mas que encontra dificuldades na sistematização e administração da produção de seus colaboradores e com a presença de atitudes cotidianas que impedem 0 melhor desenvolvimento de seus serviços.

\section{CONSIDERAÇÕES FINAIS}

A inserção em campo na empresa de consultoria de $\mathrm{RH}$, permitiu às estagiárias a articulação da prática com os processos que eram descritos apenas teoricamente, permitindo 0 desenvolvimento de suas competências como futuras profissionais da Psicologia e possibilitando a apreensão do exercício em organizações. Além disso, viabilizou reflexões acerca do lugar que estavam inseridas que podem, de alguma forma, promover o desempenho e a otimização da organização como um todo.

Acredita-se que o obstáculo impossibilitando uma prática mais efetiva nesse espaço de consultoria de $\mathrm{RH}$ está no espaço estrutural da instituição, o qual, pelo fato de concentrar todas as atividades dos profissionais de R\&S em um lugar, acaba por dificultar as atividades desempenhadas. Por várias vezes houve descontinuação de entrevistas devido a telefonemas ou entrada de outros colaboradores na sala, os quais possuem conhecimento sobre o processo e a importância de entrevistas, mas que, talvez, pela rotina cotidiana, permitem sua ocorrência. Cabe ressaltar que a permissão aqui tratada não diz respeito ao consentimento, mas a execução, propriamente dita. 
Interrupções se deram também durante a realização de testes psicológicos, estes que devem seguir parâmetros rígidos, necessitando, como apontado por Pasquali (2001), além da graduação em Psicologia, de pessoas treinadas e que tenham conhecimento acerca do instrumento, ou seja, sua aplicação é padronizada. As condições de aplicação se baseiam na qualidade do ambiente físico e psicológico, os quais, por vezes não se encontravam em harmonia.

Entretanto, é válido pontuar que no decorrer do estágio, algumas mudanças significativas e positivas foram feitas no quesito estrutural da empresa. Uma sala, anteriormente inativa, foi aberta para acolher entrevistas com os candidatos às vagas e com os clientes, possibilitando que o trabalho produtivo no setor de recrutamento e seleção relacionado a telefonemas e elaboração de parecer se centrasse em uma sala diferente.

Por fim, tem-se a centralização de trabalhos por parte dos colaboradores, fato que impede o rendimento efetivo de suas atividades e os desviam de atuações que lhe são destinadas. Sugere-se então que o contato por telefone com os possíveis candidatos, o agendamento de entrevistas e a parte do marketing em redes sociais, por exemplo, poderia ser

\section{REFERÊNCIAS}

[1] Boni, V., \& Quaresma, S. J. (2005). Aprendendo a entrevistar: como fazer entrevistas em Ciências Sociais. Em Tese, 2(1), 68-80. Recuperado em 15 de julho, 2017 de https://periodicos.ufsc.br/index.php/emtese/article/ view/18027

[2] Cruz, O., Neto. (2002) O trabalho de campo como descoberta e criação. In: Minayo, M. C. S. (Org.). Deslandes, S. F., Cruz, O., Neto, \& Gomes, R. Pesquisa social: teoria, método e criatividade. 22 ed. Petrópolis: Vozes, 51-66.

[3] Dalbosco, S. N. P., \& Consul, J. S. (2012). A Importância da Avaliação Psicológica nas Organizações. Revista de Psicologia da IMED, Passo Fundo, 3(2), 554-558. Recuperado em 15 de julho, 2017 de https://seer.imed.edu.br/index.php/revistapsico/arti cle/view/143

[4] França, A.C. L. (2007) Práticas de recursos humanos - $P R H$ : conceitos, ferramentas e procedimentos. São Paulo: Atlas.

[5] Gondim, S. M. G., \& Queiroga F. (2013). Recrutamento e seleção de pessoas. In: Borges, L. O., \& Mourão, L. (Orgs.). O trabalho e as organizações: atuações a partir da psicologia. Porto Alegre: Artmed, 376-402. realizado pela recepcionista da consultoria, permitindo que o fluxo de serviços internos fluísse e não fosse prejudicado.

Além disso, para que os colaboradores monitorem e organizem seus trabalhos de forma mais eficaz, considera-se importante a implementação do Timesheet. Para isso, deve-se conscientizá-los do valor de tal sistema e dos benefícios que ele trará. Como exemplo, todos terão acesso aos horários das entrevistas. Assim, podem evitar marcar duas entrevistas no mesmo horário e, consequentemente, evitar que o candidato à vaga fique esperando, bem como que um entrevistador tenha que esperar o outro finalizar o trabalho.

Ademais, é importante ressaltar que a instituição oferece total liberdade para seus colaboradores, incentivando-os a trazer ideias que colaborem para o crescimento da empresa e escutando a opinião dos mesmos; se importando mais com a produtividade do que com a carga horária, assim, se for do agrado ou da necessidade do colaborador, este pode até mesmo trabalhar de sua casa; incentivando-os a fazer formação fora e, se preciso for, liberam o profissional em determinado período pré-estabelecido.

[6] Hutz, C. S., Bandeira, D. R., \& Trentini, C. M. (2015). Psicometria. Artmed Editora

[7] Marras, J. P. (2009). Administração de Recursos Humanos: do operacional ao estratégico. São Paulo: Saraiva.

[8] Orlickas, E. (1999). Consultoria Interna em RH. São Paulo: Makron.

[9] Pasquali, L. (2001). Técnicas do exame psicológico - TEP. Manual - Fundamentos das técnicas psicológicas. São Paulo: Casa do Psicólogo/Conselho Federal de Psicologia.

[10] Serva, M., \& Jaime, P., Jr. (1995). Observação participante pesquisa em administração: uma postura antropológica. Revista de Administração de Empresas, 35(3), 64-79. Recuperado em 15 de julho, 2017 de http://www.scielo.br/pdf/rae/v35n3/a08v35n3.pdf [11] Verloza, V. (2009) Procedimentos utilizados por psicólogos que atuam em consultorias de gestão de pessoas para realização do processo de recrutamento e seleção (Trabalho de Conclusão de Curso). Palhoça: Universidade do Sul de Santa Catarina. Recuperado em 15 de julho, 2017 de https://www.riuni.unisul.br/bitstream/handle/12345/1 475/100448_Vanessa.pdf?sequence $=1$ 


\section{Bapítulo 11}

\section{ESTRATÉGIA DE EDUCACÃO EMPREENDEDORA ATIVA: A PUFFPET INDÚSTRIA EXPERIENCIA DO FAZER-SABER}

\section{Cecília Arlene Moraes}

\section{Elisabet Aguirre}

\section{Keiko Carolina Moraes Sasaki de Lucena}

Resumo: As expectativas dos estudantes da era digital do curso de Administração exigem novas performances de docentes. A complexidade do problema provoca forte reflexão do papel do professor em sala de aula. Este estudo propõe repensar práticas pedagógicas, apóia em vasto referencial teórico e articula-se com a metodologia ativa de ensino-aprendizagem no que se refere a aprendizagem baseada em projetos. Descreve a estratégia do método de ensino (técnica) de educação empreendedora ativa, uma experiência realizada em uma instituição pública de ensino superior, com a criação da empresa fictícia "PuffPet Indústria Universitária" pelos acadêmicos, com o reuso de garrafas de plásticos pet, em puff. Os gestores-estudantes da indústria universitária aprenderam a apreender, a conviver, a integrar pessoas e formaram ecossistemas inovadores, com práticas de gestão, compartilhando o conhecimento de produção dos puffs, por meio de oficinas. Esse espaço de criação e produção acadêmica foi alcançado, pela atuação docente como facilitador na mediação do processo de aprendizagem, no entendimento que o ensino requer respeito à autonomia e à dignidade do sujeito. Com a observação e a escuta pode-se perceber os anseios discentes. Os procedimentos efetivados estimularam a aprendizagem ativa e progressiva com o propósito do discente protagonizar a sua história, na aposta de se emancipar, tornando-se profissional empreendedor para transformar a sociedade.

Palavras-chave: Administração, sustentabilidade, método de ensino. 


\section{INTRODUÇÃO}

A era digital ou da tecnologia da informação e comunicação (TIC), são expressões utilizadas para designar avanços tecnológicos cibernéticos, advindos da Terceira Revolução Industrial pelo uso de informática e da internet das coisas nas corporações. A tecnologia e a sustentabilidade são temas emergentes em evidência na agenda política de grande parte das potências mundiais. Busca-se a inclusão social, o respeito à diversidade, e o compromisso socioambiental, para assegurar a preservação das gerações futuras.

O estudante do curso de bacharelado em Administração antenado e conectado exige uma performance diferenciada para aprender a apreender e desaprender. Dessa feita, a aprendizagem baseada em projetos é um método de ensino que consiste em permitir os alunos confrontarem as questões e os problemas do mundo real que consideram significativos, determinando como abordá-los e, assim, agindo de maneira cooperativa em busca de resoluções dos problemas.

Considerou-se a atual dinâmica do mercado, com taxa de desocupação no Brasil, segundo o IBGE, de 13,5 milhões de brasileiros em março de 2017, com maior taxa de desemprego desde 2012, afirmou o jornal Brasil Econômico (2017), em 2018 o índice caiu para $12 \%$, contudo alguns estados brasileiros assolados por disfunções de gestão e corrupção provocam instabilidade no mercado.

Neste sentido, há evidências da dificuldade em engajar-se profissionalmente em médias e grandes corporações. A instabilidade política no país reduz a oferta de vagas em concursos públicos e desempregam cargos comissionados.

Diante desse cenário, oportuniza a abertura da trilha possível da intenção de empreender, ser patrão, constituir o próprio negócio, ainda que contenha riscos, porém esses riscos são calculados e dimensionados, ainda que prevaleçam às elevadas taxas tributárias e os encargos sociais no Brasil que concorrem para dificultar o nascimento das empresas, no entanto essa pode ser a alternativa. Portanto, a profissionalização e o exercício da cidadania em ambientes adversos, tende a tornar-se a meta primordial nas instituições de ensino superior.

O mundo do trabalho mudou. O perfil do egresso em Administração também requer mudanças céleres, consistentes e significativas, para o enfrentamento dessas turbulências. Será que as instituições de ensino superior estão preparando esses futuros profissionais para que? Para quem? Para onde? Para qual mercado de trabalho? Para qual segmento?

Diante desta problemática, analisa-se e questiona-se: Qual o modelo, o método estratégico de ensino que poderia ser aplicado no curso de Administração para transformar o potencial do estudante em potência profissional, em uma aprendizagem significativa?Para os universitários do século XXI qual é o sentido da universidade frente à facilidade de acesso à informação, da participação ativa em redes sociais nos quais partilham interesses, práticas, conhecimentos e valores, sem limitações temporais/espaciais bem como diante da possibilidade de trocar idéias e desenvolver pesquisas colaborativas com profissionais do mundo inteiro?

O dilema nas instituições de ensino superior se estende desde a sua infraestrutura organizacional e instalações física de acesso para todos, professores apropriados, acervo de literatura básica e complementar, e, de pessoal de apoio. O corpo docente precisa reinventar, analisar os riscos e as mudanças provocadas pela interação com a cultura digital, dos recursos disponíveis, das interfaces e das linguagens midiáticas ligadas à prática pedagógica, ser continuamente capacitado em práxis pedagógica na tentativa de fomentar novas experiências em sala de aula, e desenvolver processos de encontros acadêmicos, para disseminar 0 conhecimento. A excelência no conhecimento em Administração e titulação do professor, não significa e nem garante o professor excelente em sala de aula no curso de Administração.

Assim, o método de Educação Empreendedora tende a ser uma estratégia para alcançar os anseios desses discentes que clamam pela aplicabilidade da teoria/prática, ensino/serviço, ou seja, um ensino diferenciado, altamente com aplicações de tecnologias em sala de aula.

Este relato descreve uma experiência pedagógica, propondo reflexão sobre ensino e a aprendizagem no contexto do ensino superior, em particular no curso de graduação em Administração de uma universidade pública brasileira que teve como referência a epistemologia baseada e inspirada nas 
metodologias ativas que visam à formação da autonomia do estudante numa fertilização cruzada de práticas de ensino e de conceitos com elevada evidência da pesquisa.

Trilhando por este caminho, o novo papel docente se inscreve como facilitador ou orientador dos trabalhos, não apenas detentor do conhecimento, ou seja, seu papel será de provocar o estudante a refletir e pensar criticamente, mas, sobretudo ao adotar uma atitude sensata ao absorver essa abordagem de ensino e explorar as possibilidades que ela traz aos alunos em suas salas de aula, buscando articular teoria e a prática para tomada de decisão. Em Berbel (2011), o docente deverá "desenvolver o processo de aprender, utilizando experiências reais ou simuladas, visando às condições de solucionar, com sucesso, desafios advindos das atividades essenciais da prática social, em diferentes contextos" (p.29). Logo, os discentes serão preparados para enfrentar os desafios da vida profissional, serem empreendedores.

Dito isso, esta experiência didática possibilitou um ensinar e um aprender cuja atividade do ensino não fosse tomada como a apresentação de uma determinada visão de mundo, consubstanciada em regras de natureza convencional, e que, desse modo, não são possíveis de serem descobertas pelo discente, mas sim ofertando condições metodológicas no sentido em que o aluno uma vez persuadido pelo docente pudesse organizar uma outra maneira a vivência formativa orientada por outras regras por outros movimentos pedagógicos.

Para elucidar este dilema, Gottschalk (2007), revela que o pragmatismo de Dewey no aprender fazendo, inaugura um empirismo que conduz em "consideração a práxis, ou seja, a ideia de que tudo deve ser ensinado em função do seu uso e da sua função na vida. Um conhecimento é considerado verdadeiro se for útil, se resolver os problemas enfrentados pelo homem" (p.462). Dewey enfatiza que o sujeito ativo, requer uma situação de autêntica experiência com propósitos definidos, interessantes e estimulador do pensamento.

Os pilares da instituição de ensino superior federal, criada em 1970, se fundamentam na pluralidade, inclusão e democracia para a formação cidadã. Prima pelo diálogo constante, entre os atores envolvidos, na conciliação do ensino, pesquisa e extensão.
Portanto, oportuniza aos docentes buscarem caminhos alternativos para o surgimento de pessoas sensíveis, respeitosas à diversidade, com força e ideais para mudar o futuro.

O curso de graduação em Administração foi reconhecido em 1978. A primeira turma do curso de Administração graduou-se em 1979, são mais de 40 anos de atividades.

Atualmente, o corpo docente está constituído por 2\% professores pós-doutores, 94\% professores doutores, $1 \%$ em fase final de doutoramento, $2 \%$ mestres e $1 \%$ especialista. Trata-se de força de trabalho competente que promete mudanças substanciais no Departamento de Administração.

Neste arcabouço institucional, o componente curricular, ofertado na modalidade de optativa, Tópicos Emergentes em Administração e ofertada para os alunos do $8^{\circ}$ semestre do curso de Administração, foi palco dos novos movimentos de aprendizagem, apostando em práticas pedagógicas inovadoras, do fazer-saber, sendo uma estratégia do método de educação empreendedora ativa. Apoiou-se no Projeto Ecolíder, criado em 2015, pela docente responsável pela disciplina como atividade de extensão, cujo projeto encontra-se registrado na instituição de ensino para servir de lastro ao desenvolvimento às práticas acadêmicas com sustentabilidade.

O projeto Ecolíder é composto por docentes e discentes do curso de Administração, sendo multidisciplinar, articulado com o grupo de pesquisa Gestão de Tecnologias Estratégicas Ecoinovadoras (TECGESI) e parcerias institucionais. Já desenvolveu ações de coleta e descarte adequado de produtos elétricos eletrônicos, proporcionou a melhoria do paisagismo da área verde da universidade, com sinalização para deficientes visuais além da promoção de palestras e workshops.

O presente estudo é uma ação estratégica do Projeto Ecolíder, para desenvolver competências e habilidades por meio da metodologia de ensino-aprendizagem ativa empreendedora capaz de provocar, instigar a criatividade, a responsabilização no desenvolvimento de ações coletivas em sala de aula em busca de mudanças comportamentais no campo da Administração.

Desta feita, estabeleceu-se um conjunto de cinco etapas para emergir um espaço criativo. $\mathrm{Na}$ concepção deste cenário, eixos temáticos 
nortearam o processo de aprendizagem: 1) leituras e resenhas de artigos e livros; 2) Criação de um grupo de whatsapp e de email, como mecanismos permanentes para a difusão de temas emergentes; 3) Uso do aparelho de celular em sala de aula para pesquisar temas comentados em sala de aula, além de promover o feedback, a integração de informação e comunicação do grupo; 4) Rodada de discussão dos temas emergentes; 5) Meta desafiadora para a construção de uma empresa com aplicação do conhecimento de práticas em Administração.

Para atender o quinto desafio de criar a empresa, foram utilizados o celular e a internet na pesquisar de textos e vídeos, para servir de inspiração e benchmarking. Um dos vídeos sobre produção de puffs, por meio de garrafas pet, chamou a atenção do alunado, pela simplicidade do produto, de fácil execução, com reuso de materiais, assegurando a sustentabilidade e ainda possibilitaria a inclusão social de pessoas com baixa escolaridade. Seria uma grande chance para vivenciar os conhecimentos aprendidos no curso de Administração. Ainda que a técnica da produção de puff seja conhecida e divulgada em vídeo na web, poderia inovar no formato dos produtos ou no uso de outros materiais para decoração.

Assim, a técnica do método de ensino ativo de fazer-saber, oportunizou o nascimento da PuffPet Indústria Universitária, empresa fictícia, organizada e gerida pelos alunos do 8o semestre do Curso de Administração, com orientação docente.

\section{REFERENCIAL TEÓRICO}

As metodologias ativas na educação inovadora vêm com o propósito de repensar o ensino aprendizado, sobretudo nos cursos de graduação com destaque para os cursos da área de saúde iniciando em 2001 com as Diretrizes Curriculares Nacionais do curso de Enfermagem e posteriormente, do curso de Medicina em seu Art.32 (Resolução no3 de 20/06/2014 (DOU 23/06/2014) e Farmácia com parecer aprovado integralmente do Conselho Nacional de Educação publicado DOU 10/08/2017 que determinam a utilização de metodologias ativas em seu processo de ensino-aprendizagem.

Compreendemos que a utilização de metodologias ativas baseia-se não apenas em resolver problemas, mas também promover a autonomia do estudante a pensar criticamente. Igualmente, permite a tomada de decisão consciente do seu papel, de experiências reais ou mesmo simuladas, de forma que o coloque em "xeque" o enfrentamento de desafios para solucionar problemas. Segundo Mitri; Siqueira-Batista; Girardi-de-Mendonça; Morais-Pinto; Meirelles; Pinto-Porto; Moreira; Hoffmann (2008) essa concepção pedagógica baseia-se no aumento da capacidade do discente em participar como agente de transformação social, durante o processo de detecção de problemas reais e de busca por soluções originais.

A metodologia ativa, assim, se caracteriza pela inter-relação entre educação, cultura, sociedade, política e escola, utilizando-se de meios criativos, centrados na atividade pedagógica dos alunos com o objetivo de propiciar a aprendizagem significativa. William James, John Dewey e Édouard Claparède, no advento da Escola Nova, defendiam uma metodologia de ensino centrada na aprendizagem pela experiência e no desenvolvimento da autonomia do aprendiz

Para corroborar com essa proposta, temos o pressuposto teórico na perspectiva metodológica do aprender fazendo, que se fundamenta na concepção de Dewey (18591952), pelo discurso pedagógico que renova as terminologias mais clássicas e reformulam algumas expressões em que há um trajeto que precede a formulação de conceito e princípios, caminho esse ancorado na experiência empírica do estudante ou mesmo na interação entre ambos. Para compreender melhor a base teórica da proposta pedagógica do aprender fazendo inspirada em Dewey, cabe aqui retomar o conceito do pragmatismo enquanto uma filosofia de vida.

O pragmatismo em Peirce (1839-1914) sustenta que o significado de um conceito (uma palavra, uma frase, um texto ou um discurso) consiste nas consequências práticas concebíveis de sua aplicação. Significa compreender que uma aprendizagem, mesmo no ensino superior, que não tenha qualquer relação com a experiência é desprovida de sentido. O pragmatismo estranha a ideia de verdade e certeza inatas ou absolutas. Dewey vem propor uma educação entendida como processo de reconstrução e reorganização de experiências pelo discente. Para tanto, elenca 
a iniciativa, a originalidade e a cooperação como descritores deste aprender.

Nesta vertente, Dewey (1959a) busca concretizar o ideal democrático da sociedade recorre à educação como um fenômeno de extremo e real significado no sentido de proporcionar um espaço escolar democrático para as diferentes classes sociais e que por meio da adoção de metodologia fundamentada no interesse e na experiência do discente, de modo que possa garantir a perpetuação dos valores sociais, pois cada aluno deve-se enriquecer com as experiências dos outros, entrando numa relação pedagógica de interajuda.

Fica-nos evidente que para Dewey, a Educação e, em especial, a escola, possui uma função de coordenar a vida mental de cada indivíduo nas diversas influências dentro do meio social onde o indivíduo vive.

O princípio educativo é fazer com que a aprendizagem de todo conhecimento leve à prática e, assim colocado, Dewey (1959b) vem propor uma educação cujo método tome em conta a experiência de cada pessoa, não como uma atividade isolada do sujeito com o mundo, mas que este se integre com todos os demais sujeitos do processo.

A educação em Dewey segundo Ozmon e Craver (2004) é um "processo pelo qual uma cultura é transmitida de geração para geração, acontecendo por meio da comunicação de hábitos, atividades, pensamentos e sentimentos dos membros mais velhos da cultura aos mais novos" (p.151). É por isso que a educação deve alçar novos vôos, fazendo parte da vida, das vivencias do cotidiano, e ademais deve impulsionar estabelecer relações, tomar consciência, construir conhecimentos e reconstruir experiências Os planos de ensino deveriam ser organizados segundo as necessidades do aluno, conciliados aos anseios do mundo do trabalho.

Em assim sendo, poder-se-ia mostrar que o bom ensino universitário deve estimular a iniciativa, promovendo condição para a produção e exploração de interesse, identificando problemas reais, para oportunizar um ambiente de oportunidades e criativo ao interesse latente de apreender do discente.

Destaca-se aqui, todavia, que a finalidade da educação para Dewey (1974) não era somente integrar o discente na sociedade, mas dotá-lo de conhecimento e competências que permitissem a sua participação na transformação da sociedade. Portanto, o conhecimento é aquele que prove da experiência e está requer uma atividade, uma ação pedagógica, gerando uma aprendizagem que a seu ver só tem significado quando está é útil para o discente que consegue ver sua aplicação concreta na vida real.

Foi exatamente nesta direção, diante do desafio lançado, que oportunizamos aos alunos do curso de Administração a possibilidade de resolver o problema, com o uso da tecnologia em sala de aula, o celular, a internet para buscar inspiração de como conceber a empresa, em processo de integração dos ecossistemas, que pudessem aplicar os conhecimentos adquiridos no curso de Administração, voltada para o terceiro milênio, com responsabilidade socioambiental, eticamente correta com processo de gestão inovador para agregação de valor a sociedade.

Logo, segundo Mitri et al (2008) a metodologia ativa tem permitido a articulação entre a universidade, o serviço e a comunidade, por possibilitar uma leitura e intervenção consistente sobre a realidade, valorizar todos os atores no processo de construção coletiva e seus diferentes conhecimentos e promover a liberdade no processo de pensar e no trabalho em equipe.

Na visão deweyana o uso da problematização no ensino-aprendizagem é de real sentido para que ocorra o conhecimento significativo, de vez que a aprendizagem se desenvolve mediante experiências pedagógicas vivenciadas pelo discente, em processo de ampliação da técnica, do intelecto ao se colocar como ator principal do processo ensino-aprendizagem. Toma assim, o princípio de que os discentes aprendem melhor realizando tarefas associadas ao conteúdo programáticos ensinados, num sentido de que se estimulados a experimentar e pensar por si mesmos, o processo da aprendizagem se concretiza.

Paulo Freire (1996), citado na obra Metodologias ativas para uma educação inovadora organizada por Lilian Bacich e José Moran, destaca a educação dialógica, participativa e conscientizadora, que se desenvolve por meio da problematização da realidade na sua apreensão e transformação. Na página XI da obra citada (2018), os 
autores destacam que " significa criar situações para despertar a curiosidade dos alunos e thes permitir pensar o concreto, conscientizar-se da realidade, questioná-la e construir conhecimentos para transformá-la superando a idéia de que ensinar é sinônimo de transferir conhecimento".

Para mobilizar essa ação pedagógica, em Dewey (1974), o professor deve apresentar os conteúdos programáticos na forma de questões ou problemas e jamais dar de antemão respostas ou soluções prontas, conceitos e definições já elaborados. Deverá sim, estimular o raciocínio dos discentes para construir seus próprios conceitos para depois confrontar com conhecimentos sistematizados. O professor deverá atuar como facilitador do processo da aprendizagem, apoiador ao desenvolvimento do espírito crítico, criativo e incessante provocador da reconstrução de experiência reforçada pela moderna didática do construtivismo e das Diretrizes Curriculares Nacionais.

A problematização se distingue, em Berbel (1998), porque visa mobilizar o potencial social, político e ético dos acadêmicos para agir politicamente, como cidadãos e profissionais em formação, como agentes sociais que participam da construção da história de seu tempo, ainda que em pequena dimensão. Trata-se de uma proposta metodológica colaborativa, construtivista e contextual com foco em desvendar a realidade e transformá-la, porque há uma intencionalidade política no ato de educar. Instiga e contribui para a mudança de mentalidade, requerendo de todos os acadêmicos (agentes sociais) envolvidos nesse processo educativo a reavaliação de seus papeis ressignificando, coletivamente, o processo de aprendizagem. Portanto, a metodologia educacional empreendedora ativa, traz a problematização como estratégia de atuação e propõe aparelhar a construção da estrutura cognitiva dos acadêmicos para solucionar problemas com temáticas específicas relativas ao ensino de sua profissão.

Mitri et al (2008) determina que uma educação voltada para as relações sociais emergentes deve ser capaz de desencadear uma visão do todo, de rede, de transdisciplinaridade e de interdependência - as quais devem ser levadas a sério, especialmente em um contexto de emergência dos novos referenciais da complexidade, do pensamento sistêmico e da ecologia (de saberes).

Na perspectiva de Dewey (1959b), não há outra saída para as questões que afligem a educação a não ser adoção de uma revolução educacional que leve em conta a experiência humana realizável como produto da ação. Resulta, portanto, ser a vida nada mais que um tecido de experiências de toda espécie ou de uma longa aprendizagem, uma vez que não podemos viver sem estar constantemente fazendo e reconstruindo o campo experiencial, percebendo mais agudamente $o$ sentido e com isso nos habilitamos a melhor conduzir o curso de Administração por meio de nossas experiências futuras. Vivemos, experimentamos e aprendemos ao mesmo tempo! Este é o processo de transformação do tecido social.

\section{METODOLOGIA}

Na percepção de Thomas Kuhn (1998), as teorias aceitas pela comunidade científica são aquelas que se coadunam, com os paradigmas do seu momento histórico. Khun descreve paradigmas como conjunto de modelos conceituais que certa comunidade acorda entre si e mantém a coesão do grupo. A mente rebelde provoca revoluções, com a probabilidade de grandes avanços, vertente esta que se assenta esse relato técnico.

Segundo Biancolino; Kniess; Maccari e Rabechini (2012) há uma distinção entre o "método de trabalho profissional e de pesquisa (aplicada ou teórica) e o método de apresentação de seus resultados, em qualquer área do conhecimento" (p.296). Esses autores conduziram nesta linha, um protocolo de propósitos profissionais de elaboração de relato técnico, de aplicação prática, porém com rigor da pesquisa científica.

O campo da administração, neste contexto para Biancolino et al (2012) "é por natureza, de objetivo aplicado, uma vez que envolve estudos direcionados ao melhor funcionamento das organizações" (p. 297). Neste sentido, apresenta-se esta experiência da aplicação de método de ensino, como uma boa prática em educação empreendedora ativa, em uma organização educacional, na disciplina Tópicos Emergentes em Administração, para os discentes do oitavo semestre do curso de Administração de uma instituição pública federal de ensino superior. 
Este ensaio na modalidade de relato técnico tem como produto final descrever a técnica usada do método de educação empreendedora ativa, que estimula a prática de trabalhos desenvolvidos pelos discentes, por meio do Projeto Ecolíder, de modo a agregar valor contributivo para discentes e docentes, que simultaneamente ensinam e aprendem. E, para a ciência da Administração a demonstração de uma boa prática educacional empreendedora ativa no processo de aprendizagem voltada para um novo perfil de egressos profissionais em administração.

O primeiro movimento foi a percepção dos anseios dos discentes em final de curso, que buscavam técnicas, tecnologias, queriam atividades práticas e expressavam que as aulas teóricas eram cansativas. Almejavam algo diferente que pudesse efetivamente contribuir em sua formação profissional. Portanto, a observação e a sensibilidade da docente junto a sua audiência foi o primeiro passo, para identificar como seria o processo de aprendizagem de participação direta e coletiva da construção do aprendizado.

O Plano de Ensino foi apresentado, demonstrando a carga horária de [64] horas/aula previstas no Projeto Pedagógico do Curso de Administração e a ementa definida pelo curso, porém havia possibilidade de inovação, tornaria possível a adequação do contexto. Portanto, seriam [30] horas/aula de atividades teóricas e [34] horas/aula de atividades práticas, contemplava as aspirações dos discentes matriculados na disciplina optativa Tópicos Emergentes em Administração.

As [30] horas/aula teóricas consistiram no design do cenário atual de forma dialógica, em rodada de conversa sobre o livro "Mindset: a nova psicologia do sucesso", de Carol Dweck (2017), o livro diz respeito a um modelo mental adequado para enfrentar desafios. Outros livros também foram apresentados, lidos e resenhados: "O ócio criativo", de Domenico Di Masi (2000) e "Modernidade Liquida", de Zygmunt Bauman (2001). As temáticas abordadas foram discutidas em sala de aula, enfatizando a criatividade, a resiliência, os aspectos da sustentabilidade para as gerações futuras, com uso também de vídeos.

Os discentes acessariam os vídeos discutidos e o conteúdo ministrado em sala de aula pelo celular em casa, como também foram incentivados a ver outros vídeos correlacionados com o tema, utilizando a técnica de sala invertida. Logo, o conhecimento de sala de aula, invadia sua vida, fazia parte dela, porque se discutia no canal do grupo pelo celular, após a aula em outros horários e até finais de semana.

Distintos materiais foram incorporados ao grupo, pelos discentes, enriquecendo o processo de aprendizagem. Discutiu-se sobre a ambisteridade organizacional, a capacidade de uma organização alinhar sua capacidade interna para ajustarem-se as pressões em um mundo competitivo. Ferramentas de gestão foram reapresentadas, PDCA, 5W2H, Design Thinking, Canvas entre outras tecnologias de gestão que apoiassem 0 processo de reaprender o conteúdo em Administração.

$\mathrm{Na}$ segunda etapa, o desafio proposto foi a criação de uma empresa, para aplicar conceitos e tecnologias de gestão. Estariam livres para se inspirar, por meio de benchmarking. A internet pelo celular foram aliados nesse processo. Vídeos, textos foram pesquisados e a aplicação da técnica de brainstorming ocorria naturalmente para desenhar o negócio e elaborar o planejamento estratégico. No turbilhão dessas ideias, nasceu a PuffPet Indústria Universitária. A organização dos times foi segundo a aptidão de cada participante, para as áreas de marketing, processos, produção, finanças e de gestão de pessoas.

Os discentes criaram a logomarca, o conceito do produto, a missão, a visão de futuro e os valores da empresa; definiram a estrutura organizacional e construíram o organograma, funcionograma, lotacionograma, o fluxo de processos para a produção do produto puff.

Para o protótipo, utilizaram como insumo garrafas pets, papelão e retalhos de tecido, além dos acessórios cola, fita adesiva, tesoura e estilete. A experiência em administração de produção, iniciou-se com o planejamento, definindo o formato da produção, optaram pela produção em célula, de forma mais colaborativa. A cadeia de suprimentos de materiais também foi analisada, bem como os aspectos financeiros, de quanto seria o preço final do produto. As figuras que se seguem demonstram parte do processo de criação dos estudantes da empresa fictícia, simulando e experienciando um processo de produção. 
Figura 1 - Logomarca produzida pelos acadêmicos do time de marketing, matriculados na disciplina Tópicos Emergentes em Administração, do curso de Administração.
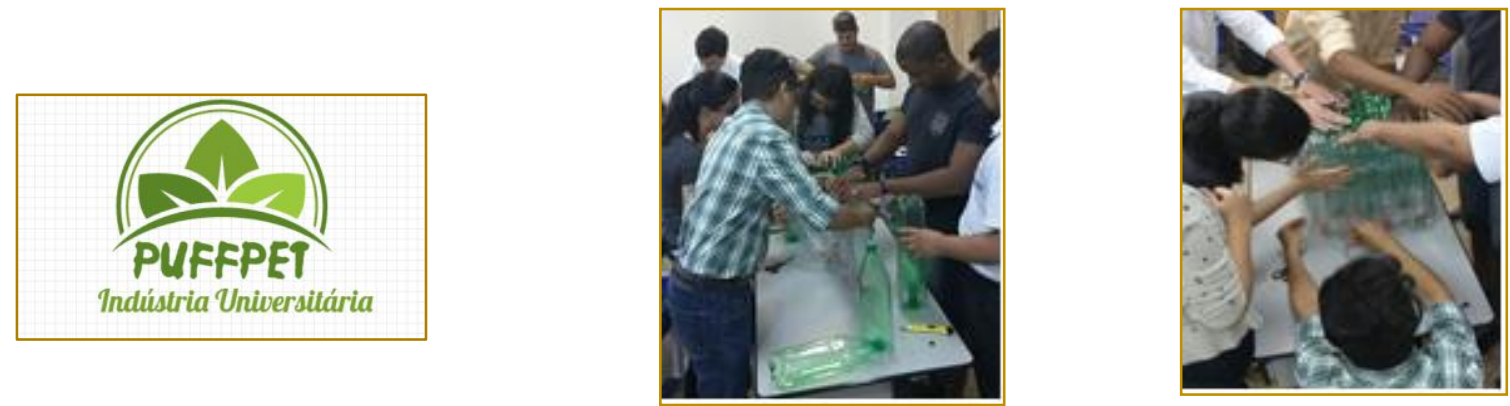

Figuras 2 e 3- Processos de produção do Protótipo do Puff organizado pelos acadêmicos do Curso de Administração, de forma colaborativa com o reuso de garrafas pets.
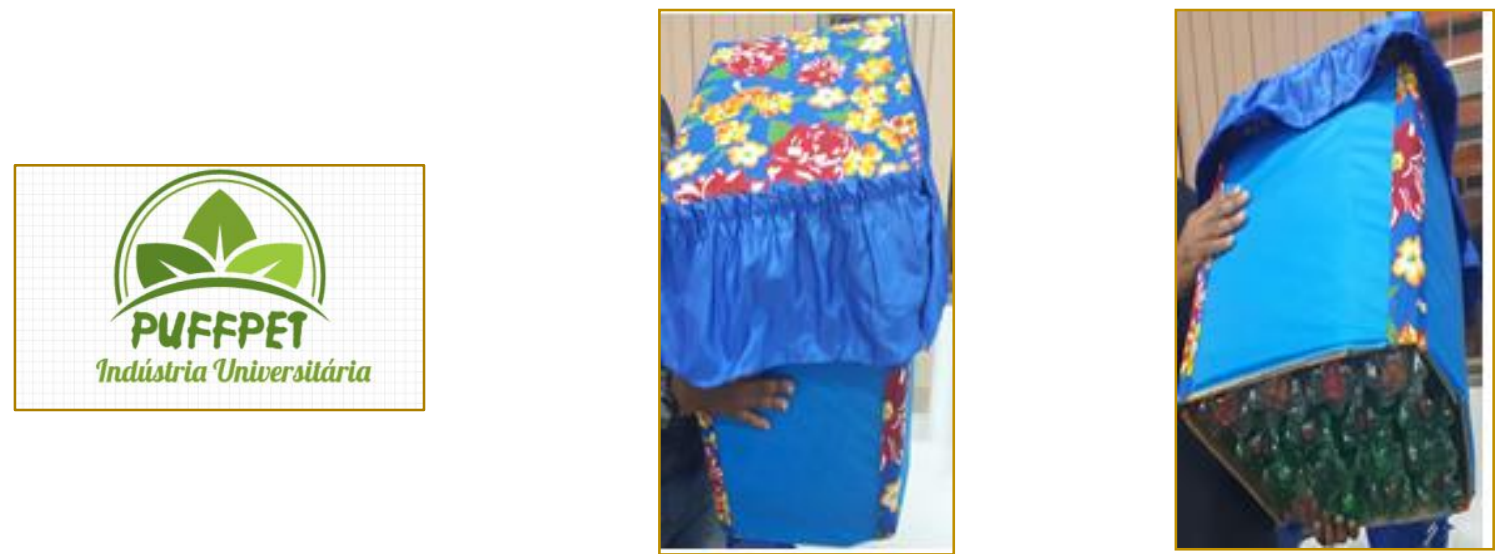

Figuras 4 e 5 - Demonstração do Protótipo da frente e do fundo do puff, produzido pelos acadêmicos da PuffPet Indústria Universitária do Curso de Administração

\section{ANÁLISE DOS RESULTADOS OBTIDOS}

Diante dos anseios requeridos pela audiência, sendo o celular a extensão da mão dos jovens universitários, foi fácil a adesão pelos estudantes pela forma lúdica de se inserir no processo de autogestão de aprendizagem. Canalizou-se a energia vibrante dos estudantes para um propósito interessante e aceito pelo grupo. Utilizou-se a observação e participação direta, pesquisa na internet para aguçar a curiosidade e instigar os alunos a perquirir outros caminhos.

O maior dilema da docente foi reter a atenção dos discentes para provocá-los a novas descobertas. A técnica usada foi a empatia, se colocar no lugar do outro, participando ativamente do processo de aprendizagem junto com o discente e "saindo de cena", para que o discente pudesse ser o protagonista da aula. A medida que a docente cedeu o lugar para as descobertas, ocorreu imediatamente a ascensão e autonomia de todos os discentes, desejosos em conhecer, interessados pelo tema proposto, tinham uma meta e aguerridos queriam conquistá-la, porque foram co-responsáveis pelo processo. Após a conquista da retenção da atenção do discente para engajar na proposta, novo dilema apareceu, traduzido pelo medo de não conseguir realizar a tarefa em tempo hábil, porque o curso era noturno, nunca fizeram nada parecido, era um mundo desconhecido. A técnica da empatia foi reforçada, para a prática do encorajamento motivacional, pelo respeito a individualidade do sujeito, por sua potencialidade e competência. Formaram-se, neste instante, os laços de confiança, para uma construção coletiva, guiada pela facilitadora presente neste percurso formativo. A aprendizagem foi coletiva e inovadora para todos os atores envolvidos, e respondeu aos anseios e demandas dos discentes, que aspiravam por um novo método de ensino. A PuffPet Indústria Universitária foi o palco para 
a aprendizagem de tecnologias de gestão, mas sobretudo de prepará-los para vida, ser bons profissionais, competentes, briosos, éticos e cidadãos em qualquer circunstâncias, prontos para enfrentar os desafios.

Nesta perspectiva, o tema responsabilidade socioambiental, predominou na consciência dos discentes, desde a primeira fase de intervenção do conhecimento. O cerne da aprendizagem foi a consciência de ser cidadão do mundo, para aprender a apreender, aprender a conviver, e atuar em inúmeras facetas organizacionais.

O uso da reciclagem e o compartilhamento do conhecimento da produção do puff, por meio de oficinas, demonstraram o aprendizado de valores humanos, de cooperação e de respeito à diversidade. $O$ convite a comunidade acadêmica e sua extensão as senhoras, que atuam na limpeza da faculdade, de empresa terceirizada, comprovam a sensibilidade despertada, pois entenderam que o produto puff poderia servir de renda para elas, bem como, o descarte adequado com 0 reuso de materiais recicláveis.

Diante do exposto e pensando na trilha composta por Bauman (2001) "o momento da modernidade fluida, são os elos que entrelaçam as escolhas individuais em projetos e ações coletivas" (p.12). Nesta vertente, quebrar as regras, na tentativa de desenvolver e emancipar os discentes, para torná-lo protagonista de sua história, no tempo e espaço, com trabalho colaborativo e coletivo, voltado para a comunidade em que vive, foi a intencionalidade desta experiência.

Reforço esse posicionamento, por compreender em Bauman (2001) a arte de "administrar significa responsabilizar-se pelo bem-estar geral do lugar, mesmo que em

\section{REFERÊNCIAS}

[1] Bacich, Lilian, Moran, José (org.). Metodologias ativas para uma educação inovadora: uma abordagem teórico-prática. Porto Alegre: Penso, 2018.

[2] Bauman, Zigmunt (2001). Modernidade Líquida. Tradução Plínio Dentzien. Rio de Janeiro: Zahar.

[3] Berbel, N.A.N. (1998). A problematização e a aprendizagem baseada em problemas: diferentes termos ou caminhos. Interface Comum Saúde, Educação, v. 2 (2)139 - 54.

[4] Berbel, N.A.N (2011). As metodologias ativas e a promoção de autonomia de nome de um interesse pessoal consciente... requer presença, e engajamento, pelo menos como uma confrontação e um cabo-de-guerra permanentes" (p. 17).

\section{CONSIDERAÇÕES FINAIS}

A estratégia educacional do método de ensino aplicado na turma do oitavo semestre noturno do curso de Administração, prima pela subjetividade, da intenção da docente em atuar por meio da educação empreendedora ativa, aguçando a sensibilidade frente a sua audiência, para perceber os anseios discentes.

Aguçar a sua curiosidade, sua crítica para resolver problemas. Para tanto, deve observar, sentir, ouvir o discente e tentar descortinar o véu que encobre o seu potencial latente. Valores como empatia, respeito a diversidade são caminhos na formação desses laços de confiança, para que o discente possa se desabrochar para o aprender. O discente autor de sua história de vida tende a se emancipar como profissional. O papel docente no campo de Administração é liderar, ser um gestor de pessoas, para que os discentes, no processo do encontro acadêmico (aula) aprendam primeiro o significado da vida. Na visão deweyana, ainda que aprendam conceitos, técnicas, e tecnologias, esses conhecimentos não são perenes, são incertos, porque a ciência é um contínuo, é uma interrogação constante e está em pleno movimento de novos saberes.

O essencial é a consciência de seu papel no mundo, como profissional empreendedor, agente social ativo em constante aprendizado, para transformar a sociedade. Quiçá o relato dessa experiência possa ser socializado a comunidade acadêmica docente, na expectativa de agregar valor em sua práxis pedagógica.

estuantes.Semina: Ciências Sociais e Humanas, Londrina, v.32, nำ, p.25-40 (jan/jun)

[5] Biancolino, C. A., Kniess, C. T., Maccari, E. A., \& Rabechini Jr., R. (2012). Protocolo para Elaboração de Relatos de Produção Técnica. Revista Gestão e Projetos, 3(2), 294-307.

[6] Brasil Econômico (2017). Desemprego atinge 13,5 milhões de brasileiros; maior taxa desde 2012. Jornal eletrônico em 31/03/2017 10:58. Recuperado em 10 de agosto de 2017 de http://economia.ig.com.br/2017-03-31/desempregodados-ibge.html 
[7] Dewey, John (1959a). Democracia e Educação. Vol. 21. 3 ed. São Paulo: Nacional.

[8] (1959b). Vida e Educação. Vol.

76. 5 ed. São Paulo: Nacional.

[9] (1974). On Education. The University of Chicago press, Chicago.

[10] Dweck, Carol S. (2017). Mindset: A nova psicologia do sucesso. São Paulo: Objetiva.

[11] Di Masi, Domenico (2000). O ócio criativo. 3. ed. Tradução Léa Manzi. Rio de Janeiro: Sextante.

[12] Gottschalk, Crisitane, Maria Cornélia (2007). Educação e Pesquisa. V.33, n. 3, São Paulo, p.459/470 (set/dez).
[13] Kohun, Thomas S. (1998). A estrutura das revoluções científicas. 5.ed. São Paulo: Perspectivas.

[14] Mitri, Sandra M., Siqueira-Batista, Rodrigo, Girardi-de-Mendonça, José Márcio, Morais-Pinto, Neila Maria, Meirelles, Cynthia de A.B, Pinto-Porto, Cláudia, Moreira Tânia, \& Hoffmann, Leandro, M.A (2008). Metodologias ativas de ensino aprendizagem na formação profissional em saúde: debates atuais. Ciência \& Saúde Coletiva. 13 (Sup 2), p.2133-2144.

[15] Ozmon, Howard A. \& Craver, Samuel M. (2004). Fundamentos Filosóficos da Educação. 6 ed. São Paulo: Artemed. 


\section{Bapítulo 12}

\section{DESENVOLVIMENTO DE HABILIDADES TÉCNICAS E ADMINISTRATIVAS: RELATO DE CAPACITAÇÃO COM ESTUDANTES QUE ATUAM EM ESTÁGIO NÃO OBRIGATÓRIO}

\section{Kamilla Clausen da Silva \\ Victória Oliveira Santos Barbosa Mendes \\ Júlia Maria Florentino da Mota \\ Alessandro Vinicius de Paula}

Resumo: O presente trabalho visa relatar a experiência de estágio obrigatório que promoveu a inserção das discentes do curso de Psicologia da Universidade Federal de Mato Grosso (UFMT) em contextos da Psicologia Organizacional e do Trabalho (POT). Tal inserção objetivou aguçar o olhar das discentes para as relações de trabalho e como tais relações afetam a subjetividade humana, de forma que durante sua formação o graduando entre em contato com a atuação do profissional de Psicologia da área de POT. O estágio foi realizado no Setor de estágios da Coordenação de Desenvolvimento Humano (CDH) da UFMT, e contemplou as etapas de planejamento e execução de um projeto de capacitação em habilidades técnicas e administrativas para estagiários não-obrigatórios remunerados da UFMT. Como metodologia, optou-se por dividir o treinamento em quatro módulos semanais que empregaram técnicas de dinâmicas e aulas expositivas. Ao fim de cada módulo, foram aplicados questionários de avaliação de encontro e, por meio de um planejamento flexível, visou-se manter um olhar sensível às demandas apresentadas pelos participantes durante todo o processo de capacitação. A partir dos resultados dos questionários, tanto de avaliação de encontro quanto de reação/satisfação, foi possível notar que a capacitação foi de grande valia e auxiliou os capacitandos no desenvolvimento das habilidades técnicas e administrativas.

Palavras-chave: Capacitação; Estágio não-obrigatório remunerado; Psicologia Organizacional e do Trabalho 


\section{INTRODUÇÃO}

Apresentamos o relato de um projeto de intervenção realizado por estagiárias do $5^{\circ}$ semestre do curso de graduação em Psicologia da Universidade Federal de Mato Grosso (UFMT), campus Cuiabá, durante o Estágio Básico III (EB III). O estágio permite a inserção em contextos da Psicologia Organizacional e do Trabalho (POT) e prevê carga horária mínima de 30h em campo e 30h de supervisões. O EB III possui como objetivo aliar a teoria com a prática e, dessa forma, proporcionar aos discentes de Psicologia o contato com diversos modelos e práticas da Psicologia Organizacional e do Trabalho (POT). Além disso, promove $\mathrm{O}$ desenvolvimento de habilidades, conhecimentos e práticas para atuação profissional através da observação participante e implementação de intervenções psicossociais na área de POT.

O estágio obrigatório aqui relatado foi realizado no $1^{\circ}$ semestre de 2017, contou como campo de estágio a Coordenação de Desenvolvimento Humano ${ }^{1}$ (CDH) da UFMT, a qual possui um Setor de estágio. Tal Setor é encarregado pela gestão de estagiários na modalidade não-obrigatório remunerado, e abrange além do campus Cuiabá da UFMT, também as unidades do interior situadas nas cidades de Sinop, Barra do Garças e Rondonópolis. Além disso, o referido Setor ainda se responsabiliza pelos estagiários vindos de instituições conveniadas: Universidade de Cuiabá (UNIC) e Instituto Federal de Mato Grosso (IFMT). O Setor presta serviço à Universidade e à população acadêmica, visando conciliar um meio de oportunidades para os alunos que queiram desenvolver suas habilidades em estágio nãoobrigatório, e ainda atender às necessidades dos setores da instituição. Com isso, O Setor atua de acordo com a Lei $n^{\circ} 11.788 / 2008$ (Brasil, 2008), que dispõe sobre o estágio de estudantes:

estágio é ato educativo escolar supervisionado, desenvolvido no ambiente de trabalho, que visa a preparação para o trabalho produtivo de educandos que estejam frequentando o ensino regular em instituições de educação superior, de educação profissional, de ensino médio, da educação

1 A equipe agradece à Coordenação de Desenvolvimento Humano e o Setor de Estágios da Universidade Federal de Mato Grosso pela parceria e apoio. especial e dos anos finais do ensino fundamental, na modalidade profissional da educação de jovens e adultos. (Brasil, 2008)

Dessa forma, o Setor de estágios oferece um importante auxílio social, considerando que esta é uma oportunidade para o futuro profissional entrar em contato com a realidade que está sendo inserido.

É importante ressaltar que a construção deste projeto de intervenção foi realizada por meio de três equipes de estagiárias, divididas em três semestres subsequentes. Assim, no semestre 2016/10 foi realizado o Levantamento de Necessidades de Treinamento (LNT), surgindo, desse modo, a proposta de Capacitação para os estagiários remunerados da UFMT. Em 2016/2으 foi formulado o planejamento e programação do projeto, enquanto que, em $2017 / 1^{\circ}$, tal proposta foi revisada e aprimorada, gerando um novo cronograma de execução com algumas alterações significativas. Para isso, foi questionado se um curso de capacitação seria uma maneira eficiente de sanar as dificuldades apontadas pelos estagiários. Com base nesta pergunta, procurou-se elaborar um cronograma de execução que englobasse da melhor forma possivel os dados colhidos por meio do LNT. Além disso, optou-se por um planejamento flexível, que pudesse ser adaptado às informações levantadas por meio de questionários de avaliação aplicados em cada encontro.

Nesse sentido, o primeiro módulo objetivou realizar um breve histórico do projeto, bem como relatar informações referentes ao setor de estágio, Lei do estágio e Avaliação de Desempenho. O segundo módulo, por sua vez, objetivou promover discussões acerca do atendimento ao público e o desenvolvimento de habilidades tais como atenção, comunicação, proatividade e paciência. Ademais, este módulo também suscitou reflexões referentes à importância do trabalho em equipe. $\mathrm{O}$ terceiro módulo teve como tema a elaboração de comunicação oficial e a importância da comunicação nas organizações. Enfim, no quarto módulo, a partir dos resultados levantados no questionário de interesses aplicado no primeiro encontro, discutiu-se o assédio moral nas Organizações.

Assim, a partir das análises das demandas apresentadas pelos estagiários nãoobrigatórios da UFMT no Levantamento das Necessidades de Treinamento, o Curso de 
Capacitação: Desenvolvendo Habilidades Técnicas e Administrativas, foco do presente relato, teve como objetivo geral realizar o treinamento de estagiários contratados pelo $\mathrm{CDH}$, com vistas à promoção de capacitação para a realização de atividades e o desenvolvimento organizacional. Ademais, o curso visou, em seus objetivos específicos, desenvolver habilidades técnicas e habilidades administrativas dos estagiários não-obrigatórios; apresentar informações que desenvolvam conhecimentos necessários ao desempenho das atividades; estreitar vínculos entre os estagiários e o setor responsável pelo acompanhamento dos mesmos e, por fim, contribuir com o desenvolvimento organizacional do Setor de estágio nãoobrigatório.

\section{REFERENCIAL TEÓRICO}

De acordo com Marras (2009), o Treinamento e Desenvolvimento (T\&D) é uma subárea de Recursos Humanos, configurando-se em "um processo de assimilação cultural a curto prazo, que objetiva repassar ou reciclar conhecimentos, habilidades ou atitudes relacionadas diretamente à execução de tarefas ou à sua otimização no trabalho" (Marras, 2009, p. 145). Ainda de acordo com esse autor, o treinamento possui objetivos específicos e genéricos. Os específicos estão ligados: 1) formação profissional, no qual são adquiridos conhecimentos para que a pessoa desenvolva de forma adequada as atividades laborais; 2) especialização, isto é, treinar de forma mais aprofundada o trabalhador para uma área de atividade específica, engendrado dessa maneira a otimização dos resultados; e 3) reciclagem, que consiste em aperfeiçoar e atualizar conceitos já aprendidos.

No que se refere ao processo de treinamento, o mesmo é dividido em quatro etapas: diagnóstico, planejamento/programação, execução e, por fim, a avaliação. Neste presente relato, conforme citado na Introdução, a etapa de diagnóstico ficou a cargo das estagiárias do Estágio Básico III (EB III) durante o período letivo 2016/1‥ Estas realizaram o Levantamento de Necessidades de Treinamento (LNT), que de acordo com Marras (2009), consiste basicamente em se propor a responder: 1ㅇ) Quem deve ser treinado? e $2^{\circ}$ ) O que deve ser aprendido? As estagiárias do EB III no período 2016/2º ficaram responsáveis pelo planejamento e programação do treinamento a ser desenvolvido para suprir as carências diagnosticadas pelo LNT, dando origem a um projeto piloto.

Segundo Marras (2009), o planejamento proporciona organizar as prioridades entre 0 necessário e o possível, tendo em vista os recursos disponíveis nas organizações. Nessa perspectiva, França (2009) apresenta que para a elaboração de um planejamento de treinamento, deve-se, primeiramente, definir quais são os Conhecimentos, Habilidades e Atitudes (CHA) de cada cargo. No que se refere ao conhecimento, realiza-se um levantamento de necessidades de conhecimentos de cada colaborador, sendo este dividido em conhecimentos de ferramentas de interatividade entre as pessoas da equipe e os conhecimentos técnicos científicos. Além disso, França (2009) discorre que nessa etapa ocorre a descrição das habilidades necessárias para que cada colaborador atinja um bom desempenho, sendo elas classificadas em habilidades voltadas à interação social, habilidades referentes ao processo e à qualidade e habilidades voltadas à obtenção de resultados. Ainda nessa perspectiva, deve-se identificar as atitudes exigidas para cada cargo através dos diversos instrumentos de mensuração. Em suma, atenta-se para o fato de que "cada cargo exige habilidades em graus diferentes" (França, 2009, p. 91).

Em relação à programação do treinamento, esta permite dividir o mesmo em módulos e analisar a importância e abrangência destes. Dessa forma, foi apenas com as estagiárias 2017/1 que o projeto piloto aqui apresentado foi adaptado, finalizado e executado. Para a adaptação da programação, as estagiárias contaram com algumas técnicas utilizadas para a realização do treinamento, sendo uma delas a aula expositiva. Conforme pontua Marras (2009), o expositor apresenta ao grupo, de forma oral, determinados conhecimentos necessários. Desta forma, apresenta-se como "uma técnica exigida em praticamente todas as ocasiões de treinamento; porém, é um instrumento limitado quanto à abrangência didática $e$, normalmente, é utilizado em conjunto com outras técnicas" (Marras, 2009, p. 158).

Além disso, empregou-se a técnica de workshop, a qual segundo Marras (2009) possibilita que os treinandos reflitam em grupo e explorem possíveis soluções para problemas do cotidiano. Utilizou-se também o 
recurso da dramatização, ainda de acordo com Marras (2009), é uma

[...] técnica muito utilizada em módulos nos quais há ênfase na análise comportamental e na reação de terceiros em uma certa situação. O treinando assume um determinado 'papel', previamente dado pelo instrutor e trabalha 0 script a exemplo de um ator de cinema ou televisão. A dramatização busca muito mais trabalhar ângulos emocionais do que racionais (Marras, 2009, p. 158).

Outra metodologia aplicada foi a roda de conversa que, segundo Bechelli e Santos (2005 como citado em Costa et al., 2015, p. 32), pode ser entendida como uma intervenção "designada por um método que possibilita a discussão, expressão de desejos e desabafos, tendo como resultado as trocas e o aprendizado". Neste sentido, Afonso e Abade (2008) salientam que a roda de conversa possui um coordenador, o qual tem a função de possibilitar a circulação da palavra, incentivando a participação de todos do grupo e delimitando limites quando preciso.

Por fim, utilizaram-se ainda dinâmicas em grupo, as quais Andrade (1999) apresenta como sendo uma técnica que configura-se em colocar um grupo de pessoas em movimento por meio de jogos, brincadeiras, vivência de situações simuladas, proporcionando assim, sensações da vida real. Nessa perspectiva, Andrade (1999) afirma que as dinâmicas devem ser aplicadas quando estabelecem-se objetivos claros com busca em resultados preestabelecidos em que os participantes poderão agir de modo autêntico, desenvolvendo o aperfeiçoamento de sua conduta em situações de auto avaliação. Elas podem ser utilizadas em "empresas, escolas, organizações em geral e aplicadas em seleção, treinamento e desenvolvimento, integração, avaliação, descontração, levantamento de necessidades e na clínica" (Andrade, 1999, p. 19).

A execução do treinamento é a terceira etapa. Consiste na aplicação prática de tudo aquilo que foi planejado e programado. Segundo Marras (2009), é importante atentar-se na qualidade da aplicação dos módulos e na eficiência dos resultados. Na qualidade da aplicação está envolvida a didática dos instrutores; preparo técnico e lógica para a execução do módulo, isto é, deixar claro os objetivos do mesmo; qualidade dos recursos utilizados, como por exemplo aparelhos multimídias; e técnicas utilizadas (aula expositiva, estudo de caso, dramatização, workshop, brainstorming, simulação, painel, simpósio, palestra e conferência).

Nessa perspectiva, França (2009) também ressalta que para 0 treinamento ser considerado como efetivo, deverá impelir uma ação, ou seja o próprio treinamento, e uma reação que são os benefícios que este trouxe para os colaboradores. Para isso, insere-se a última etapa do processo de treinamento que é a sua avaliação. Esta, possibilita identificar e comparar os resultados obtidos ao final do treinamento com aqueles esperados inicialmente. Entretanto, Marras (2009) alerta que existem resultados que muitas vezes não podem de todo ser mensurados de forma objetiva, nesses casos deve-se traçar previamente metas que conduzam a resultados ao menos observáveis ou com respostas indiretas que subsidiem a decisão de saber se a relação custo-benefício foi alcançada ou não.

Há também treinamentos que os resultados serão adquiridos a longo prazo, sendo assim fica difícil fazer uma avaliação imediata. Assim, propõe-se cinco níveis de avaliação: de reação, de aprendizado, de comportamento, de avaliação de valores e de avaliação de resultados finais (Hamblin, 1978 como citado em Marras, 2009). No trabalho aqui relatado utilizou-se a avaliação de reação. Nesta, busca-se "a reação dos treinandos com relação ao módulo aplicado e seu conteúdo, ao instrutor e às condições em que o módulo foi apresentado (local, ambiente, suporte logístico etc.)" (Marras, 2009, p. 161).

Ademais, é importante ressaltar a diferença entre treinamento e desenvolvimento gerencial. $O$ treinamento prepara o trabalhador para realizar atividades específicas para execução do seu trabalho, já o desenvolvimento oferece ao treinando uma visão mais ampla dos negócios, preparando o sujeito para alcançar coisas ainda mais além, a médio e longo prazo. Marras (2009) ainda afirma que talvez o nome mais adequado seja desenvolvimento de talentos, pois o que realmente importa no processo decisório da escolha dos participantes de um programa de desenvolvimento é o nível de talento do indivíduo potencialmente apto a ser desenvolvido. Portanto, buscou-se por meio da Capacitação realizada com os estagiários não-obrigatórios remunerados da UFMT, 
proporcionar tanto um treinamento quanto desenvolvimento.

\section{METODOLOGIA}

O curso denominado "Capacitação: Desenvolvendo Habilidades Técnicas e Administrativas", teve como cenário a Universidade Federal de Mato Grosso (UFMT), campus Cuiabá. Dividido em quatro módulos, ocorreu entre os meses de julho e agosto de 2017. Sendo o público alvo os estagiários não-obrigatórios remunerados da UFMT, ofertaram-se 60 vagas: 30 no período matutino (07:30h às $11: 30 \mathrm{~h})$ e 30 no vespertino (13:30h às 17:30h). O primeiro e o segundo módulos ocorreram, respectivamente, nos dias 10 e 21 de julho, no Serviço de Psicologia Aplicada (SPA) da UFMT. O terceiro encontro, executado em 28 de julho, seguiu-se no laboratório de informática da Secretaria de Tecnologias da Informação (STI) da UFMT e, por fim, o último encontro ocorreu na Coordenação de Desenvolvimento Humano (CDH). Além disso, metodologicamente, esta Capacitação adotou um planejamento flexível, com sensibilidade tal que diferenciava cada turma e cada encontro a fim de incorporar novas alterações constantemente.

$\mathrm{Na}$ articulação da teoria com a prática, foram utilizados diversos aportes metodológicos tais como dinâmicas, workshop, trabalhos em equipe, roda de conversa, recursos audiovisuais, aula expositiva e dialogada na tentativa de adentrar o cotidiano do estagiário para treiná-lo e desenvolvê-lo. Além disso, foram aplicados no decorrer da Capacitação: 1) questionário de interesse, no primeiro módulo, com o intuito de coletar dados para a formulação do quarto módulo; 2) questionário de avaliação do encontro, em todos os módulos, a fim de manter um planejamento flexível de acordo com o feedback dos estagiários; 3) questionário de reação/satisfação, no último módulo, para avaliar a Capacitação de modo geral.

No que se refere às dinâmicas, utilizou-se, no primeiro módulo a de "apresentação aos pares", cujo objetivo é "facilitar a integração e a identificação dos participantes do grupo" (Andrade, 1999, p. 45). Na primeira etapa da dinâmica, foram formadas duplas de estagiários (as), onde cada componente da dupla teve 3 minutos para entrevistar seu par, sendo que as informações coletadas não poderiam ser anotadas, apenas memorizadas.
Berkenbrock (2003) afirma que tal dinâmica é indicada para as ocasiões onde a maioria dos participantes não se conhece, gerando assim uma primeira interação.

No segundo módulo, com o objetivo de oportunizar uma discussão referente ao atendimento ao público, usou-se como metodologia a dramatização. Dessa forma, foi solicitado que os próprios estagiários suscitassem experiências de situações de mau atendimento. Em um primeiro momento os mesmos encenavam o caso do mau atendimento e, posteriormente, reproduziam a cena com uma possível solução do episódio. Neste módulo também houve a discussão referente ao trabalho em equipe, assim, realizou-se a dinâmica do "desafio do Marshmallow", que como apresentado por Martini, Sottille e Martins (2017), foi desenvolvida por Peter Skillman e consiste em dividir a turma em equipes de cinco ou seis pessoas para a construção de uma torre com os seguintes materiais: marshmallow, macarrão espaguete, fita e barbante. Desse modo, a equipe vencedora seria aquela que construísse a torre mais alta em 15 minutos.

No terceiro módulo, o qual tratou da importância da comunicação, foi proposta a dinâmica do "telefone sem fio corporal", que consiste em formar um círculo no qual os participantes ficam de costas e sequencialmente vão passando adiante o gesto que inicialmente foi feito, de forma que o gesto final seja o mais próximo possível do primeiro. Sobre essa forma de expressão em que utiliza-se o corpo para transmitir uma informação, Dornelles (2004) aponta que as formas de comunicações não verbais são sinais, gestos executados, retratos inventados ou observados, os quais podem ocorrer através das mãos, da cabeça, do rosto, ou seja, por meio da expressão do corpo. Pode não possuir a mesma nitidez que as palavras, porém conduz a muitas possibilidades de significado.

Já no quarto módulo, a partir do resultado levantado no questionário de interesse, aplicado no primeiro encontro, utilizou-se, sobretudo, a técnica de workshop para proporcionar reflexões e debates acerca do assédio moral.

Ademais, nos quatro módulos utilizaram-se as técnicas de roda de conversa e a aula expositiva. Foram ainda convidados profissionais com formações específicas, como uma psicóloga organizacional, uma 
docente da área de gestão, um gerente de capacitação e dois assistentes administrativos. Todos contribuíram como facilitadores do treinamento e desenvolvimento bem como no compartilhamento de suas experiências no ambiente de trabalho.

\section{APRESENTAÇÃO DOS RESULTADOS}

\subsection{PRIMEIRO MÓDULO}

No que se refere aos resultados do primeiro módulo, compareceram ao treinamento 24 pessoas na turma da manhã e 28 na turma da tarde, sendo que ambas as turmas mostraram-se bastante receptivas em relação ao que Ihes foi apresentado. No período matutino, através da dinâmica de apresentação, notou-se que os estagiários advinham de diferentes cursos da Universidade, com uma leve preponderância do curso de Psicologia e, em sua maioria, com a metade da graduação já concluída. No período vespertino, os participantes eram em sua grande parte do curso de Administração e recém-ingressos no ensino superior.

Ao serem questionados sobre as principais expectativas em relação à Capacitação, os estagiários afirmaram que buscavam melhoria das habilidades técnicas, pessoais e administrativas; possibilidade de discutir direitos e deveres no local de atividade; orientação para um bom relacionamento interpessoal e ao público; compreensão sobre - funcionamento do sistema público; obtenção de maior conhecimento para o mercado de trabalho, entre outros. Vale ressaltar que uma característica bem marcante observada na turma do período vespertino, foi a demasiada expectativa pela carga horária oferecida ao final da Capacitação.

Durante a apresentação inicial da Capacitação, na qual se expôs sobre o histórico, desenvolvimento e objetivos da capacitação, bem como sobre a lei do estágio, os participantes mostraram-se bastante curiosos, principalmente, em relação ao último tópico. As principais demandas relacionavam-se aos direitos tais como ao recesso; possibilidades de acordos com a chefia imediata a depender dos compromissos na graduação; profissionais e locais nos quais dúvidas podem ser sanadas; tempo de duração do estágio; desligamento, mudança e inserção no local de estágio.
Através da aplicação do questionário de interesse, observou-se que $80 \%$ dos estagiários indicaram a UFMT como instituição de origem, seguido de 20\% do Instituto Federal de Mato Grosso (IFMT). Além disso, $40 \%$ desenvolviam as atividades como estagiários remunerados durante o período de 1 até 3 meses; 24\% de 4 a 6 meses; $16 \%$ por mais de um ano; $12 \%$ de 7 a 9 meses e $8 \%$, de 10 a 12 meses.

Ainda segundo análise do questionário de interesse, no que se tratava das principais habilidades que desejavam desenvolver, notou-se que em ordem de prioridade a primeira habilidade escolhida foi a técnica, seguida de interpessoal e, por fim, a habilidade pessoal. A partir desses dados, amparou-se no planejamento flexível para realizar alterações no cronograma e gerar a possibilidade de desenvolvimento de tais habilidades.

Em relação aos resultados obtidos do questionário de avaliação do encontro no período matutino, $73,9 \%$ dos estagiários atribuíram a maior nota (5) ao encontro e $26,1 \%$, a segunda maior nota (4). Pontuaram também que a discussão da lei de estágio foi esclarecedora, uma vez que não tinham conhecimento aprofundado sobre este amparo legislativo. Ademais, sugeriram que ocorressem mais dinâmicas a fim de proporcionar maior interação entre os participantes. Por fim, $78,3 \%$ dos estagiários assinalaram que havia $100 \%$ de chance de participarem do próximo encontro, 13\% assinalaram $75 \%$ e $8,7 \%$ (dois capacitandos) indicaram $25 \%$.

Referente ao questionário de avaliação do encontro no período vespertino, 92,6\% atribuíram nota 5 e 7,4\% atribuíram nota 4 . Relataram também que articular dinâmicas com a exposição teórica foi de grande valia para o próprio desenvolvimento e interação do grupo. A escolha do tema também foi bastante citada neste questionário, como a possibilidade de desenvolver habilidades, de ampliar o conhecimento acerca do setor do estágio, dos seus direitos e deveres, e sobre o próprio histórico. Por fim, no item de possibilidade de participação no próximo encontro $96,4 \%$ assinalaram 100\% de possibilidade de participação e apenas uma pessoa (3,6\%) assinalou não haver possibilidade de participação. 


\subsection{SEGUNDO MÓDULO}

No segundo módulo, compareceram 23 pessoas no turno matutino e 26 no vespertino. Os capacitando tiveram a possibilidade de sanar dúvidas em relação à vestimenta, postura, entre outros fatores necessários para um bom atendimento, tanto ao público interno quanto externo ao setor em que trabalhavam. Foi ressaltado a importância da existência de um tratamento cordial entre os funcionários e a questão do bom senso em relação ao acesso à internet e redes sociais durante 0 expediente. Além disso, evitar o uso de som alto, ou conversas paralelas que possam atrapalhar o colega de serviço.

A proposta para dinamizar o encontro era que os estagiários se dividissem em grupos, relatassem um episódio de mau atendimento já vivido por alguns deles e depois reproduzissem a cena com a forma correta de se atuar. Entretanto, no período vespertino nenhum capacitando quis ou não se sentiu à vontade para contar uma história vivida de mau atendimento. Neste momento, o palestrante propôs uma atividade diferente (o "plano B"): cada grupo recebeu um papel que continha uma palavra que remetia a empatia, antipatia ou a simpatia. Cada grupo deveria contar para os demais qual palavra era, porém em forma de mímica. Assim os participantes fizeram, e a dinâmica foi concluída com sucesso.

Ademais, na execução da dinâmica do macarrão, tanto os estagiários da manhã quanto os da tarde, mostraram-se empolgados e envolvidos. Logo após, passou-se um vídeo explicativo sobre trabalho em grupo e trabalho em equipe e abriu-se uma roda de conversa. Entretanto, neste momento os capacitandos demonstraram cansaço e dispersão (em ambos os períodos), este fato gerou reflexões sobre os modelos dos encontros seguintes, para que não ficassem exaustivos, o que ressalta a importância de um planejamento flexível que absorve as demandas do processo de treinamento na hora em que ocorrem.

Nos resultados obtidos do questionário de avaliação do encontro no período matutino, $86,4 \%$ dos estagiários consideraram o módulo com nota 5, seguido de $13,6 \%$ dos participantes que atribuíram nota 4. Dessa forma, apresentaram que os momentos mais significativos foram as dinâmicas, palestras e reflexões que auxiliaram no desenvolvimento de habilidades para o trabalho em equipe e de um bom atendimento. Com base na experiência deste módulo, a probabilidade de participação da próxima etapa obteve os seguintes resultados: 91,3\% retornariam com $100 \%$ de chance e $8,7 \%$ compareceriam com $75 \%$ de chance.

Em contrapartida, referente aos resultados da aplicação do questionário de avaliação do encontro no período vespertino, notou-se que $92 \%$ dos estagiários apresentaram nota 5 , e 8\% apresentaram nota 4. Da mesma forma, $92 \%$ assinalaram que a probabilidade de comparecer no próximo módulo era de 100\% e paralelo a isso, $8 \%$ apresentaram que essa estimativa era de $75 \%$. Como sugestão para a melhoria dos próximos módulos, apareceram indicações na turma vespertina para orientar os outros estagiários acerca de conversas paralelas que atrapalhavam o desenvolvimento da capacitação bem como a sugestão de diminuição da quantidade de vídeos explicativos. Por fim, a presença de dinâmicas intercaladas com a exposição teórica tiveram bastante comentários positivos em ambas as turmas.

\subsection{TERCEIRO MÓDULO}

No terceiro módulo, compareceram 23 pessoas no turno matutino e 27 no vespertino. A dinâmica inicial foi bem sucedida e atingiu o objetivo que era descontrair e inserir o tema, uma vez que a comunicação era o instrumento chave e necessário para a efetivação da atividade.

Em seguida, foi ofertada a prática de uma das principais atividades que os estagiários realizam: comunicação externa ou interna, sendo que para isso cada estagiário pôde utilizar um computador do laboratório de informática. A professora convidada para lecionar o módulo disponibilizou, por meio de retroprojetor, o Manual de Redação Oficial da Presidência da República, disponibilizado no site do Planalto, bem como orientou os estagiários a localizarem o manual em seus próprios computadores.

Os participantes fizeram questionamentos e puderam sanar diversas dúvidas acerca da escrita de documentos oficiais tais como memorandos e ofícios, de como assinar documentos e proceder na entrega destes a outros setores. A professora ainda propôs que cada estagiário elaborasse um ofício e depois enviasse este documento para seu email comercial a fim de que fosse corrigido por ela 
e os estagiários recebessem um feedback. $\mathrm{Na}$ turma da manhã não houve tempo hábil para que pudessem elaborar o documento durante o módulo, já a turma da tarde teve esta oportunidade.

Já na segunda parte do módulo, foi proposta uma discussão sobre a importância da comunicação nas organizações, coordenada pelas estagiárias de Psicologia do EB III, na qual realizaram duas dinâmicas interativas. $\mathrm{Na}$ primeira, foram entregues papéis com nomes de animais, cada animal teve seu nome escrito em dois papéis (sem distinção se era macho ou fêmea) e, ao sinal das estagiárias, os capacitandos deveriam encontrar, através da linguagem corporal e sons dos respectivos animais, seu par. Assim, formaram-se duplas que foram utilizadas para realizar a segunda etapa da atividade. Logo após, foi proposto outra dinâmica, sendo que um integrante da dupla deveria permanecer na sala em que ocorreu a atividade inicial, enquanto outro dirigia-se para fora. O grupo que permaneceu na sala foi orientado a ler um texto e decorá-lo para explicar ao outro integrante de sua dupla, para isso tiveram 5 minutos. Foi dito que a dupla que conseguisse que seu parceiro obtivesse o maior número de informações a respeito do texto, ganharia um prêmio. Já o grupo que estava fora da sala, recebeu instruções para que quando retornassem para a dupla, ao receberem as informações acerca do texto não deveriam dar atenção ao colega e agir displicentemente durante a explicação. Posteriormente à realização da atividade, as estagiárias de Psicologia do EB III propuseram reflexão acerca do que ocorreu na dinâmica e iniciaram um debate sobre a importância da comunicação, utilizando vídeos e slides.

No que se refere à primeira dinâmica, esta foi aceita e realizada com entusiasmo pela turma da manhã, enquanto a turma da tarde foi mais tímida ao ter que imitar o animal e buscar seu par. Quanto à segunda dinâmica, ambas as turmas ficaram eufóricas e se apresentaram dispostas a participar. O grupo que tinha que decorar o texto (grupo 1), se dedicou e o grupo encarregado de agir displicentemente (grupo 2) interpretou da melhor forma possível.

Após o término da atividade, foi proposta uma reflexão, o grupo 1 relatou sentir raiva e frustração ao perceber que o colega não estava prestando atenção. Ademais, alguns estagiários afirmaram que a situação era muito semelhante a alguns momentos ocorridos em seus campos de trabalho.

Em seguida, as estagiárias do EB III que estavam coordenando esta parte do módulo, expuseram algumas informações, por meio de slides, acerca da importância da comunicação. Neste momento, em ambas as turmas, os estagiários já estavam cansados e se dispersando, portanto, optou-se por encurtar o momento de exposição e encerrar o módulo.

Os resultados da avaliação do encontro na turma matutina são apresentados da seguinte forma: $77,3 \%$ atribuíram nota 5 ao módulo e $22,7 \%$ qualificaram-no como nota 4. Em relação aos momentos mais valorosos, os participantes elencaram as dinâmicas e a elaboração de documentos oficiais realizados com a professora convidada. A probabilidade de participar da próxima etapa alcançou $73,9 \%$ com $100 \%$ de chance; $17,4 \%$ com $75 \%$; e $8,7 \%$ com $50 \%$ de chances de comparecimento.

No que refere-se ao questionário de avaliação da turma vespertina, o encontro obteve 96\% de respostas avaliando-o com a maior nota (5), 19,2\% o avaliaram com a segunda maior nota (4) e 3,8 o avaliaram com a nota 3. Os momentos mais proveitosos apresentados pelos estagiários foram os da prática de elaboração de documentos oficiais e o tema da exposição teórica. Paralelo a isso, como sugestão para os próximos módulos apresentou-se preponderante a redução de slides e conteúdos amparada na justificativa de momentos muito cansativos e com excesso de exposição. Por fim, o item de probabilidade de participação do próximo encontro obteve como resultados de $88,5 \%$ com $100 \%$ de chance; $7,7 \%$ com $75 \%$; e 3,8 com $50 \%$ de possibilidade de comparecimento.

\subsection{QUARTO MÓDULO}

No quarto e último módulo, compareceram 19 pessoas no turno matutino e 22 no vespertino. Conforme já foi dito, o tema foi selecionado através do questionário de interesse. Dessa forma, após a análise dos dados coletados concluiu-se que a maioria das temáticas solicitadas pelos estagiários já tinham sido abordadas durante os outros módulos. Entretanto, observou-se que temáticas relacionadas ao assédio moral, um tema que ainda não havia sido debatido na 
Capacitação, foi requerido por uma porcentagem considerável de estagiários no questionário e também no LNT realizado no semestre 2016/1ㅇ.

Para atendermos tal demanda, convidou-se uma psicóloga organizacional, lotada no CDH, para realizar uma discussão sobre o tema "assédio moral" no ambiente de trabalho. No primeiro momento a psicóloga convidada utilizou slides para realizar uma exposição participativa sobre a temática, buscando de forma acessível mostrar os aspectos mais importantes do assunto.

Em ambas as turmas, a psicóloga realizou um workshop. Deste modo, a atividade consistiu em dividir a turma em grupos para que pudessem discutir e relatar em uma cartolina situações em que o assédio moral no trabalho ocorre e traçassem algumas estratégias de enfrentamento. Posteriormente, às produções foram compartilhadas com o restante da turma. Nesta atividade, os capacitandos puderam expressar momentos que já viveram ou presenciaram, bem como discutir sobre quais as possíveis atitudes que se pode tomar quanto a situações de assédio moral no trabalho. Desta forma, a psicóloga reiterou o fato dos funcionários do $\mathrm{CDH}$ estarem disponíveis para ouvi-los e acolhê-los a todo momento, caso estivessem submetidos a situações como as expostas pelo grupo.

Ao término do debate conduzido pela psicóloga convidada para lecionar o último módulo, as estagiárias de Psicologia do EB III realizaram uma fala de agradecimento junto ao Gerente de Capacitação e Qualificação (no período matutino) e com o assistente administrativo (no período vespertino). Em seguida, aplicou-se o questionário de avaliação do encontro e o questionário de reação/satisfação, a fim de avaliar a capacitação de forma geral. Para finalizar o módulo, ofereceu-se um coffee break aos estagiários.

Acerca dos resultados obtidos no questionário de avaliação do encontro, destacou-se que na turma da manhã $78,9 \%$ dos estagiários qualificaram o módulo com nota 5 , seguidos de 10,5\% nota 4 e 10,5\% nota 3. Os momentos mais importantes destacados por eles foram as discussões apresentada pela psicóloga e participação dos próprios estagiários acerca do assédio moral e das experiências que foram compartilhadas. $\mathrm{Na}$ turma da tarde $81 \%$ atribuíram nota 5 ao encontro e $19 \%$ o avaliaram com nota 4. Assim como na turma matutina, os momentos mais significativos para eles foram as exposições e a possibilidade de discutir o assédio moral procurando alternativas e soluções para que ele não ocorra tanto dentro quanto fora dos ambientes do estágio.

Através do questionário de reação que foi aplicado nos estagiários em ambas as turmas, foi possível perceber quais os efeitos que a capacitação gerou para os mesmos. O questionário foi dividido em blocos de perguntas, sendo o primeiro com perguntas relacionadas à capacitação em geral, seguidas de avaliação dos facilitadores e da organização da capacitação. No final do questionário também havia um espaço reservado para comentários e sugestões. Os resultados estão nas Tabelas 1 e 2:

Tabela 1 - Resultados do questionário de reação / satisfação (turno matutino)

\begin{tabular}{|c|c|c|c|}
\hline \multicolumn{4}{|c|}{$\begin{array}{l}\text { Muito satisfeito } \\
\text { Capacitação no geral }\end{array}$} \\
\hline Interesse dos conteúdos & $63,2 \%$ & $36,8 \%$ & $0 \%$ \\
\hline Utilidade dos conteúdos & $57,9 \%$ & $42,1 \%$ & $0 \%$ \\
\hline Sequência dos conteúdos & $52,6 \%$ & $47,4 \%$ & $0 \%$ \\
\hline $\begin{array}{l}\text { Contribuição para aquisição de novos conhecimentos e } \\
\text { habilidades na melhoria do desempenho no trabalho }\end{array}$ & $63,2 \%$ & $31,6 \%$ & $5,3 \%$ \\
\hline Alcance das expectativas iniciais & $63,2 \%$ & $36,8 \%$ & $0 \%$ \\
\hline Duração da capacitação & $42,1 \%$ & $57,9 \%$ & $0 \%$ \\
\hline \multicolumn{4}{|c|}{ Formadores } \\
\hline Domínio dos conteúdos & $57,9 \%$ & $42,1 \%$ & $0 \%$ \\
\hline Clareza na apresentação dos conteúdos e atividades & $68,4 \%$ & $31,6 \%$ & $0 \%$ \\
\hline Relacionamento interpessoal com os participantes & $52,6 \%$ & $47,4 \%$ & $0 \%$ \\
\hline $\begin{array}{l}\text { Material, métodos e técnicas utilizadas durante os } \\
\text { encontros }\end{array}$ & $63,2 \%$ & $36,8 \%$ & $0 \%$ \\
\hline \multicolumn{4}{|c|}{ Organização da capacitação } \\
\hline Local onde foram realizados os encontros & $57,9 \%$ & $42,1 \%$ & $0 \%$ \\
\hline Equipamentos utilizados & $55,6 \%$ & $44,4 \%$ & $0 \%$ \\
\hline
\end{tabular}


Fonte: dados do treinamento

Tabela 2 - Resultados do questionário de reação / satisfação (turno vespertino)

\begin{tabular}{|c|c|c|c|}
\hline \multicolumn{4}{|c|}{$\begin{array}{l}\text { | Muito satisfeito } \\
\text { Capacitação no geral }\end{array}$} \\
\hline Interesse dos conteúdos & $57,1 \%$ & $42,9 \%$ & $0 \%$ \\
\hline Utilidade dos conteúdos & $57,1 \%$ & $42,9 \%$ & $0 \%$ \\
\hline Sequência dos conteúdos & $38,1 \%$ & $61,9 \%$ & $0 \%$ \\
\hline $\begin{array}{l}\text { Contribuição para aquisição de novos conhecimentos } \\
\text { e habilidades na melhoria do desempenho no trabalho }\end{array}$ & $81 \%$ & $19 \%$ & $0 \%$ \\
\hline Alcance das expectativas iniciais & $66,7 \%$ & $33,3 \%$ & $0 \%$ \\
\hline Duração da capacitação & $42,9 \%$ & $47,6 \%$ & $9,5 \%$ \\
\hline \multicolumn{4}{|c|}{ Formadores } \\
\hline Domínio dos conteúdos & $71,4 \%$ & $28,6 \%$ & $0 \%$ \\
\hline $\begin{array}{l}\text { Clareza na apresentação dos conteúdos e } \\
\text { atividades }\end{array}$ & $52,4 \%$ & $42,9 \%$ & $4,8 \%$ \\
\hline Relacionamento interpessoal com os participantes & $52,4 \%$ & $42,9 \%$ & $4,8 \%$ \\
\hline $\begin{array}{l}\text { Material, métodos e técnicas utilizadas durante os } \\
\text { encontros }\end{array}$ & $71,4 \%$ & $28,6 \%$ & $0 \%$ \\
\hline \multicolumn{4}{|c|}{ Organização da capacitação } \\
\hline Local onde foram realizados os encontros & $38,1 \%$ & $57,1 \%$ & $4,8 \%$ \\
\hline Equipamentos utilizados & $47,6 \%$ & $52,4 \%$ & $0 \%$ \\
\hline
\end{tabular}

Fonte: dados do treinamento

Além destes dados apresentados anteriormente, foram questionados os aspectos positivos da Capacitação, bem como possíveis sugestões para auxiliar a elaboração de outro evento como este. Na turma do período matutino, relataram que a Capacitação foi um momento de troca de vivências e de proporcionar conhecimentos, sobretudo sobre direitos e deveres do estagiário. Sugeriram que o projeto tenha continuação e abarque novos estagiários, além de proporcionar fóruns de debate com estagiários e chefias. Além disso, pontuaram que as temáticas poderiam ser mais específicas e focadas em um único tema. Por fim, $77,8 \%$ dos capacitandos indicaram que a nota, no geral, da Capacitação era 5 e 22,2\% assinalaram nota 4. Respondendo ao último item do questionário, 73,7\% pontuaram que havia $100 \%$ de chance de participar novamente de uma Capacitação e 26,3\% assinalaram a probabilidade de $75 \%$.

No período vespertino, no que se refere aos aspectos positivos, apontaram a questão da carga horária, as possibilidades de interação que a capacitação proporcionou (principalmente por meio das dinâmicas), bem como a agregação de conhecimentos. Como sugestões indicaram a necessidade de mais eventos de capacitação que contemplem além dos estagiários também os servidores e técnicos da UFMT. Ademais, indicaram a possibilidade de melhoria na didática e oratória dos palestrantes. Desse modo, no geral, $61,9 \%$ dos estagiários avaliaram a capacitação com a nota máxima (5) e 38,1\% com nota 4. Quando questionados sobre a probabilidade de participar novamente de uma Capacitação como essa, $85,7 \%$ pontuaram em 100\% e $14,3 \%$ julgaram ter $75 \%$ de chance.

\section{CONSIDERAÇÕES FINAIS}

Através da inserção no campo de estágio e posterior desenvolvimento e aplicação do projeto de Capacitação dos estagiários nãoobrigatórios remunerados da Universidade Federal de Mato Grosso, foi possível dar-se conta do amplo processo de desenvolvimento de habilidades técnicas e administrativas neste contexto. Nessa tarefa, visou-se a promoção de capacitação para a realização de atividades e o desenvolvimento organizacional que foi sistematizada através de quatro módulos de modo que atendesse às demandas levantadas pelos estagiários não-obrigatórios remunerados. A partir do suporte metodológico utilizado, notou-se que as técnicas aplicadas auxiliaram na potencialização da capacitação como treinamento e desenvolvimento. O auxílio de profissionais de diversas áreas do conhecimento também foi importante, pois, assim, agregou-se conhecimento de maneira multidisciplinar.

A aplicação dos questionários de avaliação de cada módulo foi relevante ao ponto que 
possibilitou um planejamento flexível dos encontros seguintes, de forma que as facilitadoras (as estagiárias de Psicologia do EB III) se apresentaram constantemente atentas às demandas levantadas e buscaram atendê-las durante a Capacitação. Além disso, os resultados obtidos através dos questionários de interesse possibilitaram um olhar acerca das expectativas dos estagiários referente à Capacitação. Por outro lado, o questionário de reação ofertou informações

\section{REFERÊNCIAS}

[1] Afonso, M. L., \& Abade, F. L. (2008). Para reinventar as rodas: Rodas de conversa em direitos humanos. Belo Horizonte: Recimam.

[2] Andrade, S. G. (1999). Teoria e prática de dinâmica de grupo: Jogos e exercícios. São Paulo: Casa do Psicólogo.

[3] Berkenbrock, V. (2003). Dinâmica para encontros de grupo: apresentação, intervalo, autoconhecimento mútuo, amigo culto, despertar, avaliação e encerramento. Rio de Janeiro: Vozes.

[4] Brasil (2008). Lei $n^{\circ} 11.788$, de 25 de setembro de 2008. Dispõe sobre estágios de estudantes. Diário Oficial da União, Seção

$$
\text { 1, pp. 3-4. Brasília, DF. }
$$
Disponível em:

http://portal.imprensanacional.gov.br/acervodou/2008/set/26.

[5] Costa, R. R. D. O., Bosco Filho, J., Medeiros, S. M. D., \& Silva, M. B. M. D. (2015). As acerca do suprimento destas expectativas, de todo o caminho percorrido durante os quatro módulos e ainda a avaliação, por parte dos estagiários, quanto à contribuição que a Capacitação Ihes conferiu.

Por fim, cabem outros estudos para uma posterior investigação em relação à uma possível articulação dos dados referentes ao curso e idade dos capacitandos de cada turma com o modo com que as discussões se colocavam durante o projeto.

rodas de conversas como espaço de cuidado e promoção da saúde mental. Revista de Atenção à Saúde (antiga Rev. Bras. Ciên. Saúde), 13(43). doi: 10.13037/rbcs.vol13n43.2675

[6] Dornelles, M. B. (2004). O desafio de comunicar o que se quer falar. Prática Educativa.

[7] França, A. C. L. (2009). Práticas de Recursos Humanos - PRH: conceitos, ferramentas e procedimentos (Cap.5, pp.87-111). São Paulo: Atlas.

[8] Marras, J. P. (2009) Administração de Recursos Humanos: do operacional ao estratégico (Cap. 10, pp.146-172) São Paulo: Saraiva, 2009.

[9] Martini, A., Sotille, S. S., \& Martins, A. R. Q. (2017). Processo De Criatividade E Inovação: Uma Comparação Entre Geração Baby Boomer E Geração Z. Cadernos De Educação, Tecnologia e Sociedade (Brazilian Journal Of Education, Technology And Society), 10(2). 


\section{Capítulo 13}

\section{NOVAS TECNOLOGIAS NO TRABALHO - DESAFIOS PARA GESTORES DA TERCEIRA IDADE}

\section{Andrezza Vaz dos Reis}

Patrícia Mara de Souza

Carlos Henrique da Mota Couto

Ionara Coelho Araújo

Ângela Cristina de Melo

Resumo: Este artigo vem trazer uma pesquisa que mostra como gestores da terceira idade lidam com os desafios das novas tecnologias e a inserção dessa categoria no mercado de trabalho. Vivemos em um período marcado por grandes transformações tecnológicas, como a globalização e internet, que estão contribuindo para o aumento da expectativa de vida e, sucessivamente, para o aumento inquestionável da população idosa. O idoso passou a ser um sujeito mais ativo e participativo na sociedade necessitando fazer parte dos benefícios trazidos pelo universo tecnológico. Lembrando que o mercado de trabalho, vivencia a transformação em relação a terceira idade, pois há um aumento dessa categoria no mundo do trabalho. Para concretizar a pesquisa foi realizado um estudo bibliográfico; pesquisa de campo, no município de Juiz de Fora com gestores da terceira idade.

Palavras-chave: Gestor da terceira idade. Tecnologia. Mercado de Trabalho. 


\section{INTRODUÇÃO}

A Organização Mundial da Saúde (OMS) vem estimando que até 2025, um de cada cinco brasileiros terá mais de 60 anos. Esse fenômeno é decorrente do aumento da qualidade de vida mundial e do consequente crescimento na média de idade da população. Esses dados mostram uma transformação para o mercado de trabalho e para esse público.

No cotidiano das organizações verifica-se que as empresas estão se modernizando e utilizando de tecnologias para se beneficiar, porém é preciso que os trabalhadores sejam treinados para lidar com essa inovação tecnológica.

O presente artigo tem por objetivo analisar como as transformações tecnológicas impactam no trabalho dos gestores da terceira idade dentro das empresas. Compreender e pesquisar sobre o crescimento de empreendedores que possuem mais de 60 anos. Analisar os gestores da terceira idade lidam com a tecnologia nas organizações.

A referida pesquisa busca identificar como a inserção da tecnologia no mundo do trabalho, impactam os gestores da terceira idade. As organizações buscam cada vez mais ganhar seu espaço no mercado que é competitivo e influenciável, criando estratégias como a modernização tecnológica para competir com os concorrentes que procuram se capacitar para participar ativamente do mercado. Essa inovação torna-se um desafio para os gestores da terceira idade.

Com a globalização e a modernização o mercado de trabalho utiliza cada vez mais das tecnologias. Dentro das organizações com o objetivo de alcançarem vantagens competitivas.

De acordo com o Sebrae (2012) há uma transformação no país que aponta que os empreendedores brasileiros com mais de 60 anos estão aumentando, e que o número de empresários nesta faixa etária não vai parar de crescer.

Dessa maneira para a realização da pesquisa foi realizado um estudo bibliográfico com autores e artigos sobre a temática, e uma pesquisa de campo com entrevista à gestores da terceira idade.

\section{O CRESCIMENTO DE EMPREENDEDORES COM MAIS DE 60 ANOS}

O envelhecimento da população é um tema que vem recebendo destaque em diversos veículos de comunicação, gera debates e produz tanto inovações quanto desafios, no que se refere à gestão coletiva dos problemas sociais. Estimativas mundiais apontam que o número de idosos e a expectativa de vida da população brasileira têm aumentado. Em 2050, de acordo com Instituto Brasileiro de Geografia e Estatística (IBGE, 2008) a expectativa de vida do brasileiro, ao nascer, será de 81,3 anos e os maiores de 65 anos serão 18\%, igualando-se aos de 0 a 14 anos. Tal fato vem despertando o interesse de muitos pesquisadores para a temática.

De acordo com Veras (2001, p. 35):

O aumento da participação social dos idosos e o surgimento de novas representações sobre a velhice e envelhecimento não podem ser explicados unicamente pelo envelhecimento da população, pois são reflexos de mudanças que implicam redefinições das formas de periodização da vida, das categorias etárias que recortam a organização da sociedade e a revisão das formas tradicionais de gerir a experiência de envelhecimento. Um processo de politização, com características próprias das sociedades contemporâneas, está alçando a velhice à dimensão pública, tornando mais evidentes os mecanismos e os agentes de sua construção social, bem como explicitando o papel desempenhado por cada um deles: o Estado através de políticas sociais, o saber científico institucionalizado e as pessoas idosas.

Como demonstra o Estatuto do Idoso (Lei no 10.74 de $1^{\circ}$ de outubro de 2003), é considerado idoso toda pessoa com idade igual ou superior a 60 (sessenta) anos (BRASIL, 2003).

No mercado de trabalho observa-se que a uma permanência dos idosos após se aposentarem no trabalho por vários motivos, entre eles: necessidade de uma renda adicional, ocupação do tempo ocioso, gosto pelo trabalho desenvolvido. Segundo o IBGE (2008) constata-se que quase $20 \%$ dos idosos aposentados no Brasil trabalham. Entre os principais motivos estão à necessidade de uma remuneração extra ou a vontade de permanecer ativo. Como demonstra Veras (2001, p. 425): 
O envelhecimento populacional não se refere nem a indivíduos, nem a cada geração, mas, sim, à mudança na estrutura etária da população, o que produz um aumento do peso relativo das pessoas acima de determinada idade, considerada como definidora do início da velhice. Este limite inferior varia de sociedade para sociedade e depende não somente de fatores biológicos, mas, também, econômicos, ambientais, científicos e culturais.

O mercado de trabalho, nas últimas décadas, recruta mão-de-obra qualificada para atender às necessidades da chamada "Era da informação". De acordo com o Sebrae (2012) depois dos 60 anos, pode ser a melhor idade para iniciar um novo negócio.

Segundo o Sebrae (2012, s/p):

O empreendedorismo tem sido um caminho escolhido por brasileiros da terceira idade como alternativa para ter uma vida mais ativa, inclusive após a aposentadoria. Estimular o desenvolvimento de atividades empreendedoras nessa faixa etária é importante para manter essa parcela da população dentro da economia produtiva. Dados do Instituto Brasileiro de Geografia e Estatística (IBGE) indicam que a população idosa, no Brasil, será de 30 milhões até 2020.

Frente às mudanças e novas tecnologias, vem um novo paradigma que traz novas tendências, bem como, o novo perfil organizacional da terceira idade dentro das empresas, como: pessoal, social, comunicacional e de mercado. Como afirmam Palma et al. (2007 apud BERNADES E SHMITZ, 2009, p. 5):

O estudo do empreendedorismo facilita a geração de insights e possibilita uma compreensão mais integrada e holística dos fenômenos. Em geral, a pessoa da terceira idade sente a necessidade de ser valorizada dentro da sociedade, portanto, deseja voltar à situação de trabalho, uma vez que hoje o ser qualificado é o trabalhador. Assim ocupações vinculadas ao auto-emprego e às oportunidades de trabalho advindas do empreendedorismo serão as novas oportunidades.
2.1 O DESAFIO DOS GESTORES DA TERCEIRA IDADE PARA LIDAR COM AS TECNOLOGIAS NA EMPRESA

O avanço da tecnologia, a necessidade das empresas atuarem de modo competitivo, a globalização, em conjunto com a socioeconômica do país, diminuíram alguns postos de trabalhos tradicionais segundo Barbosa e Santos (2001). Consequentemente as relações de emprego sofreram grandes alterações nas últimas décadas.

De acordo com G1 (2007) nas regiões Nordeste e Sul, o número de aposentados trabalhando está acima da média nacional: $24,5 \%$ e $27,3 \%$, respectivamente. Somando os aposentados que voltaram à ativa aos idosos que ainda não se aposentaram, a proporção dos que chegam aos 60 anos no mercado profissional atinge ao percentual de $30,9 \%$, assim os 5,9 milhões de idosos trabalhadores do Brasil e em 2007 ocupavam $4,5 \%$ dos postos de trabalho do País (IBGE, 2008). No quesito vínculo empregatício a maior parte dos trabalhadores idosos são autônomos (43,9\%) e assalariados $(31,4 \%$, sendo que, $9,8 \%$ deste percentual são empregados domésticos. O Sebrae (2016, s/p) coloca que:

○ Brasil tem envelhecido rapidamente. Hoje são 120 idosos para cada 100 crianças. Segundo dados do IBGE, em 2005, a faixa etária de pessoas com mais de 60 anos - que é conhecida tecnicamente por terceira idade, mas que o mercado está chamando de sênior, já representou cerca de 8,8\% dos brasileiros, com previsão de que esse número chegue a $17 \%$ em 2030, quando passaremos do $16^{\circ}$ para o $6^{\circ}$ país com maior número de idosos.

O IBGE (2008) salienta que os cargos com responsabilidade de decisão, nas empresas ocupados pelas pessoas da terceira idade, são cerca de 6,3\% com mais de 60 anos. Sendo que a questão da experiência pode ser valorizada nos cargos mais altos. O próprio IBGE tem considerado a participação da terceira idade no mercado de trabalho, como mão de obra para trabalhar no censo.

O Sebrae (2012, s/p) mostra o perfil da terceira Idade:

A época da terceira idade pode ser aproveitada como momento ideal para investir em (um negócio: diferentemente dos mais jovens, os idosos têm menos medo dos riscos e estão mais preocupados com a realização 
pessoal do que com a rentabilidade. A experiência e a maturidade profissional são favoráveis a esses empreendedores e contribuem para o sucesso de qualquer empresa.

Nesse contexto cabe ao $\mathrm{RH}$ o papel de desenvolver uma projeção do envelhecimento dentro das organizações e identificar os preconceitos existentes quanto à capacidade laborativa e cognitiva dos mais velhos, promovendo a integração entre as faixas etárias.

\section{COMO A TECNOLOGIA TEM AVANÇADO NO MERCADO DE TRABALHO}

$\mathrm{Na}$ atualidade nota-se um grande crescimento do uso das tecnologias em todas as esferas da sociedade. Nota-se que estamos participando da globalização e da informatização, que é responsável por diversas mudanças de conceitos na sociedade, alterando as formas de entretenimento, de comunicação, da educação e da comercialização. Como mostra Pacheco (2002 apud BERNADES E SHMITZ, 2009, p. 5):

Pode-se observar que a tecnologia leva à criação de espaços urbanos de produção nos quais os jovens são absorvidos e os mais velhos tornam-se rapidamente obsoletos e seus conhecimentos desvalorizados; a urbanização acelerada aumenta a segregação entre gerações deteriorando os laços familiares e contribuindo para a redução da importância dos mais velhos; a educação obrigatória proporciona aos mais jovens maior escolaridade, aumentando a probabilidade destes estarem melhor capacitados, portanto mais aptos aos melhores lugares de trabalho; a tecnologia de saúde acrescenta anos à expectativa de vida, gerando uma competição geracional pelo mercado de trabalho no qual os idosos são empurrados para os cargos de menor renda e menor prestígio.

A evolução das tecnologias modificou os hábitos da população, de tal maneira que não se vive um dia sem ter contato com algum equipamento tecnológico. Por exemplo: ao tirar dinheiro no banco, passar o cartão para fazer compras, usar o celular, ao declarar imposto de renda, fazer registro em uma loja, obter informações do mundo, entre muitos outros.

Assim como mostra Kachar (2003, p. 122)
A geração mais nova tem intimidade e atração pelos artefatos tecnológicos, assimila facilmente as mudanças, pois já convive desde tenra idade, explorando os brinquedos eletrônicos e/ou brincando com o celular dos pais. Porém, a geração adulta e mais velha, de origem anterior à disseminação do universo digital e da internet, não consegue acolher e extrair tranquilamente os benefícios dessas evoluções na mesma presteza de assimilação dos jovens.

Com o implemento da tecnologia nas organizações, buscam cada vez mais ganhar espaço no mercado competitivo criando estratégias e modernização tecnológica para esquivar-se dos concorrentes que procuram se capacitar para participar ativamente do mercado, com isso há um desafio para gestores da terceira, no sentido de manter capacitado no mercado de trabalho.

Como demonstra Silva, Silva e Manfrinato (2005, p. 2):

(...) o conceito de "tecnologia" permite uma avaliação com maior detalhamento da capacitação tecnológica de uma organização, devido ao desdobramento da microtecnologia em "tecnologia principal" e "tecnologias complementares", aplicáveis tanto para os produtos como para os processos de produção, como se pode constatar. Desta forma podemos visualizar o potencial de competitividade de uma organização, no contexto tecnológico, em um momento histórico de um determinado mercado.

O notável crescimento da população idosa no Brasil sua participação no cenário social e econômico, acrescido da expansão das tecnologias de informação, estimula o interesse do idoso pelo aprendizado da informática, do uso do celular, contribui para explorar novas tecnologias que até então não faziam parte de seu cotidiano o idoso está passa a intensificar seu interesse pelas tecnologias, que pode ser aplicado no mundo do trabalho.

\section{METODOLOGIA}

Para a referida pesquisa a metodologia seguida baseia-se em dois momentos distintos. No primeiro foi realizado um levantamento e estudo bibliográfico sobre a tecnologia no mercado de trabalho; pirâmide demográfica etária que mostra como o número de idosos vem aumentando; e o desafio da gestão na terceira idade. Para tal 
levantamento foram utilizados autores tais como: Veras (2001) e Turke (1997).

Desse modo, o desafio que se colocou para a referida pesquisa tem na investigação qualitativa seu caminho mais próspero. 0 método qualitativo é o que se aplica ao estudo da história, das relações, das representações, das crenças, das percepções e das opiniões, produtos das interpretações que os humanos fazem a respeito de como vivem, constroem seus artefatos e a si mesmos, sentem e pensam (MINAYO, 2006).

No segundo momento a pesquisa de campo, que foi realizada no município de Juiz de Fora, com três Gestores, um no ramo da Industria Gráfica, no Comércio Alimentício e Industria de Persianas. Nesse sentido foi construído um formulário de entrevista semiestruturada com questões abertas que contribuíram para compreender sobre a transformação tecnológica e os desafios para gestores da terceira idade.

\subsection{INSTRUMENTO DE PESQUISA, COLETA E TABULAÇÃO DOS DADOS}

O instrumento utilizado para coleta de dados foi um roteiro de entrevista semi-estruturado com questões abertas que permitam a percepção da concepção do desafio da gestão na terceira idade.

A entrevista caracteriza o entrevistado, questionando idade, ramo de atuação, formação, tempo como gestor. Em seguida as questões buscaram identificar como foi a transformação do mercado de trabalho com a tecnologia, e o desafio da tecnologia para o de gestor na terceira idade. O roteiro com indagações sobre: Como foi a transformação frente a tecnologia, como era a produção antes dos recursos da tecnologia e agora com a tecnologia; Esse processo ajudou? Teve dificuldades; Como está no mercado disputado e cada vez mais exigente a capacitação, modernização e a tecnologia; Em relação a idade e mudança no mercado de trabalho frente as questões postas como a maturidade e experiência ajudam.

No que tange a coleta dos dados, as pesquisas foram realizadas nos dias 08 de novembro de 2016 e 25 de fevereiro de 2017. As entrevistas forma realizadas com gestores da terceira idade no ramo da Indústria Gráfica, Comércio Alimentício e Indústria de Persianas. A entrevista foi realizada pessoalmente, gravada e transcrita.

\section{ANÁLISE DA PESQUISA}

A sociedade contemporânea está passando por várias mudanças em todas as áreas do conhecimento. Os impactos produzidos nos últimos tempos na sociedade, por meio dos avanços tecnológicos têm provocado uma profunda reestruturação no estilo de conduta, atitudes, hábitos e tendências das populações mundiais, principalmente da população idosa.

A pesquisa foi realizada com gestores da terceira idade no ramo da Indústria Gráfica, entrevistado 1 (68 anos); Comércio Alimentício, entrevistado 2 (62 anos); Indústria de Persianas, entrevistado 3 (58 anos).

\section{1- Ramo de atuação? \\ Entrevistado 1 - Industria Gráfica; \\ Entrevistado 2 - Comércio Alimentício; \\ Entrevistado 3 - Indústria de Persianas. \\ 2- Quais as áreas atua ou atuou como gestor?}

Entrevistado 1 - "Em minha carreira sempre atuei no ramo gráfico, comecei com meu pai como continuo. E a partir dos 20 anos comecei em cargos de gestão, fui chefe de planejamento (administrativo, área de supervisão da produção) de uma das maiores gráficas de Juiz de Fora, até os 35 anos, logo após sai para ser sócio gerente da empresa em que atuo hoje".

Entrevistado 2 - "Depósito e Gerência de loja e Gerência Regional, tudo dentro da mesma empresa".

Entrevistado 3 - "Entrei como auxiliar de escritório, depois passei para chefe de escritório, fazia a parte de pedidos e faturamento da empresa. Depois de 4 anos me tornei chefe do setor de compras. E após 2 anos a empresa abriu uma filial, e me convidou para ser assistente financeira, contas a pagar e a receber". 
3 - Qual é sua formação?

Entrevistado 1- "2o grau completo com curso técnico de gráfica".

Entrevistado 2 - "Ensino Médio, Técnico de Contabilidade e cursos profissionalizantes dado pela empresa".

Entrevistado 3 - "Ensino Médio e o curso de Secretariado".

4- Como foi a transformação frente à tecnologia na produção? Como era e como está?

Entrevistado 1 - "Antigamente era artes gráficas. Para trabalhar nessa área tinha que ser uma pessoa que criasse, dentro daquilo que você tinha de recurso e fazia, não tinha nada pronto, criava-se placa, desenho e etc. No ramo que eu sempre atuei que é profissional tipografo, que era o artista gráfico, criava a modelagem e demorava um dia para aplicar. Agora com a tecnologia, uma coisa que se gastava um dia para fazer como a arte, leva uma hora, contribuiu muito, inclusive artes gráficas acabou e passou a ser indústria gráfica."

Entrevistado 2 - "Antes era mais difícil, para fazer um balanço leva-se 12 horas, com a tecnologia, computadores e outras ferramentas passou a gastar 2 horas. O processo era todo manual, planilha, tirar notas, tinha que conferir mercadoria por mercadoria e descreve-las. Com a tecnologia é só jogar o código que saia a descrição do produto e colocar a quantidade recebida."

Entrevistado 3 - "A tecnologia ajudou muito! Antigamente não tinha como fazer um documento para uma empresa, salvar e depois usar o modelo para uma nova empresa. Tinha que datilografar tudo de novo. $O$ Computador dar essa facilidade, copiar e colar, somente alterando o necessário. Até mesmo as planilhas que hoje temos Excel, antes era feita a manualmente na máquina de calcular e transcritas para o mimeógrafo. A nota fiscal era tirada na máquina de escrever, assim como boletos bancários."

5- Esse processo ajudou? Teve dificuldades?

Entrevistado 1 - "Tive dificuldades para adaptação, pois foi uma transformação muito grande com máquinas e equipamentos, aprender coisas novas. Passei por capacitação e estava à frente como gestor da empresa".

Entrevistado 2 - "Tive dificuldade, porém procurei fazer treinamento e capacitação empresa sempre oferecia. Procurei ter a mente aberta!".

Entrevistado 3 - "Não muita, procurei aprender e qualificar. Nunca me acomodei!".

6- Como é estar no mercado disputado e cada vez mais exigente com a capacitação e modernização da tecnologia e seus recursos?

Entrevistado 1 - "É um investimento muito alto, a cada ano que passa são mais sofisticados e tem que estar acompanhando, pois se não fica para trás e a concorrência é pesada".

Entrevistado 2 - "É buscar pelo seu lugar, contar com a experiência e procurar capacitar para não ficar para traz".

Entrevistado 3 - "Me sinto segura, por sempre me interessar pelo serviço. Procuro estar sempre aprendendo mesmo que não seja da minha área".

7- Em relação a idade e mudança no mercado de trabalho frente as questões postas como a maturidade e experiência ajudam?

Entrevistado 1 - "A experiência ajuda principalmente a idade, traz mais segurança frente ao mercado de trabalho."

Entrevistado 2 - "Sem dúvida, ajuda muito ter experiência. Traz confiança".

Entrevistado 3 - "Adquiri muita experiência, só que algumas empresas acham que as pessoas mais velhas vem com vicio trabalhista de outras empresas, preferem pessoas que não tenham experiência. A minha experiência me traz segurança. Procuro me adequar a empresa em que estou trabalhando".

Com base na entrevista nota-se que a tecnologia foi um divisor de águas para as empresas e gestores que passaram pela transformação, capacitação, e como esse advento facilitou o serviço dentro das empresas. Percebe-se que a escolaridade não passou de ensino tecnológico, porém a experiência profissional adquirida contribuiu para o crescimento de gestores, e como descreveram na entrevista, contribui para que tivessem mais frente ao mercado de trabalho.
Com o aumento da expectativa de vida e como ressalta a pesquisa a terceira idade pretende ser ativa e ampliar a inserção dessa categoria no mundo do trabalho. Portanto, se deve compreender que o envelhecimento não significa improdutividade. Dessa maneira é relevante como o aumento da expectativa de vida traz junto uma nova realidade, que é o papel dos idosos na sociedade. 


\section{CONSIDERAÇÕES FINAIS}

Atualmente, vivemos em um período marcado por grandes transformações tecnológicas que estão contribuindo para o aumento da expectativa de vida e, sucessivamente, para o aumento inquestionável da população idosa. Com isso o idoso passou a ser um sujeito mais ativo e participativo na sociedade necessitando e buscando fazer parte dos benefícios trazidos pelo universo tecnológico; no mercado de trabalho os gestores da terceira idade passam por transformações e se adaptam para ampliar o potencial de empregabilidade da terceira idade.

Assim sendo, com base na pesquisa realizada, nota-se que os gestores da terceira idade estão ativos, e que estes contribuirão definitivamente para o mercado de trabalho, através dos conhecimentos adquiridos. E portanto, apesar das dificuldades para se adaptar com o incremento das tecnologias

\section{REFERÊNCIAS}

[1] Barbosa, Jenny D.; Santos, Rosinadja B. Ensino de Empreendedorismo: uma alternativa para a formação do administrado. Enangrad, 8, 2001, Florianópolis. Anais eletrônico. Florianópolis, 2001.

[2] Bernardes, Francisco; Schmitz, L. ANA. A UFSC como apoio ao Empreendedorismo na Terceira Idade: O Caso NTI/UFSC. Florianópolis. 2009.

[3] Brasil. Estatuto do idoso: lei federal $\mathrm{n}^{\circ}$ 10.741, de 01 de outubro de 2003.

[4] Brasília, DF: Secretaria Especial dos Direitos Humanos, 2004.

[5] chiavenato, I. Gestão de pessoas. Rio de Janeiro, 2003.

[6] G1. Cerca de 20\% dos idosos trabalham, aponta ibge. 2007. Disponível em: < http://g1.globo.com/noticias/brasil/0, ,aa1643231$5598,00-$

cerca+de+dos+idosos+trabalham+aponta+ibge.ht $\mathrm{ml}>$. Acesso em: 15 de out. De 2016.

[7] Gonçalves, José Ernesto Lima. Os impactos das novas tecnologias nas empresas prestadoras de serviços. São Paulo, RAE, v. 34, n. 1, p. 663-681, jan/fev. 1994.

[8] IBGE (Fundação Instituto de Geografia e Estatística). 2008. Perfil dos Idosos Responsáveis pelos Domicílios no Brasil 2000/IBGE. Disponível em:

<http://www.ibge.gov.br/home/presidencia/noticias/ 25072002pidoso.shtm>. Acesso em: 15 de out. de 2016. cabe às empresas se prepararem para este cenário, promovendo um ambiente organizacional que estimule a produtividade e o aproveitamento desse capital intelectual.

Mediante esses dados, pode-se notar como a "Era da informação" tem contribuído para a inserção e permanência dos mais experientes no mercado de trabalho. Os funcionários mais velhos estão sendo valorizados por serem mais treinado e experiência o que leva ao cargo de gestão ou de alto escalão dentro das empresas.

As conquistas da humanidade para o aumento da expectativa de vida trazem junto uma nova realidade: o papel dos idosos na sociedade. Com esse aumento na expectativa de vida, mostra como os gestores de terceira idade usam a experiência, maturidade para continuar ativos e ganhar espaço no mercado de trabalho.

[9] Kachar, V. Longevidade: um novo desafio para a educação. In: Terceira idade e informática: aprender revelando potencialidades. São Paulo: Cortez, 2003.

[10] Minayo, Maria C.S. (org.). Pesquisa social: teoria, método e criatividade. 6 ed. Petrópolis: Vozes, 2006.

[11] Sebrae. Prestação de serviços para idosos. 2012. Disponível em: < http://www.sebrae.com.br/sites/PortalSebrae/ideias/ como-montar-uma-empresa-de-prestacao-deservicos-para-

idosos,f6687a51b9105410VgnVCM1000003b74010 aRCRD>. Acesso em: 15 de out. de 2016.

[12] Sebrae. Aproveite a experiência para empreendedor na terceira idade. 2016. Disponível em:

<http://www.sebrae.com.br/sites/PortalSebrae/artig os/aproveite-a-experiencia-para-empreender-naterceira-

idade,4a8a8b88ba73e410VgnVCM1000003b74010 $\mathrm{aRCRD} \geq$. Acesso em: 21 de ago. de 2016.

[13] Silva, JC; Silva. M S; Manfrinato, J W. Correlação entre gestão da tecnologia e gestão ambiental nas empresas. Revista Produção, 2005.

[14] Turkle, S. A vida no Ecrã - A identidade na era da internet. Lisboa: Relógio D’Água Editores, 1997.

[15] Veras, R.P. (Org). Velhice numa perspectiva de futuro saudável. Rio de Janeiro: UERJ, UnATI, 2001. 


\section{Capítulo 14}

\section{UMA ANÁLISE JURÍDICO-AFETIVA, COM APORTES DE MACHADO DE ASSIS}

\section{Gabriella Cristina de Melo Amorim}

\section{José Nogueira de Moraes}

Resumo: O Direito cada vez mais assume um espaço abrangente nas fontes normativas, ditadas pelos princípios e analogia, inteiramente ligados ao póspositivismo, não havendo motivos para ignorar este estudo através da literatura. Assim, a discussão é levada a uma linha de análise da Literatura, como um espaço de produção do conhecimento jurídico, com a possibilidade de pensar, interpretar, criticar seus diferentes caminhos, que vêm permitindo a expansão axiológica do sistema jurídico, sem desprezo à lei, mas proporcionando uma viável composição de cenários interativos: o Direito na Literatura, e a Literatura no Direito, sendo a primeira passível de ser discutida pela ciência jurídica e aceita como arte. O póspositivismo, trazendo essa possibilidade, intervém de forma a reintroduzir ideias de justiça, reaproximando a ética do Direito. Neste trabalho, utilizou-se a obra Helena, de Machado de Assis, como material de abordagem para a concepção, disseminação e demonstração dessas ideias, porque traz elementos jurídicos e sociais fielmente ligados à perspectiva de interação, ligando o direito de família, as sucessões e o testamento com a apresentação e o reconhecimento afetivo tratado nessas relações. Exemplo disso será a apresentação de próprias falas e trechos do livro, comparadas e refletidas com base no ordenamento jurídico, de modo a acostar-se com a realidade social, para que o objetivo seja alcançado, permeando o auxílio da Literatura ao Direito.

Palavras-Chave: Práticas educativas. Literatura. Testamento. Afeto. 


\section{INTRODUÇÃO}

A utilização de obras literárias, com o propósito de compreender melhor fenômenos jurídicos, tem sido estudada por vários autores, como constatado em pesquisa eletrônica em bancos de artigos - Maranhão (2008), Fernandes (2009), Campos (2009), Maraschin (2009), Olivo (2005) - e em alguns periódicos. Observa-se que a interação Direito e Literatura estudada pelos autores citados vem demonstrando não apenas a racionalidade prática, guiada pelo positivismo, mas também uma racionalidade emocional, que explora novas possibilidades da aprendizagem jurídica.

Nesse sentido, a obra literária, como espaço de produção do conhecimento jurídico, vai além dos conceitos clássicos nos estudos que têm como foco a relação entre o direito e a literatura, uma vez que

\begin{abstract}
A par do direito na literatura, que consiste em se alcançar aspectos jurídicos na produção literária de ficção, pesquisa-se também a literatura no direito, isto é, pretende-se fazer teoria e crítica literárias em textos jurídicos, que variam de decisões judiciais a petições, com estações em excertos de doutrina; tocase em material burocrático, mas não despreza o conteúdo discursivo das próprias normas jurídicas. (GODOY, 2008, p. 9)
\end{abstract}

Desse modo, o estudo do Direito, a partir de uma obra literária, torna-se relevante pelo fato de que os fenômenos jurídicos têm demonstrado que podem ser apresentados não apenas na racionalidade prática, guiados pelas leis e fontes positivistas, mas, também, abrindo espaço para o pós- positivismo, associando a necessidade de ruptura com o absolutismo, olhando além das tradicionais hierarquias, sugerindo a interpretação, a narração, os princípios e fontes normativas análogas que já vêm tomando um abrangente espaço no ensino jurídico.

Olhando por esse prisma, percebe-se que a obra literária se constitui em um espaço de produção do conhecimento jurídico, e o seu estudo permite, por meio da interpretação, análise e crítica à expansão axiológica do sistema jurídico, sem desprezo à lei, viável composição de cenários interativos: o Direito na Literatura e a Literatura no Direito.

Dentre as várias obras literárias que possibilitam o enriquecimento do ensino jurídico, para esse estudo, optou-se pelo romance Helena (1876), de Machado de
Assis, com o objetivo de demonstrar que a obra literária abre caminhos metodológicos, sob a perspectiva pós-positivista, para o estudo do Direito.

Dada a riqueza da obra para o universo do ensino jurídico, este estudo se restringe ao aspecto jurídico da sucessão testamentária, com aportes na afetividade.

Assim, no desencadear das discussões, centralizadas na conexão Direito e Literatura, serão mostrados seus principais pesquisadores, com enfoque dos prismas Machadianos, mostrando a fusão da ficção com o real, transformando os fatos extraliterários em narrativas literárias.

Para este estudo, utilizou-se a pesquisa bibliográfica, cuja intenção é explorar as formas de contribuição científica já registrada sobre algum assunto ou fenômeno (GIL, 2007, p. 47), com tratamento qualitativo, que -[...] justifica-se pelo fato de esclarecer a relação de causa e efeito do fenômeno e consequentemente ser adequado para se chegar à sua verdade e razão.ll (OLIVEIRA, 2002, p. 60).

No que se refere ao método, a pesquisa foi conduzida por meio do método hipotéticodedutivo, desenvolvido por Popper, que tem por objetivo -[...] colocar os conhecimentos já existentes em questionamento, para surgirem novos conhecimentos\| (POPPER citado por JUNG, 2003).

Por fim, com os avanços dos estudos das teorias e ciências do Direito com a Literatura, espera-se uma interação, demonstrando que os juristas não são meros dogmáticos e centrados em sua linguagem, do mesmo modo que os autores literários não são necessariamente surrealistas e ilusórios, como creem, permitindo, assim, uma melhor compreensão da realidade vivida.

\section{DIREITO E LITERATURA: UMA POSSIBILIDADE PARA O ENSINO}

Repensar o Direito, neste início de século, é o desafio que se impõe aos juristas. E, dentre as inúmeras e mais variadas alternativas que se apresentam, o estudo do Direito $e$ Literatura adquire especial relevância.( André Karan Trindade, Roberta Magalhães Gubert) (grifo do autor)

O Direito, como ciência, tem origem nos fenômenos sociais, dedicando-se a um complexo sistema interpretativo-descritivo de 
fatos sociais, que cultiva não somente extenso processo de normas e sua valoração, mas sua interpretação e analogia, desta feita, de natureza aplicativa. (SOUZA, 2010)

Desse modo, a busca por uma estruturação metodológica do ensino jurídico, com novas possibilidades, permite uma construção teórica expansiva, viabilizando a composição de cenários, em que arte e vida se interagem. Essa construção teórica está ligada ao póspositivismo, como afirma Barroso, citando Maranhão (2008, p. 02), —O pós-positivismo é a designação provisória e genérica de um ideário difuso, no qual se incluem a definição das relações entre valores, princípios e regras, aspectos da chamada nova hermenêutica e a teoria dos direitos fundamentaisl.

O mesmo autor apresenta um relato histórico recente, escrevendo que o pós-positivismo emerge para superar o conhecimento convencional, em que o Direito estava impregnado do discurso científico do chamado jusnaturalismo (fundamentos vagos, abstratos ou metafísicos de uma razão subjetiva). Durante a segunda metade do século XX, o Direito já não pertencia mais ao positivismo jurídico somente, pois se observava a absoluta ligação entre Direito e norma e a separação rígida entre eles e a ética, não correspondendo, então, ao cenário civilizatório do momento. O pós-positivismo, no decorrer do tempo, trouxe a reintrodução das -ideias de justiça e legitimidadell bem como a promoção de -[...] uma volta aos valores, uma reaproximação entre ética e Direitol(BARROSO, Apud MARANHÃO, 2008, p. 02).

Recapitular o contexto em que o póspositivismo surgiu remete ao entendimento de que, cada vez mais, sua metodologia está calcada no anseio por novas conquistas e perspectivas, cultivando os princípios que assumiram um patamar considerável de fonte normativa, saindo da premissa de que somente as fontes subsidiárias do Direito eram justificáveis, na ausência da lei ou do costume, o que se pode observar nas afirmações de Brambilla (2010),

- pós-positivismo tenta restabelecer uma relação entre direito e ética, pois busca materializar a relação entre valores, princípios, regras e a teoria dos direitos fundamentais e para isso, valoriza os princípios e sua inserção nos diversos textos constitucionais para que haja o reconhecimento de sua normatividade pela ordem jurídica. (BRAMBILLA, 2010, p. 01)

Os paradigmas pós-positivistas constituem visões de mundo e estão estreitamente relacionados com as diferentes concepções de realidade, considerando-a como uma opção teórica na qual o direito se vê aliado à moral, colocando em tela princípios como a dignidade humana e a igualdade, influenciando a aplicação das leis e afins. (MORAES, 2007, p. 206)

E evidenciando a perspectiva humanista, o Direito busca na Literatura a humanização perdida, como leciona o jurista Germano Schwartz, professor da disciplina Direito e Literatura na Escola Superior da Magistratura do Rio Grande do Sul:

A Literatura ajuda a demonstrar que o Direito não se desvincula da realidade social que o circunda. O poder colocar-se no lugar do outro é também uma das grandes contribuições que a Literatura pode dar ao Direito, já que tal sensibilidade é escassa nos operadores jurídicos modernos'. Com isso, a Literatura pode recuperar a humanidade do Direito, que anda esquecida entre pilhas de processos, planilhas de metas e fóruns lotados. (SCHWARTZ citado por DIAS, 2007, p. 29)

Alicerçando a discussão, Dworkin (1982, p. 49) parte do princípio de que -[...] a prática jurídica é um exercício de interpretação não apenas quando os juristas interpretam documentos ou leis específicas, mas de modo gerall. Dworkin (1982), filósofo jurista contemporâneo, é reconhecido pela sua teoria do Direito como integridade, uma das principais visões contemporâneas sobre a natureza do Direito (RODRIGUES, 2005).

Em suas afirmações está a partida da interseção entre Direito e Literatura para o entendimento jurídico

Proponho que podemos melhorar nossa
compreensão do Direito comparando a
interpretação jurídica com a interpretação em
outros campos do conhecimento,
especialmente a literatura. Também suponho
que o Direito, sendo mais bem compreendido,
propiciará um entendimento melhor do que é
a interpretação em geral. (DWORKIN, 1982, p.
49)

Nessa perspectiva, a Literatura é inserida na aprendizagem jurídica, como possibilidade de expressão do Direito, tratando-se de sessão que sugere uso pedagógico da literatura, no 
que toca ao ensino jurídico (GODOY, 2008, p. 75).

Corrobora com o autor, Godoy (2007), que trata da compreensão do Direito com a Literatura: $-[\ldots]$ busca-se a literatura como instrumento e fator para a reforma do direito. Tenta-se verificar como a literatura popular poderia influenciar movimentos para mudança da legislação e das práticas judiciárias. Orienta-se para uma literatura politicamente inspirada.ll (MORAWETZ citado por GODOY, 2007, p. 02) (grifo do autor).

\subsection{DIANTE DA FICÇÃO}

Machado não se apresenta, degusta-se. Cada palavra, cada nova ideia e reflexão sobre sua obra, suas palavras, será outra vez repetida, dissecada, ecoada, escancarada. (Cristiana Vieira Jacquemin)

Joaquim Maria Machado de Assis é considerado um dos mais importantes escritores da literatura brasileira. Nascido no Rio de Janeiro, em 1839, mesmo sem ter acesso a cursos regulares, empenhou-se em aprender e superou todas as dificuldades da época, tornando-se um grande escritor.

Suas obras podem ser divididas em duas fases. Em sua fase romântica, os personagens de suas obras possuem características românticas, tendo como principais temas o amor e os relacionamentos amorosos. Dessa fase, destacam-se obras como: Ressurreição (1872), A Mão e a Luva (1874), Helena (1876) e laiá Garcia (1878).

Já em sua segunda fase, a realista, Machado de Assis abre espaço para as questões psicológicas dos personagens. Nos títulos, o autor retrata muito bem as características do realismo literário, fazendo uma análise profunda e realista do ser humano, ressaltando suas vontades, necessidades, defeitos e qualidades. Destacam-se obras como: Memórias Póstumas de Brás Cubas (1881), Quincas Borba (1892), Dom Casmurro (1900) e Memorial de Aires (1908).

Ora, o autor, como funcionário público e exímio conhecedor das Leis de seu tempo, tornou-se um exemplo clássico para os estudos do Direito e Literatura, por meio de suas obras, fazendo com que a ficção sofresse influências das leis. Suas matérias eram ligadas à família, à propriedade, à sociedade em plena transformação, enfim, impunha-se o humano como absoluto e indispensável.

E suas mulheres, e seus casais, e suas crianças, e seus padres, e suas mães, todos estavam sujeitos a uma pequena fraqueza, um desvio, um lapso. Um mau comportamento até. E com sua mão e sua pluma ele os sustentava para transformá- los em criaturas intocáveis. Só o desejo finalmente poderia subsistir. Para toda a eternidade. (Cristiana Vieira Jacquemin)

A obra Helena (1876) mostra, no enredo, que, o Conselheiro do Vale, um homem rico, tinha um caso amoroso com Ângela, uma mulher que havia migrado do estado do Rio Grande do Sul, com uma filha chamada Helena. Com o falecimento do Conselheiro, na abertura de seu testamento, constata-se que ele declara Helena sua filha e que ela deveria tomar seu lugar na família, como se dela sempre fizesse parte. Porém, ao tempo em que todos acreditavam no reconhecimento da paternidade, Helena sabia que a declaração não era verdadeira, entretanto viu aguçar sua ânsia pelo crescimento social, e acabou por aceitar a situação.

[... Há um ano, falecendo, o meu velho amigo conselheiro Vale reconheceu Helena, por uma cláusula testamentária; recomendava à família que a tratasse com afeto e carinho e designava o colégio em que ela estava sendo educada. O fato do reconhecimento e as circunstâncias que apontou, dão toda a veracidade à palavra do morto. Que prova apresenta o senhor em contrário a ela? [...] (MACHADO, 1876, p.190)

\subsection{DIANTE DA LEI}

Para que o Direito se desenvolva, é fundamental que suas estruturas sejam formadas por elementos externos a ele. (Ricardo Reis Messaggi, Ana Cecília Parodi)

Segundo Venosa (2007), nos primórdios da civilização Grega, não havia de se falar em testamento, e as antigas civilizações eram ligadas à família.

Em Roma, o testamento moldava-se valorizado, partindo da cultura como cita Monteiro (1998),

(...) os romanos tinham verdadeiro horror pela morte sem testamento. Para eles, nenhuma desgraça superava a de falecer ab intestato; maldição alguma era mais forte do que a de augurar um inimigo o morrer sem testamento. 
Finar-se ab intestato redundava numa espécie de vergonha. (MONTEIRO, 1998, p. 04)

Venosa (2007) ainda dispõe que essa valorização do testamento, com a Lei das XII Tábuas, apresentava-se em dois tipos: 0 testamento feito por ocasião dos comícios romanos (calatis comitiis), caracterizado pela manifestação ante as antigas assembleias convocadas pelo Rei (Pontifex Maximus), adaptando-se a uma forma de lei pública, atendendo à vontade do povo (Populus Romanus). Outro testamento romano era o in procintu, feito em tempos de guerra, com o exército em ordem de combate. Ambas as formas caíram em desuso, entre os séculos I e II a.C., surgindo no pós-classicismo, as formas testamentárias atuais, que são os testamentos públicos, escritos pelo tabelião, ou seu substituto, no livro de notas, de acordo com a declaração do testador, posteriormente, lido em voz alta, com a presença de duas testemunhas, e os testamentos privados, escritos pelo próprio testador, manualmente ou mecanicamente, lido e assinado por três testemunhas.

Como o testamento está, na maioria das vezes, ligado à família, vale ressaltar que a análise da estrutura familiar, no início do último século, mostra-a guiada pela religião, tendo o homem como chefe da família, com poder sobre os demais. O instituto do casamento era santificado pelo padre, na igreja, cuja presença era muito forte.

Desse modo, o Código Civil de 1916 mostrava-se fruto dessa situação, apresentando o casamento como a única forma legítima de construção familiar, concebendo filhos comuns, tratando o direito de família no modelo oitocentista ou patriarcal: isso para proteger o patrimônio familiar.

$E$, de acordo com as mudanças sociais que vinham acontecendo, em meados do século XX, a legislação cível começa a acompanhar suas alterações.

A sucessão testamentária está disposta no Código Civil (2002) em seu Livro V, Título III, artigo $1.857-[\ldots]$ toda pessoa capaz pode dispor, por testamento, da totalidade dos bens, ou de parte deles, para depois de sua mortell.

Sobre essa determinação legal, os autores que mais se destacam e suas teorias estão elencados no quadro abaixo:

Quadro 1 - Teorias de base sobre o Testamento.

\begin{tabular}{|c|c|c|}
\hline Autor/ano & Assunto & Teoria \\
\hline Clóvis Beviláqua & \multirow{3}{*}{ Testamento } & $\begin{array}{l}\text { Ato personalíssimo, unilateral, gratuito, solene e revogável, pelo } \\
\text { qual alguém segundo as prescrições da lei, dispõe, total ou } \\
\text { parcialmente, de seu patrimônio, para depois de sua morte; } \\
\text { nomeia tutores para seus filhos; ou reconhece filhos naturais; ou } \\
\text { faz declarações de última vontade. }\end{array}$ \\
\hline Maria Helena Diniz & & $\begin{array}{l}\text { O testamento é negócio jurídico (que requer para } \\
\text { sua validade agente capaz, objeto lícito e forma prescrita ou não } \\
\text { defesa em lei) destinado a produzir efeitos após a morte de seu } \\
\text { autor. }\end{array}$ \\
\hline Silvio Rodrigues & & $\begin{array}{l}\text { Testamento é negócio jurídico unilateral em que seu autor faz } \\
\text { disposição da totalidade de seus bens, ou de parte deles, para } \\
\text { depois de sua morte. }\end{array}$ \\
\hline
\end{tabular}

Fonte: Elaborado pela autora.

Feita essa exposição, necessário que se retorne a Helena, obra escrita por Machado

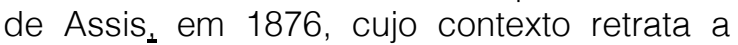
situação de sucessão testamentária, proposta de estudo deste artigo:

[...] aberto o testamento com todas as formalidades legais, o conselheiro nomeava testamenteiros Estácio, o Dr. Camargo e o padre Melchior. As disposições gerais nada tinham que fosse notável: eram legados pios ou beneficentes, lembranças a amigos, dotes a afilhados, missas por sua alma e pela de seus parentes. Uma disposição havia, porém, verdadeiramente importante. O conselheiro declarava reconhecer uma filha natural, de nome Helena[...].[...] Era declarada herdeira da parte que lhe tocasse de seus bens, e devia ir viver com a família, a quem o conselheiro instantemente pedia que a tratasse com desvelo e carinho, como se de seu matrimônio fosse. (MACHADO DE ASSIS, 2004, p.08)

Nesse diapasão, o reconhecimento da paternidade de Helena, seja biológica ou afetiva, produziria efeitos legais; a partir do respaldo do artigo 1616 do Código Civil de 
2002, Venosa (2007) ensina que

O reconhecimento, como já afirmado, tem efeito ex tunc, retroativo, daí por que seu efeito é declaratório. Sua eficácia é erga omnes, refletindo tanto para os que participaram do ato de reconhecimento, voluntário ou judicial, como em relação a terceiros. Dessa eficácia decorre a indivisibilidade do reconhecimento: ninguém pode ser filho com relação a uns e não filho com relação a outros. Vimos também que esse ato jurídico é puro, não pode ser subordinado a termo ou condição. È irrevogável, somente podendo ser anulado por vício de manifestação de vontade ou vício material. A sentença que reconhece a paternidade produz, como vimos, os mesmos efeitos do reconhecimento voluntário. (VENOSA citado por SOBRAL, 2010)

\subsection{DA AFETIVIDADE}

A efetividade encontra-se presente em todas as relações jurídicas, mas impregna, especialmente, as relações do Direito de Família das quais é marco característico. (Romualdo B. Santos).

A entidade familiar, nos primórdios de suas concepções, constituía-se do poder patriarcal e tradicional, juntamente, ligado à igreja e seus acostumes, e o pai era a figura central, seguido da esposa e de seus filhos. A ruptura desses paradigmas trouxe à família uma concepção interpretada como meio de procriação. Somente com o advento do Direito romano, começou-se a pensar em uma entidade social aliada à unidade jurídica, econômica e religiosa, mais tarde, o reconhecimento do matrimônio, no cristianismo.

Porém, afirma Maria Berenice Dias que -[...] a sociedade evolui, transforma-se, rompe com tradições e amarras, o que gera a necessidade de constante oxigenação das leis.|l (DIAS, 2007, p. 29).

E nessa perspectiva, o Código Civil de 1916 reconstrói a ideia de poder familiar, reconhecendo o direito da mãe no exercício desse poder, na ausência do pai, como dispunha o Estatuto da Mulher Casada - Lei $n^{\circ}$. 4.121/62.

Porém, somente com o advento da Constituição Federal de 1988, em seu artigo 226, § 5, a igualdade de direitos fora reconhecida, de fato, aos cônjuges, consolidando-se no Estatuto da Criança e do Adolescente - Lei №. 8.069/90, em seu artigo 21 ,

Artigo 21: O pátrio poder familiar será exercido, em igualdade de condições, pelo pai e pela mãe, na forma do que dispuser a legislação civil, assegurado a qualquer deles o direito de, em caso de discordância, recorrer à autoridade judiciária competente para a solução da divergência.

Acompanhando as transformações, a entidade familiar evoluiu, o Código Civil de 2002 reconheceu a união estável, e não menos relevante, permaneceu seu fundamental papel de interligar gerações, comunidades e operar entre os indivíduos.

Corrobora a autora Ana Carla Matos, à luz da discussão, que:

Do ponto de vista legislativo, o advento da Constituição de 1988 inaugurou uma diferenciada análise jurídica das famílias brasileiras. Uma outra concepção de família tomou corpo no ordenamento. O casamento não é mais a base única desta entidade, questionando-se a idéia da família restritamente matrimonial. Isto se constata por não mais dever a formalidade ser o foco predominante, mas $\operatorname{sim} 0$ afeto recíproco entre os membros que a compõem redimensionando-se a valorização jurídica das famílias extramatrimoniais. (MATOS, 2008, p.35) (grifo nosso)

Esse novo contorno, conquistado pela entidade familiar, trouxe a valorização da afetividade, como concepção jurídica, que aparece nas disposições de Eduardo de Oliveira Leite:

A nova família, estruturada nas relações de autenticidade, afeto, amor, diálogo e igualdade, em nada se confunde com o modelo tradicional, quase sempre próximo da hipocrisia, da falsidade institucionalizada, do fingimento. A noção de vida comum atual repousa soberana sobre sua solidariedade constantemente provocada pela intensidade afetiva.(...) Nesta ótica, a permanência das relações passa a independer de condutas preestabelecidas e formalizadas em códigos e leis, mas decorre da atitude de cada cônjuge em relação ao outro. (LEITE, 1991, $p^{*}$. 41)

Nesse sentido, Machado de Assis (1876) aduz em sua obra Helena contextos que auxiliam a base filosófica para um novo método de ensino jurídico, o Direito na 
Literatura, quando, naquela época, coloca o afeto como elemento básico de composição familiar.

Há um ano, falecendo, o meu velho amigo conselheiro Vale reconheceu Helena, por uma cláusula testamentária; recomendava à família que a tratasse com afeto e carinho e designava o colégio em que ela estava sendo educada. O fato do reconhecimento e as circunstâncias que apontou, dão toda a veracidade à palavra do morto.(grifo nosso)

Vislumbra-se que, dado o enfoque e observados os dados históricos da época em que a obra fora escrita, a sociedade vivia em plena política Imperial (1824), tendo o direito de família não devidamente regulamentado. Em se tratando de uma sociedade conservadora, resguardada pelo matrimônio, os vínculos afetivos, para incorrerem em aceitação social e reconhecimento jurídico, ensejava melhores condições e perfis.

Os filhos concebidos de relações fora do casamento, além de não possuírem direitos sucessórios, eram dados como ilegítimos e bastardos. Essa concepção, hoje, é conceituada como família monoparental, que já se fazia presente desde o período Colonial (MONCORVO, 2008), porém não consolidada, e até omitida.

De acordo com os ensinamentos de Belmiro Pedro Welter,

No Brasil, desde o texto constitucional de 1988, a finalidade da família é a concretização e a (re) fundação do amor e dos interesses afetivos entre os seus membros, pois o afeto, como demonstra a experiência e as ciências psicológicas, não é fruto da origem biológica. Significa dizer que, atualmente, promove-se a (re) personalização das entidades familiares e o cultivo do afeto, da solidariedade, da alegria, da união, além do respeito, confiança e amor, um projeto de vida comum, permitindo o pleno desenvolvimento pessoal e social de cada partícipe. (WELTER, 2009)

No decorrer do enredo do romance, o compromisso com eventual verdade fora rompido com a descoberta de que Helena, paternalmente reconhecida por meio do testamento deixado pelo Conselheiro do Vale, na verdade, não era sua filha biológica, mas, sim, afetiva. A história de sua vida e toda essa relação fora contada pelo seu verdadeiro pai, Salvador, que, com a notícia da morte de Vale, e seus frequentes encontros com Helena, expõe seus sentimentos e os fatos:
Um dia, almoçando em um botequim, li a notícia da morte do conselheiro. O fato consternou-me; mas eu peço licença para Ihes dizer tudo: de envolta com o sentimento de pesar, houve em mim alguma coisa semelhante a uma satisfação. Respirava enfim! O contrato expirava com ele; eu ia entrar na posse de minha filha. Não escrevi desde logo a Helena; fi-lo ao cabo de alguns dias. Tive duas respostas: a primeira era no sentido da minha carta; a segunda anunciavame que o reconhecera por testamento. [...] Exprimia-se com a maior gratidão e saudade a respeito do conselheiro; mas negava-se a aceitar o favor póstumo. Sabendo a verdade, não queria escondê-la ao mundo. Aceitando o reconhecimento, entendia que prejudicava direitos de terceiro, além de repudiar-me solenemente, o que não queria fazer desde que adquiria a liberdade de ação. Entre a herança e o dever, dizia ela, escolho o que é honesto, justo e natural. [...] Que mão invisível tocara no coração do conselheiro essa corda de sensibilidade? Melhor fora que ele houvesse traduzido em uma simples lembrança a afeição que tinha a Helena. Longo tempo refleti nisso; o pai lutava com o pai. [...] Mas, podia atá-la ao carro decrépito da minha fortuna, dar-lhe o pão amargo de todos os dias? A família do conselheiro ia afiançar-Ihe futuro, respeito, prestígio; a lei ia ampará-la. (MACHADO DE ASSIS, 1876, p. 202-203)

Olhando por esse prisma, a condição biológica de pai é vínculo genético, sendo necessário o seu reconhecimento para a caracterização da paternidade. Porém, essa origem biológica não devera ser de grande importância.

Em Helena, Estácio acabara de descobrir tudo, e, em silêncio, por alguns instantes

exprime:

Mas, posso eu, à vista do que acabamos de ouvir, conservar a Helena um título que rigorosamente Ihe não pertence? Helena não é minha irmã; é absolutamente estranha à nossa família; o título que nos ligava, desaparece. Por que motivo continuaríamos nós uma falsificação...

- De seu pai? atalhou Melchior.(MACHADO DE ASSIS, 1876, p. 206)

Partindo da convicção de que a afetividade constrói no indivíduo elos fortes, faz-se valer cada vez mais a verdade social, psíquica e afetiva. E assim, aduz Veloso que: 
$\mathrm{Na}$ filiação natural (a que não resulta do casamento dos genitores) há um vínculo biológico ligando o filho a seu pai, porque, certamente, todo filho tem um pai. Mas o vínculo jurídico não se estabelece, automaticamente. Só pelo fato do nascimento, neste caso, a paternidade não estará determinada, sendo necessário outro ato, o reconhecimento da filiação. (VELOSO, 1997, p. 14)

E ainda, decisão magistral do Tribunal de Justiça do Rio Grande do Sul corrobora:

Ementa: apelação cível. Investigação de maternidade. Imprescritibilidade. Filiação socioafetiva e biológica.

EFEITOS. O filho tem o direito de impugnar o reconhecimento da sua maternidade, a qualquer tempo, sem prazo decadencial. Todavia, verificada a filiação socioafetiva com os pais registrais, esta prevalecerá sobre a biológica. RECURSO IMPROVIDO. (SEGREDO DE JUSTIÇA) (Apelação Cível № 70022450381, Oitava Câmara Cível, Tribunal de Justiça do RS, Relator: Claudir Fidelis Faccenda, Julgado em 20/03/2008)

$\mathrm{Na}$ obra, a discussão entre os amigos e familiares ligados à tal descoberta de Helena, rendeu-lhes certos posicionamentos e concepções, principalmente, em relação ao fato de Salvador, pai biológico da moça, jurar como verdadeiras todas as suas histórias.

[...]nem a lei nem a Igreja se contentam com essa simples verdade. Em oposição a ela, há a declaração derradeira de um morto. A justiça civil exige mais do que palavras e lágrimas; a eclesiástica não extingue com um traço de pena, a afirmação póstuma. Demais, não espere que esse homem reproduza perante ninguém as declarações de há pouco; só o fará quando perder a última esperança. É evidente que ele nada quer alterar do que seu pai estabeleceu, e antes se sacrificará do que envergonhará a filha. Sente-se disposto a fazer o que ele recusa? (MACHADO DE ASSIS, 1876, p. 206)

Atentando para a realidade do mundo atual, conclui-se que o reconhecimento filial afetivo deve ser protegido pelo ordenamento jurídico, buscando respaldo normativo, além de também se dedicar aos princípios da solidariedade e da afetividade, como forma de construir laços afetivos e fraternos gerados pelos envolvidos, a fim de que se tornem exemplo de conduta e entendimentos superiores, reconhecendo que -A compreensão e o enfrentamento desses quadros anacrônicos demandam muito mais que um enfoque singular. Certamente exigem uma integração multidisciplinar.॥ (DIAS, 2010, p. 07)

Desta feita, seguindo o pensamento e concordando com Maria Berenice DIAS, -O afeto merece ser visto como uma realidade digna de tutela.ll Aí está registrado o quanto a Literatura caminha à frente do Direito.

\section{DO FATO À FICÇÃO: ATUALIDADES}

É costume dizer-se que contra fatos não há argumentos. Ora, só contra fatos é que há argumentos. Os argumentos são, quase sempre, mais verdadeiros do que os fatos. (Fernando Pessoa)

Famosas são as decisões judiciais que os magistrados constroem sob a perspectiva literária. O presidente do Tribunal Regional do Trabalho do Paraná, o desembargador Ney José de Freitas, é autor de livros de poesia, e concorda com a perspectiva de que a grande contribuição da Literatura ao Direito se dá no sentido de sensibilizar seus operadores, aduzindo que: -A Literatura sensibiliza, humaniza, faz com que o juiz perceba a dimensão do outro. A Literatura faz com que o juiz saia do mundo formal. Claro que ele não pode fugir da realidade processual, mas pode humanizá-lall.

Porém, apesar de admitidas tais referências da Literatura à argumentação jurídica, há juristas que são contrários a essas vertentes. Sentença de uma ação de usucapião proferida por uma juíza do Rio Grande do Sul apresentava-se da seguinte forma: -A sobrarlhe a razão / Aduz a sua pretensão / Com respeito vem pedi-la / E a justiça ouvi-la / Gleba que traz ocupada / No tempo somente sua / Em pleno gozo e uso / Deseja usucapilall. E ainda, o STF em voto contra a Lei de Imprensa, prolatou o ministro Carlos Ayres Britto: -Esparsas nuvens escuras a se esgueirar, intrusas, por um céu que somente se compraz em hospedar o sol a pino.l

A esse respeito, reflete Karam Trindade que

○ Direito não deve tentar reproduzir a forma literária, sob pena de não ser nem uma coisa, nem outra. O Direito busca a estabilização, a segurança jurídica, o mandato, a ordem; ao passo que a Literatura volta-se para o abstrato, a inovação, a dúvida, a metáfora. (TRINDADE citado por DIAS, 2010) 
Godoy corrobora com o autor em seu posicionamento: -Decisões judiciais em forma de poesia complicam a compreensão do Direito, na medida em que exigem esforço interpretativo desnecessário: apenas refletem a vaidade dos prolatores das decisões.ll (GODOY citado por DIAS, 2010)

Visões interdisciplinares, nas relações de família, trazem a perspectiva do afeto, como discussão de instituto do ordenamento jurídico, sendo tema de Congresso Internacional do IBDFAM - Instituto Brasileiro de Direito de Família - cujos assuntos tratados permeiam, inclusive, sobre sucessão e testamento.

Referência no ensino do Direito, vale citar um projeto desenvolvido pela UNISINOS Universidade do Vale do Rio dos Sinos no Rio Grande do Sul, intitulado Direito \& Literatura, que tem como objetivo -[...] estudar as interfaces entre as duas áreas do conhecimentoll (UNISINOS, 2012)

Outro projeto com o mesmo título se desenvolve na FMP - Fundação Escola Superior do Ministério Público, com formato de debates de periodicidade mensal entre acadêmicos, professores e profissionais do Direito. O objetivo da fundação é -[...] promover discussão de temas que envolvam o Direito e suas diversas formas de influência na sociedadell onde - o debate recai sobre clássicos da Literatura que abordam questões pertinentes ao saber jurídicoll (FMP, 2012).

Em artigo publicado no JUS Navigandi, revista eletrônica de grande acesso, Valadão (2012) publicou recentemente sobre Arte, Literatura e Direito: a subjetividade e a lei, em que afirma

(...) talvez possamos utilizar Stendhal, Balzac, Machado de Assis etc. na busca de captar a -realidade social efetivall onde se cria e aplica o Direito, isto é, a ficção, sem dúvida, pode nos oferecer uma grande contribuição para conhecermos o

-Sujeito de Direitoll que são os personagens em movimento, em ação e em situação de experimentação no enredo de um romance (VALADÃO, 2012, p. 1).

Outra referência importante é a publicação do livro -O estudo do direito através da literaturall, não tão recente, mas baseado em estudos realizados nos programas de pós- graduação em Linguística e em Literatura da Universidade Federal de Santa Catarina, cujo autor demonstra o propósito de -[...] encontrar campos de intersecção entre estas duas áreas do conhecimentoll (OLIVO, 2005).

\section{PARA FINALIZAR}

Quando se quer mudar os costumes e as maneiras, não se deve mudá-las pelas leis. (Montesquieu)

O objetivo deste artigo foi demonstrar a interação do Direito com a Literatura, compreendendo de que forma esse processo de conhecimento, pouco explorado, possibilita a aprendizagem jurídica, apreendendo de uma obra literária -frutos\|l para um estudo intertextual.

Avançando com o objetivo, buscou-se a realização de reflexões pelos ensinamentos dos autores permeados por essa inter-relação - Literatura e Direito - a respeito da função da Literatura, como sendo uma visão individualizada e mais intensa sobre o assunto, a fim de se tratar das possíveis contribuições entre os estudos jurídicos e literários, de uma maneira eficaz e eficiente.

O novo paradigma jurídico, dedicado e aliado ao pós-positivismo, impõe necessárias mudanças na legislação e, consequentemente, adequar-se à sociedade e suas constantes mudanças, de forma que se promova uma linguagem e ação jurídica de qualidade: justiça.

Neste estudo procurou-se discutir os fenômenos jurídicos associados à interpretação e racionalidade pós-positivista, afirmando sua possibilidade de expansão axiológica e viabilidade de sua aprendizagem. A apresentação, a discussão e a interação da obra Helena, permitiram aprofundar na evolução histórica do pensamento jurídico, aliado à sucessão testamentária e à afetividade, com suas mudanças sociais e alterações legais, formando, assim, a compreensão do ensino jurídico inteiramente ligado à sociedade.

A abertura das discussões sobre temática atual das relações familiares concluiu que ultrapassa as concepções dos paradigmas ditados pela sociedade, não sendo mais comportadas (ou suportadas) pela abrangência das diversidades socioculturais compostas pela nação.

Ao se falar das leis sucessórias e, debatendo o ponto central, o afeto, restou demonstrado que a tendência contemporânea, formada pela família (reconhecimento) socio- afetiva, tornou-se um agente formador de novos 
rumos e aspectos do ordenamento jurídico, do vínculo familiar e suas relações.

Ora, Helena é um romance escrito em 1876, com vistas e abordagens a temas que transcendem aquela época, sendo justo afirmar, como os próprios títulos discutidos pelo artigo apontam, a literatura, como nova possibilidade metodológica de ensino do Direito, capaz de auxiliar na sua aprendizagem, sem contar suas contribuições cada vez mais humanizadas.

Contudo, evidenciado pelas reflexões e

\section{REFERÊNCIAS}

[1] Andrade, Ricardo Luís Sant' Anna de. Breves considerações acerca da Sucessão Testamentária. In: Juspodivm. Disponível em < http://www.juspodivm.com.br/i/a/\%7BE57E49CF9881-44FE-BB4A-

8D54E4785D6A\%7D_ricardo_luis_breve_conside.p df>. Acesso em : 07 abr. 2012.

[2] Brambilla, Leandro Vilela. No que consiste o pós-positivismo? In: JusBrasil Notícias, extraído da Rede Luiz Flavio Gomes, 2010. Disponível em: < http://lfg.jusbrasil.com.br/noticias/2194899/no-queconsiste-o-pos- positivismo-leandro-vilelabrambilla> Acesso em 08 abr. 2012.

[3] Brasil. Código Civil Brasileiro. São Paulo: Saraiva, 2010.

[4] Dias, Maria Berenice. Famílias Modernas: (inter)secções do afeto e da lei. In: Portal Jurídico Maria Berenice Dias. 2010. Disponível em: $<$ http://www.mariaberenice.com.br/uploads/3__fam\%EDlias_modernasinter_sec\%E7\%F5es_do_af eto_e_da_lei.pdf> Acesso em: 28 jul. 12.

[5] Manual de Direito das Famílias. 4. ed. rev., atual. e ampl. São Paulo: Revista dos Tribunais, 2007.

[6] Dias, V. A. Direito e literatura: fato e ficção. In: Portal Gazeta do Povo: Vida e Cidadania. 2010. Disponível

em:< http://www.gazetadopovo.com.br/vidaecidadania/c onteudo. phtml?id=970641 > Acesso em: 20 jul. 12.

[7] Diniz, M. H. Curso de Direito Civil Brasileiro: Direito das Sucessões. 21 ed. São Paulo: Saraiva, 2007.

[8] Dworkin, Ronald. De que maneira o Direito se assemelha à literatura. In: Uma Questão de Princípio. Capítulo 6. São Paulo: 1982, Martins Fontes.

[9] Fernandes, Claudia D.; Campos, Karine M. ; Maraschin, Claudio. Direito e Literatura: uma análise interdisciplinar do fenômeno jurídico a partir dos textos literários. Disponível em: < http://reesser.wordpress.com/2009/12/18/sucessao -testamentaria> Acesso em: 17 fev. 2012. interações feitas, a partir da proposta de intersecção do romance com paradigmas de nosso ordenamento jurídico, é possível apreender, do conjunto da obra, informações suficientes para que a literatura seja discutida/debatida como espaço de produção do conhecimento jurídico, o que faz com que este artigo atenda às hipóteses, consequentemente reafirmando-as, como forma de contribuição para novas expectativas neste encontro inevitável e admirável entre Direito e Literatura.

[10] FMP, Fundação Escola Superior do Ministério Publico. Direito e Literatura.Disponível em

<http://www.fmp.com.br/faculdade/extensao/literatu ra-e-direito/3/> Acesso em 17/07/2012.

[11] GIL, Antonio Carlos. Como elaborar projetos de pesquisa. 4 ed. São Paulo: Atlas, 2007.

[12] Godoy, Arnaldo Sampaio de Moraes. Direito e literatura. Os pais fundadores: John Henry Wigmore, Benjamin Nathan Cardozo e Lon Fuller. In: Jus Navigandi, Teresina, ano 11, n. 1438, 2007.

[13] Direito \& Literatura: Ensaio de síntese teórica. Porto Alegre: Livraria do Advogado Editora, 2008.

[14] Direito e Literatura: Anatomia de um desencanto. Curitiba: Juruá, 2002.

[15] Jung, C. F. Metodologia Científica - Ênfase em Pesquisa Tecnológica. 3 ed. 2003/I. Publicação eletrônica invendável. Destina-se a Difusão Tecnológica Gratuita - Incentivo a Produção Científica Nacional. Disponível em: $<$ http://www.geologia.ufpr.br/graduacao/metodolog ia/metodologiajung.pdf>. Acesso em: 07 abr. 2012.

[16] Leite, E. O. Tratado de direito de família: origem e evolução do Casamento. Curitiba: Juruá, 1991. p. 41

[17] Machado de Assis, Joaquim Maria. Helena. 2 ed. Porto Alegre: Moderna, 2004.

[18] Maranhão, Ney Stany Morais. O fenômeno pós-positivista: considerações gerais. In: AMATRA 8. Amapá: 2008. Disponível em: < http://www.amatra8.org.br/artigos/positivismo.pdf> Acesso em: 13 mar. 2012.

[19] Matos, Ana Carla Harmatiuk. "Novas" Entidades Familiares e seus Efeitos Jurídicos. In: Família e Solidariedade: Teoria e Prática do Direito de Família. Rio de Janeiro: Lumen Juris, 2008.

[20] Messaggi, Ricardo Reis; PARODI, Ana Cecília. Direito e Literatura: O Retrato do Direito de Família, nos Contos de Dalton Trevisan. 2010. Disponivel em: <http://www.unicuritiba.edu.br/sites/default/files/u17 
/20110502120524o_direito_de_familia_e_sua_intera cao_-ana ricardo.pdf > Acesso em 20 ago. 12.

[21] Moncorvo, Maria Cecília Ribeiro. (2008) Família brasileira: do patriarcalismo colonial ao crescente poder feminino na contemporaneidade. In: Divisão de Bibliotecas e Documentação PUC/Rio. Disponível em <http://www2.dbd.puc rio.br/pergamum/tesesabertas/0610333_08_cap_02 .pdf. > Acesso em 03 jul.12.

[22] Monteiro, W. B. Curso de Direito Civil: Direito das Sucessões. 32 ed. São Paulo: Saraiva, 1998.

[23] Moraes, R.; Borges, Regina Maria Rabello (org.). Realidade, teoria e pesquisa. In: Filosofia e história da ciência no contexto da educação em ciências: vivências e teorias. Porto Alegre: EDIPUCRS, 2007.

[24] Oliveira, S. L. Metodologia Científica Aplicada ao Direito. São Paulo: Thomson, 2002.

[25] OLIVO, L. C. C. de. O estudo do direito através da literatura. Tubarão: Studium , 2005.

[26] Popper, C.; Messaggi, R. R. O direito de família a partir da literatura brasileira, nos contos de Nelson Rodrigues. In: XVIII Congresso Nacional do Conpedi, 2009, São Paulo. Anais do XVIII Congresso Nacional do Conpedi, 2009. p. 1441.

[27] Rodrigues, S. P. M. A Interpretação Jurídica no Pensamento de Ronald Dworkin: Uma Abordagem, Coimbra: Almedina, 2005.

[28] Santos, R. B. Direito e Afetividade: Estudos sobre as influências dos aspectos afetivos nas relações jurídicas. 2009. Disponível em:

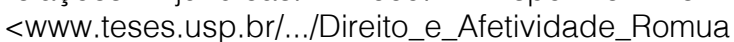

Ido_B_Santos> Acesso em 20 ago. 12.

[29] Sobral, M. A. Os efeitos do reconhecimento da paternidade sócio-afetiva. In: Âmbito Jurídico: Família. 2010. Disponível em: $<$ http://www.ambito-

juridico.com.br/site/?n_link=revista_artigos_leitura\& artigo_id=8399\&revista_caderno=14> Acesso em: $07 / 12$.

[30] Souza, M. V. S. G. de. O Direito como Ciência. In: Portal Recanto das Letras: textos jurídicos, 2010. Disponível em: http://www.recantodasletras.com.br/textosjuridicos/ 13565 Acesso em: 05 jun. 2012.

[31] Unisinos, Universidade do Vale do Rio dos Sinos. Direito \& Literatura. Disponível em<http://www.unisinos.br/direitoeliteratura/>. Acesso em 16/06/2012.

[32] Valadão, Walter Aguiar. Arte, Literatura e Direito: a subjetividade e a lei. Venda Nova do Imigrante, ES, março/ 2012. Disponível em < http://jus.com.br/revista/texto/21316/arte-literaturae-direito-a-subjetividade-e-a- lei\#ixzz22lutYTi6>. Acesso em 16/07/2012.

[33] Veloso, Zeno. Direito brasileiro da filiação e paternidade. São Paulo: Malheiros, 1997.

[34] Venosa, Silvio de Salvo. Curso de Direito Civil: Direito das Sucessões. 7 ed. São Paulo: Atlas, 2007.

[35] Welter, Belmiro Pedro. Inconstitucionalidade do processo de adoção judicial. 2009. Disponível em:<http://www.mundojuridico.adv.br/sis_artigos.a sp?codigo=611> Acesso em: 03 jul. 12. 


\section{Capítulo 15}

\section{GESTÃO ESCOLAR NO MUNICÍPIO DE SANTA MARIA/RS}

\section{Claudete Fogliato Ribeiro}

Resumo: A escola como instituição social, deve ser administrada a partir de suas especificidades, ou seja, uma organização dotada de responsabilidades e particularidades que dizem respeito à formação humana por meio de práticas políticas, sociais e pedagógicas. O presente estudo tem como objetivo verificar como se dá a Gestão Escolar e as principais dificuldades enfrentadas em seu cotidiano. Como metodologia utilizou-se do estudo de caso, tratando-se de uma pesquisa exploratória descritiva de natureza qualitativa, com entrevista destinada a direção de três escolas municipais de ensino fundamental localizadas no município de Santa Maria/RS. Os resultados destacam a importância da gestão democrática para a qualidade do ensino e mostram que, embora já tenham acontecido significativos avanços, ainda existe a necessidade de aprofundar a compreensão em torno da temática. Além de ampliar os espaços de discussão buscando a participação de todas as partes interessadas, condição fundamental para a melhoria da qualidade na educação.

Palavras-Chave: Gestão pública. Gestão escolar. Escolas municipais. 


\section{INTRODUÇÃO}

Diante da aceleração dos avanços tecnológicos, a globalização do capital e as transformações nas relações de trabalho, os cenários foram de mudanças para as políticas de gestão e de regulação da educação no Brasil. Tais mudanças interferem na gestão educacional e nos papéis dos diversos atores sociais envolvidos. Compreender esse processo e sua legislação, bem como fortalecer a discussão e as deliberações coletivas na escola, é um desafio que se coloca para toda a comunidade escolar. Pois a gestão educacional deriva-se da natureza, das funções, dos objetivos e dos valores das escolas, alicerçados no campo da formação humana e sociocultural.

A gestão educacional no setor público apresenta dificuldades significativas, devido a diversos fatores, tais como: resistências existentes por parte dos servidores; informações que nem sempre são fornecidas em tempo real; transitoriedade das políticas públicas; priorização dos aspectos políticos em detrimento das prioridades de uma gestão escolar eficiente.

Nesse sentido, preconiza-se, no presente estudo, que a escola como instituição social, deve ser administrada a partir de suas especificidades, ou seja, é uma organização social dotada de responsabilidades e particularidades que dizem respeito à formação humana por meio de práticas políticas, sociais e pedagógicas. A gestão escolar implica em analisar em que condições se realizam os processos de trabalho e as ações pedagógicas. É preciso entender a gestão como um espaço de construção política para além das questões meramente administrativas e, portanto, englobar as condições objetivas dos profissionais que atuam no dia-a-dia dos processos de ensino-aprendizagem, de democratização da gestão, e de escolha dos dirigentes escolares.

Compreender melhor a escola e sua função social, destacar as suas especificidades pode ser relevante uma vez que se vive em um momento que a autonomia faz parte da agenda de discussão de professores, gestores, pesquisadores, governo, partidos políticos, entre outros. Para um melhor entendimento, ao se defender a autonomia da escola, está se defendendo que a comunidade escolar seja independente e tenha liberdade para coletivamente pensar, discutir, planejar, construir e executar o projeto político-pedagógico almejado. No entanto, mesmo tendo essa autonomia, a escola está subordinada ao Sistema Nacional de Educação, às normas gerais do sistema de ensino e às leis que o regulam, não podendo, portanto, desobedecê-las.

Diante disso, articula-se o seguinte problema de pesquisa que constitui a diretriz básica para o desenvolvimento do presente estudo: Como é realizada a gestão escolar diante do atual contexto e complexidade do cotidiano da escola pública municipal? A partir da definição do problema de pesquisa, tem-se como objetivo geral Verificar como se dá a Gestão Escolar e as principais dificuldades enfrentadas em escolas municipais da cidade de Santa Maria/RS.

O desafio que se coloca aos gestores educacionais trata da forma de realizar os programas e projetos planejados com êxito, considerando-se os recursos cada vez mais escassos. Nessa linha de argumentação, o presente trabalho justifica-se por acreditar-se que a gestão escolar ocorre pelo comprometimento das partes interessadas com objetivos ousados, quais sejam, desconstruir as ortodoxias dos métodos tradicionais de gestão e adotar princípios novos e, ainda, aprender com os bemsucedidos.

Outro aspecto a ser considerado está relacionado a importância de se estudar como as escolas públicas estão organizando seu funcionamento quanto aos aspectos políticos, administrativos, tecnológicos, administrativos, culturais e pedagógicos, com a finalidade de dar transparência às suas ações e atos e possibilitar à comunidade escolar a aquisição de conhecimentos, dialogar, construir, transformar e ensinar.

Assim, através do presente estudo pretendese conhecer a realidade do cotidiano escolar e suas principais dificuldades, com finalidade de contribuir com informações relevantes visando sugerir melhorias nos procedimentos relacionados a gestão escolar.

\section{REFERENCIAL TEÓRICO \\ 2.1 GESTÃO EDUCACIONAL}

A gestão educacional é baseada na organização dos sistemas de ensino federal, estadual e municipal e das incumbências desses sistemas; das várias formas de 
articulação entre as instâncias que determinam as normas, executam e deliberam no setor educacional; e da oferta da educação pelo setor público e privado (LÜCK, 2000).

Cada sistema tem um papel a desempenhar no contexto educacional do País. No que diz respeito a educação básica, cabe aos Estados, Distrito Federal e Municípios ofertála, por sua vez, o ensino médio é um dever dos Estados e do Distrito Federal e a educação infantil dos Municípios. Percebe-se que, embora os entes federativos compartilhem responsabilidades, cada um possui atribuições próprias, tendo a União o papel de coordenar e articular os níveis de sistemas, os Estados e o Distrito Federal o de elaborar e executar políticas e planos educacionais e os Municípios de organizar, manter e desenvolver seu sistema de ensino através da integração com as políticas e planos educacionais da União e dos Estados.

O sistema educacional brasileiro está legalmente regulamentado pela Constituição Federal de 1988, incluindo a Emenda Constitucional n. 14, de 1996, e pela Lei de Diretrizes e Bases da Educação Nacional, entre outras. A LDB, de 1996, define os níveis e modalidades que compõem a educação nacional, além da sua forma de organização. O artigo 21 define que a educação escolar é composta pela educação básica (que abrange educação infantil, ensino fundamental e ensino médio) e pela educação superior. De acordo com a legislação vigente, é competência dos municípios atuarem prioritariamente na educação infantil e ensino fundamental; dos Estados assegurar o ensino fundamental e oferecer, prioritariamente, o ensino médio. Para Krawczyk (1999), uma vez redefinido o papel do Estado, as políticas educativas devem voltar-se para a gestão institucional responsável - a descentralização -, a profissionalização e o desempenho dos educadores, o compromisso financeiro da sociedade com a educação, a capacidade e - esforço científico-tecnológico e a cooperação regional e internacional.

Quando se refere a gestão educacional, não se pensa apenas em uma determinada organização e na racionalização do trabalho escolar para alcançar determinados resultados, ou seja, na produção institucional da escola. Refere-se às relações de poder no interior do sistema educativo e da instituição escolar e ao caráter regulador do Estado e da sociedade no âmbito educacional. As expectativas oficiais em relação às mudanças da gestão do sistema e da instituição escolar, para o conjunto de estratégias de desenvolvimento e governabilidade social e educacional, evidenciam as relações contidas na gestão educacional (Paro 1997).

Para Dourado (2007), a gestão educacional tem natureza e características próprias, ou seja, tem escopo mais amplo do que a mera aplicação dos métodos, técnicas e princípios da administração empresarial, devido à sua especificidade e aos fins a serem alcançados. Diante disso, a concepção de educação é entendida, aqui, como prática social, portanto, constitutiva e constituinte das relações sociais mais amplas, a partir de embates e processos em disputa que traduzem diferentes concepções de homem, mundo e sociedade. Nessa perspectiva, a articulação e a rediscussão de diferentes ações e programas, direcionados à gestão educacional.

Diante da mudança intensa da realidade e seus movimentos, os fenômenos e os fatos se alteram de significado ao longo do tempo; as expressões usadas para representá-los deixam de anunciar toda a riqueza da nova significação. Daí porque a mudança de denominação de Administração para Gestão Educacional. Porém, não se deve entender como uma mera substituição de terminologia das antigas noções a respeito de como conduzir uma organização de ensino.

O conceito de gestão está associado ao fortalecimento da democratização do processo pedagógico, à participação responsável de todos nas decisões necessárias e na sua efetivação mediante um compromisso coletivo com resultados educacionais cada vez mais efetivos e significativos. A essa exigência estaria vinculada a necessidade de interpenetração da dimensão pedagógica e política, na questão administrativa.

\subsection{GESTÃO DEMOCRÁTICA}

A gestão escolar democrática se fortaleceu, sobretudo a partir da década de 80 , com a descentralização de funções e atribuições do Governo Federal - possibilitada que fora pela Constituição de 1988 que, ao colocar o município como um ente do pacto federativo, municipalizou vários serviços essenciais. As questões da gestão democrática, da descentralização e da autonomia da escola estão presentes, sobre tudo, na literatura 
dirigida à escola pública. É relativamente grande a produção sobre a gestão democrática e a participação.

Segundo Lück (2005), é no ano de 1980 que o movimento em favor da descentralização e da democratização da gestão das escolas públicas é iniciado. A partir de então, surgem várias reformas educacionais e proposições legislativas, reconhecendo e fortalecendo o movimento de democratização da gestão escolar e aprimoramento da qualidade educacional.

Para tanto, o ensino deve ser pautado nos seguintes princípios, conforme Constituição Federal: igualdade de condições para o acesso e permanência na escola; liberdade de aprender, ensinar, pesquisar e divulgar o pensamento, a arte e o saber; pluralismo de ideias e de concepções pedagógicas, e coexistência de instituições públicas e privadas de ensino; gratuidade do ensino público em estabelecimentos oficiais; valorização dos profissionais do ensino; gestão democrática do ensino público, na forma da lei; garantia de padrão de qualidade.

Na Lei n. 9394/1996, a gestão democrática, enquanto princípio aparece no artigo 3o, inciso VIII: "Gestão democrática do ensino público, na forma desta lei e da legislação dos sistemas de ensino". Sobre os princípios norteadores da gestão democrática nas escolas públicas de educação básica, a LDB dispõe:

Art. 14 - Os sistemas de ensino definirão as normas de gestão democrática do ensino público na educação básica, de acordo com as suas peculiaridades e conforme os seguintes princípios:

I - Participação dos profissionais da educação na elaboração do projeto políticopedagógico da escola;

II - Participação das comunidades escolar e local em conselhos e equivalentes.

A gestão democrática parte do princípio de que todos os sujeitos devem conhecer os princípios da gestão e interferir nos processos decisórios da escola. Pressupõe, portanto, a participação coletiva nas ações que objetivam garantir 0 alcance das grandes metas definidas pela escola.

Destarte, a gestão democrática implica, portanto, a efetivação de novos processos de organização e gestão, baseados em uma dinâmica que favoreça os processos coletivos e participativos de decisão. Nesse sentido, a participação pode ser implementada e se realiza de diferentes maneiras, em níveis distintos e em dinâmicas próprias no cotidiano escolar. Por que hoje há tendência à descentralização?

É porque o mundo passa por mudanças muito rápidas. Na verdade, a globalização coloca cada dia um dado novo, cada dia, uma coisa nova. Há necessidade de adaptação e de constante revisão do que está acontecendo. Então, isso gera a necessidade de que o poder decisório esteja exatamente onde a coisa acontece. Porque, até que ele chegue aonde é necessário, já houve a mudança, as coisas estão diferentes, e aí aquela decisão já não tem mais sentido. (MACHADO, 1999, p.86)

É preciso reconhecer que a descentralização tem sido praticada tendo como pano de fundo não apenas essa perspectiva de democratização da sociedade, mas também a de promover uma melhor gestão de processos e recursos e, ainda, como condição de aliviar osorganismos centrais que se tornam sobrecarregados com 0 crescimento exponencial do sistema educativo e a complexidade das situações geradas, que inviabilizam o controle central (Barroso, 1997).

Desse modo, "a descentralização educacional não é um processo homogêneo e praticado com uma única direção. Ela responde à lógica da organização federativa" (Parente e Lück, 1996, p. 7). Como se trata de um processo que se refere à transferência de competências para outros níveis de governo e de gestão, do poder de decisão sobre os seus próprios processos sociais e os recursos necessários para sua efetivação, implica existência ou construção de competência para tanto, daí porque a impossibilidade da homogeneidade apontada. O nível de maturidade associada à competência dos grupos sociais é fator substancial na determinação da amplitude do processo.

O que vem ocorrendo na prática educacional brasileira (...) é o deslocamento do processo decisório, do centro do sistema, para os níveis executivos mais próximos aos seus usuários, ou seja, a descentralização do governo federal para as instâncias subnacionais, onde a União deixa de executar diretamente programas educacionais e estabelece e reforça suas relações com os Estados e os 
municípios, chegando até ao âmbito da unidade escolar. Da mesma forma, os sistemas estaduais vêm adotando política similar, ou seja, transferem recursos e responsabilidades com a oferta de serviços educacionais, tanto para o município, quanto diretamente para a escola. (PARENTE E LUCK, 1996, p.13)

Em associação à descentralização, a autonomia da escola é dos conceitos mais mencionados nos programas de gestão promovidos pelos sistemas estaduais de ensino, como também em programas do Ministério de Educação, uma vez que neles está presente, como condição para realizar o princípio constitucional de democratização da gestão escolar. Isto porque a autonomia de gestão da escola, a existência de recursos sob controle local, junt0a liderança pelo diretor e participação da comunidade, são considerados os quatro pilares sobre os quais se assentam a eficácia escolar (LOBO, 2009).

Ao discutir a autonomia da escola, Veiga destaca quatro dimensões consideradas básicas para o bom funcionamento de uma instituição educativa e, que segundo ela, devem ser relacionadas e articuladas entre si:

Autonomia administrativa - consiste na possibilidade de elaborar e gerir seus planos, programas e projetos;

a) Autonomia jurídica - diz respeito à possibilidade de a escola elaborar suas normas e orientações escolares em consonância com as legislações educacionais, como, por exemplo, matrícula, transferência de alunos, admissão de professores, concessão de grau;

b) Autonomia Financeira - refere-se à disponibilidade de recursos financeiros capazes de dar à instituição educativa condições de funcionamento efetivo;

c) Autonomia Pedagógica - consiste na liberdade de propor modalidades de ensino e pesquisa. Está estreitamente ligada à identidade, à função social, à clientela, à organização curricular, à avaliação, bem como aos resultados e, portanto, à essência do projeto pedagógico da escola (VEIGA, 1998, p. 16-19).

Como a liberdade e a flexibilidade são componentes imprescindíveis para a construção da autonomia, que se processa mediante o envolvimento de grupos que expressam diferentes interesses, é natural que seja um processo acompanhado de manifestações contraditórias. Estas fazem parte do processo e saber utilizar a sua energia e reconhecer as suas tendências é condição para o bom encaminhamento do processo.

Nesse modelo de gestão, a participação surge como o principal vetor para a organização da escola como um espaço democrático e caracteriza-se por uma força através da qual os componentes dessa Instituição reconhecem e assumem que têm competência, vontade e poder de influenciar a sua dinâmica educativa. Toda ênfase está no entendimento de que o êxito de uma organização "depende da ação construtiva conjunta de seus componentes, pelo trabalho associado, mediante reciprocidade que cria 'um todo' orientado por uma vontade coletiva"(LÜCK, 2005, p. 15).

A demanda dos que compõem a escola para participarem do processo decisório vem acompanhada do envolvimento de todos na realização das múltiplas tarefas de gestão. Nesse cenário, impera o conceito de autoridade compartilhada, por meio da qual o poder é delegado a representantes da comunidade escolar, e as responsabilidades são assumidas em conjunto. A gestão democrática implica, portanto, a efetivação de novos processos de organização e gestão, baseados em uma dinâmica que favoreça os processos coletivos e participativos de decisão. Nesse sentido, a participação pode ser implementada e se realiza de diferentes maneiras, em níveis distintos e em dinâmicas próprias no cotidiano escolar (LÜCK, 2000).

\subsection{GESTÃO ESCOLAR}

Diferente da gestão educacional, a gestão escolar, trata das incumbências que os estabelecimentos de ensino possuem, respeitando as normas comuns dos sistemas de ensino. Cada escola deve elaborar e executar sua proposta pedagógica; administrar seu pessoal e seus recursos materiais e financeiros; cuidar do ensinoaprendizado do aluno, proporcionando meios para a sua recuperação; e articular-se com as famílias e a comunidade, proporcionando um processo de integração.

O ensino público no Brasil está regulamentado pela Seção I - Da Educação Capítulo III da Constituição Federal de 1988, pela Lei no 9.394/96 - Diretrizes e Bases da 
Educação Nacional, Emendas Constitucionais no 11/96 e 14/96, pelas Resoluções do Conselho Nacional de Educação.

A gestão escolar para Lück (2009) e Lobo (2009) é um processo, uma atividade e um paradigma de orientação e condução da escola, voltado para a melhoria continua de seus processos pedagógicos, e que tem como foco o desenvolvimento de seus profissionais coletivamente organizados. Dela depende a qualidade do ensino orientado para promover a formação e a aprendizagem dos alunos. Para isso, os gestores promovem atividades de planejamento e avaliação de todas as ações didático-pedagógicas. Nesse sentido, para Lobo (2009) existem vários mecanismos que garantem que a escola cumpra o seu novo papel social, tais como:

a) O Plano de Desenvolvimento da Escola (PDE-Escola) é uma ferramenta gerencial que auxilia a escola a realizar melhor o seu trabalho: focalizar sua energia, assegurar que sua equipe trabalhe para atingir os mesmos objetivos e avaliar e adequar sua direção em resposta a um ambiente em constante mudança. O PDE-Escola constitui um esforço disciplinado da escola para produzir decisões e ações fundamentais que moldam e guiam $o$ que ela é, o que faz e por que assim o faz, com um foco no futuro e pode ser definido como documento central do trabalho da escola que supõe um elevado grau de participação e consenso na sua elaboração e que os seus participantes assumam compromissos para ajudar na sua implementação (BRASIL, 2011).

b)O Projeto Político Pedagógico da Escola ou Proposta Pedagógica tem o intuito permitir que cada escola seja eficaz, uma vez que exige para a sua elaboração, uma reflexão sobre o ensino que oferece e a aprendizagem dos alunos: o que e como ensinar e como avaliar para que os alunos aprendam, devendo expressar o compromisso com a aprendizagem dos seus educandos. O que requer dos professores conhecimento e reflexão acerca dos referenciais curriculares (LDB, Parâmetros Curriculares Nacionais, Diretriz Curricular do sistema de ensino a que a escola está ligada), bem como sobre questões de inclusão - nos seus diversos aspectos, avaliação e metodologia entre outros pontos.

c) O Conselho Escolar está embasado na Lei de Diretrizes de Bases da Educação Nacional no 9394/96, Art.14, Inciso II, que estabelece os princípios da educação democrática, dentre os quais informa da importância da participação das comunidades escolares locais em conselhos escolares, para as decisões do processo educativo. Legalmente ainda conta com a Lei $n^{\circ}$ 10.172/01 -- Plano Nacional de Educação - a qual tem por objetivo assegurar que toda a comunidade seja envolvida nas decisões importantes tomadas escola.

Os conselhos escolares adquirem vida e forma material nas articulações relacionais entre os atores sociais que os compõem; na forma como pais, alunos, professores, funcionários e Direção apropriam-se do espaço do conselho, enquanto o constroem, de maneira dinâmica e conflitiva. (WERLE, 2003, p. 102)

Libâneo (2001), diz que toda a instituição escolar necessita de uma estrutura de organização interna, geralmente prevista no Regimento Escolar ou em legislação específica estadual ou municipal. O termo estrutura tem aqui o sentido de ordenamento e disposição das funções que asseguram o funcionamento de um todo, no caso a escola. A concepção democrática-participativa baseia-se na relação orgânica entre a direção e a participação do pessoal da escola. Acentua a importância da busca de objetivos comuns assumidos por todos.

A figura 1, representada abaixo, apresenta uma estrutura básica das funções que expressam a organização do trabalho em uma escola. Respeitando as características distintas de cada estrutura organizacionais das escolas em função da legislação dos Estados e Municípios e ainda conforme concepção adotada pela própria escola. O Conselho de Escola tem atribuições consultivas, deliberativas e fiscais em questões definidas na legislação estadual ou municipal e no Regimento Escolar. Essas questões, geralmente, envolvem aspectos pedagógicos, administrativos e financeiros. 
Figura 1: Organograma básico de Escolas

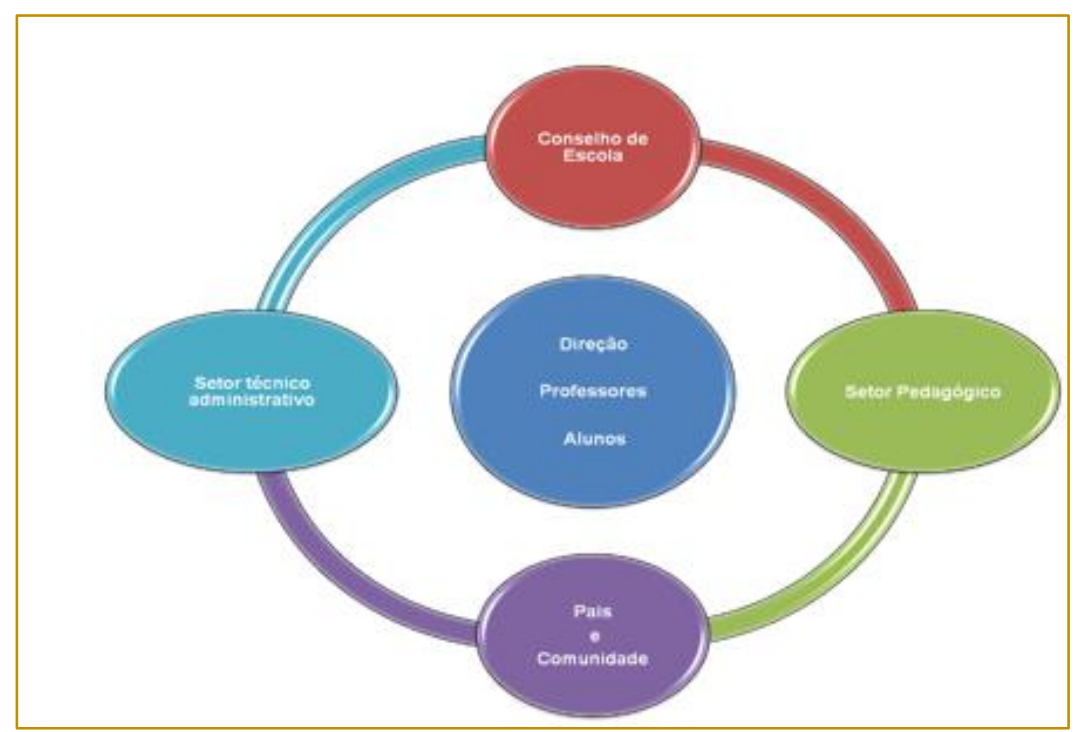

Fonte: adaptado de Libâneo (2001)

O mesmo autor relata que a escola é uma organização em sentido amplo, uma unidade social que congrega pessoas que interatuam entre si, intencionalmente, e que opera através de estruturas e processos próprios, a fim de alcançar os desígnios da instituição.

A gestão escolar ganha perspectivas dinâmicas e pedagógicas. Essa gestão é referida pelo Prêmio Nacional de Referência em Gestão Escolar (Consed, 2007) como sendo gestão de serviços e recursos, abrangendo processos e práticas eficientes e eficazes de gestão dos serviços de apoio, recursos físicos e financeiros. São destacados como indicadores de qualidade dessa dimensão: a organização dos registros escolares; a utilização apropriada das instalações e equipamentos; a preservação do patrimônio escolar; a interação escola/comunidade e a captação e aplicação de recursos didáticos e financeiros (LÜCK, 2007).

Assim, a gestão escolar é uma ação integrada e coletiva e não depende apenas das capacidades e responsabilidades individuais, mas de objetivos comuns e compartilhados e de atividades coordenadas e controladas pelos agentes do processo.

\section{MÉTODO}

Com o intuito de atingir os objetivos préestabelecidos nesta pesquisa, surgiu a necessidade de adoção de critérios metodológicos, através das técnicas de investigação, simultaneamente, a informações documentais e não documentais, através de regras estabelecidas para o método científico.

O estudo realizado junto as Escolas municipais de ensino fundamental do município de Santa Maria/RS, refere-se a um estudo de caso e caracteriza-se como sendo uma pesquisa exploratória descritiva de natureza qualitativa.

Ao tratar de um estudo de caso, Miguel (2007) afirma ser de natureza empírica que investiga um determinado fenômeno, geralmente contemporâneo, dentro de um contexto real, quando as fronteiras entre o fenômeno e a conjuntura em que ele se encontra não são claramente determinadas. Costuma-se descrever estudos de caso como pesquisa exploratória, usada em áreas nas quais há poucas teorias ou um conjunto deficiente de conhecimento, podendo ser, também, descritivos, nos quais a pesquisa tenta descrever a prática corrente (COLLIS; HUSSEY, 2005; MARTINS, 2008)

Assim, o estudo de caso é caracterizado pelo estudo profundo e exaustivo de um ou de poucos objetos, de maneira que permita o seu amplo e detalhado conhecimento, tarefa praticamente impossível mediante os outros delineamentos considerados (GIL, 1999).

Silva e Menezes (2000) estabelecem três maneiras de classificação de uma pesquisa científica as quais também serviram de base para a classificação da pesquisa desenvolvida neste estudo. Tal classificação é baseada nas seguintes proposições: quanto 
aos objetivos, quanto à natureza e quanto aos procedimentos adotados.

Quanto aos objetivos, este trabalho coloca-se na categoria de pesquisa exploratória, pois de acordo com Gil (1999), a pesquisa exploratória envolve levantamento bibliográfico, entrevistas com pessoas que tiveram ou têm experiências práticas com o problema pesquisado, e análise de exemplos que estimulem a compreensão. Este tipo de estudo tem por finalidade proporcionar um maior conhecimento para quem pesquisa um determinado assunto, visto que o pesquisador pode formular problemas mais precisos ou criar hipóteses que possam ser pesquisadas por estudos futuros.

Quanto à sua natureza, representa uma pesquisa qualitativa, pois suas características principais coincidem com as recomendações que:

Considera o ambiente como fonte direta dos dados e o pesquisador como instrumento chave; possui caráter descritivo; a análise dos dados foi realizada de forma intuitiva e indutivamente pelo pesquisador; não requereu o uso de técnicas e métodos estatísticos; e por fim, teve como preocupação maior a interpretação de fenômenos e a atribuição de resultados (GODOY, 1995, p. 58)

Conforme Richardson (1985) e Godoy (1995), a pesquisa qualitativa envolve a aquisição de dados descritivos sobre pessoas lugares e processos interativos, através do contato direto do pesquisador com a situação estudada, procurando compreender os fatos, segundo a perspectiva dos sujeitos, ou seja, dos participantes da situação em estudo. Também possibilita descrever a complexidade de um determinado problema, analisar a interação de certas variáveis, compreender e classificar processos dinâmicos vividos por grupos sociais, contribuir para o processo de mudança de determinado grupo.

De acordo com a classificação sugerida por Demo (1994) e Gil (1999), quanto aos procedimentos técnicos adotados para que fosse possível o desenvolvimento deste estudo, e com base na premissa de que nada é mais fundamental para uma teoria do que a prática e vice-versa, fez-se uso de duas modalidades de pesquisa: a pesquisa bibliográfica, caracterizada como um estudo teórico, elaborada a partir de material já publicado, composto principalmente por livros, artigos de periódicos, teses, dissertações e materiais encontrados na Internet. E também, através de uma pesquisa de campo com os gestores das escolas em estudo para que fosse permitido o amplo e detalhado conhecimento das atividades pedagógicas, a administração dos recursos e suas dificuldades no ambiente escolar.

De acordo com Minayo (2000), a pesquisa de campo visa a proporcionar um estudo sobre o modo como vem sendo tratado o tema da pesquisa em uma realidade prática, visando a confirmar os resultados obtidos a partir da pesquisa bibliográfica. Gil (1999), por sua vez, diz que a pesquisa de campo tem o objetivo de suprimir dúvidas, ou obter informações econhecimentos a respeito de problemas para os quais se procura resposta ou a busca de confirmação para hipóteses levantadas e, finalmente, a descoberta de relações entre fenômenos ou os próprios fatos novos e suas respectivas explicações.

Assim, a determinação do tipo de pesquisa vincula-se à observação das várias formas e classificações adotadas pelos autores consultados. Pressupõe-se, então, que diferentes tipos de pesquisa implicam a adoção de diferentes procedimentos para a coleta e a análise dos dados, de maneira tal que atendam aos objetivos da pesquisa.

\subsection{TÉCNICAS E PROCEDIMENTOS}

Esta pesquisa foi estruturada em duas atividades: uma teórica, de fundamentação conceitual, e outra empírica, de coleta de dados, as quais desenvolveram-se simultaneamente, uma auxiliando a outra, no sentido de atingir os objetivos propostos.

A pesquisa bibliográfica pode ser considerada o primeiro passo de toda pesquisa científica e não se trata de mera repetição do assunto, mas propicia o exame de um tema sob novo enfoque ou abordagem, podendo chegar a conclusões inovadoras (LAKATOS; MARCONI, 1995; GIL, 1999; FACHIN, 2001).

Os dados foram coletados em fontes primárias e secundárias, e as fontes primárias foram obtidas através de observação e entrevistas; as fontes secundárias provêm de livros, revistas especializadas, dissertações, teses e artigos de periódicos.

A presente pesquisa foi realizada em três escolas municipais de ensino fundamental 
(EMEF), escolhidas por acessibilidade, localizadas no município de Santa Maria/RS, sendo elas: EMEF Pão do Pobres Santo Antonio, EMEF Dom Antonio Reis e EMEF Euclides da Cunha, delimitando o universo de pesquisa. Para obtenção dos dados e observações no ambiente escolar realizou-se uma pesquisa in loco, por meio de visitas previamente agendadas. Como instrumento, para realização das entrevistas junto aos gestores, utilizou-se do questionário contendo perguntas abertas.

$\mathrm{Na}$ análise das entrevistas, foram separadas as respostas por categorias e procedeu-se a interpretação de forma simples ou múltipla, quando necessário. Os resultados e observações foram reunidos de maneira coerente e organizados visando a responder ao problema de pesquisa e apresentados por meio de análise qualitativa. Assim, a metodologia adotada propiciou a realização do trabalho, proporcionando maior segurança à inferência e, consequentemente, à apresentação das considerações finais.

\section{ANÁLISE DOS RESULTADOS}

Configurando o resultado e a discussão dos dados coletados na pesquisa realizada em três escolas municipais de ensino fundamental, na cidade de Santa Maria/RS. Como resposta aos objetivos específicos que nortearam o presente estudo, obteve-se 0 diagnóstico e as constatações apresentadas neste capítulo.

Num primeiro momento, identificam-se as práticas adotadas e a conduta dos entrevistados sobre a gestão escolar; seguida das questões levantadas sobre a organização curricular, quanto a sua concepção e avaliação.

\subsection{GESTÃO ESCOLAR}

As entrevistas foram realizadas junto as gestoras das escolas, cujas formação são pós-graduadas, trabalham nesta função há mais de três anos com a carga horária de 40h semanais, nos turnos matutino e vespertino, ficando também no noturno sempre que necessário. Em geral, apresentam certa liderança local e residem por longo período no município.

Em relação à pergunta referente à perspectiva teórica das instituições escolares, as três profissionais entrevistadas responderam que o modelo de gestão praticado é o de gestão democrática com a participação de professores, alunos, pais e conselho escolar, ou seja, há um grande avanço em se efetivar uma gestão na qual todos participam ativamente.

Constata-se que esse modelo de gestão democrática implica numa maior participação de todos os interessados no processo de tomada de decisões da escola, envolvendoos na realização de tarefas relativas ao gerenciamento escolar.

De acordo com as respostas dos entrevistados, em relação as principais dificuldades encontradas no cotidiano escolar, na qual podem, de forma geral, impossibilitar a gestão democrática. Para gestora da Escola Pão dos Pobres Santo Antônio entre as principais dificuldades estão relacionadas às impostas pela SMED (secretaria Municipal de educação) e na infraestrutura disponibilizada pela mesma, por exemplo: problemas com segurança e falta de recursos humanos, quando se quer trabalhar com professores realmente capacitados e envolvidos no projeto da escola, muitas vezes, tem-se que aceitar os designados para escola mesmo não sendo o ideal. Outra dificuldade é quanto a participação da sociedade, a mesma disse: "que estão vendo a escola sem qualificação e estrutura e "jogando" seus problemas na escola a parte de ensinamentos familiar e de sociedade.

Questionado sobre a contribuição em termos de participação dos pais no ambiente escolar foi respondido que existe participação, com a presença de pais nas entregas de boletins, os quais comparecem na escola, concordam com as colocações, porém não há efetivação no trabalho com seu filho em casa.

Em alguns casos, os pais solicitam que a escola assuma um papel disciplinador que seria próprio dos pais ou da família:

O adolescente é diferente, mas aqui nós estamos falando de menores e daí o pai chega aqui e diz assim: "A senhora faz o que quiser com ele, eu não sei o que vou fazer com ele. Mas não é assim, a escola não tem essa função. Eu acho que isso daqui é de casa, a gente dá instrução, também dá educação, mas não é nesse sentido, porque eles realmente permitem uma abertura tão grande que depois não tem como (GESTORA DA ESCOLA DOM ANTONIO REIS). 
Deste modo, para as diretoras entrevistadas as dificuldades se referem ao desenvolvimento diário, diante de atividades previstas que não são bem desempenhadas ou atéesquecidas; outra questão é a falta de professores, funcionários que possibilite a distribuição dessas para o bom andamento dos setores escolares.

Com relação a operacionalização da gestão no cotidiano da escola as gestoras responderam ter como base a gestão participativa, que aumenta as chances das tarefas serem executadas com êxito, ou seja, na medida em que um grupo unido busca novas oportunidades, há uma troca mútua de conhecimentos e conseguem detectar os problemas que ocorrem, na escola. Isto significa dizer que cada indivíduo sente-se comprometido e motivado a resolvê-los da melhor maneira possível, para bem comum da escola. Porém destacaram que as maiores dificuldades estão relacionadas ao envolvimento e comprometimento das partes interessadas. Tudo isso corrobora com a ideia que,

Aos responsáveis pela gestão escolar compete, portanto, promover a criação e a sustentação de um ambiente propício à participação plena, no processo social escolar, dos seus profissionais, de alunos e de seus pais, uma vez que se entende que é por essa participação que os mesmos desenvolvem consciência social crítica e sentido de cidadania. (LÜCK et. al., 2001, p. 18).

Conforme a gestora da Escola Euclides da Cunha, outro tipo de problema que ocorre é do relacionamento com aqueles pais que não auxiliam a escola e brigam para garantir os direitos de seus filhos de forma inadequada. Desde a mãe que queria agredir a diretora, até aquelas que querem controlar o que ocorre no recreio, as que trazem e buscam os filhos na escola.

Esta situação é um exemplo de que nem sempre a participação dos pais na escola é positiva. A mesma diretora comenta que o afastamento dos pais, especialmente das mães, facilitou a adaptação de algumas crianças no ambiente da escola,

Nesse sentido, sugere-se que a participação dos pais precisa ser construída dentro da gestão da escola, de forma a criar um ambiente positivo, uma comunicação e cooperação entre a escola e os pais para o alcance dos objetivos educativos.
Verificou-se que há o acompanhamento direto, por parte das gestoras, nos processos ensino-aprendizagem, nas reuniões pedagogias, os conselhos de classe e entrega de boletins. Relataram que realizam o levantamento frequente das necessidades da escola e a distribuição das verbas que são destinadas para a mesma.

A diretora é aquela pessoa que tem de ter "jogo de cintura", que sabe dançar conforme a música, que é capaz de fazer a ligação entre os diversos membros da escola. Uma das diretoras coloca que ela foi escolhida exatamente por sua habilidade de "mediar":

Foi relatado que nos últimos anos as escolas foram favorecidas através de Políticas Públicas, as quais enviaram verbas para reestruturação da escola e investimento em tecnologia, como: Programa dinheiro direto na escola e o Mais educação. As escolas observadas encontram-se em um bom estado de conservação, onde se percebe o cuidado com a aparência da mesma, pois o ambiente é limpo e as cadeiras, mesas, quadros, paredes, banheiros e a área das brincadeiras são bem conservados.

Nesse sentido, constata-se que uma escola bem organizada, administra com eficácia tanto seus recursos materiais quanto o trabalho humano, empregando a gestão participativa propicia as condições favoráveis às atividades de ensino e aprendizagem.

Conforme relatado pelas três gestoras escolares foi à lei 4740/03 que instituiu no município a gestão democrática, no que tange a autonomia administrativa dos estabelecimentos de ensino é exercida pela Equipe diretiva e o Conselho Escolar. Outro aspecto observado foi quanto às atribuições da direção que segundo elas desempenham toda e qualquer atividade no ambiente escolar desde a operacionalização da gestão até as atividades pedagógicas específicas. Destacam -se algumas das atribuições específicas do cargo de Diretor escolar:

a) Coordenar, conforme decisões do Conselho Escolar, a elaboração, a execução e a avaliação Projeto Político Pedagógico da Escola, observadas as políticas públicas da Secretaria de Município da Educação.

b) Representar a escola, responsabilizandose pelo seu funcionamento;

c) Coordenar a implementação do Projeto Pedagógico da Escola, assegurando sua 
unidade e o cumprimento do currículo e do calendário escolar;

d) Submeter ao Conselho Escolar, para apreciação e aprovação, o Plano de Aplicação dos recursos financeiros;

e) Submeter à apreciação da Secretaria da Educação o Plano Anual de Trabalho da Escola;

f) Organizar o quadro de recursos humanos da escola com as devidas especificações, submetendo-o à orientação, apreciação e aprovação da Secretaria de Município da Educação;

Diagnosticou-se a existência nas escolas das estâncias colegiadas, conselho e associação de pais e professores, os quais são convocados e disponibilizados as informações para que conjuntamente, com a direção, tomem as decisões. Os conselhos Escolares têm como funções a consultiva, a deliberativa e fiscalizadora. As equipes diretivas das escolas pesquisadas são formadas através de eleição, direta e secreta, pela comunidade escolar em cada estabelecimento de ensino.

Com relação às atribuições da Equipe Pedagógica, que está diretamente ligada ao ensino-aprendizagem, diagnosticou-se que desempenha o acompanhamento, desenvolvimento das atividades pedagógicas, administrativas e financeiras organiza as reuniões, as sessões de estudos, a formação continuada, acompanham a aprendizagem e a frequência dos alunos. Segundo a gestora da Escola Don Antônio Reis cabe à equipe pedagógica a "coordenação e construção do PPP, regimento escolar e planos de estudos".

Quanto à função da equipe pedagógica, Libâneo (2003, p. 331), esclarece: "Sobre supervisão e responsabilidade do diretor, a equipe escolar formula o plano ou projeto pedagógico, toma decisões por meio da discussão com a comunidade escolar mais ampla [...]".

As ações propostas no processo de gestão são realizadas através de um plano gestor que visa um trabalho em equipe e também por reivindicações e orientações da Smed. Para as entrevistadas existe autonomia pedagógica na qual é assegurada com a participação da comunidade escolar, em consonância com as políticas públicas vigentes e as normas do sistema municipal de ensino na implantação por parte de cada Escola de seu projeto político pedagógico,
Os recursos financeiros destinados as Escolas são geridos pela comunidade escolar, por meio do Conselho Escolar, para sua manutenção e outras despesas necessárias ao bom desempenho escolar. É de responsabilidade das escolas a aquisição de material permanente, o pagamento da conta de telefone, a compra e pagamento de material de limpeza.

a) Coordenar a implementação do Projeto Pedagógico da Escola, assegurando sua unidade e o cumprimento do currículo e do calendário escolar;

b) Submeter ao Conselho Escolar, para apreciação e aprovação, o Plano de Aplicação dos recursos financeiros;

c) Submeter à apreciação da Secretaria da Educação o Plano Anual de Trabalho da Escola; organizar o quadro de recursos humanos da escola com as devidas especificações, submetendo-o à orientação, apreciação e aprovação da Secretaria de Município da Educação; material expediente e manutenção do prédio escolar; a contratação de serviços de pequenos reparos nas instalações físicas da Escola e a manutenção dos equipamentos elétricos, eletrônicos e mobiliário.

Sobre a indagação quanto às prioridades no cotidiano escolar as gestoras responderam que as mesmas se envolvem com as ações que priorizavam os alunos, as ocorrências e imprevistos que interferiam na sua aprendizagem. Disseram que a ênfase da rotina escolar acontece por meio de tomada de decisões coletivas que facilitam suas ações.

Segundos relatos das gestoras, quanto a sua postura, se qualificam como sendo flexível e dinâmica. Utilizam de reuniões, jornadas pedagógicas e datas comemorativas para incentivar a interação entre os professores, e, também, se preocupam com a formação continuada dos mesmos, promovendo cursos internos e disponibilizando os docentes para cursos externos.

Outro aspecto relatado é que as mesmas agem como líderes no apoio e não há fragmentação entre direção e equipe pedagógica, isto é, os diretores agem como líderes pedagógicos: apoiam as prioridades, avaliam os programas pedagógicos, organizando e participando dos programas de desenvolvimento de funcionários e também enfatizando a importância dos 
resultados alcançados pelos alunos. Também agem como líderes em relações humanas, enfatizando a criação e a manutenção de um clima escolar positivo e a solução de conflitos, que segundo Lück (2001, p. 25) "[...] inclui promover o consenso quanto aos objetivos e métodos, mantendo uma disciplina eficaz na escola e administrando disputas pessoais". Ainda, de acordo com a mesma autora, para se ter de fato uma gestão participativa, devese tomar como base algumas ações como: compartilhamento de autoridade, delegação de poder, responsabilidades assumidas em conjunto, valorização e mobilização da sinergia de equipe, canalização de talentos e iniciativa em todos os seguimentos da organização e compartilhamento constante e aberto de informações.

Por isso, a nossa intenção em investigar a gestão escolar em instituições públicas, não foi aleatória e não se esgota com este trabalho, pelo contrário permanecerá aberta para revisões e aprimoramento, por se tratar de um tema necessário para as grandes decisões a serem tomadas no processo ensino-aprendizagem, quando o gestor executa sua tarefa de gerir.

\subsection{ORGANIZAÇÃO CURRICULAR}

Sobre o questionamento, que concepção norteou a elaboração de currículo na escola, as gestoras informaram que a smed disponibiliza a base curricular dos diferentes níveis e apósé trabalhado respeitando as especificidades de cada escola. Isso com a participação da comunidade escolar e local através de reflexões sobre escola pública, perfil do colégio, política, história, sociedade, legislação, cotidiano, condições físicas, materiais, humanas, possibilidades e limitações.

Verificou-se a existência de um acompanhamento e avaliação do currículo quanto dos resultados, nas reuniões de professores e conselhos de classe por parte das escolas pesquisadas. As quais utilizam os dados sobre o desempenho escolar para orientar o processo contínuo de melhoria do ensino, isso através do desempenho dos alunos, que é prioridade da escola e o índice IDEB.

O currículo representa no contexto da escola a base de toda a atividade de ensino; pensar os currículos de uma escola pressupõe, então, viver seu cotidiano, que inclui, além do que é formal e tradicionalmente estudada, toda uma dinâmica das relações estabelecidas. Ou seja, para poder falar dos currículos praticados nas escolas, é necessário estudar as diferenças culturais vividas nos cotidianos.

Quanto ao vínculo evidenciado entre a gestão da escola e o currículo diagnosticou-se que a gestão é pautada na efetivação do próprio currículo. Para isso, as gestoras, unanimemente, salientam sobre a necessidade de tornar o currículo escolar mais efetivo, o mesmo necessita de atualização e a maior participação da comunidade escolar nesse processo, pois este deve estar em contínua construção.

Para gestora da EMEF Dom Antônio Reis: "vêm crescendo as sensibilidades para com o currículo das escolas, porque percebemos que a organização curricular afeta a organização de nosso trabalho e do trabalho dos educandos".

Nesse sentido, sendo o diálogo, a transparência e o acesso à todas informações pertinentes ao trabalho escolar, o cuidado no julgamento de ações e pessoas, o investimento na comunicação efetiva onde todos tenham liberdade e que sua expressão seja valorizada, devem fazer parte das ações pedagógicas cotidianas, construindo 0 vínculo entre sociedade, gestão e processo de ensino.

Assim, a visão de currículo aqui esboçada implica alguns aspectos que merecem ser destacados. O primeiro deles decorre da mudança de foco do documento prescrito para a prática pedagógica na caracterização do currículo, que tem por objetivo assumir os sujeitos cotidianos das escolas como protagonistas do currículo escolar. São esses sujeitos os principais responsáveis pela realização dos currículos. O segundo aspecto a ser considerado é que qualquer iniciativa de se pensar ou de se discutir o currículo escolar precisa garantir a participação direta e insubstituível desses sujeitos. O PPP (Projeto Político Pedagógico) é uma das formas de se consolidar o currículo, pois é uma configuração de organização do trabalho pedagógico, que visa o melhoramento da qualidade de ensino. Este vai do relacionamento existente entre docente e discente até a relação entre escola e comunidade.

Nesse sentido, o envolvimento precisa ser assegurado a partir da garantia de condições 
políticas, físicas e materiais de realização dos currículos e em todos os momentos de sua discussão, sobretudo no decorrer das práticas pedagógicas. Pois, a gestão do pedagógico deve ser realizada a partir dos professores, sendo eles um dos sujeitos da prática pedagógica, ao lado dos estudantes e dos demais sujeitos da dinâmica escolar.

Segundo Ferreira (2008) a reconstrução de sua condição de trabalhadores da educação, superando ranços irrefletidos e propondo alternativas, o que implica dissociar a ideia generalizada de que seu trabalho seja constituir metodologicamente a aula para seja uma "boa aula". Tornando-se prática científica e, por isso, metódica, sistemática, criteriosamente elaborada e sustentada teoricamente. "Uma prática pedagógica de caráter social, portanto, socialmente elaborada e organizada conforme intencionalidades e conhecimentos" (FERREIRA, 2008, p.9).

\section{CONSIDERAÇÕES FINAIS}

O trabalho desenvolvido discutiu um tema extremamente importante para o contexto da gestão educacional, a gestão escolar praticada em escolas municipais do município de Santa Maria/RS. Através dessa temática, procurou-se identificar elementos que ajudem na compreensão desse contexto complexo que engloba distintas realidades e culturas. Como resposta ao objetivo geral de verificar como se dá a Gestão Escolar e as principais dificuldades enfrentadas em escolas municipais de ensino fundamental do Município de Santa Maria - RS, pode-se dizer que o mesmo foi atingido e relatado, na análise e no desenvolvimento da pesquisa.

Com relação aos objetivos específicos sobre a perspectiva teórica de gestão de cada escola em estudo, diagnosticou-se que todas adotam o modelo de gestão democrática com a participação de professores, alunos, pais e conselho escolar. O trabalho pedagógico é praticado por todos os membros atuantes no ambiente escolar, que implica no êxito e visibilidade dos objetivos e metas estabelecidos dentro da instituição escolar.

Quanto a gestão dos recursos materiais e humanos, planejamento de suas atividades, as distribuições de funções e atribuições e na relação interpessoal de trabalho é possível relatar a necessidade de investimentos nestes quesitos nas escolas pesquisadas, esses tidos como básicos para o bom funcionamento de uma unidade escolar.

O gestor não é a razão da existência da escola e nem a garantia do sucesso de uma gestão escolar. Para direcionar para uma gestão realmente democrática na escola, exige-se uma organização que envolva a participação de todos os seus membros, através de um projeto que garanta o rompimento da hierarquização do poder no interior das instâncias educativas, da fragmentação entre as tarefas de concepção e execução do trabalho e da centralização do comando. Esse é o sentido ao qual um projeto de organização do trabalho deva ser atribuído, e isso não é tarefa fácil de ser concretizada.

Diante disso, surge a necessidade da compreensão, por todos os envolvidos com a escola, de sua força e de seus limites. Nesse sentido, o projeto deve ser concebido como um processo sistêmico, que define claramente os objetivos, o tipo de ação administrativa e educativa que se quer realizar. Uma vez que a gestão escolar passa ser vista como setor social, como organismo vivo e dinâmico necessita ser organizado e entendido como tal.

Assim, é indispensável afirmar que os gestores serão apenas uma parte do contexto e que sozinhos não irão resolver a problemática existente no cotidiano escolar, contudo, se todos contribuírem, com certeza esse cenário negativo irá, no futuro, se modificar. Com base nos dados apresentados, acredita-se ser possível atingir o êxito em operacionalização e qualidade de ensino, com o apoio governamental e investimentos em recursos humanos e estrutura, levando à institucionalização de novas condutas que permitirão o desenvolvimento harmonioso da sociedade, formando cidadãos críticos e reflexivos no contexto contemporâneo.

Os assuntos tratados não tiveram a pretensão de cobrir todas as curiosidades e variáveis sobre a gestão escolar, pelo contrário, devem servir de incentivo ao aprofundamento do tema, para a descoberta de melhores caminhos que levem à uma gestão participativa e democrática.

É indispensável que as pesquisas continuem e novos trabalhos sejam realizados no sentido de evoluir na discussão deste tema. Novas problemáticas e vários questionamentos 
surgem ao final de um estudo, e podem servir de orientação para futuros trabalhos, pois o resultado obtido reflete apenas um período e um espaço delimitado. Essa delimitação permite que outros estudos ampliem e agreguem valor ao contexto estudado. Assim, indicam-se algumas vertentes para futuros trabalhos:

a) Abordar este tema nas demais escolas do município de Santa Maria;

\section{REFERÊNCIAS}

[1] Collis, J.; Hussey, R. Pesquisa em administração: um guia prático para alunos de graduação e pós-graduação. 2. ed. Porto Alegre: Bookman, 2005.

[2] Consed. Manual do Prêmio Nacional de Referência em Gestão Escolar. Ciclo Ano Base 2006. Brasília: Consed, 2007.

[3] Barroso, João. Autonomia e gestão das escolas. Lisboa: Ministério da Educação, 1997.

[4] Brasil. MEC. Lei de Diretrizes e Bases da Educação Nacional n. 9394/1996.

[5] Brasil. Constituição. Constituição da República Federativa do Brasil: promulgada em 5 de outubro de 1988. Brasília: Imprensa Oficial, 1988.

[6] Plano Nacional de Educação.

N. 101172,2001

[7] PDE Escola: Perguntas e respostas. Ministério da Educação.

[8] Secretaria de Educação Básica. Diretoria De Fortalecimento Institucional e Gestão Educacional. Coordenação Geral de Gestão Educacional. Disponível em: <http://portal.mec.gov.br>. Acessado em 17/09/2015.

[9] CURY. Gestão Democrática da Educação: exigências e desafios. Revista Brasileira de Administração da Educação. ANPAE. Porto Alegre. V.18.n.2,p 163-173, 2002.

[10] Demo, P. Pesquisa e construção de conhecimento. Rio de Janeiro: Tempo Brasileiro, 1994.

[11] Dourado, Luiz Fernandes. Gestão da educação escolar Brasília. Universidade de Brasília, Centro de Educação a Distância, 2006.

[12] Políticas e gestão da educação básica no Brasil: limites e perspectivas. Educ. Soc., Campinas, vol. 28, n. 100 - Especial, p. 921-946, out. 2007. Disponível em <http://www.cedes.unicamp.br> b) Avaliar a percepção dos docentes e comunidade em relação à gestão escolar, e

c) Propor técnicas e métodos de gestão para o ambiente escolar.

Essas indicações têm a finalidade de oferecer novos enfoques teóricos e alternativas metodológicas que podem contribuir ainda mais para a melhoria da relação entre Gestão Escolar e o processo de ensinoaprendizagem, respeitando a complexidade e dialética que demanda esse tema.

[13] Fachin, O. Fundamentos de metodologia. 3 ed. São Paulo: Saraiva, 2001.

[14] Ferreira, Liliana Soares. Gestão do pedagógico: de qual pedagógico se fala? Currículo sem Fronteiras, v.8, n.2, pp.176-189, Jul/Dez 2008

[15] Gil, A. C. Métodos e técnicas de pesquisa social. 5. ed. São Paulo: Atlas, 1999.

[16] Godoy, A. S. Introdução à pesquisa qualitativa e suas possibilidades. In: Revista de Administração de Empresas. São Paulo: v. 35, n. 2, p. 57-63, 1995.

[17] Lakatos, E. M.; Marconi, M. de A. Metodologia do trabalho científico: procedimentos básicos, pesquisas bibliográfica, projeto e relatório, publicações e trabalhos científicos. 4. ed. São Paulo: Atlas, 1995

[18] Libâneo, J. C. "O Sistema de Organização e Gestão da Escola." In: LIBÂNEO, José Carlos. Organização e Gestão da Escola - teoria e prática. 4를 ed. Goiânia: Alternativa, 2001. Disponível em: <http://www.acervodigital.unesp.br/bitstream/12345 6789/32/3/LDB_Gest\%C3\%A3o.pdf> Acesso em: set. 2015

[19] O sistema de organização e de Gestão da Escola: teoria e prática. In. Educação Escolar: políticas, estrutura e organização. São Paulo: Cortez, 2003.

[20] Lobo, M. C, Gestão Escolar. Curitiba: IESED. 2009.

[21] Lück, Heloísa. Perspectivas da Gestão Escolar e Implicações quanto à Formação de seus Gestores. Em aberto. V. 17, n. 72. p.11-33. Brasília. 2000

[22] A escola participativa: o trabalho do gestor escolar. Petrópolis, RJ: Vozes, 2005.

[23] Gestão educacional: uma questão paradigmática. 2. ed. Petrópolis: Vozes, 2007. 
[24] Dimensões da gestão escolar e suas competências. Curitiba: Editora Positivo, 2009.

[25] Machado, Ana Luiza. Formação de gestores educacionais. In:Centro de Estudos e Pesquisas em Educação, Cultura e Ação Comunitária. Gestão educacional: tendências e perspectivas. São Paulo : Cenpec, 1999.

[26] Martins, Gilberto; Theóphilo, Carlos. Metodologia da investigação científica para ciências sociais e aplicadas. 2. ed. São Paulo: Atlas. 2008

[27] Miguel, P. A. C. Estudo de caso na engenharia de produção: estruturação e recomendações para sua condução. Produção, v 17, n.1, p. 216-229, jan/abr, 2007.

[28] Minayo, M.C. S. (orgs) Pesquisa social: teoria método e criatividade. 16.ed.Petrópolis, RJ: Vozes, 2000.

[29] Krawczyk, Nora. A gestão escolar: Um campo minado. Análise das propostas de 11 municípios brasileiros. Educação \& Sociedade, ano XX, no 67, p. 112-149. Ago. 1999.

[30] Parente, Marta; Lück, Heloísa. Mapeamento da descentralização da educação brasileira nas redes estaduais do ensino fundamental. Brasília: Ipea/Consed,1999.

[31] Paro, V. Gestão democrática da escola pública. São Paulo: Ática, 1997.

[32] Richardson, R.J. Pesquisa Social: métodos e técnicas. São Paulo: Atlas, 1985.

[33] Silva, E. L.; Menezes, E. M. Metodologia da pesquisa e elaboração de dissertação. Florianópolis: LED/UFSC, 2000.

[34] Veiga, IIma Passos Alencastro. Perspectiva para reflexão em torno do projeto políticopedagógico. In: Escola: espaço do projeto políticopedagógico. Campinas, SP: Papirus, 1998

[35] Werle, Flávia Obino Corrêa. Conselhos escolares: implicações na gestão da escola básica. Rio de Janeiro: DP\&A, 2003. 


\section{Gapítulo 16}

\section{A PRODUÇ̃̃O DE SOJA NGM PODE SER UMA ESTRATEGIA VANTAJOSA PARA \\ $\mathrm{O}$ PRODUTOR BRASILEIRO?}

\section{Ramesh Mohan Thadani}

Augusto César Barreto Rocha

Resumo: Em 2013 o Brasil assumiu a liderança global nas exportações de soja. Boa parte do sucesso dos produtores nacionais coincidiu com a adoção do cultivo de soja GM (geneticamente modificada), também conhecida por soja OGM (organismo geneticamente modificado). Em área cultivada, o Brasil é o segundo maior produtor de GM no mundo, atrás dos EUA. A adoção da soja GM no Brasil foi muito rápida, pois somente em 2003 o Governo Federal autorizou seu plantio e comercialização. A produção de soja GM na safra 2015/2016 totalizou 110,1 milhões de toneladas, contra apenas 4 milhões de toneladas de soja NGM (não geneticamente modificada). Esta pesquisa aborda alguns dos fatores que diferenciam a produção de soja NGM da soja GM no Brasil, tendo como foco a soja destinada à exportação e os principais fatores e tendências que influenciam a demanda global de soja. Conclui que a somatória dos diversos cuidados operacionais para resguardar a integridade da soja NGM e suas diferenciações nos custos, permite avaliar se há vantagem competitiva na sua produção, e se seu plantio pode ser adotado como estratégia por produtores de soja. A pesquisa recomenda o aprofundamento das investigações quanto as vantagens e desvantagens da produção de soja NGM no Brasil a partir das particularidades de cada produtor rural conforme sua localização, bem como provocar reflexões quanto às tendências de consumo nos mercados globais.

Palavras-Chave: Soja NGM, estratégia, vantagem competitiva, Soja GM. 


\section{INTRODUÇÃO}

Em 2013, o Brasil passou pela primeira vez os EUA nas exportações globais de soja, conforme apurado pelo Salin (2014), em relatório do USDA (Departamento de Agricultura dos EUA). Boa parte do sucesso dos produtores nacionais, coincidiu com a adoção do cultivo de soja geneticamente modificada, conhecida como soja GM (geneticamente modificado), ou muitas vezes por soja OGM (organismo geneticamente modificado). A adoção de soja GM no Brasil muito foi rápida, e em 2016, 96,5\% da área cultivada com soja era de GM (ISAAA, 2017). Considerando a produção de 114,1 milhões de toneladas de soja na safra de 2016/2017 plantada em 2016 (CONAB, 2018a), e aplicando a taxa de adesão em área cultivada de soja GM do mesmo ano, houve produção de 110,1 milhões de toneladas de soja GM, contra apenas 4 milhões de toneladas de soja NGM.

A ISAAA (International Service for the Acquisition of Agri-biotech Applications), que é uma entidade que promove o uso de transgênicos no mundo, destacou em seu relatório anual de 2013, que foi o quinto ano seguido que o Brasil era o país que mais avançava no cultivo de produtos GM, com destaque à soja, que representava 26,9 milhões de hectares com cultivo de soja GM, sobre um total de 40,3 milhões de hectares de cultivo de transgênicos (JAMES, 2013) no país. Segundo a mesma entidade, o Brasil é atualmente o segundo maior produtor de GM com 50,2 milhões de hectares em área cultivada, o que representa $26 \%$ da área global cultivada em 2017 (ISAAA, 2017), atrás apenas dos EUA, com 40\%. Juntos, somam $66 \%$ da área cultivada com OGM no mundo. Das 3 culturas relevantes no Brasil - soja, milho e algodão - a mais adotado é a soja GM, que em 2017 representava 97\% da área cultivada com soja (ISAAA, 2017). Deve ser ressaltado, que antes de 1996, não havia comercialização de cultivo GM no Brasil, e em 1996, a área total cultivada com OGM no mundo não passava de 1,7 milhões de hectares (ISAAA, 2016). No Brasil, a Política Nacional de Biossegurança de 1995 (BRASIL, 1995) vedava a comercialização de produtos transgênicos. Em 2003, o Governo Federal publicou a Lei $\mathrm{N}^{\circ}$. 10.688, autorizando o plantio de produtos GM (BRASIL, 2003), e partir dela, sua produção e comercialização passou a ser legal. Portanto, somente em 2003 foi iniciado a adoção de OGM por parte dos agricultores brasileiros (ISAAA, 2016), e 14 anos depois, em 2017, apenas 3\% da área dedicada ao cultivo de soja era de soja NGM (não geneticamente modificada), resultando em redução drástica de sua oferta.

Esta pesquisa aborda alguns dos fatores que diferenciam a produção de soja NGM da GM no Brasil, tendo como foco a soja destinada à exportação e os principais fatores e tendências que influenciam a demanda global de soja. Não faz parte do escopo desta pesquisa, as técnicas necessárias para 0 plantio e cultivo da soja, que serão tratadas a partir da diferenciação dos custos ao agricultor, e indicação de alguns fatores importantes para resguardar a integridade qualitativa da soja NGM. A somatória dos diversos cuidados operacionais e custos do seu transporte permite avaliar se há vantagem competitiva na produção de soja NGM, e se sua produção pode ser adotada como estratégia por produtores. A pesquisa recomenda 0 aprofundamento das investigações quanto às vantagens $e$ desvantagens da produção de soja NGM a partir das particularidades de cada produtor conforme sua localização, bem como provocar reflexão quanto às tendências de consumo nos mercados globais.

\section{FUNDAMENTAÇÃO TEÓRICA}

Para o melhor entendimento do contexto da indústria do comércio de soja no Brasil e no mundo, foi utilizada a pesquisa exploratória, como indicadas pelo Prodanov e Freitas (2013), visando primeiro adquirir um entendimento mais amplo, conforme a Figura 1 abaixo: 
Figura 1: Tipos de Pesquisa Científica.

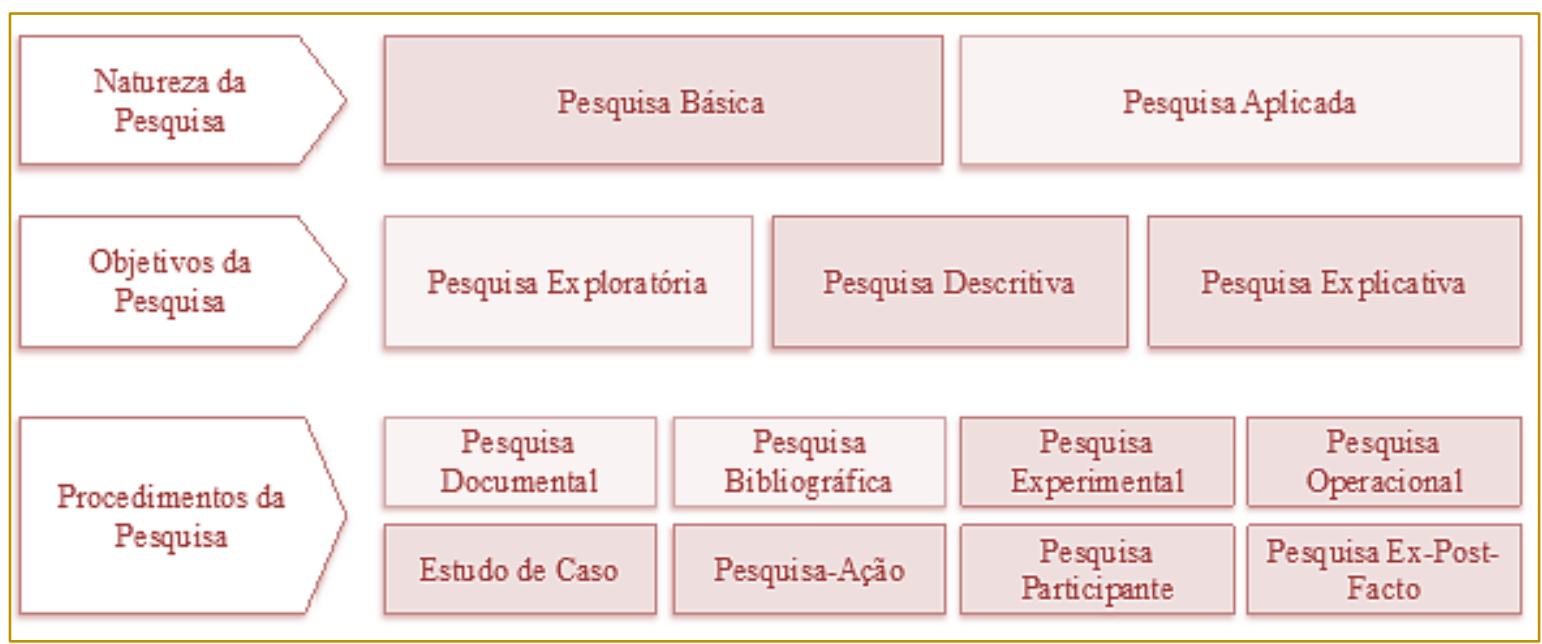

Fonte: adaptado de Prodanov e Freitas (2013).

Em seguida, levantamentos qualitativos $e$ quantitativos nortearam a abordagem da pesquisa sobre a produção, comercialização, demanda e tendências internacionais do consumo de soja GM e NGM, com uma ampla quantidade de dados secundários e relatórios sobre a dinâmica do mercados de soja.

Por fim, para avaliar a competitividade e possibilidade da estratégia da produção de soja NGM no Brasil, foi utilizado a perspectiva mais difundida da Escola de Posicionamento, conforme classificado pelo Mintzberg (1998), fazendo uma avaliação a partir dos estudos

Figura 2: Forças que Governam a Competição

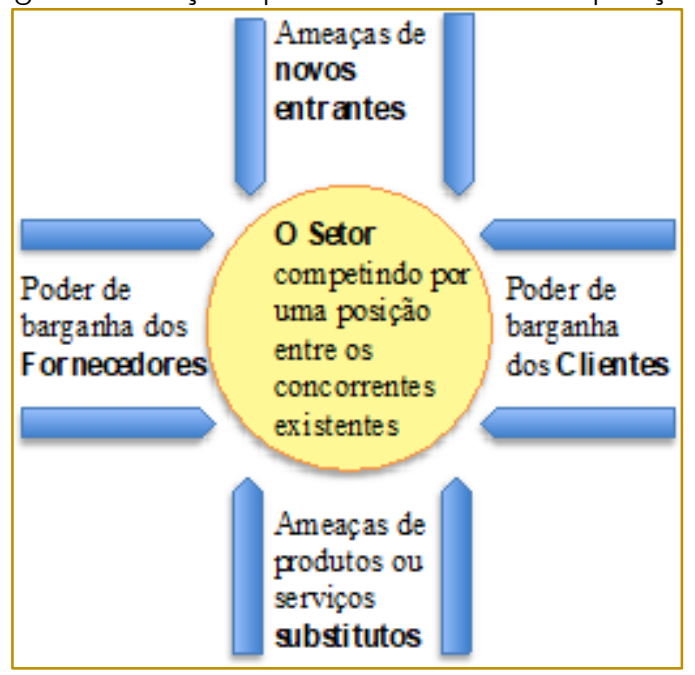

Fonte: Montgomery e Porter (1998). de competitividade e estratégia desenvolvidos por Porter (1985) e Montgomery e Porter (1998), buscando identificar se a produção de soja NGM pode ser uma estratégia a ser perseguida por produtores agrícolas brasileiros. Dois conceitos defendidos por Porter serão aplicados nesta avaliação: a análise estrutural da indústria, com o modelo das Cinco Forças (PORTER, 1985) que governam a competição em um setor, conforme Figura 2, e o modelo das Estratégias Genéricas de Competitividade (PORTER, 1985), conforme Figura 3, ambos abaixo:

Figura 3: Três Estratégias Genéricas

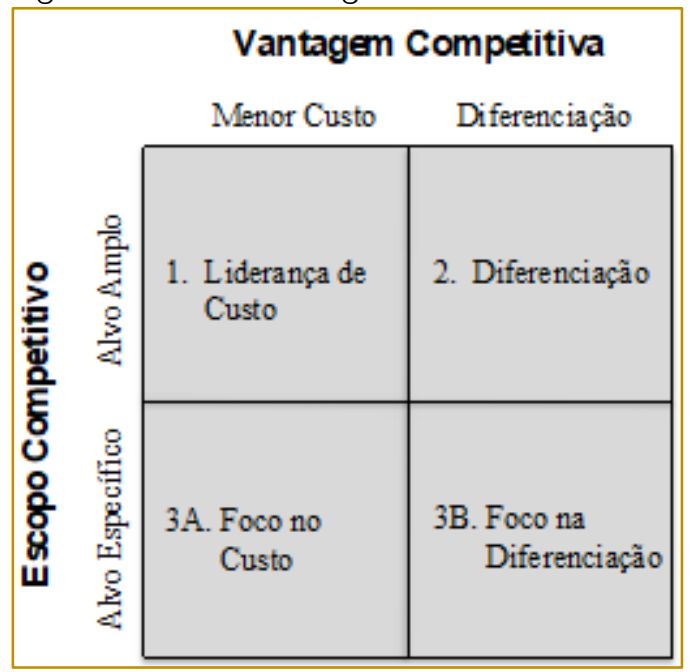

Fonte: Porter (1985). 


\section{MÉTODO DE PESQUISA}

A contextualização do comércio de soja no Brasil e no mundo, foi através de pesquisas exploratórias utilizando bibliografias variadas, avaliando o comércio global de commodities de forma abrangente considerando a relevância e a importância das Tradings (Trading Companies), e abordando sua importância no comércio internacional de commodities no Brasil. Revistas especializadas, boletins e relatórios elaborados por organismos ligados à comercialização de soja e produtos GM e NGM, artigos, reportagens, pesquisas e legislação referente à comercialização de soja e produtos NGM apoiaram a contextualização.

No desenvolvimento da pesquisa, com dados secundários, houve ampla avaliação de dados estatísticos de anuários (ABIOVE, 2018; CONAB, 2018b; FAO, 2018; MDIC, 2018; UNITED NATIONS, 2017; USDA, 2018), censos (FAO, 2018; IBGE, 2009, 2014) e relatórios (CONAB, 2018a; FAO, 2017; IMEA, 2018; ISAAA, 2016, 2017; JAMES, 2013; TAVARES, 2017) sobre o mercado brasileiro e internacional de soja, sua produção e comercialização, e tendências de consumo. Artigos e relatórios científicos (BROOKES; CRADDOCK; KNIEL, 2005; LEITÃO, 2014) sobre a segregação na cadeia logística da soja também serviram de base, por estudar especificamente os custos logísticos diferenciados para a soja NGM no Brasil.
Por fim, estudos de competitividade e estratégia desenvolvidos por Porter e Montgomery (1998; 1985) foram utilizados como referência para avaliar o potencial da produção de soja NGM no Brasil, tendo os conceitos de liderança de custo e diferenciação da Escola de Posicionamento destacado pelo Mintzberg (1998) como referência.

\section{ANÁLISE DOS RESULTADOS \\ 4.1 HISTÓRICO E PRODUÇÃO DA SOJA}

A soja, que é uma planta leguminosa de origem asiática e mais conhecida por seus grãos, passou a gerar interesse em produtores agrícolas em diversos países da Europa e nos EUA entre 1876 e 1880, chegando ao Brasil em 1882. O grão brasileiro passa a aparecer nas estatísticas internacionais somente em 1949, quando o país aparece pela primeira vez como produtor de soja (BONATO, Emídio Rizzo; BONATO, 1987).

Em 1969, o Brasil fecha o ano pela primeira vez acima de 1 milhão de toneladas - ano no qual os EUA produziram 30,6 milhões de toneladas. Passa a ganhar rapidamente representatividade na produção global a partir dos anos 1970 (BONATO, Emídio Rizzo; BONATO, 1987), como pode ser observado na Tabela 1.

Tabela 1. Representatividade do Brasil e dos EUA no cenário global da produção de soja em \% de toneladas produzidas.

\begin{tabular}{|c|c|c|c|c|c|c|c|c|}
\hline & 1950 & 1960 & 1970 & 1980 & 1990 & 2000 & 2010 & 2016 \\
\hline Brasil / Global & $0,2 \%$ & $0,8 \%$ & $3,5 \%$ & $18,7 \%$ & $18,6 \%$ & $20,4 \%$ & $25,3 \%$ & $24,5 \%$ \\
\hline EUA / Global & $49,1 \%$ & $58,7 \%$ & $70,2 \%$ & $60,2 \%$ & $48,3 \%$ & $46,5 \%$ & $34,2 \%$ & $35,0 \%$ \\
\hline EUA\& Brasil / Global & $49,3 \%$ & $59,5 \%$ & $73,7 \%$ & $78,9 \%$ & $66,9 \%$ & $67,0 \%$ & $59,5 \%$ & $59,4 \%$ \\
\hline
\end{tabular}

Fonte: elaborado pelo autor a partir de dados da FAO (2018), USDA (2018), OECD (2018) e Embrapa (1987).

Em 1996, é liberada a comercialização de soja GM nos EUA - a soja geneticamente modificada - um evento que impulsiona a produtividade e atratividade econômica do cultivo de soja. Entre 2000 e 2010, os EUA saltam $20,8 \%$ de 75,1 para 90,7 milhões de toneladas de soja produzidas, sendo que a área cultivada foi ampliada em apenas 4,2\% (ISAAA, 2017; USDA, 2018).

O Brasil, passa a adotar a produção GM somente a partir de 2003 (ISAAA, 2017), sete anos após os EUA, pois a Política Nacional de Biossegurança de 1995 vedava a comercialização de produtos transgênicos. Em 2003, o Governo Federal publicou a Lei No. 10.688 , permitindo o plantio de produtos GM. A partir dela, passou a ser autorizado produzir e comercializar a soja GM no país, que permitiu um crescimento ainda mais expressivo, pois entre 2003 e 2013, a produção salta de 49,8 para 81,5 milhões de toneladas - um aumento de 63,7\%. Considerando a expansão da área cultivada em 29,8\% no período (CONAB, 2018b), o advento da soja GM teve forte influência no crescimento, que culminou com as 
exportações Brasileiras superando pela primeira vez os EUA no comércio global de soja em 2013 (SALIN, 2014).

A soja GM passou a ocupar cada vez mais espaço no cultivo, mesmo tendo sementes mais caras que a "soja convencional" (soja NGM), e ainda pagar royalties ao detentor da patente no ato da venda da produção. Os benefícios econômicos derivados da menor necessidade de defensivos e fertilizantes, as propriedades genéticas de resistência a pragas e capacidade de ser mais produtiva em climas e solos menos favoráveis, estimulam a adoção, que segundo consenso dos agricultores, compensam os custos adicionais das sementes e dos royalties.

Atualmente, o Brasil é o segundo maior produtor global de GM em área cultivada. Antes de 1996, não havia comercialização de produtos GM no mundo, e 21 anos depois, 97\% da área de cultivo da soja no Brasil era GM- percentual maior que os $94 \%$ nos EUA. Portanto, apenas 3\% de toda área cultivada com soja no Brasil em 2017 era soja NGM (ISAAA, 2017).

\subsection{CONSUMO DA SOJA}

Segundo relatório da IISD (International Institute for Sustainable Development), a maior parte da soja em grãos é convertida para farelo, utilizado para alimentar animais. Globalmente, $87 \%$ da soja produzida foi esmagada e convertida em farelo e óleo de soja, e apenas $13 \%$ não foi esmagado e aplicado diretamente em usos para consumo humano. Dos $87 \%$ esmagados, $80 \%$ foi para ração animal, o que representou $70 \%$ de toda produção de soja em 2011 (POTTS et al., 2014). Outro relatório indicou que $75 \%$ de toda soja produzida foi utilizada para alimentar animais - principalmente suínos e aves. Entre 1967 e 2007, a produção de proteína suína cresceu 294\%, e de aves $711 \%$. No mesmo período, os preços dessas proteínas diminuíram, e a soja, que é elemento chave no modelo atual de produção de proteínas de origem animal e seus derivados, teve forte influência no resultado (WWF, 2014).

A Nações Unidas (2017) projetou a população global em 9,8 bilhões para o ano 2050 - um crescimento anual de $0,78 \%$ de taxa composta sobre a população estimada em 7,6 bilhões em 2017. No mesmo período, a Organização para Alimentação e Agricultura
(FAO, 2017) estima que a economia global irá crescer anualmente $2,19 \%$ pela taxa composta até 2050, e que o aumento da renda per capita no período será maior nas populações em países de baixa e média renda. Como consequência direta, as populações nestes países passarão a ingerir mais calorias e aumentarão a demanda por alimentos na categoria de proteína animal, laticínios e ovos. Em 2007, o consumo médio de alimentos era de apenas 2.619 $\mathrm{kcal} /$ pessoa/dia nos países em desenvolvimento. Até 2050, o consumo de calorias terá um aumento de 381 $\mathrm{kcal} /$ pessoa/dia (14,5\%) segundo estudo de Alexandratos e Bruinsma (2012). A demanda por soja irá aumentar para acompanhar o aumento de consumo de alimentos.

A introdução de OGM ajudou a aumentar a produção de soja em ritmo semelhante ao da demanda, principalmente nos dois maiores produtores, que juntos produziram aproximadamente $60 \%$ da soja do mundo - os EUA e o Brasil (ISAAA, 2016). Mas a introdução de alimentos GM também estimulou o debate na sociedade, quanto à sua segurança à saúde. A UE (União Europeia) tem sido o bloco comercial consumidor mais sensível aos questionamentos de sua população, e passou a exigir em 1997, apenas um ano após a liberação de OGM no comércio mundial, que os rótulos de alimentos indicassem a presença de OGM (MANDEMAKER, 2015). Em 2004, a UE passou a exigir que todo produto, inclusive ração animal contendo OGM, tenha essa informação nos rótulos (BROOKES; CRADDOCK; KNIEL, 2005).

Atualmente, 64 países exigem rótulo indicativo para alimentos que contém OGM (CFS, 2018), conforme pode ser observado na Figura 4. Dos principais consumidores, apenas os EUA não possui legislação federal exigindo essa informação nos rótulos, mas uma pesquisa do The Mellman Group (2015) indicou que 88\% dos entrevistados eram favoráveis à indicação de conteúdo de OGM no rótulo. A opinião dos consumidores nos diversos países tem exercido pressão sobre os governos. Na UE, cada um dos países membros pode optar por permitir o plantio, sendo que apenas 4 tem cultivado milho OGM em escala (BRANKOV, 2018). A maior economia, Alemanha, que não permite o cultivo, é um dos países que sofre forte pressão de sua população. A pesquisa de mercado da Mintel (2018) mostrou que $72 \%$ dos alemães gostariam de ter uma maior 
escolha de produtos orgânicos, e 54\% disseram que o elemento orgânico é um fator decisivo para a escolha. Na China, uma política mais liberal foi revertida em 2016, proibindo o plantio de OGM para alimentos, excetuando papaia e algodão. Os chineses também tem pressionado o estado para ter mais informações sobre OGM na sua alimentação.

Figura 4 - Mapa Mundial de adoção de legislação de rótulos de alimentos

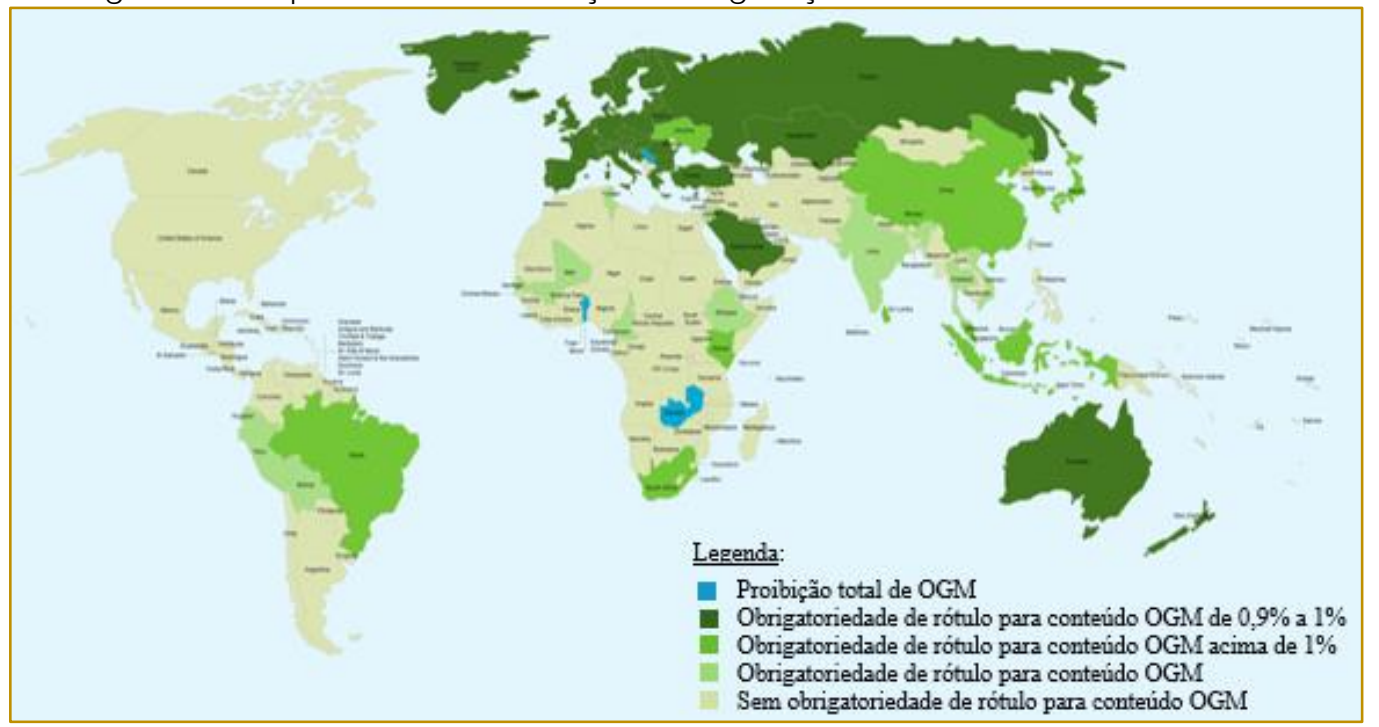

Fonte: Center for Food Safety (2018) - adaptado pelo autor

Tanto a China quanto a UE, importam produtos OGM em grandes volumes. Conforme dados das exportações brasileiras do "Complexo Soja", que compreende soja em grãos, farelo e óleo, foram exportados US\$ 31,7 bilhões, representando $14,6 \%$ do total das exportações em 2017. Somente a China e a UE somados, representaram $79,4 \%$ do valor do complexo soja exportado (ABIOVE, 2018), conforme pode ser observado na Figura 5.

Figura 5. Representatividade das exportações Brasileiras do complexo soja para a China e UE, em milhares de US\$ em 2017.

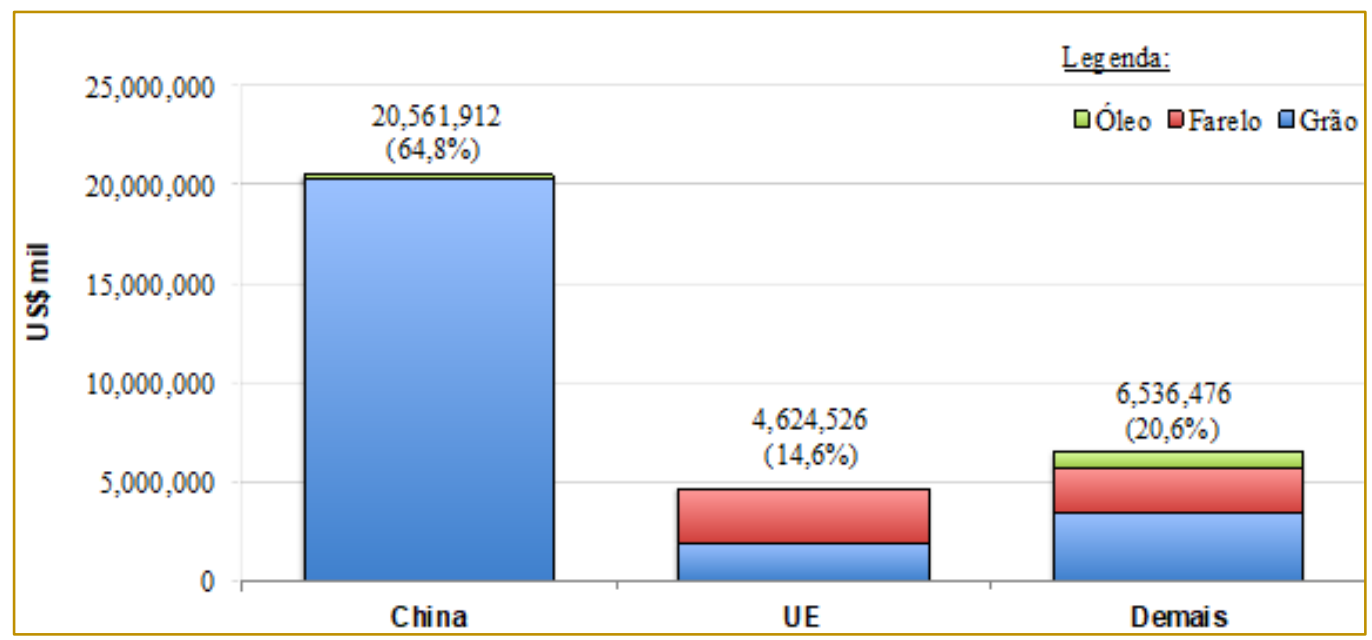

Fonte: ABIOVE (2018) - adaptado pelo autor.

A China e a UE, que tem legislação vetando o uso da soja GM para uso direto em alimentos para humanos, utilizam a maior parte da soja para alimentar aves, gado e suínos. Um exemplo, é o caso da UE, com grande área destinada à criação de animais que derivam $75 \%$ de sua proteína alimentar importados da América do Sul (HENCHION et al., 2017). O 
principal ingrediente, é a soja GM. A produção de produtos à base de animais requer grandes quantidades de alimentos: para cada quilograma de carne, leite e ovos, são necessários entre $3 \mathrm{Kg}$ e $10 \mathrm{Kg}$ de grãos (BOLAND, 2013). Isso também se traduz em demanda crescente por grãos principalmente soja, para continuar a oferecer os produtos finais aos consumidores.

Neste fato, reside também o maior elemento de discussões nos países onde os consumidores tem demonstrado resistência a OGM nos alimentos. Os rótulos nesses países, já informam sobre traços de OGM quando adicionados diretamente, mas em raros casos indicam se um insumo GM foi utilizado em fase anterior na cadeia da produção dos alimentos, como é o caso de carnes, ovos, leite e seus derivados. Pesquisa sobre consumo de proteína na UE elaborado por Visser, Schreuder e Stoddard (2014), indicou que a UE é praticamente autossuficiente na produção de carnes com 96\%, e laticínios e seus derivados com $99 \%$.

Porém, a realidade dos insumos para esta produção é bem diferente, sendo que $69 \%$ da ração rica em proteínas foi importada. Desses insumos, a situação da soja é a mais crítica, pois a UE origina apenas $3 \%$ de sua necessidade de soja dentro do bloco comercial da UE. Pelo seu conteúdo de proteína, a soja também é um dos compostos mais importantes na ração animal. Assim, a demanda por soja certamente continuará a aumentar, e um potencial aumento na demanda por soja NGM em detrimento da soja GM poderá ser uma realidade, a depender das decisões dos consumidores sobre a presença de soja $G M$ na ração animal. A organização Non-GMO Project (2017), chama atenção ao fator de ração animal como sendo chave para o futuro dos produtos NGM, dado que a maior parte da soja consumida, é destinada a alimentar animais.

O tema de alimento saudável é central em muitos países, inclusive nos EUA, e passou a ser associado a todos os tipos de alimentos livres de OGM. A Food Insider Journal (2017), destaca que em 2015 nos EUA, as vendas de produtos orgânicos alcançaram um recorde histórico de US\$ 43,3 bilhões - um crescimento de $11 \%$ sobre o ano anterior, enquanto o setor de alimentos como um todo cresceu apenas 3\% no mesmo ano. Também informou, que derivados de leite representam a segunda maior categoria, com US\$ 6 bilhões em vendas, atrás apenas da categoria de frutas e vegetais. Um destaque no mercado dos EUA, país que ainda não tem legislação obrigando a indústria a identificar nos rótulos se um alimento contém ingrediente GM, foi o anuncio público da Danone, fabricante global de produtos derivados de leite, que começou a comercializar produtos derivados de leite que não contém ração animal com OGM na cadeia alimentar do gado leiteiro a partir do verão de 2016. Sensível às opiniões e tendências dos consumidores, essa linha é comercializada em diversos países, onde os consumidores estão dispostos a pagar mais - um prêmio pelo fato de toda cadeia de fabricação do alimento comercializado ser livre de GM (Figura 6). O tema de alimento saudável é central, e passou a ser associado a ingredientes livres de OGM.

Figura 6 - Anuncio de iogurtes derivados de leite integral natural, sem ingredientes OGM

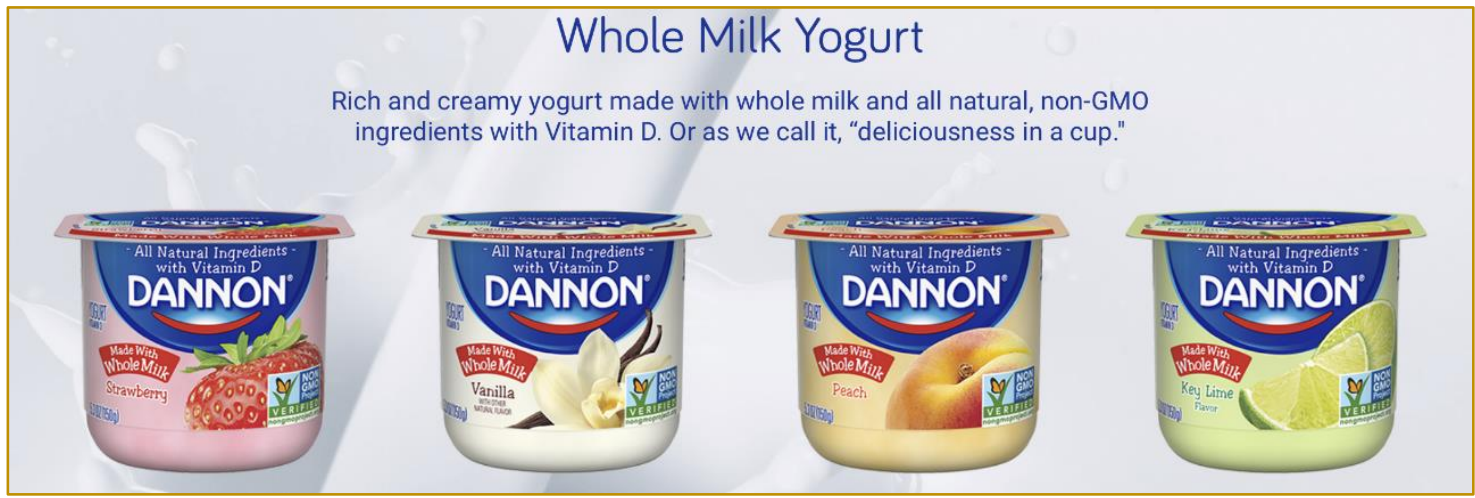

Fonte: Site institucional da Danone dos EUA (DANNON, 2018) 
$\mathrm{Na}$ Suíça, toda ração é livre de OGM na criação de gado leiteiro desde 2006 (MANN; VENUS, 2015). No Reino Unido, Alemanha, Áustria, Itália, Suíça, França, Dinamarca e Irlanda, grandes redes de supermercados como Tesco, Sainsbury's, Penny, REWE, Lidl e Coop entre outros, sensíveis às demandas dos consumidores, oferecem inúmeros produtos de laticínios, ovos e carne que não tiveram uso de OGM na ração animal. E em todos casos, os consumidores pagam um prêmio pelo produto totalmente livre de OGM.

Todas as pesquisas indicam que a tendência é crescente. A Mintel (2018) avaliou que dos lançamentos globais de alimentos entre 2016 e 2017, 29\% estavam na categoria denominada produtos naturais, que inclui produtos orgânicos e NGM. A Euromonitor, apud FoodBev Media (2016), divulgou que $55 \%$ dos consumidores procuram por indicação de produtos de origem natural ao analisar rótulos de alimentos. Ao serem confrontados sobre preços, 39\% estariam dispostos a pagar mais pelo atributo de "natural". A Nielsen (2015), em pesquisa global realizada em 60 países, destacou que dentre as características mais procuradas pelo consumidor na hora da compra, é a de NGM. A média global foi de $43 \%$, com destaque para Europa, que teve $47 \%$ de importância. É uma tendência crescente.

Se de um lado, os consumidores anseiam por produtos NGM, inclusive proteína animal e seus derivados como laticínios e ovos, e as indústrias alimentícias estão sensíveis a esta demanda crescente pelos consumidores dispostos a pagar mais por estes produtos, temos do outro lado um aumento do cultivo de soja GM nos principais produtores e exportadores, notadamente o Brasil e os EUA. Temos movimentos entre demanda e oferta em sentido antagônico, resultando em menos soja NGM sendo cultivado, enquanto a demanda dos consumidores, principalmente na Europa, mas também crescente nos EUA, está demandando mais soja NGM.

\subsection{PRECIFICAÇÃO E REMUNERAÇÃO DA SOJA}

Para atender a demanda dos consumidores, a indústria que processa a soja está disposta a pagar prêmios pela soja NGM: ela converte os produtos com ingredientes de soja NGM em produtos premium, para quais os consumidores estão dispostos a pagar mais, resultando em produtos mais rentáveis. Os prêmios que a indústria paga aos produtores rurais ainda não são uma constante, tendo variações dependendo da oferta do produto NGM. Este inclusive, é um dos fatores de incerteza, que tem direcionado a escolha de muitos produtores pela soja GM, dado que seu preço é mais certo, e fechado em contratos futuros de grandes volumes. Em abril de 2014, o prêmio pago ao produtor no Brasil pela soja NGM, foi de $17 \%$, pois a soja NGM era vendida por $\mathrm{R} \$ 70,20$ por saca, enquanto a soja GM colhia $\mathrm{R} \$ 60,00$ por saca (LEITÃO, 2014). Mesmo havendo custos maiores envolvidos no cultivo da soja NGM, e deduzindo os custos de segregação, ainda restava uma vantagem líquida de 4,3\% para o produtor rural que vendia soja NGM.

Comparado aos EUA, a situação também não é tão diferente. No final de 2014, o jornal The Blade (2014) publicou uma reportagem sobre a demanda asiática por soja NGM cultivado no Ohio, principalmente por Japão, onde a soja é utilizada diretamente em produtos alimentícios como tofu. A reportagem destacou que o prêmio pago aos produtores a depender da variedade de soja - era de US\$ 2 a 3 por bushel (medida de comercialização de grãos nos EUA). Em 20 de outubro de 2014, o preço do bushel de soja valia US\$ 9,775. O prêmio pago pela soja NGM variava entre $20,5 \%$ e $30,7 \%$ neste caso. Em 26 de dezembro de 2016, o preço médio do bushel de soja era negociado por US\$ 10,025 (MACROTRENDS, 2018). No mesmo período, segundo o The Organic \& Non-GMO Report (2016), contratos de soja NGM estavam sendo fechados pagando prêmios variando entre US\$1,15 até US\$2,35 por bushel, representando um premio ao produtor variando entre $11,5 \%$ e $23,4 \%$ - uma média de 17,45\%. Estes prêmios são valores brutos, e não consideram os custos adicionais envolvidos na produção e segregação da soja NGM.

No Brasil, os custos da soja NGM contemplam diversas variáveis, dentre quais podemos destacar a disponibilidade de sementes NGM; a necessidade de ter uma faixa de $20 \mathrm{~m}$. conhecida como borda de contenção, da qual a soja não poderá ser comercializada como NGM; a constante manutenção com defensivos; a limpeza em todo o processo; e a segregação da soja colhida, evitando a contaminação com soja GM. A tolerância máxima aceita, é de 1 grão de soja GM em cada 1.000 de NGM. Acima desse índice, a soja não pode ser comercializada como NGM 
e o produtor rural não receberá o prêmio (LEITÃO, 2014). Na atualidade, tanto o produtor rural, quanto os armazenadores e portos exportadores recebem um prêmio pela soja NGM, em virtude dos esforços necessários para mantê-los dentro da tolerância requerida de $\leq 1 / 1.000$ grão de GM entre os grãos NGM. Assegurar um transporte qualitativo deve ser um alvo nas negociações, dado que o transportador arca com custos adicionais para assegurar adequada limpeza e inspeção pós-limpeza. A tabela de custos elaborado pelo Leitão (2014) para detalhar os custos em toda cadeia logística no Brasil, elucida que, excetuando os transportadores, os demais atores recebem um prêmio líquido que compensa o esforço de segregação, tornando a soja NGM rentável, conforme demonstrado na Tabela 2.

Tabela 2. Custos da segregação da cadeia logística da soja

\begin{tabular}{|c|c|c|c|c|}
\hline EloLogístico & $\begin{array}{c}\text { Custo da Segregação } \\
(\%)\end{array}$ & $\begin{array}{c}\text { Proporção } \\
(\%)\end{array}$ & $\begin{array}{l}\text { Prêmio Reçbido por } \\
\text { Saca deSga }(\%)\end{array}$ & $\begin{array}{c}\text { Proporção } \\
(\%)\end{array}$ \\
\hline Produtor Rural & $4,30 \%$ & $51,3 \%$ & $8,42 \%$ & $40,4 \%$ \\
\hline Armazenador/Processador & $1,20 \%$ & & $11,40 \%$ & \\
\hline Transportador Rodoviário & $2,14 \%$ & & $0,00 \%$ & \\
\hline Operador Ferroviário & $0,30 \%$ & & $0,00 \%$ & \\
\hline Operador Portuário & $0,45 \%$ & & $1,00 \%$ & \\
\hline $\begin{array}{l}\text { Cadeia logística da } \\
\text { "Fazenda ao Portd" }\end{array}$ & $4,09 \%$ & $48,7 \%$ & $12,40 \%$ & $59,6 \%$ \\
\hline Tdal & $8,39 \%$ & $100,0 \%$ & $20,82 \%$ & $100,0 \%$ \\
\hline
\end{tabular}

Fonte: adaptado de Leitão (2014).

\subsection{COMERCIALIZAÇÃO DA PRODUÇÃO DE SOJA}

Porém, a grande maioria dos produtores rurais não exporta sua produção diretamente. A dinâmica do mercado é de vender a produção agrícola a grandes conglomerados com presença global, que dominam a cadeia de commodities agrícolas no mundo, desde a originação, até à sua transformação em agroindústrias. Estas empresas são globalmente conhecidas pelo termo "Trading", dado sua natureza de comercializar ("trade" em inglês) os commodities, adquirindo diretamente dos produtores e entregando a clientes em qualquer parte do globo, in natura, ou beneficiado.

A maioria das grandes Tradings são empresas verticalizadas, se encarregando de toda cadeia de logística até ao destino final. Payer (1975) já destacava em seus estudos sobre comércio de commodities nos anos 1970, que em particular, as grandes empresas globais de comércio de grãos, estavam se verticalizando. Esta concentração aumentou, e em 2015, somente 4 Tradings conhecidas pelo acrônimo de $A B C D$, foram responsáveis por $37 \%$ de todas as exportações de grãos do Brasil. (ABCD são respectivamente as empresas Archer Daniels Midland, Bunge, Cargill e Louis Dreyfus). Somados às Tradings asiáticas - principalmente chinesas, japonesas, coreanas e cingapurianos, o total chega a expressivos 82\% naquele ano (BONATO, Gustavo, 2016). Dessa forma, as Tradings assumem 48,7\% dos custos de segregação, mas ao assumir os investimentos, riscos e a coordenação das etapas seguintes à produção rural, acabam ficando com 59,6\% do prêmio líquido no Brasil (Tabela 2).

O modelo de Forças Competitivas que moldam uma estratégia, elaborado por Porter em 1979 e proposto para analisar a competição no setor industrial, pode ser aplicado no caso do produtor rural brasileiro que vende seus grãos para grandes clientes internacionais, onde o termo "indústria" representa o setor da cadeia de soja. Montgomery e Porter (1998), destacam que "a situação mais comum é a de uma empresa capaz de escolher a quem vender - em outras palavras, seleção de compradores". Continuam descrevendo, que somente pode vender para "compradores poderosos e ainda assim alcançar lucratividade acima da média, se for um produtor de baixo custo em seu segmento ou seu produto tiver alguma diferença em qualidade, ou mesmo uma característica singular". Uma característica singular ou diferenciação nesta indústria, é a soja NGM. 
Em seus estudos sobre estratégia competitiva, Porter (1985) explica como uma empresa pode criar e sustentar uma vantagem competitiva em sua indústria. Ao detalhar que a vantagem competitiva é em essência, o valor que a empresa consegue criar para os compradores de seus produtos, e que deve ser maior que o custo, ele identifica duas formas distintas de alcançar esta vantagem competitiva: liderança de custos, ou diferenciação. A liderança de custos, implica que a empresa deve ser capaz de ter os custos mais baixos de sua indústria, e portanto, consegue obter um resultado acima daquele que seus concorrentes podem obter. A sua estratégia, portanto, deve focar na busca de assegurar os menores custos. A diferenciação, por outro lado, visa oferecer um atributo diferenciado em relação aos seus concorrentes, e por conta desse atributo, consegue oferecer um maior benefício em termos de valor percebido. Ao oferecer os atributos desejados, o comprador estará disposto a pagar um prêmio pelos atributos desejados. E há nitidamente, duas categorias de produção de soja no Brasil: a soja GM, que é de baixo custo, e a soja NGM, que colhe prêmios na sua venda, na categoria de diferenciação.

\section{CONCLUSÃO}

Ao avaliar os estudos de estratégia do Porter e compará-los à indústria do comércio internacional de soja, podemos classificar os produtores rurais brasileiros como integrantes da "indústria", e as grandes compradoras internacionais, que são as Tradings, como "compradores". Pela análise da indústria através dos conceitos da relação entre as Tradings e os produtores brasileiros de soja, focando somente nesta relação na análise do modelo das Cinco Forças (PORTER, 1985), podemos concluir que os compradores detém maior influência sobre os preços que a indústria, que precisa reduzir seus custos para se manter rentável. Em 2015, as 4 Tradings ABCD, somados às principais Tradings asiáticas, eram responsáveis por originar e exportar $82 \%$ dos grãos brasileiros (BONATO, Gustavo, 2016), representando portanto, poucos e poderosos compradores. Já na indústria do cultivo de soja, não há censo oficial recente, mas no último Censo Agropecuário do IBGE de 2006, haviam 215.997 estabelecimentos de produção de soja no Brasil (IBGE, 2009). Aplicando um pareto na área cultivada, 35.503 produtores respondiam por $80,3 \%$ da área colhida, e $82 \%$ da produção. Há portanto, quantidade numerosa de vendedores na indústria. É fácil concluir que há poucos e poderosos compradores, enquanto há muitos vendedores.

Cultivar soja NGM, é portanto uma boa estratégia?

Se considerar o potencial da soja NGM diante das tendências de demanda crescente por parte dos consumidores nos mercados importadores de soja, há uma oportunidade de capturar os prêmios oferecidos. Porter destaca que há duas estratégias genéricas para a indústria quando os compradores são fortes: Liderança de Custo, que é o caso da soja GM, maximizando a produtividade com o menor custo, ou a Diferenciação, que é exatamente $\mathrm{o}$ que percebemos quando avaliamos o mercado de soja NGM, que ocupou apenas 3\% da área cultivada por soja nas lavouras brasileiras em 2017, contra os $97 \%$ da soja GM.

O produtor rural da soja NGM pode portanto, ser considerado uma liderança por diferenciação, e o cultivo da soja NGM ser uma estratégia competitiva a ser perseguida. Além de assegurar a qualidade do grão NGM, precisa assegurar que o total dos custos de segregação, armazenamento e transporte de sua região de produção sejam inferiores aos prêmios pagos pela sua soja NGM. Na medida que a tendência dos consumidores nos países importadores da soja brasileira consolidar a demanda por proteína de origem animal e seus derivados livre de OGM em toda cadeia de produção, o uso da soja GM na ração animal precisará ser substituído por soja NGM. Na atual conjuntura, é pouco provável que a Europa e Ásia serão capazes de cultivar a quantidade de soja requerida, dado os volumes sendo importados dos EUA e do Brasil.

Cabe a cada produtor rural avaliar criteriosamente sua estrutura de custos e compará-la aos prêmios oferecidos em sua região, para identificar qual a melhor opção estratégica: cultivar soja GM no caso dos prêmios não compensarem os custos adicionais de segregação, armazenamento e transporte, ou a soja NGM, também conhecida por "soja convencional", quando os prêmios compensam o esforço adicional. Este artigo visa instigar as partes interessadas, e principalmente os produtores rurais, que devem atentar aos movimentos 
dos consumidores nos países onde a soja brasileira é consumida, quanto às suas tendências de consumo, e consequências dos desejos dos consumidores finais na legislação e indústria no destino da soja

\section{REFERÊNCIAS}

[1] Abiove. Brasil: Exportações do Complexo Soja. São Paulo, 2018. Disponível em: $<$ http://www.abiove.org.br/site/index.php?page=est atistica\&area $=\mathrm{NCOyLTE}=>$.

[2] Alexandratos, N.; Bruinsma, J. World agriculture towards 2030/2050: the 2012 revision. Land Use Policy, n 12-03. Rome, 2012.

[3] Boland, Mike. Global food supply: the world's need for protein. 2013, Palmerston North: Riddet Institute, 2013. p. 40. Disponível em: <http://www.riddet.ac.nz/sites/default/files/content/2 013 Protein supply Mike Boland.pdf>.

[4] Bonato, Emídio Rizzo; Bonato, Ana Lidia Variani. A soja no Brasil: história e estatística. EMBRAPA-CNPSo. Documentos, ISSN 0101-5494, v. 21, p. 61, 1987. Disponível em: <https://www.infoteca.cnptia.embrapa.br/infoteca/h andle/doc/446431?mode $=$ simple $>$

[5] Bonato, Gustavo. New titans on the block: ABCDs lose top Brazil grains spot to Asian rivals. São Paulo, 23 mar. 2016. , p. 4. Disponível em: $<$ https://www.reuters.com/article/us-brazilgrains/new-titans-on-the-...ck-abcds-lose-topbrazil-grains-spot-to-asian-rivalsidUSKCNOWP19V>

[6] Brankov, Tatjana. How Genetically Modified Organisms ( GMOs ) enter the food chain in non-GMO producing countries. CAB International, v. 00, p. 4, 2018. Disponível em: <http://cabiblog.typepad.com/hand_picked/2018/0 1/how-genetically-modified-organisms-gmos-enterthe-food-chain-in-non-gmo-producingcountries.html>.

[7] Brasil. Lei N. 10.688 de 13 de Junho de 2003. Brasil: Casa Civil, 2003. Disponível em: <http://www.planalto.gov.br/ccivil_03/leis/2003/L10. 688.htm>. Acesso em: 10 set. 2018.

[8] Brasil. Lei N. 8.974 de 5 Janeiro de 1985. Brasil: Casa Civil, 1995. Disponível em: <http://www.planalto.gov.br/ccivil_03/leis/L8974.ht $\mathrm{m}>$. Acesso em: 10 set. 2108.

[9] Brookes, Graham; Craddock, Neville; Kniel, Bärbel. The global GM market: implications for the European food chain. An analysis of labelling requirements, market dynamics and cost implications. Brookes West, Canterbury, United Kingdom. Canterbury, 2005.

[10] CFS. International Labeling Laws. Disponível em: <http://www.centerforfoodsafety.org/issues/976/gefood-labeling/international-labeling-laws>. Acesso brasileira, pois na essência, serão os consumidores finais que irão determinar qual a melhor estratégia a ser adotada na origem da cadeia produtiva nos campos brasileiros.

em: 15 abr. 2018.

[11] Chavez, Jon. Unaltered Ohio soybeans are a prized crop globally: Asian markets clamor for local farmers' nongenetically modified crops. The Blade, p. 3, Toledo, 19 out. 2014. Disponível em: <http://www.toledoblade.com/Retail/2014/10/19/Un altered-Ohio-soybeans-prized.print>.

[12] Conab. Acompanhamento Da Safra Brasileira De Grãos Safra 2017/18 - Décimo Primeiro Levantamento. Brasilia, 2018a. Disponível em: <https://www.conab.gov.br/info-agro/safras>.

[13] Conab. Série Histórica das Safras - Soja. Disponivel em: <https://www.conab.gov.br/infoagro/safras/serie-historica-das-safras?start=20>. Acesso em: 9 set. 2018b.

[14] Dannon. Dannon Yogurt Products. Sítio Institucional, EUA, 2018. Disponível em: $<$ http://www.dannonyogurt.com/yogurt/\#plainyogurt>. Acesso em: 16 abr. 2018.

[15] De Visser, Cornelis Leonardus Maria; SCHREUDER, Remco; STODDARD, Frederick. The EU's dependency on soya bean import for the animal feed industry and potential for EU produced alternatives. Ocl, v. 21, n. 4, p. D407, 2014. Disponível em: <http://www.ocljournal.org/10.1051/ocl/2014021>.

[16] Fao. FAOSTAT-Crops. Disponível em: $<$ http://www.fao.org/faostat/en/\#data/QC >. Acesso em: 13 set. 2018 .

[17] Fao. The future of food and agriculture: Trends and challenges. United Nations. Rome, 2017. Disponível em: <http://www.fao.org/3/ai6583e.pdf>.

[18] Food Insider Journal. Organic Non-GMO: Exploring the Consumer Disconnect. v. 1, n. 1, p. 35, 2017. Disponivel em: <https://www.armstrongteasdale.com/files/Uploads/ Documents/03-17FIJ-Organic-GMO-000-DIsecure.pdf>.

[19] Foodbev Media. "Almost half of consumers" expect natural products. Disponível em: $\quad<$ https://www.foodbev.com/infoabout/>. Acesso em: 19 abr. 2018.

[20] Group, Mellman. Voters Want GMO Food Labels Printed on Packaging. Washington, 2015. Disponivel em: $<$ http://4bgr3aepis44c9bxt1ulxsyq.wpengine.netdn a-cdn.com/wpcontent/uploads/2015/12/15memn20-JLI-d6.pdf>

[21] Henchion, Maeve et al. Future Protein 
Supply and Demand: Strategies and Factors Influencing a Sustainable Equilibrium. Foods, v. 6, n. 7 , p. 21, 2017. Disponível em: <http://www.mdpi.com/2304-8158/6/7/53>.

[22] Ibge. Base de dados dos municipios. Disponível em: <ftp://geoftp.ibge.gov.br/organizacao_do_territorio/ redes_e_fluxos_geograficos/gestao_do_territorio/ba ses_de_dados/xls/Base_de_dados_dos_municipios .xls>. Acesso em: 13 set. 2018.

[23] Ibge. Censo Agropecuário 2006. IBGE Instituto Brasileiro de Geografia e Estatística. Rio de Janeiro, 2009. Disponível em: <https://biblioteca.ibge.gov.br/visualizacao/periodi cos/51/agro_2006.pdf>

[24] Imea. Agronegócio no Brasil e em Mato Grosso. Disponível em: <http://www.imea.com.br/\%5Cnhttp://www.imea.co m.br/upload/pdf/arquivos/R405_Apresentacao_MT_ Portugues_Nova_26_11_2014.pdf>. Acesso em: 27 ago. 2018.

[25] Isaaa. Global Status of Commercialized Biotech/GM Crops: 2016. ISAAA. Ithaca, 2016. Disponível em: $<$ https://www.isaaa.org/resources/publications/brief s/52/executivesummary/pdf/B52-ExecSumPortuguese.pdf>

[26] Isaaa. Global Status of Commercialized Biotech/GM Crops in 2017: Biotech Crop Adoption Surges as Economic Benefits Accumulate in 22 Years. Ithaca, 2017. Disponível em: <http://www.isaaa.org/resources/publications/briefs /53/download/isaaa-brief-53-2017.pdf>.

[27] James, Clive. Global status of Commercialized biotech / GM Crops : 2013. ISAAA. Ithaca, 2013. Disponível em: <http://www.isaaa.org/resources/publications/briefs /46/download/isaaa-brief-46-2013.pdf>.

[28] Leitão, Fabrício Oliveira. Análise sistêmica da segregação na cadeia logística da soja após o advento e a difusão dos transgênicos. 2014. 197 f. Universidade de Brasília, 2014.

[29] Macrotrends. Historical chart data soybean prices. Disponível em: <https://www.macrotrends.net/assets/php/chart_ifra me_comp.php?id=2531\&url=soybean-priceshistorical-chart-data>. Acesso em: 9 set. 2018.

[30] Mandemaker, Valtr. The question of the production of Genetically Modified Foods. 2015, Hague. United Nations International School of The Hague, 2015. p. 11. Disponível em: <http://www.munish.nl>.

[31] Mann, Stefan; Venus, Thomas. GMO free milk: A system comparison of Germany and Switzerland. Agroscope Science, n. 21, 2015.

[32] Mdic. Balança Comercial: janeirodezembro 2017 - Exportação Brasileira por Produtos, em US\$ FOB. Disponível em: <http://www.mdic.gov.br/index.php/comercio- exterior/estatisticas-de-comercio-exterior/balancacomercial-brasileira-acumulado-doano?layout=edit\&id=3056 $>$. Acesso em: 2 set. 2018.

[33] Mintel. Global food and drink trends 2018. Mintel Group Ltd., London, 2018. Disponível em: $<$ http://www.mintel.com/global-food-and-drinktrends/>.

[34] Mintzberg, Henry; Ahlstrand, Bruce; Lampel, Joseph. Strategy safari: a guided tour through the wilds of strategic management. New York: The Free Press, 1998.

[35] Montgomery, Cynthia A.; Porter, Michael E. Estratégia: a busca da vantagem competitiva. Rio de Janeiro: Editora Campus, 1998.

[36] Nielsen. We are what we eat: healthy eating trends around the world. Nielsen N.V., Global Health and Wellness Report, New York, 2015.

[37] Non-Gmo Project. Animal Feed is the Key to a About Non-GMO Future. Non-GMO Project, Washington, 2017. Disponível em: < https://www.nongmoproject.org/blog/animal-feedis-the-key-to-a-non-gmo-future/> Acesso em: 16 abr. 2018.

[38] Oecd. OECD.Stat. Disponível em: <https://stats.oecd.org >. Acesso em: 31 mar. 2018.

[39] Payer, Cheryl. Commodity Trade of the Third World. London: The Macmillan Press Ltd., 1975.

[40] Porter, Michael E. Competitive Advantage. Creating and Sustaining Superior Performance. 1. Ed. New York: The Free Press, 1985.

[41] Potts, Jason et al. The State of Sustainability Initiatives Review 2014. International Institute for Sustainable Development - IISD, Winnipeg, 2014. Disponível em: <www.iisd.org>.

[42] Prodanov, Cleber Cristiano; Freitas, Ernani Cesar De. Metodologia do trabalho científico: métodos e técnicas da pesquisa e do trabalho acadêmico. 2. ed. Universidade Feevale, Novo Hamburgo, 2013.

[43] Salin, Delmy. Soybean Transportation Guide: Brazil. U.S. Dept. of Agriculture, Agricultural Marketing Service. Washington, 2014. Disponível em:

<https://www.ams.usda.gov/sites/default/files/medi a/Soybean Transportation Guide Brazil 2013.pdf>.

[44] Tavares, Carlos Eduardo C. Estimativa do escoamento das exportações do complexo soja e milho pelos portos nacionais. CONAB, Brasilia, $2017 . \quad$ Disponivel em: <https://www.conab.gov.br/institucional/publicacoe s/compendio-de-estudos-da-conabs.

[45] THE Organic \& Non-Gmo Report. 2017 Non-GMO and Organic Grain Production Contracts. Disponivel em: <http://nongmoreport.com/articles/2017-non-gmo-and- 
organic-grain-production-contracts/>. Acesso em: 9 set. 2018.

[46] United Nations. World Population Prospects: Data Booklet. UN, Department of Economic and Social Affairs, Population Division, New York, 2017. Disponível em: $<$ https://esa.un.org/unpd/wpp/publications/files/wp p2017_keyfindings.pdf $>$.

[47] usda. Crop Production Historical Track
Records (April 2018). Crop Production Historical Track Records National Agricultural Statistics Service, n. April, p. 240, 2018. Disponível em: $<$ http://usda.mannlib.cornell.edu/usda/current/htrcp /htrcp-04-12-2018.pdf>.

[48] WWF. The Growth of Soy: Impacts and Solutions. WWF Report, Gland, 2014. Disponível em:

<http://issuu.com/wwfsoyreport/docs/wwf_soy_repo rt_final_jan_19/1?e=10667775/6569194> 


\section{Capítulo 17}

\section{RELEVÂNCIA DAS NOTAS EXPLICATIVAS SOB A ÓTICA DA SUFICIENCIA INFORMACIONAL: PETROBRAS}

\section{Victor Haruo Nitatori Rodrigues Lourenço}

\section{Isabel Cristina Sartorelli}

Resumo: O objetivo deste estudo é a análise das informações sobre disclosure do teste de impairment fornecidas nas demonstrações contábeis, verificando se são suficientes para a técnica de recálculo. A Petrobras foi a empresa estudada, considerando sua importância no cenário nacional e internacional e a aderência ao tema estudado (impairment). De caráter qualitativo, este estudo analisou as notas explicativas do relatório 20F dos anos de 2012 a 2016 com o intuito de avaliar o grau de suficiência informacional para a realização da técnica. Os resultados indicam a falta de informações relacionadas às reservas da companhia, falta de especificações de saída de caixa e de reconhecimento das unidades geradoras de caixa, o que inviabilizou o processo de recálculo, muito embora a companhia tenha cumprido todos os requisitos exigidos pela norma contábil em relação à obrigatoriedade de disclosure de informações acerca do assunto. Os resultados abrem espaço para uma discussão mais aprofundada sobre os requisitos exigidos pelas normas contábeis e a sua relevância em termos de prover informações para a avaliação econômica e financeira de companhias abertas. Como contribuição, destaca-se a bibliografia trazida sobre o teste de impairment.

Palavras-Chave: Teste de Impairment. Disclosure. Relevância da informação contábil. Notas explicativas. 


\section{INTRODUÇÃO}

Este estudo pressupõe percorrer o caminho realizado por um analista que pretende avaliar as informações fornecidas por uma companhia petrolífera, de maneira a poder conhecer quais foram as premissas e técnicas utilizadas quando do impairment do ativo imobilizado desta, propiciando uma reflexão acerca do grau de relevância das notas explicativas sobre o assunto. ${ }^{2}$

Para enquadramento desta discussão, escolheu-se a Petrobrás, tanto por sua relevância no cenário nacional quanto pela aderência ao tema em debate. Como parte do processo de avaliação e projeção dos benefícios econômicos futuros, 0 analista deve entender os aspectos que aumentam as chances de a companhia alcançar os ganhos projetados, o que passa por dois pontos: a estimação dos benefícios econômico por meio da projeção dos fluxos de caixa futuros e a avaliação da concretização desses benefícios de maneira sustentável ao longo do tempo (HITCHNER, 2010).

Um fator importante para o processo de decisão concerne a verificação das premissas utilizadas para o cálculo de ativos e passivos da companhia juntamente da relação entre os números apresentados e o quanto estes podem ser considerados prováveis ou sustentáveis no futuro próximo. Sendo verificado o grau de suficiência informacional das demonstrações contábeis por meio da possibilidade do analista "voltar no cálculo" e garantir que as bases utilizadas pela companhia são verdadeiras em suas estimativas, não havendo discrepância entre a real situação da empresa com relação as informações apresentadas.

Para analisar o disclosure foi utilizado como fonte as notas explicativas do relatório 20-F que relata não apenas dados financeiros obrigatórios por norma, mas também informações operacionais adicionais

1 Os pré-requisitos exigidos pela norma contábil para disclosure do Teste de Impairment pode balizar a análise das notas explicativas sobre o tema, uma vez que a norma contábil não proíbe o disclosure de informações adicionais que possam trazer maior transparência e detalhamento útil para os que pretendem proceder a avaliações de cunho econômico e financeiro de companhias abertas, sendo fator preponderante para o procedimento de "voltar na conta" e analisar o grau de suficiência informacional da demonstração. importantes devido aos vários problemas teóricos e técnicos específicos relacionados ao setor petrolífero, tornando impossível de se analisar a empresa utilizando apenas o que é obrigatório (DOMINGUES e GODOY, 2012).

Dessa forma, pode-se dizer que existe um alto grau de suficiência informacional quando, por meio das demonstrações da companhia é possível verificar as premissas utilizadas. Estabelece-se, desta forma, uma relação entre evidenciação e possibilidade de verificação das premissas que é explorada neste artigo, o qual pretende estudar o grau de suficiência informacional de uma demonstração contábil vis-à-vis a necessidade informacional requerida para se "voltar no cálculo".

Além da escolha da companhia, optou-se por analisar um grupo do ativo da companhia que fosse relevante considerando-se projeções de resultados futuros, o que explica a escolha pelo ativo imobilizado da Petrobras (representa, em média, mais de $70 \%$ do total ativo), já que ele pode oferecer complexidade suficiente para este estudo exploratório. Como se já não fosse suficiente a complexidade de mensuração dos ativos desta companhia, ainda se nota, na imprensa nacional, a tamanha repercussão relativa à superavaliação dos ativos ocorrida no passado recente. Ainda no ano de 2016, a companhia divulgou em seu terceiro balanço trimestral que os ajustes necessários dos ativos imobilizados não foram identificados de forma correta por meio das metodologias utilizadas. Tais fatos justificam a escolha pela referida temática.

\subsection{PROBLEMA DE PESQUISA}

Considerando o possível impacto das premissas adotadas para cálculo do impairment do ativo imobilizado no resultado projetado da companhia, este estudo exploratório pretendeu analisar o grau de suficiência informacional das demonstrações contábeis publicadas, de maneira que fosse possível verificar a possibilidade de se "voltar no cálculo" do teste e averiguar as premissas utilizadas.

O que justifica esta pesquisa é o fato de que a falta ou a parcialidade de informações pode tornar ineficiente a alocação de recursos em um mercado de capitais, instaurando um contexto de assimetria informacional entre agentes externos e internos de forma com que 
as companhias utilizem o disclosure como forma de mitigar tais efeitos negativos (HEALY; PALEPU, 2001).

Dado que a evidenciação das demonstrações contábeis é pautada pela norma vigente no mercado no qual serão comercializadas as ações, e considerando que a norma, por sua vez, oferece certa discricionariedade no uso de técnicas que podem ser utilizadas, tornase necessário conhecer quais foram as técnicas e as premissas utilizadas na preparação das demonstrações contábeis, de maneira a que se possa avaliar o grau de adequação destas à companhia enfocada, além, é claro, de obter informações suficientes para a verificação das premissas utilizadas. O sentido utilizado neste trabalho é de possibilitar o recálculo para análise do resultado histórico da Petrobras.

Sendo assim o presente trabalho visa estudar a suficiência informacional das demonstrações financeiras, notadamente, o Relatório 20-F da Petrobrás, e tem como questão de pesquisa: Qual o nível de suficiência informacional das notas explicativas para que seja possível o recálculo e a verificação das premissas utilizadas no teste impairment do ativo imobilizado?

$\mathrm{H} 1$ : "As informações disponibilizadas nas notas explicativas não são suficientes para a realização do recálculo em relação à contabilização do impairment do ativo imobilizado."

E para testar, utilizaremos as informações das notas explicativas, o que acaba por delinear uma análise qualitativa e detalhada.

Como contribuição deste estudo, tem-se a utilização do recálculo de determinado processo sobre informação contábil, algo até então pouco explorado e que pode trazer à tona a discussão sobre a relevância das informações prestadas por uma companhia, que vai muito além do cumprimento dos requisitos de disclosure, haja vista que as notas explicativas podem fornecer informações complementares para a avaliação da real situação econômica da empresa.

Este artigo está estruturado da seguinte forma, afora esta introdução: na segunda sessão, o referencial teórico, fundamentado na literatura dos aspectos normativos e em estudos sobre o impairment no setor petrolífero; na terceira, o método de pesquisa, baseada em uma análise qualitativa e quantitativa das notas explicativas do relatório 20-F; na quarta, a apresentação e análise de resultados, seguida da quinta sessão, a qual traz a conclusão.

\section{FUNDAMENTAÇÃO TEÓRICA}

Inicia-se com a conceituação das especificidades de ativos de companhias petrolíferas, para, em seguida, trazer quais seriam as principais informações acerca do disclosure do teste de impairment segundo as normas contábeis vigentes no Brasil.

\subsection{OS ATIVOS DE UMA COMPANHIA PETROLÍFERA}

A evidenciação dos ativos de uma companhia petrolífera é sempre desafiadora: basta considerar que o maior ativo de uma empresa petrolífera são suas reservas de petróleo, e estas, assim que descobertas, já podem gerar efeitos nos preços de suas ações, muito embora ainda não estejam reconhecidas em suas demonstrações contábeis (JOHNSTON, 2006).

Para as companhias petrolíferas encontrar reservas não significa uma nova fonte de receitas futuras, pois a quantidade e a qualidade do petróleo encontrado devem ser economicamente viáveis (SANTOS et al, 2010). As reservas são extremamente delicadas levando em consideração as variáveis relacionadas ao petróleo, sendo assim um dos passos mais sensíveis ao risco de erro na mensuração é o de estimação das entradas de fluxo de caixa futuros por depender diretamente dessas reservas, sendo um fator preponderante para o recálculo o detalhamento das mesmas por parte da empresa. Uma das dificuldades encontradas nessa etapa inicial do processo é este não detalhamento de quais campos e polos são partes de determinadas unidades geradoras de caixa (UGCs) e a respectiva mensuração da quantidade de suas reservas.

Ao analisar a operação de uma empresa petrolífera, prontamente se percebe que o ativo imobilizado pode gerar reflexos no resultado da companhia, já que este é elemento chave para produção (aqui inclusos extração, produção/refino e distribuição dos derivados do petróleo). Anomalias no valor do ativo imobilizado podem trazer distorções quando da análise do seu valor de recuperação, considerando o registro do ativo 
por seu custo histórico e os subsequentes ajustes calculados a partir do valor que este consegue gerar ou pelo seu valor de venda. $E$ pelo fato de que o valor de venda é extremamente difícil de se mensurar devido às especificidades do setor, a única alternativa é a estimação pelo valor em uso do ativo.

Alguns problemas contábeis em empresas do setor petrolífero são devidos à algumas características ímpares do setor, como: alto risco de encontrar poços secos; o longo tempo entre a descoberta da reserva e a realização em lucro ou em caixa; a dissociação entre os investimentos, receitas e valor das reservas (retorno); e a importância estratégica nos mercados internacionais como fonte energética (CLÔ apud DOMINGUES; GODOY, 2012).

Além disso, a indústria petrolífera é tipicamente de capital intensivo, sendo necessários altos volumes de recursos para formar seus ativos e, consequentemente, permitir a produção de petróleo e gás, a alocação desses recursos envolvem altos riscos e grandes prazos de maturação do investimento (SANTOS et al, 2010). Esses investimentos operacionais são realizados em ativos imobilizados, agregando na estrutura produtiva da companhia e resultando em um alto grau de imobilização das empresas do setor.

Sendo assim, pode-se considerar o ativo imobilizado como principal elemento da demonstração contábil quando se visa analisar a situação de uma empresa petrolífera, pois o mesmo compõe boa parte dos ativos das companhias do setor, no caso da Petrobras, representa $71,04 \%$ do total de ativos, também existindo uma relação de dependência da produção e exploração de reservas com a utilização dos ativos imobilizados, ou seja, qualquer fator preponderante para o ativo gera consequências na geração de receitas da companhia.

Para Borba et al (2009), o fato de os ativos de natureza permanente possuírem capacidade de gerar benefícios durante vários períodos, faz com que seja necessária uma análise minuciosa de seu potencial econômico (geração de resultados, lucro ou prejuízo) e financeiro (potencial de gerar caixa).

Tal análise ocorre por meio da mensuração do ativo imobilizado, feita considerando o seu valor econômico e sendo útil para diferentes decisões a serem tomadas nas organizações, como a decisão de compra ou não de um ativo, se é interessante realizar a manutenção do mesmo, quais investimentos poderão ser feitos com as entradas de caixa futuras provenientes da utilização do ativo (RAUPP; BEUREN, 2008).

Segundo as normas brasileiras a mensuração do ativo imobilizado é feita registrando o mesmo pelo seu valor de custo, sendo presumido que o valor econômico que o ativo irá gerar no futuro pelo seu uso será suficiente para cobrir ao menos o seu valor de registro, com isso nenhum ativo poderá existir por valor que não seja recuperável economicamente mediante sua venda ou utilização (SANTOS et al, 2010). Com alguns anos, o ativo mensurado pelo seu valor de custo, considerando as modificações na economia e a rapidez da evolução tecnológica, pode perder a capacidade de geração de benefícios futuros por uso do mesmo que existia na época de sua aquisição (ZANDONAI; BORBA, 2009). Essa diferença entre a capacidade atual de um ativo e o valor que foi registrado na sua compra ocasiona uma assimetria informacional entre valor relacionado ao potencial de geração de futuros benefícios e o valor divulgado para o mercado em suas demonstrações financeiras.

A garantia que essa diferença é inexistente é feita pelo teste de impairment, reduzindo controvérsias e informações diferentes na tomada de decisão ao evitar as distintas formas de mensuração e percepções do ativo (RAUPP; BEUREN, 2008). Para a realização de tal teste, é necessária a comparação do valor contábil com o fair value, definido por Zandonai e Borba (2009) como: "a quantia pela qual um item patrimonial poderia ser negociado em um mercado eficiente".

\subsection{NORMAS CONTÁBEIS REFERENTES AO IMPAIRMENT TEST}

Segundo o IAS36 (CPC01), o teste de impairment deve ser feito anualmente para alguns ativos e para todos aqueles ativos não financeiros onde exista indicação de imparidade. Como princípio geral, os ativos de uma entidade devem estar avaliados por não mais que o seu valor de recuperação (valor a ser realizado durante a vida útil do ativo). Quando o valor contábil de um ativo excede seu valor de referência, reconhece-se o impairment na medida em que a diferença entre os valores é detectada. 
Dois são os métodos para cálculo do impairment: o método dos esforços bemsucedidos e o método do custo total; a principal diferença entre eles é o tratamento das despesas relacionadas a novas reservas de óleo e gás, influenciando o resultado líquido e o fluxo de caixa. No primeiro método, os custos relacionados à identificação bemsucedida de novas reservas podem ser capitalizados, enquanto os custos dos esforços malsucedidos são considerados imediatamente como despesa. No segundo método, todos os custos, tanto do que foi bem-sucedido quanto o que foi malsucedido, tudo, todo o custo é capitalizado.

Cada método tem seu valor de referência, portanto, o teste de impairment passa a ter peculiaridades conforme cada método adotado:

a) do tempo para o teste impairment e seus indicadores: aqui analisa-se quando os eventos ou circunstâncias indicam que o valor contábil das propriedades da empresa pode não ser recuperável; as propriedades devem ser testadas sempre que mudanças no cenário indicarem que o valor contábil dos ativos pode não ser recuperável. Realizam uma análise anual que começa com o relatório sobre as reservas, a partir do qual estima-se o fluxo de caixa correspondente, quando então comparam esse valor ao valor contábil; em relação às reservas, as empresas podem considerar um fator de risco se concluírem que a estimativa (quanto às reservas) é provável ou possível, mas não se a estimativa da reserva tiver sido provada.

b) da mensuração da perda com impairment: em relação ao método dos esforços bemsucedidos, a mensuração é realizada pela comparação do valor do fluxo de caixa não descontado com o respectivo valor contábil; se o valor contábil for maior que a soma dos fluxos de caixa não descontados, então existe um valor não recuperável. Em relação ao método do custo total, é estabelecido um teto para o custo total para as reservas com estimativa provada; é feito então o teste de recuperabilidade do ativo (compara-se o valor do fluxo de caixa com o valor contábil): se o valor contábil excede 0 valor justo, reconhece-se a perda por impairment.

c) do nível no qual o impairment é realizado: quando a companhia se utiliza do método dos esforços bem sucedidos, estabelece-se, a princípio, em que nível uma deficiência deve ser avaliada, mantendo-se sempre os fluxos de caixa das diversas reservas sempre separados uns dos outros; uma vez que se atinge a deficiência estipulada, realiza-se o teste de impairment.

d) do reconhecimento da perda com impairment: por fim, a perda ou reversão é reconhecida pela companhia em sua demonstração contábil, juntamente de detalhes que foram utilizados para a realização do cálculo que são apresentados na Tabela 2 e analisados ao longo do trabalho.

\subsubsection{TRABALHOS ANTERIORES QUE ABORDARAM O DISCLOSURE DA DIVULGAÇÃO DO TESTE DE IMPAIRMENT}

De maneira ampla, Machado et al (2013) analisaram o nível de disclosure sobre o valor recuperável dos ativos de empresas brasileiras, ressaltam algumas informações que devem ser divulgadas nas demonstrações financeiras, notadamente: fatos que representem riscos e incertezas que possam afetar a continuidade da entidade; informações relativas a perda ou reversão por impairment; procedimentos que envolvem a aferição anual do valor recuperável de seus ativos; mesmo que a companhia não identifique as perdas a serem reconhecidas, as companhias devem divulgar motivos, bases, premissas e demais variáveis que suportem sua decisão de não reconhecer a desvalorização nos ativos sob seu controle.

Outros estudos já enfocaram analisaram o disclosure do teste de impairment da Petrobrás, dos quais alguns que merecem destaque encontram-se na Tabela 1: 
Tabela 1. Trabalhos que referenciam a Petrobras sob a ótica do impairment.

\begin{tabular}{|c|c|}
\hline Autor(es) & Trecho da referência \\
\hline $\begin{array}{l}\text { Borba e Alberton } \\
(2010)\end{array}$ & $\begin{array}{l}\text { "A Petrobras apresentou detalhadamente quase todas as informações exigidas, } \\
\text { inclusive os segmentos ao qual pertencem os ativos que sofreram a redução. Quanto à } \\
\text { classe, são todos imobilizados. A única informação não apresentada foi o percentual } \\
\text { da taxa de desconto utilizada na projeção de fluxo de caixa futuro descontado. A } \\
\text { empresa também informou que uma de suas controladas a Petrobras América Inc. } \\
\text { reconheceu a perda no valor recuperável do ágio por expectativa de rentabilidade } \\
\text { futura (goodwill). A Controladora (Petrobras) demonstrou através de um quadro } \\
\text { explicativo o valor da perda e explicou os fatores que levaram ao reconhecimento dela. } \\
\text { Todavia, talvez, em virtude de a perda ter ocorrido na controlada e não na controladora } \\
\text { (Petrobras), o fato foi mencionado de maneira breve e sucinta, não contemplando as } \\
\text { demais exigências do CPC-01, neste caso. O parecer dos auditores independentes } \\
\text { nada mencionou a respeito." }\end{array}$ \\
\hline Souza et al (2008) & $\begin{array}{l}\text { "Verificou-se que o número de informações apresentadas nos relatórios divulgados na } \\
\text { CVM foi substancialmente baixo em relação às informações apresentadas nos } \\
\text { relatórios divulgados na SEC. A Petrobras, nas DFP's entregues à CVM, utilizou na } \\
\text { Demonstração do Resultado do Exercício - DRE, a rubrica "Perda na Recuperação de } \\
\text { Ativos", a qual totalizou um valor de R\$ } 45.063 .000,00 \text { (quarenta e cinco milhões e } \\
\text { sessenta e três mil reais). Porém, assim como a Ambev, também não entrou em } \\
\text { pormenores em relação à prática contábil adotada." }\end{array}$ \\
\hline Ono et al (2011) & $\begin{array}{l}\text { "A empresa (Petrobras) informou valor recuperável de suas UGCs foi fundamentado no } \\
\text { valor em uso, exceto quando especificamente indicado. Os fluxos de caixa futuros } \\
\text { foram apurados pelo Custo Médio Ponderado de Capital (WACC). Cada campo de } \\
\text { exploração e produção corresponde a uma unidade geradora de caixa, e o total de } \\
\text { desvalorização apurado foi de R\$ 933,088 milhões." }\end{array}$ \\
\hline
\end{tabular}

\section{MÉTODO DE PESQUISA}

Após a revisão de literatura sobre o disclosure do teste de impairment, a Tabela 2 a seguir foi montada, de maneira a apresentar sucintamente quais devem ser os pontos de avaliação das notas explicativas da empresa escolhida quanto ao seu grau de suficiência informacional.

Tabela 2. Estruturação de análise quanti e qualitativa por meio de itens de divulgação descritos.

\begin{tabular}{|c|c|}
\hline Itens de divulgação (pontos de análise) & Composição de cada ponto de ć \\
\hline $\begin{array}{l}\text { 1) Citação referente à norma contábil utilizada } \\
\text { pela empresa segundo Machado et al (2013). }\end{array}$ & $\begin{array}{l}\text { Indicação direta ou indireta da utilização do CPC } 01 \text { ou outras } \\
\text { normas contábeis equivalentes na elaboração da demonstração. }\end{array}$ \\
\hline $\begin{array}{l}\text { 2) Valor da perda ou reversão e identificação da } \\
\text { linha onde se encontra no Balanço Patrimonial } \\
\text { segundo Borba et al (2009), Ono et al (2011) e } \\
\text { CPC 01. }\end{array}$ & $\begin{array}{l}\text { Valor da perda por impairment ou da reversão (Item } 121 \text { do CPC } \\
\text { 01). }\end{array}$ \\
\hline $\begin{array}{l}\text { 3) Condições, periodicidade e procedimentos } \\
\text { gerais do teste de impairment de acordo com a } \\
\text { IAS } 36 \text {, o CPC } 01 \text { e o SFAS } 144\end{array}$ & $\begin{array}{l}\text { Condições, indicar as premissas do teste de impairment. } \\
\text { Periodicidade, indicar se a empresa segue a necessidade anual } \\
\text { apontada pela CVM. } \\
\text { Procedimentos Gerais, principalmente o que se refere ao método } \\
\text { utilizado: teste pelo Valor em Uso ou Valor Líquido da Venda do } \\
\text { mesmo. }\end{array}$ \\
\hline $\begin{array}{l}\text { 4) Identificação e descrição dos eventos que } \\
\text { levaram ao reconhecimento da perda ou } \\
\text { reversão de acordo com Borba et al (2009), IAS } \\
36, \text { CPC } 01 \text { e SFAS } 144 \text {. }\end{array}$ & $\begin{array}{l}\text { Quais eventos levaram à empresa, que segundo o CPC } 01 \\
\text { podendo ser fontes externas de informação (mercadológicas, } \\
\text { tecnológicas, legais e econômicas) e internas (referentes ao ativo e } \\
\text { suas condições de utilização. }\end{array}$ \\
\hline $\begin{array}{l}\text { 5) Identificação das UGCs (descrição dos } \\
\text { campos e polos petrolíferos); no caso de se } \\
\text { tratar de um ativo individual (descrição da } \\
\text { natureza do ativo) a análise foi de acordo com a } \\
\text { IAS 36, o CPC } 01 \text { e a SFAS } 144 \text {. }\end{array}$ & $\begin{array}{l}\text { As UGCs necessitam ser não somente descritas, mas relacionadas } \\
\text { com os respectivos campos e polos para que se saiba exatamente } \\
\text { a quantidade de reservas relacionadas a cada unidade. Já a } \\
\text { existência de ativos individuais é improvável devido à separação } \\
\text { por polos petrolíferos (Item } 125 \text { do CPC 01). }\end{array}$ \\
\hline
\end{tabular}


Tabela 2. Estruturação de análise quanti e qualitativa por meio de itens de divulgação descritos. (continuação)

Itens de divulgação (pontos de análise)

6) Este ponto refere-se à UGCs contendo goodwill ou ativo intangível com vida útil indefinida; e o valor contábil dos ativos intangíveis com vida útil indefinida (BORBA et al, 2009).

7) Este sétimo ponto inaugura a avaliação da escolha pelo valor em uso (quesito que segue em análise até o $12^{\circ}$ ponto). Como primeira análise, tem-se a quantificação das reservas de cada UGC conforme definido pelo IAS 36, CPC 01 e SFAS 144

8) Preço do petróleo utilizado na estimação das entradas de fluxo de caixa conforme definido pelo IAS 36, CPC 01 e SFAS 144.

9) Taxa utilizada na conversão do fluxo de caixa futuro estimado à valor presente, conforme definido pelo IAS 36, CPC 01 e SFAS 144.

10) Especificação das saídas de caixa estimadas para gerar a entrada de fluxo de caixa, conforme definido pelo IAS 36, CPC 01 e SFAS 144.

11) Taxa de crescimento utilizada pela empresa para realizar a projeção das entradas de caixa, além do período da projeção, conforme indicado por Borba et al (2009), IAS 36, CPC 01 e SFAS 144.

12) Divulgação do período utilizado pela empresa para estimar o fluxo de caixa, conforme indicado por Borba et al (2009), IAS 36, CPC 01 e SFAS 144.

13) Neste último ponto, aborda-se a escolha pelo valor líquido de venda, onde pretende-se investigar a base utilizada para a estimação do valor líquido de venda do ativo, juntamente com um descritivo do processo de cálculo, conforme indicado por Borba et al (2009), IAS 36; CPC 01 e SFAS 144.

Aqui cabe destacar uma diferença: a análise qualitativa foi estruturada não utilizando como base os requisitos de disclosure e sim as informações necessárias para a realização da recálculo do teste de impairment, cujos

\section{Composicão de cada ponto de análise}

Neste caso, pressupõe-se observar a divulgação do valor dos ativos intangíveis com vida útil indefinida de forma individual e detalhada.

Quantificação de cada UGC em barris de petróleo para realização da estimativa de entrada de caixa.

Para estimar as entradas de caixa, são necessárias as informações sobre: preço do barril do petróleo baseado no último Plano Estratégico e o Plano de Negócios e Gestão; curvas de produção associadas aos projetos (polos e campos) existentes; custos operacionais de mercado e investimentos necessários para a realização dos projetos.

Para as curvas de produção, é preciso entender de forma detalhada a formação das unidades geradoras de caixa.

Preço único divulgado pelas empresas que é utilizado em todas as demonstrações financeiras, normalmente é dado o valor de um barril de petróleo Brent.

Taxa utilizada pela empresa para trazer à valor presente as entradas e saída de caixa, minimizando as diferenças do valor em relação ao tempo.

Especificação em valores e descrições de quanto seria gasto para gerar as entradas de caixa estimadas.

Qual a taxa de crescimento utilizada pela empresa para projetar as entradas de caixa que ocorrerão no futuro, sendo aplicada na projeção do orçamento ou previsões que são diretamente relacionadas às reservas e o potencial de receita.

Período que a empresa utilizou para realizar suas previsões e orçamentos. Caso seja um período mais longo, é necessária uma justificação para períodos maiores que cinco anos.

Descrição da metodologia utilizada pela empresa, se foi realizado o cálculo utilizando um preço de mercado ou não. 
Figura 1. Estrutura do recálculo do impairment.

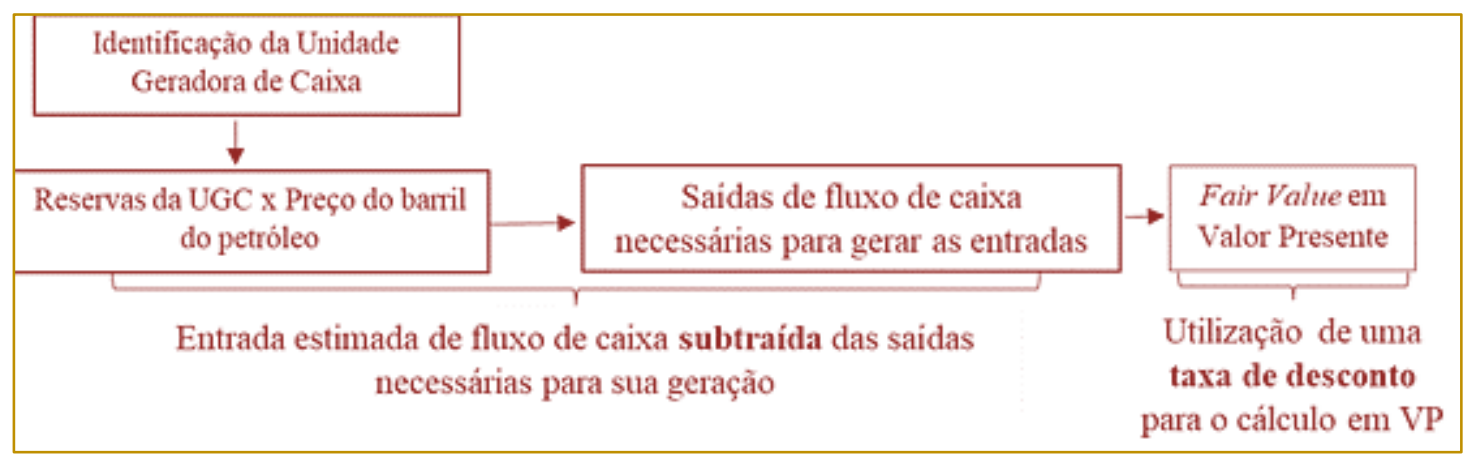

\section{ANÁLISE DOS RESULTADOS}

Para se ter um panorama do grau de suficiência informacional da Petrobras foi analisado um período de cinco anos de demonstrações contábeis, enfocando o Form
20-F da Petrobras (período de 2012 a 2016), e com base nos resultados encontrados foi construída a Tabela 6 a seguir (foram utilizados valores 0 e 1: 0 indica insuficiência informacional; 1 indica suficiência informacional):

Tabela 3. Resultados encontrados segundo os pontos de análise.

\begin{tabular}{|l|c|c|c|c|c|}
\hline \multicolumn{1}{|c|}{ Itens de divulgação (pontos de análise) } & 2012 & 2013 & 2014 & 2015 & 2016 \\
\hline Item 1: Norma contábil & 1 & 1 & 1 & 1 & 1 \\
\hline Item 2: Valor da perda ou reversão & 0 & 0 & 0 & 1 & 1 \\
\hline Item 3: Condições, Periodicidade e Procedimentos & 1 & 1 & 1 & 1 & 1 \\
\hline Item 4: Identificação e descrição dos eventos & 0 & 0 & 0 & 1 & 1 \\
\hline Item 5: Identificação e descrição das UGCs & 0 & 1 & 1 & 1 & 1 \\
\hline Item 6: Ativos intangíveis com vida útil indefinida & 0 & 0 & 0 & 0 & 0 \\
\hline Item 7: Quantificação de reservas & 0 & 0 & 0 & 0 & 0 \\
\hline Item 8: Preço do petróleo & 0 & 0 & 0 & 1 & 1 \\
\hline Item 9: Taxa de conversão para valor presente & 0 & 0 & 0 & 1 & 1 \\
\hline $\begin{array}{l}\text { Item 10: Especificação das saídas de caixa } \\
\text { estimadas }\end{array}$ & 0 & 0 & 0 & 0 & 0 \\
\hline $\begin{array}{l}\text { Item 11: Taxa de crescimento para projeção de } \\
\text { entradas de caixa }\end{array}$ & 0 & 0 & 0 & 0 & 0 \\
\hline $\begin{array}{l}\text { Item 12: Divulgação do período utilizado para estimar } \\
\text { o fluxo de caixa }\end{array}$ & 0 & 0 & 0 & 0 & 0 \\
\hline $\begin{array}{l}\text { Item 13: Base utilizada para estimação do Valor } \\
\text { Líquido de Venda }\end{array}$ & 0 & 0 & 0 & 0 & 0 \\
\hline
\end{tabular}

Aqui cabe destacar uma diferença: a análise qualitativa foi estruturada não utilizando como base os requisitos de disclosure e sim as informações necessárias para a realização da recálculo do teste de impairment.

\subsection{RESULTADOS DE CUNHO QUALITATIVO: ITENS 1, 2, 3 E 4}

No item 1, o que se pretendia obter de informação era a indicação de qual norma contábil foi utilizada pela companhia e, quando pertinente, citar alguma especificidade na aplicação de determinada norma.
No período analisado, a companhia divulgou seguir as normas IFRS. Apresentou as informações em dólares norte-americanos utilizando-se do custo histórico como base de valor, exceto para ativos disponíveis para a venda, ativos e passivos mensurados pelo valor justo. Em particular, no ano de 2013, a companhia relatou a aplicação da emenda ao IAS 36 (Impairment of Assets) esclarecendo que o escopo da divulgação é limitado ao valor recuperável dos ativos depreciados.

No item 2, o que se pretendia obter de informação era o detalhamento com indicação das UCGs relacionadas com os valores relatados no Balanço Patrimonial. O que se observou: 
- $\quad$ Em 2012 e 2013: foram divulgadas: duas divisões comuns para apresentação das perdas; informações qualitativas sobre maturidade e vida útil dos campos e uma breve justificativa das perdas ou reversões. Em resumo, apresentou informações extremamente generalistas para o recálculo do impairment.

- Em 2014, 2015 e 2016: apresentou, além do valor total de perdas e reversões, as subdivisões geográficas e um breve detalhamento de casos específicos como nos anos anteriores. Em 2014 foi feita uma subdivisão mais detalhada em quatro grupos de ativos com valores e motivações das perdas em determinados casos, incluindo indicação e justificação de testes individualizados e apontamento de falhas em reconhecimento de perdas em projetos durante a fase de planejamento.

- Em 2015 e 2016: a companhia divulgou dados qualitativos referentes às motivações das perdas ou reversões juntamente com os seus respectivos valores, além da divisão de campos de produção e óleo e gás no Brasil em que foi divulgada individualmente as perdas de campos e os polos que compõem o grupo com uma justificativa detalhada destes. Comparando-se 2015 e 2016, observa-se uma diferença no número de divisões de ativos apresentadas e retiradas (em 2016 foram adicionados dois grupos e retirado um grupo, sem nenhuma explicação condizente para tal mudança).

No item 3, o que se observou em relação à condições, periodicidade e procedimentos utilizados no teste de impairment foi:

- Condições: a companhia repete de 2013 a 2016 o mesmo conjunto de informações referentes as condições para a realização do teste de impairment como o fato de não considerar a volatilidade de curto prazo nos preços de petróleo como indicativo e apenas utilizar como indícios as tendências de longo prazo, efeitos negativos decorrentes de mudanças no volume de reservas, na curva de produção esperada, custos de extração ou nas taxas de desconto. Nada disso foi citado em relação a 2012.

- Periodicidade: informou, no período observado, que a avaliação do ativo imobilizado, do intangível com vida útil definida e do diferido é realizada quando há indicativos de não recuperação do seu valor contábil. Já os ativos vinculados a exploração e desenvolvimento da produção de petróleo e gás natural e aqueles que têm uma vida útil (como é o caso do goodwill) indefinida têm a recuperação do seu valor testada anualmente, independentemente de haver indicativos de perda de valor.

- Procedimentos: informou que o teste de impairment é realizado comparando o valor contábil de um ativo ou UGC com o seu valor recuperável, no caso estimado pela metodologia do valor em uso com base no valor presente dos fluxos de caixa futuros decorrentes do uso contínuo dos ativos, os fluxos são ajustados pelos riscos e utilizam taxas de desconto pré-imposto (derivados do custo médio ponderado de capital pósimposto). As principais premissas dos fluxos de caixa são as mesmas apresentadas na tabela de itens de divulgação.

Em relação ao item 4, de 2012 a 2014 não foi informada justificativa específica quanto a motivação de perdas e reversões de cada UGC (apenas indicou as perdas, sem detalhar a razão da alteração do valor recuperável). As únicas justificativas referem-se à divisão realizada pela empresa para divulgação das perdas, não havendo nenhuma possibilidade de um entendimento individualizado de cada unidade, tendo um caráter extremamente generalista.

Também foram informadas em 2015 e 2016, todas as motivações que levaram à perda ou reversão de cada UGC, sendo elas referentes a itens cruciais para o cálculo da recuperabilidade do ativo como: premissas de preço, aumento da taxa de desconto, apreciação do real frente ao dólar, revisão anual de reservas, postergação da expectativa de entrada de caixa, entre outros.

Conclui-se em relação a este item que a informação foi prejudicada pela ausência de detalhamento das UCGs, muito embora as informações apresentadas tenham sido importantes para o entendimento da forma que a empresa realizou o processo.

\subsection{ITEM 5: IDENTIFICAÇÃO E DESCRIÇÃO DAS UGCS}

O teste de impairment utiliza essa unidade como objeto de estudo da recuperabilidade de determinado ativo ou conjunto de ativos, portanto qualquer alteração afeta diretamente o cálculo. Para a empresa ter um alto grau de informações que sejam suficientes para o recálculo, a mesma necessitaria relatar em detalhe a forma que dividiu seu grupo de ativos imobilizados para a realização do teste, 
inclusive indicando os critérios utilizados para tais definições e as alterações que ocorreram de um período ao outro.

Durante os anos estudados este foi o único item que manteve em constância o grau de informações para o recalculo, podendo se observar:

- Em 2012, nenhuma divulgação referente as unidades foram feitas, apenas um breve relato sobre a forma que a empresa define suas UGCs.

- De 2013 a 2016 foram mantidos seis grupos, sendo eles: exploração e produção; abastecimento; gás e energia; distribuição; biocombustível; e internacional.

Há que se destacar a divisão de Exploração e Produção (E\&P) que manteve a organização e descrição durante os cinco anos estudados, variando apenas a partir de 2015 em que foi adicionada a UGC Sonda de Perfuração e em 2016 com algumas alterações devido a desativação de infraestrutura compartilhada.

\subsection{ITEM 6: ATIVOS INTANGÍVEIS COM VIDA ÚTIL INDEFINIDA}

Em relação ao item 6, os valores dos ativos intangíveis com vida útil indefinida não foram divulgados pela companhia em nenhum ano, apenas informações de cunho qualitativo referentes à classe do ativo foram divulgadas. A avaliação de vida útil indefinida é revisada anualmente para determinar se essa avaliação continua a ser justificável, caso não a mudança para definida é realizada.

\subsection{ITEM 7: QUANTIFICAÇÃO DE RESERVAS}

Informações referentes à quantificação das reservas de petróleo são importantes ao se considerar sua utilização no processo de estimação de fluxos de caixa futuros; tais dados juntamente com o preço do barril de petróleo viabilizam o cálculo da estimativa do retorno de determinado ativo. Além dos ativos de E\&P, as reservas são indiretamente ligadas com a utilização e recuperabilidade de ativos de outras UGCs como as de Refino e Distribuição.

Segundo a companhia, as reservas de petróleo e gás natural são calculadas tendo por base informações econômicas, geológicas e de engenharia; tais informações exigem a aplicação de julgamentos e revisões periódicas, uma vez que podem ocorrer indícios de alterações realizadas a partir de reavaliação de dados e/ou novas informações.

Em todos os anos pesquisados, a divulgação limitou-se apenas a informações qualitativas referentes à forma como a empresa lida com suas reservas, o que inclui tanto as reservas provadas, aquelas que são recuperáveis a partir de reservatórios conhecidos e sob condições já existentes, como as reservas não provadas que não ainda obtiveram confirmação da sua recuperabilidade.

Já os dados quantitativos divulgados são generalistas e impossibilitam o recálculo, pois para que o mesmo fosse realizado, seria necessária a especificação de quanto cada UGC possui de reserva. Sendo assim, em nenhum ano a empresa possibilitou acesso aos dados de suas reservas de forma que o recálculo do impairment fosse realizado.

\subsection{ITEM 8: PREÇO DO PETRÓLEO}

O preço do barril de petróleo é algo de extrema volatilidade no mercado internacional, justamente por isso a empresa utiliza os preços de longo prazo previstos no planejamento, orçamento e nas decisões de investimento de capital, considerados estimativas razoáveis baseadas em indicadores de mercado e experiencias passadas. Mesmo com as usuais quedas expressivas de preço que o petróleo está sujeito no curto prazo, os preços tendem a continuar a ser ditados pela oferta de mercado e demanda, sendo levado em consideração apenas as alterações definidas como de longo prazo.

Pode se considerar que existe alto grau informacional nas demonstrações quando a companhia não só divulgar o valor estimado para o próximo ano (como exigido pela norma), mas também divulgar a estimação do preço médio para os próximos anos, auxiliando no entendimento das prospecções realizadas pela empresa, permitindo uma comparação com outras companhias do mesmo setor.

Observa-se que ao longo do período analisado, a qualidade da informação a esse respeito teve melhora significativa:

- $\quad$ Em 2012 e 2013: nenhuma informação sobre o preço do petróleo (Brent) foi divulgada e nem a possível taxa de câmbio utilizada na conversão. 
- $\quad$ Em 2014 e 2015: foi divulgado o valor do preço do petróleo para o ano vigente, a longo prazo e a taxa de câmbio utilizada na conversão.

- Em 2016 as informações atingiram seu maior grau de relevância para o processo de recálculo, pois foi divulgado não somente 0 preço do petróleo e a taxa de câmbio para o ano vigente, mas também as projeções de longo prazo dos cinco anos subsequentes.

\subsection{ITEM 9: TAXA DE CONVERSÃO UTILIZADA PARA VALOR PRESENTE}

A divulgação da taxa de conversão utilizada é necessária não apenas de forma generalista, mas também referente à cada uma das UGCs da companhia, pois o cálculo é feito com base em cada unidade e não no contexto da empresa. Durante os anos estudados, pode se observar uma evolução constante:

- De 2012 e 2013, nenhuma informação referente à taxa de desconto pré-imposto derivada do WACC pós-imposto foi divulgada pela companhia, nem em um contexto generalista como era esperado, muito menos com um nível detalhamento tido como o ideal, no qual a companhia declara a porcentagem utilizada para cada UGC.

- De 2014 a 2016, a companhia divulgou de forma individual a taxa utilizada para tornar possível o entendimento a valor presente das projeções de fluxo de caixa.

\subsection{ITEM 10: ESPECIFICAÇÃO DAS SAÍDAS DE CAIXA ESTIMADAS}

O grau de detalhamento ideal deste item para o recálculo seria a especificação das saídas de caixa de cada UGC, porém as informações esclarecidas pela Petrobras são apenas de cunho qualitativo e referem-se à especificidade do setor petrolífero em reconhecer gastos.

A companhia declara que seus gastos incorridos com E\&P são contabilizados de acordo com o método dos esforços bemsucedidos e detalha suas definições de custos e despesas, porém apesar dessas informações a falta de dados quantitativos e uma relação com as UGCs afeta diretamente a possibilidade do recálculo.

\subsection{ITEM 11: TAXA DE CRESCIMENTO PARA PROJEÇÃO DE ENTRADAS DE CAIXA}

A taxa de projeção utilizada pela empresa na estimação de seus fluxos de caixa é essencial para o entendimento do cálculo realizado pela companhia, sendo necessário para realizar a extrapolação dos anos subsequentes para se chegar ao valor da recuperabilidade do ativo. Nenhuma taxa foi divulgada em nenhum dos anos analisados.

\subsection{ITEM 12: DIVULGAÇÃO DO PERÍODO UTILIZADO PARA ESTIMAR O FLUXO DE CAIXA}

O período utilizado na projeção serve como forma de entender o cálculo realizado pela empresa, porém também não foi divulgado em um contexto generalista e nem detalhado por UGC, tornando o grau de detalhamento extremamente baixo e impossibilitando o conhecimento do horizonte temporal utilizado pela Petrobras. Apenas em alguns casos específicos durante os anos analisados foi declarado o período, porém para se fazer útil a informação deve ser relacionada à todas as UGCs da companhia.

\subsection{ITEM 13: BASE UTILIZADA PARA ESTIMAÇÃO DO VALOR LÍQUIDO DE VENDA}

Mesmo sendo um item incomum para empresas petrolíferas devido a especificidade de seus ativos imobilizados, a companhia pode testar a recuperabilidade de uma UGC pelo seu valor líquido de venda, principalmente com $\mathrm{O}$ atual plano de desinvestimentos da Petrobras, se tornou algo comum durante a passagem dos anos estudados.

A importância da descrição deste item se dá pelo fato de que a metodologia da recuperação pelo valor de venda necessita de informações não só referentes ao ativo, mas em relação ao mercado e as condições de venda do mesmo. Foi observado durante o estudo que:

- Em 2012, nenhuma informação referente a esse método foi divulgada.

- $\quad$ Em 2013 e 2014, a empresa detalha o procedimento de colocação do ativo para venda, mas não declara a forma de cálculo para chegar aos valores declarados de impairment. Nesses casos as perdas se referem às sondas de perfuração, porém 
nenhuma informação faz menção aos dados e formas de cálculo utilizados.

- Em 2015 e 2016, a empresa detalha um pouco da sua política de desinvestimentos na qual alguns ativos são selecionados para serem mantidos para a venda, porém novamente a empresa apenas divulga os ativos e seus respectivos valores de perda, sem detalhar a forma como chegou nesses valores (em relação a método e dados utilizados).

\section{CONCLUSÕES}

Frente aos resultados, apenas os itens 1 e 3 foram divulgados de forma detalhada e padronizada em todos os anos pela companhia, porém ambos são de cunho qualitativo e não são utilizados no cálculo do impairment. Apesar de o item 4 também apresentar informações de cunho qualitativo, o mesmo diferencia-se pelo fato de isso ocorrer apenas nos últimos três anos analisados e não ocorrer de forma padronizada.

Esse conjunto de três itens (1, 3 e 4) não afetam diretamente o teste de impairment e consequentemente sua ausência não afetaria o recálculo, tendo caráter apenas complementar a análise das premissas utilizadas para a realização do teste.

Sentiu-se também a ausência de informações complementares a exemplo dos valores dos ativos intangíveis com vida útil indefinidas (item 6) que tiveram apenas dados qualitativos referentes às premissas. Também como a classificação de ativos como mantidos para a venda (item 13), nas quais a empresa fornece informações adicionais sobre as premissas utilizadas no processo e sobre o processo de classificação, sem entrar em detalhes sobre o cálculo do valor recuperável e impossibilitando o recálculo.

$\mathrm{O}$ item 2, referente ao valor das perdas e reversões apresentou um aumento em seu grau de suficiência informacional com 0 passar dos anos, alcançando o considerado ideal para o recálculo em 2015 e 2016, quando a companhia divulga o valor do impairment alocado em cada unidade geradora de caixa, pois o cálculo é feito de forma individual para cada um deles e o conhecimento de seu valor declarado é essencial para a análise.

A descrição e divulgação da divisão de cada UGC (item 5) foi apresentada de 2013 a 2016 e não foi divulgado em 2012, e serve como forma de não apenas entender as premissas para a divisão por parte da empresa, mas também para guiar o processo de recálculo, pois o teste de impairment é realizado individualmente em cada UGC.

Os itens 2 e 5 são relevantes para a realização do recálculo e apesar de ambos não estarem simultaneamente presentes nos períodos de 2012 a 2014, eles aumentam de forma significativa o grau de suficiência informacional dos anos e 2015 e 2016, porém mesmo assim apenas esses itens não seriam suficientes para se "voltar na conta".

Outro item importante no cálculo do impairment que está incluso no processo de projeção de entrada de caixa é o valor do barril de petróleo Brent estimado em dólar e a respectiva taxa de câmbio utilizada (item 8); em um cenário informacional ideal, essa informação deve ser apresentada não apenas para $\mathrm{o}$ ano vigente, mas para os subsequentes que foram englobados no processo de estimativa. A falta dessa informação torna impossível saber o potencial de geração de determinada UGC, o que afeta diretamente $\mathrm{o}$ grau de suficiência informacional dos anos em que o item não foi apresentado (2012 a 2014).

O mesmo pode se dizer da taxa de desconto (item 9), pois sem a definição dela não é possível trazer a valor presente a geração de caixa estimada para cada UGC, ou seja, essa informação não será útil caso ela não seja especificada para cada unidade. A taxa não foi apresentada de 2012 a 2014. Resumindo, em relação aos itens 8 e 9, estes foram apresentados de forma detalhada e suficiente apenas nos anos de 2015 e 2016.

Diversas informações de extrema importância para o recálculo não foram divulgadas pela empresa ou foram divulgadas de forma que não colaboram para o processo de "voltar na conta", principalmente no caso das informações referentes às reservas de petróleo e gás natural (item 7) que não possuem valores individuais para cada UGC divulgados, afetando diretamente a estimação do fluxo de caixa, pois sem esses dados não é possível entender o potencial de geração de entrada de caixa de determinado grupo. Além do item 7 , outros três itens importantes $(10,11$ e 12) não constam das notas explicativas, nem de forma generalizada e nem individualizada para cada UGC, impedindo assim a extrapolação dos fluxos para anos 
subsequentes. Em relação às saídas de caixa, a ausência de informações também foi sentida, pois conhecer apenas as entradas não é suficiente para ter o valor exato da recuperabilidade da UGC: muitas vezes, cada esforço para gerar uma entrada de caixa pode implicar numa respectiva uma saída de caixa.

A falta completa desses quatro itens $(7,10,11$ e 12) impede o recálculo do impairment. sem informações detalhadas e específicas desses itens não é possível a estimação do fluxo de caixa devido à falta de base referente às reservas, o que impede também a extrapolação para a visualização de um horizonte temporal mais amplo.

Em resumo, os fatos que prejudicam bastante a análise: falta de um detalhamento das UGCs, o que tornou praticamente impossível saber quais campos pertencem à quais unidades; falta de dados de reservas provadas, tornando impossível a obtenção de um fator de multiplicação para ser utilizado juntamente do preço do petróleo (convertido em real) para chegar se as futuras entradas de caixa; falta de informações acerca das saídas de caixa necessárias para sustentar as entradas; com tudo isso, o processo de recomposição do fluxo de caixa que serviu de

\section{REFERÊNCIAS}

[1] ANP - Agência Nacional do Petróleo, Gás Natural e Biocombustíveis. Resolução ANP no30/2014. Maio, 2014.

[2] Borba, J. A.; Alberton, L. Divulgação da perda por impairment em empresas auditadas pelas Big Four. Pensar contábil, v. 11, n. 46, 2010.

[3] Borba, J. A. Souza, M. M; Zandonai, F. Evidenciação da perda no valor recuperável de ativos nas demonstrações contábeis: uma verificação as empresas de capital aberto brasileiras. In: Encontro da Associação Nacional de Pós-Graduação e Pesquisa em Administração. 33. 2009, São Paulo. Anais... São Paulo: ANPAD, 2009.

[4] CPC - Comitê de Pronunciamentos Contábeis. Pronunciamento Técnico CPC 01 Redução ao Valor Recuperável de Ativos. Setembro, 2007.

[5] Domingues, J. C.; Godoy, C. R. Redução ao Valor Recuperável de Ativos: um Estudo nas Empresas do Setor Petrolífero Mundial. Revista de Educação e Pesquisa em Contabilidade (REPeC), v. 6, n. 4, 2012.

[6] FASB - Financial Accounting Standards Board. Statements of Financial Accounting parâmetro para a companhia fazer o disclosure das informações torna-se inviável.

Em relação à futuros trabalhos, sugere-se a utilização de informações do Banco de Dados de Exploração e Produção da Agência Nacional de Petróleo (ANP). Tais informações não são de livre acesso (são autorizados apenas associados da ANP segundo as normas regulatórias da própria agência), razão pela qual não utilizamos nesta pesquisa. Talvez com tal fonte de informação seja suficiente a estimação dos fluxos de caixa, dado que provavelmente essa fonte traga maior detalhamento acerca dos campos petrolíferos. Mesmo que a companhia traga informações complementares em outros documentos que não as notas explicativas, como o caso das Declarações de Comercialidade (ANP no 30/2014), que relatam que tais áreas contém petróleo ou gás em condições que tornem possível o retorno dos investimentos da companhia em fase de produção, as análises mais aprofundadas são dificultadas devido à escassez de informações detalhadas sobre as UGCs, pois tais declarações são feitas sobre possíveis campos, sem informar exatamente quais campos pertencem a cada UGC.

Standards $n^{\circ} 144$ - Accounting for the Impairment or Disposal of Long-Lived Assets. Agosto, 2001.

[7] FASB - Financial Accounting Standards Board. Statements of Financial Accounting Standards $n^{\circ} 69$ - Disclosures about Oil and Gas Producing Activities. Novembro, 1982.

[8] Healy, P. M.; Palepu, K. G. Information asymmetry, corporate disclosure, and the capital markets: A review of the empirical disclosure literature. Journal of accounting and economics, v. 31, n. 1-3, p. 405-440, 2001.

[9] Hitchner, J. R. Financial Valuation. John Wiley \& Sons, 2010.

[10] IASB - International Accounting Standards Board. International Accounting Standards no 36 Impairment of Assets. Junho, 1998.

[11] Johnston, D. C.; Johnston, D. Introduction to oil company financial analysis. PennWell Books, 2006.

[12] Machado, E. A.; Cruz, A. P. C.; Takamatsu, R. T.; Lima, G. A. S. F. Evidências de disclosure de valor recuperável de ativos em firmas listadas no novo mercado acionário brasileiro. Revista Universo Contábil, ISSN 1809-3337, FURB, Blumenau, v. 9, n. 1, p. 86-103, jan./mar., 2013 
[13] raupp, H. M.; Rodrigues, J. M.; Niyama, J. K. Disclosure sobre impairment: uma análise comparativa das companhias abertas brasileiras em 2008. Revista de Contabilidade do Mestrado em Ciências Contábeis da UERJ, v. 15, n. 1, p. 6787, 2011

[14] Raupp, F. M.; Beuren, I. M. Mensuração de Ativos Imobilizados por meio do Fair Value e do Impairment Test em uma Rede de Fotocópias. Pensar Contábil, v. 10, n. 41, 2008.

[15] Raupp, F. M.; Beuren, I. M. Proposta de mensuração de ativos imobilizados por meio do fair value e do impairment test. In Anais do $6^{\circ}$ Congresso de Controladoria e Contabilidade, Universidade de São Paulo, 2008.

[16] Santos, O. M. dos; Santos, A. dos; Silva, P. D. A. da. Reconhecimento de perdas para redução ao valor recuperável de ativos: Impairment em ativos de exploração e produção de petróleo. In: Congresso da Associação Nacional de PósGraduação em Ciências Contábeis. 4., 2010, Natal. Anais... Natal: anpcont, 2010.

[17] Souza, M. M.; Borba, J. A.; Dutra, M.H. Uma verificação das informações sobre o impairment test nas demonstrações financeiras padronizadas (CVM) e no relatório 20-F (SEC) das empresas brasileiras que negociam ADRs na bolsa de valores dos Estados Unidos. In: Congresso UFSC de Contabilidade e Finanças, 2oㅡ 2008. Anais...Florianópolis: UFSC, 2008

[18] Zandonai, F.; Borba, J. A. O que dizem os achados das Pesquisas Empíricas sobre o teste de impairment: uma análise dos Journals em língua inglesa. Contabilidade, Gestão e Governança. Brasília. v. 12, n. 1, 2009. 


\section{Capítulo 18}

\section{GOVERNANÇA PÚBLICA NA GESTÃO E OPERACIONALIZAÇÃO LOCAL DO SISTEMA ÚNICO DE SAÚDE: UM ESTUDO DE IBIRAMA (SC)}

\section{Amanda Beatriz Nasatto Corrêa \\ Bruna França Debroski \\ Marino Luiz Eyerkaufer}

Resumo: Diante dos desafios de gestão e operacionalização do SUS no Brasil, aliado ao aumento de demandas na prestação do serviço público na área da saúde, ainda à incapacidade do Estado de cobrir tais demandas, o objetivo do estudo é de explorar os princípios da governança pública numa gestão e operacionalização local do SUS. Para isso, efetuou-se uma pesquisa de campo no Município de Ibirama (SC), por meio de entrevista e análise documental. Os dados revelam que no município analisado, a Secretaria da Saúde cumpre $71,61 \%$ das responsabilidades que constam no Art. 18, da Lei 8080/90, que trata sobre a promoção, proteção e recuperação da saúde, além da organização e funcionamento dos serviços prestados. O desempenho do SUS local pode ser atribuído à governança, pois segundo os gestores da área de saúde do Município, todos os princípios da governança pública (responsabilidade, legitimidade, equidade, eficiência, probidade, transparência e accountability) são atendidos na gestão e operacionalização do sistema.Observando o desempenho do SUS local, nota-se que este destacadamente cumpre a maioria das responsabilidades de garantir a saúde básica. Isso permite concluir que o zelo aos princípios da boa governança pública podem sim inferir no desempenho dos serviços públicos.

Palavras-Chave: Governança pública, Gestão e estrutura organizacional, SUS, Ibirama (SC). 


\section{INTRODUÇÃO}

A busca por equidade vem ganhando cada vez mais força e visibilidade entre a população, um dos propósitos é a diminuição da desigualdade na área da saúde, e isso só se deu, com a implantação do Sistema Único de Saúde (SUS), por meio da Constituição Federal de 88, com os artigos 196 a 200. Para isso acontecer, foi indispensável uma ligação entre a sociedade e o Estado, que pode acontecer por meio das organizações não governamentais (ONG's) e de conselhos, que trazem ideias inovadoras e o dever de cobrar do Estado mais democratizado (BASTOS; SANTOS; TOVO, 2009).

Segundo a Constituição da Organização Mundial da Saúde (1946), saúde não é somente a ausência de doenças, mas o estado total de bem-estar tanto físico, mental e social. Seus fatores determinantes e condicionantes são a alimentação, a moradia, o saneamento básico, o meio ambiente, o trabalho, a renda, a educação, a atividade física, o transporte, o lazer e o acesso aos bens e serviços essências, na quais expressam a organização social e econômica do País (LEI №8080/90).

O SUS é constituído sobre ações e serviços de saúde, as quais, são prestadas por órgãos e instituições, nas três esferas de governo (LEI №8080/90) e de acordo com suas diretrizes, possui um sistema descentralizado, de atendimento integral e com a participação da comunidade, sendo responsabilidade da União, Estado, Distrito Federal e dos Municípios sua direção e financiamento (BRASIL, 1988).

Para que haja articulação dos elementos do sistema, o Tribunal de Contas da União - TCU (2014) assevera que a governança no setor público é composta por ações de liderança, estratégia e controle simultaneamente interligadas com a finalidade de avaliar, direcionar e monitorar a gestão pública em prol da coletividade, elementos necessários na atuação do SUS pelo seu sistema de descentralização, que trouxe melhor eficiência, eficácia e efetividade para supervisionar a gestão e atender melhor as pessoas que precisam desse serviço.

Para a governança pública ser efetiva, é necessário a atuação do Estado em conjunto com a constante participação da sociedade. Bastos, Santos e Tovo (2009) afirmam que a Constituição de 88 e a Reforma Sanitária no Brasil ajudaram com que novas perspectivas e desafios fossem impostos para a população, e assim a participação da população se tornou de suma importância para o aumento na qualidade dos serviços prestados pelo Estado.

Esse estudo tem como objetivo explorar os princípios da governança pública, investigando um cenário de gestão e operacionalização local do SUS. O SUS local deve atuar de acordo com a Lei Orgânica da Saúde (LEI №8080/90), a qual regula as ações e serviços de saúde e estabelece, entre outras, os princípios, as diretrizes e os objetivos do SUS.

A contribuição do estudo para a ciência esmaece pela integração de dados teóricos e empíricos por meio do comparativo entre o conceito de governança e o normativo da área de saúde, refletindo novas possibilidades de gestão do sistema, tão criticada na atualidade no Brasil. A contribuição prática vem de encontro com o melhor desempenho do SUS a partir da adoção dos princípios da governança pública na gestão do sistema, logo indicando assim as contribuições sociais, visto que o cidadão será o grande beneficiário de serviços mais efetivos.

Após apresentação do tema e objetivos do estudo, apresenta-se na sequência o SUS, a governança pública, seguido de estudos anteriores relacionados com o tema.

\section{REFERENCIAL TEÓRICO}

Apresenta-se nesta seção, o referencial que subsidia a discussão da governança para o SUS. Para isso discutem-se inicialmente aspectos relacionados ao próprio sistema, mas tarde a gestão e operacionalização no context2.10 do SUS, e, na parte final desta seção, uma breve abordagem sobre a governança pública, bem como estudos relevantes sobre o tema.

\subsection{SISTEMA SUS}

Com a Constituição da República Federativa do Brasil (CRFB), em 05 de outubro de 1988, foi instituída a política de saúde do Brasil, e de acordo com a mesma, a saúde é um direito de todos os cidadãos e um dever do Estado de disponibilizar tal recurso.

Segundo o Ministério da Saúde (MS) (2011) o SUS foi criado com o objetivo de promover a 
justiça social e diminuir a desigualdade no que se refere a saúde da população brasileira. Sendo assim perante esse sistema é obrigatório atender toda a população e, além disso, de forma gratuita. Salienta-se que todo esse sistema foi implementado para melhorar a qualidade de vida, sendo que os serviços prestados vão desde o atendimento ambulatório até $O$ transplante de órgãos (MINISTÉRIO DA SAÚDE, 2011).

A lei complementar 141 (2012) estabelece os valores mínimos que a União, Estado e Município devem repassar anualmente para o setor da saúde. A União deve repassar no mínimo 15\% da receita corrente líquida do respectivo exercício financeiro (artigo 198, parágrafo $2^{\circ}, I$ ), porém, esse percentual será alcançado de forma gradual, sendo $13,2 \%$ em 2016, $13,7 \%$ em 2017, 14,1\% em 2018, 14,5\% em 2019 e 15\% em 2020. O percentual estabelecido para os Estados é de $12 \%$, e para os Municípios 15\%. Vale ressaltar que cada município deve consultar sua lei orgânica, pois alguns municípios obrigam-se a destinar um percentual superior ao mínimo estabelecido na lei complementar 141. Com base no Guia prático para a gestão municipal (2015) segue a base de cálculo municipal, Tabela 1.

Tabela 1 - Base de cálculo municipal

\begin{tabular}{|c|c|}
\hline \multicolumn{2}{|r|}{ Base de cálculo municipal } \\
\hline $\begin{array}{l}\text { Total das receitas } \\
\text { municipais }\end{array}$ & $\begin{array}{c}\text { Imposto sobre Serviços de Qualquer Natureza - ISS; Imposto Predial } \\
\text { e Territorial Urbano - IPTU; Imposto sobre a transmissão de bens } \\
\text { imóveis - ITBI }\end{array}$ \\
\hline \multicolumn{2}{|l|}{+} \\
\hline $\begin{array}{l}\text { Receitas de transferências } \\
\text { da União }\end{array}$ & $\begin{array}{l}\text { Quota-Parte do Fundo de Participação dos Municípios - FPM; Quota } \\
\text { Parte do Imposto sobre a Propriedade Territorial Rural - ITR; Quota- } \\
\text { Parte da Lei Complementar no87/96 (Lei Kandir) }\end{array}$ \\
\hline+ & \\
\hline \multicolumn{2}{|l|}{$\begin{array}{l}\text { Imposto de Renda Retido } \\
\text { na Fonte - IRRF }\end{array}$} \\
\hline \multicolumn{2}{|l|}{+} \\
\hline $\begin{array}{l}\text { Receitas de transferências } \\
\text { do Estado }\end{array}$ & $\begin{array}{l}\text { Quota-Parte sobre o Imposto de Circulação de Mercadorias e } \\
\text { Serviços - ICMS; Quota-Parte do Imposto sobre a Propriedade de } \\
\text { Veículos Automotores - IPVA; Quota-Parte do Imposto sobre } \\
\text { Produtos Industrializados - IPI - Exportação. }\end{array}$ \\
\hline \multicolumn{2}{|l|}{+} \\
\hline Outras Receitas Correntes & $\begin{array}{l}\text { Receita da Dívida Ativa Tributária de Impostos, Multas, Juros de } \\
\text { Mora e Correção Monetária. }\end{array}$ \\
\hline
\end{tabular}

Fonte: Guia prático para gestão municipal, 2015.

O recurso financeiro repassado será utilizado em ações e serviços públicos de saúde, ou seja, na promoção, proteção e recuperação da saúde. O Art. 3o, da Lei Complementar 141/2012, determina que são ações e serviços públicos de responsabilidade do SUS: vigilância em saúde (incluindo sanitária e epidemiológica); total acesso a saúde, desde assistência terapêutica até nutricional; capacitação do pessoal que atende no SUS; remuneração do pessoal atuante na saúde; produção, aquisição e distribuição dos materiais utilizados nos postos de atendimento, medicamentos e equipamentos; investimento em infraestrutura e cuidados com manutenção com rede física; entre outras.
Os recursos que financiam as ações e serviços de saúde são mantidos no Fundo de Saúde, sendo que tal recurso só pode ser gasto na área da saúde (LEI COMPLEMENTAR 141, 2012). A gestão das ações e dos serviços precisa ser municipalizada, por ser indispensável para a qualidade de vida para a população. Diante disso, o direito a saúde é garantido por lei, e políticas sociais e econômicas são realizadas para a redução de riscos de doenças e promovendo a promoção e recuperação da saúde, em caráter universal e igualitário (MINISTÉRIO DA SAÙDE, 2011).

De acordo com o Art. 18 da Lei Orgânica da Saúde (Lei №8080/90), são responsabilidades da direção do SUS: 
I - planejar, organizar, controlar e avaliar as ações e os serviços de saúde e gerir e executar os serviços públicos de saúde;

Il - participar do planejamento, programação e organização da rede regionalizada e hierarquizada do Sistema Único de Saúde (SUS), em articulação com sua direção estadual;

III - participar da execução, controle e avaliação das ações referentes às condições e aos ambientes de trabalho;

IV - executar serviços:

a) de vigilância epidemiológica;

b) vigilância sanitária;

c) de alimentação e nutrição;

d) de saneamento básico; e

e) de saúde do trabalhador;

V - dar execução, no âmbito municipal, à política de insumos e equipamentos para a saúde;

VI - colaborar na fiscalização das agressões ao meio ambiente que tenham repercussão sobre a saúde humana e atuar, junto aos órgãos municipais, estaduais e federais competentes, para controlá-las;

VII - formar consórcios administrativos intermunicipais;

VIII - gerir laboratórios públicos de saúde e hemocentros;

IX - colaborar com a União e os Estados na execução da vigilância sanitária de portos, aeroportos e fronteiras;

X - observado o disposto no art. 26 desta Lei, celebrar contratos e convênios com entidades prestadoras de serviços privados de saúde, bem como controlar e avaliar sua execução;

XI - controlar e fiscalizar os procedimentos dos serviços privados de saúde;

XII - normatizar complementarmente as ações e serviços públicos de saúde no seu âmbito de atuação.

A descentralização e a transferência de responsabilidade para a esfera municipal, faz com que seja estimulada para os gestores locais novas responsabilidades e competências, além de permitir a integralidade e racionalização dos recursos por meio adequados à gestão de redes assistenciais de caráter regional e macrorregional (BRASIL, 2009).

\subsubsection{GESTÃO E OPERACIONALIZAÇÃO DO SUS}

Segundo Miranda, Mendes e Silva (2017) o único país que apresenta tamanha descentralização é o Brasil, a não diferenciação entre os federativos é um dos elementos que dificulta a organização das redes de saúde. Tem-se os municípios como os atores primordiais do sistema. Por isso, a esfera municipal é a principal dentre as demais, o que dificulta a oferta $e$ a maximização do tempo, que acaba atrasando ações e serviços de saúde.

De acordo com o art. 9 da Lei №8080/90 a direção do SUS é única em cada esfera de governo, sendo exercida pelo órgão do Ministério da Saúde no âmbito da União, pelo Conselho Nacional de Secretários de Saúde (CONASS) no âmbito dos Estados e no Distrito Federal e como Secretaria Municipal da Saúde nos municípios. Os Conselhos de Secretarias Municipais de Saúde (Cosems) são reconhecidos com entidades que representam os entes municipais, no âmbito estadual, para tratar de matérias referentes à saúde.

Os municípios considerados pequenos, via de regra, são dependentes dos repasses do Governo Federal para escorar a estrutura de saúde municipal. Observa-se também que a maioria já atingiu ou superou o limite constitucional de gastos destinados a saúde como obriga a Ementa Constitucional №29. Diante disso, uma média de gastos, em 2015, foi de $22 \%$ do orçamento próprio (MIRANDA; MENDES; SILVA, 2017).

Vermelho e Figueiredo (2017) constatam que o sistema de saúde do Brasil, tem muita dificuldade em produzir mudanças práticas de saúde em conformidade com os avanços teóricos do setor de saúde coletiva. Sobretudo, o esforço que vêm ocorrendo com os processos de formatação e qualificação profissional do SUS, é notável. Porém tais processos não estão dando 0 retorno desejado e, consequentemente, não refletindo de forma positiva nas práticas de saúde. Cabe salientar, que os processos educacionais, geralmente, priorizam apenas os conteúdos e a formatação individual dos profissionais, o que acaba por não melhorar o trabalho em equipe, e nem, a rotina dos serviços de saúde. 
No entanto o SUS tem avocado um papel dinâmico na reorientação das estratégias e modos de zelar, tratar e escoltar a saúde individual e coletiva da população. Por causa disso, conseguiu-se instigar notáveis repercussões no que tange as estratégias e modos de ensinar e aprender, sem ao menos ter modos de formação de forte potência. Logo, apresentaram-se fatores críticos como: a necessidade de re-formar os profissionais para continuarem a atuar no SUS (CECCIM; FEUERWERKER, 2004).

Segundo Trevisan e Junqueira (2007) à possibilidade de duas formas distintas de gestão para o subsistema por pré-pagamento, sendo elas: a gestão plena de atenção básica e a gestão plena do sistema de saúde. Sendo na gestão plena de atenção básica, é dever do município compor a programação municipal dos serviços básicos, além de gerenciar as unidades de laboratoriais próprios, monitorar os serviços referente a atenção básica e desempenhar as ações básica de vigilância sanitária e epidemiológica. Para usufruir dos repasses dos recursos federais, assim como para ter as unidades básicas de saúde no território do município, estatais ou privados, submetidos à gestão municipal, é necessário preencher determinadas condições, como: comprovar o funcionamento do Conselho Municipal da Saúde, manejar o Fundo Municipal da Saúde, e constituir o Plano Municipal da Saúde.

Já a gestão plena do sistema de saúde, consiste em criar a programação municipal dos serviços básicos especializados e hospitalares; bem como, administrar unidades laboratoriais e hospitalares próprios; assegurar atendimento inclusive para os não residentes, em consonância com a Programação Pactuada e Integrada (PPI); empreender o controle público nos serviços prestados na área ambulatorial e hospitalar; e realizar as ações de vigilância sanitária e epidemiológica. Nessa, as imposições são de manter o funcionamento do Conselho Municipal de Saúde e do Fundo Municipal de Saúde, para conseguir as transferências dos recursos federais, e, de ter as unidades ambulatoriais especializadas e hospitalares subordinadas a gestão municipal, inclusive as privadas que foram contratadas pelo SUS (TREVISAN; JUNQUEIRA, 2007).

Segundo Moraes e Santos (2001) constataram baixo uso da informação no processo de gestão da saúde, pouco baseada na realidade. Tais ocorrências são: baixo engajamento em atender, de maneira imparcial os usuários, não importando o seu poder aquisitivo; o processo de gestão na área da saúde ainda possui uma lógica fragmentadora e vertical, que não está em consonância com a diversidade apresentada pela real situação da saúde brasileira. Observaram também uma fragmentação interna no que tange o quantitativo, que está abaixo das experiências concretas que são orientadas por uma abordagem intersetorial nas ações de saúde.

Nesse sentido, como consequência os sistemas de informações em saúde nacional, foram estruturados a longo período com base em tecnologias antigas, o que o deixou defasado, impossibilitando melhora na adequação e flexibilidade nas responsabilidades e competências destinadas às esferas do Governo (MORAES; SANTOS, 2001).

Para Farias e Hansen (2006)a gestão tem um caráter de complexidade ímpar, requerendo um melhor gerenciamento dos relacionamentos entre divisão de ganhos e governança, pois não se encaixa mais em modelos tradicionais e centralizados.

\subsection{GOVERNANÇA PÚBLICA PARA O SUS}

A definição do direcionamento estratégico, a supervisão da gestão, o envolvimento das partes interessadas, o gerenciamento dos riscos e desastres e conflitos internos, além da auditoria e avaliação do sistema de gestão e controle, a prestação de contas e responsabilidade e a transparência, são definidas como funções da governança (TCU, 2014)

As funções da governança, a transparência e a prestação de contas são fundamentais na gestão do SUS. É por meio delas que os representantes demonstram as ações que realizaram e demonstram com o planejamento os atos que pretendem realizar. Essas funções são de suma importância para a população poder controlar e verificar a gestão, e assim evitar possíveis fraudes (GONÇALVES; GONÇALVES; TAVARES, 2011).

Os princípios da boa governança são a legitimidade, equidade, responsabilidade, eficiência, probidade, transparência e accountability (BANCO MUNDIAL, 2008). 
A legitimidade se refere ao princípio jurídico fundamental do Estado Democrático de Direito e critério informativo do controle externo da administração pública que amplia a incidência do controle para além da aplicação isolada do critério da legalidade (BRASIL, 2012).

O princípio da equidade visa garantir as condições para que todos tenham acesso ao exercício de seus direitos civis como a liberdade de expressão, de acesso à informação, de associação, de voto, igualdade entre gêneros, os direitos políticos e sociais como a saúde, educação, moradia, segurança (BRASIL, 2010).

O princípio da responsabilidade diz respeito ao zelo que os agentes de governança devem ter pela sustentabilidade das organizações, visando sua longevidade, incorporando considerações de ordem social e ambiental na definição dos negócios e operações (IBGC, 2015).

Eficiência é fazer o que é preciso ser feito com qualidade adequada ao menor custo possível. Não se trata de redução de custo de qualquer maneira, mas de buscar a melhor relação entre qualidade do serviço e qualidade do gasto (BRASIL, 2010).

O princípio da probidade trata do dever dos servidores públicos de demonstrar probidade, zelo, economia e observância às regras e aos procedimentos do órgão ao utilizar, arrecadar, gerenciar e administrar bens e valores públicos (IFAC, 2013b).

A transparência caracteriza-se pela possibilidade de acesso a todas as informações relativas à organização pública, sendo um dos requisitos de controle do Estado pela sociedade civil (TCU, 2014).

Accountability é modo claro e conciso dos agentes de governança de prestarem contas, assumindo assim, a total responsabilidade pelos seus atos e respectivamente suas consequências (IBGC, 2015).

\subsection{ESTUDOS ANTERIORES}

Farias e Hansen (2006) analisaram as relações interorganizacionais e as práticas de governança no ambiente hospitalar, tendo como objetivo caracterizar as relações a partir de uma revisão bibliográfica sobre o tema em outros tipos de arranjos produtivos. A bibliografia apontou para a terceirização como a prática mais utilizada nos hospitais.
No entanto, o estudo constata que há outras formas de relacionamento além da terceirização. Com isso, concluíram que existe uma deficiência de informações estatísticas a respeito das alianças estabelecidas ao redor da cadeia produtiva da saúde, bem como, o volume de negócios envolvidos nestas transações.

Bastos, Santos e Tovo (2009), estudaram a relação entre Capital Social e o SUS no Brasil. O estudo teve como objetivo principal construir um referencial teórico preliminar que possibilite compreender as razões que podem determinar o desempenho satisfatório das instituições de saúde no Brasil, ou seja, os mecanismos de infraestrutura social que permitem aos governos realizar seus propósitos de melhorar a qualidade de vida de sua população. Diante disso, os autores analisaram os dados de duas pesquisas, tipo survey, buscando dados empíricos que comprovem a hipótese do trabalho em questão. As pesquisas foram realizadas com moradores de Caxias do Sul e Pelotas, do Rio Grande do Sul.

O objetivo da pesquisa de Barbosa, Barbosa e Najberg (2016) foi descrever a política de regulação adotada no âmbito do SUS, considerando seus elementos conceituais e operacionais, com foco na atenção às urgências. Toma como ponto de partida a definição de regulação, derivada da economia, e descreve o processo e instrumentos de estruturação de um sistema de organização da oferta e demanda em saúde. A definição de responsabilidades entre os gestores conforma um processo de organização de um sistema de governança direcionado à efetiva regulação do sistema, em especial para ordenação da oferta e demanda em uma de suas áreas mais sensíveis - a atenção às urgências e emergências. A estruturação e funcionamento da rede de serviços nessa área podem se beneficiar do controle do fluxo e da qualidade de serviços, dependendo da capacidade de uso dos elementos constitutivos do sistema de regulação, com ênfase na sua governança.

Diferente dos estudos apresentados, pretende-se nesta pesquisa analisar os princípios da governança pública na gestão e operacionalização do SUS para melhor efetivação do serviço no município de Ibirama-SC. 


\section{MÉTODO}

Pela literatura entendeu-se o que é o papel do SUS e a governança nesse contexto, para o qual selecionou-se a Secretária de Saúde Municipal de Ibirama para avaliar o SUS local. Escolheu-se o município de Ibirama, por ser referência de boas práticas de governança na região e, também, por acessibilidade.

De forma resumida a pesquisa se caracteriza como descritiva quanto aos objetivos, predominantemente qualitativa quanto a análise de dados e quanto aos procedimentos técnicos como documental e estudo de caso.

Optou-se pela entrevista para coletar os dados da pesquisa junto a Secretária Municipal de Saúde de Ibirama. Basicamente, a entrevista contemplou três blocos, sendo eles: Caracterização da secretária de saúde local; Gestão e estruturação do SUS local; e Governança no SUS local.

Tabela 2. Questionário

\begin{tabular}{|c|c|c|}
\hline Bloco & Questões & Referência \\
\hline II - Gestão e Estruturação & 4 & Elaborado com base no referencial teórico \\
\hline III - Governança no SUS & 7 & Lei № 8080/90 \\
\hline & 2 & $\begin{array}{c}\text { IBGC (2015); BRASIL (2012) BRASIL } \\
\text { (2010); IFAC (2013b) TCU (2014) e } \\
\text { BRASIL (2010) }\end{array}$ \\
\hline
\end{tabular}

Fonte: Elaborado pelos autores.

No que tange a coleta de dados documental, analisou-se demonstrativos contábeis a partir do portal de transparência municipal e o plano plurianual da saúde de Ibirama.

\section{O ESTUDO DE CASO}

O Município de Ibirama localiza-se no Estado de Santa Catarina, região sul do Brasil. Sua população de acordo com o último censo realizado pelo Instituto Brasileiro de Geografia e Estatística - IBGE (2010) é de 17.330 pessoas e a expectativa para 2017 é de 18.721 pessoas. O IDH (Índice de Desenvolvimento Humano) é de 0,737 , o que faz a cidade ocupar no ranking estadual a posição de 140ำ de 295 no total. O município tem como área territorial 247,348 km² (IBGE, 2016) e tem como cidades vizinhas: José Boiteux, Presidente Getúlio, Rio do Sul, Lontras, Apiúna, Ascurra e Benedito Novo (PREFEITURA MUNICIPAL DE IBIRAMA, 2018).

\subsection{GESTÃO E ESTRUTURAÇÃO DO SUS LOCAL}

Segundo Brasil (2009) a descentralização e a transferência de responsabilidade para a esfera municipal, faz com que os gestores municipais acumulem mais responsabilidades e competências, pois precisam integrar e racionar os recursos de maneira adequada para a gestão de redes assistenciais de caráter regional e macrorregional. Para Miranda, Mendes e Silva (2017) os municípios são a principal esfera do Sistema Único de Saúde.

Inicialmente analisou-se as responsabilidades do Município em relação ao SUS, de acordo como Art. 18 da Lei Orgânica da Saúde (Lei № 8080/90), o qual foi respondida pela secretária da saúde. Segue na Tabela 3, um comparativo das responsabilidades e o seu atendimento. 
Tabela 3. Cumprimento das responsabilidades, das exigências definidas o Art. 18 da Lei Orgânica da Saúde.

\begin{tabular}{|l|c|}
\multicolumn{1}{|c|}{ RESPONSABILIDADE (LEI № 8080/90) } & CUMPRIMENTO \\
\hline $\begin{array}{l}\text { Planejar, organizar, controlar e avaliar as ações e os serviços de saúde e gerir e } \\
\text { executar os serviços públicos de saúde; }\end{array}$ & Sim \\
\hline $\begin{array}{l}\text { Participar do planejamento, programação e organização da rede regionalizada e } \\
\text { hierarquizada do Sistema Único de Saúde (SUS), em articulação com sua direção } \\
\text { estadual; }\end{array}$ & Sim \\
\hline $\begin{array}{l}\text { Participar da execução, controle e avaliação das ações referentes às condições e aos } \\
\text { ambientes de trabalho; }\end{array}$ & Sim \\
\hline $\begin{array}{l}\text { Executar serviços } \\
\text { a) vigilância epidemiológica; }\end{array}$ & Sim \\
\hline b) vigilância sanitária; & Sim \\
\hline c) alimentação e nutrição; & Sim \\
\hline d) saneamento básico; e & Parcialmente \\
\hline e) saúde do trabalhador. & Sim \\
\hline Dar execução, no âmbito municipal, à política de insumos e equipamentos para a saúde; \\
\hline $\begin{array}{l}\text { Colaborar na fiscalização das agressões ao meio ambiente que tenham repercussão } \\
\text { sobre a saúde humana e atuar, junto aos órgãos municipais, estaduais e federais } \\
\text { competentes, para controlá-las; }\end{array}$ & Parcialmente \\
\hline \begin{tabular}{l} 
Formar consórcios administrativos intermunicipais; \\
\hline Gerir laboratórios públicos de saúde e hemocentros;
\end{tabular} & Sim \\
\hline $\begin{array}{l}\text { Colaborar com a União e os Estados na execução da vigilância sanitária de portos, } \\
\text { aeroportos e fronteiras; }\end{array}$ & Não se aplica \\
\hline $\begin{array}{l}\text { Observado o disposto no art. 26 desta lei, celebrar contratos e convênios com entidades } \\
\text { prestadoras de serviços privados de saúde, bem como controlar e avaliar sua execução; }\end{array}$ & Sim \\
\hline $\begin{array}{l}\text { Controlar e fiscalizar os procedimentos dos serviços privados de saúde; } \\
\text { Normatizar complementarmente as ações e serviços públicos de saúde no seu âmbito } \\
\text { de atuação. }\end{array}$ & Sim \\
\hline
\end{tabular}

Fonte: Elaborado pelos autores.

De acordo com os dados apresentados na tabela 3, acima, das doze responsabilidades atribuídas aos municípios no artigo 18, da Lei Orgânica da Saúde, a Secretaria Saúde de Ibirama cumpre $71,67 \%$ dos itens, cumpre parcialmente $11,67 \%$ e não se aplica a $16,65 \%$. As principais responsabilidades que os municípios não cumprem estão relacionadas ao seu pequeno porte, não tendo capacidade de gerir laboratórios públicos de saúde e hemocentros e não se encontrando próximo a cidades portuárias. Para Trevisan e Junqueira (2007) afirmam que em uma gestão plena do sistema de saúde, o órgão teria como responsabilidade administrar unidades laboratoriais e hospitalares próprios, assegurar atendimento inclusive de habitantes de outros municípios, além de criar a programação municipal dos serviços básicos especializados e hospitalares.

Com base no Ministério da Saúde (2011) a gestão das ações e dos serviços prestados necessita ser municipalizado para garantir a qualidade de vida, além de promover acesso universal e igualitário a saúde. Mesmo que para isso a lei prevê que os municípios podem constituir consórcios intermunicipais para desenvolver em conjunto as ações e os serviços de saúde para a cobertura total das ações de saúde, o município de Ibirama quando não possui a especialidade que o usuário necessita encaminha os municípios de Rio do Sul, Lages, Blumenau, Florianópolis, Itajaí, Pomerode e Joinville, conforme sua referência em cada tipo de especialidade.

Sendo que o Art. 3o da Lei Complementar 141/2012 determina que o SUS é responsável pela: vigilância sanitária e epidemiológica; total acesso a saúde; capacitação e remuneração do pessoal atuante; além de produção, aquisição e distribuição dos materiais, medicamentos e equipamentos; e investimento em infraestrutura. Entre os programas e serviços prestados pela SMS de Ibirama estão o Centro de Atenção Psicossocial (CAPS), o Centro de Especialidades Odontológicas (CEO), a Estratégia Saúde da Família (EFS), o Posto de Atendimento Médico (PAM), o Tratamento Fora de Domicílio (TFD), a Vigilância Entomológica - Dengue, a Vigilância Epidemiológica, a Vigilância Sanitária, a 
Farmácia Central e o Serviço de Atendimento Médico de Urgência (SAMU).

A estrutura do SUS de Ibirama no âmbito municipal conforme Art. 9 da Lei № 8080/90, se dá por meio da Secretaria Municipal da Saúde como órgão gestor, e tem como finalidade administrar as ações e serviços de saúde junto com o Conselho Municipal da
Saúde - CMS, no qual, é um órgão colegiado participativo que atua na formulação de estratégias e no controle da execução da política de saúde cujas decisões serão homologadas pelo chefe do poder legalmente constituído em cada esfera do governo. A Estruturação da SMS de Ibirama, se constitui da seguinte forma, Figura 1.

Figura 1.Estrutura da Secretaria Municipal de Saúde de Ibirama.

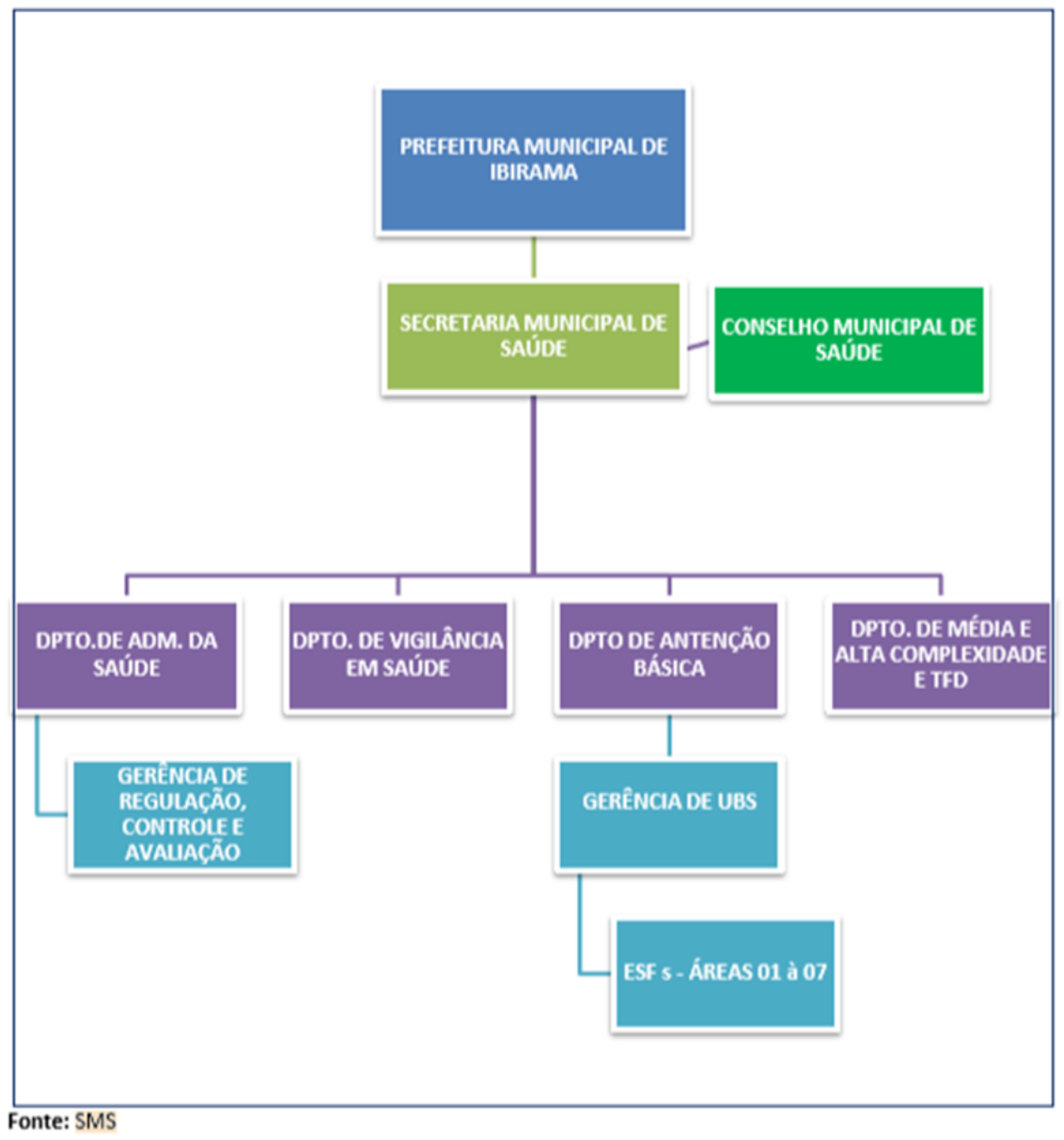

Com base na entrevista constatou-se que a estrutura, Figura 1, está desatualizada e a Secretaria de Saúde pretende revê-la, pois, a atenção básica é o principal e não pode se ter os departamentos de atenção básica separados, os demais departamentos precisam em consonância com a atenção básica, na qual, cabe ressaltar, que saúde básica é a prevenção, que se dá por meio de ações de prevenção das doenças em detrimento da ação reativa na cura das doenças adquiridas pela população.

A nova estrutura da SMS contará com mais dois conselhos municipais, o de Saneamento (COMUSA) e dos Direitos da Pessoa com Deficiência (CMDPD),ainda, pelo fato do município tem que dar conta da atenção básica, na nova estrutura a secretaria vem subordinando a atenção básica, e essa por sua vez, subordinando os departamentos que o apoiam. Outra mudança seria acrescentar as subdivisões (SAMU, CAPS, CEO) ao departamento de média e alta complexidade e TFD, cujas subdivisões ainda não constam na estrutura.

Ainda nos dados colhidos na entrevista o Município apresenta dificuldades em todas as partes da estrutura, porém, a medida que elas vão surgindo são superadas. Em contrapartida, as dificuldades mais agravantes, estão relacionadas com o CEO, CAPS e SAMU, pois são programas 
intersetoriais que atende a região, mas não há o repasse de alguns municípios cabendo assim o município de Ibirama arcar com os custos. Por esse motivo, já houve a aplicação neste ano de $19 \%$ da receita corrente liquida para a saúde, sendo que o mínimo para o ano era de $17 \%$. Segundo a Lei Complementar 141 (2012) destaca-se que assim como o município de Ibirama, alguns municípios obrigam-se a destinar mais que o mínimo constitucional estabelecido pela União.

Outra dificuldade, que o SUS de Ibirama apresenta é que o próprio paciente não conhece o funcionamento do sistema, ele entende que como é o SUS é só chegar no posto de atendimento, e que o município tem que arcar com tudo, sem saber que existem responsabilidades de cada ente. Às vezes, os próprios usuários fazem do SUS uma bagunça. É preciso ter a contrapartida do cidadão que utiliza o sistema. O usuário tem boa culpa de o SUS não funcionar como deveria funcionar pelo fato de não saber utilizar. O gestor, em seu papel, precisa começar a instruir esses usuários de que forma utilizar o sistema.

Segundo a Secretaria de Saúde, o Município conta com dificuldade de recursos na parte humana, pois há falta de profissionais, sendo que já houve concursos públicos para o preenchimento das vagas, porém não se teve inscritos para a especialização de pediatra e clínicos gerais. Mesmo com o programa Mais Médicos do Governo Federal, que tenta ajudar os municípios, não consegue atender tal dificuldade. Na parte financeira também se encontra com dificuldade, pois o município tem pouca arrecadação. Mas em contrapartida os recursos de materiais são tidos como prioridade, diante disso, não tem falta de nenhum material para os profissionais poderem exercer sua função. A secretaria de saúde está ciente de tais dificuldades, e já está realizando estudos para tentar melhorar.

Para isso acontecer, a Secretaria de Saúde busca sempre estar ciente do que está acontecendo. Por isso, ocorre reunião uma vez ao mês, com o pessoal da secretaria, gestores e servidores, equipe interna. E se por acaso, surgir algum problema, para evitar se alastrar é realizado uma reunião de urgência, para conversar sobre tal fato, sem a necessidade de procurar culpados, mas sim, focar na solução o mais rápido possível, além disso, o alerta para tal fato não se repetir. Com os enfermeiros de outras unidades, a reunião é mensal.
Desse jeito, o SUS de Ibirama é referência na região. Diante disso, a Secretaria de Saúde, afirma que existe boa participação dos conselhos, ou seja, o conselho de saúde é muito participativo.

\subsection{COFINANCIAMENTO DO SUS LOCAL}

Sabendo-se da importância da saúde na qualidade de vida da sociedade é por meio da Constituição de 1988, que se garanti que todos os cidadãos tenham acesso a saúde e é dever do Estado disponibilizar tal recurso a população. Diante isso, criou-se o SUS para cumprir com o que a CRFB (1988) estabelece.

Para cumprir com as subfunções da saúde como: atenção básica; assistência hospitalar e ambulatorial; suporte profilático e terapêutico; vigilância sanitária; alimentação e nutrição; e outras subfunções, e necessário que elas sejam financiadas com o percentual que a lei orgânica de cada município se obriga a destacar durante o ano. Salientando que esse percentual deve ser superior ao mínimo constitucional, de $15 \%$, sobre a receita corrente líquida.

Segundo a Lei complementar 141 (2012) estabelece que para o ano de 2017 o repasse anual da União para a saúde devia ser de, no mínimo, $13,7 \%$ da Receita Corrente Líquida. Para os Estados, 12\% e para os Municípios $15 \%$. Porém, geralmente os municípios têm uma lei orgânica com o percentual superior a esse, assim eles acabam obrigando-se a destinar mais que o mínimo constitucional.

Cabe ressaltar que os recursos advindos dos repasses para custear as ações e serviços de saúde devem ser mantidos no Fundo de Saúde, e obrigatoriamente só podem ser utilizados no financiamento da saúde, ou seja, esse dinheiro só pode ser gasto com despesas decorrentes da área da saúde (LEI COMPLEMENTAR №141, 2012).

Com a tabela 4 , ficam nítidos os valores e percentuais destinados a cada subfunção do município de Ibirama e de seus municípios limítrofes. Com base na Lei Complementar 141 (2012) constata-se que a Lei Orgânica do Município de Ibirama é realmente superior, assim como as dos municípios vizinhos, ou seja, via de regra como prevê a lei os municípios por meio da Lei Complementar podem destinar obrigatoriamente mais que 0 percentual estabelecido como o mínimo constitucional. Vale ressaltar, que todos os 
dados foram obtidos no portal da transparência de cada município.

Tabela 4. Valores e percentuais do Município de Ibirama e seus municípios limítrofes destinados às subfunções.

\begin{tabular}{|c|c|c|c|}
\hline Município & \multicolumn{3}{|c|}{ DESPESAS EMPENHADAS DA SAÚDE } \\
\hline Apiúna & $\mathrm{R} \$$ & 8.114 .222 & $20,86 \%$ \\
\hline Ascurra & $\mathrm{R} \$$ & 4.276 .534 & $20,64 \%$ \\
\hline Benedito Novo & $\mathrm{R} \$$ & 6.909 .769 & $24,79 \%$ \\
\hline Ibirama & $\mathrm{R} \$$ & 11.461 .591 & $21,46 \%$ \\
\hline José Boiteux & & - & - \\
\hline Lontras & $\mathrm{R} \$$ & 5.642 .615 & $15,12 \%$ \\
\hline Presidente Getúlio & & - & - \\
\hline Rio do Sul & $\mathrm{R} \$$ & 88.308 .552 & $24 \%$ \\
\hline TOTAL & $\mathrm{R} \$$ & 124.713 .283 & - \\
\hline
\end{tabular}

Com base na Tabela 4, conclui-se que no ano de 2017 o município de Apiúna destinou do total gasto em saúde: 98,95\% em atenção básica, 0,12\% em vigilância sanitária e 0,93\% em vigilância epidemiológica. Ou seja, priorizou a atenção básica muito mais que as demais. Outro município que essa situação ocorreu com valores próximos é em Benedito Novo, sendo 98,01\% para atenção básica, 0,88\% para vigilância sanitária e 1,11\% para vigilância epidemiológica, novamente destaca-se a prioridade de destinação dos recursos para a atenção básica. Assim, como os municípios de Ascurra e Ibirama que destinaram $100 \%$ dos seus recursos para atenção básica.

Já o município de Lontras, distribuiu da seguinte forma seus recursos: 90,38\% para atenção básica, $4,13 \%$ para assistência hospitalar e ambulatorial, 3,60\% para suporte profilático e terapêutico, e 1,89\% para vigilância sanitária. Por outro lado, o município de Rio do Sul, foi o que menos destinou para a atenção básica, apenas 40,08\%, e o restante dos recursos foi: 59,44\% para assistência hospitalar e ambulatorial, 0,07\% para vigilância sanitária, 0,40\% para vigilância epidemiológica. Cabe destacar, o valor destinado pelo município de Rio do Sul é extremamente mais alto que os demais municípios estudados.

Nesse sentido, para fins de exemplificação, o valor distribuído para atenção básica pelo Município de Ibirama foi de $\mathrm{R} \$ 11.461 .591$ (100\% dos recursos), e o município de Rio do Sul distribuiu apenas $40,08 \%$ e isso gerou um montante de $\mathrm{R} \$ 35.394 .422$, ou seja, como Rio do Sul teve um total de recursos muito superior aos demais, nem mesmo Ibirama destinando 100\% conseguiu ultrapassar esse montante. Fato que se deve a Rio do Sul ser uma cidade de porte superior a Ibirama, e demais, e por isso tem muito mais arrecadação. Salientando que os municípios de José Boiteux e Presidente Getúlio não apresentam o relatório demonstrativo de receitas e despesas com saúde durante o ano de 2017.

Em suma, pode-se observar que o município que gastou mais com a Atenção Básica, Assistência Hospitalar, Vigilância Epidemiológica e Ambulatória foi Rio do Sul, já com Suporte Profilático e Terapêutico e com a Vigilância Sanitária foi o Município de Lontras. Na parte de Alimentação e Nutrição não houve nenhum investimento por parte dos municípios observados.

Observando os gastos do Município de Ibirama no exercício de 2017, pode-se calcular o custo que o município teve com cada cidadão. Utilizando a formula: total do custo, dividido pelo número de munícipes, obtém-se o resultado de $\mathrm{R} \$ 661,37$ per capita. Já os municípios limítrofes obtiveram seguintes resultados: Apiúna $\mathrm{R} \$ 845,23$; Ascurra $\mathrm{R} \$ 576,97$; Benedito Novo $\mathrm{R} \$ 668,51$; Lontras $\mathrm{R} \$ 550,82$; e Rio do Sul $\mathrm{R} \$ 1.443,11$.

Miranda, Mendes e Silva (2017) afirmam que o financiamento ocorre desde a implantação do SUS, no cenário apresenta-se o endividamento do Estado e a sua mínima capacidade de atuação. Nesse sentido, forma-se um dos desafios mais significantes, conseguir garantir $\mathrm{o}$ acesso as ações e serviços de saúde de forma, universal, absoluta e igualitária. 


\subsection{GOVERNANÇA NO SUS}

Segundo Zorzal e Rodrigues (2015) o sinônimo de boa governança é gestão de desenvolvimento. Com base na entrevista executada, formou-se a Tabela 5, focada nos princípios das boas governanças.

Tabela 5. Princípios da boa governança aplicados ao SUS local de Ibirama.

\begin{tabular}{|c|c|c|c|c|}
\hline $\begin{array}{l}\text { Princípio da boa } \\
\text { governança }\end{array}$ & Atende & $\begin{array}{c}\text { Atende } \\
\text { parcialmente }\end{array}$ & $\begin{array}{l}\text { Não } \\
\text { atende }\end{array}$ & Comentário \\
\hline Responsabilidade & $X$ & & & \\
\hline Legitimidade & $x$ & & & $\begin{array}{l}\text { Atender apenas o que está na lei. Pois, os } \\
\text { serviços devem ser prestados de forma } \\
\text { igualitária, atendendo o que está prescrito na } \\
\text { legislação do SUS. }\end{array}$ \\
\hline Equidade & $X$ & & & \\
\hline Eficiência & $x$ & & & $\begin{array}{l}\text { Tentam ter qualidade máxima. Dar o menor custo } \\
\text { dentre as possibilidades. }\end{array}$ \\
\hline Probidade & $x$ & & & \\
\hline Transparência & $x$ & & & $\begin{array}{l}\text { Estão sempre acompanhando a lei, tanto que } \\
\text { saiu uma nova lei que prevê que todas as filas de } \\
\text { espera sejam publicadas, pois antes o paciente } \\
\text { não sabia pois era uma fila física, hoje na internet } \\
\text { ele consegui acessar e verificar a posição dele e } \\
\text { como essa fila está andando. }\end{array}$ \\
\hline Accountability & $x$ & & & $\begin{array}{l}\text { Como gestora do recurso da saúde, se vier uma } \\
\text { ordem fiscal necessitará fazer a conferência, } \\
\text { conferir se está tudo de acordo para depois } \\
\text { realizar o pagamento. O que é comprado, } \\
\text { sempre passa por uma conferência ou auditoria, } \\
\text { antes de ser realizado o pagamento para o } \\
\text { prestador. Para saber se o paciente foi paciente } \\
\text { foi realmente atendido, ou seja, se o profissional } \\
\text { o qual foi contratado para fazer determinado } \\
\text { serviço, realmente prestou com o serviço e } \\
\text { cumpriu com o contrato. }\end{array}$ \\
\hline
\end{tabular}

Fonte: Elaborado pelos autores.

Em relação aos princípios de governança, verifica-se que são atendidos todos os princípios da boa governança, pois a Secretaria Municipal da Saúde sempre tenta atender as normais legais. O que de acordo com o TCU (2014) torna a governança muito mais eficaz.

Para melhorar a aproximação entre o setor público e a população, ou seja, mitigar a lacuna que existe entre o governo e os cidadãos como constata o TCU (2014), pode se notar as frequentes reuniões com o pessoal da secretária, gestores e servidores, equipe interna, que ocorre uma vez ao mês e sendo mensal com os enfermeiros de outras unidades. E se por acaso, surgir algum problema, para evitar se alastrar é realizado uma reunião de urgência, para conversar sobre tal fato, sem a necessidade de procurar culpados, mas sim, focar na solução o mais rápido possível, além disso, o alerta para tal fato não se repetir. Com os enfermeiros de outras unidades, a reunião é mensal.

Com relação aos princípios da boa governança, a legitimidade basicamente é o princípio da legalidade (BRASIL, 2012). Por isso, o SUS local tem como premissa básica fazer apenas o que está previsto em lei. Assim sendo, o SUS de Ibirama é regido com base nas leis, e a Secretária de Saúde da total atenção para a execução das atividades baseadas e fundamentadas em lei.

O princípio da equidade visa garantir que todos tenham direitos iguais, sendo tanto na saúde, ou na educação, segurança, entre outros (BRASIL, 2010). À vista disso, todas as pessoas que procuram o SUS de Ibirama são atendidas e encaminhadas. Cada qual, encaminhada para o especialista dependendo das suas necessidades. Cabe ressaltar, que conforme estabelece o Ministério da Saúde (MS) (2011), esses 
atendimentos e encaminhamentos são de forma gratuita e toda a população tem acesso de forma igualitária.

Eficiência é executar as atividades entre uma relação de custo benefício no que tange qualidade e custos. Sendo assim, procura-se reduzir os custos no que é possível, porém sem perder a qualidade (BRASIL, 2010). Diante disso, o SUS de Ibirama, procura atingir o máximo de qualidade possível, sempre tentando melhorar e superar a qualidade dos serviços e ações prestadas. Além disso, também tenta reduzir os seus custos dentre as possibilidades em que se encontra.

O princípio da probidade consiste na execução do trabalho dos servidores públicos com qualidade, integridade, honestidade e retidão. (IFAC, 2013b). Por causa disso, todos os servidores públicos englobados pelo SUS devem prezar pelo atendimento com qualidade e sempre priorizar a ética no trabalho.

A transparência baseia-se no acesso universal as despesas e receitas dos órgãos públicos. Pelo fato, da sociedade poder controlar e acompanhar como está sendo distribuído o dinheiro da população e como isto está sendo feito e se está da maneira correta em conformidade com as leis (TCU, 2014). Nesse sentido, como o SUS de Ibirama está integrado no setor público, e a Secretária de Saúde é um órgão pertencente a Prefeitura de Ibirama assim sendo fundamental atender ao princípio da transparência.

Diante disso, destaca-se que o SUS de Ibirama busca sempre atender as leis, e por isso, tem rigoroso acompanhamento da legislação. Assim sendo, que emitiram uma nova lei, a qual prevê que todas as filas de espera sejam virtuais para que a população possa acompanhar de forma mais clara os andamentos das consultas e exames. Pois, antes o paciente não tinha conhecimento da ordem de atendimento pelo fato de ser uma fila física e não ter acesso a devido arquivo, com essa nova lei, as filas de espera serão publicadas e poderá verificar em qual posição se encontra. E por causa disso, o SUS local já procura se adequar a essa nova lei.

Já o princípio da Accountability basicamente é a prestação de contas dos entes públicos, que deixam claro que estão assumindo a autoria de tais atos e por consequência suas devidas responsabilidades (IBGC, 2010). Por causa disso, a Secretária de Saúde de
Ibirama, em seu papel como gestora dos recursos destinados a saúde, faz a conferência de todos os processos para confirmar se estão de acordo com o apresentado, para então fazer o devido pagamento. Sendo assim, tudo que o SUS de Ibirama compra, é preciso passar por uma conferência ou auditoria para então ser aprovado e efetuado o pagamento para o prestador do serviço. Esse procedimento é realizado com a finalidade de descobrir se o paciente foi realmente atendido, ou seja, se o prestador contratado realizou o serviço para o qual deve realizar, assim sendo, se o contrato firmado foi cumprido.

\section{CONSIDERAÇÕES FINAIS}

O objetivo de explorar os princípios da governança pública num cenário de gestão e operacionalização local do SUS foi alcançado. Constatou-se que o sistema local do SUS é estruturado em forma de Secretaria e ainda em Conselho Municipal de Saúde (CMS). Dados indicam que o conselho tem uma participação considerada exemplar.

Com relação às responsabilidades municipais que constam no art. 18, da Lei Orgânica da Saúde, à Secretaria da Saúde de Ibirama cumpre $71,61 \%$, cumpre parcialmente $11,67 \%$ e não se aplica 16,65\%.

A estrutura do SUS de Ibirama requer atualização em seu desenho organizacional. $\mathrm{Na}$ reformulação da estrutura deve contar que - SMS consta com mais dois conselhos municipais, sendo 0 de saneamento (COMUSA) e o de direito da pessoa com deficiência (CMDPD). Além disso, a atenção básica precisa ser colocada em primeiro lugar e os demais departamentos subordinados a atenção básica. E, acrescentar as subdivisões (SAMU, CAPS, CEO) ao departamento de média e alta complexidade e TFD.

Diante das dificuldades que o SUS de Ibirama apresenta as mais crônicas são: falta de repasses de alguns municípios dos programas intersetoriais, como o CEO, CAPS e SAMU; a falta de contrapartida dos usuários do sistema; falta de recursos humanos, profissionais capacitados como pediatras e clínicos gerais e falta de recursos financeiros, pelo fato da baixa arrecadação do município.Cabe salientar, que o município de Ibirama destina mais que os $15 \%$ sobre a receita corrente líquida, que é o mínimo 
constitucional obrigatório a destinar para a saúde.

Nesse sentido, a função de atenção básica, é a prioridade. Por isso, via de regra, é a função que mais utiliza recursos financeiros destinados a saúde, observa-se esse fato no município de lbirama e nos seus municípios limítrofes. Para os casos de alta e média complexidade, os pacientes são encaminhados, dependendo da especialidade, para outros municípios, como: Rio do Sul, Lages, Blumenau, Florianópolis, Itajaí, Pomerode e Joinville.

Destaca-se que a Secretaria de Saúde de Ibirama, atende a todos os princípios da boa governança, são eles: responsabilidade, legitimidade, equidade, eficiência, probidade, transparência e accountability. Em suma, os

\section{REFERÊNCIAS}

[1] Banco Mundial. Recomendaciones generales, en Chile: Estudio de evaluación em profundidad del Programa de Mejoramiento de la Gestión (PMG), Banco Mundial-Unidad de reducción de la pobreza y Gestión Económica. 2008. Disponível em: $<$ http://www.dipres.gob.cl/597/articles42963_doc_pdf.pdf>. Acesso em: 20 mai.2018.

[2] Barbosa, D. V. S.; Barbosa, N. B.; Najberg, E. Regulação em Saúde: desafios à governança do SUS. Cad. saúde colet., Rio de Janeiro, v. 24, n. 1, p. 49-54, 2016.

[3] Bastos, F. A; Santos, E; Tovo, M. F. Capital Social e Sistema Único de Saúde (SUS) no Brasil. Saúde Soc., São Paulo, v. 18, n. 2, p. 177-188, 2009

[4] Biblioteca Virtual de Direitos Humanos da Universidade de São Paulo. Constituição da Organização Mundial da Saúde em 1946. Disponível em: $<$ http://www.direitoshumanos.usp.br/index.php/OM S-Organiza\%C3\%A7\%C3\%A3o-Mundial-daSa\%C3\%BAde/constituicao-da-organizacaomundial-da-saude-omswho.html>. Acesso em: 06 jun. 2018.

[5] Brasil. (1988) Constituição da República Federativa do Brasil. Disponível em:http://www.planalto.gov.br/ccivil_03/Constituica o/Constituicao.htm.

[6] Brasil. (2012) Lei Complementar no 141. Disponível em: <http://www.planalto.gov.br/ccivil_03/leis/LCP/Lcp1 41.htm>. Acesso em: 30 jan. 2018.

[7] Brasil. Lei n.8.080, de 19 de setembro de 1990. Diário Oficial União, Brasília, DF, 19 set. 1990.Dispõe sobre as condições para a promoção, proteção e recuperação da saúde, a organização e sistemas de saúdes municipais deveriam focar apenas na atenção básica, com o intuito de prevenir a população, de modo geral, conscientizar e administrar palestras para a comunidade. Porém, a realidade é que se gasta muito mais em medicamentos e tempo em suprir as necessidades de alta e média complexidade que não se consegue priorizar a atenção básica.

Por fim, a principal dificuldade para realização deste estudo foi a falta de estudos anteriores de governança pública relacionados diretamente com o SUS, cuja limitação apresentada, sugere a realização de pesquisas futuras relacionando o SUS e a governança pública, mais especificamente ainda a relação de cada princípio de governança e os desafios encontrados nos serviços públicos da saúde.

o funcionamento dos serviços correspondentes e dá outras providências. Disponível em: <http://www.planalto.gov.br/ccivil_03/leis/18080.htm >. Acesso em: 13 mai. 2018.

[8] Brasil. Ministério da Saúde. SecretariaExecutiva. Departamento de Apoio à Descentralização. O SUS no seu município: garantindo saúde para todos / Ministério da Saúde, Secretaria-Executiva, Departamento de Apoio à Descentralização. - 2. ed. - Brasília : Ministério da Saúde, 2009.

[9] Brasil. Ministério da Saúde. SecretariaExecutiva. Subsecretaria de Assuntos Administrativos. SUS: a saúde do Brasil / Ministério da Saúde, Secretaria-Executiva, Subsecretaria de Assuntos Administrativos. - Brasília: Editora do Ministério da Saúde, 2011. Disponível em: $<$ http://bvsms.saude.gov.br/bvs/publicacoes/sus_s aude_brasil_3ed.pdf>. Acesso em: 25 jan. 2018.

[10] Brasil. Tribunal de Contas da União. Instrução Normativa ํo 63/2010. 2010.

[11] Ceccim, R. B.; Feuerwerker, L. C. M. O quadrilátero da formação para a área da saúde: ensino, gestão, atenção e controle social. Revista saúde coletiva, v. 14, n. 1, p. 41-65, 2004.

[12] Farias, F.I.D.; Hansen, P.B. Alianças estratégicas nos serviços de saúde: uma análise teórica das organizações hospitalares sob a ótica das relações interorganizacionais e da governança. Pontifícia Universidade Católica do Rio Grande do Sul. Porto Alegre, 2006.

[13] Gonçalves, A. O; Gonçalves, R. S; Tavares, A. L. O olhar dos conselheiros de saúde sobre os Relatórios de Prestação de Contas no Município de Natal (Rio Grande do Norte), Brasil.Saúde Soc. São Paulo. v. 20, n.3, p.659-672, 2011. 
[14] Ibgc. Instituto Brasileiro de Governança Corporativa. Código das melhores práticas de governança corporativa. 5.ed. / Instituto Brasileiro de Governança Corporativa. - São Paulo, SP: IBGC, $2015 . \quad$ Disponível em: <http://www.ecgi.org/codes/documents/ibgc_2016_ pt.pdf>. Acesso em: 21 mai. 2018.

[15] Ifac. Comparison of principles, 2013b. Disponivel em: $<$ http://www.ifac.org/sites/default/files/publications/f iles/Comparison-of-Principles.pdf>. Acesso em: 21 mai. 2018.

[16] Miranda, G. M. D.; Mendes, A. C. G.; Silva, A. L. A. O desafio da organização do Sistema Único de Saúde universal e resolutivo no pacto federativo brasileiro. Revista Saúde Soc., V. 26, N. 2, P. 329-335, 2017.

[17] Moraes, I. H. S.; Santos, S. R. F. R. Informações para a gestão do SUS: Necessidades e perspectivas. Informe epidemiológico, v. 10, n. 1, p. 49-56, 2001.

[18] Prefeitura Municipal de Ibirama. Disponível em <http://www.ibirama.sc.gov.br/dados-domunicipio>. Acesso em 14 mar. 2018.

[19] TCU - Tribunal de Contas da União. Governança pública: Referencial básico de governança aplicável a Órgãos e Entidades da Administração Pública e Ações Indutoras de Melhoria. 2014.

[20] Trevisan, L. N.; Junqueira, L. A. P. Construindo o "pacto de gestão" no SUS: da descentralização tutelada à gestão em rede. Revista Ciência \& Saúde Coletiva, v. 12, n. 4, p. 893-902, 2007.

[21] Vermelho, S. C.; Figueiredo, G. A percepção de secretários municipais de saúde sobre a gestão do trabalho e da educação na rede pública do Sistema Único de Saúde (SUS). Revista Saúde Soc., v. 26, n. 2, p. 382-396, 2017.

[22] Zorzal, L.; Rodrigues, G. M. Disclosure e transparência no setor público: uma análise da convergência dos princípios de governança. Informação \& Informação, v. 20, n. 3, p. 113 - 146, 2015. 


\section{Gapítulo 19}

\section{ADOÇÃO DA COMPUTAÇÃO EM NUVEM NA ESFERA FEDERAL: INOVAÇÃO NO TRIBUNAL DE CONTAS DA UNIÃO}

\section{Luana Fernandes dos Santos \\ Manoel Veras de Sousa Neto}

Resumo: O objetivo da pesquisa é identificar os principais pontos abordados pelo Tribunal de Contas da União em seu primeiro edital, quanto a inovação no setor público relacionada a adoção do serviço de computação em nuvem e orientar e ampliar o conhecimento para que outros órgãos federais possam ter a mesma iniciativa. Fez-se um levantamento de dados, a respeito da adoção da computação em nuvem, com os principais pontos estabelecidos em edital, tais como: contratação de empresas com a função de broker, localização dos dados, determinação do valor dos serviços, predominância da legislação brasileira, a exigência quanto a continuidade do negócio e disponibilização dos dados, a importância de incluir o suporte técnico e treinamento. Os principais resultados encontrados foram que apesar do assunto estar bastante difundido, existem poucas leis e políticas públicas, não há lei que determine o armazenamento de dados da administração pública no Brasil, há apenas a obrigatoriedade que sejam regidos pela legislação brasileira. Além disso, percebeu-se a importância da contratação de uma empresa como broker, pois permite um melhor gerenciamento e aproveitamento dos recursos da nuvem. No que tange às implicações, evidencia-se a revogação do edital e a amostra limitada do estudo, voltando-se apenas a um órgão.

Palavras-chave: Inovação; Computação em Nuvem; Setor Público; 


\section{INTRODUÇÃO}

A computação em nuvem é um assunto amplamente discutido nas organizações e, de forma geral, na sociedade. Este modelo está sendo mundialmente adotado por instituições públicas e privadas e garante inúmeras vantagens em relação ao modelo tradicional, dependendo dos fatores envolvidos no processo.

No Brasil, as empresas privadas, têm adotado esse tipo de serviço e tem comprovado os benefícios desse novo tipo de tecnologia. As empresas públicas, por sua vez, vem demonstrando interesse quanto a adoção desse tipo de serviço, possuindo vantagens a mais em relação ao âmbito privado, tais como: maior agilidade da administração pública, auxílios nas iniciativas de big data e dados abertos, atendimentos sazonais, mitigação de desvios e irregularidades nos processos públicos, rapidez e economia (acórdão do TCU de № 1739, 2015).

Apesar das vantagens apresentadas ainda existe uma baixa adoção do serviço de computação em nuvem no que tange aos órgãos federais, poucas políticas públicas, regulamentações e escassez na difusão quanto ao processo de adesão e os SLA's realizados sobre o tema.

Dessa forma, a presente pesquisa tem por objetivo identificar os principais pontos estabelecidos no edital de no 106/2016 publicado pelo Tribunal de Contas da União (TCU) de Brasília para adoção da computação em nuvem, inovando a forma de armazenamento e disponibilização dos dados no setor público e ampliar o conhecimento para que outros órgão federais possa ter a iniciativa de aderir o serviço tratado. Para tanto, esta pesquisa pode ser um instrumento de incentivo e esclarecimento dos principais assuntos de como pode ocorrer o processo de adesão da computação em nuvem em instituições públicas, bem como, gerar insumos para a criação de novas políticas públicas e regulamentações a respeito do tema.

Por fim, identificou-se que o TCU revogou o edital publicado de no 106/2016 por não achar completo e devido aos questionamentos realizados por parte das empresas licitadas, mas abriu novamente o edital $n^{\circ}$ 22/2017. Esse fato já é uma iniciativa de extrema importância para o cenário brasileiro da administração pública
Federal, principalmente por causa do interesse em aderir esse tipo de serviço visando almejar as vantagens prometidas, bem como um exemplo para outros órgãos interessados do governo.

Além disso, foi percebido que não existe lei que determine o armazenamento de dados da administração pública apenas no Brasil, a obrigatoriedade existente é que a legislação brasileira deve predominar sobre qualquer outra e, enfim, percebeu-se que a contratação do Broker é de suma importância para se obter um melhor gerenciamento e aproveitamento de recursos de nuvem. Em relação às implicações, destacam-se a revogação do edital e a amostra limitada do estudo em apenas um órgão, oTCU.

A pesquisa aborda ainda um referencial teórico descrevendo os conceitos principais sobre a computação em nuvem, o cenário brasileiro em relação ao tema, aborda o âmbito do Tribunal de Contas da União e suas iniciativas, além de descrever os procedimentos metodológicos, resultados e discussão, como também as considerações finais do estudo.

\section{REFERENCIAL TEÓRICO}

Em sua parte inicial, o referencial teórico relata as principais conceituações de Computação em nuvem e as vantagens atreladas a sua utilização, logo em seguida descreve de forma geral e sucinta o cenário brasileiro em relação a adoção da computação em nuvem no setor público, e por fim, descreve a iniciativa e um breve relato sobre o órgão estudado, o Tribunal de Contas da União.

\subsection{COMPUTAÇÃO EM NUVEM}

A computação em nuvem é considerada um paradigma na área de tecnologia e, ao longo dos anos, tornou-se algo cada vez mais presente na sociedade e, principalmente nas empresas, modificando a rotina da organização em relação a TI tradicional. Umas das definições amplamente utilizada sobre o tema foi criada pelo NIST (National Institute of Standards and Technology) que é uma agência governamental não-regulatória da administração de tecnologia do Departamento de Comércio dos Estados 
Unidos e que conceitua computação em nuvem como um modelo que permite acesso à rede de forma onipresente, conveniente e sob demanda a um conjunto compartilhado de recursos computacionais configuráveis que podem ser rapidamente provisionados e liberados com o mínimo esforço de gerenciamento ou integração com o provedor de serviço.

Já, Diógenes e Veras (2014), consideram computação em nuvem como um estilo de computação, no qual recursos de TI, escaláveis e elásticos, são oferecidos como serviços, para consumidores externos, por meio de tecnologias de internet. Jeffery e Neidecker-Lutz (2010), defendem que de uma forma geral, a nuvem é um ambiente de execução elástica que envolve partes interessadas (stakeholders) e disponibiliza um serviço que pode ser medido em várias granularidades e com um nível específico de qualidade.

Dessa forma, existe uma gama de definição a respeito do tema abordado, sendo de fundamental importância a sua compreensão. Entretanto, este trabalho irá voltar-se ao conceito estabelecido pelo NIST, que retrata ainda as características essenciais da nuvem, de forma geral, demonstradas a seguir.

\subsubsection{CARACTERÍSTICAS ESSENCIAIS DA NUVEM}

De acordo com o NIST, a computação em nuvem possui cinco características essenciais, relacionadas a seguir:

- Autoserviço sob demanda: prover funcionalidades computacionais de forma automática, ou seja, o cliente pode ser atendido automaticamente sem que haja a necessidade de interação com o provedor do serviço.
- Amplo acesso à rede: os recursos computacionais devem estar disponíveis para acesso através da internet, por meio de mecanismos padronizados, possibilitando o uso nos mais variados dispositivos dos clientes, tais como: celulares, tablets, laptops e estações de trabalho. computacionais (físicos ou virtuais) disponibilizados pelo provedor devem atender a múltiplos clientes, simultaneamente. Tais recursos devem ser alocados e realocados de forma automática de acordo com a demanda. Com isso, existe uma sensação de independência de localização, pois o cliente geralmente não tem o controle ou conhecimento a respeito do local exato, de onde os recursos estão sendo fornecidos.

- Rápida Elasticidade: os recursos computacionais devem ser fornecidos de forma rápida e elástica, proporcionais à demanda do cliente. Para o consumidor, os recursos disponíveis para provisionamento podem parecer ilimitado, podendo a qualquer momento, independente da quantidade, serem requisitados.

- Serviços mensuráveis: os serviços de computação em nuvem devem controlar e otimizar o uso de recursos utilizados automaticamente. Este monitoramento e controle, por sua vez, deve ocorrer de forma transparente, tanto para o provedor como para o cliente.

As cinco características mencionadas e esquematizadas abaixo (Figura 1) são essenciais para uma melhor compreensão do conceito de computação em nuvem e para identificar a diferença no que tange outros serviços semelhantes, como o caso da virtualização.

Figura 1. Características Essenciais da Computação em Nuvem de acordo com o NIST

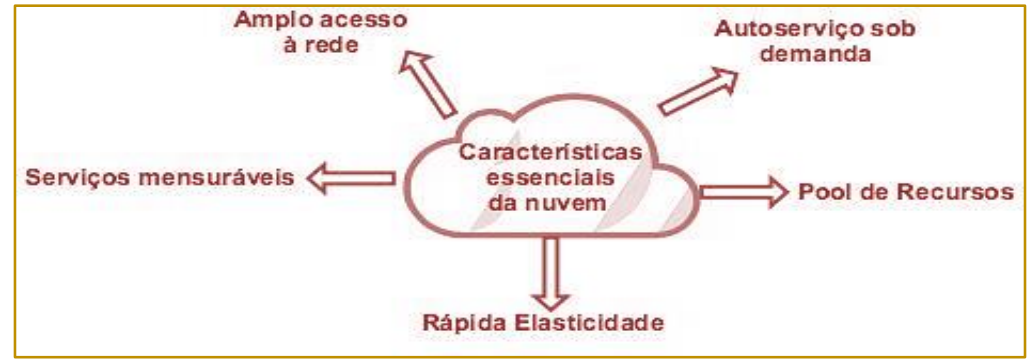


Visto o conceito e as suas características essenciais, faz-se necessário saber que existem vários modelos de computação em nuvem, sendo primordial o seu entendimento, pois serve como base para determinar um projeto, migração, implantação e aquisição de nuvens. O NIST estabelece dois modelos: um modelo baseado nos serviços disponibilizados pela nuvem e o outro modelo baseado na forma de implantação, sendo este último abordado no próximo tópico.

\subsubsection{MODELO BASEADO NA FORMA DE IMPLANTAÇÃO}

A diferença da forma de implantação entre os quatro modelos determinados pelo NIST é de fundamental importância para a compreensão deste estudo e por isso, serão elencados a seguir.

A Nuvem Privada é uma infraestrutura provisionada para uso exclusivo (privacidade) de uma organização. Normalmente, a infraestrutura de computação em nuvem é criada e gerenciada pela própria organização, no entanto, um terceiro também pode fazer este papel, dentro ou fora das instalações da organização.

Já o modelo de Nuvem Comunitária, a infraestrutura da nuvem é provisionada para uso exclusivo de uma comunidade específica, formada por diversas organizações que possuem interesses em comuns, podendo ser de propriedade, gerenciada e operada por uma ou mais organizações da comunidade, por um terceiro ou a junção destes. E assim como a nuvem privada é possível existir dentro ou fora das instalações das organizações.

Enquanto que a Nuvem Pública é disponibilizada de forma pública e pode ser criada, gerenciada e operada por empresas, academias e organizações públicas, desde que possuam grandes capacidades de armazenamento e processamento. Este modelo é um dos mais conhecidos e tem como exemplos os serviços de Dropbox, Icloud e Google Apps.

O último modelo consiste na Nuvem Híbrida que, conforme o nome sugere, consiste em possuir uma infraestrutura com a junção de duas ou mais nuvens (privada, comunitária ou pública), mas que permaneçam como entidades exclusivas e que são unidas por tecnologias padronizadas ou proprietária, possibilitando a portabilidade de dados e aplicativos. De forma, suscinta, a figura 2 demonstra as diferenças dos modelos abordados.

Figura 2. Comparativo de características de nuvem pública, privada, privada virtual e híbrida, baseado no quadro "Cloud Computing Models" do CSA.

\begin{tabular}{|c|c|c|c|c|}
\hline Tipo de nuvem & Gerenciada por & $\begin{array}{l}\text { Propriedade da } \\
\text { infraestrutura }\end{array}$ & $\begin{array}{l}\text { Localização da } \\
\text { infraestrutura }\end{array}$ & $\begin{array}{l}\text { Forma de } \\
\text { Acesso e } \\
\text { Consumo }\end{array}$ \\
\hline Pública & Terceiros & Terceiros & $\begin{array}{c}\text { Fora das } \\
\text { dependências }\end{array}$ & Compartilhado \\
\hline Virtual Privada & $\begin{array}{c}\text { Organização ou } \\
\text { Terceiros }\end{array}$ & $\begin{array}{l}\text { Organização ou } \\
\text { Terceiros }\end{array}$ & $\begin{array}{c}\text { Fora das } \\
\text { dependências }\end{array}$ & Dedicado \\
\hline Privada & $\begin{array}{c}\text { Organização ou } \\
\text { Terceiros }\end{array}$ & $\begin{array}{c}\text { Organização ou } \\
\text { Terceiros }\end{array}$ & $\begin{array}{c}\text { Dentro das } \\
\text { dependências }\end{array}$ & Dedicado \\
\hline Híbrida & $\begin{array}{c}\text { Tanto Organização } \\
\text { como Terceiros }\end{array}$ & $\begin{array}{c}\text { Tanto Organização } \\
\text { como Terceiros }\end{array}$ & $\begin{array}{c}\text { Tanto dentro como } \\
\text { fora das } \\
\text { dependências }\end{array}$ & $\begin{array}{c}\text { Tanto dedicado } \\
\text { como } \\
\text { compartilhado }\end{array}$ \\
\hline
\end{tabular}

Fonte: acórdão do TCU № 1739/2015

Os modelos apresentados devem ser utilizados de acordo com a realidade e necessidade da organização, sendo interessante abordar os seus benefícios, bem como, procurar mitigar os riscos e analisar o custo envolvido em cada padrão, para então decidir o melhor para a organização.

Vale salientar que atualmente no Brasil existem muitos órgãos do governo, como algumas universidades federais, criando e utilizando a computação em nuvem do tipo privada ou híbrida, mas o objeto deste 
estudo é o uso de nuvem pública.

\subsubsection{VANTAGENS PARA ADOÇÃO DA COMPUTAÇÃO EM NUVEM}

Existem várias fontes que abordam as vantagens ou os benefícios obtidos com a computação em nuvem, como a ISACA (2012), por meio do documento Princípios norteadores de adoção e uso da computação em nuvem, que defende como ponto positivo a agilidade ao disponibilizar os serviços, sendo difícil de alcançar com outros tipos de soluções. A contenção de custos também é considerada uma vantagem, pois os custos da nuvem são de natureza operacional, enquanto que as demais soluções precisam de investimento em infraestrutura, aquisição de tecnologia e manutenção do parque computacional, incluindo despesas fixas e variáveis.

Além dos dois benefícios citados anteriormente, a ISACA (2012) ainda elenca a multilocação, pois a nuvem permite uma melhor distribuição dos custos e capacidade diante de grupos de usuários, a confiabilidade, devido ao amplo acesso à rede e a rápida elasticidade conforme a necessidade e, por fim, o dimensionamento que permite que as empresas analisem e estabeleçam suas necessidades e soluções de valores específicos.

No que concerne a conjuntura da administração pública, Kundra (2011) descreve algumas vantagens obtidas pelo Governo norte-americano ao aderir o modelo de nuvem, tais como: eficiência, os ativos serão melhor utilizados, redução da duplicação, a consolidação do centro de dados pode ser acelerada, TI mais descomplicada e produtiva, agilidade, escalabilidade, eficácia e estímulo ao empreendedorismo.

Além das vantagens descritas, o TCU de acordo com o acórdão de № 1739/2015, descreve cinco vantagens voltadas para atividades do governo brasileiro. A primeira consiste no aumento da agilidade da administração pública na entrega dos serviços e atualização de seu parque computacional, pois os processos formais da administração pública dificulta a conservação de uma infraestrutura própria, atualizada e que atenda as demandas de seus usuários rapidamente. iniciativas de Big Data e Dados abertos, pois a maioria dos dados ainda são fechados e restritos aos funcionários, responsáveis por manipulá-los. Como terceira vantagem, temse a economicidade e disponibilidade do atendimento a picos de demanda sazonal, pois normalmente alocam grandes quantidades de recursos fixos para atender demandas específicas e por um determinado tempo, ficando o sistema ocioso no restante do ano. Como é o caso das inscrições e resultados do Enem e resultados eleitorais.

Em seguida, tem-se a mitigação de desvios e irregularidades nos processos públicos, principalmente com a contratação dos serviços de laas e PaaS, se comparado com a aquisição de máquinas, licenças de software, manutenção e suporte necessárias para manter um LPAD (Laboratório de Processamento de Alto Desempenho) próprio.

Por fim, elenca a rapidez e economia na entrega de serviços em instituições públicas descentralizadas, permitindo o acesso das informações por meio da internet, sendo mais econômico do que se comparado a algumas soluções de redes privadas existentes.

Ainda cabe acrescentar como vantagem a mitigação de gastos desnecessários e indisponibilidade do serviço, pois a administração pública possui burocracias que devem ser atendidas para a compra de bens e serviços, o que nem sempre permite a aquisição de um datacenter com toda a infraestrutura completa de uma só vez, fazendo com que se tenha gastos com energia e manutenção, por exemplo, sem que efetivamente os serviços estejam disponíveis.

Apesar das inúmeras vantagens apresentadas, faz-se necessário entender o cenário atual da organização, priorizar as vantagens, projetar os custos futuros de acordo com os serviços existentes, para então tomar a decisão quanto a migração para a nuvem. De acordo com a Gartner (2016), os CIOs (Chief Information Officer), devem analisar e entender os benefícios, as realidades e problemas associados aos diferentes domínios de negócios para decidir quanto a relevância da adoção da nuvem.

A segunda, descreve maior auxílio nas 


\subsection{COMPUTAÇÃO EM NUVEM E O GOVERNO BRASILEIRO}

Nos últimos anos, o governo brasileiro vem dando um enfoque maior para a regulamentação dos recursos da tecnologia da informação, mas ainda não existe nenhuma regulamentação específica para a computação em nuvem. Existem apenas assuntos que podem interferir de forma direta e/ou indireta, como o decreto № 8.135, o Marco da Internet, a Portaria Interministerial 141/2014 e o Plano Nacional de Banda Larga.

O Plano Nacional de Banda Larga foi criado através do decreto de № 7.175/2010 e tem como objetivo ampliar o acesso à internet no Brasil, principalmente em regiões mais carentes, bem como fornecer e aprimorar bens e serviços de tecnologia da informação. Esse fato é primordial e contribui para o uso da computação em nuvem, principalmente pelo fato de que o serviço é oferecido, na maior parte das vezes, através de links e acessos à internet.

De forma geral, o decreto № 8.135 aborda que as comunicações de dados da administração pública federal, com exceção às comunicações feitas através de serviço móvel, deverão ser realizadas apenas por redes e serviços de tecnologia da informação providas por órgãos ou entidades da administração pública federal. Além disso, dispensa a licitação para as contratações que possam, de alguma forma, comprometer a segurança nacional.

Neste aspecto, percebe-se que a adesão da computação em nuvem em órgão da administração pública federal ficou restritiva, pelo fato de o decreto afirmar que os dados deveriam ser fornecidos $e$ armazenados por órgãos ou entidades da administração pública federal, ou seja, os dados deveriam ser guardados em data centers localizados fisicamente no Brasil e disponibilizados por entidades da administração pública federal.

As empresas públicas Dataprev e SERPRO, por exemplo, são capazes de prover tal serviço, mas com isso acabava por deixar de fora as multinacionais. No entanto, existe ainda a ressalva de que deve ser observada a capacidade dos órgãos da administração pública federal de ofertar satisfatoriamente os serviços, segundo 0 próprio decreto (art. 1으, § 5oㅡㄴ, inciso II).
Após o decreto, veio a lei $\mathrm{N}^{\circ} 12.965$, de 23 de abril de 2014, entrando em vigor após 60 (sessenta) dias de sua publicação, reconhecida como o marco da internet, sendo importante por determinar os princípios, garantias, direitos e deveres voltados ao uso da internet no Brasil, como também por designar as diretrizes para atuação da União, dos Estados, do Distrito Federal e dos Municípios.

Diferente do decreto, o marco da internet não restringiu $o$ fornecimento e armazenamento dos dados por empresas públicas, apenas estabeleceu como diretriz a atuação do poder público no desenvolvimento da Internet no Brasil, provendo uma melhor infraestrutura de redes e incentivo para a criação e implantação de centro de gerenciamento, armazenamento e disseminação de dados no Brasil, segundo a (Lei 12.965/2014, art. 24, inciso VII).

Logo em seguida, veio a Portaria Interministerial 141/2014, com base no art. $1^{\circ}$, $\S 5^{\circ}$, do Decreto no 8.135 , e reafirma que as comunicações de dados da Administração Pública Federal seja ela direta, autárquica e fundacional devem ser ocorridas através de redes e serviços de tecnologia da informação providos por órgãos da Administração Pública Federal.

No entanto, ainda de acordo com 0 art. $7^{\circ}$ da portaria em questão, ficou permitido a contratação de serviços de redes de telecomunicações com fornecedores privados, desde que não exista oferta da prestação de serviço por órgãos da administração pública federal. A portaria também descreve e deixa claro os casos em que será considerado um serviço não ofertado, como por exemplo, o fato de não possuir o serviço no local onde surgiu a demanda e não atender aos requisitos demandados.

Ainda se tratando da adoção da computação em Nuvem no governo, o Ministério do Planejamento, Orçamento e Gestão (MP), no dia 12 de Maio de 2016, divulgou um manual de Boas Práticas para contratação de Serviços de Computação em Nuvem, que tem força normativa legal, vinculado a Portaria MP/STI no 20, de 14 de junho de 2016, na forma de anexo, voltado aos órgãos integrantes do Sistema de Administração dos Recursos de Tecnologia da Informação - SISP. O que demonstra um 
interesse mais intensivo em relação ao tema.

O manual determina que os dados e informações devem ser hospedados no território nacional, por uma questão de jurisdição, e ainda não permite que os órgãos do SISP contratem salas-cofre e salas seguras, como forma de redução de custos.

O Ministério do planejamento, Desenvolvimento e Gestão (MP) recentemente ainda abriu uma consulta pública em relação ao termo de referência para a contratação de serviços em nuvem, disponível no portal da Participação social, permitindo uma interação entre o governo e a sociedade. A finalidade do governo é a contratação de serviços de computação em nuvem pública sob demanda, bem como infraestrutura como serviço, gerenciamento, suporte técnico especializado e treinamento, destinados aos órgãos integrantes do SISP.

Ainda é possível citar outras iniciativas do governo que influenciaram e/ou influenciam na adoção da computação em nuvem e no avanço da mesma, como o programa $\mathrm{Tl}$ Maior, a Estratégia Nacional de Ciência Tecnologia e Inovação (2016-2019) que aborda como um dos temas prioritários a computação em nuvem, o projeto de Proteção a Dados Pessoais e a Lei 12.737, de 30 de Novembro de 2012, mais conhecida como a Lei Carolina Dieckmann que aborda sobre delitos ou crimes informáticos.

Diante do exposto, o Brasil vem avançando, ao longo dos anos, em relação a adoção da computação em nuvem, em virtude das vantagens que a contratação desse serviço oferece, beneficiando a esfera pública, possibilitando uma melhoria da gestão de TI e oferta de melhores e mais ágeis serviços para o cidadão brasileiro.

Devido a crise enfrentada pelo Brasil nos últimos anos, a redução de custos juntamente com os demais benefícios proporcionados ao contratar os serviços de nuvem é de extrema importância e supera as desvantagens na maioria das situações.

No entanto, Vinicius, Santos e Fernando (2017), realizaram estudo que identifica que a maioria das normas, leis e políticas públicas ainda estão dispersas em várias instituições do governo, o que provoca um desconforto e dificuldade na atuação dos gestores de $\mathrm{Tl}$.

Neste cenário, segundo um estudo realizado por Fernando e Veras (2016) para identificar os fatores que influenciam na esfera pública a utilização da computação em nuvem através de questionários aplicados aos gestores de TI do Rio Grande do Norte e do Governo Federal, constataram que para os gestores 0 governo federal deve fomentar o uso da computação em nuvem, sendo o principal agente, tanto nas regulamentações, como usuário ou provedor do serviço.

Portanto, percebe-se um interesse maior do governo nos últimos anos em relação a tecnologia da informação, mas as regulamentações existentes ainda são limitadas e não abordam de forma concreta o assunto da computação em nuvem.

\subsection{O TRIBUNAL DE CONTAS DA UNIÃO E A COMPUTAÇÃO EMNUVEM}

O Tribunal de Contas da União - TCU, atualmente, é o órgão de controle externo do governo federal, previsto na constituição de 1988, atuando em auxílio ao Congresso Nacional na missão de acompanhar a execução orçamentária e financeira do país e tem como visão colaborar com o aperfeiçoamento da Administração Pública para que esta seja efetiva, ética, ágil e responsável, com a finalidade de beneficiar a sociedade (Documento Conhecendo o Tribunal em sua 6. ed, 2016).

Sabe-se que a computação em nuvem está sendo amplamente adotada nos últimos anos, não só em empresas privadas como públicas em diversos países, então mediante essa realidade o TCU realizou um trabalho de levantamento dos riscos mais relevantes em relação a contratação dessa tecnologia na administração pública federal, no período entre outubro de 2014 e fevereiro de 2015 , tendo como finalidade auxiliar os auditores do TCU em suas futuras fiscalizações, orientar os gestores da administração pública e subsidiar futuros trabalhos sobre o tema em questão (Acórdão de № 1.739/2015).

O trabalho do TCU abordou assuntos fundamentais no tocante a computação em nuvem, explorou o quadro normativo brasileiro, bem como a contratação de serviços dessa tecnologia na administração 
pública federal. Além disso, foram elaboradas uma matriz de referência e uma tabela de riscos e possíveis controles.

Ao finalizar o trabalho, ainda de acordo com o Acórdão: 1.739/2015-TCU-Plenário, chegou-se à conclusão de que a computação em nuvem possui vantagens, principalmente para o âmbito público, que superaram os riscos inerentes a sua adoção. Ainda foi percebido cautela por parte dos gestores para a adoção da tecnologia mencionada, devido ao decreto 8.135/2013 e a Portaria Interministerial 141/2014. Além disso, salienta que as organizações devem identificar os riscos, fatores econômicos e técnicos para poder tomar decisão quanto a contratação do serviço de computação em nuvem.

Diante do trabalho realizado e após análise de fatores econômicos e técnicos, o TCU sentiu a necessidade e decidiu inovar aderindo 0 serviço de computação multinuvem, suporte especializado e treinamento, durante trinta meses, podendo ser prorrogado por igual período. Sendo assim, publicou um edital, em dezembro de 2016, de acordo com a Lei n. 10.520/2002, o Decreto n. 5.450/2005, a Lei Complementar n. $123 / 2006$, a Lei n.ㅇ 8.666/1993 e outras normas aplicáveis.

De acordo com Tidd, Bessant e Pavitt (2005), a inovação pode ser classificada em quatro categorias: Inovação de produto, processo, posição e de paradigma. Assim, acredita-se que a inovação no processo do TCU se deu com a alteração na forma de manutenção e fornecimento dos dados, pois o processo foi alterado para melhor atender as necessidades de mercado e a sociedade, reduzindo custos e proporcionando melhorias.

\section{METODOLOGIA}

A presente pesquisa em relação aos objetivos é descritiva, de acordo com Prodanov e Freitas (2013), este modelo ocorre quando o pesquisador registra $e$ descreve os fatos observados sem interferir neles, envolvendo o uso de técnicas padronizadas de coleta de dados.

A sua classificação com base nos procedimentos técnicos é do tipo documental, segundo GIL (2008) este modelo assemelha-se bastante com a pesquisa bibliográfica, tendo como diferença essencial a natureza das fontes, pois enquanto a pesquisa bibliográfica se utiliza, principalmente, das contribuições de vários autores sobre o tema abordado, a pesquisa documental usa materiais que ainda não receberam um tratamento analítico, ou ainda que podem ser reelaborados de acordo com os objetos da pesquisa.

No que tange a forma de abordagem do problema esta pesquisa pode ser classificada como qualitativa, conforme Sampiere, Collado e Lucio (2013) esse processo proporciona uma maior profundidade aos dados, dispersão, riqueza interpretativa, contextualização do ambiente ou entorno, detalhes e experiências únicas. Além de trazer flexibilidade e um ponto de vista novo, naturais e holísticos dos fenômenos.

Assim, a pesquisa em questão é classificada como descritiva, por descrever os principais pontos abordados no edital do TCU para adesão de serviços de computação em nuvem e por registrar o processo de revogação e reabertura, com a finalidade de servir como base para outras instituições públicas brasileiras que tenham interesse em aderir o serviço tratado.

Além disso, será realizado um levantamento de dados, através de leis e documentos públicos, a respeito da computação em nuvem voltada, principalmente, ao cenário do setor público. O TCU de Brasília será o ambiente abordado por ser um dos órgãos federais a criar um edital para aderir esse tipo de serviço. Ainda se observado as vantagens da computação em nuvem, este trabalho não só terá como participantes e interessados as instituições públicas, como também toda a sociedade brasileira. Portanto, percebe-se que a técnica de análise dos dados deste trabalho está voltada a análise de conteúdo (documental) e tida como qualitativa.

\section{ANÁLISE DOS RESULTADOS}

O planejamento para a contratação de bens ou serviços é primordial, pois possibilita que os riscos envolvidos no processo possam ser gerenciados, verifica a viabilidade do negócio, permite um alinhamento em relação a contratação e o planejamento estratégico da TI (PDTI) e da instituição (PEI), bem como um melhor gerenciamento do recurso 
público sendo aplicado de acordo com a necessidade da organização.

Esta fase é tão importante que está prevista no Decreto-Lei № 200/1967, como princípio fundamental que deverá ser seguido nas atividades da administração pública federal e na Instrução Normativa 04/2014, como a primeira fase para a contratação de soluções de informática, que é o Planejamento da Contratação, seguido da seleção do fornecedor e gestão do contrato.

Assim, as instituições da administração pública que querem aderir ao serviço de nuvem, devem iniciar realizando um planejamento, incluindo análise e levantamento dos riscos inerentes à contratação, assim como o TCU através do acórdão 1.739/2015, que serviu como base para a abertura do edital de no 106/2016, que teve sua abertura em dezembro e tinha como finalidade a contratação de serviço multinuvem, suporte técnico especializado e treinamento.

No edital supracitado, o tipo de pregão determinado foi o eletrônico tradicional, o que é estabelecido pelo acórdão 2.471/2008- Plenário do TCU e a instrução normativa 04/2014, no art. 26, para a contratação de soluções de informática, quando se enquadrarem em bens e serviços comuns. Assim, as instituições da administração pública federal que quiserem aderir o serviço de computação em nuvem e/ou multinuvem, devem também aderir a modalidade pregão eletrônico, possibilitando um maior número de participantes e diminuição de custos.

Outro fator observado, no edital, foi em relação a empresa contratada que tinha como papel ser um intermediador de nuvem ou broker, permitindo um melhor gerenciamento e aproveitamento dos recursos da nuvem. Assim, o broker possui vantagens quanto a contratação de provedores diretamente, porque permite a instituição um melhor aproveitamento das oportunidades e vantagens disponibilizadas pela computação em nuvem.

Desse modo, pode-se assumir que a contratação diretamente com provedores é possível, mas esta pode não ser a escolha ideal, pois a integração dos serviços pode tornar-se complexa e difícil de gerenciar, por parte do cliente. Por isso, recomenda-se que a empresa pública contratante, opte pela contratação do broker.
Ainda foi percebido a importância de não permitir a participação de uma mesma empresa como broker e provedora de serviço, justamente com objetivo de evitar conflitos de interesses e balancear os preços dos serviços, conforme mencionado pelo TCU de Brasília.

No que tange a localização dos dados, tema bastante discutido no âmbito da administração pública, principalmente em relação a segurança nacional, foi determinado em edital que um provedor deveria permitir que os dados do TCU residissem no território nacional, deixando o segundo em aberto, podendo localizar em outro país.

Apesar do decreto de № 8.135 e a portaria interministerial 141/2014 abordarem o tema, ainda que indiretamente, defendendo que as comunicações de dados da Administração Pública Federal devem ocorrer através de redes e serviços de tecnologia da informação fornecidos por meio de órgãos e/ou entidades do setor público. Ou seja, os dados seriam guardados em data centers localizados fisicamente no Brasil, ambos possuem exceções permitindo que seja também contratados fornecedores privados e multinacionais. Até porque, atualmente, não existe nenhuma lei que obrigue o armazenamento dos dados da administração pública apenas em território brasileiro.

Nesse âmbito, acredita-se que a importância em manter os dados no Brasil está voltado a segurança nacional e a jurisdição, sendo adequado a dados sensíveis ao governo brasileiro. No entanto, os dados abertos que devem ser acessíveis pelos cidadãos brasileiros poderiam ser armazenados em outro país, porque mesmo que armazenados em território nacional, seriam informações públicas, para atender ao princípio da transparência, permitindo também aos estrangeiros 0 acesso a tal informação.

Portanto, as entidades da administração pública que se interessam na adesão da computação em nuvem devem observar e ponderar os dados a serem utilizados, para então tomar a decisão de estabelecer que os provedores armazenem os dados apenas no Brasil e ainda escolher a melhor forma de implantação (nuvem pública, híbrida, privada, comunitária).

Percebeu-se ainda que a determinação dos 
valores dos serviços a serem oferecidos, bem como a estimativa de uso, é de suma importância para o processo de adesão da computação em nuvem na administração pública. Apesar de o edital 106/2016 demonstrar e explicar os cálculos realizados para determinar os valores dos serviços, adquiridos através de USN, servindo de base para os demais órgãos e entidades, faz-se necessário que os órgãos interessados identifiquem a sua infraestrutura atual de forma a estimar a quantidade específica de serviços necessários para a continuidade e desenvolvimento das atividades, até porque tal estimativa influenciará no valor total de contratação.

Além disso, foi identificado no edital o pagamento upfront, de forma adiantada, com a finalidade de proporcionar economia de recursos, porém não foi encontrado regulamentações estabelecidas pelo governo quanto ao pagamento antes da execução dos serviços voltado ao tema computação em nuvem, sendo um assunto a ser abordado de forma a gerar insumos para novas regulamentações. O TCU, por sua vez, realizará o pagamento adiantado devido a jurisprudência do Tribunal, dentre elas o acórdão no 276/2002-1aㅡ Câmara, que os possibilita a antecipação.

Foi possível detectar também que o TCU exigiu em edital que os dados deveriam estar disponíveis ao término do contrato de forma a ser migrados para outro provedor, visando a continuidade do negócio de forma a manter os dados disponíveis. De acordo com a NBR 22301:2013, que retrata sobre o Sistema de Gestão de Continuidade de negócio (SGCN), faz-se necessário compreender as necessidades da organização e estabelecer políticas e objetivos para a gestão da continuidade de negócio, de forma a gerenciar incidentes de interrupção.

À vista disso, essa exigência é de fundamental importância e deve ser um assunto que todas as organizações devem abordar ao pensar na contratação do serviço de nuvem, porque permite a continuidade dos processos ou ainda mitiga - tempo de interrupção para que a informação possa ser disponibilizada novamente.

O edital 106/2016, ainda abordou a predominância da legislação brasileira sobre qualquer outra. Através de tal exigência foi identificado uma preocupação quanto ao tratamento dos dados e as leis que devem regê-los, sendo bastante importante, mesmo que os dados sejam públicos, pois em caso de problemas, pode-se assegurar que a lei do Brasil é quem vai prevalecer, não ficando a mercê de nenhuma outra jurisdição.

A contratação do suporte técnico, presente no edital, foi de suma importância, pois permite a mitigação do risco quanto a interrupção do serviços e quando este ocorre, o tempo para resolução do problema pode ser determinado através de SLA's, como o exigido pelo TCU, em que a resposta aos chamados críticos devem ser em um tempo inferior a 30 minutos.

Ainda nesse contexto, o suporte remoto foi mencionado em edital sendo muito útil, pois permite uma maior agilidade na resolução do problema, devido a diminuição do tempo, tendo em vista que o responsável pela requisição não precisará se deslocar até o local que está havendo o problema. Além disso, possibilita um menor custo quanto ao valor do chamado, tendo em vista que não será necessário custear o deslocamento do funcionário até o local em que está ocorrendo o problema. No entanto, às vezes, faz-se necessário a presença física para a resolução do chamado, como em caso de substituição de peças, por exemplo, por isso, foi previsto também em edital, sendo recomendado a sua inclusão no processo de adesão.

Outro fator observado e que também deve ser seguido pelas demais organizações públicas é quanto ao pagamento do suporte através de Unidade de Serviço TécnicoUST, que equivale ao esforço padronizado de acordo com a complexidade, independente da alocação de recursos humanos. O que permite dizer que os valores serão determinados de acordo com os serviços executados, independente do currículo do funcionário que está executando as tarefas e o nível de suporte ao qual ele pertence na organização .

O conceito de computação em nuvem e as ferramentas em relação à sua utilização, como identificado, ainda causa confusão em pessoas da área de tecnologia da informação. Sendo de grande valia o treinamento no processo de migração.

Por isso, as empresas que se interessam 
em adquirir o serviço de nuvem devem também incluir o treinamento para que a equipe possa conhecer os conceitos e técnicas utilizadas tanto no processo de migração quanto na continuidade e manutenção dos dados.

Por fim, outro ponto identificado através dos resultados, foi a prática de demonstração dos serviços que é uma forma de atestar o serviço oferecido, para saber se é viável a contratação e se atende a todos os requisitos do edital. Esse procedimento é permitido de acordo com Antônio e Carlos (2013) e tem a finalidade de mitigar risco de o produto ou serviço ser inviável para a administração pública. Assim, a aprovação da amostra é uma etapa necessária para a adjudicação do objeto, podendo a empresa ser aceita ou excluída (desclassificada) ao longo do processo, mesmo que tenha apresentado o menor preço. Essa exigência deve ser seguida pelas demais organizações que pensam em criar e publicar edital, principalmente as que desejam aderir os serviços de computação em nuvem, pois é possível atestar que os dados serão armazenados e tratados conforme as regras estabelecidas.

\section{CONSIDERAÇÕES FINAIS}

O objetivo deste trabalho foi identificar os principais pontos abordados pelo TCU em seu primeiro edital de $\mathrm{n}^{\circ}$ 106/2016 para a adoção da computação em nuvem, inovando o uso do tratamento dos dados no âmbito público. Além disso, buscou-se orientar e ampliar o conhecimento para que outros órgão federais possam ter a mesma iniciativa de aderir o serviço tratado.

Para tanto, foi realizada uma pesquisa documental de forma a analisar os principais pontos estabelecidos no edital e fundamentá-los em relação às leis, proporcionando sugestões para que outras instituições possam ter como base e, até mesmo, para que possam incluir em seu escopo, ao pensar em aderir o serviço de computação em nuvem.

Ao longo desse processo, percebeu-se que a primeira etapa para as organizações que querem aderir o serviço de computação em nuvem, consiste em realizar um planejamento, de forma a atender ao Decreto-Lei № 200/1967 e a instrução normativa 04/2014.
Foi possível também identificar que a modalidade pregão eletrônico é adequada para este processo e tem vantagens por permitir alcançar um maior número de participantes e diminuição de custos.

Contatou-se ainda que a contratação de empresas com a função de broker é muito importante, pois além de intermediar a comunicação entre os provedores e o cliente, é responsável por gerenciar os serviços da nuvem, de forma a garantir todas as vantagens relacionadas ao serviço e mitigar riscos ao longo do processo.

A localização dos dados foi um dos assuntos mais polêmicos a ser tratado, pois apesar de algumas leis e documentos, tais como: O decreto № 8.135, Portaria Interministerial 141/2014 e o manual de Boas Práticas emitido pelo ministério do planejamento, retratar sobre o tema e incentivar o armazenamento de dados no Brasil, principalmente visando a segurança nacional, ainda não existe nenhuma regulamentação que obrigue tal fato, pelo contrário existem exceções que permitem a contratação de provedores nacionais, bem como internacionais.

Foi percebido ainda a importância da exigência da predominância da legislação brasileira frente a qualquer outra, pois em caso de problemas relacionados aos dados, estes não ficarão a mercê em relação às leis de outros países.

A identificação quanto a demonstração dos serviços como uma das etapas do processo, foi de suma importância, pois é um meio de confirmar que os serviços oferecidos irão atender as exigências estabelecidas em edital, visando alcançar as necessidades da administração pública.

A abordagem, por parte do TCU, no edital relacionada a migração dos dados após o término de contrato permitiu compreender que esta exigência está atrelada a continuidade dos serviços, sendo de fundamental importância, por não ficarem presos a plataformas específicas ou a fornecedores.

Vale ressaltar como implicação a revogação do edital, devido a muitos questionamentos realizados ao TCU por parte das licitantes, sendo necessária uma revisão geral dos termos.

Contudo, notou-se a importância dos serviços de computação em nuvem para o 
órgão do TCU, pois os termos já foram revisados e o edital para a contratação do serviço abordado foi reaberto através do edital 22/2017.

No que tange a limitação de pesquisa, a primeira consiste em que os pontos considerados importantes foram escolhidos pelo autor, sendo algo subjetivo. A segunda foi tomar como base apenas o órgão do TCU de Brasília, pois acredita-se que a análise em outros órgãos, permitiria uma melhor discussão. Outro aspecto foi a ausência de entrevistas que possibilitaria resultados

\section{REFERÊNCIAS}

[1] Amalho, N. C. L (2012). Um Estudo Sobre a Adoção da Computação em Nuvem noBrasil.São Paulo: USP.

[2] Daud, A. J. \& Renato, C.A.B (2013). Avaliação de Amostras em pregão para contratação de objetos de TI. Revista do TCU.

[3] Decreto n. 12.737, de 30 de novembro de 2012 (2012). Dispõe sobre a tipificação criminal de delitos informáticos. Brasília, DF.

[4] Decreto n. 3.555, de 08 de agosto de 2000 (2000). Aprova o regulamento para a modalidade de licitação denominada pregão, para aquisição de bens e serviços comuns. Brasília, DF.

[5] Decreto n. 5.450, de 31 de maio de 2005 (2005). Regulamenta o pregão, na forma eletrônica, para aquisição de bens e serviços. Brasília, DF.

[6] Decreto n. 7.175, de 12 de maio de 2010 (2010). Institui o Programa Nacional de Banda Larga. Brasília, DF.

[7] Decreto n. 8.135, de 04 de novembro de 2013 (2013). Dispõe sobre as comunicações de dados da administração pública federal. Brasília, DF.

[8] Diniz, I.V.L., Costa, L.S. \& Medeiros, M.F.M. (2017). Utilização da computação em nuvem no poder legislativo: percepções dos gestores e entraves ao uso. Revista Brasileira de Políticas Públicas (online), 7(1), 264-285. Recuperado em 26 maio, 2017, de https://www.publicacoesacademicas.uniceub.br/RB PP/article/viewFile/4586/pdf

[9] Diógenes, Y. D. \& Veras, M.V. (2014). Cloud Essentials: Guia Preparatório para o Exame CLO-001. (Ed. Alberto Garcia). Rio de Janeiro: Nova Terra.

[10] Drobik, A. \& Maoz, M. (2016). Adapting your IT Strategy for a Cloud-Dominated Business Application Environment. Gartner. Recuperado em 11, junho, 2017, de https://www.gartner.com/doc/3422117?ref=SiteSear ch\&sthkw=Advantages\%20of\%2 mais aprofundados.

Por fim, recomenda-se ampliar esta pesquisa para outros órgãos da administração pública que tenha a iniciativa de aderir o serviço de nuvem, realizando entrevistas com os envolvidos no processo, com a finalidade de aprofundar o assunto estudado, bem como voltar- se ao processo de reabertura do edital, com a finalidade de acompanhar o desfecho do processo, produzindo mais conhecimento a respeito do tema e permitindo o aumento de insumos para novas regulamentações.

Ocloud\%20 computing\&fnl=search\&srcld $=1$ 3478922254

[11] Fernando, M. F. M. M \& Veras, M. V. S. N. (2016, janeiro/abril). Uso da Computação em Nuvem no Setor Público: Um estudo de Caso com Gestores de TI do Estado do Rio Grande do Norte e do Governo Federal. Revista Gestão \& Tecnologia, Pedro Leopoldo, 16 (1) , 135-156. Recuperado em 25 maio, 2017, de https://revistagt.fpl.edu.br/get/article/view/790/644

[12] Fernando, M. M. M. (2014). Computação em nuvem no governo: caminhos para a formação de uma agenda governamental. Tese de doutorado, Universidade Federal do Rio Grande do Norte, Natal, RN, Brasil. Disponível: https://repositorio.ufrn.br/jspui/bitstream/123456789 /19532/1/MarcosFernandoMachadoDeMedeiros_TE SE.pdf

[13] Galdino, W. E. \& Souza, J. N. (2015, abril/junho). Modelo de avaliação da capacidade das organizações da administração pública federal para a adoção de software as a service (SaaS) público. Revista Serv. Público, 67 (2), 173-202. Recuperado em 25 maio, 2017, de https://revista.enap.gov.br/index.php/RSP/article/vie w/1477/761.

[14] Gil, A. C. (2008). Como elaborar projetos de pesquisa. 5. ed. São Paulo: Atlas. Gil, A.C. (2002). Como Elaborar Projetos de Pesquisa (4a ed.). São Paulo: Atlas.

[15] Godoy, A. S. (1995). Introdução à Pesquisa Qualitativa e suas possibilidades: Uma revisão histórica dos principais autores e obras que refletem esta metodologia de pesquisa em Ciências Sociais. Revista de Administração de Empresas, 35( 2), 57-63. Recuperado em 25 maio, 2017 .

de http://bibliotecadigital.fgv.br/ojs/index.php/rae/articl e/download/38183/36927

[16] Hernández, R.S.; Fernández, C.C.; Pilar, M.D.B.L. Metodologia de Pesquisa (5a ed.). São Paulo: Penso. 
[17] Information Systems Audit and Control Association - ISACA (2012). Princípios norteadores de adoção e uso da computação em nuvem. Recuperado em 25 maio, 2017, de http://www.isaca.org/Knowledge-

Center/Research/Documents/Guiding-PrinciplesCloud_whp_Por_0212.pdf?regnum =380918

[18] Kundra, V. (2011) Federal Cloud Computing Strategy. Recuperado de https://www.dhs.gov/sites/default/files/publications/ digital-strategy/federal-cloud-computingstrategy.pdf

[19] Lei n. 12.965, de 23 de abril de 2014 (2014). Dispões sobre princípios, garantias, direito e deveres para uso da internet no Brasil. Brasília, DF.

[20] Ministério da Ciência, Tecnologia e Inovação (2016). Estratégia Nacional de Ciência, Tecnologia e Inovação (2016-2019). Brasília. Recuperado em 28, maio, 2017, de http://www.mcti.gov.br/documents/10179/1712401/ Estrat\%C3\%A9gia+Nacional+de+

Ci\%C3\%AAncia\%2C\%20Tecnologia+e+Inova\%C3 \%A7\%C3\%A3o+2016- 2019/0cfb61e1-1b84-4323b136-8c3a5f2a4bb7

[21] Ministério do Planejamento, Orçamento e Gestão (2016). Computação em Nuvem: dados devem permanecer no Brasil. Governo Eletrônico. Recuperado em 11, junho, 2017, de https://www.governoeletronico.gov.br/noticias/com putacao-em-nuvem-dados-devem- permanecer-nobrasil

[22] Monti, M. Projeto de Lei (2012). Dispõe sobre o tratamento de dados pessoais.

[23] Portaria Interministerial n. 141, de 02 de maio de 2014 (2014). Dispõe sobre Comunicação de dados da administração pública federal. Diário Oficial da União. Brasília, DF. Recuperado em 28 maior, 2017, de http://pesquisa.in.gov.br/imprensa/jsp/visualiza/ind ex.jsp?data $=05 / 05 / 2014 \&$ jornal $=1$

\&pagina $=82 \&$ totalArquivos $=148 \quad \mathrm{Nbr} \quad$ ISO 22301:2013, (2013). Sistema de Gestão de Continuidade de Negócio.

[24] Prodanov, C.C. \& Freitas, E.C. (2013). Metodologia do Trabalho Científico: Métodos e Técnicas da Pesquisa e do Trabalho Acadêmico (2a. ed.). Novo Hamburgo: Universidade Fee Vale.

[25] Schubert, L., Jeffery, K. \& Neidecker, L. B. (2010). The future of cloud computing: Opportunities for European cloud computing beyond 2010 (v.1). Europa: Expert Group report.

[26] Scott, D. (2017). What ClOs Need to Know and Do to Exploit Cloud Computing. Gartner. Recuperado em 11, junho, 2017, de https://www.gartner.com/doc/3369117?ref=SiteSear ch\&sthkw=Advantages\%20of\%2 Ocloud\%20 computing\&fnl=search\&srcld $=1$ 3478922254

[27] SERPRO. Reduza os seus custos com infraestrutura de TI. Recuperado em 01, junho, 2017, de https://servicos.serpro.gov.br/ics/

[28] Serviços de Computação em Nuvem Consulta Pública (2017). Recuperado em 12, junho, 2017, de http://www.participa.br/contratacao-deservicos-de-computacao-em- nuvem/servicos-decomputacao-em-nuvem-consulta-publica

[29] Simião, J. D. \& Roberta, K. R. S. (2016, setembro). Cloud Computing: em busca da compreensão de seu uso em organizações públicas. Conferência da Associação Portuguesa de Sistemas de Informação, Porto, Portugal, 16, 178-192. Recuperado em 26 de maio, 2017, de http://capsi.apsi.pt/index.php/capsi/article/downloa d/484/438

[30] Simião, J. D., Roberta, K. R. S. \& Nobre, A. A. (2017). Computação em nuvem: averiguando o seu uso em ambientes de gestão pública. International Conference on Information System \& Technology Management, 14. Recuperado em 26 maio, 2017, de http://www.contecsi.fea.usp.br/envio/index.php/con tecsi/14CONTECSI/paper/view/45 70/2889

[31] SISP (2011). Recuperado em 10, junho, 2017, de http://www.sisp.gov.br/faq_sisp/one-faq? faq_id=13929432

[32] Tribunal de Contas da União (2016). Conhecendo o Tribunal / Tribunal de Contas da União (6. ed.). Brasília : TCU, Secretaria-Geral da Presidência. 36 p. : il. color. 1.Tribunal de Contas da União. 2. Controle externo. 3. Fiscalização. I. Título Brasil.

[33] TIDD, J.; BESSANT, J.; PAVITT, K. Gestão da inovação. 3. ed. Porto Alegre: Bookman. 2005.

[34] Vasco, L. V. S. \& Eugênia, M.E.F. (2014). A necessidade de Regulação Legislativa para Utilização do Serviço de Computação em Nuvem. Revista Estudos Legislativos, 8 (8), 81-102. Recuperado em 26 maio, 2017, de http://submissoes.al.rs.gov.br/index.php/estudos_le gislativos/article/view/154/pdf 


\section{Bapítulo 20}

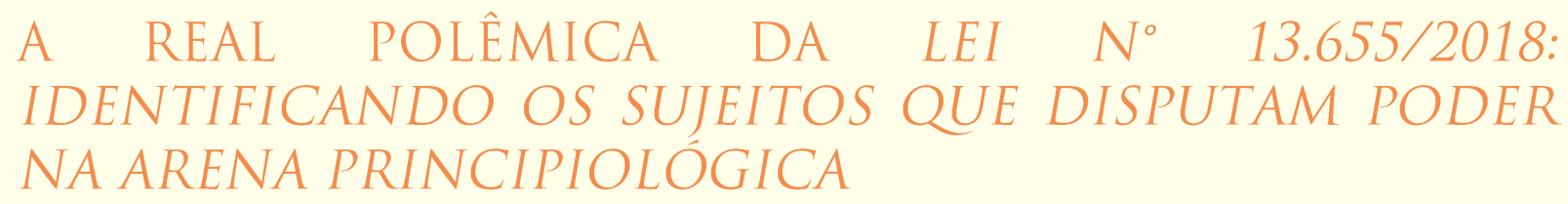

Ana Margareth Moreira Mendes Cosenza

Carlos Henrique Santana Cosenza

Resumo: Em 25 de abril de 2018, foi publicada a Lei n¹3.655, a qual acrescentou nove artigos sobre segurança jurídica e eficiência na criação e na aplicação do direito público na Lei de Introdução às Normas do Direito Brasileiro. A referida lei evidencia diretrizes de ação e tenta limitar a discricionariedade e a imprevisibilidade de decisões com base em conceitos abstratos, alheias aos seus reais impactos. Como se vive um momento de grande ativismo dos órgãos controladores, fundamentado em princípios, foi recebida com grande polêmica no mundo jurídico. Dividiu-se entre os apoiadores da retomada da segurança jurídica em prol de maior deferência entre lei abstrata e caso concreto, com a limitação da atividade criadora, trazendo previsibilidade e responsividade ao Direito Público e aqueles que defendem o reconhecimento de direitos fundamentais através dessas decisões criadoras, nas lacunas das leis, combatendo a letargia do Legislativo e do Executivo na identificação de demandas socio-jurídicas. Através de análise crítica do texto legal e dos interesses políticos nele contidos, do lugar de fala dos atores envolvidos, da discricionariedade de gestores e de controladores, buscar-se-á evidenciar como o Direito Público é utilizado como um instrumento para alcance de objetivos nobres e espúrios, conforme os interesses em voga; e como declarar o óbvio pode ser fundamental para que não se dependa de bom senso.

Palavras-Chave: Direito Público. Interpretação. Controladores. Gestão Pública. O artigo foi aprovado e apresentado no XI CASI - Congresso em Administração, Sociedade e Inovação organizado pela ECEME e UFF, em 6 e 7 de dezembro de 2018, em Rio de Janeiro/RJ. 


\section{INTRODUÇÃO}

O Brasil não possui uma legislação única especializada em Direito Administrativo. Como sua produção ocorre simultaneamente nas três esferas federativas, está esparso em diversas legislações, jurisprudências e normativos do Poder Executivo: decretos, resoluções, portarias, enunciados, regulamentos internos, manuais e etc. (CARVALHO, 2015, p.85).

Além disso, não havia uma norma federal que orientasse e limitasse essa atividade criadora da Administração Pública. A produção normativa foi muito utilizada como meio de procrastinação da devida prestação pública, através de exigências e de ritos formais que mais se prestam a restringir direitos e a manter privilégios do que a agregar valor aos processos. Reduziu-se o administrado a hipossuficiência, ante a ditadura estatal. (CARVALHO, 2015, p.57; SUNDFELD 2012, p.33, 40).

Mas o poder normativo da Administração Pública, com excessivos conceitos indeterminados e princípios, alheio às consequências, não é o único problema combatido pela Lei $n^{\circ} 13.655 / 2018$. Este tipo abstrato e irresponsivo de motivação de decisões, também se dá nos órgãos de controle (judiciais, legislativos e administrativos) elevando a insegurança jurídica.

Com o desenvolvimento das instituições de procedimentos do Direito, os profissionais jurídicos passaram a se dedicar à crítica das autoridades, analisando e interpretando o significado de normas e regras e dedicandose a regularidade procedimental. Os juízes se viram, então, ante oportunidades para asserção de direitos, gerando uma jurisprudência centrada em direitos, descolando-se da interpretação literal da lei e da autolimitação, em suas decisões.

O ativismo dos controladores e a substituição do controle de legalidade pelo de juridicidade ampliaram as obrigações estatais baseadas em conceitos legais indeterminados, dificultando a atuação do Executivo na gestão pública. A abstração da interpretação principiológica possibilita soluções opostas para casos iguais, conforme a convicção pessoal do julgador. Alvo de controles altamente discricionários, a Administração Pública passou a limitar-se às concepções dos fiscalizadores, sem inovações, em postura pró indeferimento, em nome da tranquilidade. (KRELL, 2013, p.76; SUNDFELD, 2012, p.37).

Eis a relevância da lei ํำ13.655/2018, sobre segurança jurídica e eficiência na criação e na aplicação do direito público, alterando a Lei de Introdução às Normas do Direito Brasileiro. Devolver objetividade e previsibilidade ao Direito Público, dando-Ihe boa dose de responsividade. Ainda que trate de institutos previstos em leis esparsas, em doutrinas e jurisprudências, ao declará-los como diretrizes interpretativas, indicando as condutas preferenciais à resolução dos conflitos com a Administração Pública, limita a discricionariedade interpretativa das autoridades públicas.

Assim, o presente artigo objetiva analisar o impacto das novas diretrizes de interpretação jurídica postas para o Direito Público, em nome da segurança jurídica da Administração Pública e de quem com ela se relaciona. Para tanto, identificar-se-ão os interesses e os atores em disputa de poder na arena principiológica do Direito Público. Em revisão bibliográfica, pouca pesquisa localizou-se, haja vista ser lei recente, revelando carência de análise socio-jurídica de suas implicações na vida dos gestores públicos.

\section{FUNDAMENTAÇÃO TEÓRICA}

A teoria envolvida no fato em análise repousa sobre as relações entre os poderes da República. Às vezes mais contidas em suas áreas de atuação, outras mais invasivas sobre a bandeira do controle constitucional sobre os demais, o sistema de freios e contrapesos segue sendo operado através da medição de forças entre Legislativo, Judiciário e Executivo, ao menos.

As colocações a seguir pretendem demonstrar como, no papel de controlador, exercido pelos três poderes, o Judiciário se agigantou livremente, posto que controlado apenas por suas próprias instâncias e por seu Conselho Nacional de Justiça (CNJ). Enquanto que, por outro lado, o Executivo foi contido à inação. (BRASIL. CRFB, 1988, art.92, inc.I-A; art.103-B, §4%).

\subsection{DEMARCANDO OS PERÍMETROS DO DIREITO E DA POLÍTICA}

Primeiro veio a República, em 1891, e separou três funções preponderantes do Estado em órgãos distintos, independentes e 
harmônicos entre si: Legislativo, Executivo e Judiciário. Depois, ao organizar o Judiciário, a referida Constituição incorporou o recémcriado controle de constitucionalidade concreto e difuso, aos moldes estadunidense, de modo que todos os juízes e tribunais controladores poderiam deixar de aplicar leis e atos normativos quando entendessem pela afronta constitucional. Doravante, nunca mais a separação entre os poderes foi a mesma. (BRASIL. Decreto ำ 848 do Governo Provisório apud SOUZA NETO e SARMENTO, 2013, p.110).

O controle de constitucionalidade como atribuição de Corte Superior Especializada, modalidade difusa, não dissipa tanto a atividade judicial controladora sobre os outros Poderes quanto o modelo concreto, mantido na ordem constitucional até hoje. A adoção do controle concreto elevou a judicialização de questões político-administrativas rogando-se, notadamente, pela proteção à direitos fundamentais e princípios constitucionais. (KELSEN, 1928, apud SOUZA NETO e SARMENTO, 2013, p.27, 29; CAMPOS, 1941, apud SOUZA NETO e SARMENTO, 2013, p.32).

Importa destacar que o controle de constitucionalidade deve ser feito por todos os poderes do Estado. Quando o fazem a Administração Pública e o Legislativo, diz-se controle político, em contraposição ao controle judicial. São mecanismos do controle político: os vetos dos chefes dos Poderes Executivos das três esferas aos projetos de lei; as Comissões de Constituição e Justiça das casas legislativas e a opção de a Administração afastar execução de lei ou ato normativo que julgue inconstitucional. (BRASIL. CRFB, 1988, art.66, §1; SOUZA NETO e SARMENTO, 2013, p.26).

Há, também, controle político e judicial sobre a legalidade de normas e atos infraconstitucionais. Busca-se incompatibilidades entre ato administrativo e as normas legais; entre legislações de hierarquias diferentes, ou contra disposições especiais; ente atos, normas e princípios gerais do Direito. (BRASIL. LINDB, Decreto-lei no $4.657,1942$, art. $2^{\circ}, \S 1^{\circ}$ e $\left.\S 2^{\circ}\right)$.

Desenvolvendo, cabe apresentar duas conceituações: judicialização e ativismo judicial. A primeira refere-se ao deslocamento do centro de decisão sobre importantes questões políticas, sociais e morais para 0 Judiciário. Dentre os vários motivos constam o fato de a Constituição ser analítica e tratar de vários de temas - uma vez que um conteúdo político é positivado, ele se torna um assunto jurídico passível de judicialização; existir um extenso rol de legitimados a propor ações diretas ao Supremo Tribunal Federal; necessidade de um Judiciário forte para proteção dos direitos fundamentais; descrédito das instituições políticas frente aos flagrantes casos de corrupção e ineficiência; e estratégia político-administrativa, adotada por agentes do Legislativo e do Executivo, de estimular a judicialização de assuntos controversos. Evitam, assim, decisões não populistas que os desgastarão ante a opinião pública e, atendendo apenas os que judicializam e ignorando os que não ajuizam, economizam recursos com inequidades (trato desigual). (BARROSO, 2013, p.39).

Já a segunda refere-se a uma atitude que amplia a atuação do Judiciário por meio de interpretação constitucional para suprir lacunas, omissões e determinar políticas públicas quando inexistentes ou ineficientes. Seria uma atividade criadora do Direito complementar às exercidas pelo Legislativo e Executivo, posto que cabível somente na falha daqueles. Como é impossivel prever todas as situações concretas da complexa vida, verifica-se infindável lacuna legal, só limitável pelo próprio Judiciário. (BARROSO, 2013, p.39, 40 e 42; SOUZA NETO e SARMENTO, 2013, p.32).

São fenômenos que elevam as oportunidades de o Judiciário criar Direitos e Política. Além das normas individuais concretas, através de decisões reiteradas, formam-se jurisprudências, súmulas, decisões de repercussão geral; invalidam-se leis, atos e contratos; criam-se normas que preenchem lacunas legais e definem políticas públicas. Isto é, expande-se a atuação judicial em funções estatais políticas, na cômoda posição de quem dá a última palavra sobre a regularidade do objeto da ação.

\subsection{CRÍTICAS À AMPLIAÇÃO DA ATUAÇÃO E À DISCRICIONARIEDADE DO JUDICIÁRIO}

Eclode aqui a crítica de ser o Judiciário um local de origem conservadora, de preservação de elites e refreamento de processos democráticos, ou seja, tendente a decisões contramajoritárias. Assim, infringirse-iam limitações às maiorias, permitindo que o Judiciário invalidasse decisões do legislador eleito pelo povo e retirasse a possibilidade de 
participação popular na definição das políticas públicas. Ressalta-se que o excesso de decisões contramajoritárias levariam a impossibilidade de um povo se autogovernar. (BRASIL. CRFB, 1988, art.60, §4, inc.III; BARROSO, 2013, p.40-42; LENZA, 2009, p.340; SOUZA NETO e SARMENTO, 2013, p.31-32, 36, 205; SUNDFELD, 2012, p.78).

Outro ponto fraco reside na abstração e na abertura de considerável parte das normas, as quais, não raras vezes, são utilizadas para afastar a vontade dos agentes políticos, sobrepondo-lhes a vontade dos magistrados. Normas de caráter aberto podem assumir mais de uma interpretação, sujeitas a valorações diferentes. No entanto, tais abstrações não são falhas do sistema legal, prestam-se como instrumentos para disputas de poder, como adiante será desenvolvido. Verifica-se uma crescente discricionariedade no conteúdo das decisões judiciais, com determinações ligadas a questões de mérito administrativo e político. (BARROSO, 2013, p.39, 40-42; SOUZA NETO e SARMENTO, 2013, p.31-32; SUNDFELD, 2012, p.69).

Quando se fala em ativismo judicial inevitável é requestionar a cláusula pétrea da independência entre os poderes e o princípio da indelegabilidade das atribuições de um poder para outro, sem expressa previsão legal. Ao se decidir (administrativamente, politicamente ou judicialmente) com base em valores abstratos é feita uma interpretação de Direito que Ihes decifram o teor, isto porque a rarefação de conteúdo é tanta que se mostra incapaz de revelar a norma que neles estaria contida. É assim que se o Judiciário procede no preenchimento de lacunas legais e de prestações político-administrativas. (SUNDFELD, 2012, p.63).

O cerne do problema, agora, repousa em saber a quem cabe decifrar os conteúdos desses valores abstratos e quais seriam os direitos concretos garantidos por eles, posto que competência não se presume e várias são as possibilidades de políticas públicas. Caberia à Administração, ao Legislativo, à população ou ao Judiciário? E como fica a separação dos poderes e a indelegabilidade de suas atribuições? (SUNDFELD, 2012, p.63, 74).

Em tempo, critica-se que o Judiciário tem expertise para avaliar casos específicos, mas não tem preparo para avaliar o "efeito sistêmico" de decisões que repercutem sobre políticas públicas gerais. Políticas públicas são implantadas através de atos de gestão de recursos financeiros, materiais e humanos. A implantação de uma política pública possui custos econômicos e a Administração Pública, executora da ordem, possui recursos limitados para atender todas as demandas da sociedade. Abre-se aqui o campo de desenvolvimento da Análise Econômica do Direito e o impacto da distribuição judicial de direitos em construção, antecipando e usurpando o trabalho dos agentes políticos. (BARROSO, 2013, p.39, 40-42; MARTINS, 2017; SUNDFELD, 2012, p.72, 76).

Dentre os argumentos pró-ativismo judicial, lista-se que, diante da falência política do Legislativo e do Executivo, o Judiciário brasileiro teria assumido um papel representativo ao oferecer uma resposta às demandas sociais não atendidas pela instância política; tratar-se-ia de um mecanismo de proteção às garantias fundamentais, aos valores democráticos; tornara-se, assim, mecanismo de pressão compelindo os agentes políticos a decidirem as grandes questões sociais e políticas antes que o Judiciário faça. Quanto à capacidade institucional para políticas públicas, sustentase que os juízes devem ser autocontidos e deferentes aos outros Poderes em casos de questões técnicas complexas. (BARROSO, 2013, p.40, 42; SUNDFELD, 2012, p.72).

Dialeticamente, afastando-se da judicialização da política e das decisões fundadas em preceitos abstratos, propõe-se: seria possível manter o centro de tomada de decisões políticas nas mãos do Legislativo e do Executivo, como agentes políticos representantes do povo?

Para tanto a judicialização dessas questões deve ser evitada, afinal o Judiciário é inerte. Para este fim, as legislações não devem permanecer lacunosas, se omitindo de regular as grandes questões sociais, e o Executivo precisa de boas políticas públicas e de gestão eficiente. Tendo o pleito justo analisado e atendido junto aos entes políticos, a parte autora perde o interesse de agir, reduzindo a judicialização. (BRASIL. NCPC, 2016, art.17).

Por fim, destaca-se que a complexidade e o pluralismo da sociedade contemporânea impedem que o juiz se limite a mera aplicação da lei ao caso concreto e exigem que este sub-rogue o legislador e o gestor púbico. Ocorre que o juiz não pode se abster de solucionar, da melhor forma possível, a lide 
por falta de previsão legal de perfeita aderência ao caso concreto. Na ausência de norma, em que pese a redução da previsibilidade do direito, o Judiciário cria uma, a exemplo do reconhecimento de uniões homoafetivas. Assim conclui Barroso (2013, p.41): "Mas a culpa não é nem do juiz nem dos tribunais. A vida é que ficou mais complicada, impedindo o legislador de prever soluções abstratas para todas as situações". (BRASIL. CRFB, 1988, art.5o, inc. XXXV; BRASIL. LINDB, Decreto-lei ํo 4.657, 1942,

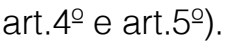

\subsection{UMA MUDANÇA NO PERFIL DO CONTROLE SOBRE OS ATOS DA ADMINISTRAÇÃO}

A atividade controladora, a elevação dos índices de judicialização e o ativismo judicial tem impactado diretamente a Administração Pública, em especial nos seguintes pontos: na fixação de políticas públicas e na responsabilização de agentes administrativos.

Os referidos fenômenos, com a acompanhante atividade criadora e discricionariedade das decisões, tem alterado conceitos e institutos fundamentais administrativistas. Nesse sentido, não mais se sustenta a impossibilidade de impugnação judicial do mérito administrativo. Este cedeu lugar ao controle por princípios, os quais são vagos, abertos e suscetíveis a várias interpretações e a valorações diferentes, definíveis durante as análises ponderadas de interesses. (SOUZA NETO e SARMENTO, 2013, p.42).

Da mesma forma, o princípio da supremacia do interesse público sobre o particular perdeu força ante a defesa de direitos fundamentais, mitigando o majoritário; assim como a legalidade administrativa estrita também não mais consegue justificar a inação da Administração frente a um comando constitucional, por exemplo, sob pretexto de não haver lei que a autorize a agir (Constituição é diretamente aplicável). O controle dos atos e normas por princípio e valores abstratos mudou a feição do sistema jurídico do país. (KRELL, 2013, p.75-76; SOUZA NETO e SARMENTO, 2013, p.42, 76).

Juntamente com 0 crescimento da judicialização desenvolveu-se o pragmatismo jurídico ou utilitarismo. O ativismo judicial busca a melhor solução e, julgando por princípios, não se vê refém dos enunciados legais. O pragmatismo retira os conteúdos metafísicos e platônicos, deixando espaço para que o juiz reflita objetivamente sobre eficiência, bem-estar e desenvolvimento social. Seu elemento constitutivo essencial é o consequencialismo: a decisão pelas consequências e resultados práticos. (BARROSO, 2013, p.263; KRELL, 2013, p.75).

O pragmatismo foi uma resposta ao realismo jurídico, o qual se insurgia ao formalismo positivista. A decisão deve considerar os resultados e não os princípios, pois estes não existem de fato e aqueles possuem custos, finalidades, ganhos e impactam terceiros. Surge, então um Direito comprometido com o resultado, responsivo às demandas sociais e em busca de efetividade legal. (BARROSO, 2013, p.263; NONET e SELZNICK, 2010, p.128).

Um Direito Responsivo considera as normas, políticas e procedimentos específicos como meros instrumentos para o alcance de uma finalidade maior como uma política pública, esta sim é o objetivo do ordenamento. A generalização da finalidade induz a flexibilidade nas organizações e normas. Esta preocupação com os resultados é uma consequência evolutiva do Direito Autônomo (burocrata e afirmador de si) para a Responsividade. Devido a sua complexidade, mais é preciso considerar a finalidade na elaboração de regras/sentenças. (DWORKING, 1976, apud NONET e SELZNICK, 2010, p.128; NONET e SELZNICK, 2010, p.129; MENEGAT, 2018).

Para decisões judiciais, administrativas e de controle que fixem políticas públicas calcular as consequências para saber os custos, tempo de retorno, o que deve ser investido é fundamental. Isto porque o agir da Administração Pública está limitado a um orçamento público finito e cheio de outras políticas a serem custeadas. (MARTINS, 2017; KELSEN, 2006, p.249).

Sobre a responsabilização de agentes administrativos, em especial as fundamentadas em conteúdos abstratos, relembra-se que as infrações administrativas têm a mesma natureza que as penais, aplicando-se os mesmos princípios de individualização da conduta e da pena, a não punição da modalidade culposa, sem previsão expressa e, principalmente, a tipificação da conduta. A constituição garante não haver crime "sem lei anterior que o defina, 
nem pena sem prévia cominação legal". (BRASIL. CRFB, 1988, art.5o, inc. XXXIX).

Critica-se, assim, a imputação de sanções administrativas sem que haja a anterioridade específica da conduta dita infracional. Verificam-se julgamentos de irregularidades justificados unicamente por valores abstratos como ilegalidade, não alcance de economicidade, ineficiência e imoralidade, quando, na verdade, tratam-se de discordância da opção discricionária administrativa, substituindo-a pela do juiz ou controlador. (KELSEN, 2006, p.249).

Aqui, destaca-se a doutrina Chevron, estadunidense, uma vez que o modelo de controle concreto foi de lá importado, a qual se trata de "um modelo de teste legal com vistas a determinar se deve conferir deferência à interpretação dada por uma agência governamental de um estatuto legal que rege a atividade desta", estabelecido pelo Supremo Tribunal Federal dos Estados Unidos. A primeira etapa consiste na verificação da clareza do texto legal, havendo o juiz aplica a lei e não defere a interpretação da Administração; em caso de vagueza no texto legal, ao juiz não cabe interpretá-la, mas avaliar se a solução da agência é razoável, se é uma das alternativas de soluções cabíveis dentro da moldura de legalidade posta pela norma. (MERRIL, 2017, p.255 apud BINICHESKI, 2017, p.30).

A análise do primeiro passo busca a intenção legislativa e a respeita em nome da separação dos poderes. Se o Legislativo decidiu de forma clara, está resolvido o assunto. Caso haja vagueza, cabe ao Executivo interpretá-la, pois o Legislativo teria delegado a ele tal competência ao optar por não legislar de forma contundente, deixando abstrações e lacunas a serem preenchidas pelo aplicador do Direito, eleito pelo povo. Restando ao juiz ver se a resposta da Administração é permissível. Em reverso a doutrina Chevron, está em voga o controle do mérito administrativo por meio de princípios e da finalidade pública, assim, faz-se uma grave ressalva quando o objeto da decisão controladora for apurar a regularidade de conduta de servidor, pela possibilidade de resultar em sanção administrativa. (MERRIL, 2017, p.255 apudBINICHESKI, 2017, p.30).

Nesses casos, é indispensável que se consiga antever a conduta irregular, para que possam cumprir lei com segurança jurídica. A aplicação de principiologia, abstrata, retira a previsibilidade do ilícito administrativo. Em matéria de Direito Penal e sanções administrativas não se deve flexibilizar a análise de legalidade e formalidade das decisões sob pena de violação da constituição, com alargamentos das interpretações sobre tipicidade de condutas eliminando as referências prévias de antijuridicidade e culpabilidade. Tem-se um Direito sancionador flexível e variante conforme os conceitos abstratos, os valores e a discricionariedade dos julgadores (controle, judicial e administrativo), isto é, de uma insegurança jurídica extrema. (BRASIL. CRFB, 1988, art.5으, inc. XXXIX; KELSEN, 2006, p.261).

A razoabilidade indica, no ramo sancionador, a pertinência de Chevron. E a justiça existente em restringir o julgador a verificação de razoabilidade da decisão tomada, com a maior deferência possível à vontade legislativa exposta no texto legal, à moldura de legalidade. E nessa direção que sobrevém a edição da Lei 13.655/2018, alterando a LINDB, ao determinar observação da realidade, do contexto e das consequências das decisões sobre regularidade de ato, contrato ou conduta administrativa. (BINICHESKI, 2017, p.30; KELSEN, 2006, p.248).

A flexibilização do julgamento do controlador, que o liberou das amarras da lei em nome dos princípios, congelou a Administração Pública, gestora de políticas, que passou a impedir resultados por motivos não jurídicos (opiniões de controladores, da imprensa e do público). Como mencionado, o "apagão das canetas" pode ser tão criminoso quanto os atos comissivos, não protegendo a população. Cabe aos três poderes se articularem discursivamente em busca de um justo meio termo, que atenda à razoabilidade $e$ coordenação de suas atuações. (RITTNER, 2018; SUNDFELD, 2012, p.37).

Cabe a lei criminalizar e punir os gestores corruptos, desonestos, e não uma gestão pouco eficiente, pois nem sempre será possível atingir o resultado ótimo em todos os programas e projetos públicos. O Estado faz parte da Economia, é agente e paciente de vários fatores macro e microeconômicos, inclusive da escassez de recursos que limita, concretamente, a sua atuação. Não pode o controlador ignorar o mundo do ser e pautar sua atuação unicamente com base no "deverser", pois Direito e Administração são ciências 
aplicadas à sociedade, não são meras retórica e teoria. (KELSEN, 2006, p.4).

\section{METODOLOGIA}

Por uma abordagem qualitativa, no método indutivo, partiu-se da análise de fenômenos específicos para generalizações universalizáveis na busca por identidades e regras gerais aplicáveis a subconjuntos dos novos artigos inaugurados pela Lei 13.6555/2018, de onde se destacaram reforços a princípios constitucionais e novos primados de extrema valia. (ZANELLA, 2009, p.59; GIL, 2007, apud, ZANELLA, 2009, p.60 e 61).

A cerca dos atores afetados, contextualizouse visando compreender as conjunturas sociais, os fenômenos jurídicos alvo pelas perspectivas dos participantes do mundo jurídico administrativo e os impactos dos métodos de interpretação do direito público. Pretendeu-se evidenciar os posicionamentos e criticá-los, sem preterí-los. (ZANELLA, 2009, p.78).

Pesquisou-se bibliografia específica sobre o tema nas seguintes bases de dados: Revista Jus Navegandi; Capes.periodicos; banco de teses e dissertações da Capes; Google Acadêmico; Revista Brasileira de Ciências Sociais (Scielo Brasil); Portal Periódicos Jurídicos; Portal de Publicações do CEJ; na base de dados das teses e dissertações de mestrado em direito da FGV; Revista Âmbito Jurídico; Revista Consultor Jurídico; Revista Direito do Estado. Foram encontrados poucos trabalhos semelhantes abordando apenas aspectos parciais da Lei 13.655/2018, ou resumidos em artigos comentados, sem maiores digressões sobre impactos e as partes afetadas pela norma. Assim, optou-se por uma pesquisa descritiva de conceitos e resultados localizados, seguida de análise crítica de conteúdos vinculados ao tema. (ZANELLA, 2009, 78 a 81).

\section{ANÁLISE DE RESULTADOS}

Feitas as contextualizações preliminares, será feita a análise dos novos nove artigos acrescidos à Lei de Introdução às Normas do Direito Brasileiro (LINDB), sobre segurança jurídica e eficiência na criação e na aplicação do direito público, posto que o art.26 foi vetado. Publicada em 25 de abril de 2018, a Lei 13.655/2018, entrou em vigor na data de sua publicação, a exceção do art.29, para o qual foi prevista uma vacatio legis de 180 (dias).

\subsection{CONDICIONAMENTO FUNDAMENTAÇÃO POR VALORES JURÍDICOS ABSTRATOS AO CONSEQUENCIALISMO}

O art.20 da LINDB trouxe para a interpretação e aplicação das normas de Direito Público por valores jurídicos abstratos o requisito de considerar as consequências práticas da decisão. Em caso de norma com conceito jurídico indeterminado, o ônus deverá ser suportado pelo emissor da decisão. Isto porque tais tipos de abstrações prestam a limitar uma moldura de legalidade a qual pode ser preenchida com mais de uma interpretação e solução possível. Por isso, o parágrafo único do referido artigo exige demonstração da adequação e da necessidade de medida ou de invalidação decretadas em decisão, ante as alternativas vislumbradas para o caso. (BRASIL. Lei 13.655, 2018, art.1우 KELSEN, 2006, p.247; KRELL, 2013, p.31).

O consequencialismo jurídico representaria uma linha interpretativa intermediária entre o rigor literal do positivismo e a discricionariedade da corrente da livre interpretação judicial e controladora. A discricionariedade deve ser exercida considerando a "análise econômica do direito", reveladora da reserva do possível. (KRELL, 2002, p.51-57; POSNER. 2010, p, XII).

O mesmo se segue no art.21 (LINDB), exigindo a especificação das consequências jurídicas e administrativas concretas da decisão, de modo a limitar futuras interpretações restritivas ou extensivas sobre $\mathrm{o}$ ato decisório, trazendo mais insegurança. $\mathrm{O}$ objetivo é que a autoridade pública se preocupe com a melhor forma de implantar a decisão, segundo a proporcionalidade e a equidade, resguardando interesses gerais e de terceiros, mitigando perdas anormais ou excessivas. (TOSTES, 2018).

Não se trata de uma condicionante a força normativa dos princípios constitucionais, mas às soluções neles fundamentadas. Não combate a discricionariedade judicial, a dos órgãos de controle ou a administrativa, mas prega a observação das soluções possíveis e das circunstâncias de fato que restringem o 
gestor público e a adequação ao caso concreto.

\subsection{PRINCÍPIO DA PRIMAZIA DA REALIDADE}

Traz para a interpretação e para a aplicação do direito público a primazia da realidade, não com o intuito de usá-la para esquivar-se do império da lei, mas como condição para delimitação da reserva do possível e redução da subjetividade. Tem importante destaque no reconhecimento de direitos aos jurisdicionados (judiciais e administrativos), bem como para fins de responsabilização de agentes públicos no exercício da gestão.

Verifica-se que este princípio surge toda vez que a análise das consequências e o contexto histórico são reclamados à aplicação da lei. Destacam-se, em especial os novos artigos 20 a 24 e o artigo 28 da LINDB. Senão, vejase:

O artigo 22 prevê que os "obstáculos e as dificuldades reais do gestor e as exigências das políticas públicas a seu cargo" sejam observados na interpretação das normas sobre gestão pública. Segue especificando que, na análise sobre regularidade de conduta ou validade de ato, contrato, ajuste, processo ou norma administrativa, observarse-ão as circunstâncias práticas condicionantes da atuação do gestor. Sem isto, a abstração pode levar a uma série de conclusões inalcançáveis, de fato.

Os demais parágrafos do artigo trataram de fixar critérios para aplicação de sanção administrativa, tal qual o que se pratica nas infrações penais: natureza, gravidade, danos efetivos à Administração Pública, circunstâncias agravantes e atenuantes e antecedentes do agente. Fixa que as sanções considerarão a "dosimetria das demais sanções de mesma natureza e relativas ao mesmo fato". Ou seja, relembra aos controladores a natureza penal das sanções, reclama a aplicação de critérios semelhantes que individualizam a conduta e a pena, medidas fundamentais a previsibilidade do Direito Sancionador. (Brasil, LINDB, art.22, § $2^{\circ}$ e $\left.\S 3^{\circ}\right)$.
4.3 MODULAÇÃO DE EFEITOS EM CASO DE INTERPRETAÇÃO OU ORIENTAÇÃO NOVA SOBRE NORMA DE CONTEÚDO INDETERMINADO

Os novos artigos 23 e 24 da LINDB, trazem a modulação de efeitos decorrentes de alteração interpretativa ou orientação sobre norma de conteúdo indeterminado. Desse modo salvaguarda a aquele que confiou e agiu em consonância com a "orientações gerais da época". Estão incluídas as jurisprudências judiciais, as deliberações das cortes de contas e as interpretações da própria Administração Pública sobre a compreensão das normas e as práticas administrativas reiteradas de conhecimento público. Trata-se de uma garantia ao jurisdicionado a ser aplicada durante a análise de juridicidade de sua conduta, é a formalização legal do brocado administrativo tempus regit actum.

O regime de transição pretende a fixação de critérios para que o novo entendimento entre em vigor "de modo proporcional, equânime e eficiente e sem prejuízo aos interesses gerais". Assim pode prever que tal entendimento somente será cobrado a partir daquele momento ou daqui a um ano, por exemplo. Esta solução já constava no art.927, $\S 3^{\circ}$ do CPC, por motivo de segurança jurídica e o interesse social. É claro que a modulação foi estendida não só para processos judiciais como para os administrativos e para os órgãos de controle, mas não é uma novidade, como citado. (ALVIM, 2018; Brasil, LINDB, art.21, parágrafo único).

\subsection{PRINCÍPIO DA CONSENSUALIDADE NA SOLUÇÃO DE CONFLITOS}

O artigo 26 da LINDB trouxe o consenso como forma de solução de conflitos e eliminação de controvérsias. Prevê que para "eliminar irregularidade, incerteza jurídica ou situação contenciosa", após manifestação do órgão jurídico, poderá a Administração celebrar compromisso entre os interessados, contendo as obrigações das partes, prazo para execução e sanções por descumprimento.

Trata-se de previsão legal para que órgãos legitimados firmem termos de ajustamento de condutas para permitir o alcance de solução "proporcional, equânime, eficiente e compatível com os interesses gerais". Dentro do conceito de órgãos de controle residem 
autoridades administrativas como controladorias internas, corregedorias, tribunais de contas e o Ministério Público. (BRASIL. Lei 7.347, 1985, art. 5으, §6웅 FERRAZ, 2018).

Verifica-se que tal dispositivo, bem como a compensação por benefício indevido ou prejuízos anormais ou injustos provocados pelos envolvidos, prevista nos $\S \S 1^{\circ}$ e $2^{\circ}$ do artigo 27 da LINDB, afrontam o $\$ 1^{\circ}$ do art.17 da Lei de Improbidade Administrativa, o qual veda "a transação, acordo ou conciliação nas ações" do tipo. Por ser uma lei geral sobre como se deve interpretar as normas de direito público, por ser uma alteração por lei posterior a Lei 8.429/1992 (Improbidade Administrativa), pode-se sustentar que a vedação mencionada foi revogada. Certo é que não há como coexistirem posto que seguem em direções opostas.

Convém destacar que há ação direta de inconstitucionalidade (ADI 5.980, rel. min. Celso de Mello) contra o $\$ 1^{\circ}$ do referido art. 17 da Lei 8.429/92, posto que a vedação de transação, acordo ou conciliação nas ações de improbidade administrativa estaria em sentido reverso às evoluções legislativas. Citam-se, além dos acordos processuais, os acordos de leniência previstos nos artigos 16 e 17 da Lei 12.846/13; a Lei 13.129/15 de arbitragem na Administração Pública e Lei 13.140/15 sobre autocomposição de conflitos e mediação na gestão pública. Injusto seria permanecer com visão draconiana para responsabilidade penal e administrativa no direito público. (FERRAZ, 2018).

Noutro ponto, não se deve perder de vista que o consenso como um meio de resolução de controvérsias. Se este for alcançado na via administrativa, não haverá interesse de agir que sustente uma ação judicial para o mesmo pedido, refreando o atual fenômeno da judicialização de questões administrativas (de cunho político e social). Aumenta a crença na autoridade executiva e reduz o excesso de demanda sobre as judiciárias, atendendo aos interesses públicos e às demandas dos administrados, tudo através de um instrumento previsto pelo Legislativo. Enfim, salvaguarda a credibilidade dos poderes estatais, recuperando legitimidade. (PERLINGEIRO, 2014, p.315 e 316).

\subsection{PRINCÍPIO DO PROCESSO ESTRUTURAL OU DAS MEDIDAS ESTRUTURANTES}

Sobre o processo estrutural, Menegat (2018) entende que é um modelo de decisão construída conjuntamente, num "cronograma ótimo para implementar as obrigações impostas", atento aos impactos para além das partes. Recomenda-se a adoção de medidas estruturantes em litígios contra a Administração Pública pela complexidade das discussões envolvidas, as quais, comumente, tem impactos múltiplos e ligados a políticas públicas, superando a dimensão limitada das lides privadas. (MENEGAT, 2018).

Tais medidas estão previstas no parágrafo único do art.21 da LINDB, quando o dispositivo menciona que as decisões devem indicar as "condições para que a regularização ocorra de modo proporcional e equânime e sem prejuízo aos interesses gerais". Menciona-se, aqui, em complementação, a aplicação do dever de cooperação entre as partes para a efetividade das decisões judiciais, conforme art. $6^{\circ}$ do CPC/2015, bem como que a lei perdeu a oportunidade de afirmar tal dever para as esferas administrativas e de controle. (MENEGAT, 2018).

Fala-se de resoluções concretas que desçam, após as discussões, aos detalhes das formas de prestação, dividas em etapas, com definição dos respectivos prazos e responsabilidades de cada parte envolvida. É bom que se incluam as possibilidades de ajustes na execução das determinações, conforme percalços supervenientes. Tudo em prol da efetividade das decisões, de modo que possam ser cumpridas, conforme os recursos disponíveis, causando os menores prejuízos possíveis. Ele traz para o julgador o problema maior da gestão: a escassez de recurso ante o crescente número de demandas sociais. (SANTOS, 2012, p.49 e 51).

\subsection{O CONCEITO DO "ADMINISTRATOR MEDIUM"}

Uma grande polêmica surge a partir do art.28 da LINDB: teria o legislador introduzido o conceito de "administrator medium", ao limitar a responsabilização dos agentes públicos aos casos de dolo ou erro grosseiro?

Ao exigir que as condutas dos administradores sejam avaliadas pela realidade, a LINDB coloca para os controladores (administrativos, legislativos e judiciais) a expectativa da efetivação da 
previsão legal, nos seus julgados. Destaca-se o recente Acórdão 1.628/2018 do Tribunal de Contas da União (TCU), no qual os novos artigos, aqui em análise, foram evocados para justificar ou não a conduta dos agentes públicos. Considerando as práticas recorrentes da administração como parâmetro através do qual se observará o dito "administrador médio". Em resumo, o TCU excluiu a responsabilidade da pregoeira por entender que a própria administração, com a prática recorrente de ter contratado empresas cujos sócios eram funcionários municipais teria induzido a mesma a crer na licitude do fato. Por outro lado, responsabilizou o homologador da licitação pela falta de zelo ao não acionar a procuradoria municipal sobre o fato, conforme exigível do "plexo de suas atribuições". (MENEGAT, 2018).

Ainda que se referencie o administrador médio através das práticas comuns da administração, verifica-se que a falta de critérios objetivos que delineiem os contornos do erro escusável é evidente. O referido art.28 da LINDB, possuía parágrafos que foram vetados pelo presidente. Notadamente, o parágrafo primeiro pretendia uma designação de condutas que não seriam consideradas como erro grosseiro, tais como a adoção de jurisprudência ou doutrina não unânime ou interpretação razoável, ainda que a posição não viesse a "ser posteriormente aceita por órgãos de controle ou judiciais". (BRASIL. Lei 13.655, 2018, vetos).

Nas razões do veto, sustentou-se que a "busca pela pacificação de entendimentos é essencial para a segurança jurídica" e que não a observar seria deixar que o agente agisse pela "sua própria convicção", gerando insegurança. Em que pese o referido argumento, verifica-se que, ao fim dos cortes, restou ao Tribunal de Contas da União (TCU) a competência de determinar os atributos e condutas do administrador médio, no caso concreto, quando verificar a razoabilidade das condutas, de modo que nenhuma previsibilidade é dada aos controlados e grande discricionariedade se abre aos juízos dos controladores. Ao controlado resta se limitar às teorias já aprovadas e, em caso de inovação, tentar predizer as visões futuras do controlador ou aderir ao "apagão das canetas", indeferindo novidades, evitando riscos. (BRASIL. Lei 13.655, 2018, vetos; RIBEIRO, 2018; RITTNER, 2018).

\subsection{RESPONSABILIDADE DO AGENTE PÚBLICO: ERRO GROSSEIRO OU DOLO $X$ DOLO OU CULPA}

Outro ponto muito discutido é o possível abrandamento na responsabilização do agente público que o art.28 da LINDB teria tentado trazer para a interpretação das normas de direito público. Isto porque o dispositivo prevê responsabilidade pessoal do agente em caso de dolo ou erro grosseiro, enquanto que $\circ \S 6^{\circ}$ do art.37 da CRFB/88, evidencia a responsabilidade do Estado pelos danos de seus agentes, assegurando ação regressiva em caso de dolo ou culpa.

A doutrina subdivide a culpa em grave, leve e levíssima. Assim, como erro grosseiro representa culpa grave, questiona-se se o art.28 da LINDB teria retirado a culpabilidade por culpa leve e levíssima, abrandando o regime constitucional. Entende-se tal dispositivo não alcança os magistrados posto que a responsabilização por decisões se dá por dolo ou fraude, na forma da legislação específica, art. 143, I, do CPC/2015 e do art. 49, I, da LC 35/79. Pretender responsabilizá-lo por erro grosseiro é negar a finalidade dos vários recursos judiciais. (DIZER O DIREITO, 2018).

O mesmo é seguido para responsabilização de membros do Ministério Público, da Defensoria Pública e da Advocacia Pública: somente em caso de dolo ou fraude, art.181, art.184 e art.187 do CPC/2015. No entanto, a jurisprudência é pacífica quanto a possibilidade de responsabilização de parecerista em caso de culpa e de erro grosseiro, ainda que em parecer opinativo facultativo ou obrigatório. Sendo um parecer vinculante, a responsabilidade é solidária posto que o Administrador não pode dele divergir. (DIZER O DIREITO, 2018).

\subsection{DA PARTICIPAÇÃO E DA PREVISIBILIDADE DAS DECISÕES}

Findando as novas medidas interpretativas, tem-se o art.29 estimulando a realização de consultas públicas antes da edição de atos normativos, de modo a viabilizar o diálogo entre as partes interessadas nos assuntos públicos tratados. $\mathrm{E}$ o art.30 definindo que as autoridades públicas devem estimular a segurança jurídica, inclusive por meio de regulamentos, súmulas administrativas e respostas às consultas. As quais terão caráter vinculante em relação ao órgão emissor. 
Tratam-se de posturas ligadas a melhores práticas de participação e transparência. (BRASIL. LINDB, 1942).

\subsection{DISPUTANDO NA ARENA DOS PRINCÍPIOS: OS ATORES.}

Sendo os princípios "casos extremos de indeterminação normativa", ainda que tratado como direito ou outro termo, verifica-se que fundamentar decisões unicamente com "conceitos abstratos" não representa uma homenagem a cientificidade do Direito, mas uma ode a arbitrariedade e, por isso, bem recebida deve ser a nova lei. Cabe, então, averiguar a quem uma grande indeterminação nas normas beneficia. (SUNDFELD, 2012, p.60 e 61).

A aplicação do Direito não é monopólio do Judiciário, sendo uma função secundária da Administração e do Legislativo, incluindo os Tribunais de Contas. A abstração do direito permite ao intérprete dizê-lo, criá-lo, e empoderar-se pela ocupação de espaços de atuação política, formando opinião pública e jurídica, além de legitimar várias causas.

Os princípios fundamentam novos conceitos e direitos em formação. São ferramentas de conveniente encaixe, "mais para cá ou para lá", conforme a finalidade pretendida pelo agente do discurso. Sujeitos a valorações e percepções de mundo, são desconectados de contextos e rearranjados em outros adequando-se a novos fins, com objetivos muito menos técnicos ou científicos do que os profissionais do Direito Administrativo de fato pretendem admitir. (SUNDFELD, 2012, p.41).

Olhando para a referida arena principiológica, identificam-se disputas de poder, reveláveis pela identificação de perdedores e ganhadores, a cada interpretação do tipo. Dentre os atores do mundo jurídico, inicia-se pelo Judiciário. A judicialização e o ativismo judicial tem sido amplamente discutidos, defendidos e repreendidos. Ora clama-se por maior deferência à lei e restrição a análise de razoabilidade da solução executiva, numa posição pró independência dos poderes que valoriza o Legislativo, com reservas de lei, e depois a Administração dona da competência delegada pelo primeiro. Ora pela representação criativa judicial ante as falhas de eficiência e inações legislativas e administrativas. (SUNDFELD, 2012, p.69).
Outras construções sobre legalidade direcionam-se ao extremo da reserva total de lei, subjugando o Executivo a meros braços do Legislativo, para quase limitar a liberdade discricionária a zero. Imaginem um mundo com uma produção legislativa tão intensa quanto a complexidade das relações sociais, sem que se possa alegar desconhecimento das leis. Não parece mais seguro juridicamente do que as normas quadros de legalidade, com suas indeterminações a serem preenchidas pelo aplicador do Direito. (KELSEN, 2006, p.249; SUNDFELD, 2012, p.40, 69).

Dentre os encarregados de gerir a coisa pública, destacam-se pelo menos dois perfis interessantes: os burocratas, criados para conter os desvios da Administração Pública, a corrupção, trazer profissionalismo, expurgar o patrimonialismo e etc; e os encarregados de fazerem a máquina funcionar, apresentando resultados. Sundfeld (2012, p.487) se refere a eles como o Direito Administrativo do Clipes e - Direito Administrativo dos Negócios, respectivamente.

Os primeiros usarão a legalidade, as opiniões já aprovadas pelos controladores, posições conservadoras e de regulação para conter o Executivo e manter os atos no caminho mais seguro e conhecido. Não se importam com a morosidade, a falta de resultados, as prioridades e os custos, desconfiam do particular. Os outros querem flexibilizar, encurtar procedimentos, entregar resultados, gerenciar a escassez, formar consensos e parcerias, decidir com base no custobenefício. Usam princípios como a continuidade dos serviços públicos, eficiência, parcerias público-privadas, interesse público, emergência e etc. (SUNDFELD, 2012, p.87 e 88).

Nessa fumaça abstrata, tem-se burocratas exigindo mais do que a lei, travando processos por meras formalidades, totalmente alheios aos fins orientadores, indeferindo em nome da tranquilidade. De outro lado, gerentes cheios de pressa, que não observam o cumprimento dos mínimos requisitos legais, não motivam adequadamente seus atos, não estudam as possíveis soluções de economicidade, não fixam parâmetros nem uniformizam procedimentos ou ignoram as próprias regras que criaram.

O Ministério Público, seguido ao longe pelas Defensorias Públicas, descobriram nos princípios e na tutela de direitos difusos, como 
custos legis, uma ferramenta de ocupação de espaços e de fortalecimento de poder político. Destacou-se na elaboração da Lei de Improbidade Administrativa para transformar a violação dos deveres de "honestidade, imparcialidade, legalidade e lealdade às instituições" em ato de improbidade administrativa. Tão abstratos que não inibem qualquer conduta e facilitam 0 enquadramento de todas elas, apesar da natureza típica e concreta das sanções penais. (BRASIL. Lei no 8.429, 1992; SUNDFELD, 2012, p.69)

As partes nas lides os usam para sustentar 0 afastamento do majoritário em nome de valores fundamentais e os especialistas em Direito Público, que reivindicam a conceituação de institutos e esclarecem a abstração, dominando pelo saber. São os tecnocratas jurídicos; os acadêmicos; os "teóricos da vida jurídica concreta"; os administrativistas privados; os tradutores do mundo administrativo; os "políticos pela via do Direito" e os "juristas políticos", todos argumentando conforme seus papéis. (SUNDFELD, 2012, p.97-99, 102-104).

\section{CONCLUSÕES}

Finaliza-se reconhecendo uma obviedade. As novas premissas a serem consideradas na interpretação do direito público, formalizadas pela Lei 13.655/2018 e encrustadas na LINDB, não são, em tudo, de fato novas. A autolimitação dos aplicadores do Direito na interpretação de valores abstratos em decisões, atos e ajustes consta na doutrina: na motivação do ato administrativo; na individualização da conduta e da pena sancionadora e no art.93, inc.IX, da CRFB/88 como requisito de validade de sentenças. (BRASIL. Lei no 13.655, 2018, art.20).

O mesmo se observa quanto à jurisprudência ou à interpretação institucional da época da prática do ato; a modulação de efeitos e as medidas estruturantes previstas no Código de Processo Civil, de aplicação subsidiária. Além disso, são práticas já realizadas nos Tribunais de Contas. Os demais pressupostos: primazia

\section{REFERÊNCIAS}

[1] Alvim, Teresa Arruda. Um olhar sobre modulação a partir da Lei 13.655/2018. Revista Consultor Jurídico, 2 de maio de 2018, 15h 35min. Disponível em: <https://www.conjur.com.br/a/quem_somos> da realidade, consideração das limitações do gestor, estímulo ao consenso e a participação, bem como a normatização de entendimentos institucionais, formalizando-os, o caráter normativo das consultas, também já estavam presentes na realidade do administrativista. (ALVIM, 2018; BRASIL. Lei no 13.655, 2018, art.20 a art.24, art.26 a art.28, art.30; BRASIL. CPC, 2015, art.6; art.927, §3ㅇ; BRASIL. Lei no 7.347, 1985, art.5으, §6ㅇ; BRASIL. Lei $n=12.846,2013$, art.16 e 17; BRASIL. Lei no 13.129, 2015; BRASIL. Lei $n^{\circ}$ 13.140, 2015; FERRAZ, 2018; MENEGAT, 2018; SUNDFELD, 2012, p.146 e 148).

Contudo, o conhecimento do direito público é elitizado e desenvolveu-se em ilhas de saber, feudos, verifica-se que o maior mérito da lei em estudo é compilar e formalizar as boas construções e institutos já em voga, como critérios de condutas lesivas, permitindo uma aplicação mais direta, proporcional, com juridicidade e previsibilidade.

Valor também há na tentativa de contornar a principiologia, retornando o pêndulo à antigas posições de maior deferência. Limitando os julgamentos "nas nuvens". Destaque para o campo dos contratos administrativos, posto que o Estado passa por crise de confiança devido a mudanças bruscas de entendimentos, decisões judiciais e dos controladores pela interrupção de ajustes unicamente por afronta a valores abstratos. (SUNDFELD, 2012, p.79).

A economia estatal carece de investimentos privados para oferecer infraestrutura, bens e serviços. Para tanto, dependem de confiança, de respeito ao pact sunt servanda, da presunção da legalidade dos atos, da continuidade dos negócios, independente de mudança de gestão; divulgação dos riscos do sistema; transparência quanto ao necessário para acessar um direito ou serviço. Veja-se que tais pontos em nada se relacionam com o controlador, a lei é para todos.

A segurança jurídica é fundamental para previsibilidade do gestor público. Não é justo que o encarregado de tão importante missão tenha que depender de bom senso. Eis a relevância da Lei 13.655/2018.

[2] Barroso, Luís Roberto. Ano do STF: Judicialização, ativismo e legitimidade democrática. Revista Consultor Jurídico, 22 de dezembro de 2008, 12h28. Disponível em: $<$ http://www.conjur.com.br/2008-dez- 
22/judicializacao_ativismo_legitimidade_democratic a? pagina $=2>$

[3] Binicheski, Paulo Roberto. A doutrina Chevron: o ocaso anunciado? Revista CEJ, Brasília, Ano XXI, v.21, n.73, p.29-39, set/dez. 2017. Disponível em: <http://www.cjf.jus.br/ ojs2/index.php/revcej/article/view/2333/2215>

[4] Brasil. Constituição (1988). Constituição da República Federativa do Brasil. Brasília, DF: Senado Federal, 1988. Disponível em: $<$ http://www.planalto.gov.br/

ccivil_03/constituicao/constitui\%C3\%A7ao.htm> Acesso em: 25 Jul. 17.

[5] Brasil. DECRETO-LEI №4.657 DE 04 DE SETEMBRO DE 1942. Lei de Introdução às normas do Direito Brasileiro. Disponível em: $<$ http://www.planalto.gov.br/ccivil_03/DecretoLei/Del4657compilado.htm> Acesso em: 20 Ago 2018

[6] Brasil. LEI № 7.347, DE 24 DE JULHO DE 1985. Disciplina a ação civil pública de responsabilidade por danos causados ao meioambiente, ao consumidor, a bens e direitos de valor artístico, estético, histórico, turístico e paisagístico (VETADO) e dá outras providências. Disponível em: <http://www.planalto.gov.br/ccivil_03/leis/L7347orig .htm> Acesso em: 23 Jun. 17

[7] Brasil. LEI № 9.784, DE 29 DE JANEIRO DE 1999. Lei que regula o processo administrativo no âmbito da Administração Pública Federal. Disponível em: <http://www.planalto.gov.br/ccivil_03/leis/L9784.ht m> Acesso em: 23 Jun. 17.

[8] Brasil. LEI № 12.846, DE 1 DE AGOSTO DE 2013. Dispõe sobre a responsabilização administrativa e civil de pessoas jurídicas pela prática de atos contra a administração pública, nacional ou estrangeira, e dá outras providências. Disponível

em: <http://www.planalto.gov.br/ccivil_03/_Ato 20112014/2013/Lei/L12846.htm> Acesso em: 23 Jun. 17.

[9] Brasil. LEI № 13.105, DE 16 DE MARÇO DE 2015. Código de Processo Civil. Disponível em: <http://www.planalto.gov.br/ccivil_03/_Ato20152018/2015/Lei/L13105.htm> Acesso em: 19 Ago. 2018 .

[10] Brasil. LEI № 13.129, DE 26 DE MAIO DE 2015. Altera a Lei no 9.307, de 23 de setembro de 1996, e a Lei no 6.404, de 15 de dezembro de 1976, para ampliar o âmbito de aplicação da arbitragem e dispor sobre a escolha dos árbitros quando as partes recorrem a órgão arbitral, a interrupção da prescrição pela instituição da arbitragem, a concessão de tutelas cautelares e de urgência nos casos de arbitragem, a carta arbitral e a sentença arbitral, e revoga dispositivos da Lei no 9.307, de 23 de setembro de 1996. Disponível em:
<http://www.planalto.gov.br/ccivil_03/_Ato2015-

2018/2015/Lei/L13129.htm> Acesso em: 23 Jun.17.

[11] Brasil. LEI № 13.140 DE 26 DE JUNHO DE 2015. Dispõe sobre a mediação entre particulares como meio de solução de controvérsias e sobre a autocomposição de conflitos no âmbito da administração pública; altera a Lei no 9.469, de 10 de julho de 1997, e o Decreto no 70.235, de 6 de março de 1972; e revoga o § 20 do art. 60 da Lei no 9.469, de 10 de julho de 1997. Disponível em:< http://www.planalto.gov.br/ccivil_03/_ato20152018/2015/Lei/L13140.htm> Acesso em: 23 Jun.17.

[12] Brasil. LEI № 13.655, DE 25 DE ABRIL DE 2018. Inclui no Decreto-Lei no 4.657, de 4 de setembro de 1942 (Lei de Introdução às Normas do Direito Brasileiro), disposições sobre segurança jurídica e eficiência na criação e na aplicação do direito público. Disponível em: <http://www2.camara.leg.br/legin/fed/lei/2018/lei13655-25-abril-2018-786606-veto-155431-pl.html> Acesso em: 20 Ago. 2018.

[13] Brasil. LEI Complementar № 35, DE 14 DE MARÇO DE 1979. Dispõe sobre a Lei Orgânica da Magistratura Nacional. Disponível em: <http://www.planalto.gov.br/CCIVil_03/ Leis/LCP/Lcp35.htm> Acesso em: 19 Ago. 2018.

[14] Carvalho Filho, José dos Santos. Manual de Direito Administrativo. 22 ed. rev. ampl. atual. Rio de Janeiro: Lumen Juris, 2009.

[15] Dalmarco, Arthur Rodrigues. Que tipos de incentivos a Lei no 13.655/2018 produzirá sobre agentes públicos? Uma análise sobre os novos comandos estruturais que foram inseridos na Lei de Introdução ao Direito Brasileiro. Coluna da ABDE: 08 de maio de 2018, 11h. Disponível em: < https://www.jota.info/opiniao-e-

analise/colunas/coluna-da-abde/que-tipos-deincentivos-lei-no-13-655-2018-produzira-sobre-osagentes-publicos-08052018>

[16] Dizer O Direito. Comentários à Lei 13.655/2018, que alterou a LINDB prevendo normas de segurança jurídica na aplicação do direito público. Segunda-feira, 30 de abril de 2018. Disponível em: https://www.dizerodireito.com.br/2018/04/comentari os-lei-136552018-que-alterou.html>

[17] Ferraz, Luciano. Lindb autoriza TAC em ações de improbidade administrativa. Revista Consultor Jurídico, 9 de agosto de 2018, 8h05. Disponível em: <https://www.conjur.com.br/2018ago-09/interesse-publico-lindb-autoriza-tac-acoesimprobidade-administrativa>

[18] Habermas, Jurgën. Direto e Democracia: entre facticidade e validade. Vol. II, 1929. Flávio Beno Siebeneichler (trad.) Rio de Janeiro: Tempo brasileiro, 1997.

[19] Kelsen, Hans. Teoria Pura do Direito. Tradução de João Batista Machado. São Paulo: Martins Fontes, 2006. 
[20] Krell, Andreas J. Discricionariedade administrativa e conceitos legais indeterminados: limites do controle judicial no âmbito dos interesses difusos. 2a Ed. rev., atual. e ampl. Poto Alegre: Livraria do Advogado Editora, 2013.

[21] Menegat, Fernando. A novíssima Lei n. 13.655/2018 e o Processo Estrutural nos litígios complexos envolvendo a Administração Pública. Revista colunistas: ano 2018, n.396. Disponível em: <http://www.direitodoestado.com.br/colunistas/fern ando-menegat/a-novissima-lei-n-13655-2018-e-oprocesso-estrutural-nos-litigios-complexosenvolvendo-a-administracao-publica>

[22] Nonet, Philippe; Selznick, Philip. Direito e Sociedade: a transição ao sistema jurídico responsivo. Vera Ribeiro (trad.) Rio de Janeiro: Revan, 2010.

[23] Perlingeiro, Ricardo. Desafios contemporâneos da justiça administrativa na América Latina. Revista de Investigações Constitucionais, 4(1), 167-205, Fevereiro: 2017b. Disponível em: <https://ssrn.com/abstract=2919991>

[24] Posner, Richard. A Economia da justiça. São Paulo: WMF Martins Fontes, 2010.

[25] Ribeiro, Leonardo Coelho. Vetos à LINDB, o TCU e o erro grosseiro dão boas-vindas ao "administrador médium". Revista Consultor Jurídico, 8 de agosto de 2018, 16h27. Disponível em: <https://www.conjur.com.br/2018-ago-08/leonardocoelho-vetos-lindb-tcu-erro-grosseiro>

[26] Rittner, Daniel. O apagão das canetas dos agentes públicos. Valor econômico, 27 Jul. 2018. Disponível

em: <https://www.pressreader.com/brazil/valorecon\%C3\%B4mico/ 20180727/281595241330600>

[27] Sundfeld, Carlos Ari. Direito administrativo para céticos. São Paulo: Malheiros, 2012.

[28] Tostes, José Souto. Nova lei no 13.655 e as consequências para a gestão pública: $O$ novo princípio da consequência jurídica, o dever de justificar e fundamentar decisões, a vinculação aos pareceres. Disponivel em: $<$ https://jus.com.br/artigos/66030/nova-lei-n-13655-e-as-consequencias-para-a-gestao-publica> Acesso em 22 Ago. 2018.

[29] Zanella, Liane Carly Hermes. Metodologia de estudo e de pesquisa em administração. Florianópolis: Departamento de Ciências da Administração/UFSC, 2009. Disponível em: <http://200.129.241.123/arquivos/Fasciculo_Metod ologia_TC.pdf> 


$$
\text { Alutary }
$$




\section{ALESSANDRO VINICIUS DE PAULA}

Doutor em Administração pela Universidade Federal de Lavras - UFLA [2015]. Mestre em Psicologia pela Universidade Federal de Minas Gerais - UFMG [2008]. Especialista em Psicologia pelo Conselho Federal de Psicologia - CFP [Psicologia Social: 2018; Psicologia Organizacional e do Trabalho: 2011]. Graduado em Psicologia pela Universidade Federal de Minas Gerais - UFMG [Licenciado: 2010; Psicólogo: 2004; Bacharel: 2003]. Atua como professor/pesquisador no Departamento de Psicologia do Instituto de Educação da Universidade Federal de Mato Grosso - Câmpus Cuiabá (IE/UFMT). Desenvolve atividades de ensino e pesquisa concentradas nas seguintes áreas: 1) Psicologia Organizacional e do Trabalho - ênfase no estudo da saúde do trabalhador; 2) Psicologia Social - ênfase no estudo das relações de gênero e saúde; 3) Formação e atuação em Psicologia.

\section{ALLISON HALEY DOS SANTOS}

Possui graduação em Bacharelado em Direito pela Universidade Federal de Campina Grande (2010) e mestrado em Gestão Pública e Cooperação Internacional pela Universidade Federal da Paraíba (2018). Atualmente é pesquisador no Núcleo de Estudos em Relações EstadoSociedade e Políticas Públicas, e professor Assistente, nível II, no Centro de Ciências Jurídicas e Sociais da Universidade Federal de Campina Grande. Tem experiência na área de Direito Público e atua principalmente como pesquisador nos seguintes temas: gestão pública, políticas públicas, relações Estado x sociedade, participação, efetividade e judicialização

\section{AMANDA BEATRIZ NASATTO CORREAA}

Mestranda no Programa de Pós-Graduação em Contabilidade (PPGC) na Universidade Federal de Santa Catarina (UFSC). Possui graduação em Ciências Contábeis pela Universidade do Estado de Santa Catarina (UDESC) (2018). Além disso, foi bolsista voluntária em projetos de pesquisa na UDESC: Modelos estratégicos de gestão interorganizacional; e Influência de variáveis contingenciais e isomorfismos institucionais nos estilos de liderança de servidores públicos do Estado de Santa Catarina. Também em 2018 foi representante titular do corpo discente do Conselho de Centro do Ceavi (CONCEAVI).

\section{ANA BEATRIZ MURILLO OVIEDO}

Formada em Relações Públicas pela Universidade de Costa Rica e em Administração pela Universidade Nacional na Costa Rica. Possui mestrado em Administração pela Universidade Federal de Uberlândia (UFU). Já atuou na iniciativa privada nas áreas de administração e relações públicas. Professora na Faculdade de Administração e coordenadora do projeto de vínculo externo desta Faculdade, na Universidade Nacional na Costa Rica. Seus principais interesses de pesquisa são ensino em administração, integração interfuncional e gestão de projetos.

\section{ANA MARGARETH MOREIRA MENDES COSENZA}

Tem titulação no Curso de Formação de Oficiais da Academia D. João VI, o qual se trata de estabelecimento de ensino equiparado ao nível superior reconhecido pelo MEC (2001-2003). É Bacharel em Direito pela Universidade do Estado do Rio de Janeiro (2004-2009) e Bacharel em Administração Pública pela Universidade Federal Fluminense (2013-2018). É Pós-graduada em Direito Público (latu sensu) pela Universidade Veiga de Almeida (2009-2011), cursa pósgraduação em Advocacia Trabalhista (Latu sensu) na Universidade Anhanguera (2016-2019) e é mestranda no Programa de Pós-graduação (Stritu Sensu) em Sociologia e Direito da Universidade Federal Fluminense (2017-2019). Tem experiência em Direito Administrativo, em 
especial Licitações e Contratos, setor no qual atua a 11 anos, passando nos seguintes órgãos Públicos: Polícia Militar do Estado do Rio de Janeiro (PMERJ), Secretaria de Segurança do Estado do Rio de Janeiro, Instituto de Segurança Pública do Estado do Rio de Janeiro e Fundação Saúde do Estado do Rio de Janeiro (FSERJ). Dentre as principais funções, destacamse chefe de execução orçamentária, pregoeiro, presidente de comissão permanente de licitações, gestor e fiscal de contratos, Chefia da Assessoria Jurídica do Comando-Geral da PMERJ e Assessora Jurídica do Subchefe Administrativo do Estado Maior Geral da PMERJ (Ordenador de Despesas). Possui diversos cursos de atualização e extensão na área de licitações, contratos administrativos e convênios, em especial os ministrados pelas seguintes instituições públicas: Escola de Contas e Gestão do Tribunal de Contas do Estado do Rio de Janeiro e Escola Superior da Procuradoria Geral do Estado do Rio de Janeiro. Atualmente está no posto de major e ocupa a função de Diretora Jurídica da Fundação Saúde (FSERJ).

\section{ANA PAULA VILAS BOAS VIVEIROS LOPES}

É aluna de pós doutorado em Engenharia de Produção da Escola Politécnica da Universidade de São Paulo. É doutora em Engenharia de Produção da Escola Politécnica da Universidade de São Paulo. Possui graduação em Engenharia Têxtil pelo Centro Universitário da FEl. Fez parte do programa de trainee da empresa Alpargatas-Santista Têxtil e trabalhou na empresa Vicunha Têxtil. Atuou como membro de apoio administrativa na Revista Production da Associação Brasileira de Engenharia de Produção. É membro do Laboratório de Gestão de Projetos - LGP (www.pro.poli.sup.b/lgp). Atuou como docente no curso de graduação de Engenharia de Produção da Escola Superior de Engenharia e Gestão (ESEG). Atuou como docente no curso de especialização de Gestão de Projetos da Fundação Vanzolini, onde orientou alunos na disciplina de Métodos e técnicas aplicadas ao TCC. Atua como docente na graduação e pós-graduação no Centro Universitário FEI

\section{ANANDA SILVA SINGH}

Engenharia de Produção pela Universidade de São Carlos (UFSCar), possui mestrado em Administração pela Universidade Federal de Uberlândia (UFU) e atualmente cursa Doutorado em Administração na Universidade Federal do Paraná (UFPR). Já atuou na iniciativa privada como Engenheira de Produção e tem experiência na docência do ensino superior em disciplinas como Gestão de Projetos, Logística, Gestão da Inovação, dentre outras. Seus principais interesses de pesquisa são educação para a sustentabilidade, empreendedorismo sustentável e inovação.

\section{ANDRÉ GERALDO DA COSTA COELHO}

Professor efetivo da área de Administração do Instituto Federal do Norte de Minas GeraisIFNMG. Como docente leciona disciplinas relacionadas à administração geral, Logística \& Produção, metodologia científica, ética e negócios, noções do direito do trabalho e do consumidor, empreendedorismos com ênfase em legislação aplicada à administração, legislação para abertura de novos negócios, legislação tributária para novos negócios, empreendedorismo de base tecnológica e social, redes e incubadoras.Mestre em Administração Profissional pela Fundação Dr. Pedro Leopoldo-FPL(2015). Especialista em Docência para Educação Profissional (2013), pelo Serviço Nacional de Aprendizagem Comercial (SENAC-MG). Possui graduação em Administração (2008) e Especialização em Gestão Empreendedora de Empresas (2011) pela Pontifícia Universidade Católica de Minas Gerais (PUC-MG). 


\section{ANDREZZA VAZ DOS REIS}

Graduada em Serviço Social na Faculdade Universo Salgado de Oliveira MBA em Gestão de Pessoas pela faculdade Instituto Metodista Granbery

\section{ANGELA CRISTINA DE MELO}

Possui Mestrado em Administração linha de Gestão e Inovação pela Fundação Pedro Leopoldo, especialização nas áreas de Gestão Empresarial, Controladoria e Docência no Ensino Superior, coordena Revista Eletrônica de Iniciação Científica da Unic Tangará, é membro do conselho científico da Revista Cathedral Online, atua como docente em cursos de pós-graduação, graduação e formação do sistema $S$ e trabalha como consultora organizacional de processos e pessoas.

\section{ANGELITA FREITAS DA SILVA}

Mestre em Administração pela Universidade Federal de Santa Maria - RS (2010), especialista em Marketing pela FAE Business School - Curitiba - PR (2002), bacharel em Administração pela Universidade Federal de Santa Maria - RS (1999). Atualmente, é professor dedicação exclusiva do Instituto Federal de Educação, Ciência e Tecnologia do Rio Grande do Sul - Campus Erechim. Membro da Comissão Assessora do INEP / MEC para o Enade - Tecnologia em Marketing.

\section{ANÍRIAN CRISTIANE UNGHARE}

Graduação em Administração de Empresas pela Universidade Paranaense (2000), Mestrado em Engenharia de Produção pela Universidade Federal de Santa Catarina (2005), Especialização em Docência do Ensino Superior pela Faculdade Assis Gurgacs (2008), MBA em Gestão Estratégica de Empresas pela Universidade Paranaense(2013), foi coordenadora de curso de pós-graduação na Universidade Paranaense (2012-3013). Participação no NDE para implementação das Faculdades de Tecnologia em Manutenção Industrial e Tecnologia em Gestão da Produção na Faculdade Senai Unidade de Cascavel $\operatorname{Pr}$ (2011). Membro do NDE e do Colegiado do Curso de Administração da Universidade Paranaense (2009-2012). Atuação como docente entre (2009- 2013) nas áreas de Administração da Produção; Gestão de Recursos Materiais e Patrimoniais; Logística e Gerenciamento da Cadeia de Suprimentos; Análise Organizacional; Organização, Sistemas e Métodos; Gestão empresarial; Empreendedorismo; Administração Industrial; Logística no Comércio Eletrônico. Atuou como Supervisora de Trabalho de Conclusão de Curso da Faculdade Salesiana Maria Auxiliadora (FSMA) (2015). Atualmente é Docente e Membro do Colegiado do Curso de Administração da Faculdade Salesiana Maria Auxiliadora (FSMA) (2014-2018) e docente do Curso de Administração; Engenharia de Produção e Sistemas de Informação na Faculdade Miguel Angelo da Silva Santos (FeMASS) (2014-2018) ministrando as disciplinas de Introdução a Administração; Administração da Produção; Metodologia Científica; Mercado de Capitais; Organização, Sistemas e Métodos; Organização do Trabalho; Gestão estratégica; Projetos de Conclusão de Curso e Orientações em Trabalho de Conclusão de Curso, ambas em Macaé RJ. Possui 20 anos de experiência no mercado de trabalho na área Administrativa e Financeira. 


\section{AUGUSTO CÉSAR BARRETO ROCHA}

Professor da UFAM (graduação, mestrado e doutorado), Doutor em Engenharia de Transportes (UFRJ), especialista em Gestão da Inovação (Universidade de Santiago de Compostela, Espanha) e certificado em Estratégia e Inovação (Massachusets Institute of Technology, EUA). Também atua como coordenador do comitê de logística do CIEAM e diretor adjunto da FIEAM na área de Infraestrutura e Transportes.

\section{BRUNA FRANCCA DEBROSKI}

Possui curso-técnico-profissionalizante em Técnico em Administração Integrado ao Ensino Médio pelo Instituto Federal Catarinense (2016) e ensino-médio-segundo-grau pelo Instituto Federal Catarinense (2016). Atualmente é Bolsista de Projeto de Pesquisa da Universidade do Estado de Santa Catarina.

\section{CARLOS HENRIQUE DA MOTA COUTO}

Graduado em Administração de Empresas e Ciências Contábeis, Especializado em Auditoria e em Docência para o Magistério Superior, Mestre em Engenharia de Produção pela UFSC. Professor da Faculdade do Sudeste Mineiro. É CEO da O2 Hiperbárica Franqueadora e Administradora LTDA. Tem experiência na área de Administração e de Ciências Contábeis, atuando principalmente nos seguintes temas: Projeto de negócios, estratégias, Custos, Administração Financeira e Sistemas de informação.

\section{CARLOS HENRIQUE SANTANA COSENZA}

Tem titulação no Curso de Formação de Oficiais da Academia D. João VI, o qual se trata de estabelecimento de ensino equiparado ao nível superior reconhecido pelo MEC (2000-2002) e Pós-graduação em Auditoria e Perícia Ambiental pela Universidade Estácio de Sá. Tem experiência em processos administrativos ligados a licenciamentos ambientais e repressão a crimes ambientais, setor no qual atua a 6 anos. Possui cursos de extensão na área como o de Proteção a natureza (CEPRONA 2017, na Guarda Civil da Espanha) e o Curso de Policiamento Ambiental pela Polícia Militar do Estado do Rio de Janeiro. Tem como linha de pesquisa e atuação a sustentabilidade do policiamento ambiental, destacando a integração entre os poderes da República, em termos de Administração Pública garantidora da natureza.

\section{CARYNA PAES BARRETO}

Mestra em Educação pela Universidade Federal de Mato Grosso (2017). Bacharel em Administração pela UFMT (2009). Especialista em Educação das Relações Étnico-Raciais no Contexto da Educação de Jovens e Adultos (2015). Integrante do Núcleo de Estudos e Pesquisas sobre Relações Raciais e Educação NEPRE/IE/UFMT. Atualmente professora (substituta) de Administração do Instituto Federal de Mato Grosso. Professora Voluntária do Departamento de Administração da Universidade Federal de Mato Grosso. Integrante do Setor de Apoio Pedagógico.

\section{CECILIA ARLENE MORAES}

Doutora em Psicologia PUC-Goiás (2012). Mestre em Saúde e Ambiente UFMT (2005). Especialista em Recursos Humanos, em Psicanálise e Educação, em Dinâmica de Grupo (UFMT). Graduada em Administração UFMT (1979). Professora Associado IV do Departamento de Administração, da Faculdade de Administração e Ciências Contábeis (FACC), da Universidade Federal de Mato Grosso. Coordenadora e docente de cursos de Pós-Graduação 
Lato Sensu da UFMT. Pesquisadora, escritora e consultora empresarial com expertise nas áreas de Gestão Estratégica, Gestão Pública, Empreendedorismo, Tecnologia Social, Governança de Risco e Compliance.

\section{CLAUDETE FOGLIATO RIBEIRO}

Mestre pelo Programa de Engenharia de Produção da UFSM, Especialista em Gestão Pública (UFSM), Especialista em Gestão Educacional (UFSM), Bacharel em Administração (UNIFRA). Licenciada pelo curso de Formação de Professores (UFSM). Atualmente Diretora Administrativa, Docente e Coordenadora do Curso de Administração na SOBRESP. Tem experiência profissional nas áreas de Finanças, Marketing e Gestão de Pessoas. Desenvolve estudos nos seguintes temas: Empreendedorismo e Meio Ambiente; Gestão Educacional; Rede de Empresas; Administração Geral; Processo Sucessório; Setor Varejista e Finanças;

\section{CREMILCE BARRETO SILVA}

Administradora, graduada em Administração pela FSMA, artigo aprovado no CASI-2018, sobre Comportamento Humano nas Organizações. Atuação na área financeira durante vinte e cinco anos em comércio local e atualmente trabalhando com Educação Inclusiva na Prefeitura Municipal de Macaé.

\section{DANIEL LYRA RODRIGUES}

Engenheiro Mecânico, com certificação Profissional pelo Asset Management Council em Diagnóstico de Gestão de Ativos, Certificação Profissional pelo IAM (Institute of Asset Management) em Gestão de Ativos, Auditor Líder ISO 9001, ISO 14001, OHSAS 18001 e Green Belt Lean e Six Sigma. Possui 17 anos de experiência e atualmente está a 2 anos na Pragma Products. Palestrante em seminários patrocinados por organizações como ABRAMAN (Associação Brasileira de Manutenção e Gestão de Ativos), SENAI (Serviço Nacional de Aprendizagem Industrial) e Grupo Informa. Participação em artigos de revistas da ABRAMAN (Associação Brasileira de manutenção e Gestão de Ativos) e ABM (Associação Brasileira de Metalurgia, Materiais e Mineração).

\section{DANIELA MARTINA ALVES AGUILAR}

Discente do 8 o período do curso de Psicologia da Universidade Federal de Mato Grosso (UFMT). Atuou como monitora da disciplina Análise Experimental do Comportamento. Participou da Comissão Organizadora da VI Semana de Psicologia da UFMT. Atualmente é membro do Projeto de Extensão de Equoterapia da UFMT.

\section{DAVID BARBALHO PEREIRA}

Mestre em Gestão Pública e Cooperação Internacional - linha de pesquisa Políticas Públicas (UFPB). Bacharel em Gestão de Políticas Públicas (UFRN). Assistente em administração da Escola de Música da Universidade Federal do Rio Grande do Norte. Concentra seus estudos nas áreas de Monitoramento e Avaliação de Políticas Públicas, Policy learning, Atenção Primária à Saúde e Gestão de Programas Sociais. É autor do livro "Primeiros passos no estudo de monitoramento de políticas públicas" 


\section{EDUARDO DE-CARLI}

Mestre e Doutor em Administração pela Universidade Federal do Paraná (UFPR). Graduado em Administração pela Faculdade Estadual de Ciências Econômicas de Apucarana (FECEA), já atuou na iniciativa privada como Administrador e tem experiência na docência do ensino superior. Desenvolve pesquisas em Administração, na área de Gestão da Inovação, Tecnologia e Sustentabilidade, principalmente sob os temas de cooperação universidade-empresa, alianças, relações interorganizacionais, capacidades relacionais, transferência de tecnologia, tecnologias e inovação social.

\section{ELBA DE OLIVEIRA PANTALE?O}

Bacharel em Administração pela Universidade Federal de Mato Grosso e especialista em Gestão de Pessoas pelo Instituto Cuiabano de Educação. Tem experiência na área de pesquisa acadêmica com os seguintes temas: Gestão Ambiental, Inovação Sustentável e Empreendedorismo Social e de Impacto. Atua no mercado de consultoria de negócios e pesquisa de informação mercadológica. Vencedora do Prêmio Belmiro Siqueira de Administração em 2017- 1 Lugar - Modalidade Artigo Acadêmico. Vencedora do Premio ICE de Investimento e Negócios de Impacto em 2017- 2 Lugar- Categoria TCC Graduação.

\section{ELISABET AGUIRRE}

Doutora em Educação pela UFMT em 2018, Mestre em Educação pela UFC 1989. Pedagoga pela UFMT 1977. Professora do sistema público de Educação Básica aposentada e professora do Ensino Superior aposentada. Integrante do Quadro docente do Centro Universitário de Várzea Grande-UNIVAG desde 1992. Pró- Reitora de Graduação do Univag. Professora do Programa de Pós-Graduação lato sensu do Univag e da UFMT nas áreas de conhecimento: Didática do Ensino Superior e Metodologia de Pesquisa. Vários artigos publicados e participação em eventos com comunicação oral nas áreas de foco de estudo.

\section{EMÍLIA ISABEL GOMES VIEIRA}

Graduanda em Administração pelo Instituto Federal de Educação Ciência e Tecnologia do Norte de Minas Gerais, IFNMG, Brasil. Curso técnico/profissionalizante em Técnico em Administração pelo instituto Federal de Educação Ciência e Tecnologia do Norte de Minas Gerais, IFNMG, Brasil.

\section{GABRIELLA CRISTINA DE MELO AMORIM}

Servidora Pública Estadual PJC/MT. Bacharel em Direito pela Faculdade de Ciências Jurídicas e Sociais Aplicadas do Araguaia - FACISA.

\section{GIULIANNA FRANCHI}

Engenheira de produção formada pelo centro universitário da FEI, com mais de 4 anos de experiência na área de planejamento no que tange ao setor industrial e financeiro. Atualmente trabalho como trainee de negócios em uma empresa de tecnologia e serviços para o varejo. 


\section{INGRID MORENO DA SILVA}

Graduada em Administração pela Universidade Federal de Pelotas. Possui experiência na área administrativa. Os temas de pesquisa são transparência no setor público e gestão de recursos humanos.

\section{IONARA COELHO ARAUJO}

Mestre em Psicologia Social com ênfase em Cognição, Organizações e Trabalho pela Universidade Salgado de Oliveira - Universo. Possui MBA em Gestão Estratégica de Pessoas pela UFJF e pós-graduação em Psicanálise: Subjetividade e Cultura pela UFJF. É psicóloga organizacional e do trabalho, formada pelo Centro de Ensino Superior- CES. Consultora empresarial na área de Gestão de Pessoas atuando em diversos sub-sistemas. É Coach de Carreira formada pelo IBC ? Instituto Brasileiro de Coaching. É docente de ensino superior nos cursos de pós-graduação e graduação nas áreas de Psicologia organizacional e do trabalho e MBA de Gestao de Pessoas.

\section{ISABEL CRISTINA SARTORELLI}

Professora Adjunta da UFSCAR (Campus Sorocaba). Doutora, mestre e bacharel em Ciências Contábeis pela FEA-USP e bacharel em Administração de Empresas pela Universidade Mackenzie. Trabalhou em multinacionais (ICI Group, Siemens e Kodak) e também no setor público (Secretaria de Planejamento e Desenvolvimento Regional do Estado de São Paulo, na Coordenadoria de Orçamento).

\section{IVANA APARECIDA FERRER SILVA}

Professora DE Adjunto IV da Universidade Federal de Mato Grosso, curso de Administração da UFMT. Doutora em Desenvolvimento Sustentável do Trópico Úmido-PPDSTU - NAEA, UFPA. Mestre em Administração pela Universidade Federal do Rio Grande do Norte (2002). Bacharel em Administração pela Universidade Federal de Mato Grosso. Membro da Rede Academia Inovação para Cidadania Empresarial e ganhadora do Premio ICE categoria graduação em 2017. Atua mais especificamente os temas: empreendedorismo social, transparência, negócios de impacto, responsabilidade social, sistemas produtivos regionais e desenvolvimento endógeno sustentável.

\section{JEAN FILIPE KREBS}

Tecnólogo em Marketing pelo Instituto Federal de Educação, Ciência e Tecnologia do Rio Grande do Sul - Campus Erechim.

\section{JOÃO CARLOS MOSQUIM}

Engenheiro Civil (PUCC) e Terminais e Oleodutos (Universidade Petrobras), Formado pela Academia de Formação de Instrutores de Gerenciamento de Projetos (AFIGP-PMI-SP). Certificação Project Management Professional (PMP), Pós-Graduação MBA (FGV), especialização em Controle Total da Qualidade (Unicamp). Professor MBA (Abramam/Pragma Academy) da Universidade Brasil, nas disciplinas Gestão de Riscos e Gestão de Projetos. Ministra cursos abertos e in company nas áreas de Gestão de Riscos, Gestão de Projetos, Gestão de Paradas. Experiência profissional de 35 anos na indústria. Voluntário: Examinador no Prêmio Nacional da Qualidade, Mentor no PMI-SP, Avaliador do Sistema de Gestão Integrado nas obras/refino, na ABRAMAN no PNQC. Membro do Consellho Deliberativo da ABRAMAN e Secretário na ISA - International Society of Automation -Campinas. Autor dos livros S. Exa., O Prazo, Gerenciamento de Paradas de Manutenção e Estórias e brincadeiras do Tio Carlinhos. 


\section{JOSÉ NOGUEIRA DE MORAES}

Doutor em Ciências Pedagógicas pela Universidad Central Marta de Abreu de Las Villas - Cuba (2007) / Universidade Estadual Paulista Júlio Mesquita Filho - UNESP - Brasil. Mestre em Letras e Linguística pela Universidade Federal de Goiás (1988). Especialista em Língua PortuguesaRedação pela CAPES (1983). Especialista em Supervisão Escolar pela Universidade Federal de Mato Grosso (1982). Graduado em Direito pela Associação Goiana de Ensino (1977). Licenciado em Letras Modernas - Francês pela Universidade Federal de Goiás (1973). Atualmente é professor da Faculdade de Ciências Jurídicas e Sociais Aplicadas do Araguaia FACISA. Conselheiro e Presidente do Conselho Municipal de Educação de Barra do Garças Mato Grosso - Brasil.

\section{JOSSEANE SOUZA DOS SANTOS}

Graduanda em Administração pela Faculdade de Ciências da Saúde - SOBRESP, atualmente atua como Coordenadora administrativa Financeira de uma Multinacional e interessa-se por docência na área da Administração.

\section{JÚLIA MARIA FLORENTINO DA MOTA}

Graduanda do curso de Psicologia pela Universidade Federal de Mato Grosso (UFMT), campus Cuiabá. Atuou como monitora da disciplina Análise Experimental do Comportamento. Atualmente, é integrante do Núcleo de Psicologia Social Comunitária (NUPSCO); Grupo de Pesquisa em Psicologia da Infância (GPPIN) e do Programa de Educação Tutorial - Conexões de Saberes, atuando neste último como bolsista de extensão.

\section{JULIANA FABIÃO}

Possui graduação em Psicologia pela Universidade Católica de Pelotas (2014).MBA em Gestão de Pessoas e em conclusão do MBA em Gestão Estratégica de Negócios Atualmente é docente da Faculdade Anhanguera Pelotas e docente da Faculdade de tecnologia do Senac. Tem experiência na área de Psicologia, com ênfase em Psicologia do Trabalho e Organizacional. Atua na Ampla Gestão de Pessoas como consultora em Recursos Humanos em Pelotas e Rio Grande.

\section{KAMILLA CLAUSEN DA SILVA}

Graduanda de Psicologia na Universidade Federal de Mato Grosso, campus Cuiabá. Integra o Núcleo de Psicologia Social Comunitária (NUPSCO); bolsista do Programa de Educação Tutorial (PET) e também desenvolve o projeto "Compreendendo as dificuldades de aprendizagem: uma experiência de intervenção psicológica no apoio escolar".

\section{KEIKO CAROLINA MORAES SASAKI DE LUCENA}

É Doutoranda em Educação (UFBA - 2017), Mestre em Educação - UFMT (2007), MBA em Gestão Estratégica - UFMT (2005) e Graduada em Pedagogia na escola e na empresa pelo UNIVAG (2003). Atualmente é Coordenadora do Regulatório Regional Nordeste do grupo Estácio e Procuradora Institucional (PI) da Faculdade Estácio de Alagoinhas. É pesquisadora com expertise na área de avaliação, regulação e supervisão do ensino superior, na docência do ensino superior (presencial e a distância), pós-graduação lato sensu. 


\section{LAURA FONSECA}

Mestre em Gestão Pública e Cooperação Internacional pela UFPB (2018). MBA em Gestão Empresarial pela Fundação Getúlio Vargas - FGV/RJ (2013). Graduação em Administração pela Universidade Federal da Paraíba (2009). Atua principalmente nas áreas de Educação para Sustentabilidade; Sustentabilidade e Desenvolvimento Regional.

\section{LUANA FERNANDES DOS SANTOS MONTENEGRO}

Tecnóloga em Redes de Computadores, pelo Instituto Federal de Educação, Ciência e Tecnologia do Rio Grande do Norte - IFRN (2010) e Bacharel em Ciências Contábeis pela Universidade Federal do Rio Grande do Norte - UFRN (2014). Especialista em Gestão de Tecnologia da informação pela Universidade Federal do Rio Grande do Norte - UFRN (2017). Foi professora/tutora do Curso de Formação Técnica em Tecnologia da Informação no Instituto Metrópole Digital - IMD/UFRN e trabalha no Instituto Internacional de Física IIF/UFRN realizando atividades com foco na implementação e administração do parque computacional e do Sistema Computacional de Memória Global Compartilhada de Alto Desempenho SGI - Altix UV 1000.

\section{LUCIANA MARIA BERNSTEIN PAVAN}

Mestre em Administração pela Universidade Nove de Julho (UNINOVE). Especialização em Gestão Empresarial com Habilitação em Docência de Graduação pelo Instituto de Ciências Sociais e Gestão Corporativa - ICSEC (2009). Possui Formação Pedagógica de Docentes para as disciplinas de Administração pelo Instituto Federal de Educação, Ciência e Tecnologia do Rio Grande do Sul (2011), Graduada em Administração e Comércio Exterior pela Universidade Regional Integrada do Alto Uruguai e das Missões (2006). Professora da Faculdade IDEAU/RS e Professora substituta do Instituto Federal de Educação, Ciência e Tecnologia do Rio Grande do Sul- Campus Erechim.

\section{LUCIANA NUNES FERREIRA}

Possui graduação em Ciências Contábeis pela Universidade Católica de Pelotas, Mestrado em Administração e Especialização em Gestão Contábil pela Universidade de Santa Cruz do Sul. Atualmente é Doutoranda no Programa de Pós Graduação em Sistemas de Produção Agrícola Familiar da UFPEL. Possui experiência nas áreas de contabilidade gerencial, custos e gestão financeira. Realiza pesquisas nos seguintes temas: Contabilidade gerencial, Gestão financeira, custos, transparência no setor público e gestão de recursos humanos. É professora dos cursos de Administração e Processos Gerenciais da Universidade Federal de Pelotas desde 2011.

\section{MANOEL VERAS DE SOUSA NETO}

Possui doutorado em Administração pela Universidade de São Paulo - USP (2001), mestrado em Engenharia Elétrica pela Universidade Estadual de Campinas - UNICAMP (1985) e graduação em Engenharia Elétrica pela Universidade Federal do Rio Grande do Norte - UFRN (1983) . É professor associado IV da UFRN atuando na área de Administração, com ênfase em Tecnologia da Informação. Coordena o grupo de pesquisa registrado no CNPQ : Estudos Organizacionais em Gestão de Projetos. Coordena a especialização em Gestão da Tecnologia da Informação na UFRN. É autor de mais de cem artigos acadêmicos e de vários livros na área de Tecnologia da Informação e Gerenciamento de Projetos com foco em Capacitação Profissional. É assessor técnico da secretaria de gestão de projetos da UFRN. Faz parte do conselho de desenvolvimento acadêmico (CDA) do Instituto Metrópole Digital (IMD) da UFRN. É membro permanente do conselho deliberativo da incubadora Inova Metrópole e do 
Conselho Administrativo do Parque Tecnológico Metrópole Digital .É professor do Programa de Pós-Graduação em Administração (PPGA) e do Mestrado Profissional em Inovação em Tecnologias Educacionais (MPITE) da UFRN. Possui experiência no setor privado e no setor público.

\section{MARIA DAS GRA?AS DA SILVA COSTA COELHO}

Especialista em Educação a Distância: Concepção e Planejamento (2012), graduada em Administração (2006) pela Pontifícia Universidade Católica de Minas Gerais - (PUC-MG). Apresenta experiências na área da Administração em diversos segmentos, e, no âmbito educacional como tutora da PUC Minas Virtual (2010 - 2013). Atualmente, é Administradora no CEFET- Unidade Curvelo - MG.

\section{MARINO LUIZ EYERKAUFER}

Possui graduação em Ciências Contábeis pela Universidade do Oeste de Santa Catarina (2002), especialização em Adm/Mkt pela Universidade do Oeste de Santa Catarina (2004), mestrado em Ciências Contábeis pela Fundação Universidade Regional de Blumenau (2007) e doutorado em Engenharia de Produção pela Universidade Federal de Santa Catarina (2017). Atualmente é professor universitário efetivo da Universidade do Estado de Santa Catarina. Tem experiência na área de Administração e Contabilidade, atuando principalmente nos seguintes temas: planejamento estratégico e orçamento empresarial, controladoria estratégica, sistemas de informação, gestão estratégica de custos e ainda gestão de riscos.

\section{PATRICIA MARA DE SOUZA}

Mestre em Administração pela Fundação Pedro Leopoldo, Especialista em Gestão de Marketing, Especialista em Gestão de Pessoas, Graduada em Administração de Empresas. Coordenadora do curso de Administração e professora na graduação nas faculdades FACSUM/FJF Juiz de Fora/MG (Grupo UNIP). Professora na pós graduação MBA Gestão de Pessoas e MBA em Finanças da Escola de Negócios Granbery (FMG) Juiz de Fora/MG.

\section{RAMESH MOHAN THADANI}

Possui graduação em Ciências Contábeis pela UFAM, especialização em Auditoria pela FGV/ISAE (Pós-graduação), especialização em Gestão de Projetos pela FUCAPI (MBA) e especialização em Inovação em Negócios pela FUCAPI/University of New Mexico (MBA). Cursando Mestrado em Engenharia de Produção pela UFAM (início em 2018). Tem experiência profissional em Auditoria Operacional (Compliance Audit), na área de Engenharia de Produção e Avaliação de Projetos de Negócios (Business Plan).

\section{RITA ELIANA MAZARO}

Pós-Doutoranda em Psicologia Social e do Trabalho pela Universidade de São Paulo (2018). Doutorado em Psicologia Social e do Trabalho pela Universidade de São Paulo (2014). Mestrado em Psicologia Social e Especialização em Gestão de Pessoas pela Universidade São Marcos (2008). Graduação em Psicologia pela Universidade São Marcos (1993). Atualmente é Professora de Psicologia Organizacional e Orientadora no Mestrado em Psicologia da UFMT. 


\section{ROGERIO DA SILVA ALIMEIDA}

Possui graduação em Administração pela Fundação Universidade Federal do Rio Grande, Mestrado em Administração pela Universidade Federal do Paraná. Atualmente é Doutorando no Programa de Pós-Graduação em Administração da Universidade Federal do Rio Grande do Sul. Atuou como coordenador do Curso de Administração da Faculdade Anhanguera e do Curso de Administração da Universidade Federal de Pelotas. Possui experiência na área de Administração, com ênfase em Teoria das Organizações, atuando principalmente nos seguintes temas: Mercantilização do Ensino, Cultura Organizacional, Poder e Controle nas Organizações.

Atualmente é Professor Adjunto da Universidade Federal de Pelotas.

\section{SILVANA SAIONARA GOLLO}

Doutora em Administração pelo Programa de Pós-Graduação em Administração da Universidade Federal do Rio Grande do Sul (2006). Mestre em Economia Rural pelo Instituto de Estudos e Pesquisas Econômicas - Universidade Federal do Rio Grande do Sul (1988). Especialista em Gestão Estratégica de Compras e Vendas (URI) e Marketing (UFRGS). Especialista em Direito Tributário ( UFRGS, 2013) e Direito Previdenciário (2015). Graduada em Administração (1983) e Graduada em Direito (2011) pela Universidade Regional Integrada do Alto Uruguai e das Missões - Campus de Erechim. É professora (DE) e pesquisadora do Instituto Federal de Educação, Ciência e Tecnologia do Rio Grande do Sul - Campus Erechim.

\section{SIMONE HIRATA}

Bacharel em Administração pela Universidade Federal de Mato Grosso (UFMT) . Especialista em Gestão Pública (UFMT) e em Design Instrucional pelo Instituto Federal de Educação, Ciência e Tecnologia de Mato Grosso (IFMT). Servidora Técnica Administrativa (Administradora) da UFMT desde 2010, onde atua na área de Gestão de Pessoas. Participa do Grupo de Pesquisa em Administração.

\section{SIMONE PORTELLA TEIXEIRA DE MELLO}

Mestre em Administração pelo PPGA-UFSC, Doutora em Educação pelo PPGEDU - UFRGS e Pós-Doutora em Administração pelo PPGA - UFSC. É Avaliadora do INEP - MEC e Colaboradora da Escola Nacional de Administração Pública - ENAP - Ministério do Planejamento. Seus interesses de pesquisa concentram-se na área de administração pública, gestão de pessoas, desenvolvimento gerencial e de equipes, competências e gestão por competências. Atualmente é professora associada da Faculdade de Administração e de Turismo da Universidade Federal de Pelotas - UFPel, RS.

\section{TATIANA BONOMI}

Sou graduada em Engenharia de Produção na FEI, Técnica em Administração pela ETEC e Técnica em Qualidade e Produtividade pelo COTIL/UNICAMP. Atualmente, trabalho na Península Participações na área de Planejamento Financeiro com a responsabilidade de gerar informações e relatórios financeiros das empresas do grupo, elaborar o orçamento anual e acompanhá-lo, além de análises financeiras e orçamentárias que são apresentadas mensalmente ao Conselho de Administração. 


\section{THAIS LOPES PESSANHA}

Engenheira de produção pela $\mathrm{FEI}$, cursou Engenharia Industrial durante 1 ano no ICAM (Institut catholique d'arts et métiers), na França. Atualmente vivendo em Bueno Aires, trabalha em Supply Chain na Bacardí, sendo responsável pelo planejamento e abastecimento de produtos importados do Chile e Uruguai.

\section{THÁLITA ANNY ESTEFANUTO ORSIOLLI}

Doutora e Mestra em Administração pela Universidade Federal do Paraná (UFPR). Graduada em Administração, já atuou na iniciativa privada como administradora e tem experiência na docência do ensino superior. Atua no grupo de pesquisa Estudos de Gestão da Inovação, Tecnologia e Sustentabilidade - EGITS. Suas temáticas de pesquisa envolvem estudos na área de Gestão da Inovação, Tecnologia e Desenvolvimento Sustentável, principalmente sob os temas de empreendedorismo sustentável, stakeholders, inovação sustentável, cooperação, cooperações interorganizacionais e transferência de tecnologia.

\section{VALENTINA SANTOS BAUERMEISTER}

Discente do 8 o período do curso de Psicologia da Universidade Federal de Mato Grosso (UFMT), campus Cuiabá. Participou da Comissão Organizadora da VII Semana de Psicologia da UFMT.

\section{VICTOR HARUO NITATORI RODRIGUES LOURENCO}

Bacharelando em Administração pela Universidade Federal de São Carlos, se formou técnico em Comércio e realizou extensão em Inovação e Estratégia na Harvard Extension School.

\section{VICTÓRIA OLIVEIRA SANTOS BARBOSA MENDES}

Graduanda do quarto ano de Psicologia na Universidade Federal de Mato Grosso - UFMT campus Cuiabá. Atualmente, integra o Programa de Educação Tutorial Conexões de Saberes e o Núcleo de Estudos de Psicologia Social Comunitária (NUPSCO) da UFMT. 


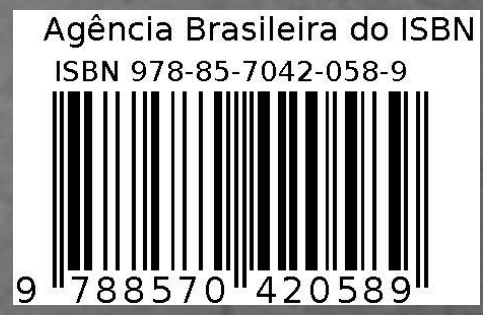

